UNIVERSIDADE DE SÃO PAULO

FACULDADE DE FILOSOFIA, LETRAS E CIÊNCIAS HUMANAS

DEPARTAMENTO DE LETRAS MODERNAS

PROGRAMA DE PÓS-GRADUAÇÃO EM ESTUDOS DA TRADUÇÃO

MARCELO VICTOR DE SOUZA MOREIRA

Os desdobramentos do funcionalismo alemão no Brasil 
MARCELO VICTOR DE SOUZA MOREIRA

\title{
Os desdobramentos do funcionalismo alemão no Brasil
}

\author{
(Versão corrigida)
}

Tese apresentada ao Programa de PósGraduação em Estudos da Tradução do Departamento de Letras da Faculdade de Filosofia, Letras e Ciências Humanas da Universidade de São Paulo, como parte dos requisitos para obtenção do título de Doutor em Letras.

Orientador: Prof. Dr. João Azenha Junior

São Paulo

2019 
Autorizo a reprodução e divulgação total ou parcial deste trabalho, por qualquer meio convencional ou eletrônico, para fins de estudo e pesquisa, desde que citada a fonte.

Catalogação na Publicação

Serviço de Biblioteca e Documentação

Faculdade de Filosofia, Letras e Ciências Humanas da Universidade de São Paulo

M838d

Moreira, Marcelo Victor de Souza

Os desdobramentos do funcionalismo alemão no

Brasil / Marcelo Victor de Souza Moreira.

orientador João Azenha Junior. - São Paulo, 2019.

$420 \mathrm{f}$.

Tese (Doutorado)- Faculdade de Filosofia, Letras e Ciências Humanas da Universidade de São Paulo. Departamento de Letras Modernas. Área de concentração: Estudos da Tradução.

1. Tradução. I. Azenha Junior, João, orient. II. Título. 


\section{ENTREGA DO EXEMPLAR CORRIGIDO DA DISSERTACÃO/TESE}

\section{Termo de Ciência e Concordância do (a) orientador (a)}

Nome do (a) aluno (a): Marcelo Victor de Souza Moreira

Data da defesa: 01/07/2019

Nome do Prof. (a) orientador (a): Prof. Dr. João Azenha Junior

Nos termos da legislação vigente, declaro ESTAR CIENTE do conteúdo deste EXEMPLAR CORRIGIDO elaborado em atenção às sugestões dos membros da comissão Julgadora na sessão de defesa do trabalho, manifestando-me plenamente favorável ao seu encaminhamento e publicação no Portal Diqital de Teses da USP.

São Paulo, 28/08/2019

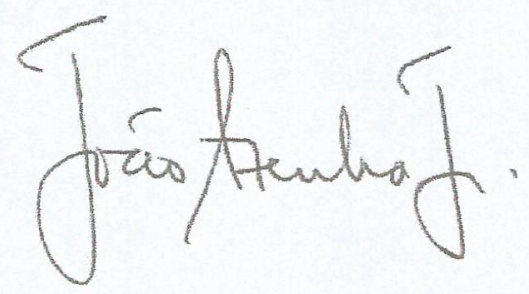

(Assinatura do (a) orientador (a) 
MOREIRA, M. V. S. Os desdobramentos do funcionalismo alemão no Brasil. Tese apresentada à Faculdade de Filosofia, Letras e Ciências Humanas da Universidade de São Paulo para obtenção do título de Doutor em Letras.

Aprovado em:

Banca Examinadora

Prof. Dr. Heloísa Pezza Cintrão

Julgamento:

Prof. Dr. Maria Cristina F. S. Altman

Julgamento:

Prof. Dr. Karin Volobuef

Julgamento:
Instituição: Universidade de São Paulo

Assinatura:

Instituição: Universidade de São Paulo

Assinatura:

Instituição: Universidade Estadual Paulista

Assinatura: 


\section{AGRADECIMENTOS}

O percurso da pós-graduação costuma ser solitário. Sendo assim, ter a sorte e o privilégio, como eu tenho, de ter pessoas especiais que possam acompanhar o caminho, ou ao menos um trecho, é um grande motivo para celebração. Dessa forma, dirijo os meus mais sinceros agradecimentos:

a meus pais, que, nos meus bons e nos meus maus momentos, deram amor incondicional, e que nunca deixaram de me apoiar em minhas decisões de carreira, dando-me suporte e conforto;

a meu irmão e minha cunhada, sempre solícitos para qualquer eventualidade, e a meus três lindos sobrinhos, três grandes alegrias de minha vida;

à Prof. Dr. Heloísa Cintrão e à Prof. Dr. Cristina Altman, pelas inestimáveis contribuições em ocasião do Exame de Qualificação;

a meus amigos dos tempos da graduação - Vinicius Martins, Maria Ângela Paschoal, Michele Lima, Giovanna Coan, Marcelo Moraes, Marta Teixeira, Marcela Ferreira, Marcio Cenzi, Mila González, Cecília Carvalho - pelos momentos de diversão e de conversas instigantes;

às amizades que fiz durante a pós-graduação - Sandra Albuquerque, Anna Schaefer, Francesca Cricelli, Dennys Silva-Reis, Silvia Cobelo, Zsuzsanna Spiry, Telma Diniz, Renata Bastianello, Giovana Marqueze, Alessandra Otero, Raquel Santos, Edgar Rosa, Flora Bonatto, Rodolpho Camargo, Gisele Rosa, Yasmin Utida, Janaína Salgado -, pois, com vocês, o percurso da pós-graduação foi repleto de momentos de alegria;

aos amigos da vida toda - Carla Verçoza, Felipe Macedo, Caio Vayego, Giselle Rocha, Fabiano Cardoso, Tatiane Vicola, Nathália Diniz, Junior Rissi, Rafael Rodrigues, Ana Hammermeister Nezu, Suzana Martins, Sérgio Casimiro, Olivia Dias, Erika Nezu, Mariinha Melo, Luiz Pereira, Ronaldo de Paula - por todos os momentos especiais que passei com vocês; 
ao Prof. Dr. John Milton e à Prof. Dr. Stella E. O. Tagnin, por todos os ensinamentos nos âmbitos, respectivamente, da historiografia da tradução e da linguística de corpus, e à Prof. Dr. Angela Zucchi, pela importante sugestão de empregar a análise bibliométrica em minha pesquisa;

à Prof. Dr. Juliana Perez e ao Prof. Dr. Helmut Galle, por terem sempre as portas abertas para mim;

ao Prof. Dr. Rui Rothe-Neves, à Prof. Dr. Luciane Corrêa Ferreira, ao Prof. Dr. Marcelo Rondinelli e à Prof. Dr. Anna Palma, da UFMG, pela confiança e pela oportunidade valiosíssima de praticar a docência na universidade;

à Prof. Dr. Christiane Nord, por estar sempre disposta a compartilhar informações fundamentais sobre o desenvolvimento do funcionalismo na Alemanha e no mundo;

ao Erick, pela incrível compreensão e paciência;

ao Programa de Pós-Graduação em Estudos da Tradução, pela oportunidade de desenvolver a presente pesquisa;

à Faculdade de Filosofia, Letras e Ciências Humanas da Universidade de São Paulo, por me acolher como aluno nesses últimos quinze anos;

à Coordenação de Aperfeiçoamento de Pessoal de Nível Superior - Brasil, pelo financiamento do projeto, sem o qual ele não teria sido possível;

e, por fim, ao meu orientador, o Prof. Dr. João Azenha Junior, por ter trilhado esse percurso comigo, sempre apontando a direção. 


\section{RESUMO ${ }^{1}$}

MOREIRA, Marcelo V. S. Os desdobramentos do funcionalismo alemão no Brasil. 2019. 420f. Tese (Doutorado em Letras) - Faculdade de Filosofia, Letras e Ciências Humanas, Universidade de São Paulo, 2019.

O presente trabalho, localizado nos domínios da historiografia dos estudos da tradução, tem como objetivo investigar o percurso do funcionalismo alemão no Brasil, com foco, por um lado, na ação de lideranças para a promoção da abordagem teórica no país e, por outro, no tratamento conceitual atribuído aos conceitos fundamentais da abordagem teórica por pesquisadores brasileiros. Ademais, o trabalho visa a propor uma metodologia útil à pesquisa histórica dos estudos da tradução, amparada por um modelo teórico interdisciplinar, bem como a contribuir para o mapeamento do campo disciplinar e para a promoção da abordagem funcionalista. Parte-se de duas hipóteses: no plano social, a disseminação do Funcionalismo teria se dado, no inicio, através da ação de lideranças funcionalistas na divulgação teórica, um posto depois assumido por agentes difusores em instituições de ensino superior no Brasil; no plano conceitual, as pesquisas fundamentadas pelo funcionalismo no Brasil fariam uso do arsenal conceitual estabelecido pela teoria em seus primeiros anos, sobretudo por meio dos trabalhos de Christiane Nord, expandindo ou reformulando os conceitos da teoria-base ao aplicá-los no exame de um problema específico de tradução. Para confirmar ou refutar essas hipóteses, são empregados, no âmbito teórico, noções de historiografia, em especial da história das ciências, assim como noções da filosofia e da sociologia da ciência e da sociobiologia. No âmbito metodológico, a linguística de corpus e a cientometria fornecem procedimentos e ferramentas de análise. Desse modo, essas abordagens são coadunadas em dois vieses de pesquisa: uma pesquisa contextual (externalista) e uma pesquisa conceitual (internalista). A partir desses dois vieses, almeja-se uma compreensão holística da difusão da teoria no Brasil. Como parte da pesquisa externalista, delineia-se um mapa do campo disciplinar no Brasil desde o seu início, nos anos de 1950, com especial ênfase ao período entre 1990 e 2005. Esse mapa revela um crescimento bastante

\footnotetext{
${ }^{1}$ O presente trabalho foi realizado com apoio da Coordenação de Aperfeiçoamento de Pessoal de Nível Superior - Brasil (CAPES) - Código de Financiamento 001.
} 
significativo do campo, sobretudo a partir da década de 1990, impulsionado por sua institucionalização. Outrora concentrada em instituições no Sudeste e no Sul brasileiros, as investigações de temas ligados à tradução disseminam-se para outras localidades, surgindo assim outros polos de pesquisa. No que tange ao funcionalismo, observa-se, conforme uma das hipóteses de trabalho, que sua entrada no âmbito dos estudos da tradução no país ocorre, de modo preponderante, pela ação dos fundadores da abordagem teórica. Seu crescimento e disseminação ocorrem apenas em tempos mais recentes, sobretudo em torno de temas como a tradução técnica, a tradução de quadrinhos e o emprego da tradução em aulas de língua estrangeira. Quanto à pesquisa conceitual, ela revela que os pesquisadores brasileiros absorvem algumas noções fulcrais do funcionalismo, tais como o fato de a tradução ser um proceder entre culturas, orientado pela função do texto traduzido. Em conformidade com as hipóteses iniciais, observa-se também que as ideias que circulam nos estudos da tradução no Brasil foram introduzidas principalmente pelas obras de Christiane Nord. Por fim, ressalta-se o fato de que o funcionalismo, como qualquer teoria, não contemplar todos os casos específicos de tradução, sendo necessária a contribuição de aportes teóricos advindos de outras áreas disciplinares, o que é um valoroso exemplo da interdisciplinaridade inerente aos estudos da tradução.

Palavras-chave: Funcionalismo alemão, História dos estudos da tradução, Vermeer, Nord, Análise conceitual. 


\begin{abstract}
$^{2}$
MOREIRA, Marcelo V. S. The developments of German functionalism in Brazil. 2019. 420ff. Thesis (Doctorate in Languages) - Faculty of Philosophy, Languages and Human Sciences, University of São Paulo, 2019.
\end{abstract}

This study, inserted in the field of historiography of translation studies, seeks to investigate the course of German functionalism in Brazil, focusing, on the one hand, on the leaderships' action to promote the theoretical approach in the country and, on the other hand, in the conceptual treatment attributed to the fundamental concepts of the theoretical approach by Brazilian researchers. Moreover, the study aims to propose a useful methodology for the historical research of translation studies, supported by an interdisciplinary theoretical model, as well as to contribute to the mapping of the disciplinary field and to promote the functionalist approach. It is based on two hypotheses: at the social level, the dissemination of Functionalism would have taken place, in the beginning, by the functionalist leaderships' actions to promote the theory, a position later assumed by promoters in higher education institutions in Brazil; and, on the conceptual level, the researches based on functionalism in Brazil would make use of the conceptual array established by the theory in its early years, especially through the studies by Christiane Nord, expanding or reformulating the concepts of the basic theory by applying them to the examination of a specific translation problem. In order to confirm or refute these hypotheses, notions of historiography are used in the theoretical scope, especially notions of history of sciences, as well as notions of philosophy and sociology of science and sociobiology. In the methodological scope, corpus linguistics and scientometrics provide analysis procedures and tools. Therefore, these approaches are linked by two research models: a contextual research (externalist) and a conceptual research (internalist). From these two models, we aim for a holistic understanding of the dissemination of the theory in Brazil. As part of the externalist research, a map of the disciplinary field in Brazil is outlined since its inception in the 1950s, with special emphasis on the period between 1990 and 2005. This map shows a very significant growth of the field, especially since the 1990s, driven by its institutionalization. Formerly centred

\footnotetext{
${ }^{2}$ This study was financed in part by the Coordenação de Aperfeiçoamento de Pessoal de Nível Superior - Brasil (CAPES) - Finance Code 001.
} 
in institutions in the Southeast and South of Brazil, research studies on themes related to translation are disseminated to other localities, thus, other research centres emerge. Regarding functionalism, it can be seen that, according to one of the hypotheses of this study, its inclusion into the scope of translation studies in the country occurs, predominantly, by the action of the founders of the theoretical approach. Its growth and dissemination only occur in more recent times, especially involving themes such as technical translation, translation of comic books, and the use of translation in foreign language lessons. As for the conceptual research, it reveals that Brazilian researchers absorb some key notions of functionalism, such as the fact that translation is a proceeding between cultures, guided by the function of the translated text. In accordance with the initial hypotheses, it is also noted that the ideas that circulate in translation studies in Brazil were mainly introduced by the works of Christiane Nord. Finally, we emphasize the fact that functionalism, like any theory, does not contemplate all specific cases of translation, requiring the contribution of theoretical inputs from other disciplinary areas, which is a valuable example of the inherent interdisciplinarity of translation studies.

Keywords: German Functionalism, History of Translation Studies, Vermeer, Nord, Conceptual Analysis. 


\section{LISTA DE GRÁFICOS}

Gráfico 01 - Tela de inclusão de documentos do SciMAT 1.1.04

Gráfico 02 - Número total de resumos por instituição acadêmica (cf. PAGANO; VASCONCELLOS, 2003, p. 5)

Gráfico 03 - Data de defesas dos trabalhos (cf. PAGANO; VASCONCELLOS, 2003, p. 7)

Gráfico 04 - Pesquisas em tradução, distribuídas por ano de publicação (ALVES; VASCONCELLOS, 2016, p. 391)

Gráfico 05 - Distribuição de artigos por ano de publicação

Gráfico 06 - Comparativo do volume de publicações de cada periódico por ano

Gráfico 07 - Volume total de artigos publicados por cada periódico

Gráfico 08 - Instituições que organizam os periódicos em que publicaram, respectivamente pesquisadores da USP e da UFSC (1992-2005) 169

Gráfico 09 - Distribuição dos artigos funcionalistas por ano ......................... 187

Gráfico 10 - Distribuição dos artigos funcionalistas por instituição ............... 188

Gráfico 11 - Distribuição dos artigos funcionalistas por ano/instituição ......... 189

Gráfico 12 - Proporção de ocorrências de temas em artigos funcionalistas .... 193

Gráfico 13 - Modelo de fatores de Katharina Reiss (REISS; VERMEER, 1984, p. 148) 


\section{LISTA DE TABELAS}

Tabela 01 - Palavras-chave-chave da porção do C1 em língua alemã 99

Tabela 02 - Ocorrência das palavras-chave-chave no texto de Snell-Hornby (1988)

Tabela 03 - Tabela de palavras-chave-chave de C1 recalculada 102

Tabela 04 - Relação das revistas especializadas (1990-2005) 154

Tabela 05 - Relação dos números temáticos de revistas de outras especialida-

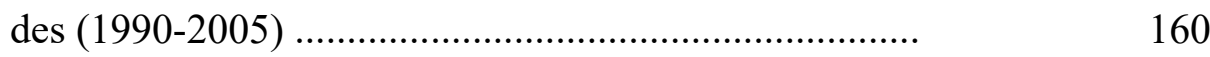

Tabela 06 - Relação das revistas especializadas consultadas (2006-2018) ....... 163

Tabela 07 - $\quad$ Autores mais produtivos e veículos de publicação (1992-2005) .... 168-9

Tabela 08 - Participação de cada instituição na produção intelectual publicada em cada período

Tabela 09 - Os 35 autores mais citados por período $173-4$

Tabela 10 - Temas mais abordados (1992-1995) $177-8$

Tabela 11 - Temas mais abordados (1996-2000) $179-80$

Tabela 12 - Temas mais abordados (2001-2005) $181-2$

Tabela 13 - Artigos com fundamentação teórica funcionalista (1994-2017) $186-7$

Tabela 14 - Autores(as) mais produtivos(as) no âmbito do funcionalismo $189-90$

Tabela 15 - Relação de palavras-chave para cada artigo funcionalista $191-2$

Tabela 16 - Autores funcionalistas mais citados 194

Tabela 17 - Documentos funcionalistas mais citados $195-6$ 


\section{Sumário}

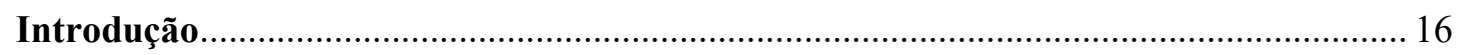

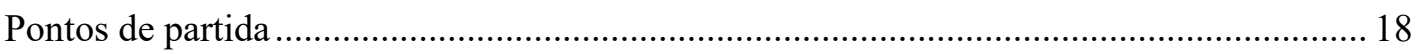

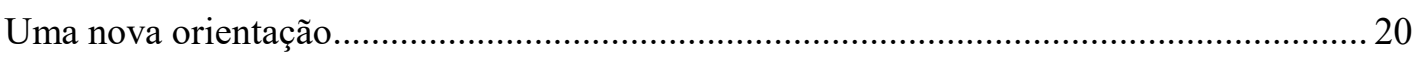

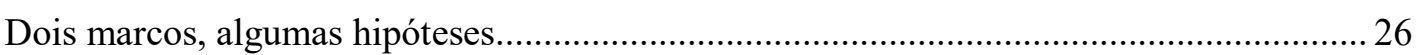

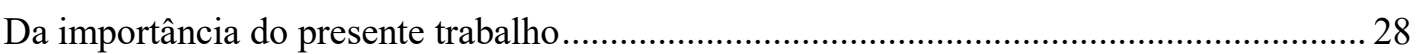

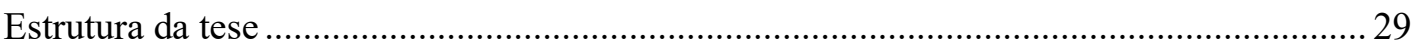

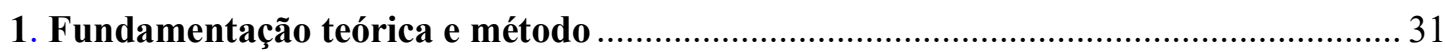

1.1. História geral e a história da ciência ….......................................................................... 33

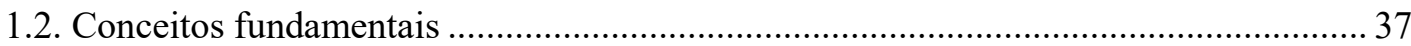

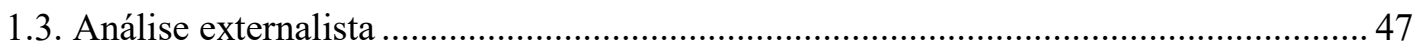

1.3.1. Contribuições para uma análise externalista .............................................................. 47

1.3.1.1. Filosofia da ciência: escola intelectual, paradigma e cinosura ................................. 48

1.3.1.2. As lutas paradigmáticas no campo científico ........................................................... 51

1.3.1.3. A questão da autonomia do campo científico .......................................................... 55

1.3.1.4. O papel das disciplinas no desenvolvimento do campo científico ........................... 58

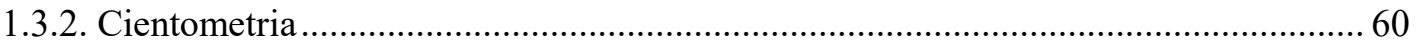

1.3.2.1. Fundamentos técnicos e teóricos da pesquisa bibliométrica ....................................62 62

1.3.2.2. O uso da cientometria para história e sociologia da ciência..................................... 68

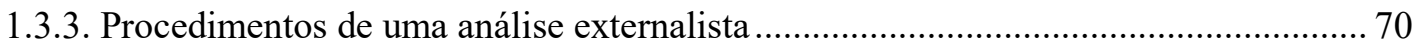

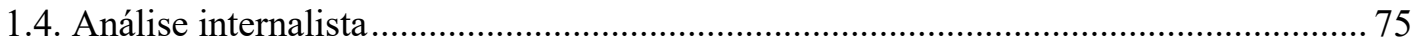

1.4.1. Contribuições para uma análise internalista .............................................................. 75

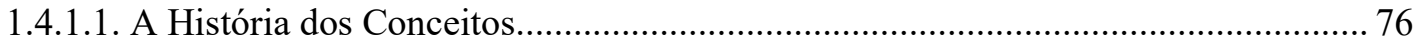

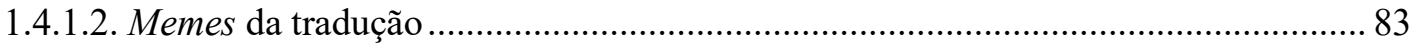

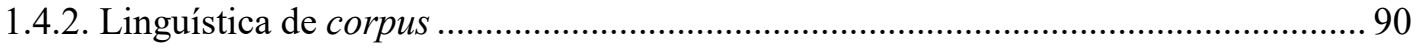

1.4.3. Procedimentos de uma análise internalista.................................................................. 97

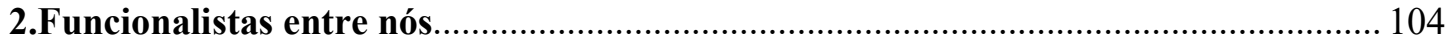

2.1. Um balanço dos estudos da tradução no Brasil .............................................................. 105

2.1.1. Os estudos da tradução no Brasil até a década de 1970 ............................................ 105

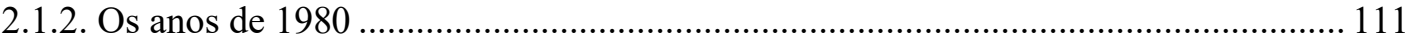

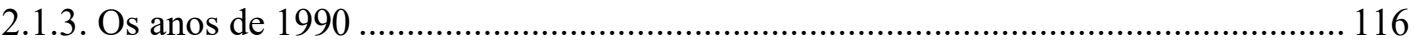

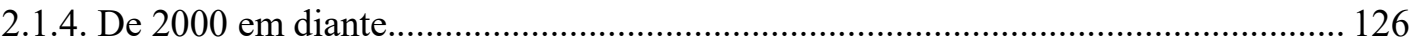

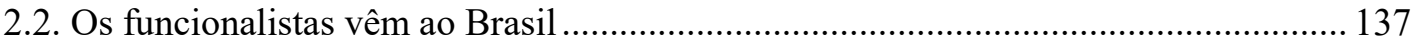

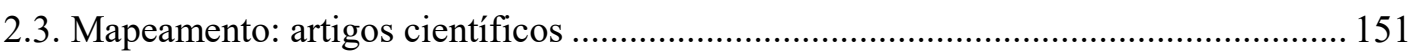


2.3.2. Trabalhos fundamentados na abordagem funcional (1992-2017) ........................... 185

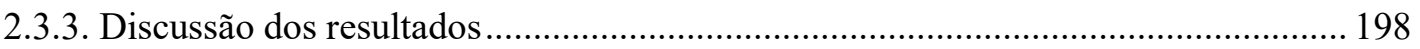

3.Os conceitos funcionalistas de tradução ..................................................................... 210

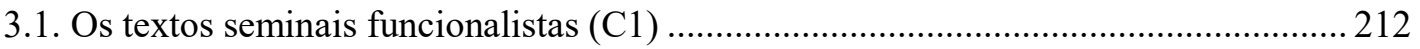

3.1.1. Katharina Reiss: por uma crítica de tradução............................................................ 212

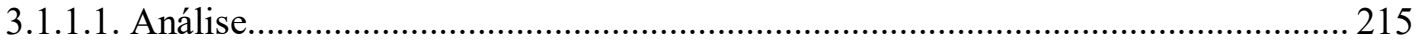

3.1.2. Hans Josef Vermeer: Esboço de uma teoria geral .................................................... 225

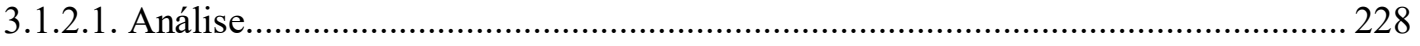

3.1.3. Hans G. Hönig e Paul Kussmaul: Descrevendo estratégias para a prática e para a

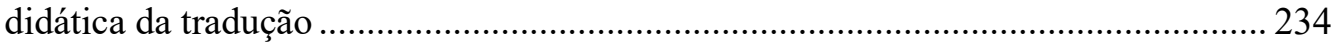

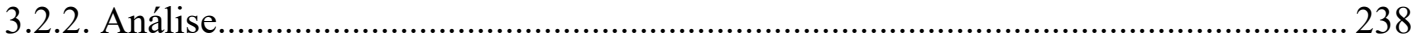

3.1.4. Hans J. Vermeer e Katharina Reiss: expandindo a teoria básica ............................. 247

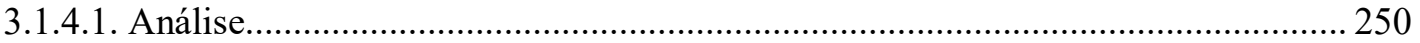

3.1.5. Justa Holz-Mänttäri: a teoria da ação translacional..................................................... 268

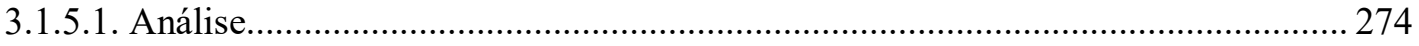

3.1.6. Christiane Nord: um modelo de análise textual ....................................................... 293

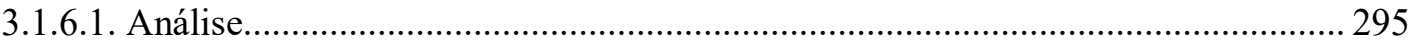

3.1.7. Mary Snell-Hornby: a abordagem integrada ............................................................ 307

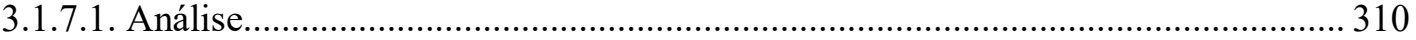

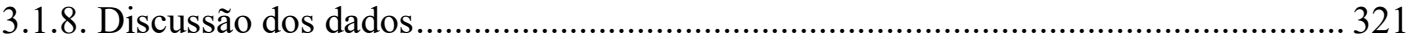

3.2. Os trabalhos de grau - um exemplar de análise (C2) .................................................... 329

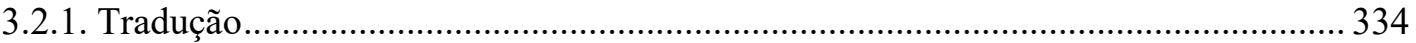

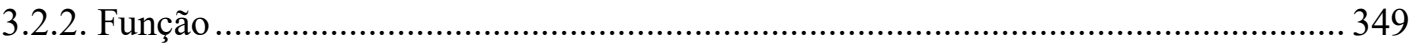

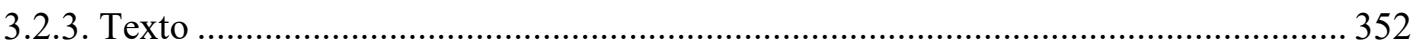

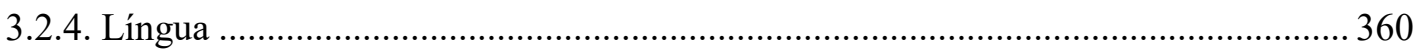

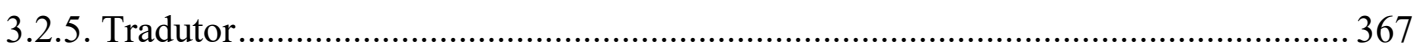

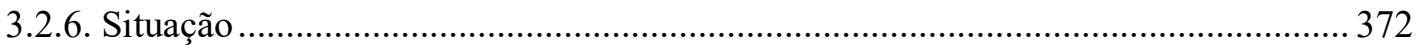

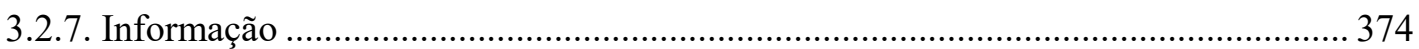

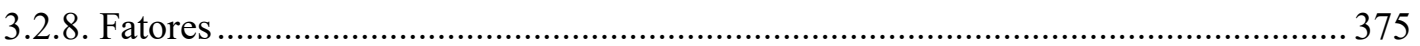

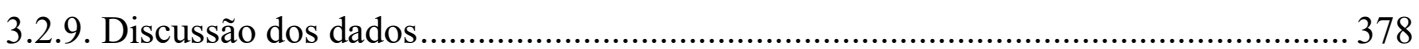

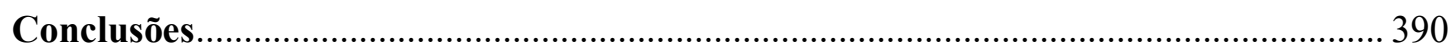

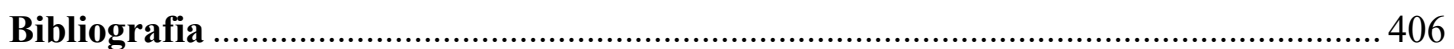




\section{Introdução}


O funcionalismo, tema do presente projeto, acompanha-me desde os primeiros passos de minha formação de pesquisador, constituindo uma parte significativa dos pressupostos teóricos de meu trabalho de Iniciação Científica. O estudo intitulado "O reconto como categoria de tradução - Aspectos da tradução/adaptação em literatura infantil" (MOREIRA, 2009), desenvolvido sob a orientação do Prof. Dr. João Azenha Junior, explorou a tradução e a adaptação voltadas ao público infantil e juvenil, bem como contribuiu para desvendar o que parece ser uma nova categoria de escrita tradutória para esse grupo receptor: o reconto. Especialmente relevantes nesse exame foram as contribuições de Christiane Nord (1989) para o âmbito dos estudos da tradução, sobretudo a sua tipologia tradutória, baseada na tipologia formulada por Reiss (cf. REISS; VERMEER, 1984), e o conceito de lealdade [Loyalität], central a sua proposta teórica.

Quando ingressei no Programa de Pós-Graduação em Língua e Literatura Alemã, o funcionalismo deixou de apenas ser parte do corpo de pressupostos teóricos e passou, ele mesmo, a ser meu objeto de estudos. Inicialmente, por trás do projeto de Mestrado esteve o desejo de tornar mais acessíveis, mediante a tradução de artigos e capítulos de livros e a sua compilação numa antologia ${ }^{3}$, os conceitos e métodos que tanto me foram úteis em minha Iniciação Científica. No entanto, ao iniciar a pesquisa, outra questão pareceu-me ainda mais pertinente (e urgente): como selecionar os textos e embasar as traduções, senão através de um estudo prévio, em que o modelo funcionalista fosse compreendido em seu momento de produção? Desse modo, abandonei (momentaneamente) o projeto de tradução e enveredei-me pelo campo historiográfico dos estudos da tradução.

Assim, em meu Mestrado ${ }^{4}$, ocupei-me com o momento de emergência do funcionalismo. Concentrando-me em suas obras mais representativas, examinei, por um lado, o estado de coisas das teorias de tradução e da formação de tradutores e intérpretes na(s) Alemanha(s), o que incluiu a leitura e a análise de textos de predecessores teóricos diretos do funcionalismo e, por outro lado, acompanhei a evolução dos principais conceitos funcionalistas. O resultado dessa pesquisa, a dissertação de Mestrado intitulada "Estudos Funcionais da Tradução: rupturas e continuidades", desenvolvida também sob a orientação do Prof. Dr. João Azenha Junior, foi defendida em abril de 2014. Sem dúvidas, o estudo lançou luz sobre importantes aspectos do funcionalismo, principalmente sobre a relação com seus predecessores teóricos e sobre as próprias relações no interior da abordagem.

\footnotetext{
${ }^{3}$ A exemplo do que fizeram Wotjak (2006) e Cardozo et al. (2009) à Escola Tradutológica de Leipzig.

${ }^{4}$ Cf. MOREIRA, 2014. Acessível em:

http://www.teses.usp.br/teses/disponiveis/8/8144/tde-27062014-111155/pt-br.php
} 
Não obstante, ainda que eu possa considerar o trabalho concluído, ao menos no tocante aos objetivos a que se propôs, logo ficou bastante evidente que havia ainda muito do tema a explorar. Com o objetivo de aprofundar a pesquisa histórica do funcionalismo, submeti, durante o processo seletivo do Programa de Pós-Graduação em Estudos da Tradução, um anteprojeto de pesquisa em que manifestei o desejo de contemplar os percursos da vertente teórica em diferentes localidades, o que, no entanto, logo se revelou um trabalho deveras hercúleo - e, olhando em retrospecto, completamente fora do escopo de uma pesquisa de Doutorado.

De fato, embora a própria história do funcionalismo, mesmo em seu momento fundador, ainda seja pouco explorada, um trabalho que contemple, de modo mais aprofundado, a história da abordagem no âmbito dos estudos da tradução no Brasil é ainda sem precedentes. Assim, ao delimitar o escopo do trabalho, optei por lançar luz sobre essa história, também como forma de tornar os preceitos da teoria mais acessíveis ao pesquisador brasileiro.

É próprio de uma tese de Doutorado partir de uma hipótese - e é, de fato, o que faço aqui. No entanto, mais do que confirmar ou refutar uma hipótese, essa é uma pesquisa de caráter essencialmente exploratório: no atinente ao percurso do funcionalismo no Brasil, há todo um mundo a descobrir. Há nesta algo em comum com toda e qualquer jornada: há de se começar sempre de um ponto de partida.

\section{Pontos de partida}

Visto que esta é uma pesquisa com propósito de continuidade, naturalmente parto de esforços anteriores, mais exatamente, dos resultados de minha dissertação de Mestrado. Conforme já mencionado, dediquei-me a uma análise dos principais conceitos utilizados pelo funcionalismo - abordagem teórica dos estudos da tradução de expressão alemã que encontra em Hans J. Vermeer, conhecido professor da Universidade de Heidelberg, sua liderança intelectual - , com o propósito de identificar as rupturas e as continuidades ocasionadas por sua emergência em sua relação com o paradigma anterior, dominado pela abordagem linguística da tradução (a que Snell-Hornby referencia pela expressão em ale- 
mão Übersetzungswissenschaft ${ }^{5}$ ). Os conceitos funcionalistas, extraídos das obras de Reiss \& Vermeer (1984), de Holz-Mänttäri (1984) e de Nord (1988), foram ora contrapostos aos conceitos sobre os quais se ergueu a abordagem linguística da tradução, ora comparados entre si, a fim de verificar se houve alterações nos sentidos atribuídos a eles por seus adeptos ao longo de um período de dez anos (1978-1988). A seleção foi direcionada por quatro parâmetros, posteriormente utilizados para agrupá-los: escolhi conceitos que propusessem ou corroborassem uma definição do ato de traduzir, que circunscrevessem e definissem o objeto da tradução, que elucidassem possíveis procedimentos de traduzir e, enfim, que descrevessem a relação entre o texto de partida e o texto de chegada. Vale ressaltar que as ferramentas da linguística de corpus e os fundamentos da teoria da história eram-me, então, pouco ou nada familiares, de modo que a definição desses critérios foi necessária para assegurar a validade da seleção e a objetividade da pesquisa.

O trabalho foi orientado por duas hipóteses: (1) o funcionalismo, a despeito de se enfatizar constantemente o seu caráter de ruptura, teria sido também constituído de importantes continuidades; (2) nos primeiros dez anos de sua existência, o funcionalismo teria introduzido os principais preceitos de sua teoria geral, cabendo a estudos posteriores a aplicação desses preceitos em áreas específicas da tradução. Com o seu término, cheguei às seguintes conclusões: (1) apesar de romper com a abordagem linguística de tradução e de contribuir para a consolidação dos estudos da tradução, a vertente funcionalista confirmou uma tendência observável em seus predecessores: a inclusão do Outro no processo tradutório e a mudança no entendimento da relação entre texto de partida e texto de chegada através da mudança da própria noção de equivalência; (2) o fato de Nord (1988) fundamentarse no quadro teórico formulado por Vermeer (VERMEER, 1978; REISS; VERMEER, 1984) e por Holz-Mänttäri (HOLZ-MÄNTTÄRI, 1984) para a criação de seu modelo de análise textual demonstra a solidez dessas propostas enquanto teorias gerais de tradução ${ }^{6}$. Acresce-se o fato de Nord relacionar o conceito de "função", basilar à vertente teórica e normalmente referente a uma visão prospectiva da tradução, com o conceito de "lealdade", de modo a valorar, em oposição ao que fizeram Vermeer e Holz-Mänttäri, também o texto de partida e seu autor, o que indica que já não havia mais a necessidade de negar os fundamentos do paradigma anterior e que ela escreve de uma posição mais segura de uma vertente em vias de consolidação. Incluo ainda a observação de que, dada sua origem em

\footnotetext{
${ }^{5}$ SNELL-HORNBY, 1986, p. 10ss.

${ }^{6}$ Cf. MOREIRA, 2014, p. 234ss.
} 
institutos de formação profissional de tradutores e intérpretes, as obras seminais funcionalistas tendem a centrar o foco sobre três questões elementares do universo da mediação intercultural: a proposta de uma nova teoria de tradução, a definição de um perfil profissional do tradutor e o desenvolvimento de um modelo didático para a aplicação do quadro teórico na formação de tradutores.

Dos elementos de minha dissertação de Mestrado apresentados acima, são retomados aqui a contextualização do momento de emergência da abordagem funcionalista e alguns dos conceitos dos textos seminais analisados no trabalho. As obras seminais são retomadas, acrescidas de outras. Do ponto de vista conceitual, retomo, portanto, de onde parei com o Mestrado e incluo agora as reflexões feitas no âmbito do funcionalismo dentro do contexto dos estudos da tradução no Brasil. A presente pesquisa, contudo, não se limita à análise conceitual, mas inclui uma investigação do estado de coisas do campo disciplinar. De fato, é imprescindível a uma análise conceitual abordar também o contexto histórico a dar significado a esses conceitos. Nesse ínterim, busco também oferecer uma contribuição para o mapeamento dos estudos da tradução no Brasil, que nos auxilia a compreender melhor o desenvolvimento da disciplina em terras brasileiras.

Contudo, como o objeto de minha pesquisa é o funcionalismo, trago a seguir uma breve contextualização de seu momento de emergência.

\section{Uma nova orientação}

Em 1986, Mary Snell-Hornby publicou o tomo Übersetzungswissenschaft - eine Neuorientierung [Ciência da Tradução - uma nova orientação]. Outro título certamente não seria mais apropriado: o tomo consiste numa coletânea de contribuições de diversos teorizadores, alguns dos quais viriam a figurar dentre os nomes mais proeminentes dos atuais estudos da tradução de língua alemã. Em comum, essas contribuições sinalizaram novas perspectivas para a Ciência da Tradução [Übersetzungswissenschaft], área de pesquisa dedicada à tradução, constituída como subárea da Linguística Aplicada.

O volume foi introduzido por um ensaio de autoria de sua organizadora, de modo a contextualizar o estado de coisas da tradução. Nesse ensaio, Snell-Hornby retrata um quadro nada animador: no âmbito da prática profissional, o alto grau de especialização e de 
competência técnica exigidos do tradutor conviveriam, lado a lado, com a ignorância e o descaso do grande público pelo trabalho de tradutores e intérpretes; no âmbito institucional, a divisão, de um lado, entre tradução literária e outras formas de traduzir e, do outro lado, uma clara dissociação entre teoria e prática a refletir-se no ensino de tradução ${ }^{7}$.

Desde tempos imemoráveis, a atividade de tradução vê-se dividida em duas áreas, cada qual desfrutando de um status diferente: de um lado, uma forma "mundana" de tradução, hoje genericamente denominada "tradução técnica", desde sempre tida como uma forma "menor" de tradução; de outro lado, a "tradução literária", domínio de atuação de artistas e escritores notáveis, bem como de tradutores dos Textos Sagrados. Por sua vez, essa disparidade de valores na atividade prática refletiu-se também no plano teórico: por dois mil anos, a teoria de tradução dedicou-se quase exclusivamente às grandes obras da literatura ${ }^{8}$. Mudanças significativas nesse contexto vieram apenas com o advento do século $\mathrm{XX}$, em que a tradução técnica, enfim, tornou-se objeto de ponderação teórica. A divisão entre essas duas áreas, no entanto, persistia. Sobre isso, Snell-Hornby relata:

\begin{abstract}
Com o surgimento da moderna Ciência da Tradução ou "translation studies", uma nova disciplina constituiu-se dessa atividade milenar: com isso, no entanto, a separação não foi superada, mas antes intensificada. De um lado, com a Ciência da Tradução alemã, desenvolveu-se uma área que foi definida como uma subárea da Linguística Aplicada; a tradução literária foi excluída como forma especial de tradução, permanecendo essencialmente domínio da Teoria Literária. De outro lado, uma área desenvolveu-se sobretudo nos Países Baixos, a qual ficou conhecida como "translation studies" [Estudos da Tradução], definida como subárea da Literatura Comparada. Cada um dos lados fala muito pouco do outro: todos falam de tradução, mas não se referem ao mesmo objeto. ${ }^{9}$ (SNELLHORNBY, 1986, p. 11)
\end{abstract}

Nesse contexto, Snell-Hornby entende como imperativa a adoção de uma abordagem integrada (e integradora), de modo a não somente reunir a discussão numa única disciplina, mas também a conceder-lhe autonomia, libertando-a de sua posição subordinada a outros campos disciplinares ${ }^{10}$.

\footnotetext{
${ }^{7}$ SNELL-HORNBY, 1986, p. 10s.

${ }^{8}$ Id., 1988, p. 1.

${ }^{9}$ Mit der Entstehung der modernen Übersetzungswissenschaft bzw. "translation studies" ist nun aus der jahrtausendealten Tätigkeit eine neue Disziplin geworden: die Trennung ist damit keineswegs überwunden, sondern eher verschärft. Einerseits hat sich mit der deutschen Übersetzungswissenschaft ein Fach entwickelt, das als Teilbereich der Angewandten Linguistik definiert wurde; das literarische Übersetzen wird als Sonderform des Übersetzens ausgeklammert und bleibt grundsätzlich Domäne der Literaturwissenschaft. Andererseits hat sich v.a. in den Niederlanden ein Fach entwickelt, das als "translation studies" bekannt geworden ist und als Teilbereich der Vergleichenden Literaturwissenschaft definiert wurde. Von der jeweils anderen Seite wird allzu wenig Notiz genommen: alle sprechen vom Übersetzen, meinen aber nicht denselben Gegenstand.

[N. do A.: salvo menção em contrário, todas as traduções contidas nesse projeto são de nossa autoria.]

${ }^{10}$ SNELL-HORNBY, op. cit., p. 12.
} 
Nesse ponto, opto por abordar alguns elementos em especial da Ciência da Tradução, a começar pela noção de traduzir. Como descreve a autora, a Ciência da Tradução esteve em grande parte erigida sobre uma concepção de traduzir pautada na substituição de signos linguísticos de uma língua natural por signos correspondentes de outra língua. $\mathrm{O}$ grau ou nível de correspondência entre os signos, no entanto, era determinado por uma noção difusa de equivalência, conceito onipresente nas teorias de tradução à época. Embora a Ciência da Tradução tenha se servido do conceito para designar a relação entre unidades diferentes - seja no nível da palavra, da frase ou até mesmo do texto - em nenhum momento chegou-se a um consenso quanto a seu significado. Com efeito, Snell-Hornby observa que, além das diferentes formas de uso e significações atribuídas ao termo nas diversas línguas, mesmo num único ambiente linguístico o termo não deixa de ser controverso:

\footnotetext{
Um cotejamento cuidadoso da literatura do domínio da Ciência da Tradução revela que o al. Äquivalenz e o ing. equivalence são empregados de formas diferentes e que mesmo os usos do respectivo conceito no interior de uma língua divergem fortemente. Diante do reconhecimento de que a equivalência tradutória não pode ser uma dimensão absoluta, tiveram início alguns esforços, especialmente na Alemanha, para relativizar e delimitar o conceito, o que levou a um estado a que não cabe qualquer outra designação a não ser um "crescimento desenfreado dos tipos de equivalência": eu descobri na literatura até agora 58 tipos diferentes de equivalência ${ }^{11}$. (SNELL-HORNBY, 1986, p. 15)
}

Em meu Mestrado, com base em definições de tradução de diversas propostas teóricas publicadas no âmbito da Ciência da Tradução, constatei que, além de diferentes, as noções de equivalência implicadas nessas teorias, quando analisadas cronologicamente, pareciam referir-se gradativamente menos a um processo de tradução que se encerra em si mesmo e mais um processo que propõe uma interação com o receptor: de início restritas à reprodução de um "mesmo" conteúdo noutra língua, as noções de equivalência passam a descrever relações mais complexas entre o texto de partida e o texto de chegada, fazendo inclusive referência a outros níveis textuais. A equivalência deixa de incidir, assim, apenas sobre o conteúdo textual e passa a incluir, por exemplo, elementos do estilo do texto e de sua função comunicativa. A ressignificação do conceito, a meu ver, é reflexo de novas ori-

\footnotetext{
${ }^{11} \mathrm{Da}$ dt. Äquivalenz und engl. equivalence unterschiedlich verwendet werden, daß selbst die Verwendungen des jeweiligen Begriffes innerhalb der einen Sprache stark divergieren, zeigt ein sorgfältiger Vergleich der übersetzungswissenschaftlichen Literatur. Mit der Erkenntnis, daß die Übersetzungsäquivalenz keine absolute Größe sein kann, entstanden nämlich besonders in Deutschland Bestrebungen, den Begriff zu relativieren und aufzugliedern, was zu einem Zustand geführt hat, den man nur als "Wildwuchs von Äquivalenztypen" bezeichnen kann: ich habe in der Literatur bis jetzt 58 verschiedene Äquivalenztypen entdeckt.
} 
entações à época no campo da linguística como um todo e, em especial, no próprio campo das teorias de tradução ${ }^{12}$.

No que concerne especificamente ao domínio das teorias de tradução, está bastante claro que essa "nova orientação" de que o funcionalismo faz parte, referida continuamente na história da tradução pelo termo "virada cultural", veio em reação à ideia de tradução defendida pela abordagem linguística. Emersas no final da década de 1970, as novas abordagens passaram a enfatizar o contexto cultural da tradução. A própria noção de tradução é construída com referência às práticas de tradução na cultura de chegada, enquanto o difuso princípio de equivalência deixa gradativamente de ser o critério para definir uma boa tradução.

Com o funcionalismo, abandona-se a busca de parâmetros para a ação tradutória no texto de partida e passa-se a buscá-los, de modo prospectivo, na função a ser desempenhada pelo texto traduzido entre seus receptores na cultura de chegada. Assim, em vez de mera substituição linguística, a tradução passa a ser definida como "transferência cultural"13. Além disso, a atividade tradutória é vista em contexto de sua função social, ou seja, como uma atividade profissional exercida por um especialista, como é próprio de uma sociedade organizada pela divisão do trabalho. Ao adotar essa perspectiva, a abordagem funcional aproxima teoria e prática da tradução - mais uma clara reação à "antiga orientação". De acordo com Snell-Hornby:

Assim, busca-se aqui uma concepção integrada, em que também se abole uma segunda e fatal dicotomia: a já mencionada separação de teoria e prática. A crítica tem realmente razão em afirmar que a Ciência da Tradução orientada linguisticamente "comprou" seu reconhecimento ao preço de uma distância dificilmente transponível entre ela e os tradutores (...) $)^{14}$. (SNELL-HORNBY, 1986, p. 12)

É evidente que a segregação entre teoria e prática traria consequências ao ensino: uma vez que a teoria não contempla a prática, ela pouco tem a contribuir para o aprendizado de uma atividade profissional. Não à toa, muito se argumentou contra a inclusão de aportes teóricos na formação de tradutores, com a alegação de que a tradução em si não é um domínio científico; outros defendiam ser desnecessária a inclusão de discussões de teor

\footnotetext{
${ }^{12}$ MOREIRA, 2014, p. 115s.

${ }^{13}$ SNELL-HORNBY, 1986, p. 13.

${ }^{14}$ Es wird hier also eine integrierte Konzeption angestrebt, in der auch eine zweite, fatale Dichotomie aufgehoben wird: das schon erwähnte Auseinanderklaffen von Theorie und Praxis. Die Kritik ist nämlich berechtigt, daß die linguistisch orientierte Übersetzungswissenschaft ihre Anerkennung mit einer nur schwer überbrückbaren Distanz zu den Übersetzern "erkauft" hat (...).
} 
teórico na prática e na didática da tradução por ser também possível fazer boas traduções sem um amparo teórico ${ }^{15}$.

Contudo, se a formação de tradutores e intérpretes não favorecia o contato com a teoria, tampouco fazia referência à atividade prática. Os métodos de avaliação estavam menos voltados a avaliar a competência tradutória e mais a competência linguística dos estudantes, devendo esses produzir traduções "com o mínimo possível de erros", a fím de se obter "uma reprodução mais fiel possível do original"16. Para os tradutores profissionais, era grave o fato de ainda se praticar a tradução dessa forma nos institutos de formação muitas vezes, como se fosse a única forma de tradução possível. Essa visão de tradução, conforme afirma Snell-Hornby, é própria de uma tradição milenar de tradução literária, bem como de uma tradição filológica:

\footnotetext{
Mas o que se perde de vista é justamente aquilo que concede ao tradutor profissional outra perspectiva: um texto é, para o filólogo, objeto de sua pesquisa; para o tradutor (e para o cientista da tradução), no entanto, ele é "um meio para um novo texto" (Vermeer, comunicação oral) ${ }^{17}$. (SNELL-HORNBY, 1986, p. 25)
}

Considera-se como marco inaugural do Funcionalismo a publicação, em 1978, do artigo "Ein Rahmen für eine allgemeine Translationstheorie" [Um quadro para uma teoria geral de translação]. Nesse artigo, Vermeer articula sua proposta de teoria geral, formulada um ano antes, durante um curso ministrado por ele na unidade de Germersheim da Universidade de Mainz, Alemanha. Assim, no contexto da formação de tradutores e intérpretes, nascia a teoria funcionalista. Seus desenvolvimentos posteriores fizeram jus à vocação teórica, prática e didática da vertente, com as publicações de Hönig \& Kussmaul (1982), de Holz-Mänttäri (1984), de Nord (1988) e de Snell-Hornby (1988). O livro Grundlegung einer allgemeinen Translationstheorie [Fundamentos de uma teoria geral de translação], fruto da parceria entre Vermeer e Katharina Reiss, é considerado hoje o "manifesto funcionalista" 18 .

Durante sua primeira década, o funcionalismo estabeleceu parte considerável das bases teóricas a serem replicadas ainda hoje. No entanto, como explica Nord (2012a), a produção teórica nesse período esteve restrita à língua alemã: até o final da década de

\footnotetext{
${ }^{15}$ SNELL-HORNBY, 1986, p. 11.

${ }^{16}$ Ibid., p. 25.

${ }^{17}$ Was aber übersehen wird, ist eben dies, daß sich für den Berufsübersetzer eine andere Perspektive ergibt: ein Text ist für den Philologen Gegenstand seiner Forschung, für den Übersetzer (und für den Übersetzungswissenschaftler) jedoch "Mittel zum neuen Text" (Vermeer, mündliche Mitteilung).

${ }^{18}$ SNELL-HORNBY, 2006, p. 52.
} 
1980, havia apenas duas publicações de Hans Vermeer em inglês (1987, 1989), uma em português (1986) e uma tradução parcial da obra de Reiss e Vermeer para o finlandês $(1986)^{19}$. Assim, restrita a uma língua pouco difundida, se comparada, por exemplo, ao inglês e ao espanhol, e formulada num estilo textual bastante hermético e academicista, a abordagem teórica enfrentou dificuldades em conquistar novos territórios (cf. MOREIRA, 2014, p. 17). Esse certamente foi um fator prejudicial para seu ingresso no Brasil, impondo entraves à sua disseminação entre nós mesmo nos dias de hoje.

Ademais, o funcionalismo enfrenta também a desconfiança de algumas correntes dos estudos da tradução. À guisa de exemplo, Anthony Pym (2017) ressalta a compatibilidade entre a vertente funcionalista e as vertentes linguísticas que a precederam, especulando que os motivos por trás da emergência do funcionalismo seriam, na verdade, de natureza política:

\begin{abstract}
Teorias da equivalência podem ser formuladas em termos linguísticos, e os tradutores podem ser treinados para lidar com faculdades da linguagem e com a linguística. Mas as versões mais radicais do funcionalismo voltado para o texto de chegada forneceram, na verdade, justificativa para a criação de uma nova disciplina acadêmica. A tarefa de treinamento de tradutores pôde então ser retirada das garras de departamentos mais tradicionais, voltados para o estudo da linguagem. A teoria da tradução tornou-se, assim, a cena de um debate sobre disputas de poder na academia. De um lado, a equivalência; de outro, o funcionalismo, opostos entre si, mesmo quando se mostravam compatíveis. ${ }^{20}$ (PYM, 2017, p. 106, tradução de Rodrigo Borges de Faveri, Claudia Borges de Faveri e Juliana Steil, grifo no original)
\end{abstract}

Abordar essa história em profundidade, como mencionei anteriormente, é um dos objetivos deste trabalho. Todavia, para introduzir a discussão e levantar algumas hipóteses acerca do ingresso e dos desdobramentos da vertente teórica no âmbito de nossos estudos da tradução, mencionarei dois marcos dessa história, a serem tratados de forma pormenorizada posteriormente nesse trabalho: a visita de Katharina Reiss a Brasília, em 1980, e de Hans Vermeer a São Paulo, dez anos depois.

\footnotetext{
${ }^{19}$ NORD, 2012a, p. 28.

${ }^{20}$ Theories of equivalence could be formulated in linguistic terms, and translators could thus be trained in faculties of language and linguistics. The more radical versions of target-side functionalism, on the other hand, justified the creation of a new academic discipline. They could remove translator training from the clutches of the more traditional language departments. Translation theory thus surreptitiously became a debate about academic power. Equivalence was on one side, "functionalism" on the other; and they were opposed, even when, as theories, they were basically compatible. (PYM, 2010, p. 49)
} 


\section{Dois marcos, algumas hipóteses}

Os casos aqui mencionados fazem parte, segundo meu levantamento, dos registros mais antigos de autores funcionalistas no Brasil. Em agosto e setembro de 1980, Katharina Reiss esteve em diversas cidades do país. Todavia, temos registro apenas de suas atividades no âmbito da Universidade de Brasília, graças aos esforços de Delton de Mattos, docente da instituição, que organizou a antologia Estudos de Tradutologia 1, na qual foram incluídos os resumos de duas conferências ministradas pela autora em ocasião de sua visi$\operatorname{ta}^{21}$.

É importante destacar que, à época, Reiss já havia publicado seus escritos mais notórios: os livros Möglichkeiten und Grenzen der Übersetzungskritik [Possibilidades e limites da crítica de tradução], publicado em 1971, e Texttyp und Übersetzungsmethode: Der operative Text [Tipo textual e método de tradução: o texto operativo], publicado em 1976. Dentre os tópicos tratados nessas obras, ela retoma nas conferências a distinção entre diferentes tipos textuais e formas de traduzir, segundo a finalidade da tradução e o destinatário do texto traduzido.

Observando os fatos, é possível esboçar algumas explicações: um ano antes, havia sido implementado na Universidade de Brasília o Bacharelado em Letras-Tradução, uma iniciativa, segundo relatam Germana Henriques Pereira e Mark David Ridd (2013), de Delton de Mattos e Ulf Gregor Baranov ${ }^{22}$. Logo, as conferências proferidas por Katharina Reiss poderiam ter feito parte das atividades promovidas por Mattos para consolidar o curso na UnB. Ele, que, assim como Reiss, já esteve vinculado à Universidade de Heidelberg, na Alemanha, contribuiu para a recepção da produção intelectual da autora ao incluí-la na antologia, registrando, assim, a passagem da docente pelo Brasil.

Salientei anteriormente nesta Introdução a atuação de Vermeer como membro fundador da vertente teórica, considerado tanto o autor do texto inaugural funcionalista quanto (co-)autor de seu manifesto. Além da posição de liderança ocupada por ele na formulação teórica, ele também desempenhou, em diversas ocasiões, o papel de divulgador do Funcionalismo. Como exemplo de sua atuação como divulgador, cito a sua presença no IV Encontro Nacional de Tradutores em 1990. Suas atividades no evento incluem uma conferên-

\footnotetext{
${ }^{21}$ MATTOS, 1981, p. 7.

${ }^{22}$ PEREIRA; RIDD, 2013, p. 71.
} 
cia plenária, a participação em mesas-redondas e num painel dedicado aos estudos da tradução. Na ocasião, ele apresenta algumas de suas proposições teóricas, pontuando sempre o afastamento das noções de tradução defendidas pelas abordagens tradicionais.

Nesses que são provavelmente os primeiros movimentos da incursão do funcionalismo no Brasil, temos, num primeiro momento, Delton de Mattos atuando como agente disseminador de reflexões alemãs acerca da tradução, abrindo as portas (para manter-me na metáfora) dos estudos da tradução no Brasil a elas; num segundo momento, vemos Hans J. Vermeer exercendo posição de liderança no Funcionalismo, não apenas no que concerne ao estabelecimento do programa básico da vertente teórica, mas também em sua divulgação. Podemos supor, assim, que o funcionalismo adentrou território brasileiro por duas vias: pela ação de agentes de disseminação teórica e pela ação de lideranças intelectuais, através de visitas e publicações, como promotores da vertente teórica no Brasil.

Assim, minha primeira hipótese é a de que, sobretudo no início da disseminação do funcionalismo no Brasil, a ação das lideranças tenha sido mais incisiva na conquista de adeptos. Após essa etapa, a divulgação da teoria teria ficado a cargo desses novos adeptos, seja via publicação de trabalhos fundamentados pelo viés funcionalista, seja via orientação de pesquisas amparadas teoricamente pelo funcionalismo. A tradução de textos seminais para a língua portuguesa seria, a nosso ver, um procedimento tardio de divulgação, que estaria ainda em curso.

Uma segunda hipótese de trabalho diz respeito ao plano conceitual da teoria. Mencionei acima, ainda que muito brevemente, a constatação a que cheguei com a conclusão de minha pesquisa de Mestrado: Nord teria enfatizado o compromisso de lealdade por parte do tradutor aos demais participantes do processo de tradução como forma de amenizar o radicalismo de seus antecessores (em especial, de Holz-Mänttäri), o que indicaria que ela escreve num momento em que a abordagem estaria, se não já consolidada, ao menos em vias de consolidação ${ }^{23}$. Dada a importância de seu trabalho às pesquisas de tradução no Brasil (provavelmente comparável, talvez superior à importância atribuída aos escritos de Vermeer), a própria reinterpretação que ela faz do critério de função teria se refletido nos trabalhos que se utilizam do Funcionalismo como fundamento teórico. Da mesma forma, creio que veremos, ainda que não de forma acentuada, outras reformulações da base conceitual da abordagem teórica, sobretudo em função dos resultados da aplicação da teoria na resolução de problemas específicos da tradução.

\footnotetext{
${ }^{23}$ Cf. MOREIRA, 2014, p. 238.
} 


\section{Da importância do presente trabalho}

Em face do contexto acima descrito e das hipóteses levantadas, essa tese de Doutorado tem por objetivo examinar os desdobramentos do funcionalismo no Brasil, a fim de investigar a integração do funcionalismo alemão a nossos estudos da tradução, tendo em vista o contexto em torno da disciplina. Quando, no entanto, penso nas contribuições do presente trabalho, percebo que elas vão além da mera reconstituição da história do funcionalismo no país. Assim, listo a seguir outras contribuições, que, neste ponto do trabalho, ainda representam objetivos secundários a serem perseguidos. Esses seriam:

1. propor uma metodologia, respaldada por um arcabouço teórico interdisciplinar, para a análise historiográfica dos estudos da tradução, tendo em conta a escassez de metodologias dedicadas a esse fim;

2. contribuir para o mapeamento dos estudos da tradução no Brasil e, de forma especial, para o mapeamento do funcionalismo no país, um tópico ainda muito pouco explorado entre nós;

3. fomentar a divulgação de conceitos centrais do funcionalismo em língua portuguesa, inclusive de materiais para os quais há poucas ou nenhuma tradução para o português ou para línguas estrangeiras de mais circulação, como o inglês e o espanhol;

4. demonstrar que a produção intelectual não ocorre no vácuo, desvinculada de um contexto cultural, intelectual e institucional, mas, sim, que representa um contínuo do mundo;

5. desvelar a conexão do funcionalismo com diferentes vertentes, de dentro e de fora dos estudos da tradução, evidenciando assim a multidisciplinaridade inerente não apenas à abordagem teórica, mas à própria disciplina.

Os objetivos acima serão retomados no capítulo de conclusão, de modo a avaliarmos como eles de fato se concretizaram. 


\section{Estrutura da tese}

A tese consiste na presente Introdução, em três capítulos de desenvolvimento e numa Conclusão. Tendo em vista que um dos objetivos de trabalho é a sistematização e o embasamento de uma metodologia voltada a investigar a história dos estudos da tradução, o capítulo Fundamentação teórica e método é dedicado a descrever a metodologia, trazendo os fundamentos teóricos a respaldar procedimentos e análise. Conduzo essa investigação sobre uma base interdisciplinar, isto é, embora faça uso do quadro teórico da história da ciência, acrescento contribuições advindas da teoria da história, da sociobiologia e da sociologia da ciência. No tocante aos procedimentos em si, agrego também contribuições de outras disciplinas: do âmbito da Linguística advêm os recursos metodológicos da linguística de corpus, enquanto dos domínios da ciência da informação extraio as técnicas e ferramentas de mapeamento científico. Reconhecemos, assim, que nosso arcabouço teórico e nossa base metodológica foram extraídos de fontes em diferentes campos disciplinares e, por isso, podem parecer desconexas em nosso trabalho, mas garantimos que cada proposta teórica e cada procedimento agrega, de modo harmônico, em nossa pesquisa, trazendo resultados bastante relevantes a que, de outro modo, não poderíamos chegar.

A metodologia, já apresentada conceitualmente no capítulo primeiro, é exemplificada nos dois capítulos seguintes, a começar pela análise contextual, no capítulo Funcionalistas entre nós. Inicio com um breve histórico do desenvolvimento dos estudos da tradução no Brasil, de modo a caracterizar o momento em que iniciou a recepção do funcionalismo no país. Em seguida, relato, de modo sucinto, a atuação dos teorizadores funcionalistas no Brasil, seja através da participação em eventos, de palestras ou de artigos publicados em periódicos de circulação nacional. Depois, faço uma descrição do estado de coisas nos estudos da tradução no Brasil, feita a partir dos dados levantados pelo mapeamento do campo disciplinar, validados através dos relatos historiográficos. Desse modo, é também possível averiguar, em primeiro lugar, quais foram os espaços ocupados pelo funcionalismo na disciplina e, em segundo lugar, quais fatores favoreceram ou dificultaram a circulação da teoria no Brasil.

A segunda parte da análise, de cunho conceitual, é feita no capítulo Os conceitos funcionalistas de tradução. Essa parte da pesquisa beneficia-se da primeira, sobretudo na seleção do corpus. Em seguida, identifico os conceitos centrais defendidos pelos textos 
seminais do funcionalismo e examino como cada um deles é definido em cada obra seminal. Depois, verifico como esses mesmos conceitos são definidos e empregados pelos pesquisadores no Brasil, não apenas para pesar diferenças e semelhanças, mas, em última instância, para identificar quais conceitos foram eleitos como relevantes às diversas pesquisas.

Nas Conclusões, ganha expressão propriamente a nossa contribuição à história do funcionalismo nos estudos da tradução do Brasil na forma de narrativa histórica. Assim, relacionamos os resultados de ambas as análises, de modo a tecer algumas considerações acerca do percurso da abordagem teórica no país. 


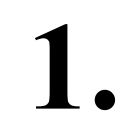

Fundamentação teórica e método 
Em tempos recentes, como reiteram diversos teóricos empenhados no tema ${ }^{24}$, a pesquisa de cunho histórico mostrou-se deveras frutífera no âmbito dos estudos da tradução. Desde seus primórdios, na década de 1960, os estudos que visam a desvendar o passado de traduções, tradutores e da própria reflexão sobre o traduzir vêm galgando espaço nas universidades, um crescimento que se vê refletido na diversidade de artigos, livros, periódicos, bibliografias e eventos dedicados ao assunto ${ }^{25}$, mas também na diversidade de enfoques de pesquisa: atualmente, aborda-se a história da práxis tradutória a partir de questões referentes ao gênero e à sexualidade do tradutor, aos contextos pós-coloniais e à relação entre história e cultura ${ }^{26}$. Em decorrência desse crescimento foram também idealizadas metodologias de pesquisa, embora sejam ainda raras as tentativas de se conceber um método histórico para a tradução ${ }^{27}$.

Todavia, esse crescimento não é igualmente expressivo no campo de investigações históricas em torno das teorias de tradução. A esse respeito, Tahir-Gürçağlar (2013) descreve uma inversão na proporção entre as pesquisas dedicadas aos dois temas ao longo da segunda metade do século XX: outrora, o foco da história da tradução esteve nas reflexões teóricas sobre o traduzir; a partir dos anos de 1980, porém, esse foi deslocado para a prática de tradução, impulsionado principalmente pela emergência dos estudos descritivos da tradução (vulgo EDT) ${ }^{28}$. Essa mudança de foco traz suas consequências para o já incipiente desenvolvimento de metodologias de pesquisa. Judith Woodsworth, docente da Concordia University de Montreal, Canadá, e um dos maiores expoentes da pesquisa histórica nos domínios dos estudos da tradução, reconhece esse problema e sugere, como forma de mitigar essa falta de modelos teóricos e metodológicos, o empréstimo de outras disciplinas ${ }^{29}$.

Seguindo essa recomendação, recorremos à história e a disciplinas adjacentes em busca de anteparo teórico e metodológico, a fim de alcançar nosso objetivo cardinal de pesquisa, o de esboçar uma história da incursão do Funcionalismo no âmbito dos estudos da tradução no Brasil, com destaque para os desdobramentos teóricos da abordagem e para as circunstâncias para a sua adoção em território brasileiro.

Em sua Teoria da História, José D'Assunção Barros, professor adjunto da Universidade Federal Rural do Rio de Janeiro (UFRRJ), define "teoria" como um "modo de pen-

\footnotetext{
${ }^{24}$ Dentre os quais, mencionamos Woodsworth (1998), Bandia \& Bastin (2006), St André (2009) e Tahir-Gürçağlar (2013).

${ }^{25}$ BANDIA; BASTIN, op. cit., p. 1.

${ }^{26}$ ST ANDRÉ, op. cit., p. 133.

${ }^{27}$ TAHIR-GÜRÇAĞLAR, 2013, p. 137s.

${ }^{28}$ Ibid., p. 135 s.

${ }^{29}$ WOODSWORTH, op. cit., p. 101.
} 
sar (ou ver)" o mundo, enquanto a metodologia seria referente a um "modo de fazer" alguma coisa ${ }^{30}$. A seu ver, ambas, no meio científico, são indissociáveis:

\begin{abstract}
Vemos, portanto, que Teoria e Metodologia são como que duas irmãs siamesas. Uma olha para o alto, buscando enxergar algo de novo no céu estrelado de todas as realidades possíveis e imaginárias. A outra, decididamente prática, aponta para o chão, em busca de soluções concretas para viabilizar ou rejeitar as hipóteses aventadas pela irmã. Teoria e Metodologia, separadas uma da outra, não têm muito sentido para a Ciência. A "teoria pura" facilmente poderia se converter em especulação. A "metodologia pura", a rigor, nem surge como possibilidade, e quando muito se converte em alguma forma de exercício aprendido mecanicamente em alguma fase inicial de treinamento artesanal ou científico. Nas Ciências Humanas, que sempre almejam produzir como resultado uma reflexão fundamentada sobre a realidade social, a Teoria e a Metodologia são gêmeas mais siamesas do que nunca. [...] (BARROS, 2014, p. 76s.)
\end{abstract}

Veremos a distinção entre os conceitos de teoria e método de forma mais pormenorizada posteriormente nesse capítulo. Aqui, basta dizer que, inspirados por essa perspectiva, optamos por integrar fundamentos teóricos e método num único capítulo. Com o propósito de oferecer uma metodologia útil para investigar a história dos estudos da tradução, respaldada por um modelo teórico que auxilie a interpretação dos resultados, dedicamos o presente capítulo a expor procedimentos metodológicos advindos da linguística de corpus e da ciência da informação e fundamentos teóricos originados da história, da história da ciência e da sociobiologia.

Iniciaremos nossa exposição com alguns princípios extraídos do âmbito da história e da história da ciência, em busca de similaridades e de uma postura metodológica. Em seguida, introduziremos os fundamentos teóricos e o método para uma análise contextual dos estudos da tradução. Por fim, apresentaremos os fundamentos teóricos e o método para uma análise conceitual.

\title{
1.1. História geral e a história da ciência
}

A relação entre ciência e história data de tempos remotos, tendo a história servido à ciência para os mais diversos fins: ora para validar novas teorias, ora para demonstrar a superioridade de uma nova proposta teórica sobre uma teoria anterior, ora como fonte de

\footnotetext{
${ }^{30}$ BARROS, 2014, p. 67.
} 
inspiração para a resolução de problemas ${ }^{31}$. Entretanto, só a partir do século XX começaram os primeiros movimentos rumo a uma institucionalização da história da ciência ${ }^{32}$.

A despeito dessa longa interação, o diálogo entre a história da ciência e a história "geral" foi raro. Até a década de 1960, o foco da história da ciência era de natureza epistemológica. Por conseguinte, pouco se discutiu acerca da relação entre a produção de conhecimento e os contextos político, econômico e social que circundaram essa produção. As primeiras interações entre as duas disciplinas vieram com o advento de uma abordagem sociológica da história da ciência ${ }^{33}$. Ainda assim, Roberto Martins (2001) observa que a abordagem sociológica não foi capaz de diminuir a distância que separam história e história da ciência, de modo que ambas tiveram desenvolvimentos de modo independente uma da outra ${ }^{34}$.

Mesmo ante a segregação entre os dois campos de estudo, é ainda possível detectar alguns pontos de aproximação, sobretudo no que tange à sua metodologia. No âmbito da Teoria da História, Jörn Rüsen (2010) identifica no método histórico um aspecto concernente à abordagem da experiência do tempo na pesquisa histórica, aspecto que ele denomina operacional-substantivo - ou simplesmente operações substanciais. Na definição metodológica de Rüsen, as operações substanciais determinariam o conteúdo material de pesquisa. Elas estariam vinculadas à necessidade do método histórico de contemplar toda a constelação de experiências temporais que interferem na construção da identidade históri$\mathrm{ca}^{35}$.

Para Rüsen, a experiência temporal é composta por três dimensões: a dimensão do tempo do homem, a dimensão do tempo da natureza e a dimensão do tempo histórico. Assim, a seu ver, o tempo humano é experimentado "sempre que as mudanças do homem e de seu mundo podem ser tornadas inteligíveis por meio de intenções, com as quais essas mudanças são produzidas" (RÜSEN, 2010, p. 115, tradução de Asta-Rose Alcaide). Trata-se, portanto, de uma percepção do tempo imbuída de significado mediante as intenções daqueles que agem para que as mudanças ocorram. Em oposição à experiência do tempo humano, a do tempo natural ocorre "sempre que as mudanças temporais do homem e de seu mundo dependem de circunstâncias e condições externas ao agir humano, não explicáveis como decorrências de intenções" (p. 115). Da justaposição entre as duas experiências tem-

\footnotetext{
${ }^{31}$ KRAGH, 2003, p. 1 ss.

${ }^{32}$ R. MARTINS, 2001, p. 22.

${ }^{33}$ Ibid., p. 27.

${ }^{34}$ Cf. R. MARTINS, op. cit., p. 41.

${ }^{35}$ RÜSEN, 2010, p. 114s.
} 
porais surge uma terceira, a percepção do tempo histórico, quando "os fatores condicionantes internos e externos do comportamento da evolução do homem e de seu mundo são integrados num conjunto de processos que permita a orientação, com sentido, das ações humanas" (p. 115s.).

De modo a contemplar cada uma das três dimensões da experiência temporal, Rüsen encontra seus correspondentes no método de pesquisa histórica, a qual, conforme sua concepção de pesquisa histórica, seria regulada, operacional e substantivamente, de três formas:

1. Hermenêutica: referente à experiência do tempo humano, a pesquisa hermenêutica "reconstrói processos temporais do passado de acordo com perspectivas de sentido coerentes com as intenções dos atores (agentes ou pacientes) desses processos" (p. 116). Desse modo, busca-se extrair das fontes a factualidade que subjaz às ações dos homens do passado. Por conseguinte, o objeto da pesquisa hermenêutica são experiências, a partir da perspectiva e do julgamento de valor de quem as vivenciou.

2. Analitica: referente à experiência do tempo natural, a pesquisa analítica "reconstrói processos temporais do passado de acordo com as perspectivas dos contextos de casualidade, que decorrem das condições estruturais sob as quais os sujeitos ao agir e sofrer (co-)produzem tais processos" (p. 116). Aqui, o tempo age como instância limitadora das possibilidades de ação do homem. Desse modo, em vez de exprimir as intenções por trás do agir, as fontes apontam para fatores contextuais que de uma forma ou de outra influenciaram essas ações.

3. Dialética: referente à perspectiva do tempo histórico, a pesquisa dialética concilia as perspectivas de reconstrução hermenêutica e analítica dos processos temporais e organiza-as em conjuntos complexos, "nos quais a direção dos processos históricos resulta de uma relação de mútua influência entre intenções e condições estruturais do agir humano" (p. 116s.). Consequentemente, entra em confluência uma multiplicidade de abordagens metodológicas das fontes, ao mesmo tempo em que é compensada a parcialidade dos dois outros métodos. 
Por sua vez, no âmbito da História das Ciências, Lilian Martins (2005) apresentanos duas abordagens de pesquisa possíveis: (1) "[u]ma abordagem conceitual (interna, internalista)," que "discute os fatores científicos (evidências, fatos de natureza científica) relacionados a determinado assunto ou problema" e; (2) "[u]ma abordagem não-conceitual (externa, externalista)," que "lida com os fatores extracientíficos (influências sociais, políticas, econômicas, luta pelo poder, propaganda, fatores psicológicos)" (MARTINS, 2005, p. 306). Um estudo completo envolveria, dessa maneira, os dois tipos de abordagem, posto que uma não pode estar dissociada da outra; ainda assim, ela vê benefícios metodológicos em distingui-las ${ }^{36}$.

Nota-se, portanto, que embora difiram quanto ao objeto de pesquisa, as duas abordagens metodológicas preveem tanto a extração e interpretação de informações factuais (internas) quanto de informações contextuais (externas) da história que se pretende contar. Ademais, ambas as abordagens enfatizam a necessidade de integrar as duas perspectivas, interna e externa, a fim de se obter, de fato, as bases necessárias para a posterior narrativa histórica.

Quanto ao nível conceitual, apesar de, segundo Roberto Martins (2001), haver maiores dificuldades de relacionar as duas disciplinas, ele não descarta a possibilidade, contanto que essa aproximação não seja feita de forma forçada ${ }^{37}$. O presente trabalho fundamenta-se sobre o quadro teórico da história da ciência. Entretanto, quando oportuno, fazemos também uso de conceitos e modelos do campo da historiografia "geral", uma vez que vemos como bastante frutíferas as contribuições desse campo.

A fim de integrar as duas perspectivas históricas mediante a abordagem dialética, organizaremos a seguir as contribuições teóricas e metodológicas, agrupando-as conforme o enfoque de pesquisa - ora internalista, ora externalista. Assim, para o primeiro, adotamos conceitos advindos da História dos Conceitos, especialmente como formulados por Reinhart Koselleck (2006a), e da sociobiologia de Richard Dawkins (2007). Para o segundo, incluiremos as contribuições da sociologia da ciência, especialmente a proposta de Pierre Bourdieu (2004, 2015).

Quanto ao âmbito metodológico, distinguimos procedimentos próprios a ambos os tipos de investigação a conduzir: a análise de corpora é, assim, empregada na abordagem internalista da história do Funcionalismo, servindo tanto à seleção como à análise dos con-

\footnotetext{
${ }^{36}$ L. MARTINS, 2005, p. 306

${ }^{37}$ R. MARTINS, 2001, p. 40.
} 
ceitos basilares da teoria; o mapeamento científico, por sua vez, encontra uso no contexto de uma abordagem externalista de pesquisa, visando a caracterizar o contexto intelectual e institucional dos estudos da tradução no Brasil entre 1990 e 2005. Ainda que destinados a abordagens diferentes de pesquisa, pode haver pontos de contatos entre os procedimentos como, no caso, de fato ocorre.

A exposição de nossos fundamentos teóricos, no entanto, nós a principiaremos com a exposição de conceitos basilares não apenas para o âmbito científico, mas também para o âmbito historiográfico como um todo. Esses não serão os únicos conceitos a serem definidos no presente trabalho; todavia, segundo nosso entendimento, são conceitos essenciais para introduzir a discussão.

\subsection{Conceitos fundamentais}

A História, primeiro domínio de qualquer estudo historiográfico, não se permite definir tão somente como o estudo do passado. Defini-la dessa forma seria admitir que há divisões distintas entre as temporalidades, ainda que o objeto da História seja os eventos de outrora contemplados em seu contexto histórico, o historiador o faz a partir de seu tempo, de cujas lentes não pode de todo se despir. Nesse sentido, Arruda (2014) afirma que, ao se fazer história, se por um lado se resignificam os eventos passados do ponto presente, por outro, a herança do passado projeta-se sobre o presente na forma de mimese ${ }^{38}$. Passado e presente estão, assim, em constante inter-relação:

O evento passado é, portanto, plenamente reorganizado e assimilado pelo presente, exprimindo, nesse passo, a busca de unificação do presente pelo evento pretérito, reduzindo o passado às suas expressões mínimas, apreensíveis e validadas pelo presente. Reversamente, as reconstruções memorialísticas do passado revelam o tecido esgarçado da sociedade que comemora, porque comporta discursos e contradiscursos, construções e desconstruções, que apontam para a dimensão fugaz do presente histórico e a validade das comemorações como espaços criativos de reflexão histórica que enlaçam, vigorosamente, a tríplice temporalidade numa unidade de sentido. É exatamente essa pletora de possibilidades que permite a imensa variedade de apropriações indentitárias [sic!] do passado." (ARRUDA, 2014, p. 33s.)

\footnotetext{
${ }^{38}$ ARRUDA, 2014, p. 32.
} 
Não obstante, não apenas o presente e o passado são postos em relação na História, mas também o futuro. Isso ocorre, pois a dialógica transtemporal não pode ser segmentada, isto é, não há descontinuidade entre passado, presente e futuro: assim como o passado anuncia o presente, o presente anuncia o futuro, o que possibilitaria a inclusão desse último num possível organom da interpretação histórica ${ }^{39}$.

Essa visão de temporalidade histórica remonta ao historiador alemão Reinhart Koselleck (2006b), segundo o qual, além das categorias de que o historiador lança mão para descrever realidades históricas, haveria duas em especial, no próprio cerne da interpretação da história, destinadas não a remeter às possibilidades da história, não à história em si: trata-se do "espaço de experiência" e do "horizonte de expectativa". Experiências e expectativas seriam, na sua opinião, categorias constituintes de toda a história ${ }^{40}$.

O conceito de "experiência" pode ser compreendido como

(...) o passado atual, aquele no qual acontecimentos foram incorporados e podem ser lembrados. Na experiência se fundem tanto a elaboração racional quanto as formas inconscientes de comportamento, que não estão mais, ou que não precisam mais estar presentes no conhecimento. Além disso, na experiência de cada um, transmitida por gerações e instituições, sempre está contida e é conservada uma experiência alheia. (KOSELLECK, 2006b, p. 309s., tradução de Wilma Patrícia Maas e Carlos Almeida Pereira)

Entre esse e o conceito de "expectativa" haveria algumas similaridades:

também ela é ao mesmo tempo ligada à pessoa e ao interpessoal, também a expectativa se realiza no hoje, é futuro presente, voltado para o ainda-não, para o não experimentado, para o que apenas pode ser previsto. Esperança e medo, desejo e vontade, a inquietude, mas também a análise racional, a visão receptiva ou a curiosidade fazem parte da expectativa e a constituem. (KOSELLECK, 2006b, p. 310, tradução de Wilma Patrícia Maas e Carlos Almeida Pereira)

Esse é, inclusive, um dos aspectos da relação entre essas categorias que as destacam das demais: experiência e expectativa não se excluem semanticamente; pelo contrário, experiência e expectativa são interdependentes: "não há expectativa sem experiência, não há experiência sem expectativa." (p. 307) Koselleck explica que, da mesma forma que as expectativas são construídas, em grande medida, a partir do exemplo do passado (seja de modo a repeti-lo, seja a fim de evitar que se repita), a surpresa ante uma expectativa frustrada converte-se numa nova experiência. Desse modo, espaço de experiência e horizonte de expec-

\footnotetext{
${ }^{39}$ ARRUDA, 2014, p. 38.

${ }^{40}$ KOSELLECK, 2006b, p. 306.
} 
tativa mantêm uma relação bastante dinâmica: "Eles constituem uma diferença temporal no hoje, na medida em que entrelaçam passado e futuro de modo desigual." (p. 313s.)

Nesse sentido, Arruda (2014) define história como "a coleção dos fatos havidos, presentes e por vir; os discursos produzidos sobre estes mesmos acontecimentos extraídos dos testemunhos e, por fim, uma representação histórica do passado, pois 'nós fazemos a história e a fazemos porque nós somos homens históricos ${ }^{41}$." (p. 43s.) O termo reúne, assim, ao mesmo tempo objeto e produto da pesquisa histórica. Nota-se que a definição do objeto da história reflete essa temporalidade complexa, não limitada apenas ao ocorrido, mas estendida ao agora e ao porvir.

Helge Kragh (2003) faz a mesma distinção entre as acepções de história: por um lado, a História $\left(\mathrm{H}_{1}\right)$ "pode descrever os fenómenos ou acontecimentos reais que sucederam no passado e, então, é objectiva"; por outro, o conceito de História $\left(\mathrm{H}_{2}\right)$ também designa a "análise da realidade histórica $\left(\mathrm{H}_{1}\right)$, isto é, no sentido da investigação histórica e seus resultados" (KRAGH, 2003, p. 23, tradução de Carlos Grifo Babo). O objeto da História $\left(\mathrm{H}_{2}\right)$ é, assim, a história $\left(\mathrm{H}_{1}\right)$. Os nossos conhecimentos do passado, todavia, resumem-se ao produto da História $\left(\mathrm{H}_{2}\right)$, que não são o passado, mas sua interpretação histórica ${ }^{42}$.

Koselleck (2006a), por sua vez, ressalta que essa distinção entre as acepções tem, ela mesma, fundamentação histórica. Até o final do século XVIII, distinguia-se entre Historie (enquanto campo disciplinar) e Geschichte (os "eventos reais"): "De modo simplificado, trata-se aqui de uma oposição plausível entre res gestae, os estados de coisas, as ações e os eventos, de um lado, e seus relatos, as narrativas históricas, as histórias [Historien], de outro." ${ }^{43}$ (p. 74) Até os anos de 1780, só se podia falar em "história" se estivesse vinculada a um sujeito ou a um objeto - por exemplo, a "história de Carlos Magno" ou a "história da França". Com as mudanças que antecederam a Revolução Francesa, passou a ser possível falar de história sem esse vínculo ${ }^{44}$ : "história" torna-se um coletivo para todas as histórias passadas e futuras, reunindo-as todas num único conceito. Posteriormente, o termo passa a absorver a acepção designada por Historie:

"A história dos eventos e a forma de sua pesquisa e relato foram então reunidos num conceito comum. As condições de ação e as condições de seu reconheci-

\footnotetext{
${ }^{41}$ Cf. RICOEUR, Paul. Temps et Récit. Paris: Seuil, 2000, p. 452, 456-8.

${ }^{42}$ KRAGH, 2003, p. 23.

${ }^{43}$ Vereinfacht handelt es sich hier um den einleuchtenden Gegensatz zwischen res gestae, den pragmata, den Handlungen und Ereignissen auf der einen Seite und den Berichten darüber, den historischen Erzählungen, den Historien auf der anderen Seite.

${ }^{44}$ KOSELLECK, 2006a, p. 80.
} 
mento, ou em outras palavras: os requisitos linguísticos e extralinguísticos de toda forma de história foram pensados juntos conceitualmente. ${ }^{45}$ " (KOSELLECK, 2006a, p. 75)

A concentração de todas as histórias numa só, designadas por um único conceito de História, parece sofrer uma guinada com o pós-estruturalismo. Como observa Tahir Gürçağlar (2013), a perspectiva pós-moderna/pós-estruturalista de história e do registro dos eventos históricos sugere não haver uma, mas várias histórias, sendo a função da historiografia refletir essa pluralidade de "verdades". Os relatos históricos são, assim, vistos como construções artificiais dos historiadores, ainda que não se queira dizer com isso que se trata de construções arbitrárias ${ }^{46}$.

Alinhada a essa concepção de história está a definição que Arruda fornece de historiografia, que significa "a análise crítica da produção gerada pelos historiadores em sua imersão temporal" (ARRUDA, 2014, p. 47). Historiografia consiste, dessa forma, na reflexão crítica sobre a história contida na produção histórica, com foco na relação entre autor, meio e obra. Atrelada a essa definição está uma visão de obra histórica, ao mesmo tempo, como criação e como narrativa com base documental. Em outras palavras: intrínseco ao relato histórico está a persona do historiador, de modo que o relato histórico possui também um caráter autoral. Ainda que o material do historiador seja o passado, sua reflexão acerca dessa base documental empírica o vincula ao presente, colocando o historiador num campo de múltiplas temporalidades ${ }^{47}$.

A historiografia não toma as obras históricas isoladas, mas sim, a partir dessa temporalidade complexa que é manifesta nas obras, assim como os universos sociais, a ambientação cultural e as motivações pessoais de seus autores. Visto que o tempo não é uma entidade abstrata, mas adquire significado segundo a percepção que temos dele, socialmente filtrado pela variedade de experiências do historiador, a historiografia tem relação próxima com a sociologia do conhecimento, sobretudo no que tange à relação do indivíduo com o seu grupo social - ou, no caso, do historiador com o meio institucional que o cerca. Por decorrência, Arruda afirma que "a finalidade última da sociologia do conhecimento é desentranhar o enraizar desse conhecimento na textura social, os modos de pensar aí secretados." (p. 50) O que diferencia as duas áreas, a sociologia do conhecimento e a historio-

\footnotetext{
${ }^{45}$ Die Geschichte der Ereignisse und die Art ihrer Erforschung und Erzählung wurden also auf einen gemeinsamen Begriff gebracht. Die Bedingungen des Handelns und die Bedingungen ihrer Erkenntnis, oder anders gewendet: die außersprachlichen und die sprachlichen Voraussetzungen jeder Art von Geschichte, wurden begrifflich zusammengedacht. ${ }^{46}$ TAHIR GÜRÇAĞLAR, 2013, p. 132.

${ }^{47}$ ARRUDA, 2014, p. 48s.
} 
grafia, é o valor atribuído à dialógica transtemporal: embora de pouca importância para a sociologia do conhecimento, é relevante à historiografia, na medida em que essa "polifonia de vozes" se combina de forma dialógica entre as sucessivas gerações, reconfigurando-se de modo permanente ${ }^{48}$.

Seguindo essa linha de pensamento, é possível estender o conceito de historiografia a outros campos do conhecimento, atuando a historiografia como uma reflexão crítica da produção de conhecimento desses campos e de suas circunstâncias históricas:

\begin{abstract}
O procedimento historiográfico em sua concepção crítica não se restringe ao campo de conhecimento da história, como já foi dito. Pode ser aplicado ao conhecimento da escrita antropográfica, geográfica, etnográfica ou sociográfica, enfatizando a dimensão da escrita em lugar da descrição, a temporalidade em lugar da espacialidade. (ARRUDA, 2014, p. 57)
\end{abstract}

Esse mesmo argumento pode ser empregado para justificar o estudo historiográfico no âmbito dos estudos da tradução - não apenas um estudo dirigido à prática de tradução e interpretação ao longo da história, como parece ser a tônica no espaço de multidisciplinaridade entre história e estudos da tradução nas últimas décadas, mas também dirigido às reflexões sobre o traduzir e o interpretar, isto é, sobre o que se produziu no âmbito teórico sobre a tradução, tomando a produção teórica em sua temporalidade e a partir de uma perspectiva crítica.

Além de avaliar a produção existente num campo de conhecimento, a historiografia pode servir ao propósito de apontar caminhos futuros ao campo. De acordo com Arruda, de modo análogo à história, a historiografia permite o acúmulo de experiências para a projeção de um horizonte de expectativas em relação ao campo historiográfico. É possível prever o futuro através das sementes de futuros possíveis contidas no passado, desde que não se queira prevê-lo em detalhes e se insira o futuro numa estrutura lógica, que considere também o passado ${ }^{49}$.

Outro conceito fundamental em nosso estudo é o conceito de ciência. Definir o que, no contexto desse trabalho, se entende por "ciência" torna-se ainda mais urgente como modo de justificar o emprego do cabedal teórico da história da ciência como quadro teórico a embasar nossas análises e resultados. Kragh (2003) distingue dois níveis de significação para o conceito de "ciência", a exemplo do conceito de "história": num primeiro nível, ciência $\left(C_{1}\right)$ pode significar uma coletânea de afirmações empíricas e formais acerca da natu-

\footnotetext{
${ }^{48}$ ARRUDA, 2014, p. 50.

${ }^{49}$ Ibid., p. 52ss.
} 
reza, constituindo, assim, um modelo acabado. Num segundo nível, ciência $\left(\mathrm{C}_{2}\right)$ tem a ver com as atividades e os comportamentos de cientistas, quando essas atividades e comportamentos estão relacionados à produção de conhecimento ${ }^{50}$.

Em termos gerais, a distinção entre as duas formas de ciência estaria na ênfase dada à história ou à ciência. Segundo observa Kragh,

Se é à história da ciência que nos queremos referir, então a ciência em causa será frequentemente a ciência no sentido $\mathrm{C}_{1}$, consistindo sobretudo na análise técnica do conteúdo de publicações científicas, conduzidas dentro de um enquadramento histórico. Entretanto, a história da ciência será ciência no sentido de $\mathrm{C}_{2}$. (KRAGH, 2003, p. 26, tradução de Carlos Grifo Babo)

Quanto à história da ciência $\left(\mathrm{HC}_{2}\right)$, há uma infinidade de aspectos a se abordar. Por um lado, o estudo da história da ciência $\left(\mathrm{C}_{2}\right)$ pode apontar para mudanças que não se refletiram propriamente no processo científico $\left(\mathrm{C}_{1}\right)$, de modo que a história da ciência se desenvolve de modo independente da própria ciência. Por outro, ainda que não seja imprescindível dominar o conteúdo de uma ciência para escrever sua história, ignorá-lo de todo pode ter resultados catastróficos para a história que se pretende contar. Seja como for, a história da ciência ocupa-se da ciência em sua dimensão histórica, sendo necessário, dessa forma, também considerar as noções de ciência ao longo do período estudado ${ }^{51}$.

Nota-se que os dois tipos de história da ciência estão contemplados acima: uma visão internalista $\left(\mathrm{HC}_{1}\right)$, focada na produção teórica de um campo científico, que corresponde à abordagem hermenêutica da historiografia geral, e uma visão externalista de história da ciência $\left(\mathrm{HC}_{2}\right)$, correspondente à abordagem analítica da historiografia geral. Essas abordagens, internalista e externalista, podem ser adotadas num estudo de modo isolado ou coadunadas de modo dialético.

Não obstante, cumpre acrescentar algumas considerações acerca do conceito de ciência propriamente dito. Em sua primeira acepção, o conceito de ciência alude ao produto do processo científico, isto é, às afirmações teóricas feitas a partir de pesquisas empíricas, tendo a natureza como objeto de investigação. Dessa forma, Kragh (2003) refere-se ao método científico das ciências naturais. Em sua segunda acepção, o conceito de ciência deposita foco sobre aspectos históricos e sociológicos dessa produção de conhecimento, o que corresponde ao olhar que as ciências humanas têm sobre a sociedade. Somos assim confrontados por duas concepções bem diferentes de "ciência", o que forçosamente nos

\footnotetext{
${ }^{50} \mathrm{KRAGH}, 2003$, p. 25s.

${ }^{51}$ Ibid., p. $27 \mathrm{~s}$.
} 
leva a explicitar com mais exatidão o nosso próprio entendimento de "ciência" no âmbito do presente trabalho.

Influenciados por uma noção positivista de ciência, alguns campos de saber atribuem o status científico apenas às ciências naturais, sob a alegação de que o conhecimento científico autêntico resulta da comprovação empírica de teorias através de um método científico rigoroso, fundamentado pela experiência baseada na orientação sensorial. Considerando que operamos no campo das ciências humanas, vemo-nos, no entanto, compelidos a adotar uma concepção mais abrangente de ciência, que encontramos nos escritos de Gerard Radnitzky (1970). Conforme define o filósofo, ciência é "um sistema, relacionando especialmente ao desenvolvimento de conhecimento" ${ }^{52 " ~(R A D N I T Z K Y, ~ 1970, ~ p . ~ x), ~ d e n t r e ~ c u j o s ~}$ componentes ele elenca os produtores de conhecimento (os pesquisadores), o processo de pesquisa, os produtos, as partes interessadas nesses produtos, o subsistema de publicação de resultados, etc. Além de se constituir, por si só, como um sistema, a ciência integraria um sistema maior, a saber, a ciência em sociedade.

Além dos conceitos de história e ciência, cumpre aqui dar seguimento à distinção iniciada anteriormente nesse capítulo entre teoria e método. Andrew Chesterman (1997) relata, de modo bastante sucinto, a origem do termo "teoria". O termo teria tido origem na Grécia Antiga, a partir da palavra theoros [ $\theta \varepsilon \omega \rho o ́ \varsigma]$, utilizada tanto para nomear a pessoa designada oficialmente a consultar o oráculo, como alguém enviado a um festival numa função oficial. Outro sentido para a palavra é "magistrado" ou, de forma mais geral, "espectador". Assim, embora reflita um sentido de julgamento racional, o cerne do termo refere-se apenas a alguém que vê com um propósito. Do substantivo surgiu o verbo, theorein [ $\theta \varepsilon \omega \rho \varepsilon \tilde{\imath} v]$, "ver", "contemplar", ou, mais exatamente, "ser um espectador". Nele está salientada a ação de ver de modo deliberado, consciente. Enfim, chegou-se a theoria [ $\theta \varepsilon \omega \rho i \alpha]$, "o olhar", "o ver", guardando uma conotação de "contemplação", "especulação" 53 .

Nota-se, portanto, que a associação entre o conceito de teoria e "visão de mundo" está presente desde a origem do conceito. No âmbito da ciência, teoria é o filtro através do qual cientistas e pesquisadores vislumbram a realidade. Nesse contexto, José Barros (2014) distingue três níveis de sentido para o termo: (1) teoria como "campo de estudos" ou como "uma espécie de território constituído por todas as realizações teóricas proporcionadas pelos praticantes de determinado campo de saber" (p. 43s.); (2) teoria como "modelos ou

\footnotetext{
${ }^{52}$ We may conceive "science" as a system essentially relating to the development of knowledge.

${ }^{53}$ CHESTERMAN, 1997, p. 1s.
} 
sistemas explicativos de que os cientistas se utilizam para compreender os fenômenos, aspectos e objetos que se relacionam às suas especialidades" (p. 44); (3) teoria como "forma específica de aprender a realidade e de enxergar o mundo", em oposição à ideia de "intuição" (p. 46). À última acepção está ligada ao chamado "modo teórico", o qual, por sua vez, alude ao método científico: no modo teórico, empreender-se-ia uma análise pautada em dados, conduzida metodologicamente e num cabedal teórico que determinaria análise e percepção de seu objeto ${ }^{54}$.

Apesar de o "modo teórico" aludir ao método científico, não devemos confundir teoria e método, ainda que o modo teórico envolva procedimentos metodológicos. No modo teórico, temos a presença de mediadores: conceitos e linguagens de observação, hipóteses, procedimentos argumentativos e comprovações empíricas, demonstrações e a verbalização dos resultados ${ }^{55}$. E é justamente nesse ponto que teoria difere de intuição: com a intuição, a apreensão do objeto se dá de modo direto, não mediado. Ainda que a intuição seja necessária ao cientista, seu escopo de ação é limitado: ela é acionada quando o pesquisador se encontra numa encruzilhada, sem elementos que lhe permitam tomar uma decisão. Uma vez a decisão tomada, o proceder científico logo retoma o controle da investigação ${ }^{56}$.

No século XX, cientistas como Albert Einstein e filósofos como Karl Popper haveriam notado que a teoria determina o que podemos observar e como, isto é, "a teoria transforma a realidade observada, ou ao menos revela certos aspectos de uma realidade observada e não outros, conforme essa teoria seja construída de uma maneira ou de outra, ou a partir de certos pontos de vista e parâmetros" (BARROS, 2014, p. 62). O principal instrumento de uma teoria são os conceitos, pois é a partir deles que se enriquece a visão. De fato, conforme afirma Barros:

É uma determinada teoria - uma certa maneira de ver as coisas - e seus instrumentos fundamentais, os conceitos, o que nos possibilita formular uma determinada leitura da realidade histórica e social, enxergar alguns aspectos e não outros, estabelecer conexões que não poderiam ser estabelecidas sem os mesmos instrumentos teóricos de que nos valemos. Desta maneira, a Teoria pode ser considerada, à partida, como fator de importância fundamental para a constituição de qualquer campo de conhecimento, o que inclui a História. (BARROS, 2014, p. 64)

\footnotetext{
${ }^{54}$ BARROS, 2014, p. 48

${ }^{55}$ Ibid., p. 53 ss.

${ }^{56}$ Ibid., p. 59.
} 
Um ponto importante de sua exposição, no entanto, é quando ele estabelece a diferença entre teoria e metodologia. A teoria, como já explicitado, tanto nos remete a uma forma de conceber um objeto de estudos ou uma realidade quanto à forma como o cientista vê o seu próprio campo de estudos. Metodologia, por sua vez, diz respeito a como conduzir uma pesquisa, eleger fontes e analisá-las - em suma, diz respeito a ações concretas voltadas à resolução de problemas. Dessa forma, enquanto a teoria determina um modo de ver, a metodologia liga-se a um fazer $^{57}$. Entretanto, as duas, teoria e metodologia, em vez de dissociadas, são instâncias de ação recíproca, não podendo estar desvinculadas num projeto de pesquisa.

Como conclusão, Barros propõe definir teoria como "um corpo coerente de princípios, hipóteses e conceitos que passam a constituir uma determinada visão científica do mundo" (p. 83). Teoria pressupõe, enfim, demonstração e diálogo com outras proposições teóricas, seja em busca de fundamentos ou para refutá-las. Por isso, as teorias se relacionam no interior de um campo de conhecimento mais vasto - e, por isso também, é impossível mover-se pelo campo científico sem se conectar com outros autores que percorreram anteriormente o caminho, formulando conceitos e hipóteses, propondo questões e respostas ou arriscando demonstrações e procedimentos argumentativos ${ }^{58}$.

No fundamento de uma metodologia, em especial num estudo historiográfico, está a seleção e exploração das fontes ${ }^{59}$. Define-se fonte como um "elemento do passado, objectivamente transmitido, material, criado por seres humanos" (KRAGH, 2003, p. 133, tradução de Carlos Grifo Babo). Entretanto, esse elemento, essa relíquia do passado não é, em si, uma fonte, mas adquire o estatuto de fonte quando pode fornecer alguma informação sobre o passado. "É o historiador", enfim, "que transforma a relíquia numa fonte através de sua interpretação" (ibid.).

Para a presente pesquisa, tomamos como fonte essencialmente o texto científico: artigos, teses e dissertações. Segundo Kragh (2003), essas fontes dizem respeito ao labor científico enquanto atividade criativa e intelectual ${ }^{60}$ e constituem as chamadas "frentes de pesquisa da ciência" (p. 138). Em suma, elas revelam os problemas com os quais se defrontaram os cientistas numa dada era e os grupos de pesquisa que se formaram em torno deles. Embora a porção mais significativa de nossos corpora de pesquisa seja constituída

\footnotetext{
${ }^{57}$ BARROS, 2014 p. 66 ss.

${ }^{58}$ Ibid., p. 83.

${ }^{59}$ Cf. BARROS, op. cit., p. 71s.

${ }^{60} \mathrm{KRAGH}, 2003$, p. 135.
} 
de fontes primárias, algumas fontes secundárias, relatos e testemunhos que caracterizam as circunstâncias de produção intelectual, são utilizadas com a finalidade de complementar dados e validar ou refutar hipóteses.

Para Barros (2014), a Historiografia desenvolve inúmeras metodologias de constituição, análise e serialização de fontes, bem como diversas formas de adotar essas fontes. A despeito dessa variedade, os fundamentos do dito "método histórico", assim afirma Rüsen (2010), seriam os mesmos. O historiador e filósofo alemão detecta, em coadunação com a já referida estrutura operacional-substantiva, uma estrutura operativa e procedimental da pesquisa histórica, constituída das seguintes etapas:

(1) Heurística: concebe-se a heurística como "a operação metódica de pesquisa, que relaciona questões históricas, intersubjetivamente controláveis, a testemunhos empíricos do passado (...)" (RÜSEN, 2010, p. 118, tradução de Asta-Rose Alcaide). Trata-se da etapa de formulação de questões de pesquisa a partir de lacunas no próprio acervo de informações de que a disciplina já dispõe, que inclui também o referencial teórico de que parte o historiador. Complementar ao levantamento das questões de pesquisa é a formulação de hipóteses e a definição das fontes mais prováveis a se obter as respostas empíricas a essas questões.

(2) Crítica: compreende-se a crítica das fontes como "a operação metódica que extrai, intersubjetivamente e controlavelmente, informações das manifestações do passado humano acerca do que foi o caso" (p. 123). É a partir da crítica que os historiadores extraem, a partir das questões de pesquisa, dados ou fatos relevantes. Esses dados são analisados no atinente à facticidade da ação humana no passado a partir de critérios de potencial plausibilidade.

(3) Interpretação: define-se interpretação como "a operação metódica que articula, de modo intersubjetivamente controlável, as informações garantidas pela crítica das fontes sobre o passado humano. Ela organiza as informações das fontes em histórias" (p. 127). A partir da interpretação, as informações extraídas das fontes são colocadas em relação com o conhecimento histórico até então construído e, assim, podem ser integradas a esse acervo, sendo elevadas à condição de fatos históricos. 
Essa estrutura, embora seja uma representação apropriada das etapas de pesquisa histórica, não inclui qualquer detalhamento dos recursos teóricos e metodológicos a serem empregados em sua execução. Cabe ao historiador, assim, a escolha.

A partir desse ponto, apresentaremos contribuições mais específicas de outras áreas ao nosso trabalho, com ênfase nas propostas, num primeiro momento, que nos oferecem subsídios teóricos para uma abordagem analítica da história do funcionalismo e, num segundo momento, das abordagens que ofertam fundamentos para uma abordagem hermenêutica. Intercaladas entre elas está a referente descrição metodológica: em primeiro lugar, introduziremos brevemente o campo de origem desses procederes. Em seguida, descreveremos o corpus com as fontes selecionadas para aquela etapa de pesquisa. Por fim, explicitaremos os procedimentos de exploração das fontes.

\subsection{Análise externalista}

\subsubsection{Contribuições para uma análise externalista}

A pesquisa contextual, no interior do presente trabalho, tem a função de desvelar circunstâncias externas à formulação e disseminação teórica. Valendo-nos da metáfora do teatro, podemos afirmar que se trata de um observar o que acontece por trás da coxia, um olhar alargado do espetáculo, que nos permite compreender motivações e processos que resultaram na apresentação diante dos olhos de seus espectadores sobre o palco.

Sem o acesso aos bastidores, poderíamos ainda desfrutar do espetáculo - isto é, o entendimento da proposta teórica não seria comprometido. Todavia, dado que o objetivo da pesquisa é traçar a história do funcionalismo, entender não apenas as motivações para a produção teórica e as circunstâncias de seu ingresso nos estudos da tradução no Brasil, mas também a própria dinâmica social de pesquisa e difusão teórica, é imprescindível para atribuir significação às próprias transformações no nível conceitual da teoria.

Assim, principiamos a exposição dos fundamentos teóricos dessa etapa de pesquisa com a introdução de alguns conceitos úteis advindos da sociologia da ciência. Segue-se a apresentação de algumas propostas dessa mesma área destinadas a compreender a dinâmi- 
ca social em ciência, com atenção especial às propostas de Radnitzky (1970) e Mullins (1983).

\title{
1.3.1.1. Filosofia da ciência: escola intelectual, paradigma e cinosura
}

Mencionamos anteriormente que a definição de ciência adotada no presente trabalho foi formulada por Radnitzky (1970), que compreende "ciência" como um sistema de produção e aprimoramento de conhecimento ${ }^{61}$. Contudo, para que esse sistema gere inovação, Radnitzky vê como indispensável a existência de um mecanismo estabilizador, uma função desempenhada pelas tradições intelectuais ou escolas de pensamento ${ }^{62}$ :

\begin{abstract}
Certas formas de olhar para a ciência podem ser apropriadamente conceituadas como tradições intelectuais ou escolas de pensamento. Enquanto os empreendimentos de pesquisa em metaciência, bem como em ciência, constituem sistemas inovadores, as tradições de pesquisa no interior das disciplinas concernentes constituem um tipo de estabilizador; elas concedem certa continuidade e certa "uniformidade em meio à diversidade" num dado campo de estudos. Qualquer escola é, assim, caracterizada por um programa e um método, por sua exploração de tarefas, atributos que são comuns ao trabalho de seus representantes ${ }^{63}$. (RADNITZKY, 1970, p. xv, grifos do autor)
\end{abstract}

Segundo o filósofo, os termos "tradição" e "escola", intercambiáveis em sua obra, tanto se referem a fenômenos na vida social ou na história quanto designam "tipos ideais" ${ }^{\text {"64 }}$. Dentre as atribuições de uma tradição estão a seleção de problemas, dos meios para abordá-los e de recursos, bem como o estabelecimento de uma rotina de pesquisa, economizando, assim, esforços e energia que podem ser redirecionados para futuras inovações ${ }^{65}$. Os ingredientes conceituais básicos de uma tradição parecem ser: (1) a transmissão de uma atitude [Haltung], através de hipóteses para o campo de pesquisa, ideais para a ciência, etc., e; (2) a transmissão de um corpo de conhecimento. São também representativas para o

\footnotetext{
${ }^{61}$ RADNITZKY, 1970, p. xiv.

${ }^{62}$ Ibid., p. Xv.

${ }^{63}$ Certain ways of loking [sic!] at science may be suitably conceptualized as intellectual traditions or schools of thought. While research enterprises in metascience as well as in science as such constitute innovative systems, the research traditions within the disciplines concerned constitute a type of stabilizer; they make for certain continuity and certain "uniformity within diversity" in a given field of study. Any given school is then characterized by a program and a method, by its task-prospecting, features which are common to the work of its representatives.

${ }^{64}$ RADNITZKY, op. cit., p. 8.

${ }^{65}$ Ibid., p. 7
} 
desenvolvimento de uma tradição as instituições sociais criadas por ela e para o seu uso (centros de pesquisa, periódicos, etc.) ${ }^{66}$.

Barros (2014), no âmbito da Teoria da História, distingue na definição de "escola" tanto uma unidade conceitual quanto a constituição social de um grupo de pesquisadores:

\begin{abstract}
Uma "Escola" (...) pode ser entendida no sentido de uma "corrente de pensamento", sempre que ocorre um padrão ou programa mínimo perceptível no trabalho de um grupo formado por um número significativo de participantes de determinada atividade ou de produtores de certo tipo de conhecimento. É ainda importante que haja uma certa intercomunicação entre esses praticantes e a constituição de uma identidade em comum, frequentemente também ocorrendo a consolidação de meios para a difusão das ideias do grupo, como é o caso de revistas especializadas controladas por seus membros ou programas veiculadas em mídias diversas. (BARROS, 2014, p. 166)
\end{abstract}

A seu ver, é requisito para uma "escola" elemento comum forte o suficiente para estabelecer uma unidade entre pesquisas e participantes, podendo esse elemento ser um padrão comum de linguagem, o método ou, até mesmo, um programa comum de pesquisa. Porém, nem sempre é possível encontrar esse elemento comum, o que torna difícil identificar uma escola de pensamento ${ }^{67}$.

As noções de tradição intelectual e escola de pensamento estão, por sua vez, relacionadas com o conceito de paradigma, conceito esse introduzido por Thomas S. Kuhn em seu livro The Structure of Scientific Revolutions [A estrutura das revoluções científicas], de 1962. Compreende-se paradigma como o conjunto de realizações inovadoras o suficiente para atrair novos partidários e ainda abertas o bastante para dar conta de todo tipo de problemas. O termo "paradigma", conforme Kuhn, está em relação estreita com o conceito de "ciência normal", que designa "a pesquisa firmemente baseada em uma ou mais realizações científicas passadas. Essas realizações são reconhecidas durante algum tempo por alguma comunidade científica como proporcionando os fundamentos para sua prática posterior.” (KUHN, 2011, p. 29, tradução de Beatriz Vianna Boeira e Nelson Boeira)

A ciência normal fundamenta-se na premissa de que a comunidade científica sabe como é o mundo. A pesquisa pauta-se por realizações científicas passadas, reconhecidas por essa mesma comunidade como fundamento para a prática científica de um dado tempo $^{68}$. Dessa forma, se relacionarmos o conceito de "ciência normal" com os conceitos introduzidos por Radnitzky (1970) e Barros (2014), podemos definir ciência normal como a

\footnotetext{
${ }^{66}$ RADNITZKY, 1970, p. 9.

${ }^{67}$ BARROS, 2014, p. 168.

${ }^{68}$ KUHN, 2011, p. 24.
} 
ciência praticada por uma determinada tradição ou escola. Não obstante, a história dos diversos campos científicos é permeada por eventos que desafiam os pressupostos da tradição. Conforme esses eventos se tornam mais frequentes, instaura-se uma crise no paradigma, bem como o surgimento de investigações extraordinárias, as quais estabelecem uma nova base para a prática científica. Kuhn define tais episódios revoluções científicas ${ }^{69}$.

Entende-se por revoluções científicas "aqueles episódios de desenvolvimento nãocumulativo, nos quais um paradigma mais antigo é total ou parcialmente substituído por um novo, incompatível com o anterior" (p. 125). A revolução científica e a consequente mudança de paradigma são precedidas por uma crise no paradigma anterior, um período de insegurança profissional gerada pelo fracasso da ciência normal em produzir os resultados esperados $^{70}$. O fracasso das regras existentes é ensejo para a busca de novas regras e, quando essa busca é bem sucedida, as novas ideias costumam atrair novos adeptos. Um paradigma não é rejeitado enquanto não houver outro que o substitua. Como afirma Kuhn, "[r]ejeitar um paradigma sem simultaneamente substituí-lo por outro é rejeitar a própria ciência" (p. 109). Uma vez que considera que, ao ser alçada ao status de paradigma, a nova teoria detém a dominância do campo científico, Kuhn rejeita as continuidades de modo quase integral.

Esse é, todavia, um ponto bastante debatido. Ao tratar do caso específico da Linguística, Hymes (1983) afirma que um modelo apenas baseado em rupturas não é capaz de representar a dinâmica das teorias linguísticas, uma vez que, a seu ver, nenhuma delas, ainda que alçada ao mainstream, teria sido capaz de anular as demais:

\begin{abstract}
No que concerne a seu aspecto político, cada abordagem reteve o domínio sobre periódicos, encontros de profissionais, manuais etc. Mas nenhuma delas reteve o domínio exclusivo da cena. Cada uma delas dominou o centro, mas não o todo. [...] Ao menos no caso da linguística, outras abordagens senão as dominantes continuaram e, às vezes, até mesmo emergiram contemporaneamente. Pode-se dizer que cada abordagem dominante foi, com sucesso, a cinosura de sua disciplina. Pode-se dizer que seus participantes, e outros em seu redor, tiveram a consciência de uma mudança revolucionária, e que de fato houve uma comunidade paradigmática. A comunidade paradigmática, entretanto, nunca veio a ser equivalente ao todo da disciplina. Tampouco isso foi devido apenas a membros remanescentes da comunidade anterior. Cada novo 'paradigma' simplesmente não teve sucesso em estabelecer uma completa autoridade ${ }^{71}$. (HYMES, 1983, p. 354)
\end{abstract}

\footnotetext{
${ }^{69} \mathrm{KUHN}, 2011$, p. 24.

${ }^{70}$ Ibid., p. 95.

${ }^{71}$ In their political aspect each approach in turn has dominated journals, professional meetings, textbooks, and the like. But neither has been exclusive holder of the stage. Each has had the center, but not the whole. [...] In the case of linguistics, at least, other approaches than the dominant ones continued, and indeed sometimes emerged, contemporaneously. One can say that each dominant approach was successfully the cynosure of its discipline. One can say that its partici-
} 
Uma explicação possível para a pluralidade de comunidades paradigmáticas num dado campo científico está no fato de adesão de um cientista a um paradigma não estar condicionada apenas às descobertas e métodos desse paradigma, mas também a suas atitudes e pontos de vista. Essas atitudes e pontos de vista, por sua vez, estão em parte relacionadas ao clima intelectual, em parte à origem social ou acadêmica do pesquisador. A adesão a um paradigma, portanto, não representa apenas a adesão a um corpo de conhecimentos ou a uma metodologia, como também a uma visão de mundo. Com base em reflexões acerca dos movimentos paradigmáticos da linguística do século XX, Hymes conclui que "(...) a afiliação à comunidade paradigmática autoconsciente implicou lealdade a uma variedade de ideias, sendo que apenas algumas delas foram essenciais a novas noções e a problemas reais" ${ }^{72}$ (p. 355).

Assim, ele prefere considerar que diferentes interesses e orientações constituíram uma mesma disciplina - no caso, a linguística. A cinosura ou comunidade paradigmática seria, em qualquer tempo, apenas uma das comunidades e das áreas de interesse perseguida por acadêmicos sérios. Nesse sentido, o conceito de paradigma de Kuhn deve ser revisto criticamente, não descartado, pois, segundo Hymes, teve uma inegável importância para a história das disciplinas científicas, sobretudo ao romper a noção de evolução científica cumulativa. Não obstante, o conceito também evoca a impressão de que a ciência está em constante revolução ${ }^{73}$.

\subsubsection{As lutas paradigmáticas no campo científico}

A convivência de diferentes cinosuras paradigmáticas nas ciências humanas não deve, no entanto, ser interpretada como a ausência de forças conflitantes em suas disciplinas. Conforme observa Kuhn, novas teorias estão imbuídas de novos conceitos, novas metodologias e, principalmente, novas formas de ver o mundo. Assim, a mudança paradigmática impõe ao cientista um processo de reeducação da própria concepção do campo de pes-

pants, and others around them, had a consciousness of a revolutionary change, and that there was indeed a paradigmatic community. The paradigmatic community, however, has never come to be equivalent to the whole of the discipline. Nor has this been due to holdovers from the past alone. Each new 'paradigm' simply has not succeeded in establishing complete authority.

${ }_{72}$ In short, membership in the self-conscious paradigmatic community has entailed allegiance to a variety of ideas, only some of which have been essential to new insights and genuine problems.

${ }^{73}$ HYMES, 1983, p. 357ss. 
quisas $^{74}$. Ademais, exige também o abandono do comprometimento do cientista com a ciência normal, inerente ao próprio desenvolvimento científico. Não por acaso, a emergência de um novo paradigma, ainda que ele não detenha o monopólio da disciplina, incita resistência por parte dos demais ${ }^{75}$.

É inegável que, com a noção de paradigma, Thomas Kuhn rompe, no âmbito acadêmico, com uma visão cumulativa de ciência que, afincada tão profundamente em nosso senso comum, perdura até hoje dentre os indivíduos não envolvidos na atividade científica. Todavia, segundo o sociólogo francês Pierre Bourdieu (2015), a dinâmica de troca de paradigmas de Thomas Kuhn contemplaria apenas a produção intelectual, pressupondo assim que a ascensão de um paradigma ao mainstream de uma disciplina teria razões unicamente epistemológicas.

Bourdieu (2004) considera que todas as produções culturais são suscetíveis de análise com pretensões científicas. Em todas elas haveria uma história e, para estudá-la, seria necessário confrontar-se com a oposição entre interpretações "internalistas" e interpretações "externalistas". Com isso, Bourdieu reconhece duas perspectivas de estudo de um campo disciplinar:

\footnotetext{
Grosso modo, há, de um lado, os que sustentam que, para compreender a literatura ou filosofia, basta ler os textos. Para os defensores desse fetichismo do texto automatizado que floresceu na França com a semiologia e que refloresce hoje em todos os lugares do mundo com o que se chama de pós-modernismo, o texto é o alfa e o ômega e nada mais há para ser conhecido, quer se trate de um texto filosófico, de um código jurídico ou de um poema, a não ser a letra do texto. Esquematizo um pouco, mas bem pouco.

Em oposição, uma outra tradição, freqüentemente representada por pessoas que se filiam ao marxismo, quer relacionar o texto ao contexto e propõe-se a interpretar as obras colocando-as em relação com o mundo social e o mundo econômico. (BOURDIEU, 2004, p. 19, tradução de Denice Barbara Catani)
}

Dada a ênfase atribuída pela filosofia da ciência à perspectiva internalista em seu tempo, Bourdieu propõe um viés teórico para uma análise externalista, introduzindo a noção de campo científico. Ele define "campo" como "o universo no qual estão inseridos os agentes e as instituições que produzem, reproduzem ou difundem a arte, a literatura ou a ciência. Esse universo é um mundo social como os outros, mas que obedece a leis sociais mais ou menos específicas” (2004, p. 20).

\footnotetext{
${ }^{74}$ KUHN, 2011, p. 148.

${ }^{75}$ Ibid., p. 193s.
} 
Um "campo" seria um microcosmo relativamente isolado e circunscrito, não submetido integralmente às mesmas leis que o macrocosmo. Conforme explica Bourdieu, o grau de autonomia dos diferentes campos e instituições dependem de como eles reagem às pressões externas. Uma das manifestações mais indistintas da autonomia de um campo seria a sua capacidade de refratar, isto é, de transfigurar as pressões externas em algo diferente, próprio da disciplina. De modo inverso, num campo heterônomo as pressões externas teriam manifestação direta ${ }^{76}$.

Além das pressões externas, um campo científico está sujeito a tensões interiores. $\mathrm{O}$ campo científico, à semelhança de outros campos, seria constituído de um espaço de disputas internas de poder. Esse espaço seria moldado pelas relações entre cientistas, equipes ou laboratórios e, em contrapartida, condicionaria a própria ação dessas instâncias:

\footnotetext{
É na relação entre os diferentes agentes (concebidos como "fontes do campo") que se engendra o campo e as relações de força que o caracterizam (relação de forças específica, propriamente simbólica, dada a "natureza" da força capaz de se exercer nesse campo, o capital científico, espécie de capital simbólico que age na e pela comunicação). Mais exactamente, são os agentes, ou seja, os cientistas isolados, as equipas ou os laboratórios, definidos pelo volume e pela estrutura do capital específico que possuem, que determinam a estrutura do campo que os determina, ou seja, o nível das forças que se exercem sobre a produção científica, sobre as práticas dos cientistas. (BOURDIEU, 2015, p. 52s., tradução de Pedro Elói Duarte)
}

A força de um agente dependeria do acúmulo, de sua parte, de capital científico, compreendido como "uma espécie particular de capital simbólico, capital fundado no conhecimento e no reconhecimento", que pressupõe "a confiança ou a crença dos que o suportam porque estão dispostos (pela sua formação e pelo próprio facto de pertença ao campo) a atribuir crédito." (p. 53) - Assim, da mesma forma como acontece em outros campos da vida social, a estrutura do campo científico seria determinada pela estrutura de distribuição de capital científico, estando capital e poder diretamente relacionados. Essa estrutura determinaria também as oportunidades de cada pesquisador, de acordo com sua posição no campo científico: para os detentores de maior poder, a própria estrutura do campo científico operaria em seu favor ${ }^{77}$.

De acordo com o sociólogo francês, há duas diferentes espécies de capital científico: o capital temporal-institucional (ou político) e o capital "puro", fundado no prestígio. O capital político estaria ligado à ocupação de posições importantes nas instituições científi-

\footnotetext{
${ }^{76}$ BOURDIEU, 2004, p. 21s.

${ }^{77}$ Id., 2015, p. 53.
} 
cas, bem como ao controle dos meios de produção (contratos, créditos, postos etc.) e de reprodução (poder de nomear e fazer carreiras). Por sua vez, o prestígio, não necessariamente vinculado ao poder político, sustentar-se-ia no reconhecimento do trabalho de um cientista. O capital científico puro, associado frequentemente a uma liderança carismática, seria fruto do reconhecimento dos concorrentes de que o contributo do cientista é relevante. Para identificar se um contributo é digno de reconhecimento, seria necessário ter tido experiência com o capital simbólico, isto é, ter também desfrutado de reconhecimento ${ }^{78}$. Ainda que considere um método passível de aperfeiçoamento, Bourdieu refere-se à bibliometria como um bom indicador de acúmulo de capital científico ${ }^{79}$.

As duas espécies de capital científico diferem-se também no que respeita a seu acúmulo. O capital "puro" seria adquirido por meio de contribuições significativas para o progresso da ciência segundo a avaliação dos pares; o capital temporal, através de estratégias políticas, dentre outras, a participação em comissões, bancas, colóquios e reuniões. A acumulação de capital temporal "é o princípio (a título de compensação) ou o resultado de um menor êxito na acumulação da forma mais específica e mais legítima do capital científico" (BOURDIEU, 2004, p. 36, tradução de Denice Barbara Catani).

O campo é uma estrutura de conflitos. No campo, agentes em posse de diferentes recursos se enfrentariam para conservar ou transformar as relações de força em voga. Nesse contexto, as ações de pesquisadores no campo científico seriam condicionadas por sua posição na estrutura de divisão de capital ${ }^{80}$. Os dominantes geralmente estão em posição de impor uma imagem do próprio campo científico que atenda melhor a seus interesses. Eles estão dedicados à "ciência normal" e almejam à conservação das estruturas de poder, impondo obstáculos aos concorrentes, sobretudo na acumulação inicial de capital:

Dado que a inovação científica não ocorre sem rupturas sociais com os pressupostos em vigor (sempre correlativos de prerrogativas e de privilégios), o capital científico "puro", ainda que esteja em conformidade com a imagem ideal que o campo quer ter e dar de si próprio, é, pelo menos na fase de acumulação inicial, mais exposto à contestação e à crítica, controversial, como dizem os anglosaxões, do que o capital científico institucionalizado, e pode ocorrer, em algumas disciplinas, que os grandes inovadores (Braudel, Lévi-Strauss, Dumézil, por exemplo, no caso das ciências sociais) sejam marcados por estigmas de heresia e violentamente combatidos pela instituição. (BOURDIEU, 2004, p. 35s., tradução de Denice Barbara Catani)

\footnotetext{
${ }^{78}$ BOURDIEU, 2015, p. 80.

${ }^{79}$ Id., 2004, p. 26.

${ }^{80}$ Id., 2015, p. 54.
} 
A resistência a novas abordagens no meio científico é um componente inerente da estrutura em que se organizam os agentes do campo científico. Conforme explica Bourdieu, esses agentes não são passivamente conduzidos pelas forças do campo, mas costumam enfrentá-las quando estão em oposição a elas. Segundo afirma, eles têm disposições adquiridas - a que Bourdieu se refere através do conceito de habitus - que pode levar esses agentes a resistir ${ }^{81}$. A noção de habitus faz alusão a uma dimensão implícita, não formalizada da prática científica. Trata-se de uma "uma consciência teórica realizada", ou seja, incorporada pelo cientista, que determina sua prática científica. Para Bourdieu, aqueles que adquirem essas disposições longe dos centros de poder correm o risco de serem constantemente marginalizados, como também podem lutar contra a estrutura do campo e trazê-la mais próxima de suas disposições ${ }^{82}$.

\subsubsection{A questão da autonomia do campo científico}

A noção de campo permitiria romper com lugares comuns aceitos em geral por pessoas que se interessam pela ciência. $\mathrm{O}$ primeiro deles seria referente à noção de ciência "pura", inteiramente autônoma e que se desenvolve segundo uma lógica interna; o segundo, à noção de "comunidade científica", que haveria se tornado, através da lógica dos automatismos verbais, uma designação forçada do universo científico como um todo. Segundo afirma Bourdieu, falar de campo significa rejeitar a ideia de que os cientistas formam um grupo unificado e até homogêneo, num mundo em que prevaleceria a generosidade entre os pesquisadores:

Esta visão idealista que descreve a prática como produto da submissão voluntária a uma norma ideal é contradita pelos factos: o que se observa são conflitos, por vezes ferozes, e competições no interior de estruturas de domínio. A visão "comunitarista" esquece-se do próprio fundamento do funcionamento do mundo científico como universo de disputas pelo "monopólio da manipulação legítima" dos bens científicos, ou seja, mais exactamente, do bom método, bons resultados, boa definição dos fins, objectos e métodos da ciência. (BOURDIEU, 2015, p. 68, tradução de Pedro Elói Duarte)

\footnotetext{
${ }^{81}$ BOURDIEU, 2004, p. 28.

${ }^{82}$ Ibid., p. 28 et seq.
} 
A busca pelo bom método, sujeita à avaliação crítica dos pares, seria a própria efetivação voluntária da submissão às normas do campo científico. No outro extremo, a noção de campo científico contestaria a visão parcial de ciência como "guerra". Segundo afirma Bourdieu, ainda que haja na ciência elementos que polarizem os cientistas, também há aqueles que os unem, tais como os fins, por exemplo, o de encontrar a verdade e combater o erro, e também uma cultura comum, que determina e possibilita a competição entre os diversos grupos de pesquisadores ${ }^{83}$.

No que tange à concepção de comunidade científica, Bourdieu observa que ela designa outro aspecto importante num campo científico, a saber, o fato de os pesquisadores envolvidos num campo poderem, num dado momento, munir-se de instrumentos que lhes permitiriam funcionar como comunidades e cuja função oficial seria preconizar medidas para proteger os valores ideais da profissão do cientista. Ele faz menção a organizações, instituições científicas e de cooperação científica que contribuem para o funcionamento de uma comunidade científica, por exemplo garantindo que os cientistas estejam alinhados a interesses e à cultura vigentes nesse campo. A influência dessas instituições na organização da comunidade científica, no entanto, só poderia ser medida considerando-se a posição dessas instituições, de quem faz parte delas e de quem as dirige no campo científico ${ }^{84}$.

Quanto à autonomia do campo científico, hoje parece ter-se chegado ao consenso de que ela não é absoluta. De acordo com Bourdieu, muitos analistas não creem nela e, assim, defendem fazer uma análise sociológica dos campos científicos centrando-se na pressão externa sobre o campo. No entanto, como vimos, um campo é constituído de pressões externas e tensões internas. Sua relativa autonomia em relação ao universo social circundante estaria baseada no fato de que "o sistema de forças constitutivas da estrutura do campo (tensão) é relativamente independente das forças que se exercem sobre o campo (pressão)" (BOURDIEU, 2015, p. 70, tradução de Pedro Elói Duarte).

A autonomia de um campo é uma conquista histórica, que se sucedeu gradativamente e que deve ser sempre renovada. Bourdieu toma as ciências naturais como exemplo: iniciada por Copérnico, ela teria se concretizado com a criação da Royal Society de Londres, com o objetivo de assegurar que a ciência fosse orientada por normas próprias. Dentre os fatores que permitiram que isso ocorresse está a matematização, um requisito de admissão que, a partir de Newton, passa a separar claramente os profissionais dos amado-

\footnotetext{
${ }^{83}$ BOURDIEU, 2015, p. 68.

${ }^{84}$ Ibid., p. 68 et seq.
} 
res. Além de reduzir o número de produtores de conhecimento, a matematização também teria reduzido o número de leitores do conhecimento produzido àqueles que dispõem do domínio das matemáticas - isso é, os próprios pesquisadores. O campo científico, dessa forma, teria adquirido autonomia fechando-se para a sociedade; as pessoas responsáveis por avaliar a produção de conhecimento seriam, a partir de então, os próprios pares, muitas vezes competidores. Como segundo efeito da matematização para as ciências naturais, em especial para a física, Bourdieu cita a mudança na noção de explicação do mundo, que passa, com Newton, a ser feita através de cálculo, para depois ser comprovada pela experimentação. O terceiro efeito seria, assim, a substituição das substâncias aristotélicas pelas formulações matemáticas abstratas, isto é, a realidade do mundo teria perdido seu poder de orientação da ciência para os cálculos matemáticos de probabilidade, e o mundo concreto, assim, teria cedido lugar para o mundo teórico ${ }^{85}$.

O processo de aquisição de autonomia na ciência leva a uma objetivação do mundo social, em especial através da criação das disciplinas. A institucionalização das disciplinas pelas universidades serviria para delimitar e proteger as fronteiras entre elas. O desenvolvimento de um campo científico caracterizar-se-ia, em primeiro lugar, pela emergência de uma prática de investigação, isto é, de agentes mais voltados à investigação do que ao ensino, e pela institucionalização da investigação nas universidades. Em segundo lugar, os cientistas enfatizariam sua distinção social e criariam uma identidade social própria, seja através da criação de associações científicas, seja através da criação de corporações. Com isso, teriam origem duas diferentes formas de distinção social para os cientistas: a figura do cientista acadêmico, através da construção de uma disciplina científica, e a figura do profissional, ligado às corporações ${ }^{86}$.

A esse processo de autonomização estaria ligado o requisito de admissão. Para entrar no campo científico, seriam exigidas indivíduo a competência e a apetência. A primeira não se limita aqui apenas ao domínio dos conhecimentos (teóricos e metodológicos) acumulados pelo campo, mas também a incorporação do conjunto de recursos teóricoexperimentais do campo, tornado sentido do jogo ou habitus científico como domínio prático de séculos de investigação. Dito de outra forma: não apenas conhecimentos teóricos e metodológicos são necessários, mas também uma forma específica de ver o mundo. A apetência, por sua vez, refere-se ao desejo de tomar parte no jogo e à própria crença no jogo e,

\footnotetext{
${ }^{85}$ BOURDIEU, 2015, p. 70 et seq.

${ }^{86}$ Ibid., p. 73 et seq.
} 
com isso, à submissão voluntária ao imperativo do desinteresse. O nascimento da ciência coincide com o nascimento da crença do desinteresse científico e, assim, com a exposição pública das atividades científicas, sob a avaliação de testemunhas, a fim de demonstrar não haver um interesse particular, egoísta na investigação ${ }^{87}$.

Assim, ainda que por trás da pesquisa científica haja uma estrutura que premia o acúmulo de capital científico, e embora seja esse um dos objetivos das ações de cientistas, sustentar a crença do desinteresse é vital à própria ciência. Segundo Bourdieu, o conhecimento científico deve ser reconhecido como fruto da razão, da lógica e do método experimental. O habitus do campo científico estabelece a argumentação e a experimentação, conforme as regras do campo, como meio de validar seus resultados. Quando eles sobrevivem às objeções, tornam-se conhecimento científico ${ }^{88}$.

Dito de outro modo, a objetividade em ciência é intersubjetividade, isto é, é fruto da validação intersubjetiva. O conhecimento científico produzido por um determinado cientista ou instituição deve ser validado por seus pares, os quais, dentro do espaço de lutas que constitui o campo, são também seus concorrentes. Contando apenas com argumentação, os resultados da pesquisa de um cientista não sobrevivem ao escrutínio da comunidade científica se a ciência empregada por um pesquisador resumir-se apenas à política, despida de reflexão lógica e do método científico.

\subsubsection{O papel das disciplinas no desenvolvimento do campo científico}

Para Bourdieu, os agentes da luta científica não são apenas pesquisadores, mas mesmo laboratórios e disciplinas. Detendo-se no caso da disciplina, ele observa que ela é um campo relativamente estável e delimitado, assim fácil de identificar: tem um nome reconhecido, está inserida em instituições, revistas, congressos, etc. Ela seria definida pela posse de um capital coletivo formado por métodos e conceitos especializados, necessários a todos que queiram fazer parte dela. O próprio habitus disciplinar determinaria a percepção e a apreciação do campo, bem como de uma tradição de pensamentos compartilhados pela coletividade dentro da disciplina. As fronteiras entre as disciplinas seriam protegidas

\footnotetext{
${ }^{87}$ BOURDIEU, 2015, p. 74 et seq.

${ }^{88}$ Ibid., p. 101.
} 
pelos requisitos de admissão, questionados pelas disciplinas afins. Ademais, pode haver intersecção entre disciplinas, que permitiria extrair informações de um número maior de fontes $^{89}$.

Bourdieu relembra a importância da noção de campo científico: ao mesmo tempo que demonstra haver certa unidade na ciência, chama a atenção para o fato de as diferentes disciplinas ocuparem uma posição no espaço (hierarquizado) das disciplinas. A seu ver, o campo científico "(...) pode ser descrito como um conjunto de campos locais (disciplinas) que têm interesses (por exemplo, o interesse de racionalidade, contra o irracionalismo, a anticiência, etc.) e princípios mínimos comuns" (BOURDIEU, 2015, p. 93, tradução de Pedro Elói Duarte). Ele cita como princípios unificadores os "instrumentos bases", sejam materiais ou teórico-metodológicos, inclusive as formas racionalizadas, formalizadas e padronizadas de pensamento e as regras do método experimental. Uma disciplina não se definiria apenas por propriedades intrínsecas, mas também por sua posição no espaço (hierarquizado) das disciplinas. Dentre os princípios aplicáveis para distinguir as disciplinas estaria a quantidade de capital coletivo acumulado (em especial, os recursos teóricoformais) e a autonomia da disciplina em relação à pressão externa. Ele identifica dois princípios de diferenciação/hierarquização entre as disciplinas: o princípio temporal e o princípio propriamente científico ${ }^{90}$.

Haveria ainda o fato de as lutas entre as disciplinas por uma posição de mais vantagem no campo científico levar a mudanças científicas resultando, por exemplo, no que Ben-David e Collins denominam "hibridização". Na hibridização, uma disciplina ajusta métodos e técnicas de um produto antigo aos materiais de uma área nova, a fim de se criar um novo produto. Trata-se, por exemplo, da migração de cientistas, inseridos num campo altamente competitivo, para um campo próximo, de estatuto mais baixo, que ofereça, assim, melhores condições de competição. Com isso, a aplicação de métodos e técnicas de seu campo de origem no novo campo ou disciplina traz a impressão de inovação, conferindo destaque a esse cientista:

Em suma, se abandonarmos a linguagem inadequada do "conflito de papéis" e da "hibridização de papéis" e a filosofia da acção que isso implica, pode dizer-se (...) que esse fenómeno surge quando os representantes de uma disciplina dominante (...) se mudam para uma disciplina dominada (...), o que implica para eles uma perda de capital, obrigando-os de alguma maneira, para recuperar os seus investimentos e para restaurar o capital ameaçado, a elevar a disciplina apropri-

\footnotetext{
${ }^{89}$ BOURDIEU, 2015, p. 92 et seq.

${ }^{90}$ Ibid., p. 94.
} 
ando-se dos conhecimentos da disciplina importada. (BOURDIEU, 2015, p. 96, tradução de Pedro Elói Duarte)

Bourdieu, no entanto, afirma que a criação de uma disciplina também pode ser um esforço coletivo voltado a um determinado fim. Só seria possível entender a ascensão e o declínio de um disciplina se tivermos em conta, ao mesmo tempo, a história intelectual e a história social do grupo, desde as características sociais do líder e de suas companhias iniciais até propriedades coletivas do grupo, tais como sua atração social e sua capacidade de ter alunos ${ }^{91}$.

Reunidos os principais fundamentos a orientar nossa percepção de nossa análise contextual, é hora de partimos para a descrição da respectiva metodologia, a começar pela apresentação do campo da cientometria.

\subsubsection{Cientometria}

O termo "cientometria" designa "uma série de métodos para analisar a estrutura e o desenvolvimento em ciência a um nível, em termos relativos, altamente desenvolvido" (KRAGH, 2003, p. 201, tradução de Carlos Grifo Babo). Esses métodos são largamente empregados nos dias de hoje pela sociologia da ciência como técnica quantitativa, voltada tanto ao estudo do crescimento de um campo científico quanto ao mapeamento da comunicação científica num dado momento da história de uma ciência ou de um campo de estudos.

A cientometria surge como uma ramificação da pesquisa bibliométrica. Entende-se por bibliometria a área de investigação e análise quantitativa de informações bibliográficas. Embora não se restrinja a publicações científicas e tecnológicas, elas constituem o principal objeto da pesquisa bibliométrica. Conforme observa De Bellis:

Obviamente, as técnicas bibliométricas, exatamente como qualquer outro conjunto de ferramentas matemáticas, não precisam estar restritas a produtos acadêmicos, quanto menos a publicações científicas. Contudo, investigar as propriedades formais do sistema de publicação acadêmica é, sem sombra de dúvidas, o seu objetivo primeiro e a área em que a sua aplicação nos instiga a levantar questões fascinantes acerca de como um dos feitos humanos mais bem estimados - o co-

\footnotetext{
${ }^{91}$ BOURDIEU, 2015, p. 97.
} 
nhecimento científico - veio a se tornar objeto de si mesmo ${ }^{92}$. (DE BELLIS, 2009, p. xi)

Não obstante, o termo "cientometria" vem enfatizar não só o tipo específico de informação a ser estudado - o documento científico - mas o fato de esse estudo incluir um juízo de valor do que pode ser considerado "científico":

No sentido mais amplo possível, a cientometria abrange todos os modelos e aspectos quantitativos relacionados à produção e disseminação de conhecimento científico e tecnológico. Estabelecidos alguns pressupostos preliminares acerca do que é, de fato, ciência e de como se pode reconhecer uma verdadeira conquista científica, a cientometria, em última instância, direciona-se à avaliação quantitativa e comparativa da contribuição de cientistas, grupos, instituições e países para o avanço do conhecimento ${ }^{93}$. (DE BELLIS, 2009, p. 3)

Ainda que as publicações sejam apenas uma das unidades possíveis de análise, a pesquisa das citações bibliográficas ocupa posição especial no campo. É certo que todos os sistemas de medida estão longe de compreender integralmente os processos de mudanças científicas e tecnológicas. No entanto, se comparadas às outras, a medida pautada nas citações bibliográficas tem posição única no campo, dado que a conexão que ela expõe entre documentos desvela, segundo acreditam alguns pesquisadores, o próprio processo científico de divulgação de descobertas ${ }^{94}$.

Antes de descrever as possibilidades trazidas pela cientometria à história da ciência, cumpre discorrer brevemente sobre os aparatos técnicos e teóricos que tornaram a pesquisa bibliométrica possível.

\footnotetext{
${ }^{92}$ Obviously bibliometric techniques, exactly as any other set of mathematical tools, do not need be restricted to scholarly products, let alone scientific reports. Investigating the formal properties of the scholarly publication system, however, is undeniably their primary target and the area where their application prompts us to ask fascinating questions about how it could happen that one of the most highly regarded human achievements — scientific knowledge - turned into the object of itself.

${ }^{93}$ In the widest possible sense, scientometrics encompasses all quantitative aspects and models related to the production and dissemination of scientific and technological knowledge. Provided some preliminary assumptions about what science actually is and how a true scientific achievement is to be recognized, scientometrics ultimately addresses the quantitative and comparative evaluation of scientists', groups', institutions', and countries' contribution to the advancement of knowledge.

${ }^{94}$ DE BELLIS, 2009, p. xiii.
} 


\subsubsection{Fundamentos técnicos e teóricos da pesquisa bibliométrica}

O estado da atual cientometria deve muito ao desenvolvimento de um aparato técnico e um aparato teórico-conceitual. Dentre os aparatos técnicos, destacamos a criação dos índices de citações, hoje considerados imprescindíveis para a maioria das pesquisas conduzidas no âmbito da cientometria. Os índices são "um componente básico de busca de informações de forma manual ou computadorizada ${ }^{95 " ~(D E ~ B E L L I S, ~ 2009, ~ p . ~ 25), ~ e m ~ q u e ~}$ estão reunidas informações essenciais de publicações científicas, tais como título, autor, ano de publicação e referências bibliográficas. A criação do Science Citation Index (SCI), em 1964, pelo Institut for Scientific Information (ISI) e sob orientação do químico Eugene Garfield foi, sem dúvida, um dos marcos decisivos da história da pesquisa bibliométrica, posto que favoreceu a exploração sistemática das regularidades estatísticas que governam os padrões de citação de autores, artigos e periódicos ${ }^{96}$.

No que concerne ao aparato teórico-conceitual, as contribuições de John Desmond Bernal, Robert K. Merton, Derek John de Solla Price e do próprio Garfield para o avanço da pesquisa bibliométrica foi de valor inestimável. Segundo De Bellis, as raízes conceituais mesmas da disciplina perpassam os insights desses autores, os quais, além de analisar aspectos metodológicos e linguísticos do discurso científico, contemplaram também a estrutura e a dinâmica de produção de conhecimento da ciência, incluindo a estrutura social de suas comunidades ${ }^{97}$.

John D. Bernal, professor de física da Brikbeck College de Londres, desempenhou papel pioneiro na História da Ciência. A partir de uma perspectiva marxista do empreendimento científico, ele sustentou a opinião de que a ciência é um assunto social, "realizado por uma comunidade internacional de pesquisadores em mútua comunicação e intimamente conectada a toda uma série de atividade humana ${ }^{98 " ~(D E ~ B E L L I S, ~ 2009, ~ p . ~ 50) . ~ A ~ c i e ̂ n c i a ~}$ atuaria como motor de mudança social e fundação de todo conhecimento humano valioso, seja ele advindo das ciências naturais ou das ciências humanas.

Porém, Bernal via a circulação de informações científicas de forma bastante crítica. Ele defendia que não as publicações científicas, mas a comunicação informal seria o prin-

\footnotetext{
${ }^{95}$ Indexes are a basic component of manual or computerized information retrieval (...)

${ }^{96}$ Cf. DE BELLIS, op. cit., p. 38.

${ }^{97}$ Ibid., p. 49.

${ }^{98}(\ldots)$ he believed that science is a social affair, carried out by an international community of networked researchers, and intimately connected to the whole range of human activities.
} 
cipal veículo de comunicação entre cientistas. Ainda assim, a publicação científica deteria o status de comunicação oficial, devendo assim ser trazida mais próximo do cotidiano de pesquisa. Em sua época haveria uma profusão de publicações e periódicos sem a necessária discriminação entre contribuições significativas e não significativas, de modo que seria forçosa uma reestruturação da comunicação científica, a começar pela abolição dos periódicos existentes e pela criação de um órgão centralizador, responsável por avaliar, armazenar e redistribuir as informações produzidas pela ciência ${ }^{99}$. Essa proposta, naturalmente, não se concretizou, o que não eclipsa o legado deixado por Bernal à cientometria, tanto no que diz respeito à visão social de ciência quanto à ênfase dada à avaliação da qualidade do conhecimento produzido pelo empreendimento científico.

A contribuição de Robert Merton, professor de sociologia da Columbia University, veio pela definição de quatro normas para a ciência que até hoje compõem a ética científica. Essas normas podem ser resumidas por quatro diretrizes-mestras:

- universalismo: todos, independente da raça, cultura, nacionalidade ou gênero, podem participar da ciência, o que presume uma igualdade de oportunidades;

- "comunismo": todo conhecimento produzido pela atividade científica é um bem comum, devendo estar disponível a todos;

- desinteresse: os cientistas devem empreender ciência desprovidos de motivações econômicas ou pessoais;

- ceticismo organizado: as alegações científicas devem ser submetidas a uma análise crítica e ter validação apenas por evidências lógicas e empíricas ${ }^{100}$.

Para Merton, em geral, os cientistas atuam guiados por essas regras, o que infelizmente não tornaria o sistema científico à prova de injustiças, uma vez que nem todo cientista ganharia o devido reconhecimento por sua contribuição. Uma manifestação dessa injusta distribuição de reconhecimento seria a tendência de cientistas de citarem seus pares mais bem conceituados, em detrimento de colegas menos conhecidos, muitas vezes com contribuições até mais significativas. Merton nomeou essa tendência "Efeito Mateus" [Matthew Effect], em referência a um trecho do evangelho homônimo: "Porque a qualquer

\footnotetext{
${ }^{99}$ DE BELLIS, 2009, p. 51s.

${ }^{100}$ Ibid., p. 54.
} 
que tiver será dado, e terá em abundância; mas ao que não tiver até o que tem ser-lhe-á tirado." (Mateus 25:29)

Garfield, por sua vez, trouxe uma nova perspectiva para as citações bibliográficas com seu artigo "Citation Indexes for Science" [Índices de citação para a ciência], publicado em 1955:

Ele se apoia na ideia de que as citações são os componentes de uma linguagem que reflete, melhor do que as palavras-chave convencionais, a estrutura profunda da comunicação científica, na qual a literatura (e a terminologia) passada está num constante estado de reinterpretação, segundo as regras transformacionais ditadas pelas práticas disciplinares ${ }^{101}$. (DE BELLIS, 2009, p. 58)

A seu ver, através das citações, é possível reconstituir o contexto intelectual de um dado campo de pesquisas e traçar hipóteses acerca de suas relações sociais.

Essa ideia teve posterior desenvolvimento pela pena de Henry Small. Segundo seu entendimento, as citações seriam capazes de mimetizar a transferência e a assimilação de ideias, uma habilidade presente em formas de linguagem mais codificadas. Ele trabalha com as concepções de "signo" e de "símbolo", enfatizando o fato de nos signos haver uma relação de continuidade entre objeto e significado (uma relação metonímica, de representação), ao passo que nos símbolos a relação entre eles ser arbitrária (logo, uma relação metafórica). Nesse contexto, a referência bibliográfica exerceria concomitantemente o papel de signo e símbolo:

\begin{abstract}
Uma referência bibliográfica é ao mesmo tempo um "signo" e um "símbolo". É um "signo," constituído da sequência habitual autor - periódico - volume - página - ano, apontando para um objeto material, o documento citado, com o qual compartilha alguns atributos formais (relação metonímica). É um "símbolo" do conceito ou conceitos articulados pelo documento citado (relação metafórica), na medida em que ele invoca o documento citado em conexão com um ponto específico do texto, assim rotulando-o com o conceito que ele deveria representar no contexto particular $^{102}$. (DE BELLIS, 2009, p. 60)
\end{abstract}

Assim como conceitos, citações não são necessariamente símbolos estáveis, de interpretação unívoca: cada cientista pode ter um diferente entendimento de um mesmo do-

\footnotetext{
${ }^{101}$ It pivoted on the idea that citations are the building blocks of a language that reflects, better than conventional subject headings, the deep structure of scientific communication, where past literature (and terminology) is in a constant state of reinterpretation according to transformational rules dictated by disciplinary practices.

${ }^{102}$ A bibliographic reference is a "sign" and a "symbol" at the same time. It is a "sign," made up of the usual sequence author-journal-volume-page-year, pointing to a physical object, the cited document, with which it shares some formal features (metonymic relation). It is a "symbol" of the concept or concepts articulated by the cited document (metaphoric relation), in the sense that it invokes the cited document in connection with a specific point of the text, thereby labeling it with the concept it is supposed to represent in that particular context.
} 
cumento. No entanto, há determinados documentos numa área disciplinar que são citados com frequência considerável, de modo sempre a representar os mesmos conceitos, tornando-se, dessa forma, símbolos-padrão desses conceitos ${ }^{103}$.

Algumas das contribuições mais influentes ao campo foram feitas por Derek de Solla Price. Nascido em Leyton, na Inglaterra, Price foi um historiador da ciência e da tecnologia, atuando como professor da Yale University desde 1959. Em seu livro Little Science, Big Science [Pequena ciência, grande ciência], ele declara o desejo de utilizar dados estatísticos e o método científico para estudar a ciência. Posteriormente, esse se tornou o compromisso do programa de pesquisa cientométrica como um todo:

\begin{abstract}
Seu trabalho subsequente no campo pode ser considerado a realização técnica do legado de Bernal, visto que levou, no decorrer de alguns poucos anos, à delineação de um paradigma para os estudos da ciência, haja visto que ele não apenas demarcou as fronteiras da nova disciplina e as condições necessárias para a sua existência, mas também mostrou, de modo concreto, como seus quebra-cabeças poderiam ser posteriormente resolvidos ${ }^{104}$. (DE BELLIS, 2009, p. 62)
\end{abstract}

Suas ideias sobre a essência e a evolução da ciência apoiavam-se em duas premissas: (1) a ciência distingue-se de outras áreas de conhecimento, dadas a sua objetividade e a sua capacidade de lidar com a observação e a manipulação de dados empíricos e; (2) ainda que durante os estágios de descoberta, as novas técnicas e ideias sejam diretamente influenciadas por fatores ligados à vida assistemática de laboratório, bem como a fatores de ordem social, psicológica e filosófica, no fim do processo, a ciência corresponde à literatura científica publicada. Se a ciência equivale às publicações científicas, no entendimento de Price, cientista é aquele que, ao menos uma vez, produziu uma publicação científica lida e aprovada por seus pares ${ }^{105}$.

Essa definição de "ciência" e de "cientista" permitiu-lhe estudar o crescimento da ciência a partir de dados quantitativos. Como resultado, Price formulou a chamada "Lei Exponencial da Ciência", que estabelece que o número de publicações de uma ciência multiplica-se, em períodos similares de tempo, por um fator constante. Kragh (2003), no entanto, questiona essa lei, argumentando, por um lado, que tal conclusão só se sustenta se forem consideradas todas as áreas da ciência física e, por outro, que essa lei (e sua represen-

\footnotetext{
${ }^{103}$ DE BELLIS, 2009, p. 61.

${ }^{104}$ His subsequent work in the field may be considered the technical fulfillment of Bernal's legacy, as it led, within a few years, to the delineation of a paradigm for science studies, in the very sense that he not only demarcated the boundaries of the new discipline and the necessary conditions for its existence, but also showed concretely how its puzzles could be solved thereafter.

${ }^{105}$ DE BELLIS, op. cit., p. 63.
} 
tação gráfica) nada dizem sobre momentos de estagnação da ciência ou de revolução científica $^{106}$.

Outra lei proposta por Price é a Lei da Produtividade. Segundo afirma, do número total de cientistas de um dado campo de pesquisas sobressai uma elite responsável pela metade das produções científicas, uma elite correspondente à raiz quadrada do total de cientistas. Em outras palavras, o avanço científico não dependeria propriamente do simples número de pesquisadores recrutados por um campo de pesquisas num dado momento da história, mas do número de cientistas "bons" - isto é, de cientistas muito produtivos. De Bellis, no entanto, alerta para o risco de forçar uma equivalência entre produtividade e qualidade. Em contrapartida, admite que produtividade acarreta frequentemente notoriedade, o que contribui para a perpetuação do já referido "Efeito Mateus" de Merton ${ }^{107}$.

Não foram apenas os estudos de Derek Price que apontaram para a tendência de distribuição desigual de elementos em ciência. Da primeira metade do século XX vieram os estudos matemáticos que dariam origem às chamadas "leis da bibliometria": os trabalhos de Alfred Lotka sobre a distribuição de artigos científicos entre autores, de Samuel Bradford acerca da disseminação de artigos sobre um determinado tema pelos diversos periódicos, e de George Zipf sobre a distribuição das palavras num texto. Lotka, Bradford e Zipf teriam usado fórmulas matemáticas e gráficos para expressar a relação entre fontes e os itens que elas produzem: autores produzindo textos, periódicos produzindo artigos sobre um dado assunto e textos produzindo palavras com determinada frequência. Em comum, todas elas teriam demonstrado uma desigualdade bastante expressiva no padrão dos processos de informação sob observação ${ }^{108}$.

Alfred Lotka, matemático, físico e estatista estadunidense, conduziu um estudo a fim de determinar em que grau cientistas de diferentes calibres contribuíam para o avanço da ciência. Desses estudos, Lotka chegou à primeira formulação de sua lei: "o número de autores produzindo $\mathrm{n}$ contribuições é aproximadamente igual a $1 / \mathrm{n}^{2}$ do número de autores que produzem apenas uma contribuição ${ }^{109}$." (p. 92). Em termos de porcentagens, de um total de autores que publicam artigos sobre um determinado tema, $60 \%$ teria publicado apenas um artigo, $15 \%$ teria publicado dois, $7 \%$ três etc. Nota-se que essa lei está relacionada com a supracitada Lei da Produtividade de Derek Price.

\footnotetext{
${ }^{106}$ KRAGH, 2003, p. 205.

${ }^{107}$ Ibid., p. 64.

${ }^{108}$ Ibid., p. 76.

${ }^{109}$ the number of authors producing $n$ contributions is approximately equal to $1 / n^{2}$ of the number of authors that produce only one contribution.
} 
Samuel Bradford, bibliotecário-chefe do London Science Museum, foi movido pelo ideal de compilar um catálogo coletivo de todo o conhecimento humano, um ideal que, no entanto, esbarrava na baixa qualidade de compilação dos índices bibliográficos. Segundo afirma, esse entrave seria em grande parte devido ao fato de artigos que versam sobre um mesmo tema estarem disseminados por periódicos diferentes ${ }^{110}$. Uma pesquisa com duas diferentes fontes bibliográficas do âmbito da geofísica mostrou, no entanto, que alguns poucos periódicos concentravam a maior parte dos artigos de um determinado assunto. Assim está formulada a sua lei:

O que a sequência acima de proporções expressa é que o volume de artigos sobre um determinado tópico está concentrado primeiramente num conjunto diminuto de periódicos centrais e então disperso noutros periódicos num grau tal que, se o conjunto de artigos relevantes for subdividido em grupos ou zonas contendo o mesmo número de itens que os periódicos centrais, um número de periódicos crescente numa progressão exponencial será necessário para preencher as zonas subsequentes $^{111}$. (DE BELLIS, 2009, p. 96)

Em comparação com as demais, a Lei de Zipf parece destoante, posto que não tematiza o tradicional cenário de agentes externos à documentação, mas traz para os holofotes o próprio discurso científico. George Zipf, professor de filologia na Harvard University, considerava a linguagem uma ferramenta complexa de comportamento, cuja estrutura estava arraigada ao contexto pessoal, social e cultural do falante. Para investigar essa estrutura oculta, no entanto, seriam necessárias investigações quantitativas dos padrões de uso na fala cotidiana.

Suas pesquisas levaram-no a observar que a relação entre a razão das palavras mais frequentes para as menos frequentes decresce também exponencialmente:

Dito de forma mais simples, a lei equivale a dizer que a vasta maioria das palavras em textos aparece apenas algumas poucas vezes e um número limitado de palavras é extremamente frequente. A distribuição das palavras num texto é assimétrica, bastante semelhante à distribuição de artigos científicos entre autores (Lotka) e de artigos entre periódicos (Bradford) ${ }^{112}$. (DE BELLIS, 2009, p. 107)

\footnotetext{
${ }^{110}$ DE BELLIS, 2009, p. 95.

${ }^{111}$ The above sequence of ratios amounts to saying that the bulk of articles on a given topic is concentrated in a small set of core journals and then scattered across other journals to such a degree that, if the set of relevant articles is subdivided in groups or zones containing the same number of items as the core, an exponentially increasing number of journals will be required to fill the succeeding zones.

${ }^{112}$ At its simplest, the law amounts to saying that the vast majority of text words appear only a few times, and a limited number are extremely frequent. The distribution of words in a text is skewed, closely resembling that of scientific papers between authors (Lotka) and articles between journals (Bradford).
} 
Zipf atribui essa assimetria na distribuição de palavras à tendência intrínseca humana de buscar um equilíbrio na ordenação dos componentes elementares da língua, a que ele se refere como "lei da economia" ou "lei do mínimo esforço": segundo essa lei, preferiríamos sempre as palavras mais comuns, curtas e de pronúncia mais fácil do que as palavras mais raras, longas e de difícil pronúncia ${ }^{113}$.

\subsubsection{O uso da cientometria para história e sociologia da ciência}

A ciência, não raro, é referida através de metáforas: ora é descrita geograficamente, como um vasto campo subdividido em áreas, ora como um quebra-cabeça, formado por unidades (documentos) que, quando juntas, formam repositórios organizados segundo domínio/assunto (periódicos), os quais, por sua vez, se desenvolvem em fontes de documentação de áreas de especialidade e disciplinas bem estabelecidas, por vezes até mesmo institucionalizadas. Buscar uma visão do todo de uma disciplina, contudo, é um empreendimento desafiador, posto que sua estrutura comunicativa está em constante mutação, seja devido a transformações nos próprios padrões de comunicação da disciplina, seja por conta das perspectivas teóricas e dos métodos aplicados na observação desses padrões ${ }^{114}$.

Para esse fim, muitos pesquisadores do âmbito da cientometria e da sociologia da ciência realizam o mapeamento do campo científico - e, assim, retornamos à metáfora geográfica. A construção de um mapa é desejável por fornecer um retrato relativamente objetivo da ciência, além de facilitar a busca de dados através de uma interface de fácil manuseio e de fornecer a base empírica para pôr construtos como "disciplina", "paradigma" e "comunidade científica" à prova. Para a formulação desses mapas, são exploradas diversas unidades de análise, por exemplo, autores, referências bibliográficas e palavras-chave. Quanto mais ocorrências - e coocorrências - houver entre elementos, mais constatações acerca da estrutura sociocognitiva do campo sob análise serão possíveis ${ }^{115}$.

Todavia, o proceder com o mapeamento científico exige cautela. De Bellis menciona a tentativa, no âmbito da cientometria, de confirmar a teoria da mudança paradigmática de Thomas Kuhn. No prefácio de sua obra seminal, The Structure of Scientific Revolutions

\footnotetext{
${ }^{113}$ DE BELLIS, 2009, p. 107s.

${ }^{114}$ Ibid., p. 141.

${ }^{115}$ Ibid., p. $142 \mathrm{~s}$.
} 
[A estrutura das revoluções científicas], Kuhn alude a possíveis sinais de mudança paradigmática nas publicações científicas:

\begin{abstract}
(...) se tenho razão ao afirmar que cada revolução científica altera a perspectiva histórica da comunidade que a experimenta, então esta mudança de perspectiva deveria afetar a estrutura das publicações de pesquisa e dos manuais do período pós-revolucionário. Um desses efeitos - uma alteração na distribuição da literatura técnica citada nas notas de rodapé dos relatórios de pesquisa - deve ser estudado como um índice possível da ocorrência de revoluções ${ }^{116}$. (KUHN, 2011, p. 14, tradução de Beatriz Vianna Boeira e Nelson Boeira)
\end{abstract}

Ainda que não tenha sido com a intenção de propor uma forma empírica de pesquisa, a hipótese levantada por Kuhn ensejou, por parte de cientistas da informação, empreender essa investigação através da análise de cocitações. O modo como empreendê-la também foi inspirado pelas palavras de Kuhn, que alega que a forma pela qual um cientista aprende a ver um novo problema em ciência como análogo a um problema antigo, previamente solucionado, é através do contato com pesquisas exemplares. Assim, se se admite que essas pesquisas existem, é sensato também presumir que elas sejam frequentemente citadas, o que as tornaria facilmente identificáveis pelo método bibliométrico. Ao mesmo tempo, no caso de uma revolução científica, essas pesquisas exemplares seriam substituídas por outras, algo que a cientometria também seria capaz de detectar ${ }^{117}$.

Com isso, a cientometria abre uma possibilidade de pesquisa da dinâmica da ciência. Não obstante, Kragh adverte para o perigo de aplicá-la de forma irrestrita e isolada: ao centrar-se na análise quantitativa, o conteúdo cognitivo, em princípio, deixa de ser considerado. Desse modo, obtém-se uma imagem formalizada da ciência, quando, de fato, o processo científico não é de todo formal, mas sim, fortemente marcado por influências informais e não racionais ${ }^{118}$. O próprio Thomas Kuhn não esconde suas restrições para com a cientometria, defendendo, em seu lugar, a adoção de um processo complexo de aprendizado e avaliação para examinar as mudanças paradigmáticas. A análise externa, a seu ver, teria valor apenas para delimitar, a partir da perspectiva "de fora", uma determinada comunidade científica ${ }^{119}$. De todo modo, está bastante claro que a pesquisa cientométrica não

\footnotetext{
${ }^{116}$ (...) if I am right that each scientific revolution alters the historical perspective of the community that experiences it, then that change of perspective should affect the structure of post-revolutionary textbooks and research publications. One such effect - a shift in the distribution of the technical literature cited in the footnotes to research reports - ought to be studied as a possible index to the occurrence of revolutions. (KUHN, 1970, p. ix)

${ }^{117}$ DE BELLIS, 2009, p. 169.

${ }^{118}$ KRAGH, 2003, p. 216.

${ }^{119}$ DE BELLIS, op. cit., p. 171
} 
pode ser um fim em si mesma, mas deve contribuir, em comunhão com estudos de natureza qualitativa, para compreender a dinâmica das comunidades científicas.

Antes de apresentarmos nosso corpus de análise para esta etapa, cumpre fazer a menção de um estudo que emprega métodos bibliométricos próximos aos descritos aqui no âmbito dos estudos da tradução. Trata-se de um mapeamento feito por Adriana Pagano e Maria Lúcia Vasconcellos (2003) do campo disciplinar nas décadas de 1980 e 1990. Como parte dos esforços de pesquisa do GT de Tradução da ANPOLL em mapear as atividades de produção acadêmica em tradução, as autoras fizeram o levantamento de trabalhos de grau dedicados ao tema, escritos por pesquisadores brasileiros em instituições no Brasil e no exterior. O levantamento, posteriormente publicado num banco de dados em formato eletrônico (CD-ROM), reúne resumos e palavras-chave de dissertações, teses de doutorado e de livre-docência ${ }^{120}$.

A partir desses dados, foi realizada primeiramente uma análise quantitativa, contabilizando-se a quantidade de trabalhos de grau produzidos no período estudado, destacando o volume de produção em cada nível (mestrado, doutorado, livre-docência), a distribuição desses trabalhos em instituições de ensino superior no Brasil e no exterior, bem como o volume anual de produções. Em seguida, deu-se a análise qualitativa, em que se procurou distribuir os trabalhos em categorias definidas com base no mapa da disciplina proposto por Holmes (2000), utilizando-se para isso as palavras-chave fornecidas pelos próprios autores. A análise incluiu também a observação dos títulos e dos resumos, de modo a tecer considerações gerais acerca deles. Além de recorrer a determinados elementos de sua metodologia, faremos uso dos resultados desse estudo em nossa própria pesquisa.

\subsubsection{Procedimentos de uma análise externalista}

A fim de mais bem caracterizar os estudos da tradução no Brasil ao longo dos anos estipulados para nossa pesquisa, empreenderemos um mapeamento do campo disciplinar. Um mapeamento científico, também conhecido por mapeamento bibliométrico, consiste numa representação "de como disciplinas, campos, áreas de especialidade e documentos ou

\footnotetext{
120 cf. PAGANO, Adriana et. al. Estudos da Tradução no Brasil / Translation Studies in Brazil. Belo Horizonte: FALE/UFMG, 2001. (CD-ROM)
} 
autores individuais estão relacionados uns com os outros" (COBO et al., 2012, p. 1609). Em outras palavras, ele visa a exibir aspectos estruturais e dinâmicos de um campo disciplinar.

Para a presente pesquisa, é importante ter em vista o contexto intelectual em que o funcionalismo ingressou nos estudos da tradução no Brasil. Assim, pretendemos identificar os autores, temas e trabalhos mais representativos do período, segundo a publicação de artigos que versam sobre tradução, interpretação e terminologia. É de nosso entendimento que a representação da estrutura da disciplina é de suma importância para traçar esse contexto.

Para tanto, contamos com o auxílio da ferramenta computacional SciMAT (Science Mapping Analysis software Tool), um software open-source desenvolvido no Departamento de Ciência Computacional e Inteligência Artificial da Universidade de Granada, Espanha. A ferramenta teria sido desenvolvida após a constatação ${ }^{121}$ de que nenhuma das ferramentas até então disponíveis era capaz de dar conta, sozinha, de todo o processo de mapeamento científico, sendo ocasionalmente necessário recorrer a outros softwares para concluir as etapas faltantes.

O SciMAT foi-nos de extrema valia principalmente para a organização e o processamento de um volume bastante significativo de dados. Durante a primeira fase da pesquisa foram cadastrados 498 artigos, publicados por 379 autores de 144 diferentes instituições e 5434 referências bibliográficas.

Contudo, antes do levantamento e pela análise de dados bibliométricos extraídos do corpus de artigos científicos, o proceder metodológico iniciou-se por uma revisão bibliográfica dos relatos e estudos historiográficos já conduzidos até o momento acerca da história dos estudos da tradução no Brasil. Assim, reunimos artigos publicados em diferentes fontes que ajudam a reconstituir a história da institucionalização da área no país, seja através da criação de cursos de tradução em nível universitário, seja através da organização de fóruns de discussão entre pesquisadores, seja, enfim, pela criação de linhas de pesquisa, áreas de concentração e, posteriormente, programas de pós-graduação em estudos da tradução. Como exemplo de fontes para esse estudo, citamos o volume organizado por Andréia Guerini, Marie-Hélène Catherine Torres e Walter Carlos Costa (2013a), as contribuições de Heloísa Gonçalves Barbosa (2009), John Milton (2015), Maria Paula Frota (2006, 2007), João Azenha Junior (2006a, 2015a), Adauri Brezolin (2006), Márcia A. P. Martins

\footnotetext{
${ }^{121}$ Cf. COBO et al., 2011.
} 
(2006, 2007) e Marie-Hélène Torres (2015). Com isso, fomos capazes de levantar hipóteses acerca da pesquisa, da prática e da didática da tradução no Brasil, bem como identificar os principais agentes, objetos e problemas que marcaram os estudos da tradução à época.

Em seguida, tentamos reconstituir os caminhos dos membros fundadores do funcionalismo no Brasil. Para tanto, fizemos o levantamento de suas publicações no Brasil em periódicos e anais de congressos. Além disso, buscamos nos currículos desses teorizadores, disponíveis online ou em publicações comemorativas, informações acerca de viagens feitas ao Brasil. No caso de Christiane Nord, a maior parte dos dados angariados acerca de suas visitas ao país foi obtida através dela mesma via comunicação pessoal. Dessa forma, foi possível avaliar a influência das ações de divulgação teórica dos autores dos textos seminais para disseminar a abordagem teórica em nosso meio.

O proceder com os artigos científicos iniciou-se, enfim, com a busca de dados. No âmbito da ciência da informação, recorre-se normalmente nessa etapa aos bancos de dados bibliográficos disponíveis online, sendo o ISI Web of Science ${ }^{122}$ (ISIWoS), o Scopus ${ }^{123}$, o Google Scholar ${ }^{124}$, e o National Library of Medicine's MEDLINE ${ }^{125}$ os mais importantes atualmente $^{126}$. No entanto, ao consultar esses bancos de dados, notamos que esses possuíam poucos ou nenhum registro dos documentos que compõem o nosso corpus. Dessa forma, optou-se pela entrada manual desses dados. Ao longo do processo de indexação, foram incluídas informações referentes à autoria dos artigos, ao veículo de publicação, à filiação institucional dos autores, ao ano de publicação, às palavras-chave e às referências bibliográficas contidas em cada artigo.

No Gráfico 1 abaixo, vemos a tela de inclusão do SciMAT. À esquerda, temos uma listagem com os artigos salvos. Para editá-los, basta apenas clicar sobre o artigo desejado. À direita, vemos a tela de edição, com informações como o título do artigo, volume e número da revista em que foi publicado e resumo. Abaixo, outras informações, que são reunidas em subdivisões próprias do banco de dados: ano de publicação, periódico, nome dos autores, sua afiliação, palavras-chave do texto e referências bibliográficas. Cada subtópico mencionado pode ser editado na aba "Knowledge base" [base de conhecimentos]. A tela de documentos [Documents] tem função central no programa, pois a partir dela podem ser

\footnotetext{
$122 \mathrm{http}: / /$ www.webofknowledge.com

${ }^{123} \mathrm{http}: / / \mathrm{www}$. scopus.com

${ }^{124} \mathrm{http}: / /$ scholar.google.com

${ }^{125} \mathrm{http}: / /$ www.ncbi.nlm.nih.gov/pubmed

${ }^{126}$ Segundo COBO et al., 2012, p. 1609.
} 
incluídos não apenas os artigos (clicando em "Add", abaixo da lista à esquerda), mas as outras informações pertinentes em nosso levantamento ${ }^{127}$.

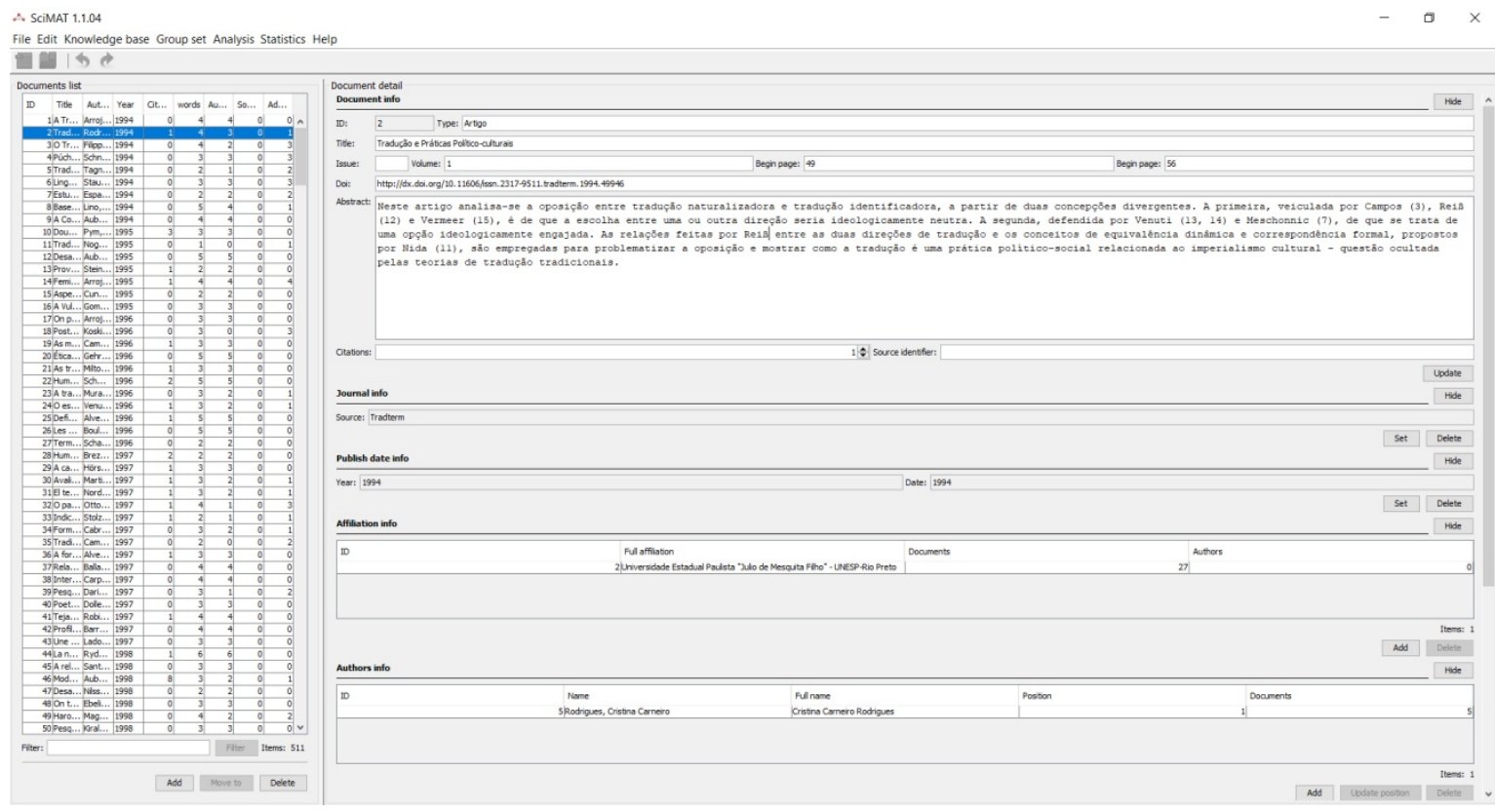

Gráfico 01: Tela de inclusão de documentos do SciMAT 1.1.04

Seguiu-se o processo de pré-processamento. Nessa etapa, foram estabelecidos os diferentes períodos de análise para um estudo longitudinal. Posto que o período de pesquisa definido por nós compreende o intervalo entre 1990 e 2005, distinguimos três diferentes períodos: o período entre 1992 e 1995, entre 1996 e 2000 e, por fim, entre 2001 e 2005. Ademais, as referências bibliográficas foram agrupadas segundo seus autores, de modo a verificar quais autores foram os mais citados num determinado período. Além disso, a exemplo do que foi feito por Pagano e Vasconcellos (2003) e, posteriormente, por Alves e Vasconcellos (2016), também as palavras-chave foram organizadas em clusters segundo o domínio temático ou aporte teórico, de forma a identificarmos os temas e as vertentes teóricas mais populares em cada período.

Cumpre aqui fazer uma observação acerca do levantamento de palavras-chave: ao observar nosso corpus, notamos que nem todas as publicações incluem os unitermos e, em muitos casos, sequer há um resumo (ou abstract) do artigo. Durante a composição do banco de dados de teses e dissertações de pesquisas no âmbito dos estudos da tradução desen-

${ }^{127}$ Para mais informações acerca de como operar o SciMAT 1.1.04, consulte o manual de instruções - SciMAT User Guide, disponível em https://sci2s.ugr.es/scimat/software/v1.01/SciMAT-v1.0-userGuide.pdf, 
volvida por pesquisadores brasileiros, Pagano e Vasconcellos (2003) já faziam menção à subjetividade na escolha de palavras-chave para trabalhos na área, bem como à ausência de identificação da afinidade teórica, questões que representaram obstáculos no agrupamento e na análise conduzida pelas autoras ${ }^{128}$. Infelizmente, esses mesmos problemas, aliados a uma falta de padronização nas publicações entre os diversos periódicos, também se fizeram observar aqui. Desse modo, na ausência das palavras-chave atribuídas pelos próprios autores, incluímos também palavras-chave atribuídas por nós. Para tanto, recorremos à linguística de corpus. Nesse sentido, todos os artigos em que não havia unitermos foram convertidos em texto para geração posterior de uma lista de palavras-chave ${ }^{129}$. Uma vez gerada a lista de palavras-chave de cada artigo, essas foram localizadas no texto e seu uso foi observado. Dessa maneira, tornaram-se mais evidentes os temas centrais do artigo. De modo a facilitar o mapeamento dos assuntos abordados no âmbito dos estudos da tradução durante o período de pesquisa aqui estipulado, procuramos definir um conjunto de palavras-chave padrão, recorrendo novamente ao texto acima mencionado de Pagano e Vasconcellos, mas complementando a lista com novos desenvolvimentos ${ }^{130}$.

Uma vez reunidos e organizados os dados, segmentamos o banco de dados de acordo com os períodos de análise e, com o auxílio do MS-Excel, fizemos o processamento desses dados, que inclui a criação de tabelas e gráficos. Os dados foram analisados segundo os seguintes índices: número de publicações por ano, número de publicações de cada periódico por ano, proporção de publicações desses periódicos, proporção de publicações segundo as instituições que organizam os periódicos, os autores mais produtivos em todo o período, a afiliação dos autores em cada período, os autores mais citados em cada período e, por fim, os temas mais abordados.

A interpretação do mapa foi conduzida a partir da associação da análise quantitativa, proveniente da confecção dos mapas científicos, com a análise qualitativa, com base principalmente nos relatos historiográficos e nos estudos prévios. Desse modo, pudemos identificar algumas tendências que caracterizaram os estudos da tradução no país entre os anos de 1992 e 2005.

Além de esboçar um panorama parcial dos estudos da tradução no Brasil, a presente análise tem o propósito de rastrear os caminhos do Funcionalismo pelas publicações de

\footnotetext{
${ }^{128}$ PAGANO; VASCONCELLOS, 2003, p. 10.

${ }^{129}$ Os procedimentos de geração de uma lista de palavras-chave é análogo ao descrito no tópico 1.4.2 do presente capítulo. Assim, não o descreveremos aqui.

${ }^{130}$ A lista com os clusters, uma breve descrição deles e as palavras-chave a eles associadas encontram-se em arquivo anexo.
} 
artigos no período. Os primeiros resultados do levantamento bibliográfico, no entanto, foram um pouco desanimadores no que concerne à busca por textos com base no funcionalismo. Assim, foi-nos necessário expandir o intervalo a considerar para a pesquisa, incluindo o período entre 2006 e 2018.

Dessa maneira, buscamos em periódicos especializados no âmbito dos estudos da tradução artigos que fizessem referência a textos escritos por autores seminais funcionalistas. Em seguida, fizemos uma consulta a cada texto, de modo a identificar se o funcionalismo representa o cerne da fundamentação teórica daquele estudo ou se é empregado pontualmente. Apenas artigos produzidos por pesquisadores vinculados a universidades brasileiras foram considerados.

Após a filtragem dos textos, empregamos novamente as ferramentas de análise de corpus para identificar, através da geração de uma lista de palavras-chave, os temas mais relevantes de cada artigo. Os dados recolhidos por esse processo foram analisados de acordo com os seguintes índices: distribuição de artigos por ano, distribuição de artigos por instituições, autores mais produtivos, temas mais recorrentes, autores e trabalhos mais citados. A análise dos temas e das citações foi de vital importância para definir o corpus da etapa subsequente, a saber, a análise internalista, para a qual dedicaremos as próximas linhas.

\subsection{Análise internalista}

\subsubsection{Contribuições para uma análise internalista}

Estabelecemos que a emergência de uma teoria representa, ao menos em tese, a introdução de uma nova forma de ver o mundo - ou elementos desse mundo. Nesse contexto, os conceitos são os principais instrumentos de uma teoria, na medida em que condensam as noções que fundamentam essa nova perspectiva. Em geral, com a nova abordagem teórica, surgem também novos conceitos ou conceitos já existentes são resignificados. Logo, a pesquisa histórica de uma dada abordagem teórica não pode prescindir de uma análise conceitual, sobretudo se o objetivo for captar as transformações na essência mesma dessa abordagem. 
Para conduzir tal pesquisa, é necessário, porém, presumir que uma teoria não se mantenha inalterada no decurso de sua história. Duas situações em que a base conceitual está sujeita a mudanças são a sua disseminação por entre diferentes grupos, cada qual com seu próprio acervo de saber técnico e experiências culturais, e a própria atividade de pesquisa, que desvela um mundo em constante transformação.

A fim de compreendemos os processos que atuam nas mudanças do acervo conceitual de uma abordagem teórica, recorremos, como já mencionado anteriormente, à Teoria da História e à Sociobiologia. Da primeira, extraímos a proposta de Koselleck de um estudo da história através das mutações dos conceitos fundamentais à vida em sociedade; da segunda, a noção de "memes" de Dawkins, que, através de uma inusitada aproximação entre ideias e genes, sugere uma explicação para a dinâmica de disseminação do saber entre as pessoas.

\subsubsection{A História dos Conceitos}

Reinhart Koselleck (1923-2006), um dos historiadores alemães mais importantes do pós-guerra, será para sempre lembrado no âmbito da disciplina como um dos fundadores e o principal teórico da História dos Conceitos [Begriffsgeschichte], definida por ele da seguinte forma:

Por "História dos Conceitos" (ingl. conceptual history) designa-se desde a década de 1950 um projeto de pesquisa nos domínios da História que compreende a língua não como epifenômeno da dita realidade ("O ser determina a consciência", Karl Marx), mas como última instância irredutível metodologicamente, sem a qual não haveria experiência, tampouco uma ciência do mundo ou da sociedade. Para a História dos Conceitos, a língua é, por um lado, indicador da "realidade" com que nos deparamos, por outro lado, é fator desse deparar-se com a realidade. A História dos Conceitos nem é "materialista", nem "idealista"; ela tanto questiona que experiências e estados de coisas são sintetizados em conceitos quanto como experiências ou estados de coisas são conceitualizados. A História dos Conceitos, nesse ponto, estabelece o intermédio entre as histórias das línguas e das coisas. Uma de suas tarefas é a análise das convergências, deslocamentos ou discrepâncias que ocorrem no decorrer da história na relação de conceito e estado de coisas. ${ }^{131}$ (KOSELLECK, 2006a, p. 99)

\footnotetext{
${ }^{131}$ Als >Begriffsgeschichte $($ (engl. conceptual history) bezeichnet man seit den 1950er Jahren ein Konzept geschichtswissenschaftlicher Forschung, das Sprache nicht als Epiphänomen der sogenannten Wirklichkeit (»Das Sein bestimmt das Bewußtsein«, Karl Marx), sondern als methodisch irreduzible Letztinstanz versteht, ohne die keine Erfahrung und keine Wissenschaft von der Welt oder von der Gesellschaft zu haben sind. Für die Begriffsgeschichte ist Sprache einerseits Indikator der vorgefundenen »Realität«, andererseits Faktor dieser Realitätsfindung. Die Begriffsgeschichte ist weder
} 
Em sua História dos Conceitos, Koselleck trabalha com determinados conceitos que condensam em si toda uma rede de significados, agregando sistemas filosóficos, formações políticas, lugares históricos, dentre outros, tanto existentes quanto futuros, na forma de projeções para o porvir. A esses conceitos, Koselleck atribui a designação "conceitos fundamentais" [Grundbegriffe]:

Tão logo conceitos desse tipo se tornam insubstituíveis e não intercambiáveis, eles se tornam conceitos fundamentais, sem os quais nenhuma comunidade política e nenhuma comunidade linguística se entenderiam. Ao mesmo tempo, eles se tornam controversos, porque diferentes falantes querem impor um monopólio de significação. [...] O fato de serem insubstituíveis e, por isso, polêmicos difere os conceitos fundamentais, extremamente complexos, dos demais conceitos. Os potenciais de mudança histórica já estão contidos em todo conceito fundamental. ${ }^{132}$ (KOSELLECK, 2006a, p. 99s.)

Associada intimamente à História dos Conceitos está a História Social. Koselleck defende a inter-relação entre as duas áreas, pois, segundo seu entendimento, sem a organização social e sem os conceitos através dos quais a sociedade busca a compreensão e a solução para os desafios que enfrenta, não haveria história, o que torna a História dos Conceitos e a História Social imprescindíveis a qualquer estudo histórico ${ }^{133}$.

Embora o historiador, ao se especializar na História dos Conceitos ou na História Social, delimite o seu campo temático, essas, diferentemente das demais áreas de especialidade da História, não consistem em aspectos específicos da História Geral - a exemplo da História das Américas ou da História da Europa Renascentista, cuja delimitação segue critérios geográficos e temporais -, mas envolvem as mais diversas áreas de domínio da história. Dessa forma, trata-se de uma delimitação "transversal" da história, posto que é aplicável a qualquer temporalização ou delimitação espacial ${ }^{134}$.

De fato, a História Social e a História dos Conceitos teriam filiação, por um lado, com a Filosofia da História, bem como com outras áreas da disciplina como a História da

\footnotetext{
>materialistisch< noch >idealistisch «; sie fragt sowohl danach, welche Erfahrungen und Sachverhalte auf ihren Begriff gebracht werden, als auch danach, wie diese Erfahrungen oder Sachverhalte begriffen werden. Die Begriffsgeschichte vermittelt insofern zwischen den Sprach- und den Sachgeschichten. Eine ihrer Aufgaben ist die Analyse von im Lauf der Geschichte auftretenden Konvergenzen, Verschiebungen oder Diskrepanzen des Verhältnisses von Begriff und Sachverhalt.

${ }^{132}$ Sobald derartige Begriffe unersetzbar und unaustauschbar sind, werden sie zu Grundbegriffen, ohne die keine politische und keine Sprachgemeinschaft auskommt. Zugleich werden sie umstritten, weil verschiedene Sprecher ein Deutungsmonopol durchsetzen wollen. [...] Unersetzbar und deshalb strittig zu sein unterscheidet die hochkomplexen Grundbegriffe von sonstigen Begriffen. Geschichtliche Veränderungspotentiale sind in jedem Grundbegriff schon enthalten.

${ }^{133}$ KOSELLECK, 2006a, p. 12.

${ }^{134}$ Ibid., p. 9.
} 
Sociedade, a História da Civilização, A História da Cultura e dos Povos e com quaisquer outras correntes da história de viés social ou cultural. Por outro lado, a origem da História dos Conceitos está ligada com a Filologia e com a Lexicografia histórica, aplicáveis também a quaisquer disciplinas de cunho histórico e filológico que abordam suas fontes através do questionamento hermenêutico ${ }^{135}$.

Além de conceitos e ordens sociais serem imprescindíveis a qualquer história, Koselleck destaca a correlação entre História dos Conceitos e História Social a partir de seus objetos. Segundo afirma, todo evento histórico foi desencadeado ou articulado de forma linguística. Ainda assim, o ato histórico não se resumiria ao ato linguístico, isto é, haveria outros fatores não linguísticos que teriam influência na história. Isso, no entanto, ficaria raramente evidente, uma vez que essas diretrizes pré-linguísticas seriam, mais cedo ou mais tarde, verbalizadas pelas pessoas, reiterando-se, dessa maneira, a importância da língua falada para antecipar eventos, colocá-los em andamento e controlá-los, mas também para fixar ou preservar um evento ${ }^{136}$. Essa última característica é acentuada quando se desloca o foco da história presente para a história passada: uma vez ocorrido o evento, o contato com ele ficaria muitas vezes limitado a seu relato verbal. A despeito disso, é importante frisar que fala e ação, língua e história não correspondem em sua plenitude ${ }^{137}$.

Para defender essa tese, Koselleck aborda três estágios que marcam a relação entre elas: (1) requisitos pré-linguísticos e extralinguísticos da história; (2) a relação entre língua e história na consumação dos fatos; (3) a relação ex post entre língua e história, isto é, após o evento concretizado ${ }^{138}$. Esmiuçaremos melhor cada um desses estágios.

Há algumas diretrizes naturais, precedentes à língua, que os seres humanos compartilham com os demais animais. Trata-se de diretrizes de ordem geológica, geográfica, biológica e zoológica que já condicionavam a história antes da existência da comunicação verbal e sem as quais não haveria, afinal, história. Elas são "condicionantes metahistóricas". Segundo Koselleck, essas são três: (1) a oposição entre antes e depois (implicada na decurso da vida, na consciência de sua finitude, motivadora natural da história, e nas relações entre as gerações); (2) a oposição entre dentro e fora (implicada na relação

\footnotetext{
${ }^{135}$ KOSELLECK, 2006a, p. 10.

${ }^{136}$ Ibid., p. 15s.

${ }^{137}$ Ibid., 16ss.

${ }^{138}$ Ibid., p. 33.
} 
entre os diferentes grupos sociais, classes, estados federais, etc.); (3) a oposição entre acima e abaixo (implicada em toda estrutura hierárquica da sociedade) ${ }^{139}$.

Com essas três oposições, Koselleck pretende reforçar a tese de que a língua e a história não se sobrepõem, dado que essas condicionantes determinavam a história antes mesmo de haver língua. Naturalmente, todas essas oposições podem ganhar forma linguística e também através da linguagem podem ser alteradas socialmente e reguladas politicamente:

\begin{abstract}
Não há uma comunidade de ação que não defina a si mesma linguisticamente. Quase sempre ela é parte de uma determinada comunidade linguística, que julga se alguém a ela pertence ou se permanece excluído. Quase sempre é a capacidade de dominar determinadas formas de falar ou determinadas linguagens especiais que decide se alguém pode ascender ou cair, mover-se pelas camadas superiores ou inferiores da sociedade. Quase sempre há diferentes normas linguísticas que separam diacronicamente, de acordo com cada geração específica, as experiências e as esperanças dos velhos e dos jovens. ${ }^{140}$ (KOSELLECK, 2006a, p. 35)
\end{abstract}

Ainda assim, elas permanecem diretrizes elementares e, nesse estágio da relação entre história e língua, o agir tem prevalência sobre o falar.

Em segundo lugar, Koselleck discute a relação entre língua e história durante os acontecimentos. O principal ponto de diferença entre elas está em suas estruturas temporais. Enquanto a história está limitada a seguir a sequência dos eventos, são possíveis, através do discurso e do uso de determinados conceitos, criar formas alternativas de história e até mesmo prognósticos ${ }^{141}$. A língua guarda experiências de eventos passados que podem ser evocadas para, ante o diagnóstico da situação presente, formular prognósticos para o futuro ${ }^{142}$.

Por fim, Koselleck discute a relação entre língua e história após o fato ocorrido, âmbito propriamente dito de ação do historiador. Uma vez transcorrido o fato, segue-se a representação histórica desse evento, o qual se dá na forma de relato. Essa é, no entanto, a única forma que temos acesso ex post ao evento. Nesse estágio, portanto, a língua tem prevalência sobre a história. Por outro lado, toda representação histórica é uma seleção, não o evento de modo integral, mas aquilo que se optou por preservar, segundo fatores relacio-

\footnotetext{
${ }^{139}$ KOSELLECK, 2006a, p. 33ss.

${ }^{140}$ Keine Handlungsgemeinschaft, die sich nicht sprachlich selbst bestimmt. Fast immer ist es die Teilhabe an einer bestimmten Sprachgemeinschaft, die darüber befindet, ob jemand dazugehört oder ausgeschlossen bleibt. Fast immer ist es die Fähigkeit, bestimmte Sprechweisen oder Spezialsprachen zu beherrschen, die darüber entscheidet, ob sich jemand höher oder tiefer, oben oder unten in der Gesellschaft bewegen kann. Fast immer gibt es unterschiedliche Sprachnormen, die generationsspezifisch die Erfahrungen und Hoffnungen der Alten oder der Jungen diachron sortieren.

${ }^{141}$ KOSELLECK, op. cit., p. 37.

142 Ibid., p. 39.
} 
nados à distância temporal entre os eventos e o historiador (oposição antes-depois), o status do historiador na sociedade (oposição acima-abaixo) e a posição do historiador frente a seu objeto de pesquisa (oposição dentro-fora) ${ }^{143}$. Como afirma Koselleck, "toda história que nós mesmos não vivenciamos ou de que tomamos conhecimento por ouvir dizer é, em qualquer tempo, anotada pela primeira vez. Aí dever-se-ia manter na lembrança o que de outra forma estaria perdido para as gerações seguintes"144 (KOSELLECK, 2006a, p. 49). Em suma, é cabível afirmar que em toda história há mais do que o historiador pode dizer.

Contudo, esses são fatores ligados à figura do historiador, com base nas condicionantes meta-históricas. Há também questões relativas à língua que podem interferir na representação histórica. Para abordá-las, será necessário, no entanto, nos aprofundarmos na estrutura temporal da língua.

Ao longo da história, os conceitos são empregados por diversos atores políticos, recebendo diferentes acepções segundo seus interesses. No entanto, muito mais do que diferentes usos, um conceito tem uma história imanente:

\begin{abstract}
A história dos conceitos não reflete de forma simples interesses materiais ou políticos - isso ela também faz. Antes, a história dos conceitos mostra que nela estão incluídos os próprios desempenhos linguísticos que todos que buscam reconhecer ou influenciar o seu mundo precisam colocar em ação. Os conceitos têm, então, também uma história própria, imanente à língua. ${ }^{145}$ (KOSELLECK, 2006a, p. 57)
\end{abstract}

Os conceitos sedimentam experiências, relacionam as nossas com experiências do passado, registradas no acervo linguístico. Confrontando os problemas passados, é possível nos prepararmos para problemas futuros ${ }^{146}$.

O ser humano acumula experiências e as conceitualiza. Com essas novas experiências, os conceitos mudam. Perceber a mudança, todavia, requer que parte da estrutura em seu entorno permaneça constante. Mesmo na identificação das transformações semânticas e pragmáticas é necessário que outros elementos semânticos e pragmáticos permaneçam

\footnotetext{
${ }^{143}$ KOSELLECK, 2006a, p. 48s.

144 Jede Geschichte, die wir nicht selbst erlebt oder durch Hörensagen erfahren haben, ist irgendeinmal zum ersten Mal aufgeschrieben worden. Da sollte in Erinnerung behalten werden, was sonst verloren wäre für die Nachgeborenen.

${ }^{145}$ Die Geschichte der Begriffe spiegelt nicht in einer simplen Weise materielle oder politische Interessen wider - das tut sie auch. Vielmehr zeigt die Geschichte der Begriffe, daß in ihr die sprachlichen Eigenleistungen enthalten sind, die jedermann aufbringen muß, der seine Welt zu erkennen oder zu beeinflussen sucht. Die Begriffe haben also auch eine eigene, sprachimmanente Geschichte.

${ }^{146}$ Ibid., p. $58 \mathrm{~s}$.
} 
iguais para, assim, as diferenças saltarem aos olhos em contraste. Isso é válido tanto ao se introduzir uma nova informação como um novo termo: seu entorno deve ser conhecido ${ }^{147}$.

Cada conceito tem muitas camadas temporais e, de fato, nem todos os significados permanecem $^{148}$. Quando se busca, em meio a um entorno repetitivo, por mudanças, deve-se ter em mente que as mudanças podem ter diferentes ritmos e velocidades. É também importante considerar que a língua não tem apenas a função de registrar a realidade:

Por um lado, ela registra - receptivamente -, o que lhe é externo, ela constata o que lhe é impingido sem ser propriamente linguístico, portanto, o mundo como existe em sua forma pré-linguística e não linguística. Por outro lado, a língua toma para si - ativamente - todos os estados de coisas e circunstâncias extralinguísticos. $^{149}$ (KOSELLECK, 2006a, p. 61)

O fato de a língua e a história terem diferentes velocidades de mudanças não permite que se estabeleça uma correspondência total entre conceito e realidade:

O significado e o uso das palavras nunca estabelecem com a dita realidade uma correspondência de um para um. Ambos, conceitos e realidades, têm cada uma a sua própria história. Essas histórias remetem, é bem verdade, uma à outra, mas elas mudam de formas diferentes. Sobretudo conceitos e realidade alteram-se em velocidades distintas, de modo que ora a conceituação da realidade, ora a realidade da conceituação adiantam-se à outra. ${ }^{150}$ (KOSELLECK, 2006a, p. 67)

Outro argumento contra a correspondência total entre conceito e realidade está nas já mencionadas temporalidades discrepantes entre história e língua. Em princípio, um conceito acumula experiências passadas e atuais, carregando consigo, assim, "(...) um rico tesouro de experiências acumuladas com o tempo, mesmo quando os estados de coisas obtidos com isso fossem cada vez mais criticados. De todo modo, trata-se, em primeiro lugar, de um conceito de registro de experiências ${ }^{151 " ~(K O S E L L E C K, ~ 2006 a, ~ p . ~ 67, ~ g r i f o ~ n o ~}$ original). No séc. XVIII, uma transformação: muitos conceitos passaram a refletir uma mudança no pensamento e na realidade, deixando, dessa forma, de expressar apenas uma

\footnotetext{
${ }^{147}$ KOSELLECK, 2006a, p. 59s.

${ }^{148}$ Cf. ibid., p. 90 s.

${ }^{149}$ Einerseits registriert sie - rezeptiv -, was außerhalb ihrer der Fall ist, sie stellt fest, was sich ihr aufdrängt, ohne selbst sprachlich zu sein, die Welt also, wie sie vorsprachlich und nichtsprachlich vorhanden ist. Andererseits verwandelt sich die Sprache - aktiv - alle außersprachlichen Sachverhalte und Gegebenheiten an.

${ }^{150}$ Wortbedeutung und Wortgebrauch verhalten sich niemals zur sogenannten Wirklichkeit in einem Verhältnis von eins zu eins. Beide, Begriffe und Wirklichkeiten, haben ihre je eigene Geschichte, die zwar aufeinander verweisen, die sich aber auf unterscheidbare Weise ändern. Vor allem ändern sich Begriffe und Realität mit unterschiedlichen Geschwindigkeiten, so daß mal die Begrifflichkeit der Wirklichkeit, mal die Wirklichkeit der Begrifflichkeit vorauseilt.

${ }^{151}$ Der Begriff schleppte also einen reichen Erfahrungsschatz mit sich, der sich über die Zeiten hinweg angesammelt hatte, auch wenn die damit erfaßten Sachverhalte zunehmend kritisiert wurden. Jedenfalls handelt es sich zunächst um einen Erfahrungsregistraturbegriff (...)
} 
experiência. Tal conceito começa, assim, a visar a "(...) uma mudança de estado com fins sociais e políticos, bem como fins religiosos. (...) Ele se torna um conceito de promoção de experiências $^{152 " ~(p . ~ 68, ~ g r i f o ~ n o ~ o r i g i n a l) . ~ U m a ~ t e r c e i r a ~ v a r i a n t e ~ s u r g e, ~ d e ~ u m ~ c o n c e i t o ~ q u e ~}$ não mais expressa uma realidade concreta: "(...) ele se desprende completamente, enfim, do contexto das experiências presentes: ele se transforma num conceito de expectativas puro, carregado de utopias. ${ }^{153 "}$ (p. 68 , grifo no original)

Com isso, Koselleck conclui que não apenas todos os conceitos fundamentais são insubstituíveis e, assim, controversos, mas também sua estrutura temporal interna permite, diferente da história, apontar para presente, passado e futuro ${ }^{154}$. Desse modo, conceitos podem estar tanto carregados de experiências passadas e presentes quanto de expectativas futuras. De fato, quanto menos carregado de experiências for o conceito, mais carregado de expectativas ele será. Considerando seu passado, os conceitos de expectativa vivem de uma recorrência conhecida de profecias não cumpridas; no que diz respeito a seu futuro, eles têm um potencial utópico que pode estimular - como, de fato, o fazem - novas ações. Apenas quando uma palavra não é mais capaz de conter todas as expectativas por ela acumuladas, ela perde sua força e sai de uso, ainda que os problemas a que essas expectativas se referem não tenham deixado de existir: eles apenas recebem novas formulações e nova definição $^{155}$.

No entanto, a esse respeito, Koselleck observa uma mudança na relação entre experiência e expectativa nos tempos modernos. Até então, as expectativas para o futuro eram construídas a partir do passado e das experiências, de modo que as experiências limitavam as expectativas. A partir de finais do século XVIII, o olhar sobre o passado é substituído pelo olhar sobre o futuro:

\footnotetext{
Assim se abre um horizonte de expectativas, no qual não se vê na democracia apenas o conceito político que ele sempre foi, mas ao mesmo tempo um conceito, vinculado à filosofia da história, para o futuro. Esperança e ação são pensadas em conjunto na democracia temporalizada. ${ }^{156}$ (KOSELLECK, 2006a, p. 82)
}

\footnotetext{
${ }^{152}$ Vielmehr intendieren sie einen Verfassungswandel in sozialer und in politischer sowie in religiöser Absicht. Auch unser Begriff >Staat « nimmt an dieser Öffnung zur Zukunft hin teil. Er wird zum Erfahrungsstiftungsbegriff.

${ }^{153}$ Nachdem unser Begriff für lange Zeit Erfahrungen, die vorausgegangen waren, registriert hatte und präsent hielt, und nachdem er sich eine neue Zukunft erschließen sollte, löste er sich schließlich ganz aus dem Kontext gegenwärtiger Erfahrungen ab: Er wurde zum utopisch angereicherten, reinen Erwartungsbegriff.

${ }^{154}$ KOSELLECK, 2006a, p. 68.

${ }^{155}$ Ibid., p. 69s.

${ }^{156}$ So wird ein Erwartungshorizont erschlossen, der in der Demokratie nicht nur einen politischen Begriff sieht, der er schon immer war, sondern zugleich einen geschichtsphilosophischen Zukunftsbegriff. Hoffnung und Aktion werden in der verzeitlichten Demokratie zusammengedacht.
} 
A inclusão de noções da História dos Conceitos a nosso cabedal teórico permite-nos abordar a questão: Afinal, como os conceitos espelham - ou não espelham - a realidade? No caso específico do tema do presente trabalho: De que modo se correspondem o conceito de tradução defendido pela teoria e a prática de tradução, a tradução concreta? Todavia, se da História dos Conceitos extraímos os meios para tentar elucidar as (possíveis) mudanças de sentido dos conceitos funcionalistas ao longo do tempo, da Sociobiologia temos os meios para compreender como esses conceitos replicaram. Especialmente produtiva à nossa pesquisa é a noção de memes.

\subsubsection{Memes da tradução}

Em 1976, o biólogo britânico Richard Dawkins publicou The Selfish Gene [O gene egoísta], livro em que apresenta a teoria da evolução a partir da perspectiva dos genes, não dos organismos. Ele defende que os organismos vivos são "máquinas de sobrevivência", criadas pelos genes como forma de perdurarem "num mundo altamente competitivo" (DAWKINS, 2007, p. 39, tradução de Rejane Rubino), assegurando, assim, a própria sobrevivência através de sua capacidade de replicação. A obra, escrita em linguagem informal e metafórica, alcançou enorme sucesso, alçando ao status de best-seller.

Além de ajudar a popularizar o tema da evolução, uma das mais notáveis contribuições desse livro foi a introdução do conceito de "meme", voltado a descrever a evolução de fenômenos culturais, sujeitos, conforme observa o autor, aos mesmos tipos de leis darwinistas que os genes. Segundo Dawkins, a "transmissão cultural é análoga à transmissão genética, no sentido de que, apesar de ser essencialmente conservadora, pode dar origem a uma forma de evolução." (p. 325) Entretanto, diferentemente da transmissão de genes, desempenhada por organismos resultantes do processo de evolução, a transmissão cultural é uma tarefa humana, e é entre os humanos que a evolução cultural atinge todo o seu potencial.

Dawkins defende que, se há um princípio fundamentalmente universal, esse é o de que a vida evolui pela sobrevivência diferencial das entidades replicadoras ${ }^{157}$. Esse princí-

${ }^{157}$ DAWKINS, 2007, p. 330 
pio seria igualmente válido a genes e memes, compreendendo-se meme como uma "unidade de transmissão cultural, ou uma unidade de imitação." (p. 330, grifo no original):

\begin{abstract}
Exemplos de memes são melodias, idéias, slogans, as modas no vestuário, as maneiras de fazer potes ou de construir arcos. Tal como os genes se propagam no pool gênico saltando de corpo para corpo através dos espermatozóides ou dos óvulos, os memes também se propagam no pool de memes saltando de cérebro para cérebro através de um processo que, num sentido amplo, pode ser chamado de imitação. Se um cientista ouve ou lê sobre uma boa idéia, transmite-a aos seus colegas e alunos. Ele a menciona nos seus artigos e nas suas palestras. Se a idéia pegar, pode-se dizer que ela propaga a si mesma, espalhando-se de cérebro para cérebro. (DAWKINS, 2007, p. 330, tradução de Rejane Rubino)
\end{abstract}

Entende-se por imitação "o processo pelo qual os memes podem se replicar." (p. 332, grifo no original) No entanto, Dawkins alerta que nem todo meme consegue se propagar. Memes duradouros, a seu ver, têm as mesmas qualidades que garantem a sobrevivência de outros replicadores: a longevidade, a fecundidade e a fidelidade de cópia. No caso dos memes, contudo, a fecundidade é a característica mais decisiva: é a sua capacidade de se propagar que garante a durabilidade das ideias no cérebro das pessoas, embora nem sempre tenham essas ideias a mesma forma; a "fidelidade de cópia", assim, resumir-se-ia a uma essência da ideia.

A vantagem de empregar o conceito de meme em nossa pesquisa é a de ele ser capaz de elucidar o processo de disseminação de ideias. Nos estudos da tradução, o conceito foi previamente adotado por Chesterman (1997) para o mesmo fim. Segundo afirma, há determinados memes que encapsulam conceitos e ideias sobre a tradução em si, os quais nomeia memes de tradução ${ }^{158}$.

A opção por empregar a metáfora do meme tem o propósito de salientar o modo como as ideias, no processo de tradução, difundem-se e transformam-se, assim como a evolução biológica envolve mutações. Sob esse prisma, a função do tradutor deixa de ser a de preservar e passa a ser a de propagar, disseminar e desenvolver. Tradutores, portanto, "são agentes da mudança" (p. 2).

Ainda que as ideias não existam de forma idêntica na mente das pessoas, há semelhanças o suficiente entre elas para estabelecer um denominador comum, o meme ${ }^{159}$. Como os genes, as boas ideias perduram, enquanto as ruins, após um tempo, desaparecem. Nesse contexto, compreende-se por "boas" as ideias mutualistas, isto é, aquelas que beneficiam

\footnotetext{
${ }^{158}$ CHESTERMAN, 1997, p. 7.

${ }^{159}$ Ibid., p. 5.
} 
tanto a si mesmas como a seu portador; por oposição, são consideradas "ruins" ideias parasitas, que eventualmente matam seu hospedeiro. Conforme afirma Chesterman, "se um meme deve sobreviver, ele deve vencer os memes rivais, isto é, ele deve conquistar novos adeptos, ganhando cada vez mais aceitação. ${ }^{160 ", ~(p . ~ 6) ~}$

Memes podem ocorrer em dependência mútua de outros memes, dessa forma constituindo memomas ou complexos de memes. Nesse sentido, poder-se-ia pensar em teorias (por exemplo, uma teoria de tradução) como um complexo de memes ${ }^{161}$. Fato comum aos memes e a seus complexos é de que, além do processo de imitação, eles são replicados pela língua. Para que sejam transferidos para além de uma barreira cultural, a tradução é necessária. A tradução opera, dessa forma, como "máquinas de sobrevivência para memes." (p. 7)

Em toda sua história, as teorias de tradução teriam sido marcadas, segundo Chesterman, por basicamente cinco ideias a emergir em diferentes momentos do tempo. A essas ideias, Chesterman atribui a denominação de supermemes:

(1) Texto-fonte [source-text]: esse supermeme concentra a noção de que a tradução é direcional, indo de um lugar a outro. Além disso, também pertence a esse complexo de memes a ideia de que a tradução é "receptáculo" para algo, quase sempre, do significado do texto-fonte. Chesterman, no entanto, dirige a sua crítica à metáfora de transporte, subjacente a esse meme. Segundo alerta, ao se transportar algo, esse algo deixa de existir em seu local de partida, o que não corresponde ao processo tradutório: a tradução não anula a existência do textofonte em sua cultura, sendo mais bem descrita como um processo de propagação.

(2) Equivalência [equivalence]: um dos supermemes mais longevos da história de teorias da tradução, a ideia de equivalência pressupõe "igualdade" de alguma natureza entre texto-fonte ou texto de partida e o seu respectivo texto- alvo ou texto de chegada. No entanto, há conceitos que descrevem a relação entre os dois textos mais brandos no tocante à demanda por "igualdade", o que reflete a percepção de um fato da realidade: equivalência absoluta só é possível nos raríssimos casos em que a retrotradução também é possível. Segundo Chester-

\footnotetext{
${ }^{160}$ If a meme is to survive, it must beat its rival memes, i.e. it must win new adherents, gain ever wider acceptance.

${ }^{161}$ CHESTERMAN, 1997, p. 6 et seq.
} 
man, em face dessa percepção da realidade, a despeito do longo domínio do supermeme, esse parece estar em declínio.

(3) Intraduzibilidade [untranslability]: estreitamente ligado ao meme anterior, o princípio de intraduzibilidade baseia-se na premissa de que, se a equivalência absoluta é praticamente impossível, assim também é a tradução. Especialmente presente no âmbito da tradução literária, esse supermeme parece ter origens filosóficas, religiosas e linguísticas. No que concerne à linguística, porém, a intraduzibilidade está vinculada a uma noção de tradução como parte dos domínios da langue, negando-se o papel da parole no processo. Para Chesterman, parece pouco sagaz a presença desse meme, hoje, no pool de memes da tradução, embora reconheça que há textos de mais fácil tradução do que outros.

(4) Livre vs. literal [free-vs.-literal]: as discussões acerca da tradução têm envolvido, desde muito tempo, a oposição expressa por esse supermeme, embora ocasionalmente fosse incluído um meio-termo entre os dois. O conflito entre tradução livre e tradução literal sempre esteve vinculado à noção de equivalência: uma tradução literal implica a equivalência formal, enquanto uma tradução literal, uma equivalência funcional (ou equivalência nenhuma).

(5) Toda escrita é tradução [all-writing-is-translating]: o oposto do supermeme da intraduzibilidade, esse meme baseia-se na concepção da semiótica de que toda escrita, mesmo a tradução, consiste no mapeamento de significados em significantes. Desse modo, se toda escrita é tradução, traduzir é plenamente possível, sendo concebido como uma reescrita. Subjaz a esse meme a noção de que o significado não é algo pré-existente, mas sim, de que ele é negociado durante os processos comunicativos e interpretativos; o significado é "produzido" historicamente e instantaneamente. Esse supermeme, conforme o autor, é especialmente mutualista, enquanto os supermemes de equivalência e de intraduzibilidade parecem mais parasitários ${ }^{162}$.

Ainda que esses supermemes, sob uma ótica diacrônica, tenham estado sempre presentes no pool de memes da tradução, cada um deles ocupou uma posição diferente através da história, de acordo com a ideia sobre tradução a prevalecer num dado tempo.

\footnotetext{
${ }^{162}$ CHESTERMAN, 1997, p. 7 et seq.
} 
De fato, um dos feitos mais interessantes do livro de Chesterman é demonstrar que a história das teorias de tradução, sejam essas teorias fruto de pesquisa sistemática ou da reflexão de tradutores sobre sua prática, pode ser contada e analisada mediante o mapeamento histórico de seus memes. Ele mesmo propõe um esboço dessa história, com foco nas tradições europeias. Segundo afirma, cada nova tentativa de solucionar um problema culmina num novo problema, isto é, "cada teoria evolui de uma teoria anterior, reagindo a ela; cada nova teoria busca corrigir ou refinar algum aspecto da precedente, ou até mesmo ofe-

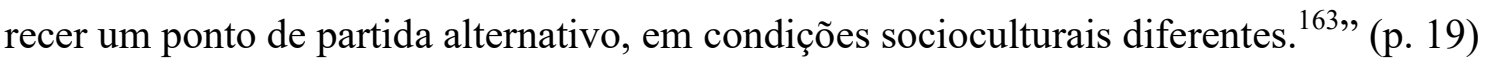

Assim são introduzidas algumas das principais correntes de pensamento da história da tradução, as quais deixaram traços ainda hoje presentes em seu pool de memes:

(1) Palavras [Words]: esse meme baseia-se na concepção de que traduzir é transportar o significado das palavras de uma língua a outra. Por trás desse meme está a noção de que as palavras se referem diretamente a elementos da realidade. A metáfora que prevalece nesse meme é a de que "traduzir é reconstruir", movendo-se os tijolos-palavras da estrutura arquitetônica de uma língua para outra. Visto que traduzir se resumiria a transportar os significados das palavras, não havia quaisquer dúvidas acerca da plena traduzibilidade.

(2) A Palavra de Deus [The Word of God]: a certeza da plena traduzibilidade começou a desvanecer quando outros níveis linguísticos (e não apenas o léxico) entraram em jogo no ato tradutório. A ignição para a mudança de perspectiva veio da tradução de textos religiosos, com base na crença de que os Textos Sagrados representam a sagrada Palavra de Deus e, por isso, não deveriam ser alterados, mas vertidos da forma mais literal possível, inclusive no atinente à sintaxe. A metáfora subjacente é a de que "traduzir é copiar", posto que o tradutor não tem autoridade para alterar o "original".

(3) Retórica [Rhetoric]: esse meme demonstra ser uma reação ao anterior, na medida em que propõe, para a tradução de textos não sagrados, uma nova postura: a ênfase aos gostos do público-alvo. Como resultado, a tradução torna-se extremamente livre. O tradutor passa a rivalizar com o autor original, resgatando a noção clássica de aemulatio. Dessa forma, a metáfora prevalecente nesse meme

\footnotetext{
${ }^{163}$ Each theory evolves out of, and reacts to, a preceding one; each new theory seeks to correct or refine some aspect of an earlier one, or even offer an alternative starting point altogether, in different socio-cultural conditions.
} 
é "traduzir é imitar", e imitar pressupõe força criativa. Ainda que o auge desse meme tenha sido o período da Renascença, há algumas manifestações suas mais recentes, sobretudo no trabalho dos pós-colonialistas (por exemplo, nas vertentes pós-modernas brasileiras).

(4) Logos: se o meme "retórica" foi uma reação à literalidade do meme anterior, esse foi uma reação à sua extrema liberdade. Emergente no Romantismo alemão, a ênfase desse meme está na equivalência formal, no estilo propositadamente marcado, estranho, estrangeiro, motivada por uma nova concepção de língua: “a língua era vista como uma força criativa, algo que moldava o mundo e a experiência humana. Língua era logos. Era a Palavra criativa. Utilizar a língua era, portanto, imitar o ato da divina criação. ${ }^{164,}$ (p. 26) O tradutor age como criador de uma cultura nacional. Logo, a metáfora que melhor define esse estágio é “traduzir é criar”. Manifestações desse meme, segundo Chesterman, seriam ainda observáveis na tradição estadunidense, especialmente na proposta de Lawrence Venuti, bem como no Desconstrutivismo de Derrida.

(5) Ciência linguística [Linguistic science]: a partir de meados do século XX, o foco das teorias de tradução desloca-se do texto literário para tradução de outros tipos textuais. Esse meme, cuja manifestação prototípica é a tradução automática, funda-se na equivalência estrita e em procedimentos linguísticos. "Traduzir é transcodificar", é uma operação linguística, é a busca por equivalência nos diversos níveis textuais. Por conseguinte, a noção de universais na linguagem era extremamente cara aos teorizadores desse tempo. Hoje, contudo, as contribuições da linguística para a tradução estão afastando o foco da equivalência, deslocando-o rumo à sociolinguística.

(6) Comunicação [Communication]: como reação ao meme anterior, em vez de uma operação linguística, a tradução passa a ser vista como uma operação comunicativa. Através desse meme, o tradutor é colocado no centro do processo de tradução, entre o autor original e o receptor final. O foco é, assim, ampliado para todo o processo sociológico de tradução. Não à toa, a metáfora que melhor define esse estágio é “traduzir é enviar uma mensagem a alguém”. Segundo Chesterman, é nessa fase da história das teorias de tradução que se enquadra o

\footnotetext{
$164(\ldots)$ language was seen as a creative force, something that gave shape and form to the world and to human experience. Language was logos. It was the creative Word. To use language was thus to imitate the act of divine creation.
} 
funcionalismo, que centra suas atenções na função do texto de chegada em seu ambiente de recepção. Mas não apenas: Chesterman identifica ainda aqui os trabalhos de Wilss (1977) e Pym (1992), entre outras contribuições.

(7) Alvo [Target]: nesse estágio, o foco está por completo no ambiente de chegada. Assim, o texto de partida cede lugar ao texto de chegada como alvo das preocupações de teorizadores e estudiosos da tradução. Introduzido pelos estudos descritivos da tradução, é uma marca desse meme a preocupação em descrever o que é a tradução, não determinar como ela deveria ser. Também aqui são abordadas questões concernentes a ideologia e poder. A metáfora que predomina nessa fase é "traduzir é manipular", pois considera-se que toda tradução implica certo grau de manipulação, por um lado, do texto de partida e, por outro, da cultura de chegada. Chesterman ainda destaca desse meme uma ampla consideração não só do produto da tradução, mas também do processo tradutório.

(8) Cognição [Cognition]: a preocupação com o processo de tradução que se insinuava no estágio anterior ganha prevalência neste meme. O foco está nos processos mentais por que passa o tradutor no exercício de sua profissão, bem como na natureza da competência tradutória do tradutor profissional. Influenciados por ideias recentes na Linguística Cognitiva e na Ciência da Cognição, as pesquisas utilizam de recursos como o TAP (think-aloud-protocol), através do qual os tradutores manifestam oralmente o que pensam enquanto traduzem, bem como, entre outros, o uso de recursos computacionais de captura de movimentos do teclado. Aqui, a metáfora predominante é "traduzir é pensar"165.

O mapeamento acima não apenas retrata a mudança das ideias sobre tradução ao longo do tempo, sugerindo, muitas vezes, um movimento que pendula entre posturas retrospectivas e prospectivas, como também manifesta uma concepção própria de desenvolvimento científico: cada nova proposta é uma reação à anterior, podendo aprofundar-se numa direção apontada no estágio anterior ou rumar numa direção totalmente oposta. Como declara Chesterman, os estágios estão apresentados numa forma mais ou menos cronológica, todavia, se por um lado alguns desses memes são concomitantes a outros, por outro

\footnotetext{
${ }^{165}$ CHESTERMAN, 1997, p. 21 et seq.
} 
lado, alguns emergem em diferentes momentos da história, em diferentes contextos e com diferentes motivações ${ }^{166}$.

Uma vez expostos os preceitos teóricos a nortear a nossa análise internalista, cumpre apresentar a metodologia dessa fase de análise.

\subsubsection{Linguística de corpus}

Ao percorrer brevemente a história recente da pesquisa da linguagem, o linguista britânico M. A. K. Halliday (2014) salienta a contribuição do desenvolvimento tecnológico para o estudo dos mais diversos aspectos da língua. Conforme afirma, o texto sempre foi a fonte de dados para a análise linguística e para a descrição gramatical. Apesar disso, em tempos mais remotos os textos utilizados nas descrições gramaticais costumavam ser, em princípio, "virtuais", isto é, frutos da imaginação e da criatividade dos gramáticos. A única forma "real" de texto até então disponível era o texto escrito, e apenas alguns gramáticos notáveis, tais como Otto Jespersen, recorreram a ele como fonte de dados ${ }^{167}$.

Com o desenvolvimento tecnológico, excepcionalmente no final dos anos de 1940, abriram-se novas possibilidades para a pesquisa linguística: gravadores passaram a capturar discursos espontâneos e computadores a viabilizar o armazenamento de dados em grandes volumes. Passados dez anos, pesquisadores da Brown University deram início aos primeiros corpora de textos escritos, prevendo posterior processamento desses textos por meio de computadores, ao mesmo tempo em que gramáticos como Halliday gravavam discursos e analisavam sobretudo as entonações e os ritmos de fala. De lá para cá, foram compilados amplos acervos computadorizados tanto de textos escritos como de textos orais $^{168}$.

A linguística de corpus faz uso desse acervo em análises voltadas, dentre outras possibilidades, à descrição linguística, à análise do discurso, de traduções e ao levantamento terminológico. Sua função, como define Berber Sardinha (2004), é a coleta e a exploração de corpora, com o propósito de servirem à pesquisa de uma língua ou variedade linguística. Sendo assim, a linguística de corpus "dedica-se à exploração da linguagem por

\footnotetext{
${ }^{166}$ CHESTERMAN, 1997, p. 20.

${ }^{167}$ HALLIDAY; MATTHIESSEN, 2014, p. 51.

${ }^{168}$ Ibid.
} 
meio de evidências empíricas, extraídas por computador" (BERBER SARDINHA, 2004, p. 3). Os textos são processados por ferramentas computacionais, focadas na identificação de ocorrências, recorrências e coocorrências de palavras ${ }^{169}$. Ao término do processamento, as ferramentas fornecem dados quantitativos acerca desses textos.

Não obstante, as ferramentas de análise de corpora também permitem análises qualitativas. De fato, Paul Baker (2006) acentua o fato de uma pesquisa baseada em corpus não poder prescindir tanto de uma análise quantitativa como de uma análise qualitativa. Ele cita Biber ${ }^{170}$, que afirma: "Padrões de associação representam relações quantitativas, que determinam em que medida atributos e variantes estão associados a fatores contextuais. Porém, interpretação funcional (qualitativa) é também uma etapa essencial em qualquer

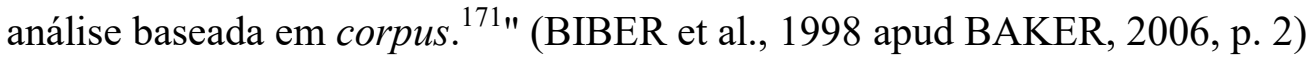

O objeto da linguística de corpus, por sua vez, pode ser definido como "bancos de textos de linguagem autêntica, criteriosamente construídos, destinados à pesquisa e legíveis por computador." (TAGNIN, 2015, p. 20) Nem todo banco de textos pode ser considerado um corpus. A esse respeito, Berber Sardinha enumera quatro requisitos definidores de um corpus: (1) um corpus deve ser composto de textos autênticos, produzidos por humanos em linguagem natural; (2) deve ser produzido por falantes nativos (assim, um corpus de aprendizes, por exemplo, precisa ser identificado de acordo); (3) deve ser criteriosamente selecionado, tendo em vista a pesquisa linguística e, acima de tudo, satisfazendo as condições de naturalidade e autenticidade, e; (4) deve ser representativo, segundo os objetivos da pesquisa ${ }^{172}$.

O fato de se enfatizar a linguagem autêntica na construção de um corpus vincula-se a uma concepção de língua como um sistema probabilístico. Trocando em miúdos: num sistema probabilístico, ainda que sejam possíveis inúmeras construções gramaticais, algumas dessas têm probabilidade maior de ocorrer ${ }^{173}$. Devido a essa característica, Berber Sardinha localiza a linguística de corpus no interior de uma vertente empirista da linguística:

\footnotetext{
${ }^{169}$ Cf. BERBER SARDINHA, 2004, p. 90s.

${ }^{170}$ BIBER, D.; CONRAD, S.; REPPEN, R. Corpus Linguistics: Investigating Language Structure and Use. Cambridge: Cambridge University Press, 1998, p. 4.

${ }^{171}$ Association patterns represent quantitative relations, measuring the extent to which features and variants are associated with contextual factors. However functional (qualitative) interpretation is also an essential step in any corpus-based analysis.

172 BERBER SARDINHA, op. cit., p. 19ss.

${ }^{173}$ Cf. TAGNIN, 2015, p. 20; HALLIDAY; MATTHIESSEN, 2014, p. 51s.
} 


\begin{abstract}
A Linguística de Corpus trabalha dentro de um quadro conceitual formado por uma abordagem empirista e uma visão da linguagem como sistema probabilístico; encaixa-se no que pode ser chamado de Linguística Empírica (119). Na linguística, empírico significa primazia aos dados provenientes da observação da linguagem, em geral reunidos sob a forma de um corpus. (BERBER SARDINHA, 2004, p. 30)
\end{abstract}

A essa abordagem estaria alinhado Halliday; do lado oposto, Noam Chomsky, fundador do Gerativismo e um dos maiores expoentes da linguística do século XX. Berber Sardinha resume essa polaridade ao afirmar que "Halliday vê a linguagem como probabilidade, enquanto Chomsky a enxerga como possibilidade [...]." (BERBER SARDINHA, 2004, p. 30, grifo no original) Apesar de muitos traços linguísticos serem teoricamente possíveis, muitos não ocorrem com a mesma frequência. A diferença de ocorrências, por sua vez, estaria relacionada com o contexto de uso da linguagem: um determinado contexto comunicativo favoreceria determinados padrões lexicais ou léxico-gramaticais em detrimento de ou$\operatorname{tros}^{174}$.

Quanto à questão da representatividade, essa está normalmente vinculada à extensão do corpus. Ele deve, em princípio, ser extenso e diversificado o bastante para contemplar uma grande quantidade de palavras de baixa frequência e de sentidos diferentes para essas palavras ${ }^{175}$. No entanto, mais importante do que sua extensão, um corpus deve ser adequado para os objetivos da pesquisa. Nesse sentido, Tagnin (2015) enfatiza a importância de se compilar um corpus norteado por critérios bem definidos, de acordo com o objetivo a que se destina, e a partir de fontes confiáveis, a fim de garantir também a confiabilidade dos resultados ${ }^{176}$.

Estabelecer o objetivo a que se destina o corpus é, de fato, o primeiro passo para a sua compilação. Em seguida, o pesquisador deve também estabelecer parâmetros para a construção do corpus, parâmetros esses que versam sobre a sua extensão e sobre as características dos textos que o compõem. Deve-se definir se o corpus terá atualizações, se será composto por textos numa só língua ou em mais de uma língua, qual será a proporção de diferentes tipos textuais, dentre outros parâmetros, sempre tendo o objetivo de pesquisa em vista. Mesmo que esses estejam estabelecidos antes da coleta, os parâmetros podem sofrer ajustes posteriores $^{177}$.

\footnotetext{
${ }^{174}$ BERBER SARDINHA, 2004, p. $31 \mathrm{~s}$.

${ }^{175}$ Ibid., p. 23s.

${ }^{176}$ TAGNIN, 2015, p. 20.

${ }^{177}$ Ibid., p. $27 \mathrm{~s}$.
} 
Compilados os textos, eles devem ser salvos em formato TXT (passível de reconhecimento pelas ferramentas de análise de corpora), limpos de elementos não relevantes para a pesquisa a ser conduzida e eventualmente anotados, isto é, enriquecido com informações adicionais, sejam elas referentes ao próprio texto ou a determinadas partes dele inclusive a palavras isoladas ${ }^{178}$.

Por fim, com auxílio das ferramentas computacionais é feita a análise. Em geral, os softwares voltados a essa finalidade apresentam as três ferramentas básicas para a análise: lista de palavras, lista de palavras-chave e concordâncias ${ }^{179}$ :

1. A lista de palavras exibe "(...) uma lista de todas as palavras num corpus, junto com suas frequências e a porcentagem da contribuição de cada palavra ao longo do corpus $^{180 "}$ (BAKER, 2006, p. 51). Nessa lista constam tanto o número de ocorrências em geral (tokens) quanto o número de palavras diferentes no corpus (types). Em geral, as palavras de maior ocorrência são palavras gramaticais, enquanto as primeiras palavras de conteúdo sugerem o tema do corpus. No final da lista estão as palavras de única ocorrência, as chamadas hapax legomena, que podem indicar tanto termos de uma área especializada como vocábulos usados criativamente.

2. A lista de palavras-chave, por sua vez, resulta da comparação de duas listas de palavras: uma do corpus de estudo e outra de um corpus de comparação, geralmente denominado corpus de referência. Segundo Tagnin, para fazer essa comparação, os programas utilizam-se de diversas opções de testes estatísticos: log-likehood (teste estatístico de máxima verossimilhança), T-score (escore-T) ou mutual information (informação mútua). Dessa forma, as ocorrências com frequências estatisticamente similares desaparecem, ressaltando apenas as palavras mais significativas do corpus. Portanto, a lista de palavras-chave "dá uma medida da saliência, ao passo que uma simples lista de palavras fornece apenas a frequência ${ }^{181 "}$ (BAKER, 2006, p. 125).

3. Por fim, o concordanciador gera linhas de concordância, isto é, "uma lista de todas as ocorrências de um termo de pesquisa particular num corpus, apresen-

\footnotetext{
${ }^{178}$ TAGNIN, 2015, p. 29s.

${ }^{179}$ Ibid., p. 31 ss.

${ }^{180}$ A word list is simply a list of all of the words in a corpus along with their frequencies and the percentage contribution that each word makes towards the corpus.

${ }^{181}$ A keyword list therefore gives a measure of saliency, whereas a simple word list only provides frequency.
} 
tada no contexto em que ocorrem; normalmente [há] algumas palavras à esquerda e à direita do termo de pesquisa ${ }^{182 " ~(B A K E R, ~ 2006, ~ p . ~ 71) . ~ A ~ p a r t i r ~ d a s ~}$ linhas de concordância, é possível identificar os padrões de coocorrência de palavras.

Além de permitir examinar a língua a partir de dados autênticos e de permitir a inclusão tanto de textos escritos quanto de textos originalmente orais (mediante a sua transcrição), o emprego da linguística de corpus permite o levantamento de dados quantitativos que conferem maior objetividade à pesquisa ${ }^{183}$. Halliday destaca o papel fundamental do uso de corpora para a teorização da língua, sobretudo no que concerne à obtenção de dados comprováveis: "O corpus é fundamental para o empreendimento de teorizar língua. Até agora, a linguística tem sido como a física de antes de 1600: com poucos dados confiáveis e nenhum senso claro da relação entre observação e teoria. ${ }^{184 " ~}$ (HALLIDAY; MATTHIESSEN, 2014, p. 51) Para tanto, o auxílio dos computadores é imprescindível. Dentre as vantagens trazidas pelo emprego de computadores na pesquisa linguística podem ser mencionadas a sua estabilidade, o maior grau de abrangência de dados passíveis de análise, a possibilidade de descoberta de novos fatos ou a contestação de opiniões e crenças prévias e uma mudança no próprio modo de se enxergar a linguagem ${ }^{185}$.

Entretanto, antes de encerrarmos essa breve exposição, cumpre ainda trazer algumas considerações acerca do estatuto da linguística de corpus. Segundo Berber Sardinha, a linguística de corpus não pode ser compreendida como uma disciplina, a exemplo das demais disciplinas vinculadas à linguística, pois ela trata de fenômenos enfocados por outras disciplinas. Desse modo, seria coerente concebê-la como uma "metodologia": "Entendendo metodologia como instrumental, então é possível aplicar o instrumental da Linguística de Corpus livremente e manter a orientação teórica da disciplina original." (BERBER SARDINHA, 2004, p. 36, grifo no original)

Apesar disso, a linguística de corpus não se resume a um mero conjunto de ferramentas. Logo, para definir a linguística de corpus como metodologia, faz-se antes necessário repensar o que se entende por metodologia: "(...) se entendermos metodologia como um

\footnotetext{
${ }^{182}$ A concordance is simply a list of all of the occurrences of a particular search term in a corpus, presented within the context that they occur in; usually a few words to the left and right of the search term.

${ }^{183}$ Cf. HALLIDAY; MATTHIESSEN, 2014, p. $51 \mathrm{~s}$.

184 The corpus is fundamental to the enterprise of theorizing language. Until now, linguistics has been like physics before 1600: having little reliable data, and no clear sense of the relationship between observation and theory.

${ }^{185}$ BERBER SARDINHA, 2004, p. 85.
} 
modo típico de aplicar um conjunto de pressupostos de caráter teórico, então a Linguística de Corpus pode ser vista como uma metodologia, pois traz consigo algo mais do que simplesmente o instrumental computacional." (p. 36, grifo no original)

Todavia, mesmo essa definição não seria de todo precisa. Berber Sardinha chama a atenção ao fato de haver algumas correntes de investigação e teorização no interior da linguística de corpus, tais como, por exemplo, as investigações do comportamento do léxico de John Sinclair, que não encontrariam lugar em qualquer outra área. Ademais, a linguística de corpus seria produtora de conhecimento novo, não podendo, dessa maneira, ser considerada apenas uma metodologia. Alternativamente, por alguns de seus principais autores atribuem a ela o estatuto de abordagem ${ }^{186}$.

No âmbito da tradução, especialmente associada à linguística de corpus está a busca por traços recorrentes em textos traduzidos, independentemente das culturas e dos gêneros textuais envolvidos. Trata-se da hipótese das "universais de tradução".

Em texto publicado em 1993, Mona Baker discorre acerca das possibilidades que se abrem aos estudos da tradução com a introdução de ferramentas de análise de corpora no então recém-constituído campo disciplinar. Contrariando uma das poucas declarações feitas por John Sinclair acerca da tradução, em que enfatiza a contribuição da análise de corpora na identificação de padrões linguísticos para a tradução automática, Baker defende que o efeito mais profundo que a linguística de corpus exerceria sobre a tradução seria "uma consequência de possibilitar-nos identificar aspectos do texto traduzido que nos ajudarão a entender o que é a tradução e como ela funciona. ${ }^{187 " ~(B A K E R, ~ 1993, ~ p . ~ 243) ~}$

Nesse sentido, ela faz menção a uma observação feita por diversos teorizadores, dentre os quais estão Gideon Toury e Itamar Even-Zohar, dois dos principais expoentes dos estudos descritivos da tradução, de que a própria atividade de traduzir imporia determinadas restrições ao comportamento tradutório, observáveis, como sintomas, através de padrões de uso linguístico característicos de textos traduzidos, padrões esses, contudo, não decorrentes da influência da língua de partida sobre a língua de chegada ${ }^{188}$. Assim, identificar esses padrões seria, na sua opinião, a tarefa mais importante da análise de corpora nos estudos da tradução. Baseados em pesquisas de pequenas proporções, alguns teoriza-

\footnotetext{
${ }^{186}$ BERBER SARDINHA, 2004, p. 36s.

${ }^{187}$ The profound effect that corpora will have on translation studies, in my view, will be a consequence of their enabling us to identify features of translated text which will help us understand what translation is and how it works.

${ }^{188}$ Cf. BAKER, 1993, p. 242.
} 
dores teriam levantado alguns traços que sugerem estar ligados à própria natureza do processo de tradução, dentre os quais se incluem:

- a tendência de textos traduzidos à explicitação, se comparados aos respectivos textos de partida ou mesmo a textos originalmente escritos na língua de chegada. Para Toury, a explicitação seria típica de todos os tipos de eventos comunicativos mediados, mesmo em interações em língua estrangeira, mas questiona se essa explicitação teria formas diferentes de se manifestar entre os diferentes tipos de comunicação;

- a tendência a elucidar possíveis ambiguidades e a apresentar formulações mais simples do que aquelas presentes no texto de partida, de modo a evitar eventuais dificuldades de compreensão;

- a tendência à formulações mais convencionais, bem como à correção gramatical;

- a tendência a evitar repetições, seja por sua eliminação ou através da substituição por sinônimos. Essa seria, segundo Toury, uma das normas mais persistentes e inflexíveis de tradução até então;

- a tendência ao exagero de determinadas características da língua de chegada, como aparente modo de "compensar" o fato de o texto não ter sido originalmente pensado para funcionar naquele ambiente;

- a tendência de traduções a constituírem um código próprio, intermediário entre as línguas de partida e de chegada ${ }^{189}$.

Baker faz, no entanto, a ressalva de que seriam necessárias mais investigações dessa natureza para que se pudesse afirmar que realmente se tratam de características universais da tradução. Para tanto, ela sugere o confronto do resultado de pesquisas empreendidas com diferentes pares linguísticos (ou, ao menos, entre a língua inglesa e diferentes outras línguas), de modo a comprovar se, de fato, essas características não resultam meramente do contato entre duas culturas específicas ${ }^{190}$.

\footnotetext{
${ }^{189}$ BAKER, 1993, p. 243ss.

${ }^{190}$ Ibid., p. 245.
} 
Reiteramos, contudo, que essa não é a única forma de pesquisa possível mediante o uso de corpora $^{191}$. O fato de destacarmos a hipótese dos universais de tradução diz respeito tão somente a seu quase status de formulação teórica sob o uso de corpora na tradução.

No presente trabalho, a linguística de corpus exerce menos o papel de uma abordagem, mais o de método. Faremos uso de seu instrumental para a identificação e a análise dos memes mais significativos da abordagem funcional em seu contexto de emergência, para posteriormente mensurarmos, mediante o contraste entre os tratamentos dados a esses mesmos elementos conceituais na pesquisa desenvolvida no âmbito dos estudos da tradução no Brasil.

\subsubsection{Procedimentos de uma análise internalista}

A primeira etapa metodológica de nossa pesquisa foi a construção de corpora, constituídos em grande parte por textos sem versão digital prévia, o que representou uma das maiores dificuldades dessa etapa. Assim, foi necessário primeiramente digitalizá-los e, em seguida, converter as imagens do formato JPEG em textos com o auxílio de um software de reconhecimento óptico de caracteres (OCR - Optical Character Recognition). Para isso, foi utilizado o sistema $A B B Y Y^{\mathrm{TM}}$ FineReader $9.0^{192}$. Após a digitalização e a conversão dos arquivos para o formato texto $M S$-Word ${ }^{\mathrm{TM}}(\mathrm{DOCx})$, seguiu-se o processo de limpeza dos corpora: os textos foram revisados, de modo a corrigir quaisquer inconsistências resultantes do processo de reconhecimento de caracteres, contando inclusive com o auxílio dos corretores ortográficos do aplicativo; depois, para evitar o risco de falsos resultados, a ortografia dos textos foi atualizada; por fim, longos trechos de citação em língua estrangeira e de exemplos foram excluídos do arquivo. Uma vez completas as edições, os documentos em formato MS-Word foram convertidos para o formato TXT, legível pelas ferramentas de processamento de corpus.

Em seguida, demos início à anotação dos corpora, com a inclusão de cabeçalhos aos textos, conforme o exemplo abaixo:

\footnotetext{
${ }^{191}$ Para exemplos das diversas possibilidades de pesquisa com corpora nos estudos da tradução, cf. VIANA; TAGNIN, 2015.

192 2008, https://www.abbyy.com/pt-br/
} 


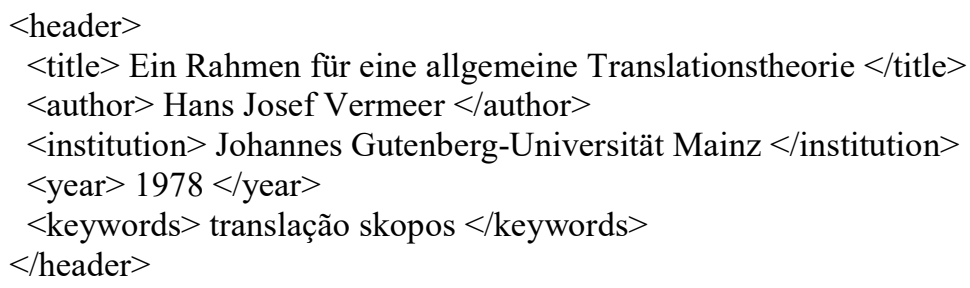

Nesse cabeçalho, reunimos informações que possam ser úteis posteriormente para selecionar os textos e conduzir análises posteriores. Incluímos informações referentes ao título, ao autor, à instituição a que esteve afiliado no momento de publicação, ao ano de publicação, além de uma lista de palavras-chave que descrevem melhor os principais tópicos abordados no respectivo texto.

A partir dos arquivos TXT, foram geradas no WordSmith Tools (SCOTT, 2016) listas de palavras de cada um dos componentes dos corpora. Além de uma relação das palavras mais frequentes, a lista de palavras proveu-nos de informações estatísticas acerca desses textos, tais como o número de ocorrências (tokens) e de palavras singulares (types). Com base nas listas de palavras, foi possível também gerar listas de palavras-chave. A cada componente de ambos os corpora foi gerada uma lista de palavras-chave em contraste com um corpus de referência. O corpus de referência de língua alemã foi compilado com o auxílio do software BootCaT Front-End (BARONI; BERNARDINI, 2004), que permite a extração de textos da web. Foram coletados sobretudo textos jornalísticos que versassem sobre os mais diversos temas (política, economia, sociedade, cultura, educação, etc.). Quanto aos textos de língua inglesa, foram utilizados como corpus de referência reportagens extraídas do jornal britânico The Guardian, também versando sobre diferentes assuntos. Dessa forma, pudemos contrastar um corpus especializado com um corpus de referência de língua geral.

No caso específico do corpus $\mathrm{C} 1$, geramos ainda uma lista de palavras-chave-chave [key keywords]. Trata-se, como observa Berber Sardinha, de uma "lista de palavras-chave que aparecem em um número de arquivos determinado" (BERBER SARDINHA, 2004, p. 112). Destarte, ela indica as palavras-chave incluídas em mais de uma lista de palavraschave de um mesmo corpus. Em nosso caso, as listas comparadas foram aquelas que elencam as palavras-chave dos textos seminais em língua alemã, visto que é imprescindível à geração dessa lista que as palavras sejam de uma mesma língua. Posteriormente, conferimos quais palavras também constam entre as palavras-chave da obra de Snell-Hornby (1998). 
Dos seis textos seminais escritos em língua alemã, em nossa lista de palavraschave-chave constam apenas palavras-chave inclusas em pelo menos cinco deles. Para que pudesse indicar os memes basilares da abordagem teórica como um todo, a lista foi objeto de refinamentos: os resultados foram avaliados em face do corpus, de modo a identificar quais representam, de fato, conceitos relevantes à teoria, com suas definições e explanações de sentido e uso, distinguindo-as de palavras presentes na lista por outros motivos. Como resultado, obtivemos a lista a seguir:

\begin{tabular}{|l|c|}
\hline Palavras-chave & Textos \\
\hline SPRACHE & 6 \\
\hline TEXT & 6 \\
\hline VGL & 5 \\
\hline TRANSLATION & 5 \\
\hline TEXTES & 5 \\
\hline Z & 5 \\
\hline ÜBERSETZUNG & 5 \\
\hline ÜBERSETZER & 5 \\
\hline ÜBERSETZEN & 5 \\
\hline TEXTE & 5 \\
\hline INFORMATION & 5 \\
\hline FUNKTION & 5 \\
\hline FAKTOREN & 5 \\
\hline SITUATION & 5 \\
\hline A & 5 \\
\hline SPRACHLICHE & 5 \\
\hline B & 5 \\
\hline
\end{tabular}

Tabela 01: Palavras-chave-chave da porção do C1 em língua alemã

À esquerda aparecem relacionadas as candidatas a palavras-chave da abordagem funcional como um todo, segundo os textos seminais reunidos em $\mathrm{C} 1$; à direita, o número de textos em que essas palavras são consideradas chave em nosso corpus. Embora traga alguns resultados interessantes, a lista ainda requer refino: ressaltamos, além do fato de algumas palavras serem flexões de um mesmo conceito [p. ex. texto: "Text" / "Texte" / "Textes"], a ocorrência de quatro possíveis abreviaturas: $v g l ., Z, A$ e $B$. Principiemos por elas.

$V g l$. [vergleiche] é uma indicação, comum em textos acadêmicos, a outros autores ou textos relacionados com determinado assunto; seu uso é análogo a nosso "cf." [confer]. Em nosso corpus, o termo é frequentemente acompanhado por outras referências bibliográ- 
ficas ou referências a trechos da própria obra, ou ainda é utilizado como modo de exemplificação. Vejamos alguns exemplos:

(vgl. etwa REISS 1969 ff., THIEL 1974a ff., WILSS 1977b und 1980a, KOLLER 1979, CARTELLIERI 1979, H. BÜHLER 1979 und 1984) ${ }^{193}$

[(cf. p. ex. REISS, 1969, passim; THIEL, 1974a, passim; WILSS, 1977b e 1980a; KOLLER, 1979; CARTELLIERI, 1979; H. BÜHLER, 1979 e 1984)]

(vgl. Kap. VI) $)^{194}$ [(cf. Cap. VI)]

Erst in deren Rahmen muss man sich dann auch über ,Wahrheit" unterhalten, weil der „Wert" einer Handlung $u$. a. auch von der Relation „Handlung :. Realität" abhängt (vgl. Irrtum, Lüge, ...) $)^{195}$.

[Apenas nesse quadro (de uma teoria do valor) há a necessidade de se discutir acerca de "verdade", pois o "valor" de uma ação depende, entre outros, também da relação "ação :: realidade" (cf. equivoco, mentira, ...)]

Assim, supomos que sua seleção pelo WordSmith Tools seja decorrente do fato de nosso corpus de referência ser composto predominantemente por textos jornalísticos, em que o uso dessa indicação é muito menos frequente. Assim, ela não teria qualquer significado conceitual em nosso corpus.

Quanto a $Z, A$ e $B$, nota-se também sua ocorrência em outras abreviações consagradas e em formas de enumeração, tais como z. B. [zum Beispiel: por exemplo], z. T. [zum Teil: em partes, parcialmente], (Z. 3) [Zeile: linha (de um texto)], Gruppe A, Gruppe B [grupo A, grupo B], u. a. [unter anderen: dentre outros], etc. $Z$ e $A$, no entanto, parecemnos especialmente interessantes, dada a sua coocorrência com palavras como $A$-Text ["texto-fonte" ou "texto de partida"], Z-Sprache ["língua-alvo" ou "língua de chegada"], ZKultur ["cultura-alvo" ou "cultura de chegada"], representando, assim, a abreviação, respectivamente, das palavras alemãs Ziel ["alvo" ou "de chegada"] e Ausgang(s) ["fonte" ou "de partida"]. Todavia, não é possível dizer se eles continuariam a ser termos-chave, não fossem as outras ocorrências mais gramaticais.

Assim, descartamos, ao menos por ora, as abreviações. Aglutinando as ocorrências das formas flexionadas de um mesmo termo, ficamos com os conceitos Sprache ["língua" ou "linguagem"], Text ["texto"], Übersetzung / Übersetzen ["tradução" / "traduzir"], Translation ["translação"], Übersetzer ["tradutor"], Information ["informação"], Funktion ["fun-

\footnotetext{
${ }^{193}$ NORD, 1988, p. 1.

${ }^{194}$ HÖNIG; KUSSMAUL, 1982, p. 78.

${ }^{195}$ VERMEER, 1978, p. 100.
} 
ção"], Faktoren ["fatores"] e Situation ["situação"]. Optamos por aglutinar os conceitos Übersetzung e Übersetzen, pois, diferente do que à primeira vista se possa supor, eles não designam sempre, de forma distintiva, o produto e o processo da tradução, podendo Übersetzung ser usada, como ficará claro na análise que se segue, também para designar o processo tradutório. No que concerne a sprachliche ["linguístico(a)"], notamos no corpus que a palavra coocorre com diferentes outras: sprachliche Äußerung [enunciado linguístico], sprachliche Form ["forma linguística"], sprachliche Gestaltung ["conformação linguística"], sprachliche Zeichen ["signos linguísticos"], entre muitos outros. Por fazerem referência à substância linguística e à sua manifestação em enunciados ou textos, pretendemos contemplar seus usos nas análises dos conceitos de língua e texto.

De modo a incluir a obra de Snell-Hornby ao levantamento de conceitos-chave, estabelecemos alguns correspondentes a eles em inglês, com base na observação do próprio texto da autora. Assim temos:

\begin{tabular}{|c|c|}
\hline Alemão & Inglês (Snell-Hornby, 1988) \\
\hline Sprache & language \\
\hline Text & text \\
\hline Übersetzung / Translation ${ }^{196}$ & translation \\
\hline Übersetzer & translator \\
\hline Information & information, meaning, message \\
\hline Funktion & function, purpose \\
\hline Faktoren & factor(s), criteria, element(s) \\
\hline Situation & situation \\
\hline
\end{tabular}

Tabela 02: Ocorrência das palavras-chave-chave no texto de Snell-Hornby (1988)

Depois incluímos o texto de Snell-Hornby, atualizando a tabela. Contrariando as expectativas, em primeiro lugar na lista não temos palavras que designam o processo tradutório. Observando, no entanto, a lista de palavras-chave gerada para cada texto, em comparação com o corpus de referência, notamos as seguintes primeiras palavras-chave: Übersetzung (Reiß, 1971; Hönig; Kußmaul, 1982); Translation (Vermeer, 1978; Reiß; Vermeer, 1984); translation (Snell-Hornby, 1988) Handeln (Holz-Mänttäri, 1984) e Text (Nord,

\footnotetext{
${ }^{196}$ Visto que Snell-Hornby não faz em inglês a distinção entre Übersetzung e Translation, reunimos os dois numa mesma linha.
} 
1988). Mesmo na lista de palavras-chave geradas com todos os textos do corpus em língua alemã, Übersetzung, Text e Translation são as primeiras palavras de conteúdo de maior chavicidade. Dessa forma, e como ficará claro na análise, o fato de Übersetzung ou Translation não constar no topo da lista deve-se muito às diferenças terminológicas entre as propostas. A nós, interessa principalmente em que medida essas diferenças terminológicas refletem uma diferença conceitual.

\begin{tabular}{|l|l|}
\multicolumn{1}{|c}{ Palavras-chave } & Textos \\
\hline Sprache & 7 \\
\hline Text & 7 \\
\hline Übersetzung / Translation & 6 \\
\hline Übersetzer & 6 \\
\hline Funktion & $6^{197}$ \\
\hline Information & $6^{198}$ \\
\hline Faktoren & $6^{199}$ \\
\hline Situation & 6 \\
\hline
\end{tabular}

Tabela 03: Tabela de palavras-chave-chave de $\mathrm{C} 1$ recalculada

Uma vez em posse da lista definitiva, partimos para a busca dessas palavras no corpus $\mathrm{C} 1$ através das linhas de concordância. Assim, percorremo-las à procura daquelas que ao menos parecem indicar uma definição ou esmiuçamento do respectivo conceito. Quando encontrada cada linha de concordância, consultamos o trecho referente a ela no texto, obtendo dessa forma mais contexto. Os trechos de definição de conceito foram, então, copiados para um arquivo do MS-Word, acompanhado de uma nota explicativa de como esse excerto se enquadra no contexto maior da obra em análise. Abaixo, um exemplo de nossa anotação:

[12] $\mathrm{Zu}$ beschreiben ist Translation als Prozess und dessen Produkt (das Translat), außerdem Zusammenhänge zwischen beiden (ihre Interdependenz).

[Translação pode ser descrita como processo e seu produto (o translato), além das circunstâncias entre ambos (sua interdependência)]

Observa-se que os números entre colchetes designam a(s) linha(s) de concordância em que os termos foram localizados, enquanto o conceito aparece no texto original em

\footnotetext{
${ }^{197} \mathrm{Na}$ lista de palavras-chave de Snell-Hornby (1988), encontrado apenas function.

${ }^{198} \mathrm{Cf}$. acima, encontrado apenas meaning.

${ }^{199} \mathrm{Cf}$. acima, encontrado apenas element.
} 
negrito. Abaixo, a nossa tradução do trecho em alemão. Incluímos o texto de partida no corpo da página apenas nesses casos; nos demais, em que o trecho citado não é objeto de análise internalista, o texto de partida localiza-se no rodapé da página.

Posteriormente, as anotações feitas acerca de cada meme foram contrastadas umas com as outras, mantendo-se a ordem de publicação dos textos, a fim de identificar diferenças nas definições. Os mesmos procedimentos foram adotados com os textos do corpus $\mathrm{C} 2$. Por fim, as informações resultadas da análise foram examinadas, dando insumo para nossas conclusões. 
2.

Funcionalistas entre nós 
A história de nosso campo disciplinar é um terreno de pesquisas bastante fértil, mas ainda pouco explorado. De fato, há uma diversidade de autores, aportes teóricos e projetos de pesquisa, cuja história é passível de exame, mediante a utilização de testemunhos e de documentos. A prova disso - e também a prova da fertilidade do campo - são alguns estudos exemplares conduzidos sobre o tema, os quais exploram fontes diversas, como, por exemplo, anais de eventos acadêmicos e trabalhos de grau defendidos em instituições de ensino brasileiras.

Entretanto, no que concerne à história do funcionalismo alemão no país, uma pesquisa que tente reconstituir o percurso da abordagem teórica no Brasil é ainda sem precedentes. Nesse sentido, estamos abrindo com o presente trabalho um novo terreno de pesquisas, com a esperança de que possa ensejar outros estudos posteriores, a partir de diferentes perspectivas e com base em diferentes objetos de pesquisa.

Neste capítulo, optamos por recuperar a história do funcionalismo no Brasil a partir de artigos científicos, dado que, retomando as palavras de Kragh (2003), eles apontam para as frentes de pesquisa do campo disciplinar. Para tanto, primeiro faz-se necessário contextualizar o campo de pesquisas, mediante o uso de informações veiculadas pelos estudos exemplares a que nos referimos acima. Assim, é com prazer que passamos agora à exposição desse contexto institucional.

\subsection{Um balanço dos estudos da tradução no Brasil}

\subsubsection{Os estudos da tradução no Brasil até a década de 1970}

Em relatos da história dos estudos da tradução no Brasil, parece haver o consenso de que seu momento inaugural foi a publicação do livro de Paulo Rónai, Escola de Tradutores, em $1952^{200}$. Nesse livro, Rónai reúne reflexões tecidas ao longo de anos de atividade como tradutor, revisor, crítico e professor, sistematizadas na forma de uma teoria de tradução. Com as novas edições, novos textos foram acrescidos ao livro, enquanto outros foram revistos e modificados, a ponto de, na quinta edição, de 1987, o livro totalizar 21 capítulos.

\footnotetext{
${ }^{200}$ À guisa de exemplo, mencionamos os trabalhos de John Milton (MILTON, 2015) e de Maria Paula Frota (2007), que estabelecem a publicação da obra como marco fundador dos estudos da tradução no Brasil, sendo o primeiro livro a versar sobre a tradução publicado no país.
} 
Contudo, esse marco fundador poderia ser considerado ainda anterior. Dedicada a explorar a gênese dessa obra, a tese de Doutorado de Zsuzsanna Spiry (2016) traz a informação de que, como era de praxe à época, alguns dos artigos a compor o livro foram publicados avulsos, previamente à sua organização no volume editado pelos Cadernos de Cultura $^{201}$. O artigo mais antigo, "Traduzir o intraduzível", foi publicado no jornal carioca Correio da Manhã em 21 de dezembro de 1947; a ele seguiram-se mais seis outros artigos, publicados no Correio da Manhã e no Diário de Notícias entre 1948 e 1950, até a compilação do tomo ${ }^{202}$.

Seja como for, o livro de Paulo Rónai, acompanhado da obra de Brenno Silveira, $A$ arte de traduzir, publicada em São Paulo em 1954, representa o início da produção intelectual dedicada à tradução no país. Conforme explica Spiry, o livro de Silveira resultou das observações e do convívio de seu autor com o grupo de tradutores da editora para a qual trabalhava, reunindo palavras e expressões do inglês que pudessem trazer problemas de tradução ${ }^{203}$. Embora não traga reflexões de cunho teórico, foi uma importante contribuição para demarcar esse momento inaugural dos estudos da tradução no Brasil.

Passado esse primeiro momento de produção bibliográfica, houve um hiato de vinte anos até a retomada da publicação de livros dedicados ao tema, com o lançamento, em 1974, do livro Byron no Brasil: traduções, de Onédia Barboza. O próprio Rónai só viria a publicar um novo volume, A tradução vivida, em 1975. Acrescem-se a esses a obra Tradução: ofício e arte, lançada em 1976 por Erwin Theodor Rosenthal, então docente da Área de Alemão da Universidade de São Paulo ${ }^{204}$. Sobre esse último, Azenha Jr. (2006a) considera que o livro se insere numa perspectiva essencialista da tradução e é permeado por uma noção de um sentido intrínseco ao texto, que não considera a intervenção do leitor, além de ser respaldado, dentre outros aspectos, pelas noções de fidelidade e equivalência e pela dissociação entre sujeito e objeto.

Azenha Jr. enfatiza ainda o papel de Rosenthal na concepção do Curso de Tradução da USP, inclusive no que tange ao arcabouço teórico a embasar suas atividades, o que teria influenciado a própria produção acadêmica de docentes e discentes da USP no mesmo período ${ }^{205}$. Presume-se, assim, que essas ideias tenham caracterizado o clima intelectual à época no âmbito da teoria e do ensino de tradução.

\footnotetext{
${ }^{201}$ SPIRY, 2016, p. 12 et seq.

${ }^{202}$ Ibid., p. 59.

${ }^{203}$ Ibid., p. 14.

${ }^{204}$ Cf. FROTA, 2006, p. 20; AZENHA JR., 2006a, p. 30

${ }^{205}$ AZENHA JR., op. cit., p. 38.
} 
Outro marco digno de nota dos estudos da tradução no Brasil foi a reforma universitária com a então nova Lei de Diretrizes e Bases da Educação Nacional (LDB), promulgada em 1968. Conforme relata Frota (2006), a nova LDB propiciou a criação dos primeiros cursos de formação de tradutores no âmbito da graduação. No mesmo ano, a Pontifícia Universidade Católica do Rio de Janeiro (PUC-RJ) criou o curso pioneiro de tradução no nível de bacharelado, sob a supervisão de Maria Candida Bordenave. Segundo Martins (2006), com a reforma universitária, a PUC-RJ teria criado quatro novas habilitações para o bacharelado em Letras, inclusive a habilitação de revisor-tradutor-intérprete. Para ela, um dos maiores desafios em sua criação teria sido conciliar a constituição de um programa que ao mesmo tempo satisfizesse as demandas do mercado e se enquadrasse na estrutura já existente havia décadas do departamento de Letras. O curso passou por vários ajustes, encontrando sua forma atual em 1978, quando a formação de tradutores foi desvinculada da formação de intérpretes $^{206}$.

Quanto ao arcabouço teórico a embasar o curso, Martins explica que - a exemplo do que vimos da análise de Azenha Jr. no concernente à produção intelectual no âmbito da tradução na USP - ele era constituído, de forma predominante, pelas ideias de Vinay e Darbelnet, Nida e Jakobson, tendo em vista a forte influência da linguística e a escassez de diferentes abordagens. Todavia, as disciplinas, de modo geral, não teriam de toda forma contado com um componente teórico proeminente; elas se subdividiam simplesmente em tradução literária e tradução técnica, sendo a tradução literária a área mais procurada ${ }^{207}$.

O segundo curso de formação de tradutores foi fundado pela Faculdade IberoAmericana de Letras e Ciências Humanas (FIA), em 1972. O relato de Adauri Brezolin (2006) acerca da criação do curso, no entanto, é precedido de uma breve contextualização da situação - ou melhor, de duas situações - a marcarem a tradução no final da década de 1960:

A primeira situação, talvez mais global, refere-se à conscientização de que a formação profissional do tradutor também devesse passar pelos bancos da universidade, uma vez que era notória a necessidade de pessoal especificamente treinado para a prática de uma atividade milenar e cada vez mais solicitada, em virtude da crescente troca de informações técnicas, científicas, literárias, entre outras. A segunda situação, em parte decorrente da primeira, e, portanto, de um ponto de vista mais global também, criava a exigência de atender à demanda por profissionais qualificados na área da tradução, daí a necessidade de se criarem cursos que contemplassem tal formação. Além disso, não podemos dissociar essa segunda situação do fato de que o Brasil, apenas com os cursos oferecidos pelas

\footnotetext{
${ }^{206}$ MARTINS, 2006, p. 23.

${ }^{207}$ Ibidem.
} 
universidades públicas, não conseguia atender à demanda por cursos universitários em geral, quiçá por cursos inexistentes. (BREZOLIN, 2006, p. 26)

A criação do curso da FIA teria sido movida pelo ideal de vários catedráticos, em especial, de Júlio García Morejón, seu principal mentor. Ele teria como diferencial a oferta de uma habilitação dupla, o bacharelado em Tradução e Interpretação e a licenciatura em Língua Estrangeira/Língua Portuguesa. No que tange à língua estrangeira, até 1978 os alunos deveriam escolher, além da língua portuguesa, outras duas línguas estrangeiras, estando as opções restritas ao alemão, ao espanhol e ao inglês. Posteriormente, dada a baixa procura, o alemão deixou de ser oferecido, e as opções teriam ficado limitadas à Tradução e Interpretação Inglês/Português e a Licenciatura em Espanhol/Português ${ }^{208}$.

Sobre o perfil do curso, Brezolin relata:

\begin{abstract}
O perfil do curso, assim como o de outros surgidos posteriormente, sempre se estabeleceu nos moldes dos Cursos de Letras, cujo enfoque mais marcante está nos aspectos filológico-lingüísticos, o que resulta na priorização do ensino de línguas. Isso não quer dizer que o ensino das línguas estrangeira e materna não deva ser adequadamente ministrado, não deve, porém, ser o fio condutor de um curso com objetivos distintos dos de Letras. (BREZOLIN, 2006, p. 26s.)
\end{abstract}

Ele explica que a ênfase ao ensino de línguas se deve à falta de conhecimentos linguísticos dos ingressantes. Ainda sobre o curso, ele nos conta que, desde seu início, teoria e prática estiveram integradas. Os professores, em seu início, teriam sido egressos do curso de Letras; mais de trinta anos depois, no entanto, a maioria dos docentes seria composta por egressos do próprio curso de Tradução, seja da graduação ou da especialização.

Com base nos dois relatos, nota-se que os primórdios da formação acadêmica de tradutores e intérpretes foram influenciados pelo clima intelectual à época: a fim de satisfazer a demanda por tradutores especializados, os cursos foram criados no interior da estrutura dos cursos de Letras já existentes, escorados na tradição linguística-filológica que dominava os estudos da tradução como um todo. Além dos cursos da PUC-RJ e da FIA, Frota (2006) informa-nos que o bacharelado em Letras passou a incluir a habilitação de tradução em outras instituições, tais como a Universidade Federal do Rio Grande do Sul (UFRGS), em 1973, a Universidade Estadual Paulista (UNESP), em 1978, e a Universidade de Brasília (UnB), em $1980^{209}$.

\footnotetext{
${ }^{208}$ BREZOLIN, 2006, p. 26.

${ }^{209}$ FROTA, 2006, p. 4.
} 
Frota confere ainda destaque "à primeira inserção da tradução em nível de pós-graduação", em 1980, "com a criação, na USP, da pós-graduação lato sensu" (FROTA, 2006, p. 4). Essa história é, entretanto, mais bem explicada por Azenha Jr. (2006a), que conta que o curso de tradução foi criado em 1978, paralelamente ao bacharelado e a licenciatura como uma nova modalidade de graduação, funcionando assim até 1980. Em 1981, ele teria passado à categoria de Curso Extracurricular: assim, nascia o Curso de Especialização em Tradução da Faculdade de Filosofia, Letras e Ciências Humanas da USP (CETRAD). Embora essa mudança tenha elevado a carga horária do curso para 1200 horas/aula, ela teria retirado a tradução da grade curricular da instituição, relegando-a à condição de curso de extensão, condição em que permaneceu por mais de uma década: ele só teria ganhado o status de curso de pós-graduação lato sensu em $1992^{210}$.

Durante esse tempo, a tradução na USP não teria um perfil próprio, sendo apenas um meio para aperfeiçoar conhecimentos de língua estrangeira. A esse respeito, Azenha Jr. comenta:

\begin{abstract}
Ao longo desse período, e acompanhando a constituição do campo disciplinar específico dos Estudos da Tradução no Brasil, a tradução na USP ainda não possuía um perfil específico, sendo entendida, basicamente, como instrumento para $\mathrm{o}$ aprofundamento dos conhecimentos em língua estrangeira adquiridos pelos estudantes na graduação. Em vários momentos, o Curso chegou mesmo a ser considerado uma etapa de transição entre a graduação e a pós-graduação, durante a qual os candidatos à pós - sobretudo aqueles formados em línguas como o alemão - teriam oportunidade de aprofundarem seus conhecimentos na língua estrangeira, antes de iniciarem o programa de mestrado ou doutorado. (AZENHA JR., 2006a, p. 29)
\end{abstract}

Além da constituição dos primeiros cursos de tradução, o período que compreende as décadas de 1960 e 1970 viu a criação dos primeiros fóruns de discussão entre acadêmicos e profissionais. Nesse contexto, é imprescindível referirmo-nos ao I Encontro Nacional de Tradutores. O evento ocorreu nos dias 23, 24 e 25 de abril de 1975 no campus da PUC-RJ, graças à iniciativa de professores universitários como Maria Candida Bordenave, fundadora e coordenadora do Curso de Tradutor e Intérprete da PUC-RJ, e Affonso Romano de Sant'Anna, diretor do Departamento de Letras e Artes. A organização do evento contou também com a participação da Associação Brasileira de Tradutores (ABRATES), à época presidida por Paulo Rónai, fundada um ano antes. $O$ fórum de discussões teve a participação de nomes como Antonio Houaiss e abordou tanto temas de natureza teórica - tais

${ }^{210}$ AZENHA JR., 2006a, p. 29. 
como a distinção entre tradução técnica e tradução literária, bem como a noção de tradução como criação - quanto temas mais ligados à atividade profissional - tais como a consciência e a ética profissional, a desvalorização e a informalidade da profissão etc. ${ }^{211}$

Diretamente do acervo de Paulo Rónai, Spiry (2016) traz o relato de Ana Maria Machado, publicado pelo Jornal do Brasil no dia 5 de maio de 1975. Segundo o relato, as 150 vagas inicialmente abertas a estudantes da PUC para o congresso foram logo preenchidas, chegando-se ao número de 300 inscritos - "uma afluência de público muito acima do previsto", conforme expressa a autora. O artigo ainda traz a informação de que muitos desses inscritos vieram de outros estados, o que comprovaria o grande interesse público no tema ${ }^{212}$. Ao término, foram publicados os objetivos, conclusões e recomendações do Encontro:

Como objetivos, mencionam-se a reunião de pessoas ligadas à atividade de tradução, a congregação dos órgãos de classe existentes (porém dispersos), e a discussão dos problemas do tradutor (reconhecimento, remuneração, relação tradutor-editor, dificuldades no ensino de tradução). Como conclusões, são destacadas a complexidade e responsabilidade da profissão de tradutor e a inexistência de fontes de consulta no Brasil (alto custo do material importado, ausência de unanimidade no uso da terminologia técnica). Por fim, recomenda-se a unificação dos esforços das associações no sentido de reconhecimento da profissão, além do estabelecimento de uma sólida política profissional do tradutor (obtenção dos direitos autorais, exigência de contratos, criação de centros de consulta e informação). (SILVA; ESQUEDA; CAMPOS, 2017, p. 1459)

A despeito do sucesso do primeiro Encontro Nacional de Tradutores, o segundo só viria a ser organizado dez anos depois, entre os dias 29 e 31 de maio de 1985, sediado novamente pela PUC-RJ e contando novamente com o auxílio da ABRATES. No texto de abertura dos Anais do II Encontro Nacional de Tradutores, reproduzido num número especial do periódico Tradução em Revista, a coordenadora do evento, Maria Candida Diaz Bordenave, compartilha as três ideias que motivaram a sua realização:

Três ideias nos inspiraram e nos impulsionaram para a realização deste Encontro. A primeira delas, a preocupação com a tradução enquanto área acadêmica. Por ser relativamente nova na Universidade - o curso da PUC-RJ, um dos mais antigos, foi iniciado com a reforma universitária de 1968 — a tradução constitui um campo importante e promissor, exigindo uma reflexão teórica sólida que considere todas aquelas áreas do saber de onde se podem extrair elementos relevantes para o seu estudo: a sociolinguística, a psicolinguística, a pragmática, a semântica, a teoria literária, a psicologia cognitiva, a filosofia, entre outras. Em segundo lugar, a relevância e a imprescindibilidade da tradução e do tradutor em

\footnotetext{
${ }^{211}$ SILVA; ESQUEDA; CAMPOS, 2017, p. 1458 et seq.

${ }^{212}$ Cf. SPIRY, 2016, p. 15 et seq.
} 
um país linguisticamente isolado como o Brasil. Este fato precisa ser enfatizado, repetida e incessantemente, e cada tradutor deve tê-lo muito presente. E terceiro, a situação profissional do tradutor. Conhecemos muito bem a injustiça que se comete a cada dia com o tradutor, em termos do seu reconhecimento intelectual e da atribuição de honorários. Assim, estes três pontos, a tradução como área acadêmica, o seu papel social e o tradutor como profissional, foram os três eixos ao redor dos quais construímos o nosso programa, e ao redor dos quais esperamos unir os nossos esforços para atingir definições claras, fixação de diretrizes, programas de ação. (BORDENAVE, 2012, p. 1s.)

A importância profissional do tradutor teria sido destacada em diversas conferên$\operatorname{cias}^{213}$. Porém, conforme observa Frota, o II Encontro Nacional de Tradutores já encontrou um ambiente acadêmico que, embora ainda embrionário, já estava desenvolvido o suficiente para ensejar novas edições. Assim, o terceiro encontro foi realizado entre os dias 26 e 28 de agosto de 1987, no campus da UFRGS, com o tema "O ensino da tradução" ${ }^{214}$. O congresso foi organizado pela professora Sara Viola Rodrigues, com foco especialmente em três áreas: tradução literária, tradução técnica e científica e interpretação. Em sua conferência de abertura, Francis Henrik Aubert destaca a importância de eventos dessa natureza para o abandono das rotinas individuais e o intercâmbio de ideias ${ }^{215}$. Numa reflexão retrospectiva acerca das primeiras edições do Encontro, Lia Wyler constata que, se o primeiro parecia mais um encontro de uma classe profissional, os demais tiveram um perfil mais acadêmico $^{216}$.

\subsubsection{Os anos de 1980}

De fato, essa mudança de perfil no congresso reflete um crescimento da presença da tradução no meio acadêmico ao longo da década de 1980. Um produto desse processo de crescimento, ao mesmo tempo um marco fundamental para o desenvolvimento dos estudos da tradução no Brasil, foi a criação do Grupo de Trabalho de Tradução da Associação Nacional de Pós-Graduação em Letras e Linguística (ANPOLL). O GT de Tradução da ANPOLL teria surgido por sugestão de Edson Rosa da Silva, professor da área de literatura da Universidade Federal do Rio de Janeiro (UFRJ), durante o I Encontro Nacional da ANPOLL, realizado em 1986. Frota observa que, ainda nessa época, o campo era muito inci-

\footnotetext{
${ }^{213}$ SILVA; ESQUEDA; CAMPOS, 2017, p. 1460.

${ }^{214}$ FROTA, 2006, p. 4.

${ }^{215}$ SILVA; ESQUEDA; CAMPOS, loc. cit.

${ }^{216}$ FROTA, loc. cit.
} 
piente, com suas atividades resumidas quase em sua totalidade ao ensino no nível da graduação. A tradução estaria apenas começando o seu percurso no âmbito da pós-graduação stricto sensu, com a criação, um ano antes, da primeira área de concentração dedicada aos estudos da tradução no Programa de Pós-Graduação em Linguística Aplicada da Universidade de Campinas (UNICAMP). Nesse contexto, Frota avalia que o GT de Tradução teria sido fundamental para aproximar os poucos docentes de tradução disseminados em diferentes pontos do país, contribuindo assim para fortalecer e expandir a área ${ }^{217}$. No que concerne ao início do GT de Tradução da ANPOLL, como vimos, em ocasião do II Encontro Nacional da ANPOLL, Frota relata:

\footnotetext{
Nela esteve presente o então coordenador do GT e seu criador, o também já mencionado professor Edson Rosa da Silva, com quem havíamos tido somente contatos telefônicos que visaram justamente a organização da reunião, na qual ele então nos informou em detalhe como se estruturava a Anpoll e como se esperava que funcionassem os GTs. Diante de sua proposta de que a coordenação do GT fosse assumida por alguém da área, foi indicado o nome da professora Maria Candida Bordenave, que o coordenou até 1989. Já nessa primeira reunião foram apresentados seis trabalhos, cujos resumos constam dos Anais (pp. 103-108), todos de professoras do Rio: Eliane Zagury, da UFRJ e da UERJ; Irène Monique H. Cubric e Vera Azambuja Harvey, ambas da UFRJ; Marcia A. P. Martins, da PUC/RJ e da Faculdade da Cidade; Maria Candida Bordenave e Maria Paula Frota, nós duas da PUC/RJ. (FROTA, 2006, p. 6)
}

Os esforços empreendidos no âmbito do GT de Tradução da ANPOLL só viriam a ser sentidos de forma mais clara na década seguinte. Dada a disseminação de pesquisas sobre a tradução em diferentes áreas e a consequente dificuldade de fazer um levantamento preciso da produção intelectual em IES no Brasil, Rodrigues (2013) examina alguns levantamentos feitos por outras autoras, de modo a estimar a quantidade de trabalhos de grau que versam sobre a tradução defendidos em universidades brasileiras. Segundo Lia Wyler, até 1989 haveria 24 teses e dissertações sobre a tradução, mas ela não indica o momento de início da contagem; Adriana Pagano e Maria Lucia Vasconcellos teriam identificado apenas sete trabalhos entre 1987 e 1989; Maria Paula Frota, por sua vez, teria encontrado seis até 1989, tendo sido a primeira delas defendida em 1973. Apesar das discrepâncias, Rodrigues salienta que se trata de um número escasso de defesas na década de $1980^{218}$.

No que concerne à produção de materiais monográficos, os números apontam para um crescimento em relação às décadas anteriores: conforme o levantamento feito por Frota (2006), até 1989 foram publicados sete livros e quatro coletâneas de artigos no Brasil dedi-

\footnotetext{
${ }^{217}$ FROTA, 2006, p. 4 et seq.

${ }^{218}$ RODRIGUES, 2013, p. 55.
} 
cados à tradução. Nesse período - mais exatamente, no ano de 1986 - foi lançado um dos livros mais significativos para a história dos estudos da tradução do Brasil: Oficina de tradução: a teoria na prática, de Rosemary Arrojo. Em seu capítulo introdutório, Arrojo propõe-se a criar um "espaço ao ofício e à prática da tradução", no qual a teoria "poderá nos auxiliar a entender o que acontece quando traduzimos e também a enfrentar o constante processo de tomada de decisões envolvido em toda tradução" (ARROJO, 2007, p. 7s., grifo no original). Assim, Arrojo aborda a prática tradutória a partir da perspectiva pósestruturalista, o que trouxe profundas transformações nos estudos da tradução no país.

De fato, Frota (2007) considera Oficina de tradução o manifesto de um grupo de estudiosos constituído nos anos de 1980, com a intenção de fazer oposição às chamadas "teorias tradicionais de tradução". Ela observa que, em princípio, os pesquisadores brasileiros dividiram-se em duas frentes opostas, a favor e contra o pós-estruturalismo. Todavia, aos poucos mesmo os mais convictos essencialistas teriam mudado suas concepções. Como consequência, teria se extinguido a ideia da transparência absoluta dos textos, da equivalência, do autor como origem primeira do original, da tradução como operação linguística, banal e impossível - senão dentre o público leigo, ao menos entre os estudiosos de tradução ${ }^{219}$.

Um exemplo das consequências do pós-estruturalismo seria o próprio curso de tradução da PUC-RJ. Martins (2006) declara que a ascensão da vertente teórica levou-os a se adaptarem a essa nova visão de mundo. Ademais, o crescimento dos estudos da tradução, com uma reflexão teórica surgida em seu interior, teria chamado a atenção para a relevância do aspecto teórico para a prática profissional e para a formação de tradutores. Assim, conforme surgiam novas abordagens, elas teriam sido incorporadas à formação de tradutores na PUC. Por conseguinte, com a reforma curricular de 1985, teriam sido criadas as cadeiras de Teoria da Tradução e de Terminologia, conquistando a teoria, assim, seu lugar de direito $^{220}$.

O crescimento da área também ganha indício palpável na criação, em 1981, da revista Tradução \& Comunicação, dirigida por Erwin Theodor e Julio Garcia Morejón e organizada pela então Faculdade Ibero-Americana (FIA). A Tradução \& Comunicação foi o primeiro periódico dedicado à tradução, com o compromisso de "divulgar conhecimentos específicos, incrementar o campo profissional, fazer um trabalho crítico constante, situar o

\footnotetext{
${ }^{219}$ FROTA, 2007, p. 153 et seq.
}

${ }^{220}$ MARTINS, 2006, p. 24. 
tradutor no lugar de relevo que lhe corresponde no cenário da cultura nacional", conforme declaram seus diretores no número de lançamento da revista. Foram lançados nove números até o ano de 1986, quando a sua publicação foi descontinuada. Em ocasião do "renascimento" da revista, Morejón (2001) atribui o hiato à "necessidade de ajustes internos na estrutura e organização do Curso de Tradutores e intérpretes" da instituição, que à época passou a se chamar Centro Universitário Ibero-Americano (UNIBERO) ${ }^{221}$.

Sendo a Tradução \& Comunicação o único periódico dedicado à tradução em atividade no Brasil nos anos de 1980, houve números especiais voltados ao tema em periódicos vinculados a outras áreas de Letras. Frota (2007) faz menção ao número 4 (1984) da revista Remate dos Mares e ao número 11 (1988) da revista Trabalhos em Linguística Aplicada, ambas organizadas pelo Instituto de Estudos da Linguagem (IEL) da UNICAMP, bem como ao número 17 (1992) da revista Ilha do Desterro, organizada pela UFSC ${ }^{222}$.

Ainda no tocante às publicações sobre tradução em outras áreas, a autora, a exemplo de José Paulo Paes, destaca o trabalho dos irmãos Haroldo e Augusto de Campos, fazendo referência a dois ensaios de Haroldo: "Da tradução como criação e como crítica", publicado originalmente em 1963 na revista Tempo Brasileiro, e "Tradução, ideologia e história”, publicado em 1984 no número 3 da Remate de Males. Além disso, ela cita dois ensaios do autor publicados em livros identificados com outros campos: "A poética da tradução", publicado em 1969 em A arte no horizonte do provável, e "Postscriptum/transluciferação mefistofáustica", publicado em 1981 em Deus e o Diabo no Fausto de Goethe $e^{223}$.

Milton (2015) também destaca a contribuição dos irmãos Haroldo e Augusto de Campos para os estudos da tradução. Ele observa que, durante os anos de 1980, a tradução literária teria recebido considerável atenção, mas a partir de fora do âmbito acadêmico, com a atuação dos irmãos. Eles teriam trazido a tradução para a linha de frente da atividade literária no Brasil, elevando o status do traduzir e concedendo-lhe prestígio acadêmico. No que concerne à teorização, o trabalho dos irmãos Campos enfatizaria a aura e os aspectos visuais da tradução. Conforme expressa o autor, Haroldo de Campos ficou famoso por cunhar o termo "transcriação", que designa a operação baseada na recriação da forma poética do texto, isto é, de sua configuração fonética e semântica, vertendo tanto conteúdo quanto forma textual. Para Haroldo de Campos, estaria na própria dificuldade de se traduzir poesia

\footnotetext{
${ }^{221}$ MOREJÓN, 2001, p. 11.

${ }^{222}$ FROTA, 2006, p. 139 et seq.

${ }^{223}$ Id., 2007, p. 140.
} 
a sua traduzibilidade. Dessa forma, a transcriação não corresponderia a uma adaptação livre, mas antes a uma fidelidade extrema, na qual a liberdade estaria na escolha de soluções nos mais diferentes níveis semióticos do poema. Dentre as soluções adotadas pelos irmãos Campos estariam a "brasilianização" de alguns elementos - por exemplo, as referências do texto - e a emulação dos padrões sonoros, com a criação de neologismos. Milton observa ainda que a reconstrução da forma do original no texto-alvo praticada pelos irmãos Campos estava em consonância com os apelos de diversos teorizadores ao longo da história da tradução. Sendo tradutores, no entanto, eles teriam claro que essa reconstrução era possível apenas em alguns momentos da tradução ${ }^{224}$.

Em 1992, Else Vieira defendeu uma tese de doutorado no âmbito do Curso de PósGraduação em Letras na Universidade Federal de Minas Gerais (UFMG), no qual ela sistematiza as considerações feitas pelos irmãos Campos numa teoria de tradução de cunho pós-colonial. Assim, em sua abordagem antropofágica, Vieira busca subverter a relação de poder entre original e tradução reiterada ao longo da história pelas teorias tradicionais de tradução. A autora destaca do ofício dos irmãos Campos o trabalho criativo na tradução, indicando que, ao atuar criativamente, além de "dessacralizar" o original, eles fariam com que a tradução assumisse outro papel: ela não só receberia do original, mas também doaria a ele.

John Milton (2015) vê no pós-estruturalismo, cujo epicentro estaria à época na UNICAMP, a primeira escola teórica da tradução no país. Segundo afirma, diante da profusão de publicações de Arrojo fora do país, a impressão que se teve no exterior foi supostamente a de que essa era a única área de pesquisa ativa em tradução no Brasil, uma impressão que ganhou expressão pelas mãos de Michaela Wolf, em ocasião da publicação do volume Übersetzungswissenschaft in Brasilien [Estudos da tradução no Brasil]. De fato, ao introduzir o volume, Wolf (1997) percorre a história das reflexões sobre a tradução no Brasil no século XX, conferindo destaque ao trabalho e às elaborações teóricas de Haroldo e Augusto de Campos, a partir dos anos de 1960, e às vertentes pós-modernas de Else Vieira e de Rosemary Arrojo, nos anos de $1980^{225}$. Os textos a comporem o volume são, por sua vez, predominantemente de autoria de Arrojo, incluindo três capítulos extraídos diretamente de Oficina de tradução.

\footnotetext{
${ }^{224}$ MILTON, 2015, p. 93 et seq.

${ }^{225}$ WOLF, 1997, p. 13 et seq.
} 
Antes de encerrar o relato do percurso dos estudos da tradução no Brasil dos anos de 1980, cumpre ainda mencionar o encerramento das atividades da ABRATES em 1988 e a concomitante fundação do Sindicato Nacional dos Tradutores (SINTRA). Fundada pela iniciativa de Paulo Rónai, a ABRATES tinha como principais objetivos o reconhecimento da profissão de tradutor e a regulamentação das condições de trabalho. Como final da ABRATES, o SINTRA tornou-se o principal órgão de representação da classe profissional.

\subsubsection{Os anos de 1990}

Se nos anos de 1980 os estudos da tradução no Brasil pareciam estar cultivando as estruturas para o seu crescimento, nos anos de 1990 esse crescimento começou a se concretizar. Um dos motores para se chegar a tal estado foi a criação da Associação Brasileira de Pesquisadores em Tradução (ABRAPT). A história de sua fundação está fortemente ligada à história do GT de Tradução da ANPOLL e dos Encontros Nacionais de Tradutores.

Maria Paula Frota relata que foi realizado em 1990 o IV Encontro Nacional da ANPOLL, sediado em Recife. Até então, as reuniões do GT de Tradução da ANPOLL seriam ocasião para pesquisadores dispersos geograficamente travarem conhecimento uns com os outros. A essa reunião, no entanto, apenas poucos puderam comparecer, o que teria mostrado que "a restrição dos trabalhos de nosso GT aos Encontros Nacionais da Anpoll acabava por impedir uma articulação e intercâmbio efetivos entre os seus membros" (FROTA, 2006, p. 8). Rosemary Arrojo, então coordenadora do grupo, teria sugerido, assim, a descentralização do funcionamento do Grupo de Trabalho, criando-se GTs regionais com coordenação própria. Os GTs regionais teriam aumentado a capacidade de organização de pesquisadores, com encontros mais frequentes, refletindo-se num aumento da produção intelectual. Em princípio, foram criados quatro GTs regionais: Rio de Janeiro, São Paulo, Minas Gerais e Rio Grande do Sul.

Como rememora Frota, foi numa reunião do GT regional de São Paulo que veio a ideia de fundar a ABRAPT, o que se efetivou no dia 03 de abril de 1992. Ao remontar a história da associação, Silva, Esqueda e Campos entrevistam Azenha Jr., que esteve na presidência da ABRAPT no triênio 1996-1998. Ele explica como veio a ideia para a sua criação: 


\begin{abstract}
A ideia surgiu da necessidade que se constatou naquele II Encontro Paulista de Pesquisadores em Tradução de que uma associação de nível nacional poderia agregar esforços no sentido de mapear o perfil de pesquisadores e a natureza das pesquisas que vinham sendo realizadas no Brasil e também de atuar, juntamente com o GT de Tradução da ANPOLL não apenas no sentido de dar visibilidade à produção desses pesquisadores, como também de atuar junto às agências de fomento, a fim de garantir à tradução um lugar entre as várias rubricas que abrigavam projetos de pesquisa fomentados por essas mesmas agências federais e estaduais. (AZENHA JR. apud SILVA; ESQUEDA; CAMPOS, 2017, p. 1461)
\end{abstract}

Em seu estatuto, a ABRAPT estabeleceu os objetivos de congregar pesquisadores de tradução, estabelecer canais de contato entre pesquisadores e órgãos ou entidades de fomento à pesquisa, patrocinar e divulgar conferências, cursos, congressos e outros eventos, facilitar o acesso de associados a materiais de utilização direta ou indireta na pesquisa em tradução, bem como bolsas e viagens de estudo ou pesquisa, promover intercâmbio com entidades semelhantes no país e no exterior e publicar boletim informativo com as pesquisas dos associados. Após firmar o estatuto da instituição, elegeu-se a primeira diretoria: Mário Laranjeira, da USP, como presidente e Rosemary Arrojo, da UNICAMP, como vicepresidente $^{226}$.

Frota relata que esse foi um período bastante produtivo no âmbito dos estudos da tradução no Brasil. Ainda que a reunião do GT de Tradução da ANPOLL de 1990 tenha tido pouca adesão, o IV Encontro Nacional de Tradutores, realizado no mesmo ano na USP, foi, a seu ver, um sucesso de organização, o que se refletiu na qualidade dos trabalhos apresentados ${ }^{227}$. O evento, organizado por John Milton, contou com pesquisadores brasileiros e estrangeiros, contando inclusive com a presença já referida de Hans J. Vermeer como conferencista.

De fato, Frota observa que nessa época se intensificou o intercâmbio com pesquisadores de renome no âmbito internacional. Além do IX Encontro Nacional da ANPOLL, houve também em 1994 o V Encontro Nacional de Tradutores, sediado na Universidade Federal da Bahia (UFBA) e organizado - como seria a partir de então em todos os Encontro Nacional de Tradutores - em parceria com a ABRAPT, além de outros encontros menores. Ela ainda enfatiza a importância da criação do CITRAT:

Em 1992, além de nossa reunião em Porto Alegre [o V Encontro Nacional da ANPOLL] e da criação da Abrapt, foi criado o CITRAT, Centro Interdeparta-

\footnotetext{
${ }^{226}$ SILVA; ESQUEDA; CAMPOS, 2017, p. 1462.

${ }^{227}$ FROTA, 2006, p.11 et seq.
} 
mental de Tradução e Terminologia, na Faculdade de Filosofia, Letras e Ciências Humanas da USP. Esse Centro já vinha sendo proposto há anos pelo professor Francis Aubert, com vistas a institucionalizar na USP os estudos da tradução e da terminologia, uma vez que também nessa universidade a nossa área não encontrava um espaço próprio na estrutura departamental e programas de pósgraduação. Entre outras iniciativas importantes do CITRAT, destaca-se, em 1994, o lançamento da revista TradTerm, a qual veio pôr fim ao hiato, já aqui referido, que se havia criado em 1986 com a suspensão de nossa única revista, Tradução \& Comunicação. Também foram publicados pelo CITRAT os anais dos dois Encontros de Tradutores que acabo de mencionar [o V e VI Encontro Nacional de Tradutores], o que veio a se repetir no futuro. (FROTA, 2006, p. 12)

No texto de apresentação da revista, Aubert e Alves (1994) expõem o contrassenso entre os desenvolvimentos da tradução ao longo das décadas de 1970 e 1980, inclusive no âmbito acadêmico, e o fato de não haver então um meio de divulgação para a produção intelectual na área, o que dificultaria o acesso e a livre circulação de informações e debates acerca da tradução no país. Com isso, a revista nasce com a proposta de

acolher trabalhos de pesquisadores dedicados à tradução, incluindo os voltados para a reflexão teórica, para a análise de dados, para as questões éticas, metodológicas, instrumentais e ideológicas pertinentes à tradução, nas mais diversas vertentes, sem restrições quanto ao modelo teórico nem a campo específico - tradução literária, técnica etc. (AUBERT; ALVES, 1994, p. 11)

Além disso, com a revista, a comissão editorial procura oferecer um espaço de intercâmbio entre teoria e prática, aceitando contribuições de tradutores e intérpretes acerca de sua rotina profissional, além de oferecer espaço de divulgação e crescimento para o campo de pesquisas em terminologia, tanto de caráter descritivo como normativo ${ }^{228}$.

O VII Encontro Nacional da ANPOLL teria apontado para mudanças na dinâmica dos estudos da tradução no país. Sediado em João Pessoa em 1996, o evento contou com a participação de poucos pesquisadores de IES de São Paulo, do Rio de Janeiro e do Rio Grande do Sul. Por outro lado, o GT regional de Minas Gerais, até então restrito a pesquisadores da UFMG, passou a incluir pesquisadores de outras universidades mineiras. Outro indicativo de mudanças foi a presença significativa de pesquisadores vinculados à UFSC, como reflexo do salto de desenvolvimento que os estudos da tradução experimentaram na instituição durante o biênio, com a criação do Núcleo de Estudos da Tradução (NET); nesse mesmo ano de 1996 foi lançado o primeiro número da revista Cadernos de Tradução, segundo periódico dedicado à tradução em atividade à época. Frota celebra ainda a presença mais significativa da UFBA, como vimos, sede do V Encontro Nacional de Tradutores,

\footnotetext{
${ }^{228}$ AUBERT; ALVES, 1994, p. 12 et seq.
} 
e da UFC, que naquele mesmo ano seria a cada do VI ENTRAD, organizado por Tito Lívio Cruz Romão e pelos dirigentes da $\mathrm{ABRAPT}^{229}$. Assim, a tradução começaria a dar sinais de disseminação, o que teria possibilitado a criação de novas regionais e o despontamento de novos centros de especialidade. Após a reunião, dois novos GTs regionais foram criados: o GT de Santa Catarina, com a coordenação de Mauri Furlan e vice-coordenação de Marie-Hélène Torres, ambos da UFSC, e o GT da Bahia, com coordenação de Luiz Angélico da Costa, da UFBA.

As indicações de crescimento na área também ganham expressão na produção intelectual. Como vimos, no levantamento feito por Frota (2006, 2007), entre 1952 e 1990 haviam sido publicados apenas treze livros e cinco coletâneas dedicados aos estudos da tradução, bem como um periódico em atividade durante seis anos ${ }^{230}$. Em comparação, durante a década de 1990, foram publicados o livro de José Paulo Paes, Tradução: a ponte necessária (1990); Procedimentos técnicos da tradução, de Heloísa Barbosa (1990); As (in)fidelidades da tradução, de Francis Aubert (1993); O poder da tradução, de John Milton (1993); Poética da tradução, de Mário Laranjeira (1993); Tradução, desconstrução e psicanálise, de Rosemary Arrojo (1993); Tradução: teoria e prática, de John Milton (1998, republicação do livro anterior do autor, de 1993); Tradução e diferença, de Cristina Carneiro Rodrigues (1999); Ossian no Brasil, de Ofir B. de Aguiar (1999); Tradução técnica e condicionantes culturais. Primeiros passos para um estudo integrado, de João Azenha Junior (1999); Literatura e cinema: da semiótica à tradução cultural, de Thaïs F. N. Diniz (1999).

Durante os anos de 1990, foram publicadas também sete coletâneas de textos: em 1991, Tradução: teoria e prática, organizada por Malcolm Coulthard e Carmen Rosa Coulthard (UFSC); em 1992, O signo desconstruído: implicações para a tradução, a leitura e o ensino, organizada por Rosemary Arrojo (UNICAMP); em 1994, Letras em tradução, organizada por Ana Beatriz Ferreira e outros alunos da PUC-Rio; em 1996, Teorizando e contextualizando a tradução, organizada por Else R. P. Vieira, e Limites da traduzibilidade organizada por Luiz Angélico da Costa; em 1998, Tradução: a prática da diferença, organizada por Paulo Ottoni; finalmente, em 1999, Tradução e multidisciplinaridade, organizada por Marcia A. P. Martins ${ }^{231}$.

\footnotetext{
${ }^{229}$ FROTA, 2006, p. 13.

${ }^{230}$ Id., 2007, p. 138.

${ }^{231}$ FROTA, 2006, p. 20 et seq.
} 
No que tange aos periódicos, além dos já mencionados TradTerm e Cadernos de Tradução, entrou em atividade em 1997 a revista Cadernos de Literatura em Tradução, organizada pela USP em cooperação com a ABRAPT e o CITRAT. A revista foi fundada não com o propósito primário de publicar artigos científicos, mas de veicular traduções literárias, especialmente de poesia - o que não exclui a publicação de tradução de prosa ou de artigos sobre a tradução literária.

Contudo, a despeito da fundação desses três periódicos, Frota cita ainda alguns números dedicados inteiramente à questão da tradução: o número 17 da Ilha do Desterro (UFSC) e o número 11 da Trabalhos em Linguística Aplicada (UNICAMP), publicados em 1992; o número 8 de Letras (UFSM), publicado em 1994; e os de Range Rede - revista de literatura (UFRJ) e Com Textos - revista do Departamento de Letras da UFOP, ambos de 1995; e os números 33 e 36 da Ilha do Desterro (UFSC), publicados respectivamente em 1997 e $1999^{232}$.

Nesse período, seria possível também observar a proliferação de cursos de tradução nos mais diversos níveis - graduação, extensão, especialização e livres - que gerariam uma demanda por professores especializados e, assim, a inclusão dos estudos da tradução em linhas de pesquisa em vários programas de pós-graduação. Com isso, a pesquisa na área teria se intensificado, bem como a consequente publicação de trabalhos e intercâmbio entre as universidades dentro e fora do país ${ }^{233}$. De fato, Brezolin (2006) menciona uma corrida aos cursos de pós-graduação stricto sensu a partir do final da década de 1980, o que teria tido reflexos no âmbito da pesquisa ${ }^{234}$.

O reflexo dessa corrida rumo aos cursos de pós-graduação stricto sensu é medido no referido estudo de Pagano e Vasconcellos (2003). A análise desses dados aponta algumas tendências interessantes. Pagano e Vasconcellos identificaram, entre 1987 e 2001, 54 dissertações de mestrado, 39 teses de doutorado e 2 teses de livre-docência, chegando-se a um total de 95 resumos. Embora as dissertações de mestrado correspondam à maior parte dos trabalhos defendidos durante esse período (56,8\% do total), o número de teses de doutorado, que representa $41,1 \%$ do total, é bastante significativo. Dado o estágio embrionário da área, seria esperado um número de teses inferior; conjectura-se, assim, que a expansão da área no exterior tenha tido seus reflexos na pesquisa no país.

\footnotetext{
${ }^{232}$ FROTA, 2006, p. 22.

${ }^{233}$ Id., 2007, p. 142 et seq.

${ }^{234}$ BREZOLIN, 2006, p. 27.
} 
Heloísa Barbosa (2009) compartilha dessa hipótese. Nesse contexto, ela destaca a contribuição dos pesquisadores do eixo Leuven-Tel Aviv desde os anos de 1970, bem como os escritos de Mary Snell-Hornby, marcando a "virada cultural" no campo, e de Mona Baker. Em verdade, Baker não teria contribuído apenas como pesquisadora, ao exercer papel pioneiro no emprego da linguística de corpus na tradução, além de suas contribuições em outros domínios do traduzir, mas também através da fundação da editora St. Jero$m e$, em $1995^{235}$. Hoje, a St. Jerome é uma das editoras mais relevantes para o nosso campo disciplinar, divulgando estudos em diferentes domínios da tradução.

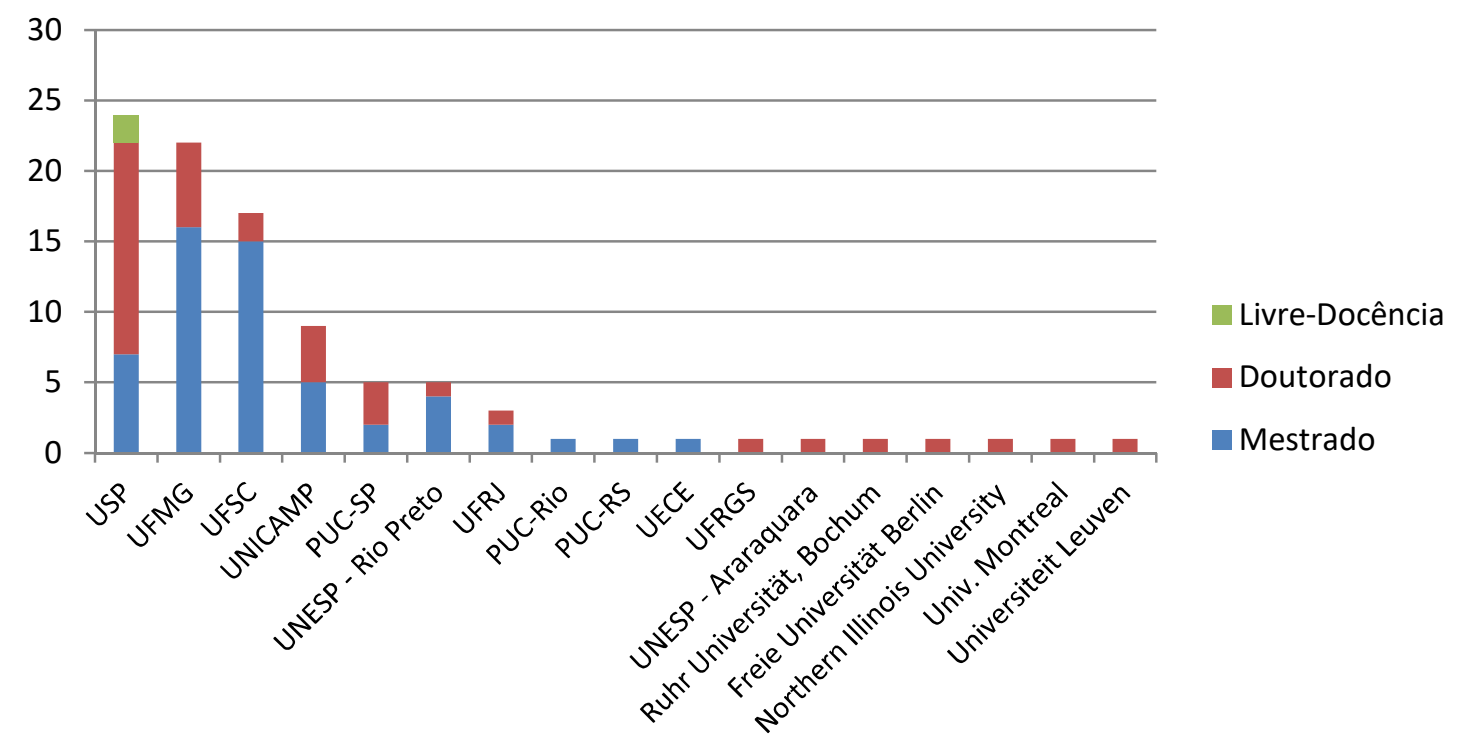

Gráfico 02: Número total de resumos por instituição acadêmica (cf. PAGANO; VASCONCELLOS, 2003, p. 5).

No que tange à distribuição entre as instituições, a análise demonstra que

os 95 resumos cadastrados se distribuem, quanto à instituição na qual a tese ou dissertação foi defendida, em 4 universidades federais (UFMG, UFSC, UFRJ e UFRGS), 4 universidades estaduais (USP, UNICAMP, UNESP (campi Rio Preto e Araraquara) e UECE) e 3 universidades católicas (PUC-SP, PUC-RIO e PUCRS). Foram registrados trabalhos de doutoramento defendidos em 5 universidades estrangeiras nos Estados Unidos, Alemanha, Bélgica e Canadá. (PAGANO; VASCONCELLOS, 2003, p. 6)

O gráfico acima, reconstituído a partir dos dados e dos gráficos desse mesmo estudo, mostra a distribuição de dissertações de mestrado, teses de doutorado e de livre-

\footnotetext{
${ }^{235}$ BARBOSA, 2009, p. 33.
} 
docência entre as instituições. Abaixo, o gráfico mostra a distribuição desses mesmos trabalhos de grau pelos anos.

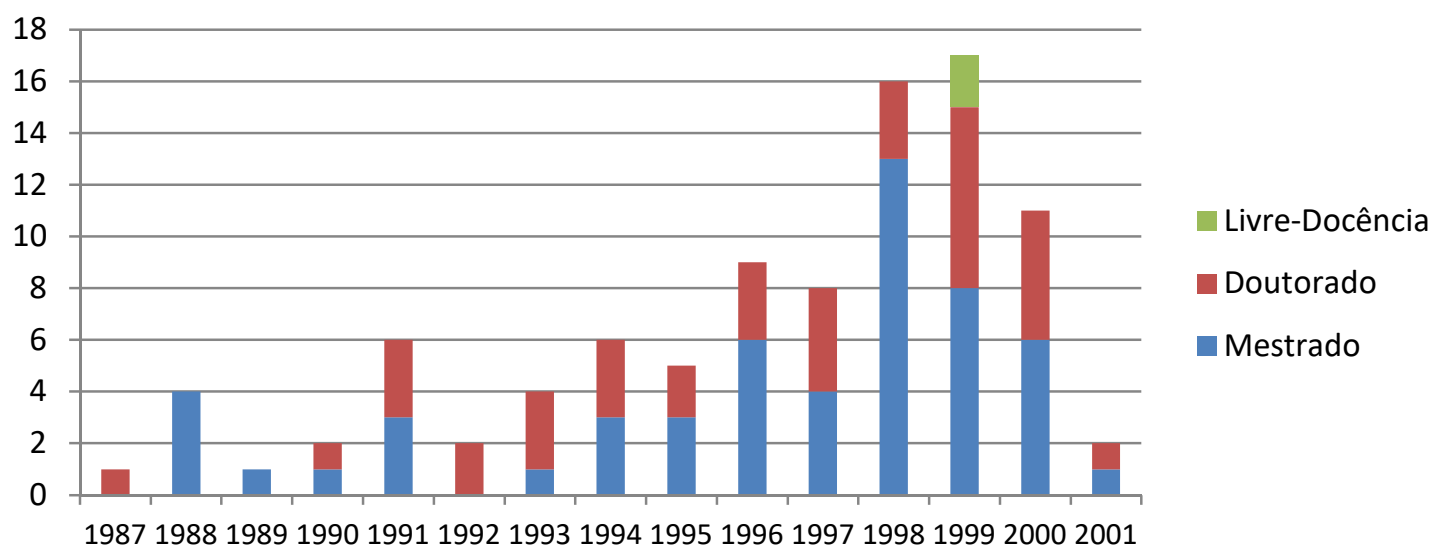

Gráfico 03: Data de defesas dos trabalhos (cf. PAGANO; VASCONCELLOS, 2003, p. 7).

Rodrigues (2013) faz uso dos dados levantados por Pagano e Vasconcellos para expandir a análise. Em primeiro lugar, ela faz menção ao crescimento da produção intelectual no âmbito da tradução ao longo dos anos de 1990, com especial consideração ao aparente boom no campo de pesquisas entre os anos de 1998 e 2000. Ela encontra duas prováveis justificativas, a primeira consistindo nos debates mantidos por pesquisadores adeptos a diferentes abordagens dentro dos estudos da tradução. Ela observa que os Grupos de Trabalho realizados durante os Seminários do Grupo de Estudos Linguísticos do Estado de São Paulo (GEL) nos anos de 1980, bem como os Encontros Nacionais de Tradutores, foram palco de alguns desses debates, informação confirmada por Rosemary Arrojo na Apresentação de seu livro $O$ signo desconstruído. A segunda justificativa diz respeito à ampliação das perspectivas da tradução no Brasil, ocasionada, em primeiro lugar, pela valorização da formação acadêmica do tradutor e pelo aumento da oferta de cursos de formação, que desencadeou uma ampliação no mercado de trabalho para professores e, assim, o reconhecimento da tradução como uma área acadêmica. Isso ocorreu de maneira gradual, com os primeiros cursos surgindo entre as décadas de 1960 e 1970, mas a exigência de titulação dos professores a partir do final dos anos de $1980^{236}$.

\footnotetext{
${ }^{236}$ RODRIGUES, 2013, p. 57 et seq.
} 
Quanto à distribuição de trabalhos em cada instituição, ela avalia a presença da tradução nos programas de pós-graduação à época ${ }^{237}$. Ela compara os dois casos de mais trabalhos defendidos - o da USP e o da UFMG - e encontra situações bastante discrepantes: embora na USP houvesse seis programas em que seria possível a inserção de uma pesquisa em tradução, ela só existia como linha de pesquisa em um, a saber, o Programa de Língua e Literatura Inglesa e Norte-americana, no qual havia a linha de pesquisa "Teorias da tradução" como parte de uma área de concentração "Teorias críticas”. Por sua vez, até 1998 só haveria na UFMG um programa de pós-graduação, a Pós-Graduação em Letras, com duas áreas de concentração: Estudos Linguísticos e Estudos Literários. Segundo Rodrigues, Else Vieira teria sido a orientadora de vários desses 22 trabalhos defendidos na UFMG. Em 1998, o programa teria sido desmembrado em dois: a Pós-Graduação em Letras: Estudos Literários (POSLIT) e a Pós-Graduação em Letras: Estudos Linguísticos (POSLIN), sendo que na POSLIN se inseriria a linha de pesquisa "Estudos da Tradução"238.

Até 2001, a UFSC contava com linhas de pesquisa em tradução em apenas três diferentes programas de pós-graduação: os programas de Linguística, de Inglês e de Literatura. Ainda assim, com 17 teses e dissertações, produziu o terceiro maior volume de trabalhos de grau acerca da tradução. Por outro lado, a UNICAMP, casa da abordagem pósestruturalista da tradução, também teria a inserção mais longeva da tradução em seus programas de pós-graduação: o Programa de Linguística Aplicada, criado em 1986, tinha três áreas de concentração no mestrado: "Ensino e aprendizagem de língua estrangeira e segunda língua, "Ensino e aprendizagem de língua materna" e "Tradução",239.

Com isso, nota-se que os movimentos de institucionalização dos estudos da tradução, com espaços para produção e divulgação de conhecimento, surtiram resultados. $\mathrm{O}$ desenvolvimento tecnológico, em especial a internet e o correio eletrônico, tornaram mais fácil o intercâmbio entre os pesquisadores e, assim, a organização da área. No entanto, Frota observa que isso ocorreu não sem consequências para os dispositivos já existentes para cumprir esse papel. Para ela, essa teria sido a causa de uma crise de identidade do GT de Tradução da ANPOLL, cujo ápice teria sido no biênio 1996-1998. A esse respeito, ela comenta:

\footnotetext{
${ }^{237}$ Reportaremos apenas os quatro primeiros casos no tocante ao volume de trabalhos defendidos.

${ }^{238}$ RODRIGUES, 2013, p. 60 et seq.

${ }^{239}$ Ibid., p.62 et seq.
} 
O fato é que, salvo raras exceções, estávamos todos vinculados a programas de pós-graduação, já éramos todos pesquisadores no sentido restrito do termo, fosse como professores ou como doutorandos. Assim sendo, contávamos com as estruturas de nossos programas institucionais e com as interlocuções que normalmente têm lugar nas relações de orientação de tese. Com o adensamento da área, um novo ritmo de trabalho se apresentava tanto aos doutores já estabelecidos, que enfrentavam grande demanda, quanto aos recém-doutores e àqueles em fase de conclusão de suas teses. Volte-se a acrescentar a isso a concorrência, digamos assim, de todos os outros fóruns nos quais tínhamos interesse. Mas a pergunta que cabe fazer é a seguinte: não seria essa justamente a situação mais condizente com os objetivos da Anpoll, associação de pós-graduação e pesquisa? Não seria paradoxal esse nosso desencontro com o GT quando aparentemente começávamos a ter as condições mais favoráveis para lhe imprimir um papel condizente com os propósitos da Anpoll? (FROTA, 2006, p. 14)

A essa pergunta, Frota não oferece uma resposta definitiva, mas marca que essas questões teriam perdurado por algum tempo, e estariam relacionadas à definição do papel do GT da ANPOLL no contexto da formação de tradutores e de pesquisadores, na divulgação de resultados e em sua relação com outros grupos, por exemplo, a ABRAPT.

A autora relembra a reunião do GT de Tradução naquele biênio, no qual teria ficado a amarga constatação de que o GT "havia tornado-se redundante." Segundo relata, sobretudo as atividades da UFMG e da UFSC, que reportaram uma produção intelectual profícua, além do volume de divulgação acadêmica promovido pelos Cadernos de Tradução, indicariam que as atividades do GT de Tradução seriam desnecessárias: "[...] por tais regiões entenda-se, a rigor, a UFMG e a UFSC, ou seja, aquelas atividades relatadas eram atividades que prescindiam do GT para sua realização, eram atividades regulares daqueles programas de pós-graduação." (FROTA, 2006, p. 15) A seu ver, uma exceção parecia ser o GT de São Paulo, visto que as atividades no estado eram marcadas pela dispersão geográfica, exigindo assim a ação de uma unidade centralizadora.

Nesse contexto de evidente crescimento, cumpre ainda fazer uma breve observação acerca do ensino de tradução à época. Em maio de 1995, Raffaella de Filippis Quental defendeu uma dissertação de mestrado questionando o papel da teoria na formação de tradutores no Brasil e no mundo, cujos resultados ela revela em artigo publicado no mesmo ano. Segundo afirma, haveria uma clara tendência, entre professores e alunos de tradução, de considerar a teoria de tradução como algo problemático, estando esse posicionamento mais evidente na organização curricular dos cursos de formação de tradutores e intérpretes. Após analisar o currículo de 22 instituições de formação no Brasil e no exterior, examinando o lugar da teoria nesses cursos, Quental (1995) constata que, ainda que as comparações apontem diferenças no que tange, por exemplo, ao volume de matérias linguísticas - mais 
frequentes nas grades curriculares de cursos no Brasil do que no exterior - a diferença, a seu ver, não seria tão marcante no concernente à presença da teoria ${ }^{240}$.

Assim, tanto na Europa quanto no Brasil, a carga horária dedicada a matérias de teoria da tradução seria exígua, em comparação com a presença de matérias práticas na composição da grade curricular. Ela dá os exemplos da PUC-Rio e da UFJF: ainda que o curso da PUC-Rio, o primeiro em operação no Brasil, tenha sido criado em 1970, as matérias que o compõem foram sendo acrescentadas ao longo do tempo. Como relata Quental, a disciplina "Teoria da tradução" só foi acrescentada à grade em 1985, sem haver outra disciplina antes que cumprisse o papel de veicular conhecimentos teóricos. Assim, dos vinte e oito créditos do curso de formação, apenas dois créditos seriam dedicados à teoria. Por sua vez, o caso da UFJF demonstraria que a teoria da tradução não tem apenas uma presença limitada, como também tende a ser a primeira a ser eliminada em casos de reestruturação do currículo. Ela relata que modificações propostas internamente no currículo de Letras resultaram na aglutinação de duas disciplinas, "Teoria da Tradução I" e "Teoria da Tradução II", que juntas perfaziam cinco créditos. Após a junção, a disciplina única de Teoria da Tradução teria passado a ter apenas quatro créditos, enquanto nenhuma mudança teria ocorrido nas demais cadeiras do curso. Desse modo, Quental chega à conclusão:

\footnotetext{
Os resultados da análise de currículos indicam pelo menos dois fatos relativos ao espaço institucional reservado à teoria e à prática nos cursos de formação de tradutores: em primeiro lugar, teoria e prática não aparecem interligadas nos currículos de tradução, constituindo uma clara dicotomia; em segundo, a julgar pelo lugar dispensado à teoria, com um peso até 13 vezes menor do que o da prática, seu papel é secundário na formação de tradutores. (QUENTAL, 1995, p. 39)
}

O papel secundário da teoria estaria ligado à visão que tanto alunos como docentes teriam dela: assim, se para os alunos a teoria da tradução é algo "estranho e misterioso", a maioria dos professores tem uma visão dicotômica da tradução, exaltando o caráter prático e concreto da atividade em oposição ao caráter abstrato da teoria. Contudo, segundo a linha pós-estruturalista a que a autora está vinculada, não seria possível dissociar teoria da prática, uma vez que a teoria consistiria num conjunto de crenças sobre a tradução que orientam e até mesmo determinam a atividade tradutória. Assim, a causa na dissociação entre teoria e prática na formação de tradutores estaria na própria teoria - e aqui ela se refere às abordagens linguísticas tradicionais, segundo as quais

\footnotetext{
${ }^{240}$ QUENTAL, 1995, p. 38.
} 
para ser satisfatória, a teoria deveria fornecer uma explicação "científica" para a tradução, baseada num conhecimento tão profundo, preciso e universal que permitisse elucidar de uma vez por todas as operações mentais envolvidas no seu processo e, conseqüentemente, estabelecer critérios objetivos e definitivos - em outras palavras, "científicos" - para sua execução e avaliação. (QUENTAL, 1995, p. 43)

Esse posicionamento não é recebido sem controvérsias. Como vimos, Martins (2006) afirma que o próprio Curso de Tradução da PUC-Rio sofreu, ao longo dos anos de 1980, transformações com a emergência das novas teorias, que teria motivado a inclusão da cadeira de Teoria da Tradução e Terminologia, em $1985^{241}$. Permanece, no entanto, a questão se o acréscimo de uma disciplina dedicada a apresentar o aspecto teórico da tradução seria suficiente para mudar, na mente dos alunos, uma concepção de tradução - e de teoria da tradução - que estaria profundamente arraigada não apenas no senso comum, mas até mesmo entre alunos e professores dos cursos de formação.

\subsubsection{De 2000 em diante}

Se os anos de 1990 testemunharam um crescimento expressivo na produção intelectual no âmbito dos estudos da tradução, os anos de 2000 parecem ter visto o início de sua consolidação no meio acadêmico. O primeiro indicativo desse processo foi a fundação, em 2004, do primeiro programa de pós-graduação stricto sensu no Brasil dedicado à área, a Pós-Graduação em Estudos da Tradução (PGET) da UFSC, que poucos anos após seu início vivenciou uma considerável expansão. Guerini, Torres e Costa (2013b) atribuem o sucesso do programa a três fatores: (1) um espírito interdisciplinar, interdepartamental, interregional e internacional da parte do PGET, supostamente devido à participação de professores estrangeiros e brasileiros de diversas partes, ao envolvimento de outros departamentos nas pesquisas e ao contato com universidades de dentro e de fora do país; (2) uma postura antiburocrática, para professores e alunos, e de estímulo à inovação, que se refletiria em ações como uma política de acolhimento de novos doutores, o credenciamento baseado em produtividade, ajustes periódicos das linhas de pesquisa, acolhimento professores visi-

\footnotetext{
${ }^{241}$ MARTINS, 2006, p. 24.
} 
tantes etc.; (3) o peso da tradução literária no programa, numa tendência contrária aos primeiros desenvolvimentos dos estudos da tradução como uma disciplina autônoma - mais próximos da linguística do que dos estudos literários ${ }^{242}$. Além do PGET (UFSC), foram criados outros três programas de pós-graduação em estudos da tradução em IES no Brasil: o POSTRAD, da Universidade de Brasília, aprovado pela CAPES em 2011, o TRADUSP, da Universidade de São Paulo ${ }^{243}$, aprovado pela CAPES em 2012, e o POET, da Universidade Federal do Ceará, em 2014 244 . De acordo com Milton (2015), haveria ainda a perspectiva de novos programas na Universidade Federal da Paraíba (UFPB), na Universidade Federal de Uberlândia (UFU) e na Universidade Federal do Rio Grande do Sul (UFRGS $^{245}$.

Além da fundação de novos programas dedicados à disciplina, cresceu o número de programas de pós-graduação em que os estudos da tradução estejam presentes como áreas de concentração ou linhas de pesquisa. Dentre as instituições brasileiras no âmbito das quais, segundo o levantamento de Pagano e Vasconcellos (2003) teriam sido defendidos dois ou mais trabalhos dedicados à tradução, Rodrigues (2013) observa que a tradução teria perdido força apenas na PUC-SP; quanto às instituições em que foi computada apenas uma defesa, ela teria ganhado espaço na PUC-Rio e na Universidade Estadual do Ceará (UE$\mathrm{CE}$ ). Ademais, a autora cita ainda outras instituições em que a tradução ingressou no âmbito da pós-graduação, baseada no banco de pesquisadores cadastrados no Grupo de Trabalho de Estudos da Tradução (GTTRAD, antigo GT de Tradução da ANPOLL): a Universidade Federal da Bahia (UFBA), a Universidade Federal de Juiz de Fora (UFJF), a Universidade Federal de Goiás (UFG), a Universidade Federal do Paraná (UFPR), A Universidade Federal do Espírito Santo (UFES), a Universidade Estadual do Rio de Janeiro (UERJ) e, claro, a já mencionada Universidade de Brasília $(\mathrm{UnB})^{246}$.

Rodrigues ainda identifica algumas características da presença da tradução no ambiente acadêmico no Brasil: até 2001, a tradução estaria dividida entre os departamentos de literatura e de linguística; em 2013, ela teria passado a se vincular apenas aos departamentos de linguística. A pesquisa, mesmo a pesquisa empírica, também passaria a ser feita com embasamentos teóricos, quer dizer, não mais de forma intuitiva e ateórica. Além disso,

\footnotetext{
${ }^{242}$ GUERINI; TORRES; COSTA, 2013, p. 15 et seq.

${ }^{243} \mathrm{O}$ TRADUSP, programa em que se insere o presente trabalho, foi encerrado em 2018.

244 TORRES, 2015, p. 115 et seq.

${ }^{245}$ MILTON, 2015, p. 103.

${ }^{246}$ RODRIGUES, 2013, p. 65 et seq.
} 
haveria a presença cada vez maior de temas político-ideológicos, contextualizações históricas e do olhar sobre a tradução em seu plano de produção. Assim, Rodrigues constata:

\begin{abstract}
Principalmente, avalio que a tradução está saindo da marginalidade em que tradicionalmente era colocada e se transformando em uma disciplina que ajuda a entender os processos interculturais de trocas linguísticas. Não é por acaso que a tradução se insere, em vários programas, em áreas dedicadas ao estudo das relações entre linguagem e sociedade. Além disso, a própria diversidade de abordagens leva à discussão, ao debate e promove os estudos. (RODRIGUES, 2013, p. 67s.)
\end{abstract}

Em 2016, Maria Lúcia Vasconcellos revisitou o tema, em parceria com Daniel de Sousa Alves, dando continuidade ao levantamento. No entanto, por razões operacionais, a pesquisa contemplou apenas o período entre 2006 e 2010. Isso de modo algum desvalida seus resultados, considerando que eles examinaram um corpus de 269 resumos de trabalhos de grau defendidos em IES brasileiras. Eles justificam a opção por persistir no levantamento de teses e dissertações devido "ao espaço institucional que elas ocupam - por marcarem a conclusão de etapas de formação de pesquisadores(as) na disciplina - e à disponibilidade de acesso desses textos, por meio do site Domínio Público [...]" (ALVES; VASCONCELLOS, 2016, p. 378).

Ao relatar os primeiros passos da pesquisa, Alves e Vasconcellos fazem menção a um problema que ainda persiste: a falta de uma "Área de Conhecimento" dedicada aos estudos da tradução nos índices oficiais. Assim, pautaram-se pela busca por "palavraschave", empregando os termos "tradutologia", "estudos da tradução" e "tradução"247.

Uma vez delimitados os trabalhos a serem utilizados, eles passaram a verificar as afiliações institucionais das teses e dissertações, comparando os dados obtidos com o estudo anterior ${ }^{248}$. Esse procedimento revelou indicativos bastante significativos do desenvolvimento da área no país: em primeiro lugar, os dados apontam para um crescimento da produção intelectual sobre a tradução superior a $180 \%$ no comparativo com os dados referentes ao período entre 1987 e 2001. Em segundo lugar, observou-se que a UFSC, a USP e a UFMG mantiveram o status de principais centros de pesquisa em tradução no Brasil. Todavia, os dados mostram que a UFSC consolidou-se como maior centro de formação de pesquisadores no âmbito dos estudos da tradução, ultrapassando as demais no que tange à produtividade: se antes os trabalhos defendidos na instituição correspondiam a $17,9 \%$ do

\footnotetext{
${ }^{247}$ ALVES; VASCONCELLOS, 2016, p. 383.

${ }^{248}$ Aqui nos referimos naturalmente a PAGANO; VASCONCELLOS, 2003.
} 
total de trabalhos registrados, essa proporção subiu para $26,8 \%$. Por outro lado, USP e UFMG tiveram uma queda: segundo o estudo de 2003, elas eram responsáveis, respectivamente, por $25,3 \%$ e $23,2 \%$ da produção intelectual na área; no estudo de 2016 , esses números caíram para $21,9 \%$ e $10 \%{ }^{249}$.

As explicações para esse desempenho são encontradas na própria estrutura institucional dessas universidades. Segundo os autores, a ascensão da UFSC estaria ligada à consolidação da Pós-Graduação em Estudos da Tradução (PGET), consequência, portanto, de um movimento de institucionalização da área. Quanto à UFMG, eles especulam que a redução percentual da participação da universidade esteja relacionada com o fato de não ter havido alterações, no que tange à configuração dos programas de pós-graduação, que beneficiassem a pesquisa em tradução ${ }^{250}$.

Alves e Vasconcellos também destacam os desenvolvimentos da UFRGS e da UECE: ambas as instituições saltaram de uma participação de 1\% no estudo de 2003 para, respectivamente, $4,8 \%$ e 4,5\%. O crescimento da participação da UFRGS estaria relacionado com a consolidação do projeto TERMISUL, com foco no âmbito da terminologia; o crescimento da UECE, por sua vez, estaria ligado à criação do Mestrado Acadêmico do Programa de Pós-Graduação em Linguística Aplicada da instituição, com uma linha de pesquisa dedicada a Tradução, Lexicologia e Processos Cognitivos.

De modo geral, os números parecem sugerir uma relação estreita entre institucionalização e produtividade. Eles chegam à conclusão de que "quanto maior a institucionalização do campo disciplinar na Instituição de Ensino Superior, maior parece ser a sua evolução em termos de produção de trabalhos acadêmicos" (ALVES; VASCONCELLOS, 2016, p. 388). Além do crescimento da área, Alves e Vasconcellos identificam uma dispersão das pesquisas entre as regiões do Brasil:

\footnotetext{
Enquanto nos dados publicados em 2003, pode-se notar uma concentração das pesquisas sobre tradução em apenas seis Unidades da Federação (Santa Catarina, São Paulo, Minas Gerais, Rio Grande do Sul, Ceará e Rio de Janeiro), no levantamento 2006-2010, treze Unidades da Federação estão representadas (Alagoas, Bahia, Ceará, Distrito Federal, Espírito Santo, Mato Grosso do Sul, Minas Gerais, Paraná, Rio de Janeiro, Rio Grande do Norte, Rio Grande do Sul, Santa Catarina e São Paulo). (ALVES; VASCONCELLOS, 2016, p. 388s.)
}

\footnotetext{
${ }^{249}$ ALVES; VASCONCELLOS, op. cit., p. 385 et seq.

${ }^{250}$ ALVES; VASCONCELLOS, 2016, p. 387.
} 
O vínculo institucional dos trabalhos, no que tange aos programas de pós-graduação em que foram defendidos, fornece mais um sinal da institucionalização da área: enquanto os dados referentes às últimas décadas do século indicam apenas um trabalho $(1,1 \%$ do total analisado) defendido num programa de pós-graduação com clara referência à tradução - sob a nomenclatura "Linguística - Tradução", através dos dados referentes à segunda metade da primeira década do século XXI, somos informados que 58 trabalhos $(21,6 \%$ do total analisado) foram defendidos num programa de pós-graduação em "estudos da tradução" ${ }^{251}$. Com a fundação de outros três programas de pós-graduação dedicados aos estudos da tradução, essa proporção tende a aumentar nos índices mais recentes.

No que respeita à produtividade, os autores observam um crescimento ainda mais expressivo do que o indicado pelo estudo de 2003: entre 1987 e 2001, a média de trabalhos publicados foi de cinco pesquisas por ano, com ápice em 1999, com 17 pesquisas; entre 2006 e 2010, essa média sobe para quase 53, com ápice em 2007, quando foram defendidas 68 teses e dissertações sobre tradução. O gráfico 3, extraído diretamente do estudo de Alves e Vasconcellos, ajuda a ilustrar essa evolução:

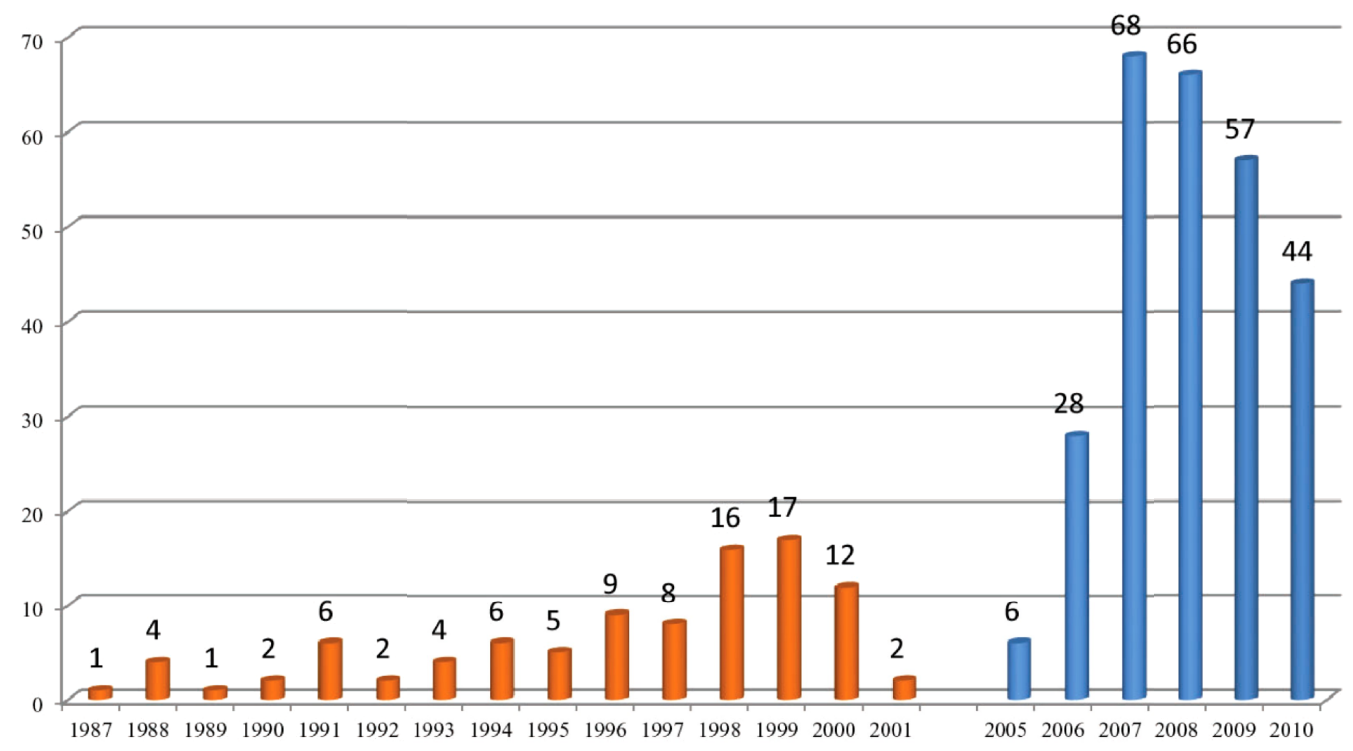

Gráfico 03: Pesquisas em tradução, distribuídas por ano de publicação (ALVES; VASCONCELLOS, 2016, p. 391).

${ }^{251}$ ALVES; VASCONCELLOS, 2016, p. 390. 
Antes de passarem para o caso específico da análise de pesquisas na interface linguística sistêmico-funcional e linguística de corpus, os autores apresentam os dados referentes aos temas desses trabalhos. Para identificá-los, as palavras-chaves fornecidas pelos próprios autores das teses e dissertações foram agrupadas em clusters. Alves e Vasconcellos reconhecem a controvérsia desse procedimento, uma vez que atividades de classificação são, segundo afirmam, "epistemológicas por natureza e, assim sendo, costumam ser alvo de questionamentos e críticas, também de natureza epistemológica" (p. 392). Desse modo, eles reiteram que os agrupamentos foram fundamentados pela percepção subjetiva deles, servindo menos como um resultado conclusivo e mais como um convite à reflexão e à discussão.

Uma vez salientada a posição dos autores, eles apresentam os resultados a que chegaram. Eles observam que, desconsiderando os termos "tradução" e "estudos da tradução", termos referentes a estudos literários foram os mais frequentes, observados em 53 trabalhos. Em segundo lugar, ficaram os termos relativos a estudos sobre alteridade, cultura e identidade (34 trabalhos), seguidos por termos referentes a estudos de corpora (26 trabalhos) e por termos ligados ao estudo do léxico (26 trabalhos). Os termos ligados a estudos de tradução audiovisual (24 trabalhos) e à linguística sistêmico-funcional (17 trabalhos), objeto último das reflexões dos autores do artigo, fecham a lista. Alves e Vasconcellos ressaltam que, dada a extensão do levantamento, foram incluídos apenas os clusters que agrupam mais de vinte palavras-chave, além do cluster relacionado à linguística sistêmicofuncional. Infelizmente, a lista completa e detalhada dos clusters não foi incluída ao arti$\mathrm{go}^{252}$.

Ainda que, ao traçar esse mapeamento, Alves e Vasconcellos salientem, assim como foi feito por Pagano e Vasconcellos (2003), que "um mapa não é o território mapeado" 253 , mas uma representação do campo disciplinar, ele nos auxilia a identificar tendências importantes dos estudos da tradução no Brasil, bem como os problemas enfrentados pela área. $\mathrm{O}$ estudo deixou evidente que determinados problemas como a falta de parâmetros de indexação e a falta de reconhecimento dos estudos da tradução por parte dos órgãos oficiais de ciência ainda persistem. Por outro lado, ele traz dados animadores, que indicam tendências positivas na área, sobretudo os movimentos de descentralização e de institucionalização da pesquisa.

\footnotetext{
${ }^{252}$ ALVES; VASCONCELLOS, 2016, p. 393 et seq.

${ }^{253}$ Ibid., p. 402.
} 
Analisando o princípio da história da institucionalização dos estudos da tradução no Brasil, Vasconcellos identifica esforços nesse período inaugural para criar uma identidade do campo disciplinar, sobretudo através da criação de espaços de intercâmbio como o GT de Tradução da ANPOLL e as diversas edições do Encontro Nacional de Tradutores. Haveria, assim, "uma tendência centrípeta para garantir a unidade na luta por visibilidade institucional" (VASCONCELLOS, 2013, p. 41). Agora mais próximos dessa unidade, que se reflete, por exemplo, na presença cada vez mais destacada da tradução nas linhas de pesquisa dos programas de pós-graduação em IES brasileiras - e mesmo com alguns programas de pós-graduação dedicados exclusivamente aos estudos da tradução - são observadas "tendências centrífugas de expansão", haja vista a "configuração mutante dos pesquisadores que constituem os Estudos da Tradução no Brasil" e que criam novas formas "de conhecimento experto, para a configuração da tecnologia que se move em alta velocidade em direção ao diálogo com disciplinas afins, para a configuração das novas capacidades eletrônicas de produzir e disseminar conhecimento" (Idem). Além da disseminação da pesquisa por instituições de ensino superior em todo o país, a pesquisa torna-se mais diversificada: bastaria comparar, por exemplo, as áreas temáticas em que se organizava o Encontro Nacional de Tradutores em seus primórdios e em tempos mais recentes. Silva, Esqueda e Campos (2017) informam-nos que os Anais do III Encontro Nacional de Tradutores, realizado em 1987, foram divididos em cinco grandes temas: pesquisa e teoria na formação do tradutor, estruturação do ensino da tradução, problemas específicos de tradução, tradução literária e interpretação de conferências ${ }^{254}$. Por sua vez, a última edição até então realizada do evento, em 2016, trouxe quinze áreas temáticas: Tradução e Terminologia; Estudos da Interpretação; Tradução Audiovisual; Estudos da Tradução e Corpora; Abordagens Cognitivas da Tradução; Tradução Especializada; Tradução e Interpretação de Línguas de Sinais; Tradução Literária; História e Historiografia da Tradução; Tecnologias da Tradução; Tradução, Crítica e Ética, além das três novas áreas: Tradução e Estudos Clássicos, Tradução e Mercado de Trabalho; Tradução e Localização ${ }^{255}$.

Contudo, a área ainda enfrenta problemas difíceis de serem solucionados. Em primeiro lugar, o reconhecimento da tradução dentre as instituições de fomento, como a CAPES e o CNPq, ainda não teria vindo ${ }^{256}$. Torres (2015) explica que, a despeito de sua autonomia em âmbito internacional, os estudos da tradução ainda não constariam na tabela de

\footnotetext{
${ }^{254}$ SILVA; ESQUEDA; CAMPOS, 2017, p. 1461.

255 Ibid., p. 1468.

${ }^{256}$ RODRIGUES, 2013, p. 67 et seq.
} 
Áreas de Conhecimento do CNPq, de modo que os pesquisadores precisam recorrer, no momento de pedido de auxílio, às áreas mais próximas, como literatura comparada ou a linguística aplicada. Também, o fato de não haver uma subárea da tradução teria efeitos também sobre bolsas de produtividade. Essa modalidade de bolsa é conferida apenas a pesquisadores que se destaquem entre seus pares $^{257}$. Não havendo representantes da área na CAPES, deixa de haver apoio institucional, o que, segundo Barbosa (2009), faria com que nomes importantes da área não compareçam aos principais eventos sobre estudos da tradução, mas voltem suas atenções para eventos maiores em outras áreas. Ela faz menção ainda a casos de evasão de pesquisadores que, tendo defendido seus trabalhos de grau com um tema sobre tradução, buscam realocação em outras áreas mais promissoras ${ }^{258}$.

Numa pesquisa na plataforma Lattes, Barbosa identificou que a maior ocorrência de tradução entre currículos individuais e de grupos de estudo referia-se a traduções como produto, como modalidade de produção bibliográfica nas mais diversas áreas do saber, feita por pessoas que não necessariamente têm formação profisssional como tradutores. A decisão da CAPES de aceitar traduções como produção acadêmica beneficiaria, segundo a autora, mais os pesquisadores das ciências "duras", que publicam traduções em suas áreas de especialidade sem serem tradutores. Assim, em vez de uma área de estudos consolidada, a tradução mostra-se uma prática sem qualquer formação exigida ${ }^{259}$. Dado esse panorama, ela conclui que:

Essas duas situações da tradução na base de dados do CNPq revelam como ela é entendida ainda por muitos: não como um campo de pesquisa, mas como um fazer. Vê-se, portanto, que, até hoje, como observou Snell-Hornby (1995, p. 134), os Estudos da Tradução e Interpretação se vêem, muitas vezes, "tolhidos pelas restrições da burocracia e do preconceito”. (BARBOSA, 2009, p. 32)

Para que os estudos da tradução sejam reconhecidos pelos órgãos oficiais, Torres sugere a inclusão dos estudos da tradução na Grande Área Multidisciplinar da CAPES, em que se reconhecem áreas interdisciplinares, com a finalidade de atender às necessidades de organização do processo de avaliação e fomento realizadas pela própria agência de fomento. Além disso, seria necessária a cooperação em nível internacional, inclusive através da

\footnotetext{
${ }^{257}$ TORRES, 2015, p. 118.

${ }^{258}$ BARBOSA, 2009, p. 30.

${ }^{259}$ Ibid., p. 32.
} 
organização de congressos internacionais, e incentivo à institucionalização da área mediante a criação de novos programas de pós-graduação ${ }^{260}$.

No que tange à divulgação das pesquisas, Milton nota uma tendência dos pesquisadores brasileiros de restringirem suas publicações a periódicos brasileiros. Nesse contexto, Milton afirma: "Conforme espero ter demonstrado, parece que já há uma massa crítica considerável nos estudos da tradução no Brasil, mas essa massa crítica demonstrou relativamente pouco interesse no mundo exterior. Publicamos muito pouco fora do Brasil." 261 (MILTON, 2015, p. 104) Essa afirmação teria sido feita com base em dados de publicação da revista Target, principal periódico de nossa área internacionalmente, segundo os quais, em 27 anos do periódico, apenas dois artigos de pesquisadores baseados no Brasil teriam sido publicados pela revista, não havendo qualquer outra submissão que tivesse sido rejeitada de autores no país. Milton especula que haja, inclusive, uma pressão para se publicar predominantemente em português, questionando-se se esse não seria ainda um resquício de um déficit de nossa cultura colonial prévia ${ }^{262}$.

Essas questões, como vimos, não afetavam apenas a produção intelectual. Mencionamos na seção anterior que, próximo do final do século, o GT de Tradução da ANPOLL enfrentava uma crise de identidade. Algumas medidas tomadas nas primeiras gestões do novo século ajudaram a amenizar a crise. Frota (2006) menciona a informatização do GT, com um cadastro online de pesquisadores, bem como o projeto de mapeamento da produção intelectual da época - de que resultou o trabalho de Pagano e Vasconcellos, referido repetidas vezes no presente capítulo - e a busca por iniciativas para a inclusão dos estudos da tradução dentre as áreas de concentração das agências de fomento ${ }^{263}$.

No que concerne à ABRAPT, Silva, Esqueda e Campos (2017) mencionam problemas surgidos durante os triênios de 2002-2004, durante a gestão de Stella E. O. Tagnin (USP), e de 2005-2007, durante a gestão de Fabio Alves (UFMG), gestão que marcou o fim da hegemonia paulista na coordenação da associação. José Luiz V. R. Gonçalves (UFOP), que assumiu a coordenação da ABRAPT (2007-2010) após a gestão de Fabio Alves, relata acerca dos problemas burocráticos enfrentados nesse período:

\footnotetext{
${ }^{260}$ TORRES, 2015, p. 119 et seq.

${ }^{261}$ As I hope to have shown, it seems that there is already a considerable critical mass in Translation Studies in Brazil, but this critical mass has shown relatively little interest in the outside world. We publish very little outside of Brazil. ${ }^{262}$ MILTON, 2015, p. 104 et seq.

${ }^{263}$ FROTA, 2006, p. 16 et seq.
} 
A gestão que havia sido anterior foi a da Professora Stella Tagnin, da USP, na qual houve a realização do Encontro de Tradutores em Fortaleza, que foi o IX Encontro Nacional depois que houve essa transição para a gestão do Professor Fábio Alves e por uma série de problemas a associação não foi regularizada e ficou parada. Parece que havia uma série de problemas com relação ao registro, na parte contábil de cartório da associação. (informação verbal). (SILVA et al., 2017 , p. 1465 s.)

No que tange a seu envolvimento com o décimo ENTRAD - acrônimo através do qual o Encontro Nacional de Tradutores passou a ser designado -, Gonçalves comenta:

Foi num encontro da ANPOLL que alguns colegas sugeriram que nós, aqui da UFOP, na época eu e a Professora Irene Hirsch, assumíssemos, tomássemos a frente para regularizarmos a associação e assim poder reativá-la e realizar o encontro de tradutores. Houve uma eleição e nós fomos empossados. $\mathrm{Eu}$, como presidente, e a professora Eliana Franco, na época da UFBA, ficou como vicepresidente. E a Professora Irene Hirsch, que era da UFOP, ficou como primeiratesoureira. Então nós retomamos a associação e fizemos todos os procedimentos para regularizá-la em termos contábeis, em termos burocráticos, em termos de registro... Toda essa parte burocrática que estava emperrada. A associação tinha sede em São Paulo e por uma série de problemas burocráticos, estava inativa e nós tivemos que fazer todo esse processo para reativá-la. (informação verbal). (SILVA et al., 2017, p. 1466)

Após essa gestão, que culminou no X ENTRAD, sediado pela Universidade Federal de Ouro Preto (UFOP) entre 7 a 10 de setembro de 2009 - cinco anos após a edição anterior - a ABRAPT retomou a organização regular do ENTRAD, tendo sido promovidas outras duas edições do evento: em 2013, na UFSC, e em 2016, na UFU. Em 2019, XIII Encontro Nacional de Tradutores e VII Encontro Internacional de Tradutores será sediado pela UFPB.

Por fim, Milton (2015) aborda o pouco contato entre a formação universitária de tradutores e a profissão de tradutor. Em levantamento realizado em 2001, Milton observa que muitos dos estudantes de tradução nas universidades optam por esse curso como forma de melhorar seus conhecimentos linguísticos; de modo análogo, o mercado tem preferência por graduandos e graduados em Tradução para postos em cursos de línguas a pessoas graduadas em Língua e Literatura. Ele chama a atenção, porém, para o fato de haver pouca pesquisa recente nesse campo. A partir dos poucos dados disponíveis, ele afirma que apenas 30\% dos graduados em Tradução pela UNESP de Rio Preto, por exemplo, exercem a profissão após o término da faculdade. Esse percentual, segundo Milton, seria ainda menor nas universidades particulares. Por outro lado, na Europa esse índice sobe para 50\%. Dentre as possíveis causas para tanto, ele menciona: (1) a falta de conhecimentos linguísticos 
na admissão dos alunos desses cursos; (2) o fato de cursos de formação de tradutores estarem dentro dos departamentos de Humanidades, nos quais os docentes têm um treinamento de natureza linguística e literária, em vez de um treinamento profissional; (3) o pouco acesso, ao longo da formação, às áreas técnicas; (4) e a falta de contato com indústrias e áreas de atuação profissional dos tradutores ${ }^{264}$.

A falta de parâmetros de boa formação profissional, observada por Snell-Hornby há duas décadas na Europa, continua a ser premente no Brasil. Barbosa (2009) também atribui as deficiências na formação de tradutores às dificuldades de emancipar-se da influência dos tradicionais departamentos de línguas haja vista que, de modo geral, os cursos de tradução estão vinculados aos cursos de Letras. Ela alega ainda que os currículos e mesmo os docentes são os mesmos dos cursos de formação de professores, sendo que muitos professores não têm a formação profisssional na área de tradução. Ela aborda ainda outras questões, como a recusa do mercado em remunerar propriamente os tradutores, o plágio de traduções no mercado editorial, a questão da cessão de direitos autorais pelas traduções às editoras e a falta de referência, nos trabalhos de grau, aos tradutores das obras do referencial teórico, ainda que a ABNT estipule que o nome do tradutor seja incluído junto à referência ${ }^{265}$.

Diante desse panorama, Barbosa avalia que a força política necessária aos estudos da tradução só poderia vir da união de pesquisadores, professores e profissionais através de suas entidades de representação. Ela percebe que o âmbito acadêmico já percebeu isso, tendo convidado ao GT do ANPOLL grupos de profissionais para ampliar o diálogo. A questão, no entanto, é a dificuldade de acadêmicos e profissionais se entenderem. Para promover o entendimento, a Academia teria que se voltar mais à formação profissional de tradutores, levando em conta também o mercado de tradução ${ }^{266}$.

Após esboçar um panorama do processo de institucionalização dos estudos da tradução no Brasil, é hora de traçarmos outro panorama essencial à nossa análise: o da presença dos funcionalistas entre nós.

\footnotetext{
${ }^{264}$ MILTON, 2015, p. 106 et seq.

${ }^{265}$ BARBOSA, 2009, p. 40.

${ }^{266}$ Ibid., p. 41.
} 


\subsection{Os funcionalistas vêm ao Brasil}

Nessa seção, tentaremos reconstituir a história da presença dos autores dos textos seminais do funcionalismo no Brasil, seja através de viagens documentadas ou de publicações. Esse levantamento serve a um propósito bem específico: verificar o impacto que a presença dos funcionalistas teve nos estudos da tradução no país.

O primeiro indício da presença de funcionalistas trata de um caso já mencionado por nós na Introdução deste trabalho; ele remonta a 1980, com a visita de Katharina Reiss ao Brasil. Num breve currículo incluído numa antologia de textos, organizada por Nord e Holz-Mänttäri (1993) em celebração aos 70 anos da teorizadora consta que Reiss esteve pela primeira vez no país entre agosto e setembro de 1980, com atividades acadêmicas no Rio de Janeiro, Brasília, Salvador, Belo Horizonte, São Paulo, Curitiba e Porto Alegre ${ }^{267}$. Vimos que a passagem da autora por Brasília ganhou registro escrito em 1981, quando Delton de Mattos organizou e publicou a coletânea de textos Estudos de Tradutologia 1. Nesse volume estão reunidas contribuições de jovens pesquisadores da Universidade de Brasília e de professores experientes da Universidade de Heidelberg, dentre as quais os mencionados dois ensaios de autoria de Katharina Reiss. No primeiro deles, que recebeu o título "Comprender un texto - ¿qué significa para el traductor?" [Compreender um texto: o que significa para o tradutor?], Reiss aborda alguns fatores que influenciam a compreensão que um tradutor faz do texto de partida, com consideração especial à idade do texto, à persona de seu autor, à linguagem empregada em sua construção e até mesmo a características intrínsecas do próprio tradutor.

No segundo ensaio, intitulado " - Miseria y esplendor de la traducción — o bien: ¿Qué tiene que ver la traducción con los hombrecitos verdes de Marte?" [Miséria e esplendor da tradução - ou: O que tem a ver a tradução com os homenzinhos verdes de Marte?], a teorizadora, numa clara alusão ao texto de José Ortega y Gasset $(1947)^{268}$, trata de alguns dissabores da atividade do tradutor, bem como de algumas conquistas - ou mesmo de situações jocosas, como é o caso referido pelo título, em que um erro de tradução deu margens

\footnotetext{
${ }^{267}$ Cf. HOLZ-MÄNTTÄRI; NORD, 1993, p. 9.

${ }^{268}$ Cf. também a tradução de K. Reiss a esse texto (ORTEGA Y GASSET, 1976).
} 
à sugestão de que haveria vida em Marte, alimentando assim o imaginário popular com "homenzinhos verdes"269.

Embora nenhum dos textos se detenha no tópico da função comunicativa da tradução, há algumas menções à escolha dentre diferentes formas de traduzir. No primeiro ensaio, ao elencar os fatores a serem considerados pelo tradutor na recepção do texto de partida, Reiss cita, dentre vários, o tipo de tradução a desempenhar: se uma tradução primária, através de que o tradutor estabelece uma comunicação direta entre o autor do texto de partida e o receptor do texto de chegada; se uma tradução secundária, com a função de retratar, na língua de chegada, a comunicação estabelecida entre autor e receptores na língua de partida; ou se ainda uma mescla de ambos os procederes ${ }^{270}$ : "Qual dos três papéis desempenhará depende, na maioria dos casos, da finalidade de uma tradução concreta ou também do gênero de determinado texto. ${ }^{271 " ~(R E I S S, ~ 1981 a, ~ p . ~ 35, ~ t r a d u c ̧ a ̃ o ~ d e ~ V i n i c i u s ~}$ Martins, nossa revisão).

No segundo ensaio, ao discorrer sobre as "misérias da tradução", Reiss observa que são muitas as críticas dirigidas à tradução, da parte de críticos profissionais ou amadores, que não consideram, em suas avaliações, o fato de que o produto de uma tradução depende de muitos fatores, tais como, por exemplo, a finalidade do traduzir:

Costumam-se emitir juízos negativos também quando o crítico não conhece as diferentes finalidades para as quais pode servir uma tradução, bem quando ele supõe uma diferente da que seguiu o tradutor. Pois não só existem textos de diferentes tipos e gêneros, como também diferentes tipos de tradução, segundo a finalidade a que deve servir uma tradução, segundo o destinatário para quem se traduz um texto. A tradução deve servir para fins científicos, - por exemplo versões justapostas para pesquisar línguas desconhecidas e suas estruturas divergentes da língua-alvo? Deve servir a tradução ao ensino de línguas estrangeiras para propor fenômenos gramaticais da outra língua - na chamada "grammar translation"? Ou a tradução quer facilitar a compreensão do conteúdo textual - por exemplo traduções em prosa de poesias? Ou ainda deve-se traduzir uma obra amena de maneira que o leitor veja concretizado seu desejo de poder gozar desta obra sem desagradáveis estruturas complexas - como eu denomino, numa tradução comunicativa? Sem levar em conta a possibilidade de múltiplas finalidades é possível tachar qualquer tradução de defeituosa. Miséria da tradução! ${ }^{272}$ (REISS, 1981b, p. 113, tradução de Vinicius Martins, nossa revisão)

\footnotetext{
${ }^{269}$ REISS, 1981b, p. 123.

${ }^{270}$ As definições de "tradução primária" e "tradução secundária" advêm de Diller \& Kornelius (1978, p. 3ss.).

${ }^{271}$ Cuál de los tres papeles desempeñará, depende en la mayoría de los casos de la finalidad de una traducción concreta o también del género de texto dado.

${ }^{272}$ Suelen emitirse juicios negativos también cuando el crítico no conoce las diferentes finalidades a las que puede servir una traducción, y cuando él supone otra que la que ha perseguido el traductor. Pues, no sólo hay diferentes tipos y géneros de textos, sino también diferentes tipos de traducción, según la finalidad a que debe servir una traducción, según el destinatario para quién se traduce un texto. ¿Ha de servir la traducción a fines científicos, - p. ej. versiones yuxtalineales para investigar lenguas desconocidas y sus estructuras divergentes de la lengua término? ¿Debe servir la traducción en la enseñenza [sic!] de lenguas extranjeras a la inculcación de fenómenos gramaticales de la otra lengua - en la llamada "grammar translation"? O ¿quiere ayudar la traducción a la mejor comprensión del contenido de un texto - p. ej. traduc-
} 
Outro tópico para o qual a autora dedica aqui apenas algumas palavras, mas que representa o cerne de sua proposta teórica, é sua tipologia textual. Nos ensaios, Reiss apenas menciona haver, segundo uma tipologia textual relevante à tradução, fundamentalmente três tipos de textos:

Qualquer texto tem, por assim dizer, três modos de existência; é um indivíduo (exceto textos totalmente padronizados, como por exemplo formulários de todo tipo); mas ainda sendo indivíduo, costuma ser a realização de determinado gênero textual com suas convenções linguísticas e textuais, que variam de uma comunidade linguística para outra; e, além disso, costuma ser a realização de um dos três tipos de texto (segundo uma tipologia de textos apropriada ao fenômeno da tradução), os que se distinguem porque o autor apenas deseja comunicar um conteúdo, dar informações (= tipo informativo), deseja comunicar conteúdos artisticamente organizados (= tipo expressivo) ou deseja comunicar conteúdos organizados persuasivamente, destinados a insinuar ao leitor uma relação ativa (= tipo operativo). Os métodos de tradução dependem, em amplo grau, do respectivo tipo de texto. Sobre isso, tratei em detalhe em outro lugar, de maneira que agora não quis me aprofundar na matéria. Em suma, cabe dizer o seguinte: a batalha decisiva do tradutor acontece no texto individual, a estratégia e a tática, no entanto, são orientadas pelas exigências do gênero e do tipo respectivo do texto em questão. ${ }^{273}$ (REISS, 1981b, p. 117s., tradução de Vinicius Martins, nossa revisão)

No ano seguinte, a PUC-RS publicou no periódico Letras de Hoje mais um artigo de Reiss, intitulado "Como averiguar o grau de dificuldade de uma tradução". Nesse artigo, como o próprio nome sugere, a teorizadora expõe uma metodologia, com propósitos didáticos, para avaliar a dificuldade da tradução de um determinado texto a partir de três aspectos textuais: o aspecto sintático, o aspecto semântico e o aspecto pragmático. Para Reiss, o aspecto pragmático tem predomínio sobre os demais ${ }^{274}$.

ciones en prosa de poesías? O bien ¿hay que traducir una novela amena de manera que el lector vea cumplido su deseo de poder gozar de esta novela sin molestas estructuras extrañas - en una traducción comunicativa como lo llamaría yo? Si no se tiene en cuenta la posibilidad de varias finalidades, es posible tachar a cualquier traducción de defectuosa. ¡Miseria de la traducción!

${ }^{273}$ Cualquier texto tiene, por decirlo así, tres modos de existencia; es un individuo (excepción hecha de textos totalmente estandardizados, como p. ej. formularios de toda clase); pero aun siendo individuo, suele ser realización de determinado género de texto con sus convenciones lingüísticas y textuales, que varían de una comunidad lingüística a la otra; y además de esto suele ser realización de uno de tres tipos de texto (según una tipología de textos apropiada al fenómeno de la traducción), los que se distinguen según que el autor sólo quiera comunicar un contenido, dar informaciones (= tipo informativo), que quiera comunicar contenidos artísticamente organizados (= tipo expresivo) o que quiera comunicar contenidos organizados persuasivamente, destinados a insinuar al lector una reacción activa (= tipo operativo). Los métodos de traducción dependen, en amplio grado, del respectivo tipo de texto. De esta cuestión he tratado en detalle en otro lugar, de manera que ahora no quisiera profundizar en la materia. En resumen cabe decir lo siguiente: la batalla decisiva del traductor se hace a nivel del texto individual, la estrategia y la táctica, sin embargo, se orientan por las exigencias del género y del tipo respectivo del texto en cuestión.

${ }^{274}$ REISS, 1982, p. 7 et seq. 
Desse texto, gostaria de chamar a atenção para a definição de tradução de Katharina Reiss, que já estabelece a equivalência da função do texto como critério principal para as decisões tradutórias:

\footnotetext{
Com respeito ao termo de "tradução", referimo-nos à tradução como ato de comunicação integral. Isso significa que um texto há de ser traduzido mantendo-se no processo tradutório a função comunicativa do texto original (segundo as leis do tipo e gênero de textos a que pertence o texto individual). (REISS, 1982, p. 13, tradução de Elisabeth Heuser e Ignacio Antonio Neis)
}

No que concerne à função da linguagem, notamos também aqui a discriminação de funções que remete à tipologia textual da autora: função informativa, função informativo-emotiva, função evocativa e função persuasiva ${ }^{275}$. Conforme nossa interpretação, enquanto textos que exercem função informativa e a função informativo-emotiva poderiam ser classificados dentre os textos informativos, textos que exercem função evocativa enquadrar-se-iam dentre os textos expressivos e os textos de função persuasiva têm seu lugar dentre os textos operativos.

A publicação desse, a exemplo dos dois primeiros textos, pode estar também ligada à visita da autora ao Brasil. Além da referida passagem pelo país em 1980, a teorizadora esteve em outubro de 1982 em Porto Alegre. Ainda que no texto não apareça qualquer indicação disso, a proximidade das data de publicação e da visita oferece fortes indícios de que esse texto sumarize o conteúdo de algumas das palestras da teorizadora no país.

No que diz respeito a Hans Vermeer, cumpre salientar que um de seus primeiros atos de divulgação em terras brasileiras deu-se, contudo, de forma indireta. Em 1986, Vermeer publicou o livro Esboço de uma teoria da tradução pelas Edições Asa, com sede em Lisboa. O livro, voltado inicialmente para o público português, foi concebido como um livro didático, em que a sua teoria é apresentada de forma simples e apoiada por diversos exemplos. Em que pese a obra não ter sido originalmente dirigida a nós, o material em português tornou-se uma possível fonte de referências para o pesquisador brasileiro.

Como primeiro exemplo de sua atuação como divulgador no Brasil, citamos a já referida presença do teorizador no IV Encontro Nacional de Tradutores, sediado na Universidade de São Paulo entre os dias 1 e 6 de abril de 1990. Vermeer proferiu, durante o evento, uma conferência plenária, com o título "Aplicação de princípios da Teoria da Recepção à Teoria da Tradução". Em sua conferência, realizada no dia $1^{\circ}$ de abril, ele evocou as teo-

\footnotetext{
${ }^{275}$ REISS, 1982, p. 15.
} 
rias modernas de recepção, que negam a existência do texto enquanto fenômeno objetivo, intersubjetivo, de modo a demonstrar a contribuição dessas teorias a uma teoria de tradução. Sob essa perspectiva, um texto seria constituído no momento de interação entre um "texto-oferta" e o receptor. Compreende-se por "texto-oferta" o texto produzido por um autor, posto à disposição de outros indivíduos e grupos para que eles constituam a sua própria interpretação. Dessa forma, o "texto-oferta" teria realidade (subjetiva) apenas para seu produtor e apenas enquanto "texto-em-produção". Uma vez concluído o texto, esse seria remetido a uma realidade objetiva, inatingível a todos os seres humanos, posto que cada recepção implicaria uma interpretação particular desse texto por parte de seu receptor, modificando dessa forma o texto-oferta e convertendo-o em tantos "textos-recepção" diferentes entre si quantos receptores houver ${ }^{276}$.

Para os estudos da tradução, a definição acima de texto demanda repensar o status do texto de partida no processo tradutório. Pois, se aceitarmos a premissa de que não há uma só forma de interpretar um mesmo texto e, da mesma maneira, admitirmos que o texto de partida, tal como pensado por seu autor, está inacessível a seus receptores, então não seria possível pensar numa forma única de traduzir:

\footnotetext{
$\mathrm{O}$ real e verdadeiro texto de partida para uma tradução é sempre um texto indi- $_{2}$ vidual, subjectivo e subjectivamente interpretado e percebido por um tradutor e que difere, portanto, em princípio de todos os outros textos ${ }_{2}$ possíveis ("realizáveis", "constituíveis") a partir dum texto-oferta.

Daí que (e é esta uma das razões porque) todas as traduções feitas a partir dum texto-oferta diferirão necessariamente entre si (porque não existe, insisto, um único (ou seja "o") texto de partida em nível de ocorrência, mas só um texto de partida individualmente constituído pelo respectivo tradutor em determinada situação da sua vida). E é este texto (o texto ${ }_{2}$ individual) a única base para o tradutor. (VERMEER, 1990a, p. 48)
}

A participação de Vermeer, no entanto, não se limitou à conferência. No mesmo dia, tomou parte de uma mesa-redonda acerca da formação do tradutor, na qual esboçou, em linhas gerais, um plano piloto para a formação de tradutores e intérpretes no nível de graduação na Universidade de Heidelberg: uma formação com mais ênfase nas competências textuais e culturais do que em competências linguísticas ${ }^{277}$. Ele ainda participou de um painel, no dia 4 de abril, dedicado à apresentação de linhas de pesquisa em tradução. No painel, ele tentou apresentar duas propriedades de sua concepção de "agir translatório"

\footnotetext{
${ }^{276}$ VERMEER, 1990a, p. 47.

${ }^{277}$ VERMEER, 1990b, p. 93.
} 
[translatorisches Handeln]: (1) traduz-se em diferentes níveis e (2) questões culturais interferem no processo de tradução.

Além das contribuições de Vermeer, cumpre ainda fazer referência às participações de Jazely Gonzalez da Silva Nunes, à época leitora de português da Universidade de Heidelberg, e de Margret Ammann, orientanda de Vermeer na mesma instituição. Ambas também teriam contribuído com a divulgação da abordagem teórica mediante apresentação de comunicações, participação em oficinas e distribuição de exemplares dos livros recémpublicados na Alemanha.

O currículo do autor, hospedado pelo website da Universidade de Mainz ${ }^{278}$, indica, contudo, que esse não foi o único evento de que Vermeer participou em 1990 no Brasil. Ele também faz referência a compromissos no Goethe Institut do Rio de Janeiro, na Faculdade Ibero-Americana e na UFRGS. Esses compromissos incluem não apenas palestras sobre temas ligados à teoria de tradução, mas também a apresentação de um projeto para a formação de professores de interpretação. A esse projeto, Azenha Jr. (2015b) faz menção em sua avaliação do papel do funcionalismo na formação de tradutores na USP. Ele relata a esse respeito:

\begin{abstract}
No ano seguinte, 1991, tivemos uma vez mais a visita de Vermeer, desta vez para a tentativa de celebrar um acordo entre a USP e a Universidade de Heidelberg voltado à formação de intérpretes para o par de línguas alemão-português. O objetivo do acordo era o de formar catorze intérpretes que, quando de seu retorno ao Brasil, atuariam como multiplicadores junto a universidades brasileiras na formação de intérpretes para alemão.Decisiva para a viabilização do acordo foi a iniciativa de Ruth Mayer, que conseguiu a adesão de várias empresas alemãs de São Paulo para o financiamento da infraestrutura de trabalho dos intérpretes formados, em especial para a criação de um laboratório de treinamento de intérpretes.

Por razões que não cabe discutir aqui, o acordo acabou não se realizando, mas a vinda de Vermeer, acompanhado por sua assistente, Margret Ammann, e também pela leitora de português, Jazely Nunes, rendeu importantes encontros de trabalho, além de palestras que, mais uma vez, divulgaram as ideias do Funcionalismo alemão de forma mais acessível do que aquela expressa nas obras de meados dos anos de 1980. (AZENHA JR., 2015b, p. 160s.)
\end{abstract}

Nessa ocasião, ele também esteve, acompanhado de Margret Ammann, no campus de São José do Rio Preto da Universidade Estadual Paulista (UNESP) para ministrar as palestras "Currículos de tradução na Alemanha - O mercado interno europeu e as consequências para a tradução e interpretação", "Factores da tradução: scenes-\&-frames" e "O trabalho prático com textos". No ano seguinte, foi publicado um artigo de Vermeer no já

\footnotetext{
${ }^{278}$ Publikationsliste: https://vermeer.fb06.uni-mainz.de/publikationsliste/ [Acesso em 20/03/2019]
} 
mencionado número especial da revista Ilha do Desterro de 1992. No artigo, intitulado "Is Translation a Linguistic or a Cultural Process?" [Seria a tradução um processo linguístico ou cultural?], Vermeer propõe definições para os conceitos de língua e cultura, para depois defender o argumento, a partir de diferentes perspectivas, de que a tradução, em vez de um processo de transcodificação, restrita ao domínio linguístico, é um processo de transferência entre culturas. De fato, ele define tradução da seguinte forma:

\begin{abstract}
Ao contrário, uma importante conclusão da conclusão acima exposta seria que a tradução é, antes, produção ("design") de um texto-alvo para um "escopo" [propósito] específico numa situação-alvo para um destinatário (ou grupo de destinatários) alvo específico, a partir de um texto-fonte já existente. (E cabe aos fatores que acabamos de mencionar e à habilidade individual do tradutor decidir quanto do texto-fonte e seus elementos serão ou poderão ser levados em consideração nesse processo de design.). ${ }^{279}$ (VERMEER, 1992, p. 45)
\end{abstract}

Pouco tempo depois, outro artigo de Vermeer (1994) é publicado no Brasil, dessa vez pela UNICAMP. Nesse artigo, ele observa que todas as coisas no mundo - que incluem não apenas as pessoas, mas os textos e as línguas - estão em constante evolução, sujeitas às ações do tempo e da situação. Eles seriam, assim, processos. Na tradução, os textos de partida e de chegada também estariam sujeitos à ação do tempo, inseridos em diferentes circunstâncias e, assim, não poderiam ser iguais em sua forma, conteúdo, função, sentido e "valor" ${ }^{280}$. Com isso, Vermeer opõe-se à exigência por equivalência entre os textos, postura assumida pelas teorias tradicionais de tradução. Aqui, veremos algumas ideias bastante presentes na teorização de Vermeer, tais como o texto como produto de uma situação, a língua como parte integrante de uma cultura e a função do texto como critério direcionador das escolhas tradutórias.

Em sua última visita documentada ao Brasil, em 1995, Vermeer ministrou um curso de pós-graduação de curta duração no campus de Assis da UNESP, intitulado "História da prática e teoria da tradução e interpretação literária, científica e religiosa desde as origens até o século XX". Além disso, ele ofereceu também um minicurso em ocasião do IV Encontro de Professores de Línguas e Literaturas Estrangeiras (EPLLE) e III Encontro Paulista de Pesquisadores em Tradução, ocorrido entre os dias 20 e 22 de setembro de 1995 . O

\footnotetext{
${ }^{279}$ On the contrary, an important conclusion from the foregoing conclusion would be that translation is rather a target text production ("designing") for a specific "scope" in a target situation for a specific target addressee (or addressee group) starting from an already existing source text. (And it is left to the just mentioned factors and the individual translator's skill in how far the source text and its elements will or can be taken into consideration in this designing process.)

${ }^{280}$ VERMEER, 1994, p. 5.
} 
minicurso recebeu o título "Quo vadis, fidus interpres? - A formação de tradutores e intérpretes" e teve como foco a proposta de um

currículo para a formação de tradutores/intérpretes com base no "learning how to learn", ou seja, não a acumulação de conhecimentos e competências cada vez mais especializados, mas a aquisição de uma metodologia bem fundada que permitirá ao futuro profissional agir com competência na variedade de campos para os quais será solicitado. (VERMEER, 1996, p. 157)

É curioso, no entanto, que Vermeer não atuou apenas como divulgador da abordagem funcionalista no Brasil, como também percorreu o caminho de volta, divulgando as teorias brasileiras na Alemanha, em especial o pós-estruturalismo de Rosemary Arrojo. Na edição de 1990 da revista TEXTconTEXT, periódico organizado por Vermeer e publicado pela Universidade de Heidelberg, ele publica em inglês "O literário e o desejo do intraduzível: algumas reflexões sobre Grande Sertão: Veredas" (cf. ARROJO, 1990), comunicação apresentada por Arrojo no IV Encontro Nacional de Tradutores, do qual, como vimos, Vermeer também fez parte. Posposto a esse artigo, Vermeer (1990b) incluiu uma reflexão própria acerca das ideias de Arrojo, destacando convergências e divergências entre as reflexões dela e a sua.

Alguns anos mais tarde, Vermeer escreveu um prefácio para a já citada coletânea de Michaela Wolf (1997) sobre os estudos da tradução no Brasil. Nesse prefácio, ele relata o princípio de seu contato com Arrojo e sua obra:

Quando, em 1986, a minha ex-colega Jazely Gonzalez da Silva Nunes presenteou-me, logo após a publicação do livro de Rosemary Arrojo, Oficina de Tradução - A teoria na prática, com o livrinho fino de 85 páginas durante um período como docente visitante, eu o li com bastante interesse. Pouco tempo depois, conheci Rosemary pessoalmente. A admiração pela pessoa e pela obra prevaleceu até hoje e ainda aumentou. O motivo é facilmente reconhecível: nesse meio tempo, desenvolvi minha "Skopostheorie" (de cujos desenvolvimentos posteriores participou, dentre outros, também uma brasileira: Margret Ammann) e constatei, já em 1983, desde um primeiro contato com Justa Holz-Mänttäri (à época em Turku, na Finlândia), que estávamos ambos em trilhas muito semelhantes (cf. a teoria sobre a ação translacional de Holz-Mänttäri). Em 1986, constatei que Rosemary Arrojo foi a terceira a escrever, de forma totalmente desvinculada de nós, uma teoria paralela, estritamente funcional da tradução. As ênfases são um pouco diferentes: Em sua teoria - que permaneceu geral - Justa Holz-Mänttäri depositou ênfase no âmbito dos textos de especialidade; de forma central, Rosemary Arrojo trata da tradução literária em sua abordagem igualmente geral. ${ }^{281}$ (VERMEER, 1997, p. 7)

\footnotetext{
${ }^{281}$ Als mir meine damalige Kollegin Jazely Gonzalez da Silva Nunes 1986 kurz nach Erscheinen von Rosemary Arrojos Oficina de Tradução - A teoria na prática das schmale Bändchen von 85 Seiten während einer Brasiliengastprofessur schenkte, las ich es mit großem Interesse. Wenig später lernte ich Rosemary persönlich kennen. Die Begeisterung für die Person und das Werk hat bis heute angehalten und ist noch gestiegen. Der Grund ist leicht einzusehen: Ich hatte inzwi-
} 
Nota-se, portanto, que o que move Vermeer a investir na divulgação do pós-estruturalismo de Rosemary Arrojo são as semelhanças que ele identificou entre essa vertente e a sua abordagem funcional. Nesse volume, ele também atuou como tradutor, vertendo para o alemão os textos "As questões teóricas da tradução e a desconstrução do logocentrismo: algumas reflexões", "Sobre interpretação e asceticismo: reflexões em torno e a partir da transferência" e "Desconstrução, psicanálise e o ensino de tradução", todos de autoria de Arrojo.

Em 1997, Wolfgang Lörscher, professor da Universidade de Leipzig com passagens pelo Brasil, organizou um número especial da revista Ilha do Desterro, dedicado aos estudos da tradução na Alemanha. Como paradigma representativo dos estudos da tradução de língua alemã, Lörscher incluiu artigos de funcionalistas como Christiane Nord, Hans G. Hönig e Paul Kussmaul. Em seu artigo, Hönig (1997) compreende a tradução a partir da metáfora da engenharia: como uma atividade construtiva, a tradução não se limitaria à superfície da ponte, que permite o transporte de um ponto A para um ponto B, mas envolveria também a estrutura que a sustenta. Ele descreve as macroestratégias subjacentes à tradução, bem como suas complexidades dentro do quadro funcionalista, fazendo também referência às condições de trabalho do tradutor profissional.

Kussmaul (1997), por sua vez, opta por fazer um balanço da abordagem funcionalista até o momento. Seu exame parte das influências da linguística contrastiva sobre os preceitos da vertente teórica, para depois abordar o modelo de tipologia textual de Katharina Reiss, o quadro teórico esboçado por Hans Vermeer até o conceito de grau necessário de precisão desenhado por ele e por Hans Hönig no livro Strategie der Übersetzung [Estratégia de tradução], o qual examinaremos com mais pormenores no próximo capítulo. Ao término, ele constata que o valor didático da abordagem funcionalista está em servir como guia para as decisões tradutórias.

Por fim, Nord (1997a) aborda a didática da tradução, em busca de um critério de avaliação para os trabalhos de estudantes de tradução. Ela observa que, segundo o funcionalismo, o critério norteador de decisões tradutórias é a função do texto de chegada, distin-

schen meine "Skopostheorie" entwickelt (an deren Weiterführung u.a. auch eine Brasilianerin: Margret Ammann mitgearbeitet hat) und bei einer ersten Begegnung mit Justa Holz-Mänttäri (damals Turku, Finnland) bereits 1983 festgestellt, daß wir auf einer ganz ähnlichen Linie lagen (vgl. Holz-Mänttäris Theorie über translatorisches Handeln). 1986 stellte ich nun fest, daß auch Rosemary Arrojo ganz unabhängig von uns als dritte eine parallele strikt funktionale Theorie des Übersetzens geschrieben hatte. Die Schwerpunkte liegen ein wenig anders: Justa Holz-Mänttäris Schwerpunkt ihrer durchaus allgemein gehaltenen - Theorie liegt im Bereich der Gebrauchstextübersetzung; Rosemary Arrojo geht in ihrem ebenfalls allgemeinen Ansatz zentral auf das literarische Übersetzung ein. 
guindo dois tipos básicos de tradução: uma tradução que tenha a função de documentar um texto de partida e uma tradução que sirva entre seus receptores como um instrumento comunicativo. A opção por um tipo de tradução dependeria, dentre outros fatores, do encargo de tradução, isto é, das instruções do cliente acerca de quais características ele deseja para o texto traduzido.

Embora não tenhamos encontrado qualquer outro indício da presença de Hans Hönig e Paul Kussmaul no Brasil, Christiane Nord exerceu - e até hoje exerce - um importante papel de divulgadora do funcionalismo entre nós. Azenha Jr. (2015b) relata acerca de uma iniciativa do Instituto Goethe, no início dos anos de 1990, para promover a formação de professores de alemão e de tradutores para essa língua. Dentre os eventos organizados pelo instituto, ele destaca o "Seminar Z8 - Übersetzer in München", do qual pôde participar nos anos de 1992 e 1994. Esse evento teria reunido tradutores e professores de tradução de várias partes do mundo em Munique, a fim de trocarem experiências didáticas postas em prática em suas instituições de origem e entrarem em contato com as didáticas de formação de tradutores e intérpretes aplicadas na Alemanha. Ele destaca o contato, nas duas ocasiões, com Christiane Nord, importante representante do funcionalismo, sobretudo em sua divulgação ${ }^{282}$ :

\begin{abstract}
A atuação de Christiane Nord nesses cursos que envolviam tradutores e professores de tradução para o par de línguas alemão/português foi de fundamental importância para a divulgação mais rápida das ideias funcionalistas nos países de origem dos participantes, seja no plano da pesquisa de pós-graduação em tradução, àquela altura ainda bastante incipiente, ao menos entre nós, seja na estruturação de cursos para a formação de tradutores e na definição de estratégias didáticas, pois Nord e seus colegas de Heidelberg já dispunham àquela época de larga experiência na formação de tradutores voltada ao mercado de trabalho. (AZENHA JR., 2015b, p. 162)
\end{abstract}

Esse contato teria sido fundamental para a recepção e acolhida das ideias funcionalistas no Brasil, posto que a proposta funcionalista vinha ao encontro dos anseios para a formação de tradutores e para uma mudança de perspectiva para o ensino da tradução menos vinculado ao ensino de língua estrangeira e mais focado na dimensão cultural da atividade.

Em nosso levantamento, encontramos quatro artigos de Christiane Nord publicados no Brasil: além do referido artigo publicado na revista Ilha do Desterro, a TradTerm publicou um artigo da autora também em 1997, intitulado "El texto buscado - los textos auxilia-

\footnotetext{
${ }^{282}$ AZENHA JR., 2015b, p. 161 et seq.
} 
res en la enseñanza de traducción" [O texto almejado - os textos auxiliares no ensino de tradução]; no ano de 2000, saiu pelos Cadernos de Tradução o artigo "Training Functional Translators" [Formando tradutores funcionais]; finalmente, em 2005, a TradTerm publica um novo artigo de Nord, com o título "Translating as a purposeful activity: a prospective approach" [Traduzir como uma atividade com propósito: uma abordagem prospectiva]. Além disso, foram publicadas duas entrevistas com a teorizadora, ambas publicadas na revista Cadernos de Tradução: a primeira, de autoria não identificada, foi publicada em 2000, e vem acompanhada de uma lista anexa com a produção bibliográfica de Nord; a segunda, feita por Monique Pfau e Meta Elisabeth Zipser, foi publicada em 2014.

Cumpre ainda mencionar a primeira tradução de um texto seminal da teorizadora, publicada em 2016. Trata-se do artigo "Lealdade em vez de fidelidade: proposta de uma tipologia funcional da tradução", tradução de um dos textos mais relevantes da autora (ver NORD, 1989), no qual ela detalha o conceito de lealdade e propõe uma tipologia de traduções a partir da distinção entre duas funções básicas para a tradução: a função de documento de uma comunicação anterior e a função de instrumento comunicativo. A tradução foi realizada por Cristiane Krause Kilian, ligada ao Grupo Termisul, da UFRGS, e foi revista por outro aluno da UFRGS, Renan Lazzarin, e por Luciane Leipnitz, docente da UFPB, cuja formação inclui passagens pela UFRGS e pela Universidade de Leipzig, Alemanha.

No que concerne às visitas da autora, Nord informou-nos, numa comunicação pessoal, acerca de sua primeira vez no Brasil, em setembro de 1993. Na ocasião, após uma estada em Córdoba e em Buenos Aires, na Argentina, ela esteve em Santa Maria e no Goethe Institut de Porto Alegre. Depois, em julho de 1999, ela relata acerca de um período de duas semanas em que atuou como professora visitante na Universidade Federal do Paraná, ministrando palestras sobre tradução literária para o espanhol e uma disciplina de 15 aulas sobre teoria, método e didática de tradução. No mesmo período, a UFPR sediou o IV Congresso Brasileiro de Professores de Alemão realizado pela Associação Brasileira de Associações de Professores de Alemão (ABRAPA), no qual ela proferiu uma conferência, intitulada "Vertikal statt horizontal: Die Übersetzungseinheit aus funktionaler Sicht" [Vertical em vez de horizontal: as unidades de tradução a partir de uma perspectiva funcional]. Nessa conferência, ela abordou a dificuldade de se definir uma unidade de tradução - especialmente uma que tenha valor didático. A seu ver, as unidades de tradução devem ser discriminadas de acordo com a função pretendida para o texto. Isso significa que as unidades de tradução não se restringem a um nível linguístico, mas podem contemplar os diferentes 
níveis num mesmo texto. Além da conferência, Nord ministrou um workshop sobre os diferentes tipos de problemas de tradução.

Em 2004, Nord esteve na USP em ocasião da defesa da tese de Doutorado, coorientada por ela, de Maurício Mendonça Cardozo (2004), à época já vinculado a Universidade Federal do Paraná (UFPR). Em 2006, durante uma permanência mais prolongada na América Latina, ela ministrou em Florianópolis um minicurso de 9 aulas no âmbito da recém fundada Pós-Graduação em Estudos da Tradução da UFSC. Nesse curso, ela aborda aspectos específicos do funcionalismo tradutológico, tocando em questões como a intertextualidade como problema de tradução, a tradução literária e uma estilística comparada do par linguístico espanhol-alemão. Ela também ministrou uma palestra sobre tradução de textos bíblicos, com o título "¿Para qué volver a traducir el Nuevo Testamento? Aspectos funcionales de la traducción de textos bíblicos" [Para que voltar a traduzir o Novo Testamento? Aspectos funcionais da tradução de textos bíblicos]. Em 2007, após atuar como docente visitante na Universidad Nacional de Asunción, no Paraguai, Nord estendeu sua permanência na América Latina a convite de Cardozo. Assim, ela repetiu em Curitiba o minicurso e a palestra ministrados no ano anterior em Florianópolis.

Por fim, em 2015, Nord retornou a Florianópolis, permanecendo entre os dias 23 de março e 01 de abril. Durante esse período, a teorizadora ministrou um minicurso acerca da teoria e da metodologia da tradução funcional. Após o término, deu a palestra inaugural do primeiro semestre, com o título "La incertidumbre y el escopo: un procedimiento top-down para resolver las dudas en la traducción" [A incerteza e o escopo: um procedimento topdown para resolver as dúvidas em tradução]. Além da oferta de minicurso, um dos motivos da presença de Nord em Florianópolis foi o lançamento da tradução para o português de seu livro seminal, Textanalyse und Übersetzen. A tradução, que recebeu o título Análise textual em tradução: bases teóricas, métodos e aplicação didática, foi coordenada por Meta Elisabeth Zipser e envolveu alguns dos ex-orientandos da docente da UFSC, além da própria Christiane Nord. Apesar da festa de lançamento, o livro só foi publicado em 2016.

A tradução da obra seminal de Christiane Nord pode ser indubitavelmente considerada um marco na recepção do funcionalismo no Brasil, tendo em vista que é a primeira tradução de um dos livros monográficos mais influentes da abordagem teórica. Nord expressa a relevância desta publicação no prefácio da edição brasileira, escrito em outubro de 2013: 
Agora, passados 25 anos da primeira edição alemã, apresentamos aqui a edição brasileira da obra, que me deixa especialmente feliz. Tudo isso mostra que o interesse por este livro continua muito presente e que os estudantes da área preferem lê-lo em sua própria língua. Quantas vezes, quando em conferências ou palestras, sou abordada por jovens que, com brilho nos olhos, me dizem: "eu li o seu livro"! E, ao dizerem isso, se referem a este livro e não a qualquer outro que eu tenha escrito. Isso me deixa muito orgulhosa. (NORD, 2016a, p. 5, tradução de Meta E. Zipser, grifos nossos)

Com isso, temos dois itens especialmente significativos da produção intelectual da autora (ver também NORD, 2016b, como mencionado acima). Esperamos que esse seja apenas o início para as traduções de textos seminais funcionalistas.

Cumpre ainda fazer menção à presença de Mary Snell-Hornby no Brasil. Tivemos contato com uma entrevista com a teorizadora, feita por Gustavo Althoff, então doutorando pela UFSC, e por Alice Leal, à época doutoranda na Universidade de Viena, e publicada na revista Scientia Traductionis em 2011. Além disso, temos conhecimento de apenas duas traduções da autora publicadas em periódicos brasileiros: "Venutis 'foreignization': Das Erbe von Friedrich Schleiermacher in der Translationswissenschaft?" [A 'estrangeirização' de Venuti: o legado de Friedrich Schleiermacher aos Estudos da Tradução?], feita por Marcelo V. S. Moreira e revista pela Prof. Dr. Tinka Reichmann, publicada no periódico Pandaemonium Germanicum (USP) em 2012; e "Communicating in the Global Village: On Language, Translation and Cultural Identity" [Comunicação na aldeia global: sobre linguagem, tradução e identidade cultural], publicado em 2014 pela revista Belas Infiéis (UnB) com tradução de Matheus Bezerra Evaristo e da Prof. Dr. Cristiane Roscoe Bessa, ambos da UnB.

Em seu currículo, disponível no site da Universidade de Viena ${ }^{283}$, constam apenas duas visitas ao Brasil: em junho de 1997, na Universidade Federal do Ceará, e em setembro de 2006, na Universidade Federal de Santa Catarina. Contudo, nos Anais do XI Congresso Latino-Americano de Germanistas, organizado pela Associação Latino-Americana de Estudos Germanísticos (ALEG) em 2003 nas cidades de São Paulo (SP), Paraty e Petrópolis $(\mathrm{RJ})$, consta a participação da teorizadora com a comunicação "Thomas Manns Erzählungen als 'heiliges Original': Durch die Jahrzehnte in englischer Übersetzung" [Os contos de Thomas Mann como o "sagrado original": através das décadas na tradução para o inglês]. Ela faz referência a esse evento posteriormente, no livro The Turns of Translation

\footnotetext{
${ }^{283}$ https://transvienna.univie.ac.at/en/about-us/people/professors/ [Acesso em 21/03/2019]
} 
Studies: New paradigms of shifting viewpoints? [As viradas dos estudos da tradução: novos paradigmas ou mudanças de pontos de vista?]:

Em setembro de 2003, participei do $11^{\circ}$ Congresso da Associação LatinoAmericana de Estudos Germanísticos no Brasil. Ao todo, durou sete dias e foi sediado por três diferentes lugares: passamos os primeiros três dias, com a conferência de abertura, várias conferências plenárias, painéis de discussão e comunicações em dez diferentes seções, na Universidade de São Paulo, os dois dias seguintes, com mais plenárias e painéis, na histórica cidade colonial de Paraty, terra-natal de Julia da Silva-Bruhns, mãe de Heinrich e Thomas Mann, e ele foi concluído - com um painel de discussões final, relatórios nas seções e palestras de encerramento - na cidade imperial de Petrópolis, onde o escritor austríaco Stefan Zweig viveu por muitos meses antes de dar cabo da própria vida em fevereiro de 1942. [...] As línguas do congresso eram o português, o alemão e o espanhol. A avaliação geral feita durante os relatórios de cada seção e nas palestras de encerramento em Petrópolis foram impressionantes: concordou-se que o congresso trouxe inovações, sobretudo através das perspectivas ganhas por sua abordagem intercultural e interdisciplinar. Isso ficou claro, em parte, nos tópicos de algumas das seções, tais como "literatura e mídia", ou "o desafio de Sigmund Freud - suas obras em tradução", ou "discursos em metrópoles num contexto global", mas também nas novas ideias emergentes nas ligações entre estudos germânicos e a América Latina: o desespero de Stefan Zweig, por exemplo, levou a discussões sobre o "discurso transnacional do Holocausto" e daí para a experiência latino-americana de regimes ditatoriais, como evidente no Parque de la Memoria para os desaparecidos em Buenos Aires ou em esculturas de um artista colombiano expressando a tragédia da guerra civil. No frigir dos ovos, como observado na palestra de encerramento, os estudos germânicos migraram de sua posição dogmática e monolítica na qual o alemão era a grande língua de cultura e ciência, para uma posição mais relativa mas frutífera em meio à pluralidade de línguas e culturas no mundo globalizado de hoje com suas necessidades de diálogo internacional e intercultural. ${ }^{284}$

Dessa forma, nota-se que a multidisciplinaridade e a posição mais afeita ao diálogo ocupada agora pelos estudos germânicos remetem à própria essência dos estudos da tradução, incentivando-a a escrever o próprio exame da história dos desdobramentos de seu campo disciplinar.

\footnotetext{
${ }^{284}$ In September 2003 I attended the 11th Congress of the Latin American Association for Germanic Studies in Brazil. It lasted seven days in all and was held in three different places: the first three days with the ceremonial opening, several plenary lectures, panel discussions and papers in ten different sections, were spent at the University of São Paolo, the next two days, with more plenaries and panel discussions, at the historic colonial town of Paraty, birthplace of Julia da Silva-Bruhns, the mother of Heinrich and Thomas Mann, and it was concluded - with a final panel discussion, reports on the sections and closing lectures - in the imperial city of Petrópolis, where the Austrian writer Stefan Zweig lived for several months before taking his life in February 1942. [...] The conference languages were Portuguese, German and Spanish. The general assessments made during the section reports and the closing lectures in Petrópolis were impressive: it was agreed that the Congress had broken new ground, above all through the perspectives gained by its interdisciplinary, intercultural approach. This was shown partly in the topics of some of the sections, such as "Literature and media" or "The challenge of Sigmund Freud - his works in translation" or "Discourses on megacities in a global context", but also in the new insights emerging from the links between Germanic Studies and Latin America: the despair of Stefan Zweig, for example, led to discussions on the "Transnational Holocaust discourse" and from there to the Latin American experience of dictatorship, as shown in the Memorial Park for the desaparecidos in Buenos Aires or in sculptures by a Colombian artist expressing the tragedy of civil war. All in all, as was observed in the concluding lecture, Germanic Studies has moved from its dogmatic, monolithic standing where German was the great language of scholarship and science, to a more relative but fruitful position among the plurality of languages and cultures in the globalized world of today with its need for international and intercultural dialogue.
} 
O relato do percurso dos autores funcionalistas traz indícios do processo de recepção da teoria no Brasil. No entanto, para medir o seu impacto, é essencial compreender o contexto intelectual em que essa história ocorre.

\subsection{Mapeamento: artigos científicos}

Nessa seção, voltaremos nossas atenções para os artigos científicos publicados em periódicos dedicados exclusivamente à área de estudos da tradução, bem como em números especiais dedicados ao tema de revistas de outras áreas. O mapeamento cumpre aqui dois objetivos: (1) lançar luz sobre o contexto intelectual em que o funcionalismo ingressou nos estudos da tradução no país e (2) verificar a presença do funcionalismo em pesquisas sobre tradução nesse período.

Nesse ponto, fazemos nossas as palavras de Pagano e Vasconcellos, salientando que "um mapa não é o território mapeado" (PAGANO; VASCONCELLOS, 2003, p. 2), mas uma representação do campo, sujeita a limitações metodológicas. É sabido que, embora o artigo científico seja uma das formas mais eficazes de divulgação de pesquisa, há quem opte por outras vias de divulgação, como participações em congressos, palestras, minicursos ou mesmo a publicação de livros e capítulos em antologias. Além disso, mesmo entre aqueles que optam pelo artigo científico, nem sempre esses serão publicados por revistas exclusivas da área, haja vista a disseminação de artigos sobre tradução em periódicos dedicados a outras áreas de Letras. Ademais, posto que nos limitamos a publicações feitas dentro do território brasileiro, nossa pesquisa não contempla os casos de pesquisadores que optaram apenas por divulgar seus resultados por meio de publicações em âmbito internacional.

Com isso, admitimos a parcialidade do mapa aqui representado. Contudo, acreditamos que, a despeito dessas limitações, os dados aqui presentes signifiquem uma valiosa contribuição para compreender o nosso campo disciplinar entre a década de 1990 e os primeiros anos do século XXI. 


\subsubsection{Corpus: artigos científicos (1992-2005)}

Num artigo publicado nos Cadernos de Tradução, organizados pelo Programa de Pós-Graduação em Estudos da Tradução (PGET) da Universidade Federal de Santa Catarina, em ocasião dos dez anos de fundação da revista, Maria Paula Frota (2007) faz um balanço da história dos estudos da tradução no Brasil, para a qual se considera a publicação de Escola de tradutores de Paulo Rónai, em 1952, como marco inaugural. Embora parta desse marco, seu relato concentra-se sobretudo no período após a fundação da revista, em 1996.

Nesse relato, Frota identifica, desde o início do movimento de institucionalização do campo disciplinar no país nos anos de 1960, um caráter nômade dos estudos da tradução, posto que esses surgem como subárea ou linha de pesquisa nos diversos departamentos de Letras de institutos de ensino superior no Brasil. Esse nomadismo, a seu ver, refletese na publicação de artigos em revistas de outras áreas e mesmo nos números temáticos organizados por essas revistas ${ }^{285}$.

É certo que esse "caráter nômade" de nossos estudos da tradução ainda não tenha sido até hoje de todo superado. Ainda assim, no período a que ela se refere nessa passagem, havia ainda menos opções de publicação em revistas especializadas no referido campo de interesse: de fato, durante os anos de 1980, a primeira e única revista em vigor, a Tradução \& Comunicação, organizada pela outrora Faculdade Ibero-Americana de Letras e Ciências Humanas ${ }^{286}$ (UNIBERO), publicou nove números até o encerramento de suas atividades em 1986. Desde então, houve um vazio de periódicos especializados no tema, estendendo-se esse vazio por oito anos - até a fundação, em 1994, da revista Tradterm, organizada pelo Centro Interdepartamental de Tradução e Terminologia (CITRAT) da Universidade de São Paulo. Até o ano 2000, havia apenas três periódicos dedicados à tradução em atividade: além dos já mencionados Tradterm e Cadernos de Tradução, a revista Cadernos de Literatura em Tradução, organizada pelo CITRAT-USP, com primeiro volume publicado em 1997.

\footnotetext{
${ }^{285}$ FROTA, 2007, p. 144.

${ }^{286}$ Hoje integrada à Rede Anhanguera Educacional.
} 
Com o início do novo milênio, em consonância com o boom de desenvolvimento da área no Brasil ${ }^{287}$, novas revistas foram fundadas, e mesmo a Tradução \& Comunicação, após quinze anos, voltou a publicar um novo número. Além das novas revistas, outros números temáticos foram organizados em revistas de outras áreas. Não obstante, ainda persiste a disseminação de artigos sobre a tradução em números não temáticos de revistas de outros domínios do saber, o que torna o seu rastreamento uma tarefa bastante dispendiosa. Desse modo, optamos por selecionar para análise apenas as revistas e os números temáticos dedicados aos estudos da tradução publicados entre os anos de 1990 e 2005. O rastreamento desses volumes pauta-se, em sua maior parte, pelo levantamento realizado por Frota, anexo a sua contribuição ${ }^{288}$.

Dessa maneira, salientamos que não é nosso intento criar um mapa completo dos estudos da tradução desse período, posto que estaríamos ignorando o livro, um veículo de produção de papel preponderante no campo disciplinar no Brasil, bem como outras publicações nesse formato, que incluem as coletâneas. Conforme aponta De Bellis, as ciências humanas, em oposição às ciências naturais, não favorecem propriamente a pesquisa bibliométrica, dadas características que são próprias desse campo do saber: a preferência pelo livro ao artigo científico, o interesse sobretudo em questões regionais ou locais e a consequente publicação em língua nacional e a adoção, como fontes de consulta, de materiais mais antigos do que aqueles normalmente utilizados pelas ciências naturais, com um vínculo muito mais frouxo em relação às frentes de pesquisa mais recentes ${ }^{289}$. Ainda assim, é de nosso entendimento que o levantamento de referências contidas nos artigos publicados nessas revistas possam ao menos fornecer, a partir de dados concretos e do método científico, uma ideia geral da configuração dos estudos da tradução no Brasil.

Ao longo da pesquisa, foram levantados dois corpora de artigos científicos. $\mathrm{Na}$ primeira fase da pesquisa, foram reunidos artigos publicados entre 1992 e 2005 em periódicos especializados nos estudos da tradução e números especiais voltados ao tema. Esse levantamento, como veremos, teve o propósito de fornecer dados para o mapeamento do campo disciplinar como um todo. Na segunda fase da pesquisa, coletamos apenas artigos em revistas especializadas amparados pelo funcionalismo, com o objetivo de identificar tendências da pesquisa no âmbito dessa abordagem teórica no Brasil.

\footnotetext{
${ }^{287}$ FROTA, op. cit., p. 148.

${ }^{288}$ Id., 2006, p. $21 \mathrm{~s}$.

${ }^{289}$ DE BELLIS, 2009, p. xii.
} 
Segue uma relação dos periódicos especializados a comporem o corpus levantado durante a primeira fase de pesquisa:

\begin{tabular}{|c|c|c|}
\hline \multicolumn{1}{|c|}{ Revista (Filiação) } & 1a. publicação & No. volumes \\
\hline Tradterm (USP) & 1994 & 13 \\
\hline Cadernos de Tradução (UFSC) & 1996 & 16 \\
\hline Tradução \& Comunicação (UNIBERO) & 2001 (1981) & 5 \\
\hline Tradução em Revista (PUC-RJ) & 2004 & 2 \\
\hline Scientia Traductionis & 2005 & 1 \\
\hline
\end{tabular}

Tabela 04: Relação das revistas especializadas (1990-2005)

Para a ausência da revista Cadernos de Literatura em Tradução em nosso corpus, atribuímos duas justificativas: o fato de a revista publicar apenas temas relacionados com a tradução literária, o que pode interferir na análise estatística, favorecendo a tradução literária além do que lhe é devido, e o fato de privilegiar traduções comentadas sobre artigos científicos, o que não está de acordo com os requisitos estipulados para a construção desse corpus.

A criação da TradTerm sucedeu a fundação do Centro Interdepartamental de Tradução e Terminologia (CITRAT) da Universidade de São Paulo. O CITRAT iniciou suas atividades em 1992, em consonância com o crescente interesse acadêmico na atividade tradutória, manifesto, segundo a apresentação do primeiro número da revista, pela presença da tradução como linha de pesquisa no âmbito da Pós-Graduação em Linguística Aplicada do Instituto de Estudos da Linguagem da Universidade de Campinas (IEL-UNICAMP) e no programa de Semiótica e Linguística Geral da Faculdade de Filosofia, Letras e Ciências Humanas da Universidade de São Paulo (FFLCH-USP), e pela fundação da Associação Brasileira de Pesquisadores em Tradução (ABRAPT) ${ }^{290}$. Tendo em vista a falta de meios de divulgação de pesquisas empreendidas na área desde o já mencionado encerramento do periódico Tradução \& Comunicação, em 1986, a diretoria pró-tempore do centro definiu como prioridade a criação de uma revista dedicada a divulgar pesquisas relacionadas às

${ }^{290}$ AUBERT; ALVES, 1994, p. 9. 
áreas de sua competência — a tradução e a terminologia —, moldando assim o perfil que a TradTerm sustenta mesmo hoje.

Entre 1994 e 2005, foram publicados onze volumes (treze números) da TradTerm com periodicidade anual, exceto nos anos de 1997 e 1998, quando a revista foi lançada semestralmente. Devido a dificuldades enfrentadas pelo CITRAT, não houve a publicação de um novo volume em $1999^{291}$. Com a retomada das publicações no ano 2000, a revista voltou à periodicidade anual. Dessa maneira, no período descrito foram publicados ao todo 84 artigos sobre temas ligados à tradução, 36 sobre terminologia, 28 resenhas e duas publicações de outra natureza.

Além de publicar artigos e resenhas referentes a assuntos diversos no âmbito da tradução e da terminologia, a TradTerm conta com blocos temáticos e alguns números especiais. O primeiro número de 1998 traz artigos produzidos no âmbito do acordo de cooperação entre a USP e a Universidade de Oslo. Trata-se de textos expostos num seminário interdisciplinar sobre linguística e tradução realizado em Oslo em abril de 1997. Em comum, esses textos trazem a preocupação com a descrição linguística da tradução, na intersecção entre os estudos da tradução e a linguística contrastiva ${ }^{292}$.

O volume sete, publicado em 2001, versou exclusivamente sobre a terminologia, como resultado das atividades da Escola Internacional de Inverno de Terminologia, sediada pelo CITRAT entre os dias 17 e 27 de junho de 2000. Assim, o volume, organizado por Ieda Maria Alves (USP), reúne a reprodução de algumas conferências ministradas durante o evento, com destaque a trabalhos que identificam a interação da terminologia com outras áreas, tais como a tradução, a documentação e a lexicografia ${ }^{293}$. Posto que nossos esforços estão concentrados na reconstituição dos estudos da tradução no Brasil, apenas os artigos que tratavam da relação entre a terminologia e a tradução foram incluídos em nossa pesquisa.

Em 2003, além de artigos referentes a temas diversos relacionados à tradução e à terminologia, o número nove do periódico incluiu um bloco temático, concentrando pesquisas com foco nas modalidades de tradução, desenvolvidas a partir dos procedimentos tradutórios da Stylistique Comparée de Jean-Paul Vinay e Jean Darbelnet. O bloco, organi-

\footnotetext{
${ }^{291}$ AZENHA JR., 2000

${ }^{292}$ AUBERT, 1998.

${ }^{293}$ ALVES, 2001.
} 
zado por Francis Henrik Aubert (USP), é composto por cinco artigos, além de um texto de apresentação de autoria do organizador ${ }^{294}$.

Em 2004, enfim, foi a vez da linguística de corpus ganhar um número inteiramente dedicado a ela. Sob a organização de Stella E. O. Tagnin (USP), a publicação reúne doze artigos de pesquisadores atuantes dentro e fora do Brasil, com o intuito de popularizar a vertente de investigação ${ }^{295}$. Esse volume dá sequência a um processo de divulgação iniciado com a organização, dois anos antes e também pelas mãos de Tagnin, de outra publicação dedicada ao tema: o número especial da revista Cadernos de Tradução, sobre o qual discorreremos com mais detalhes posteriormente.

De fato, os Cadernos de Tradução veicularam seu primeiro número dois anos após a primeira publicação da TradTerm, unindo-se a ela na divulgação científica no âmbito dos estudos da tradução. O periódico foi elaborado inicialmente pelo Grupo de Trabalho de Tradução da Universidade Federal de Santa Catarina (UFSC); a partir de 2004, passou a integrar o programa de Pós-Graduação em Estudos da Tradução da instituição, criado um ano antes. Desde então, tem sido uma profícua divulgadora de pesquisas: entre 1996 e 2005 foram publicados dezesseis números da revista: de 1996 a 1999 com periodicidade anual; a partir de 2000 com periodicidade semestral. Nesses dezesseis números foram veiculados 204 artigos, 120 resenhas de traduções e de livros teóricos sobre a tradução, 12 entrevistas com tradutores e seis publicações de outra natureza.

No site da revista, reitera-se o compromisso com a contribuição científicoacadêmica para os estudos da tradução:

\begin{abstract}
O objetivo principal da revista é publicar resultados de pesquisas no campo dos estudos da tradução no Brasil e no exterior e acompanhar o debate na área, cuja interdisciplinaridade lhe é inerente. Publica regularmente artigos de alta qualidade, com efetiva contribuição científico-acadêmica para a Área. Além disso, os critérios adotados para a seleção dos trabalhos são: ineditismo, originalidade, clareza, relevância para a área. (Extraído da seção "Capa" do site dos Cadernos de Tradução ${ }^{296}$ )
\end{abstract}

Num artigo publicado nos Cadernos de Tradução, Juliana A. Silva, Fátima G. Daniel e Marileide D. Esquerda (2007) avaliam o papel do tradutor em artigos publicados pela revista entre 1996 e 2000. A fim de justificar a escolha do corpus, elas destacam o prestígio do periódico no contexto acadêmico nacional e internacional, refletido tanto pela

\footnotetext{
${ }^{294}$ AUBERT, 2003.

295 TAGNIN, 2004.

${ }^{296}$ Endereço: https://periodicos.ufsc.br/index.php/traducao/index (Acesso 12/09/2018)
} 
avaliação feita pela CAPES - à época, os Cadernos de Tradução foram avaliados com conceito Qualis B; hoje, já desfrutam do conceito Qualis A1 — e pela adesão de pesquisadores no Brasil e no exterior: segundo as pesquisadoras, a participação de autores estrangeiros chegava a aproximadamente $30 \%{ }^{297}$.

Assim como ocorreu com a revista TradTerm, também foram publicados números especiais dos Cadernos de Tradução, bem como blocos temáticos. O primeiro volume especial foi publicado em 2001. Organizado por Thaís Flores N. Dias (UFMG), traz artigos relacionados à tradução intersemiótica. Diniz (2001) relembra-nos de que o termo, cunhado por Jakobson, designa a procura por equivalência, isto é, por semelhanças em sistemas semióticos diferentes, sem deixar de lado a existência de um sentido textual a ser traduzido para outro sistema. Essa tradução, contudo, nunca reconstituirá a plenitude do texto e, se for considerado que o sentido é fruto da interpretação do receptor, é inviável avaliar uma tradução, independente do sistema linguístico ou semiótico, com base no critério da fidelidade. Assim, os artigos da coletânea analisam a transposição de sentidos entre o palco, o cinema, a televisão, a literatura e a música, ilustrando procedimentos pós-modernos amparados por teorias da tradução, tais como a citação, a reescrita, a colagem e a reciclagem. Além dos 15 artigos dedicados ao tema, foram incluídas duas bibliografias comentadas: a primeira referente às adaptações de Shakespeare e a segunda ao campo de pesquisas como um todo.

No primeiro semestre de 2002 foi lançado o número nove dos Cadernos de Tradução, dedicado à Linguística de Corpus. O fascículo, como mencionado, organizado por Stella E. O. Tagnin (USP), foi intitulado "Tradução e corpora" e conta com nove artigos dedicados à pesquisa tradutológica com base em corpus e uma seleção de material bibliográfico sobre o tema. Tagnin justifica a organização do volume mencionando a incipiência da área ainda nos estudos da tradução no Brasi1 ${ }^{298}$. A publicação, assim, teve o intuito de oferecer referenciais teóricos e metodológicos para novas pesquisas, contemplando a teoria, a prática e o ensino da tradução.

No segundo semestre de 2002, outro número especial foi publicado. Organizado por Fábio Alves (UFMG), o volume traz sete artigos, escritos por autores oriundos de instituições no Brasil, na Alemanha, no Canadá, na Espanha e na Dinamarca, que relatam pesquisas realizadas no âmbito da abordagem processual em tradução, isto é, dedicadas a in-

\footnotetext{
${ }^{297}$ SILVA; DANIEL; ESQUERDA, 2007, p. 74 et seq.

${ }^{298}$ TAGNIN, 2002.
} 
vestigar os processos cognitivos envolvidos no ato de traduzir. Em seu breve exame da história da vertente processual, Alves destaca o crescimento significativo do interesse de pesquisadores em questões ligadas ao processo de tradução, da aplicabilidade dos resultados da pesquisa e do desenvolvimento metodológico, sobretudo mediante a inclusão de ferramentas computacionais, que garantem mais rigor científico e replicabilidade dos estudos. Nesse sentido, os artigos incluídos nesse número propor-se-iam a discutir o processo de tradução através de três diferentes abordagens: a análise diacrônica da produção teórica e metodológica no âmbito da vertente, o exame dos princípios e parâmetros metodológicos então adotados na pesquisa e as possibilidades de aplicação dos resultados na formação de tradutores $^{299}$. Como de praxe, ele também inclui uma seleção bibliográfica com referências sobre o tema.

Em 2003, no semestre seguinte, é lançado mais um número especial dos Cadernos de Tradução, dessa vez dedicado a abordar as questões da retradução e da adaptação. $\mathrm{O}$ volume foi organizado por John Milton (USP) e por Marie-Hélène Catherine Torres (UFSC) e inclui onze artigos referentes à proposta temática, bem como um levantamento bibliográfico de materiais para consulta posterior. Tendo em vista a pouca atenção que era dispensada a esses temas nos estudos da tradução de modo geral, os organizadores reuniram contribuições de diferentes localidades no mundo, visando a trazer mais clareza às questões que envolvem a retradução e a adaptação de obras a novas culturas ${ }^{300}$.

No ano seguinte, Marco Rocha, Iria Sponholz e Regina Márcia Gerber (UFSC) organizaram e publicaram um volume dedicado à tradução automática e à tradução assistida por computadores. Em sua apresentação, após um breve histórico do papel dos sistemas computacionais na história da tradução, sobretudo no que tange à tradução automática, eles destacam o papel hoje desempenhado pelos sistemas de tradução assistida por computador (em inglês, CAT-tools) na tradução profissional e a carência de estudos a esse respeito no Brasil $^{301}$. Desse modo, o volume tem o intuito de estimular novas pesquisas na área, trazendo dez artigos relativos ao papel da tecnologia na pesquisa e na prática da tradução.

Por fim, em 2005 foi publicado um dossiê, como bloco temático, no número 16 dos Cadernos de Tradução. Diferentemente dos demais volumes citados, neste apenas parte da revista é dedicada a um tema, a saber, os desafios inerentes às diversas modalidades de

\footnotetext{
${ }^{299}$ ALVES, 2002, p. 14.

${ }^{300}$ MILTON; TORRES, 2003.

${ }^{301}$ ROCHA; SPONHOLZ; GERBER, 2004, p. 10 et seq.
} 
tradução audiovisual (TAV) e de tradução intersemiótica. Assim, além de seis artigos sobre temas diversos, foram incluídos oito artigos voltados exclusivamente a esse tema especial.

Outra revista dedicada à tradução de circulação regular incluída em nosso corpus foi a Tradução \& Comunicação. Como mencionado, o periódico é o mais antigo dedicado ao tema, editado pelo antigo Centro Universitário Ibero-Americano (UNIBERO). Após a interrupção das atividades em 1986, a revista retorna em 2001, publicando seu número 10, com nova formulação gráfica, sob a direção de Regina Helena E. Alfanaro. No prefácio dessa edição, Julio García Morejón atribui a causa do silêncio da revista à necessidade de ajustes internos na estrutura e na organização do curso de formação de tradutores e intérpretes da UNIBERO. Entre 2001 e 2005, a revista Tradução \& Comunicação publicou 43 artigos e ensaios, 16 resumos de teses e dissertações defendidas em instituições de ensino superior no Brasil, três resenhas e quatro textos de outra natureza.

Em tempos mais recentes, a Pontifícia Universidade Católica do Rio de Janeiro (PUC-RJ) iniciou as atividades do periódico Tradução em Revista. Criado em 2004, é organizado pela área de Estudos da Tradução do Departamento de Letras da universidade, estando, desde 2006, vinculado ao Programa de Pós-Graduação em Estudos da Linguagem. Entre 2004 e 2005, foram publicados dois volumes por meio impresso, totalizando dezesseis artigos no período. O segundo volume, publicado em 2005, foi republicado no formado eletrônico dez anos depois.

Por fim, o periódico Scientia Traductionis foi criado em 2005 na UFSC, com o propósito de servir como veículo de divulgação das pesquisas realizadas no interior do PGET, programa a que esteve vinculado. Em cumprimento a uma solicitação apresentada pela CAPES, que restringia o número de revistas ligadas a um mesmo programa de pósgraduação, a publicação da revista foi interrompida em 2014. Com um único número publicado em 2005, Scientia Traductionis contribui com apenas cinco artigos para o nosso corpus.

Além das revistas voltadas à tradução, incluímos números especiais dedicados à tradução de revistas originalmente voltadas às Letras. A seguir, vemos a tabela com os números especiais dedicados aos estudos da tradução, publicados entre 1992 e 2005, a que tivemos acesso: 


\begin{tabular}{|c|c|c|}
\hline Revista (Filiação) & Números & Ano/public. \\
\hline Ilha do Desterro (UFSC) & $28,33,36$ & $1992,1997,1999$ \\
\hline Trab. em Lingüística Aplicada (UNICAMP) & 19 & 1992 \\
\hline Letras (UFSM) & 8 & 1994 \\
\hline ALFA (UNESP) & N. especial & 2000 \\
\hline Crop (USP) & 6 & 2001 \\
\hline Gragoatá (UFF) & 13 & 2002 \\
\hline Revista Brasileira de Linguística Aplicada (ALAB) & v. 2/ n. 2 & 2002 \\
\hline D.E.L.T.A. & N. especial & 2003 \\
\hline
\end{tabular}

Tabela 05: Relação dos números temáticos de revistas de outras especialidades (1990-2005)

No topo da lista, vemos o periódico Ilha do Desterro, vinculado ao programa de Pós-Graduação em Letras: Inglês e Literatura Correspondente da Universidade Federal de Santa Catarina. Em atividade desde 1979, o periódico destina-se à publicação de artigos e resenhas inéditos relacionados às áreas de Inglês, Literatura e Estudos Culturais.

Durante o período estipulado para pesquisa, a Ilha do Desterro organizou três números especiais referentes a assuntos do domínio da tradução. O primeiro foi publicado em 1992, com o título "Studies in Translation". Esse número foi editado por Malcolm Couthard, doutor em Sociolinguística pela Universidade de Birmimgham, hoje professor emérito da Aston University e professor visitante da UFSC. Em sua introdução, ele salienta a volta da popularidade da tradução no meio acadêmico e anuncia o objetivo da coletânea de conciliar teoria e prática da tradução: ainda que por diferentes abordagens, os autores dos artigos publicados teriam em comum o interesse em melhorar a qualidade das traduções através de um entendimento melhor dos problemas teóricos e práticos gerados no processo tradutório $^{302}$. O volume traz dez artigos sobre temas diversos, inclusive um artigo escrito por Hans Vermeer, no qual discute as implicações linguísticas e culturais no processo de tradução. Além dos artigos, o volume traz uma seção de resenhas e uma bibliografia ampla sobre a tradução.

O segundo número especial, publicado em 1997, traz um panorama dos desenvolvimentos de então dos estudos da tradução na Alemanha. O volume foi editado por Wolfgang Lörscher, docente na Universidade de Leipzig, e traz contribuições de diferentes ver-

${ }^{302}$ COULTHARD, 1992, p. 7. 
tentes em voga na Alemanha, inclusive textos de Hans G Hönig, Paul Kussmaul e Christiane Nord, podendo ser considerado como uma verdadeira porta de entrada para o Funcionalismo no Brasil. O próprio Lörscher, em sua introdução à antologia, distingue entre as contribuições dois diferentes grupos: Hönig, Kußmaul, Nord e Radegundis Stolze como representantes da vertente funcionalista e Wilss, Wotjak e ele próprio como adeptos de uma vertente processual ${ }^{303}$.

O terceiro e último número selecionado da revista Ilha do Desterro foi publicado em 1999, dedicado às traduções de Shakespeare ao redor do mundo, com foco nos pontos de contato entre estudos da tradução e teoria crítica. O volume foi organizado por José Roberto O'Shea, docente da UFSC, que destaca a multidisciplinaridade no tratamento desse tema, a exemplificar pela diversidade observada entre os próprios autores das contribuições: conforme afirma, os textos foram escritos por um grupo de autores que incluem linguistas, professores de teatro, especialistas em Shakespeare, críticos teatrais, atores, diretores e tradutores profissionais. A escolha pela produção shakespeariana também não foi ao acaso: Shakespeare não é só conhecido ao redor do mundo, como suas produções são constantemente objeto de apropriação, adaptação, deslocamento e subversão, tornando-se Shakespeare co-autor em diferentes produções que reafirmam a identidade cultural daqueles que o adaptam ou o traduzem ${ }^{304}$.

Outra revista a organizar um número especial para a tradução foi a revista Trabalhos em Linguística Aplicada, vinculada ao Programa de Pós-Graduação em Linguística Aplicada pelo Instituto de Estudos da Linguagem da UNICAMP. A revista tem o propósito de estimular a constante renovação e ampliação da área da Linguística Aplicada, veiculando artigos sobre os seguintes temas: interculturalidade e identidades; educação linguística; tecnologias e redes sociais; tradução; multimodalidades e intermidialidades; antropologia linguística; políticas linguísticas; discursos e políticas. O número 19, publicado no primeiro semestre de 1992, foi organizado por Rosemary Arrojo, então docente da instituição. Ao apresentar o volume, Arrojo destaca o papel de submissão desempenhado pela tradução, bem como a associação usualmente feita entre a tradução e a derivação, o feminino e a ausência, para depois mostrar como a pós-modernidade procura subverter essas associações. Desse modo, os artigos reunidos nesse volume refletem uma visão pós-moderna da

\footnotetext{
${ }^{303}$ LÖRSCHER, 1997, p. 9.

${ }^{304}$ O'SHEA, 1999, p. 10.
} 
tradução, sendo muitos deles amparados pela Desconstrução de Jacques Derrida. Ao todo, são onze artigos incluídos na coletânea.

A revista Letras está vinculada ao programa de Pós-Graduação em Letras (PPGLetras) da Universidade Federal de Santa Maria (UFSM). Com publicação semestral, dedica um número por ano aos estudos linguísticos e um aos estudos literários. Em 1994, o número 8 da revista, organizado por Zília Mara P. Scarpari (UFSM) trouxe contribuições diversas sobre a tradução. A decisão de dedicar um número aos estudos da tradução é justificada pela organizadora através do movimento de revisão em curso à época da própria noção de tradução e do desejo que essas mudanças reflitam-se no ensino de tradução no Brasil, além do crescimento da participação de tradutores no mercado de trabalho. $\mathrm{O}$ volume conta com doze artigos de autores de diferentes instituições dentro e fora do país.

A revista $A L F A$, organizada pela Universidade Estadual Paulista "Júlio de Mesquita Filho" (UNESP), destina-se a divulgar trabalhos nas mais diversas linhas de pesquisa da linguística. No ano 2000, foi publicado um número especial, organizado por Marcos Siscar e Cristina Carneiro Rodrigues, ambos à época docentes da UNESP de São José do Rio Preto, reúne, em sua maioria, trabalhos apresentados no VII Encontro Nacional de Tradutores e I Encontro Internacional de Tradutores, realizados na Universidade de São Paulo em setembro de 1998. São onze artigos desenvolvidos na intersecção entre a Desconstrução e a Pós-modernidade por pesquisadores brasileiros. Ademais, foram incluídas duas traduções de textos escritos por Jacques Derrida, completando assim o volume.

A edição supracitada da revista $A L F A$, contudo, não foi o único produto do VII Encontro Nacional de Tradutores: a revista Crop, da área de Língua e Literatura Inglesa e Norte-Americana da FFLCH-USP, lançou em 2001 um volume intitulado "Emerging Views on Translation History in Brazil", baseado em trabalhos apresentados no evento, voltados a explorar a história de traduções e tradutores no Brasil. Tendo organizado o volume, John Milton destaca o crescimento da pesquisa historiográfica no âmbito dos estudos da tradução. Além de contar com sete artigos escritos por pesquisadores brasileiros, a coletânea inclui um texto seminal de Lieven D'Hulst, professor da Universidade Católica de Leuven, em que esboça uma proposta metodológica de pesquisa historiográfica para a teoria e a prática da tradução a partir das questões cruciais a orientarem o discurso da retórica clássica.

A revista Gragoatá, vinculada aos programas de pós-graduação em Estudos de Linguagem e em Estudos de Literatura da Universidade Federal Fluminense (UFF), desti- 
na-se à publicação de textos de excelência nas áreas de linguagem e literatura. Em 2002, com organização de Fernando Afonso de Almeida e de Paula Glenadel Leal, foi publicado um número dedicado aos estudos da tradução. Essa edição traz catorze artigos e uma resenha sobre temas diversos ligados ao fenômeno tradutório.

A Revista Brasileira de Linguística Aplicada é uma publicação ligada ao Programa de Pós-Graduação em Estudos Linguísticos (POSLIN) da Universidade Federal de Minas Gerais, com a missão de estimular a pesquisa no âmbito da Linguística Aplicada. Em 2002, o volume 2 (número 2) da revista foi dedicado à tradução, apresentando doze artigos baseados em trabalhos expostos no VIII Encontro Nacional de Tradutores, realizado na UFMG em 2001.

Por fim, em 2003 foi lançado um número especial da revista D.E.L.T.A.: Documentação e Estudos em Linguística Teórica e Aplicada. O periódico é publicado pela Pontifícia Universidade Católica de São Paulo (PUC-SP) e volta-se à divulgação de artigos inéditos sobre assuntos referentes ao fenômeno linguístico. O volume 19 foi organizado por John Robert Schmitz (UNICAMP) e Maria Aparecida Caltabiano (PUC-SP) e traz onze artigos considerados representativos das mais diversas ramificações de pesquisas realizadas no âmbito dos estudos da tradução no Brasil.

A segunda fase do levantamento, focada apenas em artigos fundamentados pela abordagem funcionalista ${ }^{305}$, contemplou, além das revistas já descritas nesse tópico, ainda outras três, criadas após o ano de 2005. Trata-se dos periódicos In-Traduções, Traduzires e Belas Infiéis. A tabela abaixo traz os dados da quantidade de volumes consultados:

\begin{tabular}{|c|c|c|}
\hline \multicolumn{1}{|c|}{ Revista (Filiação) } & Nos. consultados & No. volumes \\
\hline Tradterm (USP) & $2006-2018$ & 20 \\
\hline Cadernos de Tradução (UFSC) & $2006-2018$ & 33 \\
\hline Tradução \& Comunicação (UNIBERO) & $2006-2013$ & 13 \\
\hline Tradução em Revista (PUC-RJ) & $2006-2018$ & 23 \\
\hline Belas Infiéis (UnB) & $2012-2017$ & 14 \\
\hline In-Traduções (UFSC) & $2009-2015$ & 13 \\
\hline Traduzires (UnB) & $2012-2013$ & 4 \\
\hline Scientia Traductionis (UFSC) & $2006-2014$ & 15 \\
\hline
\end{tabular}

Tabela 06: Relação das revistas especializadas consultadas (2006-2018)

\footnotetext{
${ }^{305}$ Ver próximo subtópico.
} 
O periódico In-Traduções consiste em mais uma criação da UFSC e esteve, também ele, vinculado à Pós-Graduação em Estudos da Tradução. Com onze números regulares e dois números temáticos, a revista esteve ativa entre os anos de 2009 e 2015.

As Belas Infiéis são uma revista vinculada ao Programa de Pós-Graduação em Estudos da Tradução (POSTRAD) da Universidade de Brasília (UnB) e estão em atividade ainda hoje. Criada em 2011, no mesmo ano que o programa a que está ligada, a revista veio com o objetivo de ampliar os espaços de difusão de produção científica na área. Com duas publicações por ano, a revista já está no oitavo volume, totalizando, entre 2011 e 2019, dezessete números.

Por sua vez, a revista Traduzires, outra criação da UnB, foi fundada em 2012 e contou com apenas quatro números. Tendo em vista de que a revista esteve também vinculada ao POSTRAD, especulamos que o interrupção das publicações tenha sido devida, a exemplo dos periódicos Scientia Traductionis e In-Traduções, ao fato de haver mais de um periódico ligado a um mesmo programa de pós-graduação.

\subsubsection{Mapa dos estudos da tradução segundo artigos científicos (1992-2005)}

O seguinte mapeamento é feito a partir de diferentes índices, que nos fornecem uma variedade de informações: a distribuição de artigos segundo o ano de publicação, o volume de artigos publicados de cada periódico selecionado, os autores mais produtivos, as instituições com mais pesquisas publicadas, os autores mais citados nos artigos e os temas mais abordados pelas pesquisas. Enquanto a periodização do primeiro índice é anual, a dos demais segue uma segmentação de aproximadamente cinco anos: de 1992 a 1995, de 1996 a 2000, e de 2001 a 2005.

Segundo nosso levantamento, dentre os periódicos selecionados para análise, foram publicados 503 artigos que versam sobre temas ligados à tradução e à interpretação: 20 artigos em 1992, 21 artigos em 1994, sete artigos em 1995, 35 artigos em 1996, 47 artigos em 1997, 28 artigos em 1998, 36 artigos em 1999, 35 artigos em 2000, 62 artigos em 2001 e em 2002, 49 artigos em 2003, 43 artigos em 2004 e 58 artigos em 2005. O gráfico abaixo mostra melhor essa distribuição: 


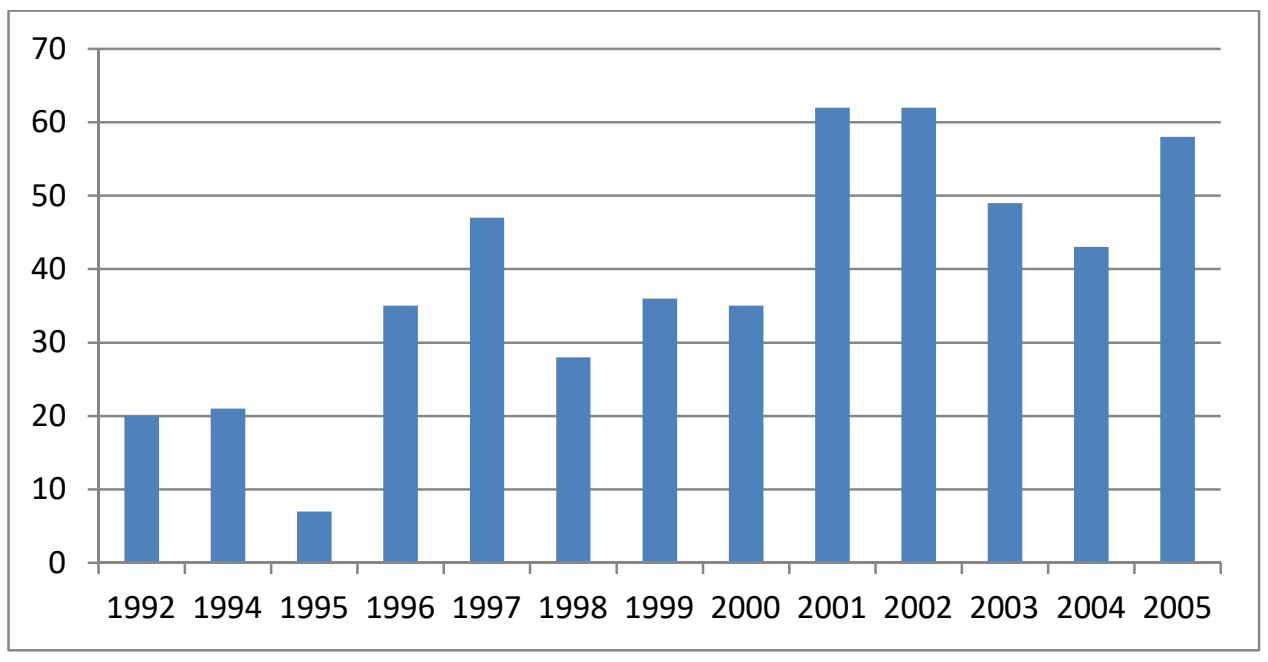

Gráfico 05: Distribuição de artigos por ano de publicação.

Conforme vimos na primeira seção deste capítulo, depois de que o periódico Tradução e Comunicação teve sua publicação interrompida em 1986, a área careceu de meios de publicação de artigos até o ano de 1994, quando a revista TradTerm publicou seu primeiro volume. Assim justificamos a ausência dos anos de 1990, 1991 e 1993 da listagem. O ano de 1992 está representado no gráfico graças ao lançamento de um número especial da revista Ilha do Desterro, publicado pela UFSC, e de um número especial da revista Trabalhos em Linguística Aplicada, publicado pela UNICAMP.

O primeiro pico de crescimento ocorreu no ano de 1996, quando entrou em operação a revista Cadernos de Tradução. Esse crescimento não é mais evidente, pois em 1994, além da primeira edição da TradTerm, foi lançado um número especial da revista Letras, publicado pela UFSM. O elevado número de publicações de 1997 deve-se ao fato de, entre 1997 e 1998, a TradTerm ter publicado dois volumes em cada ano, bem como a outro número especial da revista Ilha do Desterro, dessa vez dedicado à tradutologia alemã. Ainda que a TradTerm não tenha sido publicada em 1999, o número de artigos subiu em comparação com o ano anterior, graças a um extenso número da Ilha do Desterro, dedicado à tradução e à adaptação das obras de William Shakespeare. A partir do ano 2000, os Cadernos de Tradução passam a publicar dois volumes por ano, enquanto a TradTerm volta a publicar apenas um número por ano.

O crescimento expressivo no número de publicações em 2001 é decorrente da retomada das atividades da revista Tradução \& Comunicação, após quinze anos de hiato. 
Nesse ano também é lançado um número especial da revista Crop, organizada pela Área de Inglês da USP, dedicado à historiografia da tradução. Os números referentes às publicações dos anos de 2002 e 2003 continuaram a ser complementados por números especiais das revistas Gragoatá, da UFF, Revista Brasileira de Linguística Aplicada, da UFMG, e D.E.L.T.A., da PUC-SP. Em 2004 houve uma queda no volume de artigos publicados, a despeito do início das operações do periódico Tradução em Revista, organizado pela PUC$\mathrm{RJ}^{306}$. Por fim, em 2005, também tem início a publicação da revista Scientia Traductionis.

Os próximos dois gráficos ajudam-nos a compreender o papel dos periódicos na promoção dos estudos da tradução no meio acadêmico brasileiro. O primeiro estabelece, ano após ano, o comparativo do volume de artigos publicados por cada revista. No segundo gráfico, temos a proporção de cada periódico no volume total de artigos publicados.

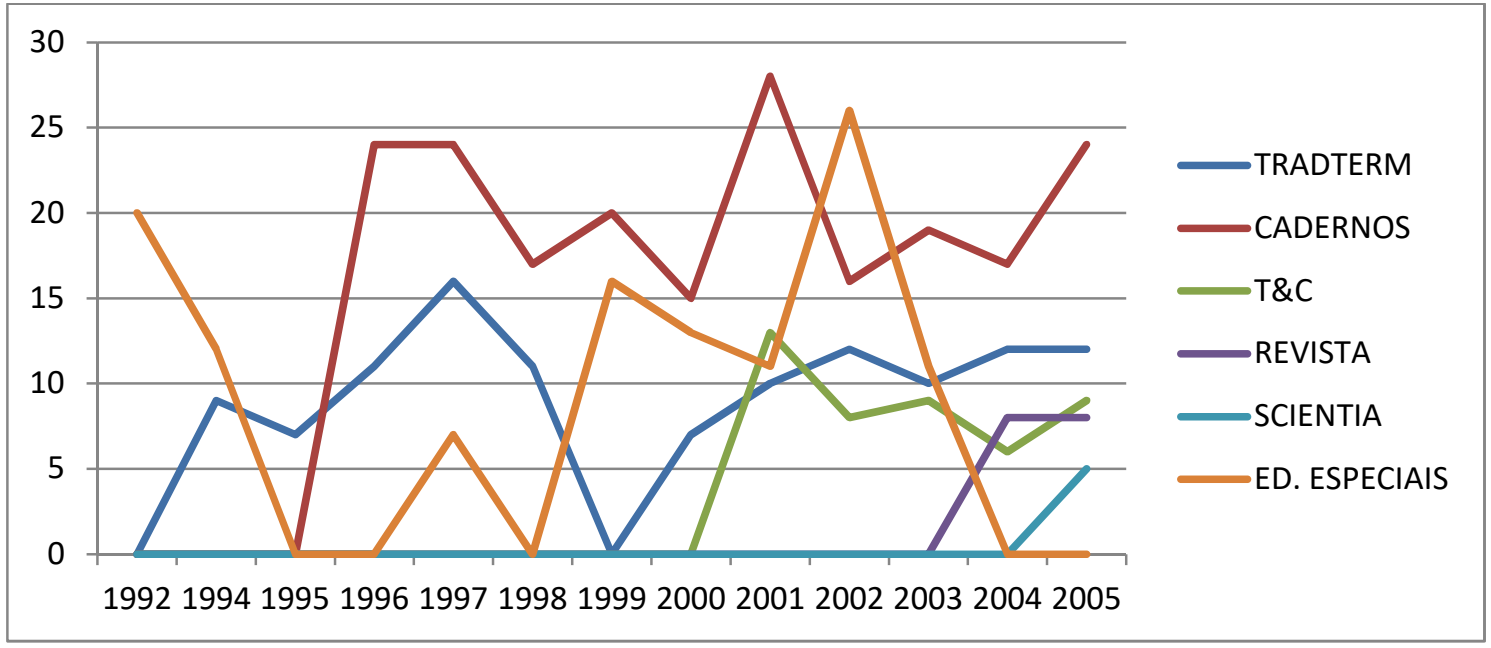

Gráfico 06: Comparativo do volume de publicações de cada periódico por ano.

\footnotetext{
${ }^{306}$ Embora tivéramos acesso apenas ao sumário do primeiro número da revista Tradução em Revista, optamos por considerá-lo nos dois primeiros índices. A falta de acesso aos textos, no entanto, impossibilitou sua inclusão nos demais índices.
} 


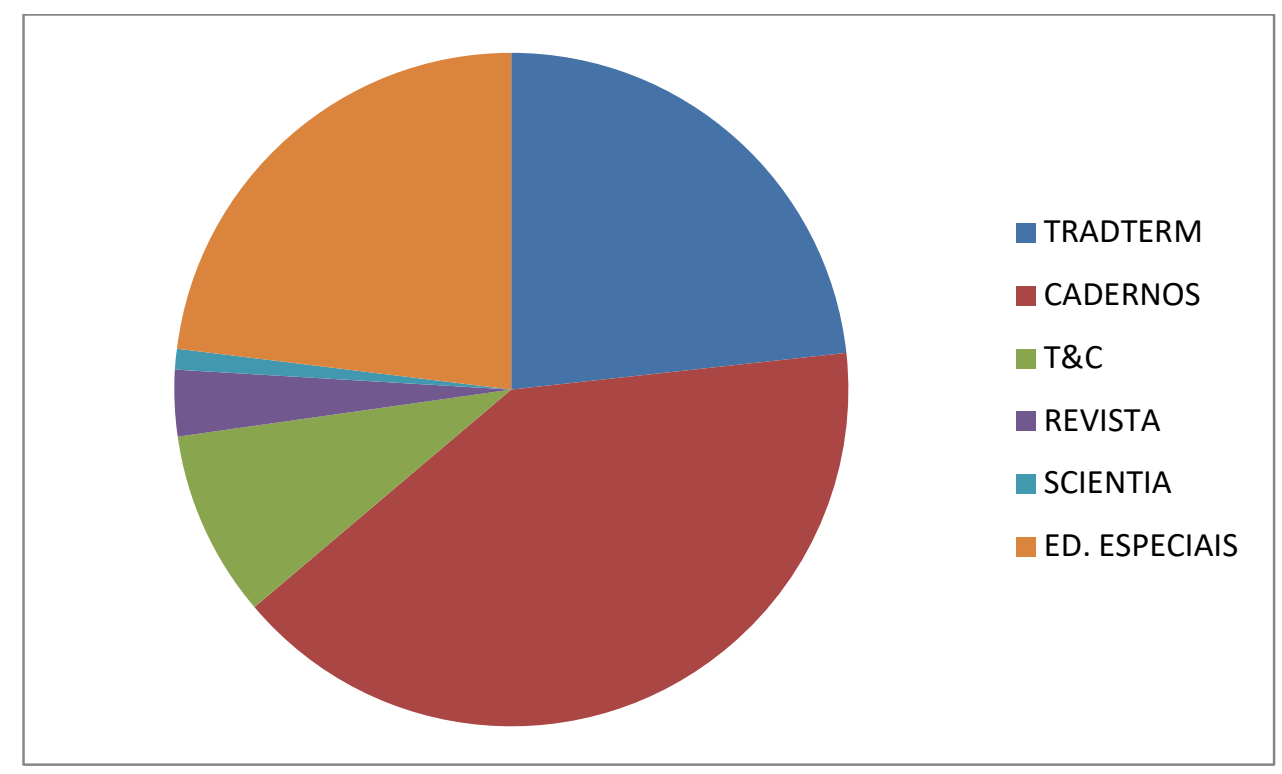

Gráfico 07: Volume total de artigos publicados por cada periódico.

Em primeiro lugar, os gráficos ressaltam o papel de liderança dos Cadernos de Tradução no que tange a número de artigos publicados (40,63\% do total). Desde seu início, o volume de artigos publicado pelo periódico supera os demais, tendo sido ultrapassado apenas em 2002 pela somatória de artigos publicados pelas revistas Gragoatá e Revista Brasileira de Linguística Aplicada. Com publicações em português, inglês, espanhol, francês e italiano - visando, sobretudo, à internacionalização, com a participação de autores brasileiros e estrangeiros - o periódico ganhou destaque no âmbito dos estudos da tradução no Brasil.

Em segundo lugar, o gráfico destaca o papel dos números especiais dedicados à tradução em revistas de outras áreas das Letras. Tendo em vista o volume de publicações do conjunto de números especiais, equivalente ao volume de publicações da TradTerm - respectivamente $23,10 \%$ e $23,30 \%$ - nota-se que, mesmo com a existência de periódicos já consolidados dedicados ao tema, elas exercem um importante papel na divulgação de pesquisas em tradução mesmo antes dos periódicos específicos da área.

Uma vez contemplado o panorama das publicações, passamos a olhar para seu interior, a começar pelo levantamento dos autores mais produtivos ao longo de todo o período. $\mathrm{Na}$ tabela abaixo, temos a relação de autores, as filiações deles ao longo do período e o número de artigos publicados: 


\begin{tabular}{|c|c|c|}
\hline Autores & Afiliação & Documentos (Periódico) \\
\hline Francis Henrik Aubert & USP & 9 (7 TradTerm; 1 T\&C; 1 DELTA) \\
\hline John Milton & USP & $\begin{array}{l}9 \text { (4 Cadernos; } 2 \text { TradTerm; } 2 \text { Crop; } \\
1 \text { DELTA) }\end{array}$ \\
\hline Rosemary Arrojo & UNICAMP; Binghamton (EUA) & $\begin{array}{l}8 \text { (3 TradTerm; } 1 \text { TLA; } 1 \text { Cadernos; } 1 \\
\text { Ilha; } 1 \text { ALFA; } 1 \text { DELTA) }\end{array}$ \\
\hline Diva Cardoso Camargo & USP, UNESP-Rio Preto & 7 (4 TradTerm; 2 T\&C; 1 Gragoatá; ) \\
\hline Célia Maria Magalhães & UFMG & 7 (4 Cadernos; 3 TradTerm) \\
\hline Paulo Roberto Ottoni & UNICAMP & $\begin{array}{l}6 \text { (2 TradTerm; } 1 \text { TLA; } 1 \text { ALFA; } 1 \\
\text { DELTA; } 1 \text { T\&C) }\end{array}$ \\
\hline Fabio Alves da Silva Jr. & UFMG & $\begin{array}{l}6 \text { (3 TradTerm; } 2 \text { Cadernos; } 1 \text { DEL- } \\
\text { TA) }\end{array}$ \\
\hline Adriana Silvina Pagano & UFMG & $\begin{array}{l}6 \text { (2 Cadernos; } 1 \text { TradTerm; } 1 \text { ALFA; } \\
1 \text { Crop; } 1 \text { DELTA) }\end{array}$ \\
\hline Mauri Furlan & UFSC & 6 (6 Cadernos) \\
\hline Maria Lucia Vasconcellos & UFSC & 6 (4 Cadernos; 1 DELTA; 1 T\&C) \\
\hline Stella E. O. Tagnin & USP & 5 (4 TradTerm; 1 Cadernos) \\
\hline Walter Carlos Costa & UFSC & 5 (4 Cadernos; 1 Ilha) \\
\hline Cristina C. Rodrigues & UNESP-Rio Preto & $\begin{array}{l}4 \text { (1 TradTerm; } 1 \text { TLA; } 1 \text { Letras; } 1 \\
\text { ALFA) }\end{array}$ \\
\hline John Robert Schmitz & UNICAMP & 4 (2 TradTerm; 2 T\&C) \\
\hline Marcia A. P. Martins & PUC-Rio & $\begin{array}{l}4 \text { (1 TradTerm; } 1 \text { Cadernos; } 1 \text { Ilha; } 1 \\
\text { Gragoatá) }\end{array}$ \\
\hline Maria Paula Frota & PUC-Rio & $\begin{array}{l}4 \text { (1 TradTerm; } 1 \text { Cadernos; } 1 \text { Le- } \\
\text { tras; } 1 \text { ALFA) }\end{array}$ \\
\hline Christiane Nord & $\begin{array}{l}\text { Magdeburg (Alemanha); } \\
\text { Orange Free State (Áfr. Sul) }\end{array}$ & 4 (2 TradTerm; 1 Cadernos; 1 Ilha) \\
\hline Ivone Castilho Benedetti & USP & $\begin{array}{l}4 \text { (1 TradTerm; } 1 \text { Cadernos; } 1 \text { T\&C; } \\
1 \text { Revista) }\end{array}$ \\
\hline Maria José R. F. Coracini & UNICAMP & $\begin{array}{l}4 \text { (1 TradTerm; } 1 \text { Cadernos; } 1 \text { T\&C; } \\
1 \text { ALFA) }\end{array}$ \\
\hline Marie-Hélène C. Torres & UFSC & 4 (4 Cadernos) \\
\hline Thaís Flores N. Diniz & UFMG & 4 (4 Cadernos) \\
\hline Lia Wyler & USP; PUC-Rio & 4 (2 Crop; 1 Cadernos; 1 DELTA) \\
\hline Danilo A. Nogueira & & 3 (1 TradTerm; 1 Cadernos; 1 T\&C) \\
\hline Ofir Bergemann de Aguiar & UFG & 3 (2 TradTerm; 1 Cadernos) \\
\hline Maria da Graça Krieger & UFRGS & 3 (3 TradTerm) \\
\hline Ruth de Oliveira & Paris 3 (França) & 3 (2 T\&C; 1 TradTerm) \\
\hline Lenita Maria R. Esteves & UNICAMP; USP; UNIBERO & 3 (1 TLA; 1 Letras;1 T\&C) \\
\hline Paulo Henriques Britto & PUC-Rio & 3 (3 Cadernos) \\
\hline Márcio Seligmann-Silva & UNICAMP & 3 (2 Cadernos; 1 DELTA) \\
\hline
\end{tabular}




\begin{tabular}{|l|l|l|}
\hline Wolfgang Lörscher & Leipzig (Alemanha) & 3 (1 Cadernos; 1 Ilha; 1 Letras) \\
\hline Paulo Oliveira & UNICAMP & 3 (1 Cadernos; 1 T\&C; 1 ALFA) \\
\hline
\end{tabular}

Tabela 07: Autores mais produtivos e veículos de publicação (1992-2005).

Através da listagem, verificamos que os autores mais produtivos ao longo do período são professores catedráticos das IES consideradas, segundo o histórico da primeira seção desse capítulo, mais representativas para a área, seja pelo volume de pesquisas defendidas - USP, UFSC, UFMG - seja por seu pioneirismo na criação de cursos de graduação PUC-RJ, UNIBERO, UFRGS, UNESP - ou de linhas de pesquisa na pós-graduação - UNICAMP.

Observando o caso específico dos pesquisadores da USP e da UFSC, nota-se que há uma tendência de valorizar o periódico publicado pela própria instituição: no caso da USP, apenas John Milton e Ivone Benedetti não publicaram a maioria de seus artigos nos periódicos vinculados à instituição - neste corpus, as revistas TradTerm e Crop. No caso da UFSC, todos os autores vinculados à universidade preferiram publicar nos periódicos vinculados à própria instituição - nesse corpus, as revistas Cadernos de Tradução e Ilha do Desterro. Essa tendência fica ainda mais clara quando verificamos a relação entre filiaçãopublicação de pesquisadores vinculados às duas universidades:

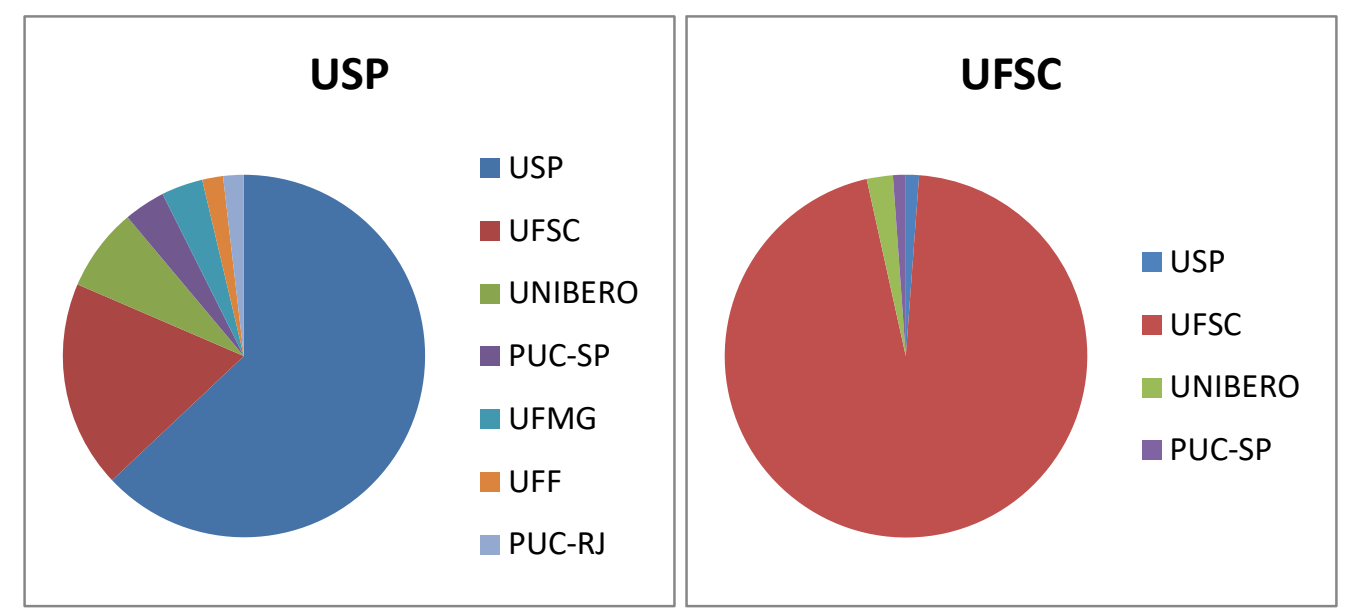

Gráfico 08: Instituições que organizam os periódicos em que publicaram, respectivamente pesquisadores da USP e da UFSC (1992-2005). 
Os gráficos parecem confirmar a tendência que apontamos, bem como os números: entre 1992 e 1995, sete artigos foram publicados por pesquisadores vinculados à USP, todos publicados pela TradTerm (USP); no mesmo período, apenas um artigo foi publicado por um pesquisador vinculado à UFSC, a saber, pela revista Ilha do Desterro (UFSC). Entre 1996 e 2000, doze artigos de pesquisadores da USP foram publicados: oito pela TradTerm, quatro pela revista Cadernos de Tradução (UFSC); no caso da UFSC, o número de artigos saltou para 51, todos publicados por revistas organizadas pela instituição: 50 pelos Cadernos de Tradução, um pela Ilha do Desterro. Por fim, entre 2001 e 2005, pesquisadores da USP publicaram 35 artigos: 19 artigos saíram em revistas da USP (15 pela Tradterm, quatro pela Crop), seis artigos foram publicados nos Cadernos de Tradução, quatro pela revista Tradução \& Comunicação (UNIBERO), dois pela revista D.E.L.T.A. (PUCSP), dois pela Revista Brasileira de Linguística Aplicada (UFMG), um pela Gragoatá (UFF) e um pela Tradução em Revista (PUC-RJ); de pesquisadores da UFSC, computamos 34 artigos: 30 foram publicados por revistas organizadas pela UFSC (25 pelos Cadernos de Tradução, cinco pela Scientia Traductionis), dois pela Tradução \& Comunicação, um pela TradTerm e um pela D.E.L.T.A. É interessante notar que, se mais da metade dos documentos escritos por pesquisadores da USP foram publicados por revistas vinculadas à sua instituição, essa proporção sobe, no caso da UFSC, a sua quase totalidade.

Destacamos ainda da listagem a presença de Danilo Nogueira, tradutor profissional de renome na área, o que demonstra a busca por diálogo, da parte do profissional ou da organização dos periódicos, entre as esferas acadêmica e profissional da tradução. É importante sobretudo destacar, no âmbito do presente trabalho, a presença de Christiane Nord na lista, com quatro publicações, sendo ela um dos poucos autores vinculados a universidades estrangeiras dentre os autores mais produtivos segundo nosso levantamento. Sua presença nessa lista é indicativa dos esforços dos teorizadores funcionalistas de divulgar a abordagem teórica entre nós.

A participação de cada IES na produção de conhecimento no âmbito dos estudos da tradução fica mais clara ao verificarmos, de modo geral, o vínculo dos autores dos artigos. Para essa e as próximas medições, dividimos os dados em três períodos: de 1992 a 1995, de 1996 a 2000 e de 2001 a 2005. A tabela abaixo traz apenas os números referentes às instituições de ensino superior brasileiras, comparando o percentual de sua participação na publicação de artigos em cada período. 


\section{Instituição}

1992-1995

1996-2000

2001-2005

Universidade Estadual de Campinas - UNICAMP

Universidade de São Paulo - USP

Universidade Federal de Santa Maria - UFSM

Universidade Est. Paulista - UNESP-Rio Preto

Pontifícia Universidade Católica - PUC-Rio

Universidade Federal de Santa Catarina - UFSC

Pontifícia Universidade Católica - PUC-RS

Universidade Federal de Minas Gerais - UFMG

Universidade Federal do Rio de Janeiro - UFRJ

Universidade Fed. do Rio Grande do Sul - UFRGS

Pontifícia Universidade Católica - PUC-SP

Centro Universitário Ibero-Americano - UNIBERO

Universidade Federal de Goiás - UFG

Universidade Est. Paulista - UNESP-Araraquara

Universidade Federal do Paraná - UFPR

Universidade Estadual de Londrina - UEL

Universidade Federal do Rio Grande - FURG

Universidade São Francisco - USF

Centro Universitário Newton Paiva (Newton)

Universidade São Judas - USJT

Universidade Estadual do Ceará - UECE

Universidade de Brasília - UnB

Universidade Federal Fluminense - UFF

Universidade de Santa Cruz do Sul - UNISC

Universidade do Estado do Rio de Janeiro - UERJ

Universidade Federal da Bahia - UFBA

Universidade Federal de Juiz de Fora - UFJF

União das Fac. dos Grandes Lagos - UNILAGO

Centro Univ. das Fac. Metr. Unidas - FMU

Universidade Federal de São Carlos - UFSCar

Universidade Federal do Mato Grosso - UFMT

Universidade Estadual do Mato Grosso - UNEMAT

Associação Alumni/São Paulo

Universidade Federal de Ouro Preto - UFOP

Univ. Fed. do Estado do Rio de Janeiro - UNIRIO

Centro Universitário do Norte Paulista - UNORP

Universidade Fed. de Mato Grosso do Sul - UFMS

Universidade Federal do Espírito Santo - UFES

\begin{tabular}{|c|c|c|}
\hline $25,00 \%$ & $9,14 \%$ & $6,87 \%$ \\
\hline $14,58 \%$ & $6,45 \%$ & $12,03 \%$ \\
\hline $10,42 \%$ & - & - \\
\hline $8,33 \%$ & $3,23 \%$ & $5,84 \%$ \\
\hline $4,17 \%$ & $5,91 \%$ & $4,12 \%$ \\
\hline $2,08 \%$ & $27,42 \%$ & $11,68 \%$ \\
\hline $2,08 \%$ & - & $0,69 \%$ \\
\hline- & $6,99 \%$ & $11,34 \%$ \\
\hline- & $2,15 \%$ & $0,69 \%$ \\
\hline - & $1,61 \%$ & $3,78 \%$ \\
\hline- & $1,08 \%$ & $1,72 \%$ \\
\hline- & $0,54 \%$ & $1,03 \%$ \\
\hline - & $0,54 \%$ & $1,03 \%$ \\
\hline - & $0,54 \%$ & - \\
\hline- & $0,54 \%$ & $0,34 \%$ \\
\hline- & $0,54 \%$ & $0,34 \%$ \\
\hline - & $0,54 \%$ & $0,34 \%$ \\
\hline- & $0,54 \%$ & - \\
\hline - & $0,54 \%$ & - \\
\hline- & $0,54 \%$ & - \\
\hline- & - & - \\
\hline- & - & $1,03 \%$ \\
\hline - & - & $1,03 \%$ \\
\hline - & - & $0,69 \%$ \\
\hline - & - & $0,69 \%$ \\
\hline- & - & $0,69 \%$ \\
\hline - & - & $0,69 \%$ \\
\hline - & - & $0,69 \%$ \\
\hline- & - & $0,34 \%$ \\
\hline- & - & $0,34 \%$ \\
\hline- & - & $0,34 \%$ \\
\hline- & - & $0,34 \%$ \\
\hline- & - & $0,34 \%$ \\
\hline- & - & $0,34 \%$ \\
\hline - & - & $0,34 \%$ \\
\hline- & - & $0,34 \%$ \\
\hline- & - & $0,34 \%$ \\
\hline- & - & $0,34 \%$ \\
\hline
\end{tabular}

Tabela 08: Participação de cada instituição na produção intelectual publicada em cada período.

Vislumbrando o desempenho das instituições de ensino superior ao longo dos três períodos, podemos traçar algumas conclusões. No período de 1992 a 1995, além de dois números da TradTerm (1994-1995), organizados pelo CITRAT-USP, foram publicados um 
número especial da Trabalhos em Linguística Aplicada (1992), organizada pela UNICAMP, um número especial da Ilha do Desterro (1992), organizado pela UFSC e um número especial da Letras (1994), organizado pela UFSM. Em primeiro lugar, salvo o caso de Ilha do Desterro, a publicação dos demais volumes favoreceu a veiculação de pesquisas na própria instituição a que os periódicos estão vinculados. Isso é especialmente evidente no caso da UFSM: em terceiro lugar no primeiro período, a instituição não registra publicação de artigos nos dois outros períodos. Por outro lado, o bom posicionamento da UNICAMP não se deve apenas aos artigos trazidos por sua revista: esse é um momento de clara ascensão da vertente pós-estruturalista, liderada por Rosemary Arrojo e Paulo Ottoni, cujo epicentro esteve justamente na UNICAMP. Ademais, é preciso considerar que a primeira linha de pesquisa em estudos da tradução num programa de pós-graduação no Brasil foi, como vimos, o Programa de Linguística Aplicada da Universidade Estadual de Campinas.

O segundo período tem início justamente com a primeira publicação da revista $\mathrm{Ca}$ dernos de Tradução. Nos índices anteriores, vimos que o periódico, desde sua fundação, caracterizou-se pelo elevado volume de publicações em cada número. O início das atividades da revista pode explicar o salto quantitativo deveras expressivo de artigos publicados pela instituição: entre 1996 e 2000, a UFSC, que no período anterior totalizava apenas $2,08 \%$ de participação no montante de pesquisas publicadas em artigos, saltou para a primeira posição com 27,42\%; em segundo lugar, a UNICAMP foi responsável por 9,14\% dos artigos publicados. É importante enfatizar que esses elevados números de pesquisas publicados pela UFSC antecedem a criação do PGET e, portanto, não são um reflexo do aumento de pesquisas decorrente desse evento. Enquanto USP, UNESP/Rio Preto e PUCRJ mantêm suas boas posições no ranking, temos também a ascensão da UFMG, da UFRJ e da UFRGS, refletindo o bom desempenho dessas instituições nos estudos relatados na primeira seção.

O terceiro período traz uma distribuição mais equilibrada do volume de artigos entre as instituições: a USP representa nesse período 12,03\% das publicações; a UFSC, $11,68 \%$ e a UFMG, em terceiro lugar, representa 11,34\%. Esse ranking assemelha-se aquele divulgado por Alves e Vasconcellos (2016), referente ao período entre 2006 e 2010. Esse pode ser um indício de que, uma vez consolidados os veículos de divulgação, não é necessário a uma instituição alimentá-los com pesquisas realizadas internamente, mas abrilos para contribuições de toda a comunidade científica. Outra semelhança em relação àquele trabalho está na disseminação da pesquisa: se entre 1992 e 1995 tínhamos apenas sete 
instituições brasileiras representadas, nesse último período temos 32 instituições. Embora a hegemonia da USP, da UFSC e da UFMG seja inegável, a proporção entre a participação de cada uma delas não está tão distante quanto a das demais.

Cumpre ainda trazermos à discussão os temas mais discutidos ao longo dos quase quinze anos que compreende nossa pesquisa. Para tanto, iniciamos com a relação dos autores mais influentes em cada época. Nessa lista, reunimos apenas os trinta e cinco autores mais citados em cada período, acompanhado do número de citações. Como critério de desempate, os autores com mesmo número de citações foram ordenados conforme a quantidade de trabalhos citados.

\begin{tabular}{|c|c|c|c|c|c|c|}
\hline & \multicolumn{2}{|l|}{ 1992-1995 } & \multicolumn{2}{|l|}{$1996-2000$} & \multicolumn{2}{|l|}{ 2001-2005 } \\
\hline & Autores & Oc. & Autores & Oc. & Autores & Oc. \\
\hline 1 & Arrojo, Rosemary & 16 & Baker, Mona & 23 & Venuti, Lawrence & 41 \\
\hline 2 & Derrida, Jacques & 9 & Derrida, Jacques & 21 & Baker, Mona & 40 \\
\hline 3 & Nida, Eugene A. & 8 & Venuti, Lawrence & 21 & Arrojo, Rosemary & 27 \\
\hline 4 & Bassnett, Susan & 7 & Arrojo, Rosemary & 20 & Aubert, Francis $\mathrm{H}$. & 25 \\
\hline 5 & Mounin, Georges & 6 & Bassnett, Susan & 20 & Toury, Gideon & 23 \\
\hline 6 & Steiner, George & 6 & Catford, John C. & 17 & Berman, Antoine & 21 \\
\hline 7 & Toury, Gideon & 5 & Toury, Gideon & 16 & Vinay, Jean-Paul & 21 \\
\hline 8 & Benjamin, Walter & 5 & Campos, Haroldo de & 15 & Lefevere, André & 20 \\
\hline 9 & Newmark, Peter & 5 & Benjamin, Walter & 14 & Bassnett, Susan & 19 \\
\hline 10 & Aubert, Francis $\mathrm{H}$. & 4 & Jakobson, Roman & 14 & Darbelnet, Jean & 18 \\
\hline 11 & Coulthard, Richard & 4 & Nord, Christiane & 13 & Milton, John & 17 \\
\hline 12 & Lefevere, André & 4 & Lefevere, André & 13 & Derrida, Jacques & 16 \\
\hline 13 & Freud, Sigmund & 4 & Vermeer, Hans J. & 13 & Nida, Eugene A. & 16 \\
\hline 14 & Seleskovitch, Danica & 4 & Costa, Walter Carlos & 12 & Cabré, Maria T. & 15 \\
\hline 15 & Campos, Haroldo de & 4 & Shakespeare, William & 11 & Jakobson, Roman & 15 \\
\hline 16 & Reiss, Katharina & 4 & Halliday, Michael. A. & 11 & Pym, Anthony & 14 \\
\hline 17 & Jakobson, Roman & 4 & Newmark, Peter & 11 & Tagnin, Stella E. O. & 13 \\
\hline 18 & Rónai, Paulo & 4 & Reiss, Katharina & 11 & Laviosa, Sara & 13 \\
\hline 19 & Venuti, Lawrence & 4 & Mounin, Georges & 10 & Halliday, Michael A. & 13 \\
\hline 20 & Campos, Geir & 4 & Vinay, Jean-Paul & 10 & Kenny, Dorothy & 13 \\
\hline 21 & Taber, Charles R. & 4 & Paz, Octavio & 9 & Snell-Hornby, Mary & 13 \\
\hline 22 & Graham, Joseph F. & 4 & Nida, Eugene A. & 9 & Ferreira, Aurélio B. & 13 \\
\hline 23 & Chamberlain, Lori & 4 & House, Juliane & 9 & Tirkkonen-Condit, Sonja & 12 \\
\hline 24 & Vermeer, Hans J. & 3 & Borges, Jorge Luis & 8 & Bowker, Lynne & 12 \\
\hline 25 & Lederer, Marianne & 3 & Aubert, Francis $\mathrm{H}$. & 8 & Sinclair, John & 12 \\
\hline 26 & Wilss, Wolfram & 3 & Wilss, Wolfram & 8 & Benjamin, Walter & 12 \\
\hline 27 & Barthes, Roland & 3 & Delabastita, Dirk & 8 & Mounin, Georges & 12 \\
\hline 28 & Benjamin, Andrew & 3 & Paes, José Paulo & 8 & Campos, Haroldo de & 11 \\
\hline 29 & Campos, Augusto de & 3 & Snell-Hornby, Mary & 8 & Meschonnic, Henri & 11 \\
\hline
\end{tabular}




\begin{tabular}{|r|l|r|l|r|l|r|}
\hline 30 & Catford, John C. & 3 & Darbelnet, Jean & 8 & Herman, Theo & 11 \\
\hline 31 & Kussmaul, Paul & 3 & Niranjana, Tejaswini & 8 & Frota, Maria Paula & 11 \\
\hline 32 & Laplanche, Jean & 3 & Vieira, Else R. & 7 & Mason, lan & 11 \\
\hline 33 & Rosenthal, Erwin T. & 3 & Robinson, Douglas & 7 & Tymoczko, Maria & 11 \\
\hline 34 & Vinay, Jean-Paul & 3 & Simon, Sherry & 7 & Alves, Fabio & 10 \\
\hline 35 & Bass, Alan & 3 & Barbosa, Heloísa G. & 7 & Delisle, Jean & 10 \\
\hline
\end{tabular}

Tabela 09: Os 35 autores mais citados por período.

A primeira coisa que salta a nossos olhos ao examinar os dados referentes ao período 1992-1995 é a quantidade de referências aos trabalhos de Rosemary Arrojo, que supera em quase uma vez o número de referências do segundo colocado, Jacques Derrida. Essa discrepância, bem como o fato de ambos os defensores do pós-estruturalismo ocuparem o primeiro lugar, pode ser um indicativo de que houve de fato a constituição de uma Escola Brasileira de Tradutologia através da figura de Arrojo. Vale, contudo, lembrar que foi publicado pela UNICAMP durante esse período o número especial da revista Trabalhos em Linguística Aplicada, organizado pela própria Rosemary Arrojo, o que pode ter influenciado a seleção de artigos. Além de autores vinculados à vertente pós-moderna da tradução, há também referências de trabalhos de autores ligados à abordagem linguística tradicional da tradução - por exemplo, os trabalhos de Eugene Nida e Georges Mounin - e de autores ligados aos estudos descritivos da tradução - como Susan Bassnett e Gideon Toury. No que tange à referência a autores brasileiros, destacam-se Francis Aubert, Haroldo e Augusto de Campos, Paulo Rónai e Geir Campos, além da própria Arrojo. A listagem sugere que, mesmo no que havia de referências genuinamente brasileiras, os estudos da tradução no Brasil eram marcados pela coocorrência de abordagens linguísticas e pós-modernas.

Destacamos também a presença de três funcionalistas na lista: Katharina Reiss, citada em quatro artigos, Hans Vermeer e Paul Kussmaul, citados cada um em três artigos. Desse conjunto, três foram escritos por pesquisadores atuantes no Brasil: um artigo de Cristina Carneiro Rodrigues (1994), publicado pela TradTerm; um artigo de Susana Kampff Lages (1992), publicado pela Trabalhos em Linguística Aplicada; um artigo de Rosani Umbach (1994), publicado pela revista Letras. Esse é um indício de que textos funcionalistas, ainda que timidamente, já circulavam nos estudos da tradução no país.

No segundo período temos, a partir de uma amostragem maior de textos, algumas mudanças: a primeira posição, ocupada antes por Rosemary Arrojo, passa a ser de Mona Baker, destacando-se, de modo especial, o seu livro In Other Words. A coursebook on 
translation. Não obstante, a pós-modernidade continua representada pelos trabalhos de Derrida, Arrojo e dos irmãos Campos. Essa representatividade recebeu a contribuição da edição especial da revista ALFA, publicada no ano de 2000, cujas contribuições são dedicadas, em sua maioria, à abordagem desconstrutivista.

A presença de mais brasileiros nesse período aponta para uma produção intelectual em ascensão no país, com nomes como Walter Carlos Costa, José Paulo Paes, Else Vieira e Heloísa Barbosa. Vemos também, pela presença de nomes como Juliane House e de Michael A. K. Halliday que a linguística sistêmico-funcional também ganha espaço no campo, enquanto as presenças de Lawrence Venuti, Tejaswini Niranjana e Sherry Simon apontam para questões ligadas a dimensões políticas da tradução. As obras de William Shakespeare têm posição privilegiada no ranking graças ao número especial de 1999 da revista Ilha do Desterro, dedicado a abordar traduções e adaptações da obra do poeta e dramaturgo inglês ao redor do mundo.

Dentre os funcionalistas, além de Katharina Reiss e Hans Vermeer, vemos a ascensão de Christiane Nord e de Mary Snell-Hornby. Nord e Vermeer foram citados por treze documentos, Reiss por onze e Snell-Hornby por oito. No entanto, esses números devem ser vistos com cautela: dos treze documentos que fazem referência a obras de Vermeer, apenas cinco são de pesquisadores atuantes no Brasil; no caso de Nord, esse número cai para três. Dentre os onze documentos que citam trabalhos de Reiss, apenas dois foram escritos por pesquisadores do país e dos oito textos que citam Snell-Hornby apenas três são contribuições brasileiras. Dos trabalhos de brasileiros que fazem menção aos textos funcionalistas destacam-se, pela quantidade e diversidade de textos funcionalistas citados, os trabalhos de Cassio Rodrigues (1997), dedicado à revisão da bibliografia acerca dos processos mentais envolvidos na tradução, e de João Azenha Jr. (1996), feito com base em sua tese de doutorado, relativo aos condicionantes culturais envolvidos na tradução técnica.

Assim, de modo geral, é possível atribuir os bons números de citações de autores funcionalistas sobretudo ao número especial da revista Ilha do Desterro, publicado em 1997, dedicado à tradutologia alemã, bem como aos três artigos publicados por Christiane Nord durante o período.

O terceiro momento traz uma listagem mais diversa. Os nomes de Lawrence Venuti e de Mona Baker estabeleceram-se no mainstream dos estudos da tradução no Brasil. Embora Rosemary Arrojo continue numa posição elevada no que tange às citações - estando no terceiro lugar - o número de citações é quase a metade do segundo colocado, enquanto o 
número de citações a Derrida o fez cair dez posições. Ainda que as abordagens descritivas e pós-modernas tenham vindo para tomar o lugar da abordagem linguística, autores vinculados a essa abordagem continuam a ter um número considerável de citações.

Os números especiais da TradTerm e dos Cadernos de Tradução dedicados à linguística de corpus trouxeram ao ranking autores importantes dedicados ao tema, como John Sinclair, Dorothy Kenny, Sara Laviosa, Lynne Bowker e Stella Tagnin, e mesmo parte das contribuições largamente citadas de Mona Baker foram escritas nesse âmbito. Por sua vez, a citação a Maria T. Cabré e a Fabio Alves apontam para o crescimento, respectivamente, das áreas de terminologia e de estudos cognitivos - lembrando que ambas foram temas de números especiais nesse período.

No entanto, destacamos o fato de que nessa terceira lista apenas Mary SnellHornby, como representante funcionalista, figura entre os autores mais citados. Dos treze documentos que a citam, oito são de trabalhos desenvolvidos no âmbito dos estudos da tradução no Brasil: um artigo de Sinara de Oliveira Branco (2001), à época vinculada à UFSC, sobre o significado dos empréstimos do inglês para a relação entre a cultura brasileira e culturas hegemônicas de língua inglesa, em especial a cultura estadunidense; um artigo de John Robert Schmitz (2001), docente da UNICAMP, publicado na revista Tradução \& Comunicação, acerca da serventia do conceito de equivalência atualmente na tradução literária; um artigo de Cassio Rodrigues (2002), à época vinculado à UFSC, incluído no número especial dos Cadernos de Tradução dedicado à pesquisa empírica dos processos mentais em curso durante a tradução, no qual ele faz uma revisão bibliográfica acerca de trabalhos publicados nessa área de pesquisas; um artigo de Luciane Corrêa Ferreira (2002), à época da PUC-RS, publicado na Revista Brasileira de Linguística Aplicada, acerca do emprego da Teoria da Relevância para elucidar casos de tradução de ironia; um artigo de Marcia Martins (2002), docente da PUC-RJ, publicado pela revista Gragoatá, no qual ela faz uma revisão crítica acerca das contribuições da abordagem descritiva da tradução; um artigo de Reynaldo Pagura (2003), docente da PUC-SP, publicado na revista D.E.L.T.A., o qual lança luz sobre a interpretação de conferência, destacando as diferenças entre interpretação e tradução e as implicações dessas diferenças na formação de profissionais para as duas atividades; um artigo escrito por dois docentes da UFMG, Fabio Alves e Célia Magalhães (2004), incluído no número especial da TradTerm dedicado à linguística de corpus, em que os autores exploram a interface entre essa metodologia de pesquisa e a pesquisa processual da tradução; por fim, um artigo de Heloísa Cintrão (2005), docente da 
USP, publicado também na TradTerm, em que ela argumenta em favor de uma formação que favoreça a capacidade de análise linguística e literária no ensino de tradução, de modo a desenvolver a competência leitora dos alunos. A despeito da quantidade de trabalhos que citam Snell-Hornby, não significa que eles explorem conceitos da vertente funcionalista, dada a diversidade de assuntos e abordagens presentes nos trabalhos da autora, não restritos, portanto, a um viés funcionalista.

No entanto, apenas com a análise das palavras-chave poderemos ter uma ideia mais clara da presença do funcionalismo no país. Aqui, contudo, cabe uma ressalva: assim como Alves e Vasconcellos (2016) fazem em sua análise, assim faremos nós: a classificação de palavras-chave em clusters envolve questões epistemológicas que dependem, em grande medida, da interpretação de quem faz a classificação. Essa questão é ainda mais controversa, se considerarmos que, tendo em vista que uma parcela considerável dos artigos nem ao menos sugeriam palavras-chave, foi necessário propor, com base na linguística de corpus, palavras-chave que identificassem os principais temas desses artigos. Assim, em vez de uma proposta definitiva, a presente classificação serve como um convite à discussão de parâmetros de indexação mais precisos. Ademais, salientamos a necessidade de tais parâmetros envolverem toda a comunidade de pesquisadores dedicados aos estudos da tradução, para que, a partir de suas diferentes áreas de especialidade, possam ser identificadas formas mais claras de classificar os trabalhos segundo tema, domínio de pesquisa e aporte teórico.

Segue abaixo a tabela com os clusters com palavras-chave mais citadas durante o período entre 1992 e $1995^{307}$ :

\begin{tabular}{|l|r|r|}
\hline Clusters & Oc. & \multicolumn{1}{l|}{$\%$} \\
\hline Pós-modernidade & 17 & $17,17 \%$ \\
\hline Teorias da tradução & 15 & $15,15 \%$ \\
\hline Tradução literária & 8 & $8,08 \%$ \\
\hline Foco no tradutor & 8 & $8,08 \%$ \\
\hline Terminologia & 5 & $5,05 \%$ \\
\hline Item lexical como unidade de tradução & 5 & $5,05 \%$ \\
\hline Dimensão política da tradução & 4 & $4,04 \%$ \\
\hline Tradução poética & 3 & $3,03 \%$ \\
\hline Alteridade, cultura e identidade & 3 & $3,03 \%$ \\
\hline Linguística & 3 & $3,03 \%$ \\
\hline
\end{tabular}

\footnotetext{
${ }^{307}$ Anexo a esse trabalho incluímos uma listagem detalhada com as palavras-chave incluídas em cada cluster, bem como a explicação detalhada de cada cluster.
} 


\begin{tabular}{|l|r|r|}
\hline Métodos de traduzir & 2 & $2,02 \%$ \\
\hline Ensino e pesquisa da tradução/interpretação & 2 & $2,02 \%$ \\
\hline Avaliação de tradução & 2 & $2,02 \%$ \\
\hline Recursos computacionais & 2 & $2,02 \%$ \\
\hline Pragmática & 2 & $2,02 \%$ \\
\hline Estudos da interpretação & 2 & $2,02 \%$ \\
\hline Funcionalismo & 2 & $2,02 \%$ \\
\hline Processo tradutório & 1 & $1,01 \%$ \\
\hline Linguística Sistêmico-Funcional & 1 & $1,01 \%$ \\
\hline Linguagem/Discurso de especialidade & 1 & $1,01 \%$ \\
\hline Shakespeare & 1 & $1,01 \%$ \\
\hline Tradução técnico-científica & 1 & $1,01 \%$ \\
\hline Adaptação, autoria e os limites do traduzir & 1 & $1,01 \%$ \\
\hline Estudos contrastivos & 1 & $1,01 \%$ \\
\hline Sociolinguística & 1 & $1,01 \%$ \\
\hline Filosofia e tradução & 1 & $1,01 \%$ \\
\hline Estudos do texto & 1 & $1,01 \%$ \\
\hline Análise do discurso & 1 & $1,01 \%$ \\
\hline Semântica & 1 & $1,01 \%$ \\
\hline Unidade de tradução & 1 & $1,01 \%$ \\
\hline Teoria da Relevância & 1 & $1,01 \%$ \\
\hline
\end{tabular}

Tabela 10: Temas mais abordados (1992-1995).

Conforme esperado, o tema mais popular foi a pós-modernidade, em que se inclui o pós-estruturalismo de Derrida e Arrojo. O fato de o cluster "Teoria da tradução" aparecer na sequência demonstra uma tendência dessa época de um número acentuado de trabalhos com discussões teóricas acerca da natureza da tradução. A "Tradução literária" divide o terceiro lugar com estudos com "Foco no tradutor". Uma das importâncias da TradTerm a serem destacadas aqui está no fato de eles trazerem destaque também à questão da terminologia, o que justifica sua posição elevada no ranking, junto a pesquisas que se concentram em investigar a tradução de um item ou categoria lexical particular.

Nas posições inferiores, encontramos áreas de menor prestígio e áreas em ascensão, dentre as quais alguns aportes teóricos, como a teoria da relevância, a interface entre tradução e análise do discurso e a abordagem sistêmica-funcional, com apenas uma ocorrência no corpus. A abordagem funcionalista conta com duas ocorrências - abaixo, inclusive, da linguística: o texto de Vermeer publicado pela Ilha do Desterro e de um texto de Roseli Umbach (1994), que analisa a tradução dos neologismos de Guimarães Rosa a partir de um 
tipo de análise proposto por Paul Kussmaul, amparada no reconhecimento do contexto e da função do texto traduzido.

No entanto, para verificar se a abordagem funcional é ou não uma abordagem em ascensão, é necessário verificar os demais períodos. Assim, apresentamos abaixo a tabela referente ao período 1996-2000:

\begin{tabular}{|l|r|r|}
\hline Clusters & Oc. & \multicolumn{1}{l|}{$\%$} \\
\hline Teorias da tradução & 45 & $9,83 \%$ \\
\hline Tradução literária & 45 & $9,83 \%$ \\
\hline Pós-modernidade & 29 & $6,33 \%$ \\
\hline Estudos contrastivos & 23 & $5,02 \%$ \\
\hline Shakespeare & 22 & $4,80 \%$ \\
\hline Adaptação, autoria e os limites do traduzir & 20 & $4,37 \%$ \\
\hline Ensino e pesquisa da tradução/interpretação & 17 & $3,71 \%$ \\
\hline Foco no tradutor & 17 & $3,71 \%$ \\
\hline Historiografia da teoria e da prática de tradução & 17 & $3,71 \%$ \\
\hline Filosofia e tradução & 16 & $3,49 \%$ \\
\hline Alteridade, cultura e identidade & 15 & $3,28 \%$ \\
\hline Tradução poética & 14 & $3,06 \%$ \\
\hline Dimensão política da tradução & 11 & $2,40 \%$ \\
\hline Tradução de teatro & 11 & $2,40 \%$ \\
\hline Linguística & 10 & $2,18 \%$ \\
\hline Funcionalismo & 9 & $1,97 \%$ \\
\hline Linguística Sistêmico-Funcional & 9 & $1,97 \%$ \\
\hline Tradução técnico-científica & 9 & $1,97 \%$ \\
\hline Avaliação de tradução & 8 & $1,75 \%$ \\
\hline Terminologia & 8 & $1,75 \%$ \\
\hline Tradução audiovisual & 8 & $1,75 \%$ \\
\hline Métodos de traduzir & 3 & $1,53 \%$ \\
\hline Recepção & 3 & $0,66 \%$ \\
\hline Processo tradutório & 7 & $1,53 \%$ \\
\hline Semântica & 7 & $1,53 \%$ \\
\hline Linguagem/Discurso de especialidade & 7 & $1,53 \%$ \\
\hline Recursos computacionais & 6 & $1,31 \%$ \\
\hline Estudos Descritivos & 5 & $1,09 \%$ \\
\hline Tradução de humor & 5 & $1,09 \%$ \\
\hline Item lexical como unidade de tradução & 5 & $1,09 \%$ \\
\hline Tradução intersemiótica & 5 & $1,09 \%$ \\
\hline Estratégias de tradução & 4 & $0,87 \%$ \\
\hline Estudos do texto & 4 & $0,87 \%$ \\
\hline Estudos de corpus & 4 & $0,87 \%$ \\
\hline Sociolinguística & 3 & $0,66 \%$ \\
\hline Tipologia textual & 3 & \\
\hline Modalidades de tradução & 2 \\
\hline
\end{tabular}




\begin{tabular}{|l|r|r|}
\hline Pragmática & 2 & $0,44 \%$ \\
\hline Ética na Tradução & 2 & $0,44 \%$ \\
\hline Tradução jornalística & 2 & $0,44 \%$ \\
\hline Análise do discurso & 2 & $0,44 \%$ \\
\hline Ensino de línguas e tradução & 1 & $0,22 \%$ \\
\hline Ensino de terminologia & 1 & $0,22 \%$ \\
\hline Retraduções & 1 & $0,22 \%$ \\
\hline Tradução de música & 1 & $0,22 \%$ \\
\hline Poética de tradução & 1 & $0,22 \%$ \\
\hline Estudos da interpretação & 1 & $0,22 \%$ \\
\hline Tradução comentada & 1 & $0,22 \%$ \\
\hline Práticas editoriais & 1 & $0,22 \%$ \\
\hline Disciplinas adjacentes & 1 & $0,22 \%$ \\
\hline Tradução de literatura infantil & 1 & $0,22 \%$ \\
\hline
\end{tabular}

Tabela 11: Temas mais abordados (1996-2000)

Antes de analisarmos as tabelas, relembremos os números temáticos lançados nesse período. Em 1998, a TradTerm lança um número especial com artigos produzidos no âmbito do seminário interdisciplinar sobre linguística e tradução realizado em Oslo em abril de 1997, cujo foco, portanto, esteve na intersecção entre estudos da tradução e linguística contrastiva. Nos anos de 1997 e 1999, foram lançados dois números temáticos da revista Ilha do Desterro: o primeiro, como vimos, dedicado à tradutologia alemã, com foco nas abordagens funcionalista e processual da tradução; o segundo, dedicado às traduções e adaptações da obra de William Shakespeare. Em 2000, a revista ALFA lança um número especial, com artigos produzidos no âmbito do VII Encontro Nacional de Tradutores e I Encontro Internacional de Tradutores, com foco na intersecção entre desconstrução e pósmodernidade. Com isso, sabemos que há a probabilidade de maior ocorrência de palavraschave agrupadas nos clusters "Estudos Contrastivos", "Funcionalismo", "Processo tradutório", "William Shakespeare" e "Pós-modernidade". Em que pese a publicação dos números especiais, os clusters "Teoria da tradução" e "Tradução literária" foram os mais citados. Nesse período, também tivemos o crescimento de áreas como pesquisas referentes aos limites da tradução ("Adaptação, autoria e os limites do traduzir"), pesquisas em torno da didática da tradução e dedicadas a avaliar o status do ensino e da pesquisa de tradução e interpretação no país ("Ensino e pesquisa da tradução/interpretação"), pesquisas no âmbito da história de traduções e da reflexão sobre o traduzir ("Historiografia da teoria e da prática de tradução") e textos em torno de reflexões filosóficas sobre a prática de traduzir ("Filoso- 
fia e tradução"). Por outro lado, com a inclusão de outras revistas que não reservam um espaço para a terminologia, a proporção de pesquisas voltadas à terminologia e à tradução de itens lexicais tiveram uma ligeira queda no período.

O funcionalismo foi considerado tema em nove trabalhos: em dois artigos de Christiane Nord (1997b, 2000), um artigo de Hans Hönig (1997), um de Paul Kussmaul (1997), um de Radegundis Stolze (1997), um de João Azenha Junior (1996), um de Maria Lucia Vasconcellos (1996), um de Maria António Ferreira Hörster (1997) e um de Sonia Maria Gomes Ferreira (1999). Analisando apenas os trabalhos publicados por pesquisadores atuantes no Brasil, constatamos que o artigo de Maria Lucia Vasconcellos faz referência ao funcionalismo como uma dentre várias abordagens a proporem uma definição para o conceito de "função" no âmbito dos estudos da tradução; no artigo de Sonia Maria Ferreira, o funcionalismo provê uma definição de tradução que serve para rebater as críticas contra o emprego de tradução em aulas de LE, o que não seria suficiente para considerá-lo funcionalista; por fim, o artigo de João Azenha Junior incorpora o funcionalismo como arcabouço teórico, justificando a ocorrência de condicionantes culturais numa tradução técnica.

Assim, chegamos ao estudo dos temas do último período sob análise, conforme registrado na tabela abaixo:

\begin{tabular}{|l|r|r|}
\hline Clusters & Oc. & \multicolumn{1}{l|}{$\%$} \\
\hline Tradução literária & 66 & $10,12 \%$ \\
\hline Teorias da tradução & 34 & $5,21 \%$ \\
\hline Alteridade, cultura e identidade & 34 & $5,21 \%$ \\
\hline Estudos de corpus & 33 & $5,06 \%$ \\
\hline Terminologia & 31 & $4,75 \%$ \\
\hline Ensino e pesquisa da tradução/interpretação & 25 & $3,83 \%$ \\
\hline Foco no tradutor & 24 & $3,68 \%$ \\
\hline Tradução intersemiótica & 24 & $3,68 \%$ \\
\hline Historiografia da teoria e da prática de tradução & 24 & $3,68 \%$ \\
\hline Adaptação, autoria e os limites do traduzir & 23 & $3,53 \%$ \\
\hline Recursos computacionais & 21 & $3,22 \%$ \\
\hline Pós-modernidade & 17 & $2,61 \%$ \\
\hline Processo tradutório & 17 & $2,61 \%$ \\
\hline Estudos contrastivos & 17 & $2,61 \%$ \\
\hline Item lexical como unidade de tradução & 16 & $2,45 \%$ \\
\hline Linguística & 15 & $2,30 \%$ \\
\hline Dimensão política da tradução & 14 & $2,15 \%$ \\
\hline Tradução técnico-científica & 14 & $2,15 \%$ \\
\hline Tradução audiovisual & 13 & $1,99 \%$ \\
\hline Estudos Descritivos & 12 & $1,84 \%$ \\
\hline
\end{tabular}




\begin{tabular}{|l|r|r|}
\hline Tradução poética & 11 & $1,69 \%$ \\
\hline Modalidades de tradução & 11 & $1,69 \%$ \\
\hline Semântica & 10 & $1,53 \%$ \\
\hline Linguagem/Discurso de especialidade & 9 & $1,38 \%$ \\
\hline Retraduções & 9 & $1,38 \%$ \\
\hline Estudos do texto & 9 & $1,38 \%$ \\
\hline Métodos de traduzir & 8 & $1,23 \%$ \\
\hline Filosofia e tradução & 8 & $1,23 \%$ \\
\hline Avaliação de tradução & 7 & $1,07 \%$ \\
\hline Tradução de teatro & 7 & $1,07 \%$ \\
\hline Ensino de línguas e tradução & 7 & $1,07 \%$ \\
\hline Análise do discurso & 7 & $1,07 \%$ \\
\hline Tradução de literatura infantil & 7 & $1,07 \%$ \\
\hline Tipologia textual & 6 & $0,92 \%$ \\
\hline Práticas editoriais & 6 & $0,92 \%$ \\
\hline Tradução de textos religiosos & 6 & $0,92 \%$ \\
\hline Tradução jornalística & 5 & $0,77 \%$ \\
\hline Localização & 5 & $0,77 \%$ \\
\hline Recepção & 4 & $0,61 \%$ \\
\hline Estratégias de tradução & 4 & $0,61 \%$ \\
\hline Funcionalismo & 3 & $0,46 \%$ \\
\hline Linguística Sistêmico-Funcional & 3 & $0,46 \%$ \\
\hline Shakespeare & 3 & $0,46 \%$ \\
\hline Sociolinguística & 3 & $0,46 \%$ \\
\hline Poética de tradução & 3 & $0,46 \%$ \\
\hline Estudos da interpretação & 3 & $0,46 \%$ \\
\hline Tradução comentada & 3 & $0,46 \%$ \\
\hline Pragmática & 2 & $0,31 \%$ \\
\hline Disciplinas adjacentes & 2 & $0,31 \%$ \\
\hline Teoria da Relevância & 1 & $0,15 \%$ \\
\hline Ética na Tradução & 1 & $0,15 \%$ \\
\hline Tradução de humor & 1 & $0,15 \%$ \\
\hline Ensino de terminologia & 1 & $0,15 \%$ \\
\hline Tradução juramentada & 1 & $0,15 \%$ \\
\hline Estudos filológicos & $0,15 \%$ \\
\hline Unidade de tradução & \\
\hline & & \\
\hline
\end{tabular}

Tabela 12: Temas mais abordados (2001-2005)

Cumpre mais uma vez relembrar os números temáticos publicados nesse período: em 2001, a TradTerm publicou alguns artigos frutos das atividades da Escola Internacional de Inverno de Terminologia. No mesmo ano, os Cadernos de Tradução publicaram um número temático voltado à tradução intersemiótica. Ainda no mesmo ano, foi publicado 
um número especial da revista Crop, dedicado a temas envolvendo a pesquisa historiográfica da tradução. Em 2002, os Cadernos de Tradução lançaram dois números temáticos: no primeiro semestre, um número dedicado à linguística de corpus e, no segundo semestre, dedicado às abordagens processuais da tradução. Em 2003, a TradTerm lançou um bloco temático dedicado às modalidades de tradução. No mesmo ano, a Cadernos de Tradução lançou um número dedicado a questões de retradução e adaptação. Em 2004, os Cadernos de Tradução lançaram um volume dedicado à tradução automática e a ferramentas computacionais de auxílio ao tradutor e a TradTerm lançou, também ela, um número temático dedicado à linguística de corpus. Por fim, em 2005, os Cadernos de Tradução publicaram um bloco temático dedicado à tradução audiovisual.

Tendo as edições especiais acima mencionadas em vista, muitos assuntos podem ter sido favorecidos. É esperado um crescimento de artigos publicados no âmbito da "Terminologia", "Tradução intersemiótica", "Historiografia da teoria e da prática de tradução", "Estudos de corpus", "Processo tradutório", "Modalidades de tradução", "Retraduções", "Adaptação, autoria e os limites do traduzir", "Recursos computacionais" e "Tradução audiovisual". Nota-se que a maioria desses termos está entre as quinze primeiras ocorrências - com exceção da "Tradução audiovisual", "Modalidades de tradução" e "Retraduções". Com relação à participação proporcional, apenas "Historiografia da teoria e da prática de tradução" e "Adaptação, autoria e os limites do traduzir" tiveram uma redução percentual em comparação com o período anterior.

A tradução literária sedimenta-se como principal ramo de pesquisa em tradução no país, reiterando um domínio da tradução literária no centro das reflexões sobre tradução que remontam a milênios - e que foi rompido apenas com a abordagem linguística de tradução. As reflexões teóricas acerca da tradução, bem como questões ligadas ao papel da cultura e a discussão entre alteridade e identidade em tradução também ganham terreno. Os dados também demonstram a crescente preocupação com o ensino de tradução e com a revisão da própria área de estudos, e a discussão em torno da visibilidade do tradutor coloca o cluster "Foco no tradutor" em posição privilegiada.

Por outro lado, houve uma clara queda do número de trabalhos fundamentados pela pós-modernidade. Sobre o papel da pós-modernidade nos estudos da tradução no Brasil, Barbosa comenta: 
nett (1980) e Gentlzer (sic!) (1993), não foi a que se preocupou com as teorias antropofágicas dos irmãos Campos $(1972,1976)$, mas os estudos em torno do pensamento de Jacques Derrida, encabeçado por Rosemary Arrojo (1986, 1992, 1993). Esta, teórica de grande influência, não só por suas publicações, mas também pelas suas atividades associativas (no GT de Tradução da ANPOLL, que coordenou, por exemplo), acadêmicas e de ensino, e pelas orientações de estudos de pós-graduação que realizou foi seguida de perto não só por Paulo Ottoni (1998, 2005), mas por muitos outros pesquisadores, alguns ligados mais diretamente a departamentos voltados para o estudo da língua e literatura francesas. (BARBOSA, 2009, p. 36)

Quanto à primeira hipótese levantada pela autora, tivemos comprovação ao analisarmos os autores mais citados em nosso corpus. No que respeita ao papel do pósestruturalismo em nosso campo, Barbosa faz a ressalva de que a abordagem derridiana parece ter favorecido mais à filosofia da linguagem do que aos estudos da tradução e interpretação. Ao explorar a relação entre sujeito e objeto, essa vertente teria elegido a tradução como um caso particular. Ao negar a possibilidade da comunicação humana, ela, a seu ver, não prestaria serviço algum aos estudos da tradução. Ademais, levados ao extremo, os estudos da tradução de base derridiana seriam de pouca serventia à análise e avaliação de traduções, posto que postula que tudo vale em tradução, já que ninguém é completamente responsável pelos sentidos que cria. Dessa forma, qualquer crítica de tradução seria vista como uma atitude autoritária de prescrição, pois qualquer sentido poderia ser criado a qualquer momento e por qualquer pessoa. Além disso, essa vertente poderia trazer desconforto ao ensino, seja da perspectiva do professor ou do aluno, tendo pouca aplicabilidade na didática de tradução. Logo, ainda que Barbosa acredite na sobrevivência dessa linha de pesquisa, ela cederia lugar a outras no caso do ensino e análise de traduções ${ }^{308}$.

Essa é uma possibilidade para explicar a queda da pós-modernidade dentre o volume de publicações acerca da tradução. No entanto, uma outra possibilidade estaria simplesmente no fato de as edições temáticas destacarem alguns temas em detrimento de outros, sobretudo considerando que a maioria dos temas eleitos para números e blocos temáticos não costuma se beneficiar da abordagem pós-moderna, mais frutífera em discussões de ordem literária e filosófica. Desse modo, novas pesquisas seriam necessárias para elucidar esse caso.

Outra queda expressiva especialmente relevante para o presente trabalho é o volume de trabalhos produzidos no âmbito do funcionalismo: segundo nossos levantamentos, foram apenas três: um artigo de Marta Rosas (2003), um de Christiane Nord (2005) e um

\footnotetext{
${ }^{308}$ BARBOSA, 2009, p. 34.
} 
de Ladjane Maria Farias de Souza (2005), sendo o único produzido por uma pesquisadora filiada a uma IES brasileira. Nesse artigo, Souza busca estabelecer um diálogo entre o modelo de análise textual de Nord e os preceitos teóricos de Arrojo e de Bakhtin, depois testando o modelo através da análise de dois textos jornalísticos. O funcionalismo de Nord não existe no artigo por si só, mas em diálogo com outras vertentes teóricas, constituindo apenas parte desse pressuposto teórico.

Com isso, vemos que, apesar dos esforços dos autores seminais funcionalistas em divulgar a abordagem teórica no Brasil, até o ano de 2005 não houve, segundo o estudo com os artigos científicos, uma produção expressiva o suficiente para identificar tendências de aplicações da teoria. Vimos que, de fato, uma parcela considerável da produção funcionalista em circulação no Brasil deve-se, antes, a autores de fora, que incluem os autores dos textos seminais funcionalistas - mas não se resume a eles. Desse modo, em busca de tendências de aplicação da teoria, vimos a necessidade de expandir a busca por textos funcionalistas.

\subsubsection{Trabalhos fundamentados na abordagem funcional (1992-2017)}

Como vimos na seção anterior, o levantamento limitado entre os anos de 1992 e 2005 não foram suficientes para indicar caminhos para o desenvolvimento da abordagem funcional no âmbito dos estudos da tradução no Brasil. Assim, foi necessário expandir o período de abrangência para contemplar pesquisas mais recentes. Entretanto, tendo em vista que o mapeamento traçado no tópico anterior tinha como principal objetivo caracterizar o contexto de recepção do funcionalismo no país, restringimo-nos nessa segunda fase apenas ao levantamento de artigos fundamentados completa ou parcialmente pelos conceitos funcionalistas, estendendo nossa pesquisa até o ano de 2017. A busca por textos funcionalistas orientou-se sobretudo pela presença de referências a textos de autoria dos autores fundadores da vertente teórica.

O levantamento feito com nosso primeiro corpus, que compreende o período entre 1992 e 2005, revelou 50 artigos com menção a algum texto escrito pelos autores fundadores. A consulta a cada um desses artigos, no entanto, mostrou-nos que apenas quinze desses artigos foram completa ou parcialmente fundamentados pela vertente funcionalista. 
Desses, apenas três foram escritos por pesquisadores vinculados a universidades brasileiras: os artigos de Azenha Jr. (1996), Umbach (1994) e Souza (2005).

A extensão da periodização mostrou-se frutífera: em todo o período, encontramos 93 artigos com referências funcionalistas. Dentre eles, 43 (46,23\%) foram completa ou parcialmente fundamentados pela abordagem funcionalista, 36 deles escritos por pesquisadores vinculados a universidades brasileiras. Assim, temos um total de 39 artigos.

\begin{tabular}{|c|c|c|c|}
\hline Revista & Vol/ano & Autor(a)s $s^{309}$ & Filiação(ões) \\
\hline LETRAS & $8(1994)$ & UMBACH, Rosani U. K. & UFSM, BRA \\
\hline CADERNOS & $1-1(1996)$ & AZENHA JR., João & USP, BRA \\
\hline SCIENTIA & $1(2005)$ & SOUZA, Ladjane & UFSC, BRA \\
\hline TRADTERM & $12(2006)$ & AZENHA JR., João & USP, BRA \\
\hline$T \& C$ & $15(2006)$ & ZIPSER, Meta E. & UFSC, BRA \\
\hline$T \& C$ & $15(2006)$ & RIECHE, Adriana C. & PUC-Rio, BRA \\
\hline SCIENTIA & $2(2006)$ & LEAL, Alice & UFSC, BRA \\
\hline SCIENTIA & $4(2007)$ & VANNUZINI, Adriana M. S. & UFSC, BRA \\
\hline TRADTERM & 15 (2009) & TEIXEIRA, Elisa Duarte & USP, BRA \\
\hline$T \& C$ & 19 (2009) & POLCHLOPEK, Silvana & UFSC, BRA \\
\hline CADERNOS & $24-2(2009)$ & BLUME, Roswitha F. & UFSC, BRA \\
\hline IN-TRADUÇÕES & $2-3(2010)$ & POLCHLOPEK, Silvana & UFSC, BRA \\
\hline IN-TRADUÇÕES & $2-3(2010)$ & POLCHLOPEK, Silvana & UFSC, BRA \\
\hline CADERNOS & $25-1(2010)$ & EVERS, Aline & UFRGS/UFRJ, BRA \\
\hline TRADTERM & $16(2010)$ & AZENHA JR., João & USP, BRA \\
\hline TRADTERM & $16(2010)$ & ABREU, Roberto de & USP, BRA \\
\hline TRADTERM & $16(2010)$ & LEITÃO, Renata G. de C. & USP, BRA \\
\hline CADERNOS & $27-1(2011)$ & BRANCO, Sinara de O. & UFCG, BRA \\
\hline$T \& C$ & $22(2011)$ & POLCHLOPEK, Silvana & UTFPR, BRA \\
\hline BELAS INFIÉIS & $1-1(2012)$ & LOURENÇO, Fernanda M. & UFSC/PUC-RS \\
\hline BELAS INFIÉIS & $1-1(2012)$ & ARAÚJO, Angelica A. & UFCG, BRA \\
\hline T\&C & $24(2012)$ & POLCHLOPEK, Silvana & UTFPR/UFSC \\
\hline TRADUZIRES & 1-1 (2012) & BRANCO, Sinara de O. & UFCG, BRA \\
\hline BELAS INFIÉIS & $2-1(2013)$ & LIBERATTI, Elisângela & UFSC, BRA \\
\hline TRADUZIRES & $2-1(2013)$ & NATALINO, Laís G. & UFSC, BRA \\
\hline IN-TRADUÇÕES & 5-8 (2013) & SANTANA, Patrícia M. S. & UFRJ, BRA \\
\hline REVISTA & $14-1(2013)$ & AZENHA JR., João & USP, BRA \\
\hline TRADTERM & $24(2014)$ & MIKAELYAN, Yulia & USP, BRA \\
\hline IN-TRADUÇÕES & $6-10(2014)$ & ARAGÃO, Sabrina & USP, BRA \\
\hline SCIENTIA & 15 (2014) & GUEDES, Clara Peron & UFPEL, BRA \\
\hline TRADTERM & $26(2015)$ & MALASZKIEWICZ, Paula & UFRGS, BRA \\
\hline CADERNOS & $35-2(2015)$ & RIGO, Natália Schleder & UFSC, BRA \\
\hline TRADTERM & $27(2016)$ & SILVA, Bárbara Zocal & USP, BRA \\
\hline TRADTERM & $27(2016)$ & LIBERATTI, Elisângela & UFSC, BRA \\
\hline
\end{tabular}

${ }^{309}$ Em casos de coautoria, colocamos apenas o nome de um dos autores para fins de identificação. 


\begin{tabular}{|l|l|l|l|}
\hline TRADTERM & $28(2016)$ & PONTES, Valdecy O. & UFC, BRA \\
\hline CADERNOS & $36-2(2016)$ & PONTES, Valdecy O. & UFC, BRA \\
\hline BELAS INFIÉIS & $5-1(2016)$ & BARBOSA, Diego Mauricio & UFSC/UFG \\
\hline BELAS INFIÉIS & $5-3(2016)$ & GONÇALVES, Davi Silva & UFSC, BRA \\
\hline CADERNOS & $37-2(2017)$ & SANTOS, Emerson C. P. & UFC, BRA \\
\hline
\end{tabular}

Tabela 13: Artigos com fundamentação teórica funcionalista (1994-2017).

Os dados referentes a esse corpus serão tratados por meio estatístico a partir de alguns índices: distribuição dos artigos por ano, distribuição entre as instituições a que estão filiados seus autores, autores mais produtivos, autores mais citados, trabalhos mais citados e, por fim, temas.

Começamos assim pela distribuição dos trabalhos pelo tempo. Como se vê no gráfico abaixo, a distribuição de artigos fundamentados pelo funcionalismo é bastante irregular:

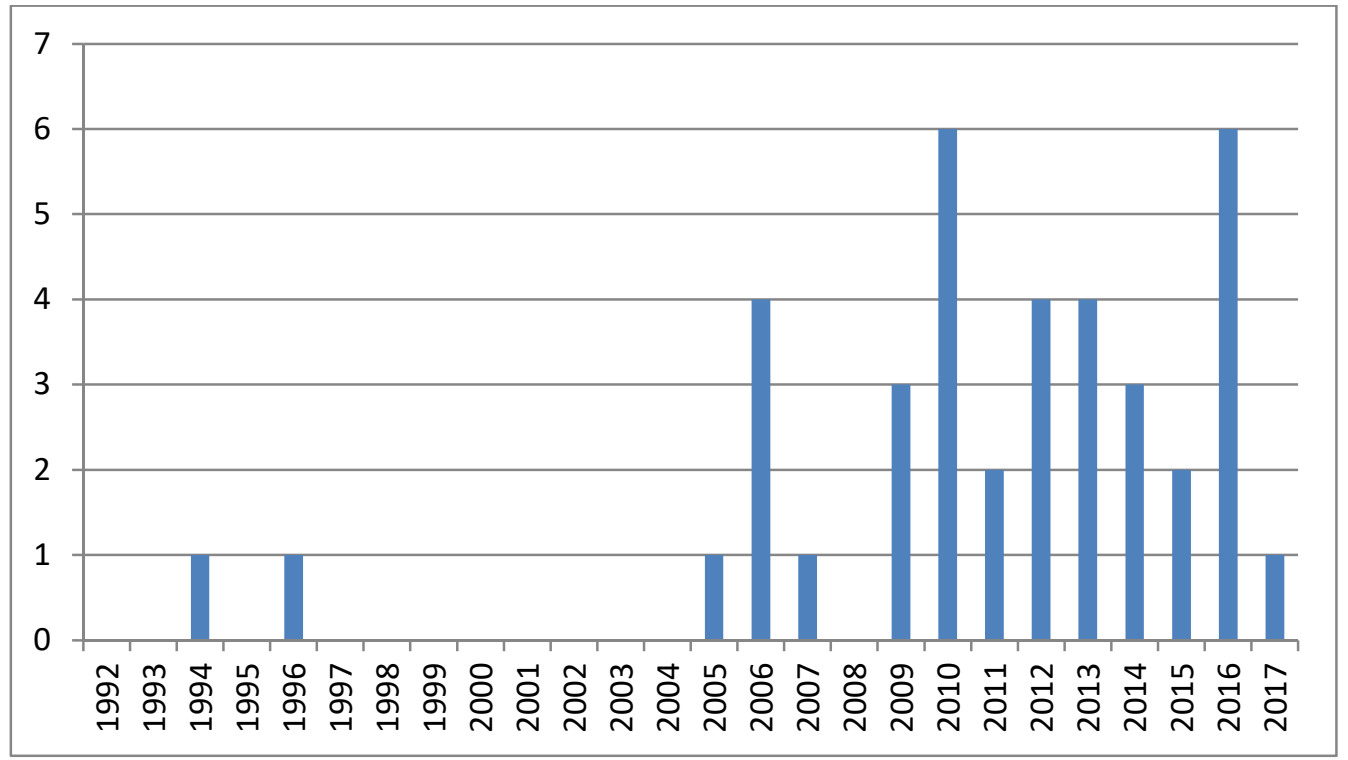

Gráfico 09: Distribuição dos artigos funcionalistas por ano.

Observa-se que, até 2005, a produção de artigos fundamentados pelo funcionalismo em instituições brasileiras era ainda bastante incipiente. Esse parece representar um período em que a divulgação dos conceitos funcionalistas parecia ainda ser bastante dependente de autores do exterior. A partir de 2005, aumentou consideravelmente a produção de trabalhos respaldados pelo funcionalismo. Esse parece ser um indício de que a teoria funciona- 
lista começa a se sedimentar nos estudos da tradução no país, ainda que seja difícil estimar o espaço ocupado pelo funcionalismo sem considerar a proporção total de trabalhos publicados no período.

Aparentemente, o funcionalismo começou a sedimentar-se nos estudos da tradução no Brasil a partir de 2005 e, com maior intensidade, a partir de 2010, com picos de crescimento nesse e no ano de 2016. Todavia, ainda é bastante irregular a proporção de artigos publicados respaldados pelo funcionalismo.

O gráfico a seguir mostra a distribuição do montante total de artigos pelas instituições a que estão vinculados seus autores.

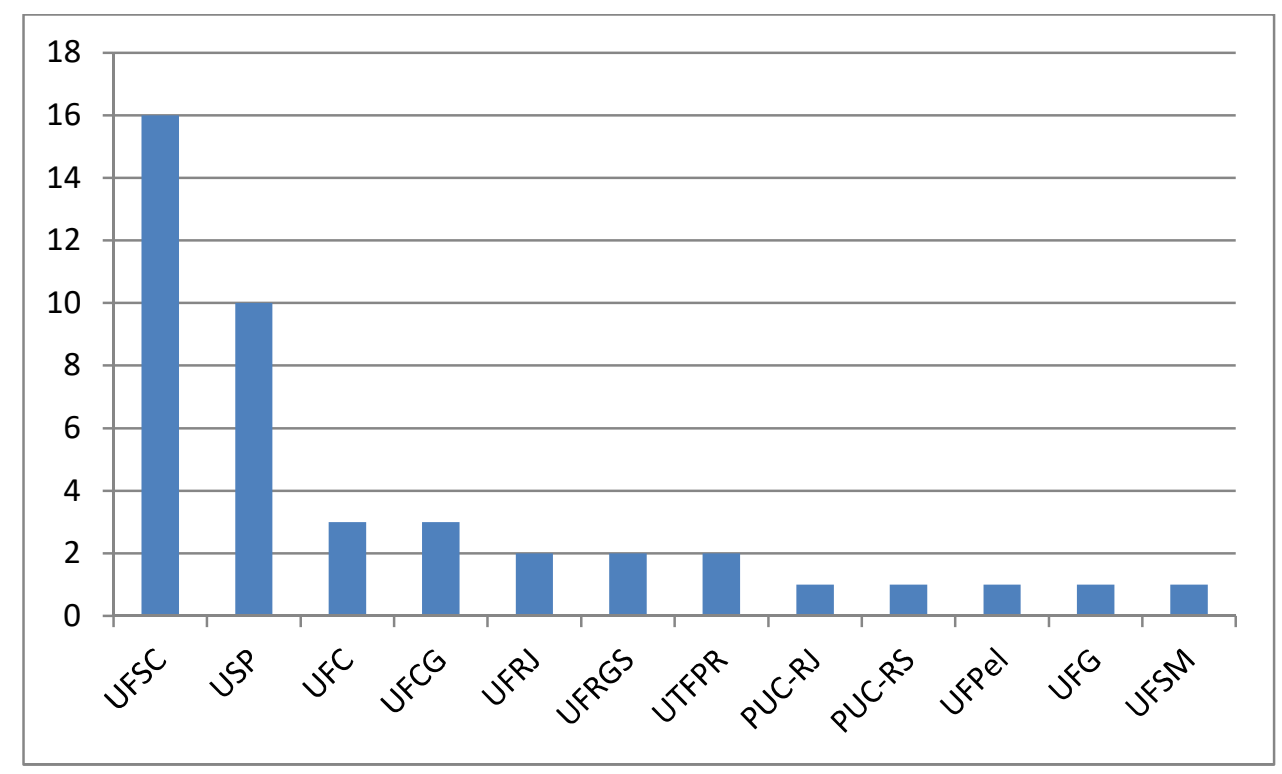

Gráfico 10: Distribuição dos artigos funcionalistas por instituição.

As informações obtidas através do gráfico acima permitem-nos conjecturar que a UFSC seja a principal promotora de pesquisas fundamentadas pelo funcionalismo, com 16 artigos. A USP fica em segundo lugar, com dez artigos. Em terceiro lugar estão a UFC e a UFCG, com três pesquisas. O gráfico a seguir mostra-nos a distribuição de trabalhos conforme o ano e a instituição, o que nos permite encontrar tendências. 


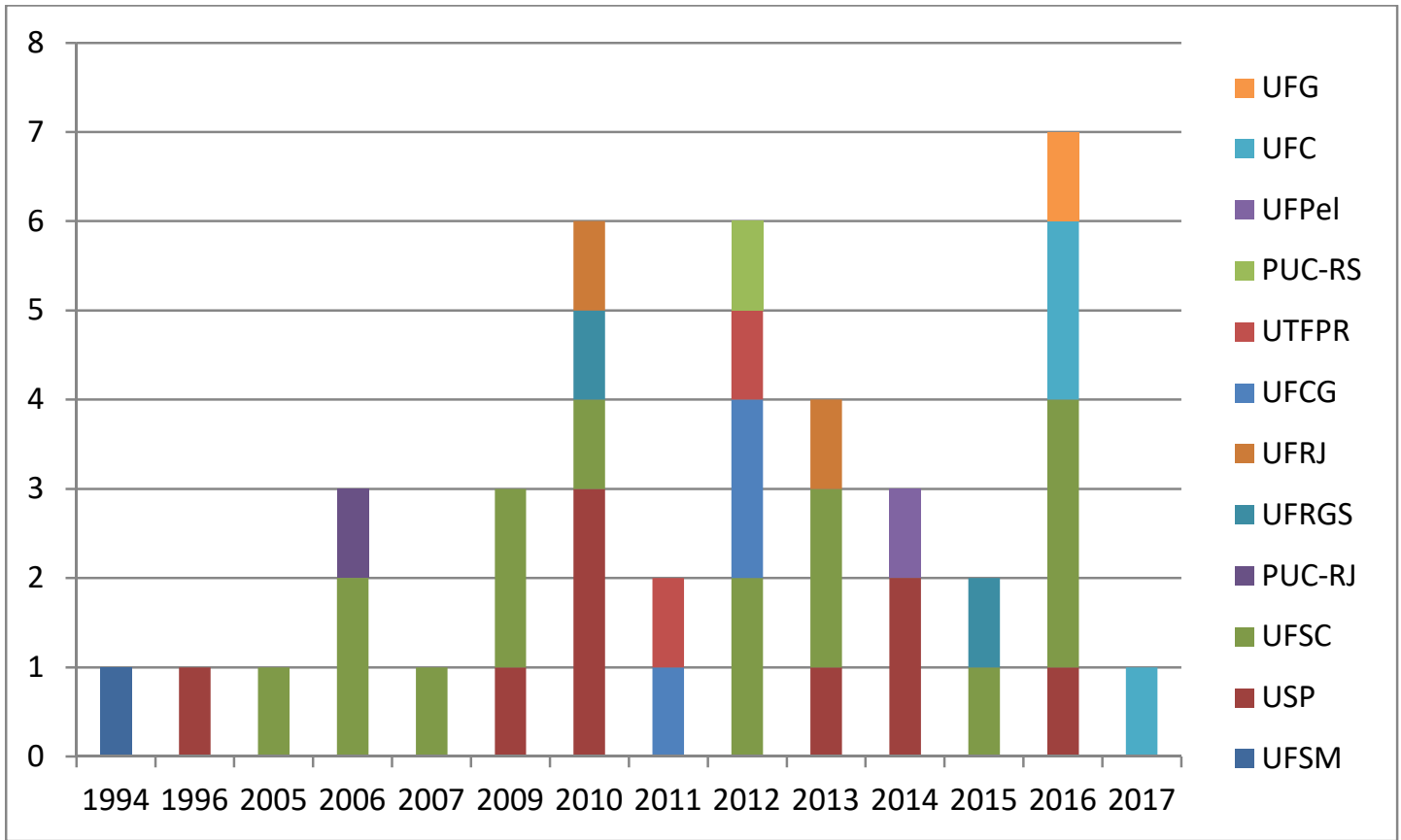

Gráfico 11: Distribuição dos artigos funcionalistas por ano/instituição.

Através do gráfico, nota-se que a UFSC começa a participar da produção de artigos respaldados pelo funcionalismo a partir do movimento de institucionalização dos estudos da tradução, com a fundação do PGET, em 2004. Nesse mesmo ano, Meta Elisabeth Zipser, já docente da instituição, defende seu doutorado na USP, podendo assim iniciar um projeto de pesquisa e orientação em torno do funcionalismo. Por outro lado, ainda que o maior volume de artigos no âmbito do funcionalismo não tenha sido produzido na USP, ela não deixou de contribuir para o desenvolvimento do funcionalismo, estando presente em diversos momentos desse período, sobretudo através da atividade de João Azenha Jr. Quanto à UFCG e à UFC, nota-se que a participação dessas instituições na produção e divulgação de pesquisas funcionalistas ocorre em períodos mais recentes, sobretudo através do engajamento, respectivamente, de Sinara de Oliveira Branco e de Valdecy Pontes.

$\mathrm{Na}$ tabela a seguir, teremos uma noção mais clara da produtividade de cada um dos autores:

\begin{tabular}{|l|l|r|}
\hline Autor(a) & Filiação & 6 \\
\hline POLCHLOPEK, Silvana & UFSC/UTFPR (desde 2011) & 4 \\
\hline AZENHA JR., João & USP & 3 \\
\hline BRANCO, Sinara & UFCG & 3 \\
\hline ZIPSER, Meta & UFSC & 2 \\
\hline LIBERATTI, Elisângela & UFSC & . \\
\hline
\end{tabular}




\begin{tabular}{|l|l|r|}
\hline PONTES, Valdecy & UFC & 2 \\
\hline PEREIRA, Livya & UFC & 2 \\
\hline AIO, Michele & UFSC & 2 \\
\hline UMBACH, Roseli & UFSM & 1 \\
\hline SOUZA, Ladjane & UFSC & 1 \\
\hline TEIXEIRA, Elisa & USP & 1 \\
\hline ABREU, Roberto de & USP & 1 \\
\hline LEITÃO, Renata & USP & 1 \\
\hline MIKAELYAN, Yulia & USP & 1 \\
\hline BLUME, Roswitha F. & UFSC & 1 \\
\hline MALASZKIEWICZ, Paula & UFRGS & 1 \\
\hline REUILLARD, Patrícia & UFRGS & 1 \\
\hline EVERS, Aline & UFRGS & 1 \\
\hline HUBERT, Dalby & UFRGS & 1 \\
\hline PINTO, Rafael S. & UFRGS & 1 \\
\hline BORBA, Rodrigo & UFRJ & 1 \\
\hline ALMEIDA, Hutan & UFSC & 1 \\
\hline LOURENÇO, Fernanda & UFSC & 1 \\
\hline MARTINS, Tahne & PUC-RS & 1 \\
\hline ARAÚJO, Angelica A. & UFCG & 1 \\
\hline COSTA, Maria José & UFSC & 1 \\
\hline NATALINO, Laís G. & UFSC & 1 \\
\hline SANTANA, Patrícia & UFRJ & 1 \\
\hline ARAGÃO, Sabrina & USP & 1 \\
\hline GUEDES, Clara Peron & UFPel & 1 \\
\hline VANNUZINI, Adriana & UFSC & 1 \\
\hline RIGO, Natália Schleder & UFSC & 1 \\
\hline MOZZILLO, Isabella & UFPel & 1 \\
\hline SILVA, Bárbara Zocal & USP & 1 \\
\hline BARBOSA, Diego & UFG & 1 \\
\hline AIRES, Leomaris & UFSC & 1 \\
\hline SILVA, Maitê & UFSC & 1 \\
\hline GONÇALVES, Davi Silva & UFSC & SFC \\
\hline SANTOS, Emerson C. P. & UFC & 1 \\
\hline RIECHE, Adriana C. & PUC-RJ & 1 \\
\hline & & 1 \\
\hline
\end{tabular}

Tabela 14: Autores(as) mais produtivos(as) no âmbito do funcionalismo.

Assim, vemos que a autora com mais artigos funcionalistas publicados nesse período é Silvana Ayub Polchlopek. De fato, ela é a responsável, segundo os dados, por levar o funcionalismo à Universidade Tecnológica Federal do Paraná (UTFPR), em 2011, após concluir seu doutorado na UFSC, sob orientação de Meta E. Zipser. Em segundo lugar, temos João Azenha Jr. como o mais produtivo da USP, com quatro artigos. Zipser e Sinara de Oliveira Branco, por sua vez, ocupam a terceira posição com três artigos, sendo Sinara a 
grande responsável pela promoção do funcionalismo na UFCG. Elisângela Liberatti e Michele Aio, da UFSC, Valdecy Pontes e Livya Pereira, da UFC, ocupam a quarta posição, com dois artigos.

No entanto, antes que possamos fazer uma discussão mais aprofundada sobre esses dados, cumpre verificar o tema desses artigos. Com auxílio da linguística de corpus, definimos de três a cinco palavras-chave para cada artigo, de modo a melhor identificar os temas abordados por ele. Abaixo, segue a tabela com os resultados:

\begin{tabular}{|c|c|}
\hline Artigos & Palavras-chave \\
\hline UMBACH (1994) & Neologismos, tradução literária, Guimarães Rosa \\
\hline AZENHA JR. (1996) & Marcadores culturais, Tradução técnica, Trabalho do tradutor \\
\hline SOUZA (2005) & Tradução jornalística, diálogo, Nord \\
\hline AZENHA JR. (2006b) & Linguística textual, marcadores culturais, tradução de alunos \\
\hline ZIPSER (2006) & Tradução do fato noticioso, Nord, Esser \\
\hline RIECHE (2006) & $\begin{array}{l}\text { Tradução, equivalência, localização de software, Nida, Lefevere, aborda- } \\
\text { gem funcionalista }\end{array}$ \\
\hline LEAL (2006) & Tradução literária, modelo de Nord \\
\hline VANNUZINI (2007) & Tradução de literatura infanto-juvenil, ilustrações, Tintenherz \\
\hline TEIXEIRA (2009) & Tradução de receitas, características textuais do gênero "receita" \\
\hline POLCHLOPEK/AIO (2009) & Tradução técnica, Papel do tradutor, terminologia, Azenha \\
\hline $\begin{array}{l}\text { BLUME/HUMMITZSCH } \\
\text { (2009) }\end{array}$ & Tradução de contos, mediação cultural, David Katan \\
\hline POLCHLOPEK et al. (2010) & Tradução técnica, Papel do tradutor, terminologia, Azenha \\
\hline $\begin{array}{l}\text { POLCHLOPEK/ZIPSER } \\
\text { (2010) }\end{array}$ & $\begin{array}{l}\text { Marcadores culturais, Tradução de embalagens, traduções de alunos, } \\
\text { Nord }\end{array}$ \\
\hline EVERS et al. (2010) & Tradução literária, Edgar Allan Poe, adaptação \\
\hline AZENHA JR. (2010) & Tradução, transferência cultural, textos de especialidade, texto literário \\
\hline ABREU (2010) & Marcas de oralidade, Tradução de romance, Raymond Queneau \\
\hline LEITÃO (2010) & Tradução de quadrinhos, tradução de onomatopeias, mangás \\
\hline BRANCO (2011) & Tradução, Ensino de língua estrangeira \\
\hline POLCHLOPEK (2011a) & Tradução de textos jornalísticos, representação cultural, Zipser \\
\hline $\begin{array}{l}\text { LOURENÇO/MARTINS } \\
(2012)\end{array}$ & Tradução de textos jornalísticos, morte de Khadafi, cultura, Zipser, Nord \\
\hline ARAÚJO/BRANCO (2012) & Tradução, Ensino de língua estrangeira \\
\hline POLCHLOPEK et al. (2012) & Tradução, Funcionalismo, Nord, função, Reiss, Vermeer \\
\hline BRANCO (2012) & Estudos da Tradução, Ensino de língua estrangeira \\
\hline LIBERATTI (2013) & Tradução de quadrinhos, tradução dialetal, Chico Bento, Bagno, Nord \\
\hline NATALINO (2013) & $\begin{array}{l}\text { Tradução, Semiótica, Tramas de ênfase, tradução de anúncios publicitá- } \\
\text { rios }\end{array}$ \\
\hline SANTANA (2013) & Processo de tradução, iniciador, Nord, skopos \\
\hline AZENHA JR. (2013) & Competência linguística, competência cultural, formação de tradutores \\
\hline MIKAELYAN (2014) & Tradução de humor, tradução literária, literatura russa, Dotlátov \\
\hline ARAGÃO (2014) & Tradução de quadrinhos, tradução de humor, \\
\hline
\end{tabular}




\begin{tabular}{|l|l|}
\hline GUEDES/MOZZILLO (2014) & Marcadores culturais, tradução técnica, papel do tradutor, Azenha \\
\hline $\begin{array}{l}\text { MALASZKIEWICZ et al. } \\
\text { (2015) }\end{array}$ & Conceptualização metafórica, anatomia, artérias e veias \\
\hline RIGO (2015) & Tradução de textos acadêmicos, tradução para LIBRAS \\
\hline SILVA (2016) & Tradução de quadrinhos, tradução de nomes, tiras de "Mafalda" \\
\hline LIBERATTI (2016) & Tradução de quadrinhos, didática da tradução, material didático \\
\hline PONTES/PEREIRA (2016a) & Tradução, Ensino de língua estrangeira, Abordagem funcionalista, Nord \\
\hline PONTES/PEREIRA (2016b) & Tradução, Ensino de formas de tratamento, Variação linguística \\
\hline BARBOSA et al. (2016) & Tradução de vídeo, Tradução de língua de sinais para português \\
\hline GONÇALVES (2016) & Tradução para o teatro, Christopher Hamptom \\
\hline SANTOS (2017) & Tradução de poema, LIBRAS, Edgar Allan Poe, O Corvo \\
\hline
\end{tabular}

Tabela 15: Relação de palavras-chave para cada artigo funcionalista.

Através dessa tabela, vemos com mais clareza os temas sobre os quais os artigos foram escritos. Observando a produção dos autores mais produtivos, vemos que a tradução técnica foi um tema bastante explorado por Azenha Jr. e, principalmente, por Polchlopek. Outro tema bastante recorrente na produção de Azenha Jr. foi a formação de tradutores, a partir de sua experiência docente. No que tange à produção de Zipser, seja sozinha ou em parceria com orientandos, sobretudo Polchlopek e Aio, o terma da tradução de textos jornalísticos emerge com frequência. Liberatti explora de modo recorrente a tradução de quadrinhos, seja pelo viés da prática ou da didática. Por fim, Valdecy Pontes, Livya Pereira e Sinara de Oliveira Branco compartilham o tema do emprego da tradução em aulas de língua estrangeira.

O gráfico abaixo demonstra qual é a proporção de cada um dos diversos temas no corpus: 


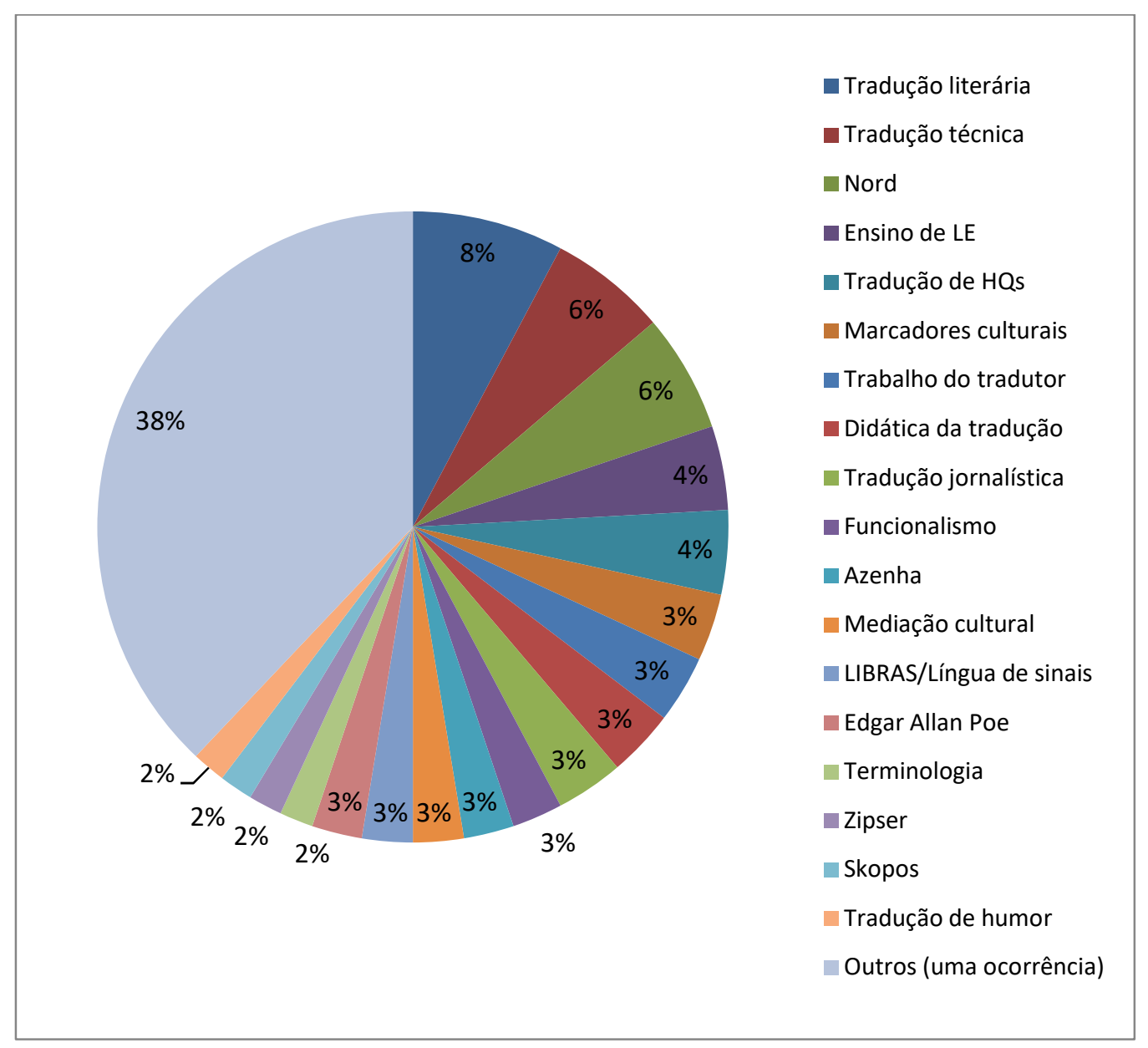

Gráfico 12: Proporção de ocorrências de temas em artigos funcionalistas.

Nota-se que os principais temas são tradução literária (8\%), tradução técnica $(6 \%)$, Nord (6\%), ensino de língua estrangeira (4\%) e tradução de histórias em quadrinhos (4\%). Curioso notar que, embora a tradução literária seja a área de aplicação mais frequente do funcionalismo segundo nosso levantamento - o que contraria o senso comum de que o funcionalismo não serviria à tradução literária - os artigos, em vez de refletirem projetos de pesquisa maiores - no nível de mestrado ou doutorado - fundamentados pelo funcionalismo, parecem reportar exercícios de tradução literária.

Fizemos ainda um exame das referências funcionalistas citadas pelos autores, em busca dos autores e dos trabalhos mais citados. A lista dos autores mais citados segue abaixo: 


\begin{tabular}{|c|c|}
\hline Autores(as) & Ocor. \\
\hline NORD, Christiane & 30 \\
\hline VERMEER, Hans & 16 \\
\hline REISS, Katharina & 16 \\
\hline ZIPSER, Meta & 10 \\
\hline AZENHA JR., João & 7 \\
\hline SNELL-HORNBY, Mary & 6 \\
\hline POLCHLOPEK, Silvana & 6 \\
\hline LEAL, Alice & 4 \\
\hline KUSSMAUL, Paul & 2 \\
\hline SCHMITT, Peter & 2 \\
\hline HOLZ-MÄNTTÄRI, Justa & 2 \\
\hline LIBERATTI, Elisângela & 2 \\
\hline LAIÑO, Maria & 2 \\
\hline DEMÉTRIO, Ana Paula & 2 \\
\hline BARRIENTOS, Brenda & 2 \\
\hline HÖNIG, Hans & 1 \\
\hline ACCÁCIO, Manuela & 1 \\
\hline AlO, Michele & 1 \\
\hline MELO, Noemi & 1 \\
\hline KUPSCH-LOSEREIT, Sigrid & 1 \\
\hline FREITAS, Simoni & 1 \\
\hline FANAYA, Patrícia & 1 \\
\hline CARDOZO, Maurício & 1 \\
\hline BRANCO, Sinara & 1 \\
\hline
\end{tabular}

Tabela 16: Autores funcionalistas mais citados.

Nota-se que, assim como indicado pela recorrência de palavras-chave, Christiane Nord é a autora mais citada em trabalhos respaldados pelo funcionalismo - o que parece indicar que a recepção do funcionalismo no Brasil ocorreu sobretudo através da proposta teórica da autora. Em seguida, como era esperado, vêm Hans J. Vermeer e Katharina Reiss. Meta E. Zipser e João Azenha Jr. são os autores brasileiros com mais trabalhos citados, o que sugere que eles atuaram como instâncias disseminadoras do funcionalismo no Brasil.

Abaixo temos a lista das referências mais frequentes. De modo a considerar apenas as referências minimamente significativas, limitamos essa lista para incluir apenas aquelas referências com citações em pelo menos dois documentos: 
NORD, Christiane. Text analysis in translation. Amsterdam: Rodopi, 1991.

NORD, Christiane. Translating as a purposeful activity: functionalist approaches explained.

Manchester, UK: St. Jerome, 1997.

ZIPSER, Meta. Do fato à reportagem: as diferenças de enfoque e a tradução como represen-

tação cultural. Tese de Doutorado. São Paulo, FFLCH-USP, 2002.

AZENHA Jr., João. Tradução técnica e condicionantes culturais - primeiros passos para um estudo integrado. São Paulo: Humanitas/ USP, 1999.

REISS, Katharina; VERMEER, Hans Josef. Grundlegung einer allgemeinen Translationstheori-

e. Tübingen: Niemeyer, 1984.

SNELL-HORNBY, Mary. Translation Studies: an integrated approach. Amsterdam, Philadel-

phia: John Benjamins Publishing Company, 1988.

REISS, Katharina. Type, kind and individuality of text - Decision making in translation. In:

VENUTI, L. The Translation Studies Reader. New York: Routledge, pp. 160-171, 2000.

NORD, Christiane. Kommunikativ handeln auf Spanisch und Deutsch. Ein übersetzungsori-

entierter funktionaler Sprach- und Stilvergleich. Wilhelmsfeld: Gottfried Egert, 2003.

REISS, Katharina. Möglichkeiten und Grenzen der Übersetzungskritik. München: Hueber, 1971.

REISS, Katharina. Texttyp und Übersetzungsmethode. Der operative Text (2a. ed.). Heidelberg: Groos, 1983.

SNELL-HORNBY, Mary. (ed.) Übersetzungswissenschaft. Eine Neuorientierung. Tübingen: Francke Verlag (UTB für Wissenschaft: Uni-Taschenbücher; 1415), 1986.

REISS, Katharina; VERMEER, Hans Josef. Fundamentos para una teoria funcional de la traducción. Trad. Sandra García Reina; Celia Martín de León; Heidrun Witte. Madrid: Akal, 1996.

LEAL, Alice. Funcionalismo e Tradução Literária: o modelo de Christiane Nord em três contos ingleses contemporâneos. Scientia Traductionis № II. Florianópolis: PGET/UFSC, 2006. POLCHLOPEK, Silvana Ayub. A interface tradução-jornalismo: um estudo de condicionantes culturais e verbos auxiliares modais em textos comparáveis das revistas Veja e Time. Dissertação (Pós-Graduação em Estudos da Tradução), Universidade Federal de Santa Catarina, Florianópolis, 2011.

AZENHA Jr., João. Tradução técnica, condicionantes culturais e os limites da responsabilidade do tradutor. Cadernos de tradução, v. 1, n. 1, p. 137-149, 1996.

NORD, Christiane. Einführung in das funktionale Übersetzen. Tübingen: Francke (UTB), 1993.

VERMEER, Hans Josef. Skopos and commission in translational action. Transl. Andrew Chesterman. 1989. In: VENUTI, Lawrence. The translation studies reader. London/New-York: Routledge, 2000, p. 221-232.

SCHMITT, Peter A. - Die „Eindeutigkeit” von Fachtexten: Bemerkungen zu einer Fiktion. In: SNELL-HORNBY, M. Übersetzungswissenschaft: eine Neuorientierung. Zur Integrierung von Theorie und Praxis. Tübingen: Francke, 1986, pp. 252-282.

AZENHA Jr., João. Aspectos culturais na produção e na tradução de textos técnicos de instrução alemão-português: teoria e prática. Tese de Doutorado. São Paulo, 1994.

LIBERATTI, Elisângela. Ara, Chico; Aw, Chuck: uma tradução funcionalista de quadrinhos do Chico Bento. 2012. 165 p. Dissertação (Mestrado em Estudos da Tradução). Universidade Federal de Santa Catarina. Florianópolis - SC. Disponível em: www.pget.ufsc.br/curso/dissertacoes/Elisangela_Liberatti_-_Dissertacao.pdf. 


\begin{tabular}{|c|c|}
\hline $\begin{array}{l}\text { NORD, Christiane. El funcionalismo en la enseñanza de traducción. Mutatis Mutandis. Vol. 2, } \\
\text { No. 2. 2009. pp. } 209 \text { - 243. Disponível em: <http://goo.gl/7kdLWX>. Acesso em: } 03 \\
\text { mar.2015. }\end{array}$ & 2 \\
\hline $\begin{array}{l}\text { NORD, Christiane. Texto base-texto meta. Un modelo funcional de análisis pretraslativo. } \\
\text { Tradução e adaptação de Cristiane Nord. Castelló de la Plana: Publicacions de la Universitat } \\
\text { Jaume I, Espanha, } 2012 .\end{array}$ & 2 \\
\hline $\begin{array}{l}\text { ZIPSER, Meta E.; POLCHLOPEK, Silvana. A. Introdução aos Estudos da Tradução. Curso de } \\
\text { Licenciatura de Letras Espanhol na Modalidade a Distância. Florianópolis: UFSC, } 2011 .\end{array}$ & 2 \\
\hline $\begin{array}{l}\text { DEMÉTRIO, Ana Paula de Carvalho. A tradução como retextualização: uma proposta para o } \\
\text { desenvolvimento da produção textual e para a ressignificação da tradução dentro do ensino } \\
\text { de LE. 2014. 198f. Dissertação (Mestrado em Estudos da Tradução) - Centro de Comunica- } \\
\text { ção e Expressão. Universidade Federal de Santa Catarina, Florianópolis, } 2014 .\end{array}$ & 2 \\
\hline $\begin{array}{l}\text { LAIÑO, Maria José. A tradução pedagógica como estratégia à produção escrita em LE a } \\
\text { partir do gênero publicidade. 2014. 234f. Tese (Doutorado em Estudos da Tradução) - Cen- } \\
\text { tro de Comunicação e Expressão. Universidade Federal de Santa Catarina, Florianópolis, } \\
2014 .\end{array}$ & 2 \\
\hline $\begin{array}{l}\text { BARRIENTOS, Brenda Rocio Ruesta. Os quadrinhos da Mateina no ensino de Espanhol lín- } \\
\text { gua estrangeira: à luz da tradução funcionalista. 2014. 252f. Dissertação (Mestrado em } \\
\text { Estudos da Tradução) - Centro de Comunicação e Expressão. Universidade Federal de Santa } \\
\text { Catarina, Florianópolis, } 2014 \text {. }\end{array}$ & 2 \\
\hline $\begin{array}{l}\text { HOLZ-MÄNTTÄRI, Justa. Translatorisches Handeln: Theorie und Methode. Helsinki: Suoma- } \\
\text { lainen Tiedeakatemia, } 1984 .\end{array}$ & 2 \\
\hline $\begin{array}{l}\text { VERMEER, Hans Josef. Ein Rahmen für eine allgemeine Translationstheorie. Lebende Spra- } \\
\text { chen } 23,1978, \text { p. 99-102. }\end{array}$ & 2 \\
\hline $\begin{array}{l}\text { NORD, Christiane. Defining Translation Functions: The translation brief as a guideline for the } \\
\text { trainee translator. Ilha do Desterro (Brasilien), Special Issue Translation Studies in Germany, } \\
\text { Florianopólis, ed. Wolfgang Lörscher, } 2.1997,39-53 \text {. }\end{array}$ & 2 \\
\hline $\begin{array}{l}\text { NORD, Christiane. Comunicarse funcionalmente en dos lenguas. In: FABER, Pamela; JIMÉ- } \\
\text { NEZ, Catalina; WOTJAK, Bernd. Léxico especializado y comunicación interlingüística. Grana- } \\
\text { da: Granada Lingüística, } 2004 .\end{array}$ & 2 \\
\hline
\end{tabular}

Tabela 17: Documentos funcionalistas mais citados.

Em primeiro lugar, destacamos dessa lista a comprovação, como vinha se insinuando nos índices anteriores, de que a recepção do funcionalismo no Brasil se deu sobretudo através da obra de Christiane Nord. Os textos mais citados são, em primeiro lugar, a tradução para o inglês de seu texto seminal (NORD, 1988) e a obra introdutória escrita por Nord para a editora St. Jerome, na qual ela elucida, em língua inglesa, os principais conceitos e métodos introduzidos e sistematizados pelos funcionalistas. $\mathrm{O}$ fato de ambas as obras estarem em língua inglesa demonstra que, como aventado anteriormente, a língua alemã pode, sim, ser vista como um obstáculo para a recepção teórica do funcionalismo no Brasil.

Em segundo lugar, não podemos deixar de destacar a importância dos trabalhos de Meta Zipser e de João Azenha Jr. para a promoção do funcionalismo no país. Ambos os 
textos, resultantes da pesquisa de doutoramento dos autores, servem hoje como referência bibliográfica para gerações mais novas de pesquisadores. Não está claro, contudo, se o fator motivador das citações é apenas o pioneirismo desses autores ou se há questões institucionais envolvidas - pode-se especular, por exemplo, de que as constantes referências à obra de Meta Zipser estejam de alguma forma relacionadas com o fato de a maioria dos artigos levantados nesse estudo ter sido escrita por pesquisadores vinculados à UFSC. Para avaliar essa hipótese, seria necessário cruzar as informações dos currículos dos pesquisadores em busca, por exemplo, de indícios como orientação de trabalho. Deixamos aqui a sugestão de um possível desdobramento para a presente pesquisa.

De todo modo, o fato de encontrarmos bastantes teses e dissertações em meio às referências bibliográficas como obras de consulta para os princípios teóricos defendidos pelo funcionalismo indica que há aqui o estabelecimento de um espaço para o funcionalismo no país. As referências parecem sugerir que esse espaço seja justamente a UFSC, posto que os trabalhos referenciados foram, em sua maioria, lá produzidos. Ainda que as frequentes citações a trabalhos produzidos na UFSC seja, em certa medida, devido ao fato de a maioria dos trabalhos coletados nesse corpus ter sido escrita por pesquisadores ligados à instituição não torna menos significativa a atuação da universidade de irradiar os preceitos funcionalistas no âmbito dos estudos da tradução no país.

A listagem também confirma outra hipótese traçada com vistas em índices anteriores: os trabalhos aqui listados, sobretudo as teses e as dissertações, voltam-se à tradução técnica, ao emprego da tradução como ferramenta didática em aulas de língua estrangeira e, até mesmo, à tradução de quadrinhos, além dos trabalhos que exploram a interface tradução-jornalismo. Esse fato só fortalece nossa hipótese de que a grande quantidade de artigos acerca da tradução literária estão mais ligados a exercícios de tradução literária do que a pesquisas sistemáticas de tradução literária respaldadas pelo funcionalismo.

Assim, o conjunto de índices acima permite-nos identificar algumas tendências do desenvolvimento do funcionalismo no Brasil. Aparentemente o funcionalismo encontra uma área fértil no âmbito da tradução técnica, do ensino de língua estrangeira e na tradução de quadrinhos. Assim, nossa escolha para os trabalhos a serem analisados no próximo capítulo orientam-se por essas tendências. Escolhemos trabalhos que representem esses temas, a partir da lista de referências acima, dando preferência a teses sobre dissertações e trabalhos de autores mais produtivos sobre os menos produtivos. Ademais, não se pode ignorar o papel fundamental dos trabalhos de Azenha Jr. e Zipser para esse contexto, de modo que 
eles foram também incluídos no corpus de análise. Desse modo, nosso corpus de análise ficou da seguinte forma:

- AZENHA Jr., João. Aspectos culturais na produção e na tradução de textos técnicos de instrução alemão-português: teoria e prática. Tese de Doutorado. São Paulo, 1994. [tradução técnica]

- ZIPSER, Meta. Do fato à reportagem: as diferenças de enfoque e a tradução como representação cultural. Tese de Doutorado. São Paulo, FFLCH-USP, 2002. [tradução de textos jornalísticos]

- LIBERATTI, Elisângela. Ara, Chico; Aw, Chuck: uma tradução funcionalista de quadrinhos do Chico Bento. 2012. 165 p. Dissertação (Mestrado em Estudos da Tradução). Universidade Federal de Santa Catarina. Florianópolis - SC. [tradução de quadrinhos]

- LAIÑO, Maria José. A tradução pedagógica como estratégia à produção escrita em LE a partir do gênero publicidade. 2014. 234f. Tese (Doutorado em Estudos da Tradução) - Centro de Comunicação e Expressão. Universidade Federal de Santa Catarina, Florianópolis, 2014. [tradução e ensino de LE]

No próximo capítulo, esses trabalhos serão analisados no que concerne ao tratamento conceitual dado aos principais conceitos funcionalistas, de modo a identificar como foi a recepção desses conceitos no Brasil. Antes, contudo, cabe formular uma síntese dos dados e das discussões apresentadas nesse capítulo.

\subsubsection{Discussão dos resultados}

No Brasil das décadas de 1950 a 1970, a exemplo do que ocorria no mundo, o conceito de tradução dominante, na parca produção intelectual dedicada ao tema, era marcado pela dissociação entre sujeito e objeto, pressupunha a existência de um sentido intrínseco ao texto de partida e escorava-se nas noções de fidelidade e equivalência como critérios de avaliação. Essa concepção do traduzir era veiculada por livros concebidos com base na experiência de tradutores - quase sempre tradutores literários - ou nas ideias cultivadas por 
acadêmicos das áreas de linguística e de literatura comparada. De uma forma ou de outra, é notório que a tradução não desfrutava de lugar próprio nas universidades.

Nesse contexto, a reforma universitária propiciou o primeiro movimento de institucionalização dos estudos da tradução, através da criação de cursos de tradução e interpretação em níveis universitários, seja como cursos de graduação, de extensão ou de pósgraduação lato sensu. A criação desses cursos teria sido motivada pelo reconhecimento da necessidade de uma formação universitária para tradutores e intérpretes, em face da crescente exigência do mercado por profissionais qualificados. Ela gerou demanda por professores especialistas e, consequentemente, impulsionou o desenvolvimento de um campo de pesquisas para conferir respaldo teórico à formação prática. A despeito disso, muitos dos cursos criados nesse período centravam a sua didática no aperfeiçoamento de conhecimentos de língua estrangeira.

É importante lembrar que os cursos de formação de tradutores e intérpretes, bem como a decorrente pesquisa, originaram-se no âmbito dos cursos de Letras, servindo-se por muito tempo da estrutura prévia desses cursos. Logo, embora haja iniciativas que levem os estudos da tradução mais próximos da almejada autonomia, por exemplo, com a criação de programas de pós-graduação dedicados ao tema, a tradução ainda se encontra, de maneira geral, confinada nessa mesma estrutura, em áreas de concentração ou em linhas de pesquisa de programas mais amplos de Letras.

Outro importante momento da institucionalização do campo foi a criação das associações de pesquisadores e dos fóruns de discussão, ferramentas cruciais para fomentar o crescimento da área de pesquisas. Exemplar nesse sentido foi a atuação do Grupo de Trabalho de Tradução da ANPOLL. Criado em 1984, o GT destinou-se a reunir pesquisadores e a organizar a pesquisa no campo da tradução conduzida em programas de pós-graduação em todo o país. Embora o próprio crescimento do campo, aliado ao desenvolvimento das telecomunicações, tenha levado seus membros a rever o papel do GT em tempos mais recentes, não se pode negar a relevância do grupo como catalisador do avanço nos estudos da tradução.

O desenvolvimento da área não trouxe consequências apenas para o GT de Tradução da ANPOLL. Algumas décadas antes, ele teria impactado também os eventos acadêmicos promovidos com o objetivo de estimular o intercâmbio entre pesquisadores, profissionais e entusiastas da tradução e da interpretação. Como exemplo, mencionamos o caso do Encontro Nacional de Tradutores: inicialmente criado para fortalecer a abordagem teó- 
rica da tradução, o evento conciliou, em suas primeiras edições, temas referentes à realidade profissional do tradutor com temas de natureza mais acadêmica. Com o tempo, as discussões acadêmicas tornaram-se dominantes, diminuindo assim o papel das discussões de cunho profissional. Com isso, teoria e prática pareceram desenvolver-se segregadas uma da outra.

Além da criação de associações e eventos acadêmicos, uma contribuição fundamental para a institucionalização do campo disciplinar foi a criação de periódicos destinados a publicar artigos científicos com temas relacionados apenas com os domínios dos estudos da tradução. O primeiro dessa natureza - o periódico Tradução \& Comunicação - foi criado no início dos anos de 1980 como um importante canal de divulgação de pesquisas, essencial a um campo disciplinar em expansão. Com a interrupção das publicações a partir de 1986, alguns teóricos recorreram a revistas devotadas a áreas mais gerais das Letras, organizando números especiais dedicados à tradução. Essa prática continuou mesmo com o retorno das revistas especializadas, como a TradTerm e os Cadernos de Tradução.

Neste trabalho, é sobretudo através de periódicos que somos informados acerca dos desdobramentos dos estudos da tradução no Brasil. O crescimento da área foi marcado profundamente pela emergência do pós-estruturalismo de Rosemary Arrojo, Paulo Ottoni e Jacques Derrida, na segunda metade da década de 1980. A nova abordagem teórica causou forte impacto no modo de pensar a tradução: a pressuposição de um sentido intrínseco para o texto de partida deu lugar ao reconhecimento de que o sentido textual é construído no momento de recepção; a orientação comum segundo critérios como a fidelidade e equivalência foi substituída por um olhar prospectivo, que examina o contexto para o qual se traduz. Por conseguinte, ela trouxe consequências também para a pesquisa, tornando-se a abordagem mais influente na área no Brasil, como atestam os artigos publicados sobretudo ao longo da década de 1990, e para o ensino nos cursos de tradução, que passaram a incluir matérias de teoria da tradução em seus currículos. Com isso, a exemplo do que ocorreu no mundo, os estudos da tradução no país também vivenciaram uma "virada cultural", que afetou a estrutura institucional do campo disciplinar entre nós. Essa é uma prova de que, da mesma forma que o contexto institucional determina a produção intelectual, essa influencia e pode modificar também o contexto institucional.

A institucionalização é, indubitavelmente, um fator imprescindível para o desenvolvimento de um campo disciplinar. Com a inserção cada vez maior da tradução nos programas de pós-graduação, ela passou a ser reconhecida como um tema de pesquisa de mé- 
rito próprio. No entanto, outros fatores teriam estimulado o desenvolvimento dos estudos da tradução no Brasil. Dentre eles estão o crescimento da área no exterior e a demanda por professores qualificados nos novos cursos de tradução no nível universitário. De fato, a esse motivo é atribuído o elevado número de doutorados em tradução registrado entre as décadas de 1980 e 1990. No âmbito acadêmico, a qualificação de docentes está quase sempre associada a titulações e, como se nota pelo histórico da área, o caso dos estudos da tradução não foi diferente.

Segundo indícios encontrados nos relatos historiográficos, as pesquisas em tradução estiveram, em seus primórdios, bastante concentradas em instituições de ensino superior das regiões sudeste e do sul do Brasil. Com o crescimento dos estudos da tradução, houve também a descentralização das pesquisas e do ensino. O caso do GT de Tradução da ANPOLL é ilustrativo: de início com adesão predominante de pesquisadores filiados a instituições em São Paulo, Rio de Janeiro, Minas Gerais e Rio Grande do Sul, locais onde foram criados os primeiros GTs regionais, logo testemunhou o envolvimento de outras instituições, por exemplo de Santa Catarina, da Bahia e do Ceará, e a posterior criação de GTs em algumas dessas localidades.

Os dados referentes à produção acadêmica confirmam a referida dispersão. Em suas reflexões acerca da história do campo disciplinar, Vasconcellos (2013) observa uma primeira tendência centrípeta na institucionalização dos estudos da tradução, manifesta pela criação dos grupos de trabalho e dos fóruns de discussão; posteriormente, essa primeira tendência deu lugar a uma tendência centrífuga, manifesta pela dispersão do campo, seja pela disseminação da pesquisa, seja pela variedade de temas.

O caso da UFSC enquadra-se nesse processo de descentralização, em especial se comparado ao desenvolvimento dos estudos da tradução em instituições como a USP e a UNICAMP. Numa revisão da criação da PGET, Andréia Guerini, Marie-Hélène Torres e Walter Carlos Costa (2013b), docentes vinculados ao programa, relatam que o grupo fundador do programa não se reuniu inicialmente em torno de um programa de pós-graduação, como é o costume, mas em torno da revista Cadernos de Tradução e, depois, num Núcleo de Tradução ligado ao GT de Tradução da ANPOLL ${ }^{310}$.

Analisando as publicações do periódico, logo se nota sua importância para o desenvolvimento do campo disciplinar na instituição: em toda a sua história aqui examinada, mas de modo mais perceptível em seus primeiros anos, os Cadernos de Tradução publica-

\footnotetext{
${ }^{310}$ GUERINI; TORRES; COSTA, 2013, p. 14.
} 
ram abundantemente pesquisas conduzidas na UFSC, reforçando o que parece ser uma tendência no campo, a saber, a preferência por publicar em revistas ligadas à própria instituição a que se está vinculado. O benefício é mútuo: por um lado, ao incluir um montante representativo de artigos, alimentado pelas pesquisas desenvolvidas na universidade responsável por sua publicação, o periódico ganha notoriedade e torna-se um importante veículo de divulgação acadêmica; por outro lado, com muitos trabalhos divulgados, a instituição ganha prestígio naquela área e emerge como um importante centro de pesquisas. E sabemos que prestígio é um capital simbólico.

A estratégia de acumulação de capital parece ter sido bem sucedida: em 2004, a UFSC dá mais um passo rumo à institucionalização da área, com a criação da PGET, programa de pós-graduação stricto sensu dedicado exclusivamente à área dos estudos da tradução. Concomitante à criação desse programa pioneiro no Brasil, a instituição lançou mais um periódico, a Scientia Traductionis, dedicado à divulgação da produção discente no interior desse programa. Alguns anos depois, em 2009, mais um periódico vinculado à PGET - In-Traduções - foi criado. Ambos, no entanto, foram descontinuados, tendo lançado seus últimos números, respectivamente, no ano de 2014 e 2015, devido a uma solicitação da CAPES para reduzir o número de revistas ligadas a um mesmo programa de pósgraduação $^{311}$.

Guerini, Torres e Costa sugerem ainda outros fatores relevantes para o pioneirismo da UFSC: "1. um espírito interdisciplinar, interdepartamental, inter-regional e internacional; 2. uma postura antiburocrática e de estímulo à inovação e 3. o peso da tradução literária no programa" (GUERINI; TORRES; COSTA, 2013b, p. 15). Nesse contexto, gostaríamos de abordar o terceiro fator mencionado pelo trio: conforme nossos levantamentos, a tradução literária sempre esteve, de fato, entre os temas mais recorrentes de pesquisa na área. Segundo os próprios,

[d]e fato, parece ter havido um descompasso entre a evolução internacional da disciplina, que se desenvolve cada vez mais fora do campo literário, e o persistente interesse pela tradução literária. $\mathrm{O}$ fenômeno é particularmente forte no Brasil, onde mestrandos, doutorandos e, pesquisadores em geral, mantêm um vivo interesse pela tradução literária, como pode ser constatado pela relação de comunicações dos últimos congressos da Associação Brasileira de Pesquisadores em Tradução (ABRAPT). (GUERINI; TORRES; COSTA, 2013b, p. 19s.)

\footnotetext{
${ }^{311}$ FURLAN; ALTHOFF, 2014, p. 1.
} 
A nosso ver, a tradução literária, uma preocupação central ao longo de toda a história nas reflexões acerca da atividade tradutória, desfruta de imenso prestígio no Brasil. Além da tradição milenar, esse prestígio em tempos atuais pode ser ao menos parcialmente explicado pela atuação dos irmãos Campos, que lançaram luz sobre aspectos diferentes do ofício (ou seria da arte?) da tradução literária e cujas ideias estão em consonância com a abordagem pós-moderna a ascender ao mainstream do campo no país. O foco na tradução literária, portanto, contribui certamente para a angariação de pós-graduandos.

Independente dos demais mecanismos envolvidos no crescimento dos estudos da tradução da UFSC, é inegável que a criação da PGET foi o de maior impacto. Comparando a produção intelectual entre as décadas de 1980 e 1990 com a de anos mais recentes, como fazem Alves e Vasconcellos (2016), percebe-se que a Universidade Federal de Santa Catarina supera as demais no tocante ao volume de trabalhos defendidos, sobretudo a partir de 2007, quando foram concluídas as primeiras dissertações de Mestrado da PGET. Esse é um indicativo de que a criação de programas de pós-graduação em estudos da tradução são um grande estímulo para a pesquisa na área.

É compreensível que isso aconteça: se as pesquisas em estudos da tradução estão dispersas em programas mais amplos das Letras, também estarão dispersos os recursos que incluem desde laboratórios a bolsas de pesquisa ou auxílios para a participação em eventos. Assim, o acesso aos recursos depende ainda mais de questões relativas ao poder político. Com a criação de um programa de pós-graduação dedicado exclusivamente ao campo disciplinar, há a concentração de recursos, tornando mais atrativa a pesquisa nessa área. $\mathrm{O}$ incentivo à pesquisa traz consigo a criação de meios de divulgação, a notar, por exemplo, pelo aumento de revistas dedicadas aos estudos da tradução nos últimos anos. Vale lembrar que, em vista de sua iniciativa pioneira, até 2011 a PGET foi o único programa de pós-graduação stricto sensu dedicado exclusivamente aos estudos da tradução e, assim, por anos enfrentou pouca concorrência de outros programas.

O caso da USP é um pouco diferente. O processo de institucionalização da USP remonta à década de 1970, com a criação do Curso de Tradução em nível de graduação. Em 1981, a tradução deixou a estrutura curricular da universidade e passou à condição de curso extracurricular: assim foi criado o Curso de Especialização em Tradução (CETRAD). Em 1992, o CETRAD mudou de status novamente: de curso de extensão, ele ascendeu à categoria de pós-graduação lato sensu. Em razão da grande demanda pelo curso, estabeleceu-se um intercâmbio bastante produtivo entre a pós-graduação lato sensu e a 
pós-graduação stricto sensu, domínio em que a tradução esteve presente em linhas de pesquisa dos programas vinculados às diversas áreas do Departamento de Letras Modernas da USP $^{312}$. Em 1994, foi criado o CITRAT e, com ele, a revista TradTerm. No ano de 1997, outra revista dedicada aos estudos da tradução publicou seu primeiro número: a revista Cadernos de Literatura em Tradução, com o propósito de veicular traduções comentadas e artigos referentes à tradução literária.

Com isso, nota-se também o acúmulo de capital simbólico por parte da USP: além do prestígio de que a instituição desfruta como um todo, o intercâmbio do Curso de Especialização com o nível da pós-graduação stricto sensu incentivou as pesquisas, algo evidente não apenas na exploração do mapa do campo disciplinar traçado com base nos trabalhos de grau, mas também no levantamento de artigos científicos. Nesse contexto, é essencial, contudo, considerar a tendência a que apontamos anteriormente: a de pesquisadores do campo dos estudos da tradução favorecerem os periódicos publicados pela instituição a que estão vinculados. Esse mesmo fenômeno foi observado na USP, embora com menos ênfase do que o ocorrido na UFSC. Desse modo, os dados sugerem haver uma relação entre o controle dos meios de divulgação e o acúmulo de capital simbólico, uma hipótese a ser colocada à prova por investigações posteriores.

Nesse quadro, cabe ainda citar a relação da USP com a ABRAPT. Na reconstituição da história da associação, Silva, Esqueda e Campos (2017) informam-nos que, até o triênio 2005-2007, o cargo de presidente da associação foi ocupado majoritariamente por membros do corpo docente da USP: Mário Laranjeira entre 1992 e 1995, João Azenha Jr. entre 1996 e 1998, John Milton entre 1999 e 2001 e Stella E. O. Tagnin entre 2002 e 2004. Além disso, John Milton atuou mais de uma vez nesse período como organizador de eventos, em especial, do Encontro Nacional de Tradutores ${ }^{313}$. Essa relação só vem a reiterar o prestígio da instituição e consequente acúmulo de capital científico.

Logo, ainda que o controle dos meios de divulgação possam justificar, por exemplo, o volume de artigos publicados por pesquisadores da USP, apenas o acúmulo de capital científico pode explicar o montante de pesquisas defendidas na instituição nos domínios dos estudos da tradução, em tempos bastante anteriores à criação de um programa de pósgraduação próprio à área, o TRADUSP (Programa de Pós-Graduação em Estudos da Tradução da USP), iniciado em 2012.

\footnotetext{
${ }^{312}$ AZENHA JR., 2006a, p. 30.

${ }^{313}$ SILVA; ESQUEDA; CAMPOS, 2017, p. 1461 et seq.
} 
No mesmo ano de criação do PGET, o CETRAD foi extinto por uma Resolução da Reitoria da Universidade de São Paulo, que visava a encerrar todos os cursos de pósgraduação lato sensu na universidade. Azenha Jr. (2015a) relata que, com o término do CETRAD, os departamentos voltaram suas atenções para consolidar a tradução no nível da graduação. Em 2008, dois anos depois de formada a última turma do CETRAD, as habilitações de língua estrangeira passaram a oferecer a ênfase em tradução ${ }^{314}$. Só então, os olhos da instituição voltaram-se novamente à pós-graduação.

Com a primeira linha de pesquisas em tradução num programa de pós-graduação, a tradução na UNICAMP, a despeito de seu pioneirismo, perdeu espaço ao longo dos anos. Durante a década de 1980, foi sede do pós-estruturalismo no país, o paradigma no mainstream. Esse esteve centrado fortemente na figura de Rosemary Arrojo, docente da instituição entre 1984 e 2002. Com a mudança da teorizadora para a Binghamton University, nos Estados Unidos, a influência de sua líder intelectual diminuiu, o que pode ter acarretado na perda de força desse paradigma. A isso soma-se o fato de a UNICAMP não ter empreendido outros esforços em favor da tradução, como, por exemplo, a criação de um programa de pós-graduação ou de um periódico exclusivo da área. Esse talvez parece ter sido o caso na UFMG, com a migração de Else Vieira, principal representante da Antropofagia modernista em tradução, parte das abordagens pós-modernas. A esse despeito, no entanto, a UFMG não deixa de figurar dentre as instituições mais produtivas no meio, em grande medida graças aos esforços de Fabio Alves, Célia Magalhães e Adriana Pagano.

No que tange aos periódicos, o levantamento de artigos científicos apontou-nos para uma realidade curiosa. Mesmo após a criação da TradTerm e dos Cadernos de Tradução, houve ainda a organização de vários números especiais dedicados à tradução em periódicos voltados a áreas mais amplas das Letras. Entre 1992 e 2005, foram organizados, ao todo, dez números especiais, sendo apenas quatro deles números temáticos, isto é, relacionados a um tema ou a uma vertente teórica específicos no âmbito dos estudos da tradução. Assim, se os números especiais publicados entre 1986 e 1994 visavam a suprir a falta de mecanismos de divulgação teórica no campo disciplinar, há de se pensar em outras razões para que publicações dessa natureza não tenham cessado após esse período.

Algumas justificativas plausíveis são o estímulo a um campo em crescimento e o desejo de pesquisadores, vinculados a instituições que não contam com periódico próprio dedicado à tradução, de ainda assim oferecer sua contribuição com seus próprios recursos,

\footnotetext{
${ }^{314}$ AZENHA JR., 2015a, p. 43 et seq.
} 
muitas vezes como em decorrência de um evento ligado à tradução sediado naquela instituição. No entanto, não está descartada a possibilidade de que, em certa medida, essas publicações estejam relacionadas com o processo de acúmulo de capital científico, a partir da divulgação das pesquisas conduzidas nessas mesmas instituições.

A despeito do crescimento da área, decorrente desse movimento de institucionalização, os estudos da tradução ainda não foram reconhecidos como campo disciplinar nas Áreas de Conhecimento da CAPES, do CNPq e das agências de fomento estaduais. Essa falta de visibilidade traz problemas institucionais, como a falta de acesso a determinadas formas de financiamento e a falta de representação junto a essas agências, com impacto nas pesquisas. Esse, acrescido do fato de a imagem predominante de tradução nessas agências ser menos um campo de pesquisas e mais um "fazer", é um desafio a ser ainda superado no futuro do campo disciplinar.

Desse modo, passamos ao mapeamento da abordagem funcionalista no Brasil. Destacamos, em primeiro lugar, a presença dos fundadores do funcionalismo no país, seja fisicamente, seja através de publicações. Antes mesmo de haver uma vertente funcionalista, Katharina Reiss esteve aqui em duas ocasiões, divulgando as reflexões surgidas de sua experiência didática. Suas intervenções, contudo, limitaram-se à década de 1980, período em que se iniciava o crescimento do campo disciplinar no Brasil.

$\mathrm{Na}$ década seguinte, foi a vez de Hans J. Vermeer divulgar sua proposta teórica em terras brasileiras. Além das tentativas imediatas de propagar o funcionalismo, Vermeer veio em busca de parcerias com universidades brasileiras para a formação de professores de tradução. Recordamos que à época havia uma grande demanda por professores qualificados para ocupar as cadeiras de tradução das universidades. Assim, o que Vermeer oferecia poderia ser de mútuo benefício: por um lado, Heidelberg sedimentava-se na Alemanha como um importante centro de formação de tradutores, uma expertise de que professores no Brasil poderiam também se valer; por outro lado, a formação de professores poderia ser um viés de divulgação dos preceitos funcionalistas.

De fato, o viés da educação parece ter sido um importante acesso do funcionalismo entre nós. Citamos o caso do Seminar Z8, do qual participaram alguns pesquisadores brasileiros, dentre os quais João Azenha Junior. Através do evento, esses pesquisadores tomaram contato com o funcionalismo alemão, sobretudo através de Christiane Nord, antes de ela sedimentar-se como a grande divulgadora do funcionalismo em todo o mundo. 
No Brasil, Nord esteve em seis ocasiões e publicou quatro artigos, além de ministrar palestras e minicursos. Seus esforços de divulgação teórica têm como característica elucidar conceitos que, nos primeiros escritos de Vermeer e Holz-Mänttäri, parecem-nos bastante herméticos. Com isso, Nord torna-se também uma "tradutora" dos preceitos funcionalistas, bem antes de agir como tradutora de fato. Nesse ponto, referimo-nos especialmente à tradução feita por ela da obra seminal de Katharina Reiss e Hans Vermeer (2014), bem como a tradução de sua própria obra seminal para o espanhol (2012b) e a sua participação na tradução da mesma obra para o português (2016a).

Os funcionalistas atuaram como instâncias replicadoras dos memes funcionalistas, engajando-se na divulgação da abordagem teórica. A despeito disso, o estudo bibliométrico com base nos artigos acadêmicos demonstrou que, passada a primeira onda de divulgação teórica, não houve a ação de continuidade desse movimento, como fica evidente através da queda proporcional do volume de publicações com base funcionalista nos primeiros anos do século XXI.

Podemos refletir acerca de algumas razões prováveis para isso. A primeira delas diz respeito à dinâmica das abordagens teóricas no campo. No momento de ingresso do funcionalismo no Brasil, o campo estava sobre a influência do pós-estruturalismo, que guarda alguns pontos de contato com a abordagem funcional. Assim, o funcionalismo teria disputado espaço com um importante opositor. Observa-se que houve, da parte de Vermeer, uma tentativa de estabelecer um diálogo entre as duas vertentes, de modo a firmar cooperação no âmbito dos estudos da tradução no Brasil.

Outro provável motivo diz respeito à língua. Ainda que as publicações dos autores dos textos seminais no Brasil tenham sido feitas em idiomas mais acessíveis a nós, tais como o espanhol e o inglês, os textos seminais em si por muito tempo estiveram, de modo predominante, em língua alemã. Um indício que sustenta a nossa hipótese está no fato de que, dentre os textos escritos por esses autores, os dois mais citados por pesquisadores brasileiros - coincidentemente, ambos de autoria de Christiane Nord - consistem numa tradução e numa obra introdutória, as duas em língua inglesa. A língua - e a proximidade com a cultura alemã - pode também ser um dos motivos para as visitas mais frequentes desses autores, com a exceção de Vermeer, aos estados do sul brasileiro.

Além das justificativas supracitadas, é ainda possível que a recepção morna do funcionalismo nos primeiros anos de divulgação teórica em terras brasileiras se deva à referida inclinação de pesquisadores a temas relacionados com a tradução literária. É sabido que, ao 
menos internacionalmente, o emprego do funcionalismo em pesquisas ligadas à tradução do texto literário é visto com desconfiança, dada a crença de que os preceitos da teoria não seriam adequados para contemplar a complexidade envolvida nessa forma artística do traduzir.

Assim, a extensão do levantamento bibliográfico proveu-nos com novas informações. Conforme esperado, os dois principais pólos de pesquisa em tradução no país, ao menos no que se refere ao volume de produção intelectual na área - a UFSC e a USP - são também as duas instituições que mais reúnem artigos amparados pelo funcionalismo. Com essa afirmação, reconhecemos a possibilidade de os dados terem sido influenciados pela dominância dos periódicos de ambas as instituições, possibilidade essa mitigada pela inclusão de outros periódicos, organizados por outras universidades, e destacamos a necessidade de pesquisas futuras para confirmar ou refutar essa declaração.

No que concerne aos autores e às obras mais citadas por esses trabalhos, constatamos, igualmente em conformidade com as expectativas, que os escritos de Christiane Nord foram a principal fonte para os preceitos funcionalistas. Dentre os autores brasileiros, destacam-se João Azenha Jr. (USP) e Meta Elisabeth Zipser (UFSC).

Além de seu papel indiscutível no desenvolvimento dos estudos da tradução, conforme salientado em diversas passagens do presente capítulo, Azenha Jr. foi pioneiro no emprego do funcionalismo como anteparo teórico de uma pesquisa científica no país. Dessa forma, ele também foi um dos primeiros pesquisadores brasileiros a atuar como divulgador da abordagem teórica, seja através de uma exposição detalhada dos preceitos funcionalistas em sua tese, seja através da produção de artigos e conferências que fazem uso dessa vertente teórica - ele é o segundo pesquisador brasileiro funcionalista mais produtivo de nosso levantamento -, seja ainda através da orientação de trabalhos. Como exemplos de trabalhos orientados por Azenha Jr. sob o viés funcionalista, mencionamos as dissertações de Mestrado de Scheffelmeier (2001), Mundt (2001) e Moreira (2014) e a tese de Doutorado de Zipser (2002).

De fato, a tese de Zipser despontou como o trabalho de grau produzido no Brasil mais citado em nosso levantamento, o que faz dela uma importante referência funcionalista no país. Além das publicações, a docente da UFSC também estimula a produção intelectual através das atividades de pesquisa conduzidas no âmbito do grupo de pesquisa Tradução e Cultura (TRAC), sob sua coordenação. O grupo visa a abordar temas localizados na fronteira entre a tradução e outros campos do saber, tais como o jornalismo, o ensino e a hi- 
permídia, e fundamenta-se, conforme declaram Zipser, Costa e Soares (2016), na teoria do skopos de Vermeer e, principalmente, nas propostas teóricas de $\operatorname{Nord}^{315}$. Além disso, ela também orienta trabalhos respaldados pelo funcionalismo - os trabalhos de Almeida (2005), Polchlopek (2011b) e Laiño (2014), apenas para citar alguns exemplos - e, mais recentemente, coordenou a referida tradução da obra seminal de Nord (1988) para o português brasileiro.

Em que pese o fato de o maior volume de artigos fundados no funcionalismo ter sido escrito por pesquisadores da UFSC e da USP, o estudo bibliométrico trouxe indicações de que há, também aqui, um processo de descentralização em movimento. Além de Azenha Jr. e Zipser acima mencionados, Silvana A. Polchlopek (UFTPR), Sinara de Oliveira Branco (UFCG), Elisângela Liberatti (UFSC), Valdecy de Oliveira Pontes (UFC), Livya Lea Pereira (UFC) e Michele de Abreu Aio (UFSC) figuram dentre os autores mais produtivos no âmbito da abordagem funcional no Brasil. Observa-se que, dentre eles, há três que estão vinculados a outras universidades, o que parece sugerir que há projetos de pesquisa amparados pelo funcionalismo em desenvolvimento nessas instituições.

Por outro lado, é importante enfatizar que, dentre os autores acima, mesmo aqueles com vínculos com outras universidades tiveram passagem pela UFSC: como vimos, Polchlopek defendeu a tese de Doutorado na instituição, sob a orientação de Zipser; Branco também defendeu o Doutorado na universidade, valendo-se do funcionalismo nordiano; Valdecy Pontes fez seu pós-doutorado na UFSC e Livya Pereira, que foi orientanda de Pontes, cursa atualmente o Doutorado na instituição. Desse modo, podemos pensar na UFSC como um centro de irradiação de pesquisas de natureza funcionalista.

Desse modo, vemos Azenha Jr. e Zipser atuando como agentes difusores da abordagem teórica. Eles atuam como agentes replicadores dos memes funcionalistas, garantindo a permanência deles no pool de memes de tradução no país. Com a migração de Polchlopek, Branco e Pontes para outras instituições, é possível que eles também divulguem o funcionalismo em novos projetos. Com isso, a vertente espalha-se para novas localidades, podendo lá fomentar novas investigações. Os desdobramentos desse movimento de descentralização, no entanto, só poderão ser avaliados no futuro.

\footnotetext{
${ }^{315}$ COSTA; ZIPSER; SOARES, 2016, p. 10.
} 
3.

Os conceitos funcionalistas

de tradução 
A análise conduzida no capítulo precedente forneceu-nos alguns indícios acerca de como foi o movimento de ingresso e expansão do funcionalismo nos estudos da tradução no Brasil. Vimos que houve dos funcionalistas alemães os esforços de divulgar o funcionalismo entre nós através da presença em grandes congressos e seminários ligados aos estudos da tradução. O efeito, contudo, foi aquém do pretendido e a vertente teórica tardou a servir de base para um corpo considerável de trabalhos.

No entanto, a atuação de pesquisadores brasileiros como difusores da teoria para a abordagem funcionalista não deve ser desprezada. De fato, ela foi fundamental para iniciar o processo de sedimentação da presença funcionalista nas universidades brasileiras. Como fonte de fundamentação teórica, a pesquisa bibliométrica aponta os trabalhos de grau de João Azenha Júnior e Meta Elisabeth Zipser como especialmente influentes. Além disso, também baseado na análise de autores, parece haver a formação de diferentes grupos funcionalistas em torno de questões específicas da tradução: em torno de Meta Elisabeth Zipser, na Universidade Federal de Santa Catarina (UFSC), a pesquisa envolvendo temas na fronteira entre tradução e jornalismo, tradução e ensino e tradução e hipermídia; em torno de Sinara de Oliveira Branco, na Universidade Federal de Campina Grande (UFCG) e de Valdecy de Oliveira Pontes, na Universidade Federal do Ceará (UFC), a pesquisa acerca do emprego de traduções no ensino de língua estrangeira. A comprovação dessas tendências, no entanto, requereria uma pesquisa mais alongada, que contemple outras fontes como anais de congressos, livros publicados e até mesmo uma pesquisa mais profunda nos bancos de teses e dissertações das instituições de ensino superior brasileiras.

A pesquisa bibliométrica também apontou alguns indícios acerca das áreas de aplicação mais frequente da teoria funcionalista. Destacam-se, como vimos, as pesquisas dedicadas à tradução literária, à tradução técnica, à tradução de quadrinhos e ao ensino de línguas estrangeiras mediante exercícios de tradução. As publicações voltadas à tradução literária, contudo, parecem menos obra de um estudo sistemático de grau e mais um exercício de pesquisa, visto que a eles não encontramos dissertações ou teses que expandissem o apresentado nos artigos, ou ao menos que o fizessem fundamentados pelos conceitos funcionalistas.

A partir dos resultados obtidos pela análise externalista, definimos um dos corpora de análise do capítulo presente. Trata-se de um corpus de trabalhos de grau defendidos em instituições brasileiras de ensino superior que explorassem as áreas de aplicação da teoria mais frequentes, com a exceção da tradução literária. Esses trabalhos também destacaram- 
se em nossa pesquisa bibliométrica, recebendo, assim, a validação de seus pares. Ainda que a tradução de textos jornalísticos não despontasse como um tema especialmente frequente, a tese de Zipser revelou-se uma importante fonte de consulta, sendo um dos trabalhos em português brasileiro sobre o funcionalismo mais citados de nosso corpus de artigos acadêmicos. Desse modo, nada mais justo do que incluí-la.

O objetivo da seguinte análise é identificar quais conceitos funcionalistas foram considerados mais relevantes para os pesquisadores no Brasil em suas áreas de aplicação, bem como de que modo esses conceitos foram incorporados, isto é, se, ao aplicar esses conceitos em suas pesquisas, os acadêmicos brasileiros teriam expandido-os ou transformado-os. Logo, nada mais elementar do que comparar as definições dos conceitos com sua origem, a saber, as definições fornecidas pelos próprios pioneiros do funcionalismo alemão. Com isso, nosso primeiro corpus é composto por textos seminais dos funcionalistas (C1).

A análise de cada texto é precedida de um histórico dele e de seu autor ou de sua autora. Como vimos, os conceitos selecionados para exame foram escolhidos a partir de procedimentos da linguística de corpus, discriminados nesse processo como conceitoschave (ou "supermemes"). Trata-se dos conceitos de "tradução", "função", "texto", "língua", "tradutor", "situação", "informação" e "fatores". Após a primeira análise, é feita uma síntese, apontando-se elementos convergentes e divergentes na definição desses conceitos nesses textos seminais. Em seguida, os mesmos conceitos são analisados segundo sua definição nos trabalhos de grau brasileiros, ou seja, segundo os componentes do segundo corpus (C2). A síntese descreve convergências e divergências entre as definições dentro do próprio corpus e na comparação com $\mathrm{C} 1$.

\subsection{Os textos seminais funcionalistas (C1)}

\subsubsection{Katharina Reiss: por uma crítica de tradução}

No capítulo introdutório tratamos, ainda que sem muitas pormenorizações, do estado da Ciência da Tradução (al. Übersetzungswissenschaft) no momento de emergência do Funcionalismo, com especial consideração ao fato de seu desenvolvimento ter sido dissociado da prática tradutória. Mencionamos também como essa segregação entre teoria e 
prática agravou a debilitada estrutura de formação de tradutores e intérpretes, sobretudo pela falta de parâmetros objetivos para orientar os exercícios e as avaliações dos alunos.

Alguns dos primeiros esforços da tradutologia moderna para mitigar esse problema vieram de Katharina Reiss. Para alguns, dentre os quais Hans Vermeer (1993), o nome de Reiss está associado a contribuições pioneiras bastante significativas para a área, algumas até mesmo consideradas marcos dos estudos da tradução de língua alemã ${ }^{316}$. Nascida em 1923 em Reinhausen, hoje distrito da cidade de Duisburg, oeste da Alemanha, formou-se em Língua Espanhola pela Universidade de Heidelberg em 1944. Tão logo completou seus estudos, iniciou sua atividade docente, uma vez que, com o final da Segunda Guerra Mundial se aproximando, os docentes espanhóis retornaram à terra natal. Ela exerceu a função de professora assistente até março de 1945, quando o Instituto de Tradução e Interpretação da universidade fechou em decorrência do final da guerra. Ela retornou à função em 1946, responsável pelas aulas de gramática do espanhol, cultura espanhola e tradução. Reiss (2004) relata que durante sua graduação, a tradução sempre fora objeto de fascinação e interesse, mas também de consternação, especialmente no que tange a críticas de tradução feitas sem base em fundamentos ou justificativas. Nesse contexto, a atividade docente serviu de ensejo para aprofundar suas reflexões ${ }^{317}$.

Entretanto, sua experiência prática com a tradução veio apenas após o doutorado, com a tradução de textos do espanhol, dentre os quais está a já mencionada tradução da obra seminal de José Ortega y Gasset, "Miseria y esplendor de la traducción", para o alemão. Essas experiências forneceriam posteriormente material para as suas reflexões teóricas. Quanto a isso, Reiss afirma:

As experiências obtidas por meio de uma prática própria de tradução são, a meu ver, imprescindíveis para quem queira se ocupar com a teoria do traduzir - até para que se previna de construir "castelos de vento" teóricos. Junto com a experiência adquirida com a prática da tradução, a prática docente deu então o impulso determinante para a sistematização de questões teóricas ${ }^{318}$. (REISS, 2004, p. 274.)

Durante os anos à frente do Departamento de Espanhol da Universidade de Heidelberg, Reiss ocupou-se de questões referentes justamente à crítica tradutória. Christiane

\footnotetext{
${ }^{316}$ VERMEER, 1993, p. 11.

${ }^{317}$ REISS, 2004, p. 273.

${ }^{318}$ Die bei eigener Übersetzungspraxis gemachten Erfahrungen sind m.E. unverzichtbar für jeden, der sich mit der Theorie des Übersetzens befassen will - schon damit er davor bewahrt wird, theoretische „Luftschlösser" zu bauen. Neben der aus der Übersetzungspraxis gewonnenen Erfahrung gab dann den entscheidenden Anstoß zur systematischen Befassung mit theoretischen Fragen die Unterrichtspraxis.
} 
Nord (2004), que foi sua aluna, rememora que Reiss costumava dar ênfase a critérios ainda pouco convencionais à crítica de tradução, tais como o "sentimento linguístico" (al. Sprachgefühl), a estilística comparada e a relação com a situação e com o tempo de produção ${ }^{319}$.

O livro Möglichkeiten und Grenzen der Übersetzungswissenschaft [Possibilidades e limites da crítica tradutória] começou a ser formulado paralelamente à docência, desde 1965, baseando-se justamente em sua atividade docente. Sua publicação, em 1971, foi um marco na história das teorias e do ensino de tradução no mundo de expressão alemã, dada a escassez de materiais teóricos apropriados à formação de tradutores. A esse respeito, Kupsch-Losereit conta-nos que tomou conhecimento da obra por uma colega de Germersheim. Segundo relata, os determinantes extralinguísticos e a importância deles para a tradução foram-lhe "quase um choque pragmático" (KUPSCH-LOSEREIT, 2004, p. 217), tornando-se a obra, assim, base para as suas aulas.

Reiss (1971) inicia o livro com uma reflexão do papel da tradução em sua época. Ela descreve o momento histórico como um período em que a diplomacia e o intercâmbio entre os povos ganham cada vez mais peso, assim como a tradução, via de comunicação entre culturas diferentes. Consequentemente, cresceria também a exigência por traduções melhores, o que demandaria o desenvolvimento de uma crítica de tradução pautada por critérios de avaliação objetivos. O propósito de seu trabalho é, portanto, elaborar critérios objetivos e categorias apropriadas à avaliação de todos os tipos de tradução ${ }^{320}$.

Contudo, Katharina Reiss alerta à necessidade de se observarem as características próprias aos diferentes tipos textuais e de se adequar a crítica a elas, pois, a seu ver, não seria possível adotar medidas iguais a tipos de textos diferentes. Dessa forma, ela busca elaborar um modelo ao mesmo tempo abrangente o bastante para incluir todos os tipos textuais, mas detalhado o suficiente para torná-lo praticável $^{321}$. Sua busca passa pela sistematização de uma tipologia textual que agrupa gêneros textuais com características semelhantes e pelo levantamento das estratégias tradutórias mais condizentes com os propósitos comunicativos de cada tipo de texto.

Em seu tempo, os critérios objetivos para uma crítica de tradução ainda não haviam sido, segundo Reiss, suficientemente identificados, justificados e descritos sistematicamente, encontrando-se ainda diluídos entre critérios subjetivos. Por outro lado, a falta de crité-

\footnotetext{
${ }^{319}$ NORD, 2004, p. 253.

${ }^{320}$ REISS, 1971, p. 7.

${ }^{321}$ Ibid., p. 8.
} 
rios para a crítica ainda estaria ligada a outro problema dessa época: a falta de uma noção mais precisa das possibilidades e dos limites da tradução e, em última medida, a falta mesma de uma teoria geral de tradução. Uma tentativa de formular uma teoria geral de tradução seria feita posteriormente por Hans Vermeer.

É imprescindível notar que, ao abordar a crítica de tradução, a autora não poderia se esquivar de tratar também da tradução em si. Assim, percebe-se que a descrição de seu modelo de crítica tradutória também dá indícios da própria concepção que Reiss tem da tradução, que tentaremos elucidar a seguir.

\subsubsection{Análise}

Katharina Reiss define TRADUÇÃO como um processo de mediação entre dois polos, culminando na formulação de um texto escrito na língua de chegada (LC) constituído, por sua vez, da relação com um texto escrito na língua de partida (LP):

[45-46] Jeder Übersetzungsprozess ist ein bipolarer Vorgang, der sich in der Gestaltung eines zielsprachlichen Textes unter ständiger Rückbindung an einen ausgangssprachlichen Text erfüllt. Dabei muss der Übersetzer sich ständig bemühen, optimale Äquivalenzen in der Zielsprache zu finden und sich ebenso konsequent am ausgangssprachlichen Text orientieren, um sich der Adäquatheit dieser Äquivalenzen zu versichern. Soll dann das Resultat dieses Prozesses, die konkret vorliegende Übersetzung beurteilt werden, so bedarf es dazu objektiver und sachgerechter Kriterien ${ }^{322}$.

[Toda tradução é um processo bipolar que se concretiza na construção de um texto na língua de chegada sob a constante restrição por parte de um texto na lingua de partida. Nesse processo, o tradutor deve empenhar-se continuamente a encontrar equivalências ideais na língua de chegada e também orientar-se, sem se desviar, pelo texto em língua de partida, a fim de assegurar a adequação dessas equivalências. Para avaliar o resultado desse processo, a tradução concreta, são necessários critérios especificos e objetivos.]

O processo tradutório, como fica evidente na definição acima, teria fortes vínculos com as noções de equivalência e adequação, estando amparado na escolha de equivalentes na LC dos elementos textuais do texto de partida (TP). Nesse contexto, o tradutor teria o com-

${ }^{322}$ REISS, 1971, p. 11s.

[N. do A.: os números em colchetes fazem referência às linhas de concordância em que os termos, destacados em negrito, ocorrem. O negrito, portanto, é nosso.] 
promisso de assegurar a adequação de suas escolhas, a fim de obter uma representação do texto de LP na LC, sem exclusões, adições ou distorções em relação ao texto original.

Nota-se que, enquanto produto, a tradução é concebida como um texto derivado de outro, não podendo a crítica tradutória esquivar-se do cotejamento da tradução com o seu correlato na LP. Nesse ponto, Reiss censura a postura de críticos que avaliam a obra traduzida como um texto original e autônomo, sem consulta à obra de que teve origem. A seu ver, apenas através da comparação entre os textos é possível avaliar se o tradutor se submete às intenções comunicativas do autor. Nesse sentido, uma crítica negativa a um texto traduzido deveria ser embasada por sugestões, da parte do crítico, de soluções mais de acordo com o objetivo da comunicação.

Estabelecer um contraponto do texto de LP na LC, no entanto, demandaria um proceder diferente para diferentes tipos de texto. TEXTOS são aqui definidos como conteúdos numa determinada forma linguística. Nesse sentido, a substância a dar materialidade aos textos seria a LíNGUA, um conceito, na presente proposição teórica, compreendido segundo a definição formulada por Karl Bühler (1879-1963). Com vistas a elucidar o "evento linguístico concreto", o psicólogo, filósofo e linguista alemão examina as relações do signo linguístico com o emissor, com o receptor e com os objetos ou constelações de fatos do mundo no processo comunicativo. A partir da relação do signo linguístico a cada uma dessas instâncias, Bühler distingue uma função da linguagem correspondente: da propriedade do signo linguístico de se relacionar com os objetos e fatos da realidade originar-se-ia sua função de representação (al. Darstellung); da propriedade do signo linguístico de expressar a "interioridade do emissor" teria origem a sua função de expressão (al. Ausdruck); por fim, da propriedade do signo linguístico de desencadear uma ação sobre o receptor viria sua função de apelo (al. Appell).

Reiss argumenta que as mesmas FUNÇÕES desempenhadas pela língua no nível microestrutural podem também ser observadas no nível macroestrutural, isto é, no nível do texto:

[3-6] Bei der Analyse muss, da jeder Text nur mit dem Mittel der Sprache zustande kommt (für mathematische Formeln etwa erübrigt sich eine Übersetzung), untersucht werden, welche Funktion die Sprache im vorliegenden Text jeweils ausübt. Nach Karl Bühler ist Sprache gleichzeitig Darstellung, Ausdruck und Appell. Nun brauchen diese drei Funktionen nicht in jeder sprachlichen Äußerung qualitativ gleichrangig zu sein. In dem einen Text (oder Textabschnitt) mag die Darstellung überwiegen, der andere lebt von der Ausdrucksfunktion, wieder ein anderer ist vom Wesen her Appell an den Hörer oder Leser. Selbstverständlich wird nicht immer ein ganzer Text ausschließlich nur eine der Funktionen 
der Sprache widerspiegeln. In der Praxis gibt es zahllose Überschneidungen und Mischformen. (...) ${ }^{323}$.

[Visto que todo texto se realiza apenas com os recursos da língua (embora fórmulas matemáticas possam dispensar tradução), na análise é necessário examinar quais funções a língua exerce em cada texto. Segundo Karl Bühler, a língua é ao mesmo tempo representação, expressão e apelo. Essas três funções não precisam estar representadas de forma qualitativamente igual em cada expressão linguistica. Assim, num texto (ou em segmentos de texto) pode prevalecer a representação, noutro a função expressiva pode ser essencial, e outro ainda pode ser, em sua essência, um apelo a ouvintes ou leitores. É óbvio que nem sempre um texto inteiro refletirá exclusivamente apenas uma das funções da língua. Na prática há inúmeras sobreposições e formas mistas. (...)]

Desse modo, Reiss considera que as características essenciais de um texto derivam de sua função textual predominante. Por conseguinte, a tradução de um texto deveria servir à preservação dessas características essenciais. A função do texto passa, assim, a ser vista como principal diretriz no estabelecimento de critérios do processo tradutório e de crítica do texto traduzido. Para se chegar então a esse texto seria necessário, em primeiro lugar, determinar o tipo textual a que o original pertence. Com base nas funções da linguagem descritas por Bühler, Reiss discrimina três tipos textuais:

[3-6] (...) Doch lässt sich je nach dem Übergewicht der einen oder anderen Funktion der Sprache in einem gegebenen Text bereits eine Unterscheidung von drei Grundtypen rechtfertigen: der Darstellungsfunktion der Sprache gemäß - inhaltsbetonte Texte; der Ausdrucksfunktion entsprechend - formbetonte Texte; und der Appellfunktion zufolge - appellbetonte Texte. Dabei sind unter inhaltsbetonten Texten jene zu verstehen, die das Hauptgewicht auf die Vermittlung von Inhalten, von Informationen legen. Formbetonte Texte dagegen vermitteln zwar auch Inhalt, aber, die sprachliche Form, in der dies geschieht, ist die dominierende Komponente des Textes ${ }^{324}$.

[(...) Contudo, conforme o predomínio de uma ou outra função da língua num dado texto, já se pode justificar uma distinção de três tipos textuais fundamentais: textos conformes à função de representação da língua: textos com ênfase no conteúdo; textos correspondentes à função de expressão: textos com ênfase na forma; e textos correspondentes à função de apelo: textos com ênfase no apelo. Nesse contexto, podem-se entender textos com ênfase no conteúdo como aqueles cujo peso está na veiculação de conteúdos e de informações. Nos textos com ênfase na forma, por outro lado, ainda que também veiculem conteúdo, a forma linguística por meio do que isso ocorre é o componente dominante.]

Como vimos, todo texto transmite uma informação numa determinada forma linguística, compreendendo-se INFORMAÇÃO apenas como o conteúdo semântico de um texto. Informação e forma seriam, assim, fatores constituintes desse texto. No entanto, para a

\footnotetext{
${ }^{323}$ REISS, 1971, p. 32.
}

${ }^{324}$ Ibid. 
tradução não bastaria apenas distinguir entre as dimensões lógica e estética da linguagem. Restringir a discussão à distinção entre essas duas dimensões faria com que se negligenciasse a dimensão dialógica, referente aos interlocutores do processo comunicativo. A essa terceira dimensão estariam ligadas mais intimamente as funções expressiva e apelativa da linguagem e, por extensão, do texto.

O protótipo do texto com ênfase no conteúdo semântico é, na presente formulação teórica, o texto técnico. Em traduções desse tipo textual, o objetivo fundamental seria a equivalência de informação, sua correção e sua integridade. Entretanto, nem sempre correção significa a correspondência com a realidade: na tradução de textos literários, essa correspondência é suspensa. De fato, em textos com ênfase na forma, como costumam ser os textos literários, a invariância da informação teria papel secundário, se comparada com o que ocorre com a construção estética. Grosso modo, enquanto em textos com ênfase no conteúdo a transmissão de informações deveria estar em conformidade com as normas e convenções da LC, nos textos com ênfase na forma as normas seriam ditadas pela LP. Em textos com ênfase no apelo, em muitos casos nem ao menos seria exigida a invariância de informação, desde que se atinja a um efeito comunicativo análogo.

Em seu horizonte de reflexões, Reiss inclui ainda textos compostos de uma forma predominantemente verbal, mas que recebem o auxílio de um meio não verbal para chegar a um receptor. Esse tipo textual, de caráter híbrido, recebe a denominação de textos áudiomidiáticos (al. audiomediale Texte). Ela observa que, embora o componente não verbal seja também constituinte de significado, apenas o componente verbal é passível de tradução. Visto que o que difere textos áudio-midiáticos dos demais tipos textuais é a presença de recursos não verbais na construção de sentido do texto, e não propriamente a função textual, um texto áudio-midiático poderia também se enquadrar em outras classificações da tipologia textual.

Considerando que cada tipo textual pode dar ensejo a problemas de tradução distintos, Reiss faz menção às competências exigidas dos tradutores no ato de tradução desses diferentes tipos textuais. Segundo explica, por um lado, o tradutor literário deveria dispor de talento artístico, posto que a tradução literária, em vez da mera comunicação, promove a transmissão de valores estéticos. Por outro lado, é exigido do tradutor técnico não apenas o domínio da terminologia do respectivo campo de especialidade, mas também os conhecimentos técnicos exigidos para a compreensão do texto. 
Nesse ponto, é importante destacar que, por mais que advogue a favor da equivalência, Reiss reconhece ser impossível preservar na tradução todos os elementos do texto na LP e, conforme argumenta, está justamente aí a importância da tipologia textual: ao identificar o tipo textual a que o texto na LP pertence, seria também possível detectar o que lhe é essencial. A tradução seria assim um compromisso a ser cumprido com ponderação plena, a partir do constante exercício de identificar o que é crucial e distingui-lo do que pode ser "sacrificado", isto é, de avaliar o que é mais e o que é menos relevante à tradução e em que aspectos a equivalência de um elemento pode ser privilegiada em detrimento de outros.

A defesa da equivalência na tradução repousa sobre a noção de equivalência entre as línguas. Na concepção de língua da autora, a tradução só seria possível graças ao fato de haver equivalência entre as línguas naturais no nível da langue. Caberia ao tradutor, assim, encontrar os equivalentes ideais, no nível da parole, entre diversos equivalentes potenciais no nível da langue. Para tanto, segundo a teorizadora, o tradutor deve recorrer a FATORES decorrentes do contexto textual ou "linguístico", pois as palavras adquirem significado em contexto. A esses fatores, Reiss atribui a denominação de "instruções intralinguísticas" (al. innensprachliche Instruktionen) e distingue quatro diferentes tipos de instruções:

- Instruções semânticas: dizem respeito ao significado denotativo de palavras e expressões. Nos casos em que se busca a equivalência de conteúdo, seria preciso avaliar o significado das palavras em seu contexto linguístico - tanto em seu microcontexto, isto é, em sua relação com as palavras imediatamente vizinhas, não ultrapassando o nível da frase, quanto em seu macrocontexto, em sua relação com o texto todo.

- Instruções lexicais: referem-se ao significado conotativo de palavras e expressões, assim como às diferenças de significação na LP e na LC. Embora defenda a equivalência entre as línguas, Reiss reconhece não haver equivalência lexical plena, o que impede o espelhamento lexical no processo tradutório. Assim, seria necessária atenção a problemas relacionados com terminologias, metáforas, homônimos, palavras de difícil tradução, jogos de palavras, etc., visando menos à equivalência lexical e mais à sua adequação. Em certa medida, a escolha deveria orientar-se por exigências do próprio tipo textual: problemas relacionados a metáforas, por exemplo, 
exigiriam ocasionalmente soluções diferentes em textos com ênfase no conteúdo e em textos com ênfase na forma.

- Instruções gramaticais: relativas às diferenças estruturais entre as línguas. Salvo os casos em que questões ligadas ao tipo textual ou à situação exigem o contrário, procurar-se-ia sempre na tradução a correção gramatical segundo as normas da LC e a adequação aos aspectos estilísticos e semânticos relevantes da estrutura gramatical da LP.

- Instruções estilísticas: relacionadas com a correspondência entre o estilo do texto original e o estilo da tradução. Na decisão acerca do estilo textual, no tipo de linguagem a ser adotado, pesaria sobremodo o tipo textual: a recriação do estilo do autor do texto na LP seria exigida em especial de textos cuja ênfase está na forma e no apelo, ao passo que textos jurídicos e científicos, por exemplo, teriam suas próprias normas de estilo em cada língua.

As escolhas tradutórias, entretanto, não se limitariam aos fatores internos do texto. Como bem observa Reiss, a decisão sobre equivalentes ideais na LC não deve prescindir de considerar os "determinantes extralinguísticos", definidos como "fatores extralinguísticos que levam o autor de um texto a fazer uma determinada escolha dentre os recursos postos à disposição por sua língua materna, a fim de se fazer entender a seu ouvinte ou leitor [...]" (REISS, 1971, p. 69s.). Esses fatores estão essencialmente ligados à situação comunicativa na qual ocorre a tradução.

Em busca de definições para o conceito de SITUAÇÃO, Reiss recorre aos escritos de Eugene A. Nida e de Georges Mounin. Nida reuniria no conceito de situação tanto o contexto comunicativo, isto é, as circunstâncias em torno da comunicação original, incluindo questões relativas ao tempo, autor, público e objetivo, quanto o contexto cultural da língua de $\operatorname{partida}^{325}$. Mounin, por sua vez, compreenderia situação como todas as informações geográficas, históricas e culturais que, embora nem sempre estejam explícitas no texto, são de suma importância à sua tradução ${ }^{326}$. Para Reiss, essas definições não são o bastante para a tradução e a crítica tradutória:

[16-19] (...) Gemessen an der Komplexität der Sachlage erscheint diese sprachwissenschaftliche Auffächerung der „Situation" nach geografischen, histori-

\footnotetext{
${ }^{325}$ NIDA, Eugene A. Towards a Science of Translating. p. 243. Cf. REISS, 1971, p. 70.

${ }^{326}$ MOUNIN, Georges. Die Übersetzung. p. 120. Cf. REISS, op. cit., p. 71.
} 
schen, sozialen und kulturellen Angaben für die Belange des Übersetzens und der Übersetzungskritik allerdings noch zu pauschal. Es sei daher versucht, das bisherige Verständnis des Situationskontextes, wie es bei Nida und Mounin vorliegt, zu differenzieren und zu vervollständigen. $\mathrm{Zu}$ diesem Zweck unterscheiden wir als außersprachliche Determinanten: den engeren Situationsbezug, den Sachbezug, den Zeitbezug, den Ortsbezug, den Empfängerbezug, die Sprecherabhängigkeit und die affektiven Implikationen, deren Relevanz für den Übersetzungsprozess und die Übersetzungskritik im folgenden zu prüfen sein wird $^{327}$.

[Contudo, tendo em vista sua complexidade, essa descrição, a partir da linguística, dos fatores que compõem a "situação" segundo aspectos geográficos, históricos, sociais e culturais parece ainda genérica demais para os interesses da tradução e da crítica tradutória. Tentamos, assim, diferenciar e completar o entendimento até então do contexto situacional como representados por Nida e Mounin. Para esse propósito, distinguimos como determinantes extralinguísticos a situação imediata, a relação com o objeto, a relação com o tempo, a relação com o lugar, a relação com o receptor, a dependência do falante e as implicações afetivas, cuja relevância para o processo de tradução e para a crítica tradutória deverá ser comprovada a seguir.]

Segue abaixo uma descrição mais detalhada de cada tipo de determinante extralinguístico:

- A situação imediata: refere-se a elementos constituintes da ação descrita no texto, que evocam situações enfrentadas (ou ao menos imaginadas) pelo leitor. Dado esse vínculo com a realidade, o autor poderia deixar lacunas no texto facilmente preenchidas pelo conhecimento do leitor de determinadas situações. No caso da tradução, seria necessário que o tradutor estivesse em condição de se imaginar na mesma situação para, apenas então, ele encontrar o equivalente ideal na LC.

- O objeto do texto: diz respeito aos conhecimentos específicos do tradutor (e do público específico para o qual se traduz) sobre o tema abordado no texto, isto é, a sua área de domínio, o que seria relevante principalmente na tradução técnica. Os determinantes referentes ao objeto do texto influenciariam sobretudo na escolha lexical.

- O tempo: especialmente marcante na tradução de textos antigos, a relação entre texto e tempo diz respeito não apenas ao objeto representado, mas até mesmo à língua. Como um organismo vivo, a língua traria marcas de seu próprio tempo, exigindo do tradutor a adoção de uma postura específica para lidar com as diferenças linguísticas e culturais entre o tempo de produção de um texto e o de sua tradução.

\footnotetext{
${ }^{327}$ REISS, 1971, p. 71.
} 
- O espaço: questões associadas ao espaço dizem respeito às diferenças entre culturas, costumes ou elementos do sistema social e da realidade dos diferentes povos. Quando há um determinante dessa natureza manifesto no texto na LP que não encontra correspondente na LC, temos, de fato, um problema de tradução. No entanto, segundo Reiss, a escolha de um método para contornar esse problema depende, acima de tudo, do tipo textual.

- O receptor: consideram-se determinantes referentes ao receptor do texto na LP, não ao receptor da tradução. Considerando-se que é para esse público que o autor do texto escreve, os determinantes referentes ao receptor manifestar-se-iam no texto através de expressões idiomáticas, citações, provérbios, coloquialismos, metáforas, entre outros elementos textuais reconhecíveis para esse público. No processo tradutório, cumpriria o tradutor ter o seu próprio público em mente, adaptando as formas da LP em conformidade com os usos dos receptores da LC.

- O falante/autor do texto: trata-se de determinantes referentes à história do autor e ao contexto em que vive, os quais têm influência sobre seu estilo. Em geral, consistiriam em fatores extralinguísticos como a origem do autor, o tempo histórico em que viveu, sua formação, sua filiação a uma escola literária, etc. Reflexos desses determinantes no texto seriam observáveis principalmente no léxico, na sintaxe e no estilo.

- As implicações afetivas: são, segundo a autora, aspectos ligados à afetividade dos falantes na língua. Dizem respeito ao uso da língua para expressar humor ou ironia, sarcasmo ou desprezo, irritação ou ênfase. São considerados determinantes extralinguísticos, uma vez que as instruções linguísticas não bastariam para elucidar a implicação afetiva por trás do texto, sendo assim necessário recorrer ao contexto da situação. Reiss entende que são nas implicações afetivas que ficam mais evidentes os limites da crítica de tradução.

Nota-se que, em todos eles, além das influências da situação comunicativa, há de se considerar também a influência da mudança de cultura sobre o texto. Desse modo, é imprescindível que o tradutor contemple em sua formação, além da aquisição de competências linguísticas, também a aquisição de competências culturais. Nota-se aqui que, embora Reiss reconheça a influência da cultura sobre o texto, ela nada diz sobre a influência cultural sobre a língua, algo que será determinante posteriormente na Skopostheorie. Os 
três critérios de análise - tipo textual, instruções intralinguísticas e determinantes extralinguísticos - interfeririam, todos eles, na concepção do texto; ao mesmo tempo, o texto refletiria todos esses elementos.

É necessário ainda acrescentar à equação a figura do TRADUTOR. Conforme observa Reiss, a recepção de um texto constitui um processo hermenêutico, através de que o receptor constrói o sentido textual. Quando esse receptor é o tradutor, o processo hermenêutico incluiria reflexões acerca de soluções para possíveis problemas de tradução. No entanto, como todo processo interpretativo, a construção de sentido sofreria a interferência de fatores subjetivos, ligados à própria pessoa do tradutor. Dentre esses fatores estariam suas competências linguísticas e culturais, sua história de vida, seu conhecimento de mundo e a familiaridade com o tipo textual. Com base em sua interpretação dos elementos de um texto na LP, sejam esses elementos de nível lexical, semântico, gramatical ou estilístico, o tradutor definiria sua estratégia e orientaria as soluções de tradução.

Desse modo, por mais que o tradutor tome decisões guiadas por parâmetros objetivos, essas são inevitavelmente influenciadas por fatores alheios ao seu controle. Consequentemente, o fato de toda tradução resultar de um trabalho interpretativo não só justificaria as diferenças entre traduções de um mesmo texto, não havendo, assim, traduções que sejam fundamentalmente iguais em todos os aspectos textuais, como também explicaria o seu caráter "provisório": o intérprete de um texto teria suas próprias limitações, estabelecidas por suas habilidades mentais e linguísticas, seu tempo e espaço, sua formação e capacidade interpretativa, entre outros fatores. Dessa forma, apenas a (falta de) habilidade do tradutor estaria sujeita a críticas, não uma decisão de tradução ponderada, ainda que o crítico não concorde com ela.

Além dos fatores acima enumerados, referentes às competências do tradutor e às circunstâncias em seu entorno, Reiss menciona ainda a estrutura de personalidade do tradutor. Ela evoca a tipologia de personalidade descrita por Eduard Spranger que, em última medida, é fruto de uma série de abstrações e simplificações. Segundo a teorizadora, alguns tipos de personalidade são mais adequados a traduções de determinados tipos, dadas as diferentes posturas do tradutor associadas a esses tipos de personalidade. Ela aventa, desse modo, à possibilidade de associar a tipologia de personalidades com sua tipologia textual.

Após enumerar os fatores que interferem no processo tradutório, Reiss passa a abordar os casos em que não se pode falar, a seu ver, de tradução propriamente dita, isto é, os casos que não se enquadram dentro da definição de tradução abaixo: 
[358-359] Unter einer Übersetzung sei hier die zielsprachliche Version eines Ausgangstextes verstanden, deren vornehmstes Bestreben es ist, den Originaltext nach Maßgabe des Texttyps, seiner innersprachlichen Instruktionen und der darin wirksam werdenden außersprachlichen Determinanten in der Zielsprache wiederzugeben. Im Blick auf diese Definition kann natürlich nicht mehr von einer Übersetzung die Rede sein, wenn die zielsprachliche Version zu einem speziellen, nicht schon mit dem Original verfolgten Zweck oder für einen nicht vom Originalautor, sondern vom Übersetzer oder seinem Auftraggeber ins Auge gefassten speziellen Leserkreis angefertigt wird. In diesen Fällen handelt es sich eher um Adaptationen, Paraphrasen, mehr oder weniger freie Bearbeitungen, Resümees, Inhaltsangaben u. dgl. mehr ${ }^{328}$.

[Por tradução, entende-se aqui a versão na língua de chegada de um texto de partida, cujo esforço primordial é reproduzir o texto original na língua de chegada, segundo as diretrizes do tipo textual, de suas instruções intralinguísticas e dos determinantes extralinguísticos a atuar no processo. Tendo essa definição em vista, é evidente que não se pode mais falar de tradução nos casos em que a versão na língua de chegada é produzida para atender a um objetivo especial que não se busca atingir com o texto original, ou é dirigida a um público leitor não vislumbrado pelo autor do original, mas pelo tradutor ou por seu contratante. Nesses casos, trata-se mais de adaptações, paráfrases, revisões mais ou menos livres, resumos, sumários, dentre outros tipos semelhantes.]

São casos em que o texto em LC exerce uma função diferente do original ou é destinado a um público específico, não correspondente com o público a que o original foi pensado. A esses casos, Reiss atribui a denominação "transferências" (al. Übertragungen). Esses casos abarcariam ainda a tradução de textos artísticos e literários em que há um desvio do "temperamento artístico" do tradutor em relação ao autor do texto original, não havendo mais correspondência entre eles. Desse modo, em vez de um tradução, teríamos uma emulação (al. Nachdichtung), uma criação sobre outro texto.

Apesar de não serem consideradas traduções, Reiss não coloca em dúvida a validade dessas transferências, não questionando sua legitimidade, tampouco as classificando como inferiores. A seu ver, o que deve ser questionado é se, com um propósito diferente daquele que exerce o original, o texto na língua de chegada pode ainda ser chamado de tradução. Essa diferenciação, no entanto, é considerada importante, inclusive para proteger o tradutor de críticas não justificadas.

Segundo a teorizadora, a observação dos três conjuntos de fatores - tipo textual, instruções intralinguísticas e determinantes extralinguísticos - seria suficiente para verificar a adequação das traduções. Isso muda, contudo, no caso das transferências. Nesse caso, a adequação deve tomar como norte o objetivo especial a que se destina o texto em LC.

\footnotetext{
${ }^{328}$ REISS, 1971, p. 91.
} 
A partir do exposto até então, podemos observar que ainda à época de Reiss o conceito de tradução está vinculado ao texto de partida: se o objetivo do texto em LC não for o objetivo do autor do texto em LP, mas definido pelo tradutor ou pelo contratante, então não se trata mais de tradução. Ao desempenhar uma função que não é prevista pelo autor do texto na língua de partida, uma transferência não poderia ser considerada uma tradução, o que deve estar explícito, inclusive para mostrar ao crítico a partir de que critérios (que não são a equivalência de função) ele deve fazer sua crítica.

Por outro lado, o respeito às demais formas de transferência leva Reiss a encerrar seu texto redefinindo o conceito de tradução, distinguindo dois tipos: a tradução orientada por um princípio de adequação ao texto em LP - a tradução propriamente dita - e a tradução orientada por um princípio de adequação a um objetivo e a um contexto de recepção específico - isto é, as "transferências". Cada tipo de tradução exigiria uma postura diferente da parte do crítico: enquanto a primeira exigiria a busca por correspondências, com o texto original, o segundo exigiria do crítico atenção ao objetivo específico para o texto em LC.

Essas considerações teóricas tiveram novos desdobramentos com a pesquisa de livre-docência de Katharina Reiss, publicada em 1976. No entanto, um novo marco para a abordagem funcionalista viria apenas em 1978, com a publicação do texto inaugural da Skopostheorie de Vermeer.

\subsubsection{Hans Josef Vermeer: Esboço de uma teoria geral}

Considerado um dos maiores expoentes da moderna teoria da tradução no âmbito de expressão alemã, Hans J. Vermeer nasceu em Iserlohn, no oeste alemão, em 1930. No ano de 1950, iniciou os estudos na Universidade de Heidelberg, onde formou-se tradutor das línguas inglesa e espanhola. Essas foram apenas duas das muitas línguas em que ele se tornou fluente. Em 1953, fez intercâmbio na Universidade de Lisboa, adquirindo posteriormente o título de graduação em tradução do português, língua que, segundo Mary SnellHornby (2012), era sua favorita para traduzir, interpretar e ensinar. Além das diferentes línguas nacionais, Freihoff (2012) menciona ainda o interesse de Vermeer pela psicologia, pela sociologia e pela teoria da interação. Em 1962, defendeu sua tese de doutorado na 
Universidade de Heidelberg, com o título "Adjektivische und verbale Farbausdrücke in den indogermanischen Sprachen mit è-Verben. Ein Beitrag zur Frage der Wortarten und zum Problem der Übersetzbarkeit" [Expressões adjetivais e verbais ligadas a cores nas línguas indo-germânicas com verbos $\bar{e}$. Uma contribuição para a questão das classes de palavras e para o problema da traduzibilidade]. Após a defesa, passou a ensinar línguas do Sul da Ásia como o urdu e o híndi no Departamento de Línguas Modernas da mesma instituição. Vermeer escreveu sua livre-docência no âmbito da linguística contrastiva histórica, com a obtenção do título em 1968. Ele permaneceu em Heidelberg até 1971, quando assumiu a cátedra de Linguística Geral e Aplicada na unidade de Germersheim da Universidade de Mainz. Em 1984, retornou a Heidelberg como professor da cadeira de Estudos da Tradução com ênfase em língua portuguesa. Após a aposentadoria, em 1992, passou a atuar como professor visitante em diferentes universidades na Áustria, Turquia e de volta, enfim, a Germersheim, onde foi sagrado Doutor honoris causa por sua contribuição ao estabelecer os fundamentos dos estudos da tradução modernos na Alemanha, numa pequena cerimônia realizada no dia 17 de janeiro de 2010. Dezesseis dias depois, ele faleceu em sua casa em Heidelberg $^{329}$.

Vermeer formulou a base de sua proposta teórica em seus anos como docente da Universidade de Mainz. Durante o semestre de verão de 1977, ele ministrou uma palestra, em que expôs suas considerações teóricas sobre a tradução. Nela estavam presentes também seus colegas Hans G. Hönig, Sigrid Kupsch-Losereit e Paul Kussmaul. A esse respeito, Kussmaul relata:

\begin{abstract}
As ideias de Vermeer, à época, foram uma revelação a mim e a alguns de meus colegas. Partindo de uma lembrança pessoal, em 1977 Hans Vermeer deu uma palestra sobre a teoria da tradução no Departamento de Linguística Aplicada em Germersheim, como era então chamado, e Hans Hönig, Sigrid Kupsch-Losereit e eu éramos parte do público. Vermeer recebia perguntas de bom grado, e não demorou muito para que a palestra se tornasse uma discussão animada entre nós três e Vermeer. Essa troca ocorreu várias vezes ao longo de toda a palestra, e depois fiquei me perguntando o que Vermeer faria com o script de sua apresentação. Pouco tempo depois, ele publicou os resultados na forma de artigo (Vermeer 1978) e foi nesse artigo que ele estabeleceu os fundamentos para a sua teoria do skopos. ${ }^{330}$ (KUSSMAUL, 2012, p. 167)
\end{abstract}

\footnotetext{
${ }^{329}$ SNELL-HORNBY, 2012b, p. 285s.

${ }^{330}$ Vermeer's ideas were at the time a revelation to me and some of my colleagues. To begin with a personal reminiscence, in 1977 Hans Vermeer gave a lecture on the theory of translation at the Department of Applied Linguistics in Germersheim, as it was then called, and Hans Hönig, Sigrid Kupsch-Losereit and I were part of the audience. Vermeer welcomed questions, and very soon the lecture developed into a lively discussion between the three of us and Vermeer. This exchange often carried on throughout the whole lecture, and I asked myself what Vermeer would actually do with his scripts. Soon after he published the results as a paper (Vermeer 1978), and it was in this paper that he laid the foundations for his skopos theory.
} 
De fato, no artigo, intitulado "Ein Rahmen für eine allgemeine Translationstheorie" [Um quadro para uma teoria geral de translação], Vermeer agradece a todos que, "com sua participação, ajudaram a levantar e a elucidar questões fundamentais" (VERMEER, 1978, p. 99). Ele introduz o artigo com o que, em sua opinião, constitui uma "teoria geral da translação", apresentando, assim, a própria estrutura de seu texto: (1) a definição do conceito de "translação"; (2) a base teórica; (3) a sua classificação na Linguística Aplicada; (4) um modelo de translação com seus subcomponentes, um modelo de recepção, produção e reprodução, com base num modelo geral de interação; (5) um inventário de regras; e (6) uma estilística complexa para a análise de estruturas textuais. Nesse quadro, Vermeer destaca a apresentação do modelo de translação como o elemento crucial de sua proposta.

Marina Dudenhöfer (2012) observa que esse artigo propôs-se a apresentar uma teoria completamente desenvolvida. Ela qualifica o artigo como "denso", no sentido de que nenhuma palavra foi desperdiçada. Embora perceba um tom mais descontraído em publicações posteriores de Vermeer, ela nota que seus primeiros trabalhos mantiveram o tom "seco", feitos para serem lidos como textos acadêmicos ou "científicos". De acordo com Dudenhöfer, ainda que Vermeer tenha posteriormente conduzido sua teoria às vezes por caminhos surpreendentes, ele nunca contradisse a sua proposta inicial ${ }^{331}$.

Michael Cronin (2012), professor da cátedra de francês da Trinity College Dublin, na Irlanda, lamenta o fato de que a reputação de Vermeer tenha ficado restrita à ideia de skopos. Segundo afirma, a própria traduzibilidade da noção de skopos em termos pedagógicos e profissionais obscureceu o significado completo do que Vermeer estava tentando fazer em sua busca por novas formas de pensar e por novos campos de conhecimento. Dono de uma produção profícua e diversa, com estudos sobre filologia histórica, sobre a história da tradução e sobre as línguas do Sudoeste Asiático, dentre outros temas, Vermeer não teria tido o devido reconhecimento pelo fato de sua produção acadêmica ter sido escrita, em sua maioria, em língua alemã ${ }^{332}$. Mary Snell-Hornby (2012) compartilha dessa opinião, ressaltando, assim como faz Dudenhöfer acima, seu estilo hermético de escrita, mesmo para os padrões de escrita acadêmica alemã: ora denso e sofisticado, ora elíptico e com afirmações elusivas ${ }^{333}$.

\footnotetext{
${ }^{331}$ DUDENHÖFER, 2012, p. 12.

${ }^{332}$ CRONIN, 2012, p. 7.

${ }^{333}$ SNELL-HORNBY, 2012b, p. 287.
} 
Rebuscado e econômico, sobretudo se considerarmos as limitações próprias do gênero textual "artigo científico", o texto delineia os princípios básicos da Skopostheorie, sem, no entanto, preocupar-se em elucidar todos os conceitos apresentados. Assim, Vermeer informa-nos que sua proposta teórica será objeto de futuros desenvolvimentos.

\subsubsection{Análise}

Vermeer (1978) principia sua exposição a partir da revisão terminológica. Tendo em vista o objetivo de estabelecer uma teoria geral, ele introduz o conceito de TRANSLAÇÃo (al. Translation) como um hiperônimo para "tradução" (al. Übersetzen) e "interpretação" (al. Dolmetschen) ${ }^{334}$. A seu ver, tradução e interpretação distinguem-se pelo fato de a tradução ser passível de correção uma vez concluída. Assim, presume-se que a tradução (1) parta de um texto original numa forma fixa, que possa ser consultado repetidas vezes e (2) resulte num texto numa forma fixa, que possa ser revisto repetidas vezes.

Com o intuito de caracterizar o seu objeto de pesquisa, Vermeer oferece a seguinte definição para o conceito de translação:

[8-10] Bei einer Translation wird ein Text aus einer Sprache A in eine Sprache $Z$ übertragen (genauer: ein in einer Sprache A formulierter Text in einer Sprache $\mathrm{Z}$ re-formuliert).

„Translation" ist Sondersorte von Transfer - vgl. Transfer von Bildern in Musik, Transfer einer Zeichnung in ein Bauwerk, ... Unterscheidendes Merkmal für Translation sei die Verwendung menschlicher Sprache, sodass von einer spezifischen Sprache A in eine andere spezifische Sprache $Z$ transferiert wird ${ }^{335}$.

[Numa translação, um texto numa língua $P$ é transposto para uma língua $C$ (ou melhor: um texto formulado numa língua $P$ é re-formulado numa língua $C$ ).

"Translação" é um tipo especial de transferência - cf. transferência de imagens para música, transferência de um desenho para uma construção... Característica distintiva para a translação seria o emprego da linguagem humana, de modo que se transfere de uma língua P especifica para outra língua $C$ especifica.]

Nota-se pelo excerto que, segundo Vermeer, translação significa transferência enquanto "reformulação" ou "re-produção" de um texto noutra língua. Desse modo, a translação é descrita como uma atividade produtiva; sua especificidade está no emprego da lin-

\footnotetext{
${ }^{334} \mathrm{O}$ primeiro a propor o conceito de "translação" como conceito superordenado para as modalidades de tradução e interpretação, no entanto, não foi Vermeer, mas outro pesquisador alemão, Otto Kade (cf. MOREIRA, 2014).

${ }^{335}$ VERMEER, 1978, p. 99.
} 
guagem humana, mais especificamente, pelo envolvimento de duas línguas diferentes. Elemento definidor de língua é sua propriedade de possuir símbolos - que a linguística convencionou chamar de signos linguísticos - com traços de conteúdo cognitivo relativamente distintos.

Essa definição remete-nos à definição de tradução feita por Roman Jakobson. Em seu célebre artigo, "On Linguistic Aspects of Translation" [Aspectos linguísticos da tradução], Jakobson defende a tese de que, para conhecer o significado de uma palavra, não é necessário conhecer a realidade extralinguística a que ela estaria associada, mas, sim, a sua definição. Para definir uma palavra, contudo, faríamos uso de recursos linguísticos. Portanto, o significado de um signo linguístico nada mais seria do que sua "tradução" para outro signo linguístico (ou para um conjunto de signos linguísticos) por que possa ser substituído. A seu ver, há três maneiras de interpretar um signo verbal: através de sua tradução por signos de sua própria língua, por signos de outra língua ou por um sistema não verbal de signos. Desse modo, Jakobson discrimina três diferentes formas de tradução:

\footnotetext{
A tradução intralingual ou reformulação [rewording] consiste na interpretação dos signos verbais por meio de outros signos da mesma língua.

A tradução interlingual ou tradução propriamente dita consiste na interpretação dos signos verbais por meio de alguma outra língua.

A tradução intersemiótica ou transmutação consiste na interpretação dos signos verbais por meio de sistemas de signos não verbais. (JAKOBSON, 2010, p. 81, trad. Izidoro Blikstein e José Paulo Paes, grifos no original)
}

Desse modo, além de compreenderem a tradução como uma reformulação com outros signos linguísticos, Jakobson e Vermeer teriam em comum o fato de reconhecerem diferentes formas de transferência, ainda que Vermeer, em princípio, não vislumbre a noção de tradução intersemiótica.

A elucidação do conceito segue enfatizando outras de suas características:

[11] „Translation" ist damit zugleich Sondersorte von Reden. „Rede" ist Sondersorte von Handeln (vgl. „,verbales Handeln":: ,,aktionales Handeln"); Handeln ist intentionales Sich-Verhalten. — Jedes Handeln verläuft in einer gegebenen Situation, ist Teil der Situation und verändert sie zugleich. Reden ist Teilverbalisierung von Situation und zugleich situationsverändernd ${ }^{336}$.

[Desse modo, "translação" é também um tipo especial de falar.

A "fala" é um tipo especial de agir (cf. "agir verbal" :. "agir acional”); agir é um comportar-se intencional. - Todo agir ocorre numa determinada situação, é

\footnotetext{
${ }^{336}$ VERMEER, 1978, p. 99.
} 
parte da situação e também a altera. Falar é verbalização parcial da situação e, ao mesmo tempo, é modificador da situação.]

A associação estabelecida entre translação e fala, bem como entre fala e ação encontram eco em outras teorias em circulação à época. Num artigo intitulado Falsche und richtige Fragestellungen in der Übersetzungstheorie [O falso e o verdadeiro na teoria da tradução], o notório linguista romeno Eugenio Coseriu (2010, p. 255) também define a tradução como "uma especificidade do dizer", menos por envolver dois códigos linguísticos diferentes e mais por tratar-se de um dizer com um conteúdo pré-estabelecido pelo texto de partida. Ele também percebe a tradução mais como ação e menos como processo.

As características acionais na translação, na teorização de Vermeer, têm como fundamento a teoria da ação, ramo da filosofia dedicado à análise de movimentos voluntários complexos da parte dos seres humanos. Contudo, a relação entre fala e ação também foi feita no âmbito da filosofia da linguagem. Entre 1952 e 1954, John L. Austin (1962) deu uma série de palestras na Universidade de Harvard, EUA, nas quais explica que, além de sua capacidade enunciativa, a língua também dispõe de capacidade para realizar ações, em determinadas situações, por meio da enunciação. É o que fazemos, por exemplo, quando mentimos, fazemos uma pergunta ou uma promessa, quando um pároco batiza alguém ou quando um juiz de paz declara um casal unido em matrimônio. Segundo Austin, isso é possível devido a uma força ilocucional dessas asserções ${ }^{337}$.

A ação de falar tende a resultar em textos. Nesse contexto, Vermeer acrescenta que toda ação ocorre numa determinada SITUAÇÃO, sendo determinada por ela: age-se para a manutenção de uma situação ou para a sua mudança. Conforme explica, uma situação limita o escopo da ação do sujeito e oferece as diretrizes para se agir. No caso da fala, a situação determinaria o que pode (e deve) ser dito, ajudando a moldar, assim, o próprio texto. No entanto, conforme explica o teorizador, age-se segundo a percepção que se tem da situação em que se encontra. Perceber - e também avaliar - uma situação dependeria em parte da cultura em que se está inserido; em parte também por fatores idiossincráticos. Com isso, podemos concluir que os elementos de uma situação que ganham manifestação no texto dependem, em primeiro lugar, de fatores culturais e, em segundo, de características do próprio indivíduo - sua história, sua formação, seu grupo social etc. Logo, a situação não seria percebida da mesma forma por todos os indivíduos.

\footnotetext{
${ }^{337}$ AUSTIN, 1962, p. 99.
} 
O TEXTO, inserido no contexto de uma situação comunicativa, é considerado base e objeto da translação. De forma mais perceptível na tradução do que na interpretação, estariam envolvidas duas diferentes situações de ação: a situação de produção do TP com suas manifestações no texto e uma nova situação de comunicação com um novo público numa nova cultura, a saber, a situação de produção do TC. Segundo Vermeer, se a forma de perceber e a forma de avaliar uma situação é em parte determinada culturalmente, então lidase na translação com dois sistemas diferentes de percepção e avaliação. A situação, contudo, interferiria não apenas na produção textual, mas também na sua recepção, isto é, em como o receptor interpretará o texto. Visto que a translação envolve diferentes formas de percepção, seria impossível estabelecer correspondência completa entre texto e translato.

A influência da cultura em nossa percepção de mundo seria determinante até mesmo para o conceito de LínGUA. Conforme explica Vermeer, os signos linguísticos simbolizam, dentre outros, coisas e classes do "mundo", não como eles realmente são, mas como nós os percebemos. Assim, os significados dos signos linguísticos refletem uma percepção parcial do mundo - como é condição da percepção humana - e uma "teoria", isto é, uma opinião comum aos membros de uma dada cultura sobre a realidade, herdada de gerações anteriores. Através dessa "teoria", visões de mundo que são específicas de uma sociedade se vinculam ao signo linguístico. Logo, também os signos linguísticos, ao menos parcialmente, ganhariam propriedades particulares em cada cultura.

Para a translação, relevante é que a relação entre o mundo como percebemos e essa ideia hereditária sobre o mundo se relacionam de modos diferentes em diferentes línguas e culturas, devendo essas diferenças ser consideradas na translação: não se deveria considerar apenas o aspecto linguístico dos textos na translação, pois ela é uma ação entre culturas, não meramente entre línguas. De fato, quando Vermeer afirma que uma teoria da translação deve se amparar numa teoria da cultura e que uma teoria da linguagem pode ser vista como subordinada a uma teoria da cultura, está implicada a noção de que a língua é parte da cultura.

A translação é considerada, ao mesmo tempo, um processo de transferência e de interação entre culturas. Logo, não se trata de um processo unidirecional, que ruma da cultura de partida para a cultura de chegada. O TRANSLADOR exerceria o papel de receptor e produtor de mensagens - logo, de "reprodutor" de uma mensagem prévia. Podendo trabalhar sozinho ou num grupo de pessoas, o translador, como detalha Vermeer, recebe a mensagem numa cultura, transfere-a a uma estrutura heterocultural e retransmite-a a um recep- 
tor noutra cultura. A transferência ocorreria na mente do translador por um processo hermenêutico. Como interação, a translação seguiria as regras da interação: traduz-se para alguém, i.e., tem-se sempre um interlocutor em mente. Sem detalhar, o teorizador enumera alguns FATORES a interferir numa interação: a situação, os parceiros da interação, o código (verbal ou não verbal), o registro e o nível linguístico (fonema, morfema, sintaxe, léxico, etc.).

Devido a certas circunstâncias, tais como a situação de produção/recepção de texto, as competências de produção/recepção textual, o contexto cultural de que cada pessoa tem origem etc., uma MENSAGEM não se manteria inalterada no processo de translação: a mensagem formulada por um emissor em sua mente não corresponderia integralmente à mensagem concretizada no texto, assim como essa não corresponderia integralmente a mensagem interpretada pelo receptor. Desse modo, não seria possível falar em invariância da mensagem na translação.

Vermeer afirma que toda ação é intencional. No caso de uma ação comunicativa como a translação, a ação teria valor para o emissor por sua intenção, isto é, pela FUNÇão pretendida por ele. Para o receptor, a ação teria valor pela interpretação que faz da intenção do produtor (uma função interpretada). O sucesso da ação estaria na correspondência entre as duas coisas. A translação é, sob esse prisma, também uma ação intencional: busca-se um objetivo e, como tal, seu sucesso está condicionado à realização desse objetivo. Segundo Vermeer, essa é a regra fundamental da translação:

[30] Regel 1 (Skoposregel): Interaktion (und als deren Sondersorte: Translation) wird von ihrem Zweck (Skopos) bestimmt, ist eine Funktion ihres Zwecks. ${ }^{338}$

[Regra l (regra do skopos): Interação (e como tipo especial de interação: translação) é determinada por seu objetivo (skopos), é uma função de seu objetivo.]

Nota-se que Vermeer atribui a esse objetivo e a essa função a denominação "skopos". O termo, vindo do grego ( $\sigma \kappa о \pi \circ \varsigma)$, significa "propósito" e faz parte da reformulação terminológica proposta pelo autor. Do termo veio a designação da teoria, Skopostheorie ou teoria do $\operatorname{skopos}^{339}$.

\footnotetext{
${ }^{338}$ VERMEER, 1978, p. 100.

${ }^{339} \mathrm{Na}$ tradução de "Skopostheorie", optamos por manter o termo grego, a exemplo do que propõe Anthony Pym (1996), de modo a evitar interpretações enviesadas pelo uso do termo em português "escopo". A manutenção do termo grego foi a opção usada na tradução do livro seminal de Christiane Nord (2016a), mas curiosamente não foi a escolha na tradução da obra introdutória de Pym, Exploring translation theories, para o português (cf. PYM, 2017, p. 97s.).
} 
Se a função da translação é considerada, no âmbito da Skopostheorie, como seu critério principal, ela é determinada, via de regra, com o público receptor em vista:

[3-5] 5.3. Der Empfänger ist dem Zweck zuzuordnen: Der Empfänger ist „Element" des Zwecks. - Das Wie einer Interaktion hängt wahrscheinlich primär von den Relationen zwischen den Interaktionspartnern ab ( - Beachte: Mithörer $-)$.

Unterregel 1a (soziologische Regel): Der Zweck ist als Empfängerabhängige beschreibbar. $^{340}$

[O receptor deve ser associado ao objetivo: O receptor é "elemento" do objetivo. - o "como" de uma interação depende, decerto em primeiro lugar, das relações entre os parceiros da interação (-Note: co-ouvinte -).

Sub-regra 1' (regra sociológica): O objetivo é descritível como dependente do receptor.]

Almejar "comunicação" (al. Verständigung) no processo translatório significa aqui almejar a compreensão da mensagem pelo receptor, de modo que não haja protestos em seu feedback. Para que haja comunicação, considera-se necessário que o receptor perceba a mensagem como coerente em si e com a sua situação. Nesse contexto, a situação seria determinante para avaliar se houve entendimento na comunicação, visto que seu sucesso estaria condicionado a sua adequação a essa situação. Esse é o fundamento da segunda regra:

[38] Regel 2 (Kohärenzregel): Geglückt ist eine Translation, wenn sie vom Empfänger als hinreichend kohärent mit seiner Situation interpretiert wird und kein Protest, in welcher Form auch immer, zu Übermittlung, Sprache und deren Gemeintem (Sinn) folgt. ${ }^{341}$

[Regra 2 (regra da coerência): Uma translação é bem sucedida caso seja interpretada pelo receptor como suficientemente coerente com a sua situação e caso não haja protesto algum, seja da forma que for, no tocante à transmissão, à linguagem e a seu intencionado (sentido).]

Segundo afirma Vermeer, não há a translação perfeita, pois não há uma só maneira de se traduzir, nem mesmo o translador trabalha em condições ideais. Além de se almejar a coerência interna, a translação deveria almejar também a coerência com o TP. O translador deveria interpretar o TP segundo sua situação e, a partir dessa interpretação, produzir uma translação coerente. Assim, ainda que o critério norteador seja a função do texto na cultura de chegada, Vermeer afirma o vínculo que o translador deve estabelecer entre TC e TP. Essa é a terceira regra:

\footnotetext{
${ }^{340}$ VERMEER, 1978, p. 101.

${ }^{341}$ Ibid.
} 
[47-48] „Geglückt" ist eine Translation also vollends dann, wenn letzteres der Fall ist.

Regel 3 (Fidelitätsregel): Eine Translation strebt nach kohärentem Transfer eines Textes. ${ }^{342}$

[ "Bem sucedida" é então uma translação quando, enfim, ocorre o último caso. Regra 3 (regra da fidelidade): Uma translação almeja a transferência coerente de um texto]

As regras estão ordenadas hierarquicamente. A primeira regra definiria quais fatores são relevantes para a translação em curso, enquanto as outras duas regras hierarquizariam esses fatores. Visto que a função, segundo essa concepção teórica, destaca quais fatores são relevantes no processo, presume-se que nem todos possam ser contemplados nele. Assim, a translação não seria um processo reversível, cuja retrotradução resultaria no TP.

A mudança de função na cultura de chegada, segundo Vermeer, não invalida a coerência entre TP e TC, apenas impõe regras adicionais para a translação. Desse modo, mesmo os casos em que texto e translato não têm funções correspondentes ainda poderiam ser considerados traduções. Observa-se aqui, portanto, um ponto claro de distinção entre a proposta de teoria geral de Vermeer e o modelo de Reiss: ainda que a função seja, em ambos os casos, critério norteador para o processo, para Vermeer deve-se buscar a coerência, não a equivalência entre os textos.

As noções teóricas de Vermeer apresentadas aqui encontraram na obra de Hans Hönig e Paul Kussmaul sua primeira aplicação didática, como veremos a seguir.

\subsubsection{Hans G. Hönig e Paul Kussmaul: Descrevendo estratégias para a práti- ca e para a didática da tradução}

Presentes na referida palestra em que Vermeer expõe as noções básicas de sua teoria do skopos, Hans G. Hönig e Paul Kussmaul logo se tornaram seus adeptos e entusiastas do funcionalismo. A esse respeito, Kussmaul comenta que a proposta teórica de Vermeer teve nele um efeito libertador, "como se a teoria da tradução finalmente fosse posta nos eixos" (KUSSMAUL, 2004, p. 223). Para Hönig, o maior mérito de Vermeer foi (e é) o de "retirar a teoria da tradução do domínio da linguística contrastiva, enquadrá-la na pragmá-

\footnotetext{
${ }^{342}$ VERMEER, 1978, p. 101.
} 
tica e abri-la a abordagens interdisciplinares, psicolinguísticas, relativas aos Estudos Culturais e à Teoria da Ação" (HÖNIG, 2004, p. 135). O entusiasmo dos autores certamente encontra fundamento em suas experiências ao longo de sua formação acadêmica e mesmo posteriormente, como docentes na Área de Linguística Aplicada - hoje Área de Estudos da Tradução, Estudos Linguísticos e Culturais - da Universidade de Mainz, na Alemanha.

Hans G. Hönig nasceu em 1941 na cidade alemã de Stuttgart. Ele estudou Anglística e Germanística na Universidade de Tübingen, na Alemanha, e no Trinity College, em Dublin, Irlanda. Segundo conta, ao longo de sua graduação, ainda que suas traduções para a língua materna fossem mais bem avaliadas do que suas traduções para o inglês, elas eram acompanhadas por correções sugeridas segundo critérios que ele não conseguia entender e para as quais não recebia qualquer justificativa convincente. As alegações de seus avaliadores, segundo seu entendimento, baseavam-se quase sempre num "sentido secreto" do texto literário, acessível apenas a estudiosos e críticos da obra em questão ${ }^{343}$.

Passados alguns anos, com o início de sua docência, as coisas não pareciam ter evoluído muito. Ele relembra que a proposta de ensino de tradução de sua época não contemplava o treinamento profissional de tradutores. Ainda que faltasse a ele e a seus colegas a experiência profissional de traduzir com prazos e honorários, esse déficit parecia incomodar apenas a poucos, uma vez que a tarefa da universidade supostamente não era treinar os alunos para a rotina profissional. "Antes, tratava-se de praticar, exemplar e meticulosamente, a tradução de textos realmente desafiadores - assim, quem tivesse aprendido, certamente

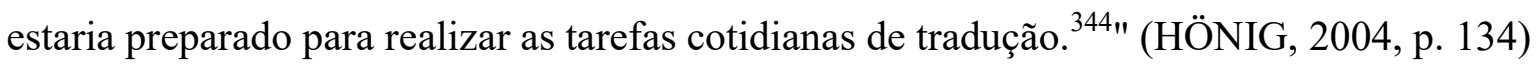

Paul Kussmaul traz um relato semelhante. Nascido em 1939 também em Stuttgart, iniciou, assim como Hönig, seus estudos em Germanística e Anglística na Universidade de Tübingen, passando posteriormente pela Universidade de Newcastle, no Reino Unido, e na Universidade de Munique, de volta à Alemanha. Por concentrar sua formação no âmbito dos Estudos Literários, inclusive com tese de doutorado sobre a relação entre Bertold Brecht e o drama inglês na Renascença, os conceitos da Linguística pareceram-lhe, à primeira vista, abstratos demais. Sua incursão na disciplina ocorreu de forma gradual, e foi através dela que ele teve os primeiros contatos com as teorias de tradução. De acordo o relato das reminiscências de seu percurso pelos estudos da tradução, concomitante ao início de sua atividade docente na Universidade de Mainz, em 1971, Kussmaul teve contato com as i-

\footnotetext{
${ }^{343}$ HÖNIG, 2004, p. 133.

${ }^{344}$ Es ginge vielmehr darum, das Übersetzen von wirklich anspruchsvollen Texten exemplarisch und akribisch zu üben wer dies gelernt habe, sei dann gewiss auch in der Lage, die übersetzerischen Routinegeschäfte zu erledigen.
} 
deias veiculadas pela Escola de Leipzig e com o livro de Katharina Reiss aqui anteriormente abordado, além dos escritos de Eugene Nida, nos EUA, e de Georges Mounin, na Fran$\mathrm{ça}^{345}$.

A migração, no âmbito da linguística, de teorias mais sistemáticas para teorias de cunho mais comunicativo, em especial a teoria dos atos de fala, parece espelhar seu caminho pelos estudos da tradução. Aos poucos, a preocupação com a equivalência no nível linguístico deu lugar à atenção para o papel da função comunicativa na tradução, sobretudo com o impulso dado pela obra de Reiss e pela distinção feita por Nida entre equivalência formal e equivalência dinâmica. Sua consolidação ocorreu, enfim, com a proposta teórica esboçada por Vermeer em 1977.

Com a concepção da Skopostheorie, Hönig e Kussmaul encontraram as premissas que nortearam seus próprios caminhos pelos estudos da tradução, ostentando com orgulho a alcunha de "funcionalistas". A fim de solucionar um problema dessa nova vertente teórica, a saber, a carência de critérios objetivos para orientar tanto as decisões tradutórias como a avaliação da qualidade das traduções, Hönig e Kussmaul escreveram Strategie der Übersetzung: Ein Lehr- und Arbeitsbuch [Estratégia da tradução: livro-texto e livro de atividades], publicado em 1982. Sobre a concepção do livro e a sua relação com a nova abordagem teórica, Kussmaul conta-nos:

Uma tese central do artigo era a de que a meta e o objetivo de uma traduçãosão
determinados pelas necessidades e pelas expectativas do leitor em sua cultura.
Vermeer deu a isso o nome de "skopos", e a dita "fidelidade ao original", isto é, a
equivalência, estava subordinada a esse skopos. (...) Quando Hans Hönig e eu es-
crevemos nosso livro Strategie der Übersetzung, que foi publicado em 1982, as
ideias de Vermeer foram um fundamento bem importante para nós. No entanto, o
conceito de "skopos" àquela época ainda não havia se desenvolvido como con-
ceito-chave. Nós utilizamos para a nossa representação da comunicação através
do traduzir os conceitos de "continuidade de função" e de "mudança de fun-
ção". ${ }^{346}$ (KUSSMAUL, 2004, p. 223s.)

A didatização da proposta teórica não foi sem fundamento: como Hönig e Kussmaul afirmam no prefácio da obra, a formação de tradutores era marcada pela descrença, por parte tanto de estudantes como de docentes, em relação aos benefícios de uma teoria para a

\footnotetext{
${ }^{345}$ KUSSMAUL, 2004, p. 222.

${ }^{346}$ Eine Kernthese des Aufsatzes bestand darin, dass Ziel und Zweck einer Übersetzung von den Bedürfnissen und Erwartungen des Lesers in seiner Kultur bestimmt wird. Vermeer nannte dies „Skopos", und die sogenannte „Treue gegenüber dem Original", also die Äquivalenz, war diesem Skopos untergeordnet. (...) Als Hans Hönig und ich unser Buch Strategie der Übersetzung schrieben, das 1982 erschien, waren Vermeers Ideen für uns eine ganz wichtige Grundlage. Der Begriff "Skopos" hatte sich damals allerdings noch nicht allgemein als Kernbegriff herausgebildet. Wir benützten für unsere Vorstellung von Kommunikation mittels Übersetzen die Begriffe „Funktionskonstanz" und „Funktionsveränderung".
} 
prática e para o ensino de tradução. A didática baseava-se em exercícios de tradução préformulados e padronizados. Ademais, a noção de competência tradutória também confundia-se com a competência linguística, deixando-se, assim, de considerar questões referentes, por exemplo, à situação comunicativa ${ }^{347}$.

Assim, a proposta do livro, além de diminuir a distância entre teoria e prática, é desenvolver a competência tradutória do estudante. Em vez de oferecer estratégias de tradução estabelecidas a priori, os autores desejam capacitar os estudantes para reconhecer a situação de tradução, a função comunicativa almejada e, assim, a elaborar estratégias próprias para aquele processo comunicativo específico. O livro está organizado em duas partes: na primeira parte, intitulada "Das heilige Original" [O original sagrado] são trazidas para discussão questões gerais referentes à tradução, tais como a situação comunicativa, a relação entre os interlocutores e até a própria noção de língua. Na segunda parte, "Der andere Text" [O outro texto], são abordadas questões mais ligadas ao microcosmo textual, tais como os atos ilocucionais, as palavras e a organização sintática do texto. Em 2004, mesmo após mais de vinte anos de publicação, os autores observam que ele se tornou um best-seller na área ${ }^{348}$.

Após a publicação, tanto Hans Hönig quanto Paul Kussmaul decidiram explorar com mais profundidade a competência tradutória. Hönig dedicou parte de sua carreira à investigação dos processos cognitivos em curso na mente do tradutor e à questão da consciência dos tradutores acerca de suas próprias decisões tradutórias. Além de também investigar os processos cognitivos, Kussmaul também pesquisa acerca de questões ligadas à didática de tradução e da criatividade ao traduzir.

Hans Hönig esteve à frente do Instituto de Anglística, Americanística e Anglofonia da Universidade de Mainz até a sua morte, em 2004, na cidade de Landau, Alemanha, com 63 anos. Paul Kussmaul ocupou o cargo de diretor acadêmico do departamento de Linguística Aplicada e Estudos Culturais da mesma instituição até a sua aposentadoria, em 2005.

\footnotetext{
${ }^{347}$ HÖNIG; KUSSMAUL, 1982, p. 9s.

${ }^{348}$ HÖNIG, 2004, p. 136.
} 


\subsubsection{Análise}

Hönig e Kussmaul (1982) contam-nos que o estímulo para a escrita do livro está na desconstrução de uma visão limitadora de tradução e da competência tradutória. Em seu tempo, considerava-se a tradução como um talento, cujas técnicas seriam adquiridas apenas através da prática. Essa noção de traduzir, embora especialmente contraproducente na formação de tradutores e intérpretes, teria sido preponderante entre estudantes e docentes de tradução. De fato, essa noção do traduzir estaria em consonância com o valor atribuído à atividade na República Federativa Alemã na década de 1970, isto é, a de uma atividade cujas dificuldades não seriam propriamente reconhecidas, sendo, assim, delegada a pessoas sem formação profissional específica.

Por trás da desvalorização do trabalho de tradução estaria também a ideia de que a tradução se resume à mera troca de palavras de uma língua por palavras de outra língua, visando-se à equivalência no nível dos signos. Essa noção, com fundamentos na abordagem linguística de tradução, em especial nas vertentes dedicadas ao desenvolvimento de sistemas de tradução automática, não levaria em conta o significado das palavras para o público-alvo. Um dos autores citados pela dupla é Werner Koller. Segundo afirmam, Koller entende a tradução do ponto de vista linguístico, como a transcodificação ou substituição de elementos do inventário de uma língua por elementos do inventário de outra. Eles criticam o fato de essa noção do traduzir considerar apenas a parte visível e material do processo.

Logo, em vez de aderirem à vertente em voga, a abordagem da linguística tradicional à tradução, Hönig e Kussmaul optam por aproximarem-se da corrente pragmática em ascensão. Eles observam que a língua, material mesmo da atividade de tradução, é definida pelas diversas correntes teóricas de acordo com os objetivos do teorizador e do foco de sua investigação. Dessa forma, no caso de sua proposta teórica, compreende-se LíNGUA segundo o seu uso:

[28-32] Wir grenzen deshalb noch einmal ganz klar ab: Unsere Theorie begnügt sich nicht damit, Aussagen zu machen über das Verhältnis der materiellen Sprachzeichen in einem AS-Text zu denen in seinem Pendant in einem ZS-Text. Für uns ist nicht Sprache als Produkt einer Tätigkeit Gegenstand der Erörterung, sondern Sprache als Handeln.

Nun könnte durchaus der Einwand gemacht werden: Sprache und Handeln haben doch gar nichts miteinander zu tun. Sprache ist Sache der Linguistik, also 
der Sprachwissenschaft, aber Handeln? Das ist allenfalls das Ergebnis von Erfahrungen, abhängig von Entscheidungen, die nicht sprachgebunden sind.

Gerade in diesem Punkt hat jedoch die Linguistik in den letzten Jahren eine bemerkenswerte Wandlung durchgemacht. In der pragmatisch orientierten Sprachwissenschaft wurden die Begriffe „Handeln" und „Sprache" bzw. „Sprechen" einander immer mehr angenähert. ${ }^{349}$.

[Por isso, vamos demarcar as diferenças mais uma vez para que fique bem claro: nossa teoria não se dá por satisfeita em apenas fazer afirmações sobre a relação dos signos linguísticos materiais num texto na LP com os signos correspondentes num texto na LC. Para nós, não é a língua enquanto produto de uma atividade o objeto de discussão, mas a língua como ação.

Nesse ponto, seria de todo modo possivel levantar a objeção de que língua e ação nada têm a ver uma com a outra. A língua é coisa da linguística, isto é, dos estudos linguisticos, mas e a ação? Ela é, quando muito, resultado de experiências, a depender de decisões que não estão ligadas com a língua.

Mas foi exatamente nesse ponto que a linguística fez uma mudança considerável nos últimos anos. No viés pragmático da linguística, os conceitos de "ação" e "lingua" foram aproximados ainda mais.]

Percebe-se que, nesse ponto, Hönig e Kussmaul incluem em sua teoria a noção de língua defendida por Vermeer - língua como ação. Ao mesmo tempo, essa noção corresponde a um novo entendimento do ato linguístico trazido, por exemplo, pela teoria dos atos de fala, que, conforme mencionado, faz parte do arcabouço teórico dos autores. Essa visão pragmática da língua afeta também a noção de texto e a própria noção de TRADUÇÃO:

[7] Ein Text - und damit auch eine Übersetzung — ist also grundsätzlich als eine Kommunikation zwischen einem Sender und den Empfängern zu betrachten. Seine Bewertung muss von den Voraussetzungen und Interessen der Empfänger ausgehen. ${ }^{350}$

[Um texto - e, com isso, também uma tradução - deve, portanto, ser visto fundamentalmente como uma comunicação entre um emissor e os receptores. Sua avaliação deve partir das condições prévias e dos interesses dos receptores.]

Texto e, consequentemente, também a tradução são definidos como uma comunicação entre emissor e receptor, cuja pertinência e adequação devem ser determinadas pelo próprio receptor, com base em seus interesses e pressupostos. Assim, fica evidente que a tradução não é mesmo um processo estritamente linguístico, cujos parâmetros encontramse tão somente no texto em língua de partida, o que influencia a própria compreensão de qual deve ser a competência tradutória. Segundo os autores, a competência tradutória não é adquirida automaticamente do aprendizado de uma língua estrangeira, pois envolve outros fatores além do conhecimento linguístico. De fato, seria impossível exigir do tradutor uma

\footnotetext{
${ }^{349}$ HÖNIG; KUSSMAUL, 1982, p. 34.

${ }^{350}$ Ibid., p. 12.
} 
competência plena da língua estrangeira - ou mesmo da língua materna - havendo assim sempre o risco de deixar escapar pequenas diferenciações entre os sistemas linguísticos. Esse risco diminuiria, no entanto, se o tradutor tiver bem desenvolvida sua competência tradutória, que o colocaria em alerta antes que ele cometesse um erro grave de tradução pela falta de conhecimentos da língua estrangeira.

A competência tradutória é, assim, definida como um "levar a sério" a tradução como texto e o receptor como destinatário, assim como faria qualquer emissor de um texto. No entanto, diferente da relação estabelecida nos demais casos entre um emissor e o seu texto, a tradução não resultaria de uma necessidade comunicativa de seu emissor:

[12] Übersetzen ist für uns also primär eine textgebundene Kommunikation zwischen dem Übersetzer und einem identifizierbaren Kreis von Adressaten. Die übersetzerische Kommunikation unterscheidet sich von anderen Formen der schriftlichen Kommunikation im wesentlichen darin, dass weder die Inhalte, noch die Funktion des Textes aus einem individuellen Mitteilungsbedürfnis des Senders und Textgestalters, nämlich des Übersetzers, hervorgehen. Damit werden alle kommunikativen Funktionen - von der Funktion des Textes bis zur Funktion des einzelnen Wortes - zu Variablen, die auf den jeweiligen Kommunikationszweck hin neu zu bestimmen sind.

[O traduzir é para nós, em primeiro lugar, uma comunicação, através de um texto, entre o tradutor e um grupo identificável de destinatários. A comunicação tradutória distingue-se das outras formas de comunicação escrita essencialmente pelo fato de nem os conteúdos, nem a função do texto procederem de uma necessidade de comunicação do emissor e do criador do texto, isto é, do próprio tradutor. Com isso, todas as funções comunicativas - desde a função do texto até a função de cada palavra - tornam-se variáveis que devem ser determinadas novamente a cada caso, a partir do respectivo objetivo comunicativo.]

A partir então de uma perspectiva pragmática, Hönig e Kussmaul afirmam que frases são, via de regra, polissêmicas. Contrapostas a elas estão os enunciados, os quais, conforme explicam os teorizadores, se diferenciam delas por estarem relacionados a um evento comunicativo. Os significados dos enunciados não seriam procedentes apenas dos objetos e conceitos a que se referem, mas também da posição que adquirem num sistema - isto é, do uso associado a esse signo. Por sua vez, todo uso linguístico serviria a uma FUNÇÃo comunicativa particular. Isso significa dizer que, para o tradutor, um enunciado só teria sentido no contexto de enunciação, tendo em vista a sua FUNÇão comunicativa. Assim, para Hönig e Kussmaul, mais do que palavras e frases, são os enunciados o objeto de tradução. Em vez de nortear o processo tradutório a partir de um critério normativo precedente à tradução, eles acham mais cabível adotar um critério variável, a saber, a função comunicativa da tradução. 
Contudo, os enunciados não são tomados de forma dissociada, mas integrados num texto. O TEXTO é um objeto significativamente mais complexo que os meros enunciados. Conforme explicam Hönig e Kussmaul, ele ganha materialidade é através da língua, tendose em mente uma perspectiva tridimensional de língua, isto é, uma noção de língua que, além de associar significante e significado, forma e substância, acrescenta o nível pragmático como definidor de sentido. Para além de uma ação, considera-se o texto, nesse viés pragmático, como uma transformação, ou melhor, uma tradução.

Da linguística textual, eles evocam também a definição de texto como conjunto ordenado de instruções ao interlocutor, cabendo a este realizar essas instruções. De acordo com essa perspectiva, o receptor compreende essas instruções no contexto de sua situação comunicativa, a qual já foi antecipada pelo emissor, que formulou as instruções de modo a exercer o efeito comunicativo almejado. É interessante notar, contudo, que definir o texto como um conjunto de instruções, ao mesmo tempo, aproxima Hönig e Kussmaul de uma postura posteriormente adotada por Holz-Mänttäri (o texto como instrução), mas negada por Vermeer (o texto como informação).

Um ponto para o qual Hönig e Kussmaul chamam continuamente a atenção é a falta de diálogo entre as instâncias teóricas e práticas da tradução. Eles consideram imprescindível a uma formação de tradutores satisfatória uma teoria que considere a prática e a transmissão de estratégias de tradução. Para que a tradução exerça sua função comunicativa, seria preciso que o tradutor vislumbrasse problemas potenciais para a tradução e também elaborar estratégias para contorná-los. Esses problemas seriam provenientes muitas vezes da variedade de fatores envolvidos na tradução, intricados uns nos outros, que dificultam o agir. Assim, de modo a oferecer auxílio ao tradutor, a teoria de tradução costuma buscar regularidades no processo tradutório. Os autores observam, no entanto, que é impossível definir estratégias fixas e universalmente válidas para o processo tradutório, visto que a definição de estratégias para uma tradução particular depende da respectiva SITUAÇÃo comunicativa, em constante mudança, variando caso a caso. Por outro lado, as variáveis não seriam de todo imprevisíveis. O tradutor poderia resolver problemas de tradução, por exemplo, compreendendo a lógica interna da construção textual.

Um dos fatores que tornam a tradução um processo tão complexo é a disparidade entre a INFORMAÇÃo que desejamos veicular e o que de fato é dito, bem como entre o que é dito pelo emissor e o que compreendido pelo receptor. De fato, os significados de um texto não seriam preexistentes à comunicação, mas construídos através da relação entre emissor 
e receptor. Dentro do processo comunicativo, caberia ao receptor, em última instância, estabelecer, no contexto da situação comunicativa em que está inserido, o significado do texto - que não é necessariamente o mesmo significado que o emissor, inserido noutra situação comunicativa, tinha intenção de veicular. Ainda assim, não se pode afirmar que a correspondência entre o que o emissor diz/escreve e o que o receptor ouve/lê é de todo impossível. Segundo os teorizadores, há, sim, correspondência na maioria dos casos, mas isso só ocorre, pois o emissor procura prever a recepção do destinatário. Nesse contexto, significado não seria propriamente a "informação" por trás de uma enunciação, mas aquilo que o receptor pode entender desse enunciado. Para a Skopostheorie, o receptor de um texto procura relacionar os enunciados de um texto com a situação comunicativa em que esse receptor se encontra, isto é, tornar esse texto coerente com sua situação.

O TRADUTOR é considerado, em primeiro lugar, o receptor do TP. Assim como qualquer outro receptor de um texto, o tradutor também tentaria relacionar o texto com sua situação. Contudo, ele não é o receptor típico, tampouco o processo de recepção conduzido por ele iguala-se ao do receptor original: ao mesmo tempo em que ele simula as condições de recepção do receptor típico desse texto, compreende-o sempre com vistas à tradução. Ele estaria, portanto, numa situação comunicativa diferente do receptor original da tradução. Simular a recepção do destinatário "típico", no entanto, não seria tão simples, uma vez que o tradutor teria outro interesse com o texto e outra relação com seu emissor. Dado que a relação entre o emissor e o receptor seria responsável pela atribuição de significado ao texto, o texto teria para o tradutor um significado diferente do que teria para o destinatário original. Uma das diferenças da recepção do tradutor, em comparação com o destinatário original do texto de partida, estaria no fato de sua recepção já levar em conta a função do texto de chegada entre seus receptores. Isso demonstra que o TP não é uma estrutura pronta de significados, mas sim, uma oferta de instruções a serem realizadas conforme o interesse e a situação do tradutor. Essas dificuldades se interporiam, independente da competência linguística e cultural do tradutor.

Além de receptor do TP, ele é emissor do TC. Assim, ele precisaria ter uma clara ideia do grupo receptor a que sua tradução se destina. Sem uma noção clara de quem é o seu público, ele não poderia definir o interesse com que ele mesmo recebe o texto, pois, considerando que a recepção do tradutor é feita com vistas à tradução, o tradutor teria dificuldades em definir seu papel de receptor do texto de partida enquanto a posição de destinatário na língua de chegada não estiver preenchida. Assim, conhecer o destinatário e a 
função comunicativa que o TC deve exercer para ele seria o primeiro passo no processo tradutório.

Com base no modelo de Dieter Stein (1980) ${ }^{351}$, Hönig e Kussmaul apresentam o processo de tradução: diferente do emissor do TP, que parte de uma intenção comunicativa para chegar ao texto, o tradutor faz o caminho contrário: ele analisa o TP e, assim, identifica a intenção comunicativa do emissor, que é exercer um efeito comunicativo no destinatário - essa é, de fato, a função, o propósito do texto. Uma vez identificada a provável intenção do emissor, ele se volta aos destinatários do texto na LC e ajusta essa intenção para esse público. Em seguida, ele formula um TC que exerça a função comunicativa mais próxima possível do TP na cultura de chegada. A partir do momento que se realiza através do destinatário, a função comunicativa marca o fim do processo comunicativo.

Hönig e Kussmaul apoiam-se no modelo de Stein, mas com ressalvas. Para eles, não é imprescindível que a intenção comunicativa do emissor do TP seja mantida na tradução o máximo possível, pois tudo dependerá do destinatário. Haveria, dessa maneira, duas formas diferentes de tradução, uma pressupondo a manutenção e a outra a mudança de função, cada qual com estratégias igualmente legítimas. Essa posição afasta-os também de Katharina Reiss, que, como vimos, estabelece a fronteira entre a tradução e a adaptação no limite da manutenção da função textual entre TP e TC. A crítica da tradução não deve condenar uma tradução que tenha uma função diferente da que foi atribuída ao TP, mas, sim, um TC destinado a uma determinada função, que falhou em cumpri-la. Na crítica, identificar a função da tradução e definir seu objetivo comunicativo continua sendo o primeiro passo para o "diagnóstico". Depois disso é que vêm as análises de desvios de norma linguística, de referência semântica e dos graus de diferenciação.

O tradutor não seria, com isso, um "conversor linguístico passivo", que reproduz o conteúdo do texto tal como lá está, mas um agente com poder de decisão, que faz o intermédio entre as particularidades do TP e as necessidades do destinatário de chegada. Sua ação dependeria, contudo, das regras estabelecidas na sua relação com os destinatários da tradução, no contexto da situação deles, assim como das orientações do encargo de tradução. Definir a função do texto em LC seria tarefa do tradutor ou de seu contratante. Essa decisão deve levar em conta o contexto sociocultural, pois esse determina o que pode ser dito e, posteriormente, como dizer. Logo, observa-se que, na mesma medida em que essa

\footnotetext{
${ }^{351}$ STEIN, Dieter. Theoretische Grundlagen der Übersetzungswissenschaft. Tübingen, 1980.
} 
proposta teórica confere mais liberdade ao tradutor, também confere a ele mais responsabilidade.

Mesmo num contexto artificial como o de uma sala de aula, Hönig e Kussmaul enfatizam que numa tradução deve-se considerar o destinatário potencial e uma função para o texto traduzido, pois ao fazê-lo, o aluno insere a tradução numa estrutura comunicativa, sem a qual ele não pode definir os interesses a partir dos quais ele lerá o TP, restando como critério apenas a equivalência de conteúdo.

Segundo Hönig e Kussmaul, as diferenças socioculturais manifestas nos textos não devem ser vistas, no caso da tradução, como questões marginais. O texto, enquanto uso linguístico, é, em si, visto como parte integrante de uma sociocultura:

\begin{abstract}
[216-218] Jeder Text kann als der verbalisierte Teil einer Soziokultur verstanden werden. Es ist unmöglich, ihn aus dieser Einbettung zu lösen, wenn man nicht weiß, zu welchem Zweck dies geschehen soll. Oder umgekehrt betrachtet: Wenn ein Text-Empfänger einmal damit beginnt, die sozio-kulturelle Einbindung des verbalisierten Textes zurückzuverfolgen, so wird er - vom einen zum anderen geleitet - sich schließlich gar nicht mehr in der Lage sehen, diesen Prozess irgendwo sinnvoll zu unterbrechen.

[Todo texto pode ser compreendido como a parte verbalizada de uma sociocultura. É impossível desprendê-lo dessa posição quando não se sabe com que propósito isso deve ocorrer. Ou visto de maneira oposta: se, certo dia, o receptor de um texto começar a rastrear o vínculo sociocultural do texto verbalizado, ele então - guiado de um ponto a outro - não verá a si mesmo em posição de interromper esse processo num ponto que faça sentido.]
\end{abstract}

A língua, nesse contexto, forneceria apenas os materiais para expressar algo - o que pode ser (e é) dito, no entanto, é determinado por convenções socioculturais - ou seja, por critérios extralinguísticos.

Além disso, as determinantes socioculturais definem a forma de comunicação, o que incluem as normas e convenções de gêneros textuais. De acordo com os autores, há um vínculo entre tipo textual e situação comunicativa, na medida em que uma situação comunicativa arquetípica costuma estar associada a um tipo textual. O mesmo ocorreria com a função do texto. De fato, os gêneros textuais são definidos como a junção de fatores situacionais determinados socioculturalmente e regulados por convenções. Assim, não seria possível dizer que a situação comunicativa, tampouco as convenções ligadas a um tipo textual não apresentam diferenças entre as culturas. Nesse sentido, Hönig e Kussmaul alertam para o fato de não ser possível traduzir um texto de um determinado gênero textual sem respeitar o contexto social e as convenções textuais da cultura para que esse texto é 
traduzido. Seria possível, portanto, mover a função do texto, que ganharia forma no gênero textual. Aqui agem então especificidades socioculturais, por exemplo, nas características de um tipo textual.

Hönig e Kussmaul opõem-se à ideia, que ganhou a designação de Hipótese SapirWhorf, de que a língua é estritamente determinada pela cultura e que, assim, o que é expresso numa língua não pode ser expressa noutra. Isso significa dizer que, em certa medida, haveria a possibilidade de desprender um texto de seu contexto sociocultural para direcioná-lo a um novo público na cultura e língua de chegada. Isso é necessário, pois os próprios critérios de uso de uma língua vêm de seu contexto sociocultural.

O caminho para trazer um texto marcado por um contexto sociocultural a outro está no ponto de encontro entre a função textual do TC e os determinantes socioculturais. De acordo com a função da tradução, o tradutor pode decidir que elementos da cultura de partida podem e devem ser recuperados para que o texto exerça essa função. O grau necessário de diferenciação (al. notwendiger Grad der Differenzierung) é uma estratégia de tradução estabelecida caso a caso: o objetivo do texto determinaria o que é necessário ao TC e o que pode ser descartado. Em outras palavras: a função textual definiria o grau de diferenciação entre o contexto sociocultural da LP e da LC a se refletir no texto traduzido em todos os níveis textuais, inclusive o semântico. Nesse contexto, o processo de monossemantização de uma palavra na tradução deve evocar da palavra apenas o significado (ou os significados) necessário para que o texto exerça sua função comunicativa.

A tarefa do tradutor não seria, assim, transferir, transpor para a língua de chegada todo o potencial significativo de uma palavra, mas priorizar os significados da palavra que cumpram o objetivo comunicativo almejado. O grau necessário de diferenciação faz parte das estratégias durante o processo tradutório. O proceder estratégico do tradutor durante o processo de tradução consiste em (1) receber o texto de partida como tradutor, relacionando-o com sua situação de tradutor; (2) refinar o encargo de tradução e definir a função comunicativa do texto de chegada segundo as expectativas pragmáticas de seu destinatário; (3) a partir da função comunicativa, estabelecer o grau necessário de diferenciação a orientar também a produção do texto de chegada. A tarefa cotidiana do tradutor é refletir sobre o grau necessário de diferenciação em todos os níveis textuais, de modo que se atinja ao objetivo comunicativo idealizado pelo tradutor. Para os autores, todos os níveis textuais semântica das palavras, construções sintáticas, elocuções, etc. - devem ser traduzidos segundo a função pretendida para o texto. Isso significa que todos os níveis textuais estão 
inter-relacionados. Se um nível não faz jus à função, o texto como um todo pode deixar de ter a função que lhe é destinada.

A tradução não poderia prescindir de uma etapa cognitivo/interpretativa. Compreensão resultaria de um processo interpretativo e, assim, consciente e intencional. Como vimos, apenas os significados relevantes na situação comunicativa em questão são ativados. O significado das palavras dependeriam, em primeiro lugar, dos significados possíveis de uma palavra e, depois, do significado próprio àquela situação específica. Por outro lado, só a situação comunicativa não bastaria para definir o significado de uma enunciação, a despeito das palavras que a compõem. A interpretação, assim, fundamenta-se em componentes internos e externos do texto. A recomendação dos autores é determinar na fase de interpretação do texto o significado de uma palavra do TP no seu contexto específico.

O processo de recepção do tradutor, em oposição ao do destinatário original do texto, costuma ser interrompido, muito devido à falta de competência na língua estrangeira - o que, no final das contas, acometeria a todos os tradutores. Nesses casos, Hönig e Kussmaul apontam para a necessidade de refletir conscientemente acerca do significado de uma expressão para o texto. $\mathrm{O}$ tradutor poderia contar com dicionários para resolver questões de polissemia, escolhendo a acepção de uma palavra mais coerente com o texto. Os autores observam ainda que a polissemia é fundamentalmente potencial, mas o tradutor deve lidar com ela cotidianamente.

Quanto ao estilo textual, diferentes FATORES interferem nas escolhas tradutórias. Esses fatores incluiriam a situação, o grau de familiaridade, fatores relativos ao emissor ou à sua relação com o receptor, tempo e espaço de comunicação, origem geográfica, posição social e gênero dos interlocutores - Há também fatores ligados ao uso linguístico, por exemplo, a mídia de comunicação (oral ou escrita), quantidade de interlocutores (monólogo ou diálogo) e área de uso linguístico (refletido, p. ex., no uso de jargões profissionais).

Como pudemos observar, Hönig e Kussmaul aplicaram diferentes noções sistematizadas pela proposta teórica de Vermeer. No entanto, é importante reconhecer que o texto inaugural da teoria do skopos trazia apenas um esboço dessa teoria. Posteriormente, Vermeer expandiu suas considerações, incorporando em seu quadro teórico as contribuições de Katharina Reiss, ainda bastante influentes à época. 


\subsubsection{Hans J. Vermeer e Katharina Reiss: expandindo a teoria básica}

Os primórdios do intercâmbio entre Katharina Reiss e Hans J. Vermeer são relatados por eles em ensejos diferentes. Em 1993, numa antologia de artigos organizada por Justa Holz-Mänttäri e Christiane Nord em comemoração aos setenta anos de Reiss, Vermeer escreve um breve histórico de suas interações com a teorizadora. De acordo com Vermeer, o primeiro encontro entre eles teria sido ainda em ocasião de seu ingresso como estudante no Instituto de Tradução e Interpretação da Universidade de Heidelberg, em 1950. Ela, quase tão jovem quanto ele, teria sido uma de suas primeiras professoras, causando-lhe uma impressão marcante por veicular aos alunos não apenas conhecimentos gramaticais e vocabulares, mas também uma "postura" de vida.

Alguns anos depois, Reiss e Vermeer tornaram-se colegas de profissão. Em 1970, ela trocou a Universidade de Heidelberg pelo Departamento de Línguas Românicas da Universidade de Würzburg. Entrementes, Vermeer migrou do Instituto de Cultura Sulasiática para a área de linguística, assumindo, como vimos, a cadeira de Linguística Aplicada no campus de Germersheim da Universidade de Mainz em 1971. Vermeer dá mais detalhes sobre o reencontro deles:

\footnotetext{
Nós nos reencontramos num congresso. E desde então trabalhamos muito juntos. Em 1974, a sra. Reiss recebeu em Mainz o título de livre-docência com pesquisas sobre o "tipo textual operativo" e assumiu, um ano depois, a docência em Germersheim. Encontrávamo-nos toda semana e discutíamos intensivamente sobre a nossa área - Katharina Reiss fumando em meu sofá particular, de que a rígida administração da universidade queria me privar, e observando, com crescente nervosismo, o meu vaivém inquieto naquela sala ampla. A sensatez da sra. Reiss foi a grande responsável de que não nos perdêssemos da realidade. Não sei se eu pude, de minha parte, oferecer algo a ela, que se movia pela nossa área de atuação com muito mais confiança e segurança. ${ }^{352}$ (VERMEER, 1993, p. 1)
}

O relato de Reiss é um pouco mais lacônico. Numa revisão de seu percurso pelos estudos da tradução - e de como tornou-se parte dessa disciplina - ela explica que a oportunidade para escrever sua tese de livre-docência (al. Habilitation) teria surgido durante um

\footnotetext{
${ }^{352}$ Auf einer Tagung trafen wir uns wieder. Und haben seitdem viel zusammengearbeitet. 1974 wurde Frau Reiß in Mainz mit Untersuchungen zum "operativen Texttyp" habilitiert und übernahm ein Jahr später einen Lehrauftrag in Germersheim. Wir trafen uns allwöchentlich und diskutierten intensiv über unser Fach - Katharina Reiß auf meinem privaten Sofa rauchend, das mir eine gestrenge Universitätsverwaltung hatte vorenthalten wollen, und mein unruhiges Auf- und Abgehen im geräumigen Zimmer mit wachsender Nervosität beobachtend. Frau Reiß' besonnene Art sorgte dafür, daß die Realität nicht verlorenging. Ich weiß nicht, ob ich ihr, die sich in unserem Fach so viel sicherer und selbstbewußter bewegte, meinerseits etwas geben konnte.
} 
congresso. Após concluída a tese, recebeu o título no âmbito da área de linguística aplicada da Universidade de Mainz. Foi a partir de então que ela passou a se consolidar o seu status de estudiosa da tradução:

\begin{abstract}
Desde então - se eu me lembro corretamente - designavam-se a mim com cada vez mais frequência como estudiosa da tradução, mas só passaram a me olhar assim nos anos seguintes, enquanto eu, além de minha atividade em Würzburg, dava aula todas as semanas em Germersheim e ocupava-me - também principalmente devido à colaboração estimulante e proveitosa com H. J. Vermeer -, de modo cada vez mais intensivo, com temas relacionados aos estudos da tradução. ${ }^{353}$ (REISS, 2004, p. 275)
\end{abstract}

Da cooperação entre eles resultou o livro Grundlegung einer allgemeinen Translationstheorie [Fundamentos de uma teoria geral de translação], publicado em 1984. O livro surgiu da tentativa de articular preceitos teóricos que ambos vinham desenvolvendo isoladamente anos antes. Assim, a correlação entre tipo textual e estratégia de tradução estabelecida por Reiss foi incorporada ao quadro teórico de Vermeer na forma de uma "teoria específica" - correspondente à segunda parte da obra. Visto que, conforme a "teoria geral" de Vermeer - a que se destina a primeira parte do livro -, a equivalência não é o objetivo a ser almejado na tradução, o caso de equivalência entre as funções do TP e do TC começou a ser visto apenas como uma das relações possíveis entre os textos. Apesar dos esforços de ambos em defender a ideia de que não haveria discrepâncias entre as diferentes propos$\operatorname{tas}^{354}$, Nord (1997c, p. 12) é da opinião de que as duas partes do livro não constituem um todo homogêneo.

Em sua introdução, os autores manifestaram o objetivo de estabelecer as bases de uma teoria geral a que posteriormente pudessem vincular-se outras teorias referentes a problemas específicos da tradução. Logo, não era intenção deles formular uma teoria fechada ou concluída, mas sujeita a acréscimos vindouros ${ }^{355}$. Dado o elevado grau de abstração das contribuições advindas da Ciência da Tradução, Reiss e Vermeer afirmaram sobretudo o compromisso com a prática:

\footnotetext{
${ }^{353}$ Von da an - wenn ich mich recht erinnere - wurde ich immer öfter als Übersetzungswissenschaftlerin apostrophiert, begann mich selbst aber erst in den folgenden Jahren als solche zu betrachten, während ich zusätzlich zu meiner Tätigkeit in Würzburg allwöchentlich in Germersheim einen Lehrauftrag wahrnahm und mich - vor allem auch aufgrund der anregenden förderlichen Zusammenarbeit mit H. J. Vermeer - immer intensiver mit übersetzungswissenschaftlichen Themen auseinandersetzte.

${ }^{354}$ Cf. REISS; VERMEER, 1984/1991, p. 12.

${ }^{355}$ Ibid., p. vi.
} 
Não se trata aqui de um mero construto teórico abstrato. Antes, foi estabelecida, a todo o momento e de forma deliberada, a relação com a prática. É objetivo dos estudos da tradução não apenas examinar cientificamente a prática da translação e a problemática atrelada a ela, mas também oferecer orientação confiável e fundamentada teoricamente (...). ${ }^{356}$ (REISS; VERMEER, 1984, p. vi)

De fato, o vínculo com a prática seria, segundo os autores, condição para a existência de uma teoria, definido o conceito de teoria como a "interpretação e a associação de

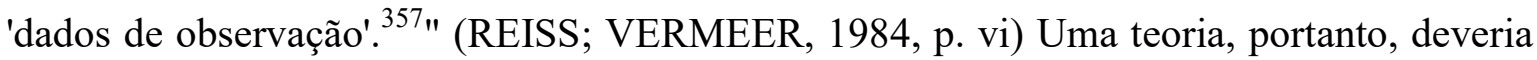
ser construída a partir de dados práticos, não de forma insular. A nosso ver, esse foi um importante ponto de ruptura frente a uma teorização mais focada às potencialidades das estruturas linguísticas do que ao falar concreto, como era característico da Ciência da Tradução.

Nesse sentido, vale ressaltar ainda que, embora a teoria do skopos tenha claramente contribuído para a constituição de um novo campo disciplinar, Reiss e Vermeer não tinham à época esse objetivo em vista: ao definirem tradução e interpretação como fenômenos tanto culturais como linguísticos, compreendendo a língua como parte de uma cultura, eles localizaram a tradução nos domínios da linguística aplicada, e essa nos domínios dos estudos culturais ${ }^{358}$. Dessa maneira, eles almejaram não o rompimento com a linguística, mas com a abordagem linguística da tradução, a partir de uma nova compreensão do traduzir e do interpretar.

Após concluída sua livre-docência, Katharina Reiss estabeleceu-se na Universidade de Mainz, atuando como diretora do Departamento de Línguas Românicas da instituição até a sua aposentadoria, em 1988. Em 1994, atuou como professora visitante na Universidade de Viena. Durante o curso "Aspectos dos Estudos da Tradução", Reiss proferiu oito palestras sobre diferentes questões envolvendo a disciplina. Posteriormente, o conteúdo dessas palestras foi organizado e publicado por Mary Snell-Hornby e Mira Kadric (REISS, 1995). Durante sua carreira, percorreu o mundo ministrando cursos e palestras em defesa de seu modelo funcionalista com raízes na equivalência tradutória.

Em 2002, recebeu o título honorífico da Universidade de Genebra. No mesmo ano, participou da criação da Fundação Eugen Biser em Munique, dedicada a promover diálogo do cristianismo com outras religiões e culturas. Participou da curadoria da instituição de

\footnotetext{
${ }^{356}$ Es handelt sich dabei nicht um ein bloß abstraktes Theoriegebäude; vielmehr wurde vorsätzlich immer wieder der Bezug zur Praxis hergestellt. Translationswissenschaft will nicht nur die Praxis der Translation und die damit zusammenhängende Problematik wissenschaftlich ergründen, sondern eben dieser Praxis auch theoretisch durchgedachte zuverlässige Hilfestellung leisten (...).

${ }^{357}$ Unter "Theorie" versteht man die Interpretation und Verknüpfung von "Beobachtungsdaten".

${ }^{358}$ REISS; VERMEER; 1984, p. 1.
} 
2002 a 2018. Faleceu em Munique no dia 16 de abril de 2018, um dia antes de seu nonagésimo quinto aniversário.

Por sua vez, Vermeer mostrou-se bastante atuante na divulgação do funcionalismo dentro e fora da Alemanha. Suas ações difusoras incluem a organização do periódico TEXTconTEXT dentre os anos de 1986 a 2001 e dos volumes da série th (translatorisches handeln) entre os anos de 1989 e 1990 . Além disso, conta com uma produção bibliográfica voltada a outros temas ligados à linguística, à lusitanística, à indologia, ao ensino de línguas e aos estudos da tradução, em especial à historiografia das traduções.

Após a sua aposentadoria, em 1992, Vermeer ainda atuou como professor visitante na Turquia. Em 2008, retornou a Universidade de Mainz, onde permaneceu até 2010, recebendo o título de doutor honorário da instituição no mesmo ano, no dia 17 de janeiro. No dia 4 de fevereiro de 2010, Vermeer faleceu em sua casa em Heidelberg.

\subsubsection{Análise}

De início, nota-se que Vermeer retoma algumas escolhas terminológicas do estudo anterior: o termo translação [Translation] é novamente empregado como hiperônimo para designar os processos de tradução [Übersetzen] e de interpretação [Dolmetschen]. O termo translato [Translat], por sua vez, designa o resultado desses processos e translador [Translator] o agente da translação, esteja ele atuando como tradutor ou como intérprete. A necessidade de uma redefinição terminológica é salientada pelos autores na introdução do livro. Segundo afirmam, os novos termos são decorrentes de uma proposta de mudança paradigmática:

Culturas - e as línguas nelas - são como paradigmas (KUHN, 1978). Novos paradigmas usam uma nova terminologia ou conferem novos significados à terminologia anterior. Culturas/línguas não apenas sucedem umas às outras, elas também existem concomitantemente às outras, da mesma forma que paradigmas em estágios diferentes no que tange à percepção e perceptibilidade do "mundo". As translações, mesmo entre línguas com estruturas de superfície semelhantes (ex. alemão - francês - inglês), só são possíveis se já conhecemos os paradigmas das culturas/línguas (as "teorias" da percepção de mundo das respectivas culturas/línguas). ${ }^{359}$

\footnotetext{
359 Kulturen - und Sprachen in ihnen - sind wie Paradigmen (Kuhn 1978). Neue Paradigmen benutzen eine neue Terminologie bzw. die alte Terminologie in neuer Bedeutung. Kulturen/Sprachen folgen nicht nur einander, sie sind
} 
Assim, a referência às mudanças paradigmáticas, além de explicar algumas circunstâncias em torno da translação, faz alusão à proposta dos teorizadores de uma nova perspectiva de um novo "paradigma" - no âmbito dos estudos da tradução, sugerindo, assim, a ruptura com os axiomas defendidos pela abordagem orientada pela equivalência. A nova terminologia teria a função de sinalizar novos conceitos e novos pontos de vista para fenômenos existentes na translação. Nesse ponto, cumpre reiterar que o objetivo da dupla era romper com a abordagem linguística de tradução, não com a linguística.

Ainda que trate da translação de modo geral, Vermeer menciona os fatores distintivos entre tradução e interpretação: a tradução caracteriza-se pelo fato de partir de um texto veiculado por um suporte fixo e permanente - seja ele escrito ou oral - e resultar num texto que possa ser posteriormente conferido e corrigido pelo tradutor. A interpretação, por sua vez, resulta num texto efêmero, de ocorrência única, com possibilidades remotas de controle e correção posteriores. Vermeer enfatiza, contudo, que um texto só pode ser considerado uma tradução se puder ser corrigido pelo próprio tradutor e não apenas por uma instância externa - por exemplo, um revisor. Apenas quando satisfeitas essas condições, uma translação pode ser designada como tradução ou interpretação. Dessa forma, Vermeer procura evitar a associação comumente feita entre a tradução e o meio escrito, a interpretação e o meio oral, uma vez que ambos os meios podem veicular traduções e interpretações.

A TRANSLAÇÃO é, também aqui, definida como um processo de transferência. Por transferência, compreende-se a transformação de um signo, enquanto elemento de um sistema de signos que possui potencial para forma e função, noutro signo, também elemento de um sistema de signos. Vermeer descreve três diferentes formas de transferência: (1) transferência entre ações não verbais; (2) transferência entre uma ação não verbal e uma ação verbal; (3) transferência entre ações verbais. Em princípio, a translação corresponderia ao terceiro caso. Contudo, ainda que Vermeer esteja restrito ao meio verbal em suas considerações, traz uma definição de translação ampla o bastante para incluir ações não verbais.

A definição de translação não se limita à transferência de ações verbais, mas, sim, agrega outros elementos. Segundo Vermeer, a translação é um "tipo especial de transferência cultural" (REISS; VERMEER, 1984, p. 13). É uma forma de transferência entre cultu-

natürlich auch gleichzeitig nebeneinander, aber auch hier wie Paradigmen unterschiedlichen Zustandes bezogen auf die Erfassbarkeit und Erfassung von "Welt". So sind Translationen, auch bei ähnlicher Oberflächenstruktur (z. B. deutsch französisch - englisch) erst möglich, wenn man die Kultur- bzw. Sprachparadigmen (die "Theorien" der Welterfassung der betreffenden Kulturen/Sprachen) schon kennt. 
ras que, a partir de um TP, produz um TC. A essa definição estão atrelados alguns conceitos fundamentais, a começar pelos conceitos de LÍNGUA e de cultura:

\begin{abstract}
[81-82] Eine Sprache (= Lekt) ist Element einer Kultur. Die Sprache ist das konventionelle Kommunikations- und Denkmittel einer Kultur. Kultur ist die in einer Gesellschaft geltende soziale Norm und deren Ausdruck.

Kultur ist all das, "was man wissen, beherrschen und empfinden können muss, um beurteilen zu können, wo sich Einheimische in ihren verschiedenen Rollen erwartungskonform oder abweichend verhalten" (Göhring 1978, 10). ${ }^{360}$

[Uma língua (=leto) é elemento de uma cultura. A língua é o meio convencional de comunicação e de raciocínio de uma cultura. Cultura é a norma social em voga numa sociedade, bem como a expressão dessa norma.

Cultura é tudo aquilo "que é preciso saber, dominar e sentir para estar em condições de avaliar em que aspectos os membros daquela sociedade estão se comportando, em seus diferentes papéis, em conformidade ou em discordância com as expectativas" (Göhring, 1978, p. 10).]
\end{abstract}

Nota-se pelo excerto que a cultura é definida como o arcabouço de conhecimentos e habilidades que moldam o comportamento de uma dada sociedade. Nesse contexto, a língua está incluída nesse arcabouço. Vermeer, contudo, expande o conceito de língua, identificando-o como um conceito polissêmico:

[43-44] Sprache ${ }_{1}$ kann Oberbegriff für alle Mittel sein, mit denen die Mitglieder einer Gemeinschaft untereinander in Kommunikation treten. Solche Kommunikationsmittel sind Zeichen, die über sich hinaus auf anderes hindeuten. Sprache ist ein "semiotisches Gefüge" aus solchen Zeichen. ${ }^{361}$

[Lingua ${ }_{1}$ pode ser um termo genérico para todos os meios através dos quais os membros de uma comunidade se comunicam uns com os outros. Esses meios de comunicação são signos que apontam para algo além deles mesmos. A língua é um "sistema semiótico" composto desses signos.]

Vermeer enumera três características essenciais a essa definição de língua: (1) ser constituída por signos dotados de significado, independente se esses signos são verbais ou não verbais; (2) constituir-se num sistema, através do qual os signos estabelecem uma relação de determinada natureza uns com os outros; (3) ser capaz de estabelecer comunicação entre indivíduos, sendo necessário, para tanto, que o signo tenha função supraindividual, isto é, ele deve ser compartilhado por diferentes indivíduos.

Um segundo significado para o conceito de língua é derivado do primeiro:

\footnotetext{
${ }^{360}$ REISS; VERMEER, 1984, p. 26.

${ }^{361}$ Ibid., p. 20.
} 
[58-62] Sondersorte des vorgenannten Sprachbegriffs [ $\uparrow$ 2.2.1.] ist die menschliche Lautsprache (und deren Ableitungen): Sprache ${ }_{2}=$ "Lekt".

Unmittelbare ("sekundäre") Ableitungen aus menschlicher Lautsprache sind z. B. die Schriftsprache, die Fingersprache Taubstummer. ${ }^{362}$

[Forma especial do conceito de língua previamente citado é a linguagem verbal humana (e seus derivados): Lingua $_{2}=$ "leto".

Derivações imediatas ("secundárias") da linguagem verbal humana são, p. ex., a linguagem escrita e a datilologia da comunidade surda-muda.]

Vermeer observa que, ao longo da história, a linguagem escrita pôde adquirir certa autonomia ante a linguagem oral. Dessa forma de língua também derivam, de modo mais direto, as placas e sinais. Por "leto", no entanto, não se teria em mente apenas as línguas nacionais, mas também as distinções em níveis mais particulares: as línguas regionais (dialetos), restritas a um grupo social (socioleto) ou até mesmo linguagem própria de um indivíduo (o idioleto). Um terceiro significado para o conceito diz respeito ao que normalmente designamos por "linguagem formal", "linguagem coloquial", estando, assim, mais associado a questões de estilo textual.

Além de se tratar de uma transferência entre culturas diferentes, a translação envolveria uma ação criativa, que resultaria num texto voltado a uma comunidade receptora diferente da comunidade a qual o texto de partida esteve originalmente voltado. Cumpre, assim, esmiuçar o conceito de TEXTO defendido pela vertente funcionalista:

[28-29] Der Mensch lebt in der Welt des Alltags, der Gedanken, Traditionen, Konventionen, in (für ihn) realen und "fiktiven" Welten. Nehmen wir an, im Kontinuum der "möglichen Welten" sage/schreibe jemand etwas Sinnvolles an einem bestimmten Ort zu einer bestimmten Zeit: Er produziert (als "Produzent") einen "Text".

Ein solcher Text wird zu einem (mehr oder minder) bestimmten Zweck für jemanden produziert. Er ist eine "Handlung", die man im Hinblick auf einen anderen (oder mehrere andere) zur Erreichung eines Zwecks ausführt. Mit einer solchen Handlung will man mit einem oder mehreren anderen in Gedankenaustausch usw. - wir sagen allgemein: in "Interaktion" - treten. Soweit es sich um primär sprachliche Interaktion handelt, sprechen wir von "Kommunikation". ${ }^{363}$

[O ser humano vive no mundo de rotinas, pensamentos, tradições, convenções, em mundos reais (para ele) e ficcionais. Consideremos que, no contínuo dos "mundos possiveis", alguém diga/escreva algo significativo num determinado local e num determinado tempo: ele produz (na posição de "produtor") um "texto". Um texto assim é produzido por alguém com um objetivo (mais ou menos) determinado. Ele é uma "ação", realizada tendo uma pessoa (ou várias pessoas) em vista para atingir a um objetivo. Com uma ação dessa natureza almeja-se a troca de pensamentos com uma ou mais pessoas - digamos de modo geral: almeja-se uma "interação". Contanto que se trate de uma interação linguística, falamos de "comunicação".]

${ }^{362}$ REISS; VERMEER, 1984, p. 21.
${ }^{363}$ Ibid., p. 18. 
Um texto teria origem a partir do momento em que alguém, no contínuo de "mundos possíveis", diz ou escreve algo. O texto resultaria de uma ação produtiva, voltada a um determinado objetivo. Aqui, Vermeer introduz uma ideia a ser mais bem desenvolvida posteriormente por Holz-Mänttäri: texto é uma ação, que se realiza no contexto de outra ação (ou outras ações) com uma meta comum em vista. A produção de texto não seria, assim, uma ação isolada, tampouco ocorre no vácuo:

[1-2] Eine Handlung ist offensichtlich von inneren und äußeren situationellen Umständen der Produktion abhängig: Man kann nicht zu jeder Zeit und an jedem Ort x-beliebiges sagen oder schreiben; man würde $u$. U. nicht verstanden oder sozialen Sanktionen ausgesetzt (z. B. dem Urteil, man sei nicht recht bei Trost). Produzent und Rezipient (Empfänger) eines Textes gehören als "Kommunikationspartner" zur "Situation". Da beide neben ihrer sozial-kulturellen Einbettung in eine menschliche Gemeinschaft gleichzeitig eine individuelle "Geschichte" haben, gehen abgesehen von der Einmaligkeit von Ort und Zeit eines Geschehens auch diese individuellen Merkmale in die Textproduktion und -rezeption ein. $^{364}$

[Uma ação é evidentemente dependente de circunstâncias internas e externas à situação de produção: não se pode dizer ou escrever algo qualquer a qualquer tempo e em qualquer lugar; fosse assim, correr-se-ia o risco de não ser compreendido ou de sofrer sanções sociais (por exemplo, não ser considerado muito bem da cabeça).

O produtor e o receptor de um texto faz parte de uma "situação" na posição de "interlocutores". Tendo em vista que ambos, além de estarem inseridos socioculturalmente numa comunidade humana, terem, ao mesmo tempo, uma "história" individual, além da singularidade de espaço e tempo de um evento, também essas características individuais interferem na produção e na recepção do texto.]

Nota-se, portanto, que a ação é, em certa medida, determinada pela situação em que ocorre. A SITUAÇÃo é composta pelo "contexto cultural prévio, condições atuais do ambiente de interação, circunstâncias psicológicas e sociais dos interlocutores e a relação entre eles" $^{365}$ (REISS; VERMEER, 1984, p. 18). Com isso, Vermeer esboça, ainda de forma incompleta, um modelo de comunicação, enumerando fatores referentes aos indivíduos participantes do processo comunicativo e a circunstâncias exteriores. Nesse modelo, um produtor produz um texto a um receptor (produtor e receptor são, portanto, "interlocutores"). Ao produzir o texto, o produtor pratica uma ação, essa dependente de circunstâncias situacionais (em que se incluem tempo e lugar) e circunstâncias referentes a uma cultura ou a culturas.

\footnotetext{
${ }^{364}$ REISS; VERMEER, 1984, p. 18.

365 [Die "Situation" besteht aus] kulturellen Vorgegebenheiten, aktuellen äußeren Gegebenheiten und inneren und sozialen Bedingungen der Kommunikationspartner und ihres Verhältnisses zueinander. (Tradução revisada a partir da tradução para o inglês, cf. REISS, VERMEER, 2014, p. 17)
} 
No centro de gerência do processo de translação está o TRANSLADOR. No modelo comunicativo acima exposto, o translador desempenha ao mesmo tempo o papel de receptor do TP e de produtor do translato. Entretanto, seu trabalho iria além do trabalho de um "mediador linguístico": por um lado, ele não apenas exerceria a função de instância intermediária entre dois indivíduos, mas atuaria criativamente; por outro, ele não estabeleceria o intermédio apenas entre línguas, mas entre culturas. Para tanto, considera-se imprescindível que ele conheça os paradigmas das línguas e culturas envolvidas, isto é, a visão de mundo característica dessas línguas e culturas:

[21] Ein Translator muss also die Ausgangs- und Zielkulturen kennen, er muss "bikulturell" sein. ${ }^{366}$

[Um translador precisa então conhecer as culturas de partida e de chegada, ele precisa ser "bicultural".]

Vermeer opõe-se à concepção de translação como um processo de comunicação em duas fases. A seu ver, adeptos dessa concepção consideram o significado constante, universal e, portanto, passível de translação. Nas teorias que embasam essa noção de translação, língua e cultura estão dissociadas; a translação ocorre apenas entre línguas, pressupondo-se que há entre as línguas níveis seguros de correspondência. Por se restringir ao nível linguístico, o processo estaria limitado a operações formais. Além disso, admite-se como possível a hipótese da translação perfeita.

As duas fases caracterizam-se por uma primeira fase de recepção e compreensão do TP e por uma segunda fase de reprodução "fiel" do sentido do TP na LC, num processo pautado na transcodificação. O translador atuaria como um "relay": ele receberia um texto na LP e o reformularia num texto na LC; o que ocorre em sua mente, contudo, permanece desconhecido. Entende-se que o texto produzido por ele deverá ser recebido numa situação equivalente à situação de recepção do TP e que os fenômenos culturais constituem-se como uma fonte de dificuldades, não como algo inerente ao processo. Ademais, só seriam admitidos os casos em que o TP e o translato exercessem a mesma função.

Vermeer defende que a translação não está limitada a operações linguísticas de transcodificação. Assim, ele favorece uma noção de translação como "informação" acerca de uma comunicação prévia. Em sua proposta, assim observa, a interpretação do translador interfere no texto resultante do processo:

\footnotetext{
${ }^{366}$ REISS; VERMEER, 1984, p. 26.
} 
[41] Wir möchten also noch einmal betonen: ein Text ist kein Text, sondern wird als je der und der Text rezipiert und, z. B. durch einen Translator interpretiert, in je eigener Weise tradiert.

Mit anderen Worten:

Es ist nicht möglich, Translation als Transkodierung toute simple der/einer Bedeutung [vgl. Vermeer 1972, 61-71] eines Textes zu verstehen. Translation setzt Verstehen eines Textes, damit Interpretation des Gegenstandes "Text" in einer Situation voraus. Damit ist Translation nicht nur an Bedeutung, sondern an Sinn/Gemeintes [vgl. Vermeer 1972, 221], also an Textsinn-in-Situation, gebunden. $^{367}$

[Queremos enfatizar mais uma vez: um texto não é um texto, mas é recebido como um texto assim ou assado e, p. ex., é interpretado por um translador e é transmitido de uma forma própria.

Expresso de outra forma:

Não é possível entender a translação como transcodificação pura e simplesmente do/de um significado (cf. Vermeer, 1972, p. 61-71) de um texto. Translação pressupõe a compreensão de um texto e, com isso, a interpretação do objeto "texto" numa situação. Dessa forma, a translação está vinculada não apenas ao significado, mas ao sentido/intencionado (cf. Vermeer, 1972, p. 221), ou seja, a sentido textual em situação.]

Isso ocorre, pois o sentido do texto é construído no momento de recepção. A interpretação do texto, assim, deve levar em conta a situação comunicativa em que o texto está inserido, uma vez que a situação contribui na construção de sentido de um texto. $O$ texto não tem uma natureza imanente, mas sua natureza depende da situação.

Para Reiss e Vermeer, a perspectiva de translação como "informação" acerca de um TP representa uma abordagem própria, distinta da perspectiva de tradução como um processo comunicativo em duas etapas. Nesse contexto, cumpre, no entanto, elucidar o que se entende por INFORMAÇÃO:

[30] Information wird hier insofern als Oberbegriff für Sprachfunktionen gebraucht, als ein Produzent einem intendierten Rezipienten(kreis) formal und situationsbedingt mitteilt (genauer: mitteilen möchte [dazu $\uparrow$ 3.5.1.]), was und wie er seine Äußerung verstanden wissen möchte. ${ }^{368}$

["Informação" é empregado até aqui como termo genérico para funções da linguagem, quando um produtor comunica (ou, mais exatamente, deseja comunicar [sobre isso $\uparrow$ 3.5.1.] a um (grupo) receptor, de modo formal e a depender da situação, o que de seu enunciado ele quer que seja entendido e como.]

As funções da linguagem referidas no excerto são as "funções linguísticas" descritas, entre outros, por Karl Bühler e Roman Jakobson. Com base no exemplo de um discurso de Cícero, Vermeer argumenta que, uma vez que esse discurso, depois de proferido, ganha forma escrita, há uma mudança no processo comunicativo: não se trata, assim, de uma extensão

\footnotetext{
${ }^{367}$ REISS; VERMEER, 1984, p. 58.

${ }^{368}$ Ibid., p. 61.
} 
do público a que se dirige a comunicação, pois os próprios objetivos de comunicação alteram-se ou são acrescidos por outros. A escrita do texto representaria um segundo evento comunicativo, que informaria um novo público acerca do primeiro evento comunicativo. Desse modo, a translação não poderia ser vista como a continuação da informação com outro código; ela poderia "apenas informar acerca de uma informação de partida" (REISS; VERMEER, 1984, p. 64).

A translação informa acerca de fenômenos ligados a um TP, sejam esses fenômenos referentes a seu sentido, a seu efeito ou a sua forma. Por "informação", entende-se aqui também como um momento intencional da parte do produtor no processo comunicativo. A informação poderia ser verbal ou não-verbal. É requisito que seja intencional, logo não se poderia equacionar "informação" com "comunicação" (um gesto não intencional pode ser comunicativo, sem representar uma informação).

Vermeer reconhece que houve outras propostas em seu tempo que defenderam a translação como informação. Todavia, segundo afirma, ainda que elas tenham demonstrado que a transcodificação não abarca todos os casos de translação, elas teriam falhado em mudar por completo a perspectiva da translação - de uma visão retrospectiva, que se fundamenta nas instruções dadas pelo TP, para uma visão prospectiva, atenta às necessidades do receptor do translato. Ele justifica a crítica a essas propostas, demonstrando que, ao contrário do que afirmam, a translação não deve necessariamente almejar à equivalência entre funções dos textos.

Ele observa que, para uma teoria de translação que a compreende como uma "informação" acerca de outro texto, dois fatores são de extrema importância: a interpretação que o translador tem do TP e a função que o translador escolhe para o TC. Essa função não precisaria corresponder à função atribuída ao TP. Segundo Vermeer, a mudança de função textual é consequência das distâncias culturais, espaciais e temporais entre a produção do TP e a sua translação. Culturas e línguas seriam estruturas próprias, nas quais os elementos estariam em relação de modo particular, e seus valores seriam definidos ante essa relação. Além da mudança linguística, a translação envolveria uma reconfiguração tanto da relação entre a situação comunicativa e o que dessa situação ganha manifestação no texto quanto dos valores da cultura de partida e da cultura de chegada. Os textos, como espécimes de uma cultura e língua, também seriam estruturas compostas de elementos diversos, cada qual com um determinado valor decorrente de sua relação com os demais elementos. Ao 
transferi-lo para outra estrutura cultural e linguística, os valores de seus elementos também mudariam.

A mudança de função não seria só possível, como é o caso mais frequente, sendo parte de um processo natural e inevitável. Para Vermeer, é mais simples compreender que a mudança de função é possível se mantivermos em mente que a translação, em vez de continuação de um processo comunicativo anterior, desencadeia um novo processo comunicativo numa nova situação comunicativa.

A nova perspectiva também afeta a própria definição de texto:

[33-34] Ein Text ist sozusagen ein Informationsangebot an einen Rezipienten seitens eines Produzenten. (Die Art des Angebots hängt von den situationellen Umständen $a b$, wie soeben dargelegt wurde.) Der Translator formuliert einen Zieltext, der als Text somit ebenfalls ein Informationsangebot an einen Rezipienten ist. Ein Translat ist somit als Informationsangebot bestimmter Sorte über ein Informationsangebot darstellbar.

[Um texto é, por assim dizer, uma oferta de informação a um receptor por parte de um produtor. (O tipo de oferta depende das circunstâncias situacionais, como exposto anteriormente.) O translador formula um texto de chegada, que, enquanto texto, é também uma oferta de informação a um receptor. Um translato pode, assim, ser representado como uma oferta de informação de um tipo específico sobre uma oferta de informação.]

Ao definir o texto e, consequentemente, também o translato como oferta de informação, o teorizador espera legitimar uma tomada de decisões criativa e responsável por parte do translador.

Vermeer se opõe à noção de texto (e translação) como uma instrução - em contraste com o que fazem Hönig \& Kussmaul e Holz-Mänttäri. Segundo explica, a linguística da instrução estabelece que as palavras e os enunciados são instruções da parte de um produtor e dirigidas a um receptor, de quem se espera uma reação específica. Dessa maneira, produtor e receptor estariam em posição assimétrica, conferindo ao produtor o poder de decidir quando e como dar uma instrução.

Para ele, considerar o texto uma instrução aproxima a noção de translação a um processo de comunicação em duas fases, pois estaria pressuposta uma única forma de compreender o texto, o que tornaria possível obter uma tradução perfeita. O teorizador, como vimos, enfatiza que cada receptor compreende um texto e reage a ele de uma forma diferente. Um texto, assim, não seria uma instrução, pois não haveria como prever, com absoluta certeza, qual seria a reação do receptor, tampouco se sua reação seria como desejada. Um texto pode ser interpretado de diferentes formas e, dependendo da interpretação, 
voltar-se a uma situação de recepção específica. Assim, é inconcebível entender a informação veiculada pelo texto como uma instrução pura e simples: um texto não estabelece suas normas de interpretação e de uso, mas sim, é oferecido segundo algumas normas vigentes de comportamento. Caberia ao receptor aceitá-la ou não, o que o colocaria em condição comparável a do produtor, sendo tão responsável quando ele na produção de sentido do texto.

Considerando, então, que não existe apenas uma translação possível, tampouco que haja a translação ideal, entende-se a translação como uma operação não reversível, na medida em que em apenas alguns casos a retrotradução resulta num texto idêntico ao TP. Essa possibilidade torna-se ainda mais remota se houver mudança de função do translato em relação ao TP.

Vermeer observa que, sobretudo nas culturas ocidentais, uma translação informa seu receptor acerca de uma comunicação prévia mediante a simulação ou "imitação": o translato "representa" o TP na cultura de chegada. Essa forma de representação costuma ser interlingual e intercultural e, salvo os casos de tradução literária, não se identifica explicitamente como uma translação. Não à toa, Reiss (1971) já sugeria que traduções não fossem avaliadas pelos críticos como originais, mas como textos derivados, a partir do cotejamento.

Como vimos, uma importante consequência de se definir translação como informação foi deslocar o olhar da língua e da cultura de partida para a língua e a cultura de chegada. Afinal, só se oferece uma informação se houver a possibilidade de ela ser interessante ao receptor. As expectativas do receptor do translato seriam decisivas em definir como traduzir ou interpretar. Dessa forma, seria necessário ter uma estimativa da situação de recepção do translato. Ainda assim, a translação não é um fenômeno exclusivo da cultura de chegada, mas também da cultura de partida, pois começa nela e nela pode também se refletir.

Vermeer explica que o produtor cria o texto sempre com um receptor em vista, ainda que não tenha exata precisão de quem é esse receptor. De modo análogo, o translador não conhece com exatidão seu receptor ou as expectativas comunicativas de seu público. Assim, ele agiria orientado pela estimativa que faz acerca das expectativas desse público, com base nas informações de que dispõe acerca desse grupo receptor. Em algumas ocasiões, parte dessas informações viriam do próprio contratante. 
Enquanto uma ação parte de uma determinada situação e é orientada pela estimativa que se tem acerca dessa situação, uma translação partiria de uma situação em que já há uma "ação prévia", isto é, o TP. Assim, a questão não seria se ocorrerá a ação e como, mas sim, se a ação terá continuidade, o que dela terá continuidade e como. Segundo Vermeer, as ações podem ser descritas como reações (num sentido mais amplo) a determinadas situações. Conforme se observa uma recorrência em determinadas situações, reconhecem-se também padrões de ação. Em torno dessas recorrências constroem-se as normas: normas são prescrições para comportamentos recorrentes em determinados tipos de situação.

O sucesso de uma translação estaria em adequar-se ao contexto comunicativo em que o receptor se encontra, o que significa adequar-se às regras de transmissão de informação de uma dada cultura e língua e para uma determinada função. Uma ação deve tanto ser adequada à situação como deve visar a atingir a um determinado objetivo, por vezes alterando essa situação. Tendo em vista que o translato e o TP são instrumentos comunicativos inseridos em situações comunicativas diferentes, as regras que orientam a concepção de uma oferta de informação acerca de uma oferta de informação difeririam daquelas que orientam a concepção de uma oferta de informação primária, uma vez que subjazem em diferentes culturas noções distintas de translação.

Vermeer enfatiza outro aspecto da translação de seus escritos anteriores: a translação como ação intencional. Uma ação seria sempre voltada a um objetivo. Condição para a ação seria a escolha, por parte do agente, dentre várias variantes possíveis numa dada cultura e numa dada situação. Entretanto, ainda que não haja uma única forma de agir e, assim, a escolha é uma parte importante do processo, mais importante do que como agir seria atingir ao objetivo almejado, o que vale também à translação:

[351] Die Dominante aller Translation ist deren Zweck. ${ }^{369}$

[Dominante em toda a translação é seu objetivo.]

A função do translato é, assim, definida não apenas como um critério relevante à translação, mas o principal critério a orientar as decisões do translador - uma função que, no entanto, precisa ser justificada. Como vimos, no contexto de sua proposta teórica, Vermeer denomina essa função através do termo skopos. "Objetivo", "função" e "skopos" são, nessa obra, quase sempre empregados como sinônimos. Não obstante, "função" tem dupla signi-

\footnotetext{
${ }^{369}$ REISS; VERMEER, 1984, p. 96.
} 
ficação na obra de Vermeer: como sinônimo de "skopos" e como codependência regular entre dimensões.

Na translação, intenção e interpretação tornam-se, aqui, componentes da função: o emissor faz uma avaliação da ação, determina seu "valor" através de sua intenção, isto é, da função almejada para a ação; o receptor, por sua vez, o faz a partir de sua interpretação dessa ação, ou seja, do que interpreta ser a função com que o emissor agiu. No que tange à função, Vermeer observa ainda que (1) os fins justificam os meios; (2) é possível haver mais de um objetivo (logo, não há só um objetivo para a translação e, assim, não há só uma forma de se traduzir); (3) mesmo numa translação, não há só um objetivo, de modo que se deve priorizar quais são os objetivos centrais e quais são secundários; (4) o objetivo precisa ser justificável. No que tange ao primeiro ponto, Vermeer afirma que "o que se faz é secundário em vista do objetivo do fazer e de sua realização" (REISS; VERMEER, 1984, p. 98). Esse foi um dos aspectos da teoria funcionalista mais criticados, pois alude a uma postura pouco ética, tornando-se objeto de revisão teórica por outros autores (ver 4.1.6.1).

A função do translato é definida conforme as expectativas do receptor:

[8-10] Der intendierte Rezipient ("Adressat") kann als Sondersorte (Untermenge) des Skopos beschrieben werden. Die Durchführung einer Interaktion hängt von den Relationen zwischen den Interaktionspartnern mit ab. (...)

Wir formulieren als Unterregel zur Skoposregel:

Der Skopos ist als rezipientenabhängige Variable beschreibbar (soziologische Regel). ${ }^{370}$

[O receptor pretendido ("destinatário") pode ser descrito como tipo especial (subconjunto) do skopos. A efetivação de uma interação depende também das relações entre os interlocutores. (....)

Formulamos essa como regra subordinada à regra do skopos:

O skopos pode ser descrito como variável dependente do receptor. (regra sociológica)]

Esses seriam os principais critérios na definição de estratégias para a translação.

Caberia ao translador a decisão do quê, de quando e como traduzir ou interpretar, com base em seus conhecimentos da cultura de partida e da cultura de chegada - nesse sentido, é também decisão do translador, em primeiro lugar, aceitar o trabalho. Como mencionado, a compreensão e interpretação do TP por parte do translador seria imprescindível. Condição para que ele chegue a essa compreensão é (1) ter experiências semelhantes ou complementares às dos interlocutores, (2) ter uma aculturação semelhante e (3) ter uma disposição semelhante. Essas pré-condições, além de indicarem a necessidade de o translador ser bi-

\footnotetext{
${ }^{370}$ REISS; VERMEER, 1984, p. 101.
} 
cultural, também indicam que ele não precisa conseguir traduzir/interpretar "tudo" que consta no TP.

Além de orientar-se segundo a função do translato, a translação almejaria a coerência intratextual, i. e., o texto deveria ser coerente em si e deveria parecer coerente ao receptor com a sua situação comunicativa, a mensagem deve fazer sentido para o receptor no contexto de sua situação:

[75] Die vom Translator produzierte Nachricht (das Translat) muss mit der Zielrezipientensituation kohärent interpretierbar sein. ${ }^{371}$

[A mensagem produzida pelo translador (o translato) precisa ser interpretada como coerente com a situação do receptor de chegada.]

Ao afirmar que a translação segue as mesmas condições que qualquer outra interação, Vermeer refere-se ao fato de se buscar, na interação, a comunicação entre as partes e de se avaliar o sucesso de uma interação pela ausência de protestos.

Além da coerência intratextual, o translador deve buscar a coerência intertextual, ou seja, a coerência entre TP e TC:

[403] Eine Translation strebt nach kohärentem Transfer eines Ausgangstexts. ${ }^{372}$

[Uma translação almeja à transferência coerente de um texto de partida.]

Essa coerência dependeria de como o translador compreendeu o TP, assim como depende do skopos do translato. De Vermeer, ela recebe a designação "fidelidade" (al. Fidelität).

A regra da fidelidade não é violada com a mudança de função. Segundo Vermeer, é possível que as funções do TP e do TC difiram-se por três razões: (1) uma tradução, enquanto ação produtiva, pode servir a outros propósitos; (2) pode haver uma mudança de skopos de modo a atender a um interesse do receptor; (3) mudança de contexto cultural e de valores na translação, isto é, diferença de valores entre a cultura de partida e a cultura de chegada.

Na segunda parte do livro, Reiss orienta sua teorização de modo a alinhar-se ao quadro teórico proposto por Vermeer. De acordo com a teorizadora, a língua só interessa ao tradutor enquanto "meio de comunicação" de tudo aquilo que uma cultura deseja expressar. Não se trata, portanto, de uma forma unidimensional de comunicação, que possa

\footnotetext{
${ }^{371}$ REISS; VERMEER, 1984, p. 113.

${ }^{372}$ Ibid., p. 114.
} 
ser igualada a outras formas de comunicação, isto é, a outras línguas: ao relacionar os conceitos de língua e cultura, a língua ganha um novo plano de complexidade: elas são moldadas pelos contextos culturais, que posteriormente se refletem nelas.

Segundo observa, o translador, no processo de translação, está ao mesmo tempo dentre os elementos da cultura de partida e da cultura de chegada. A translação seria orientada segundo as expectativas do translador (e de seu contratante) acerca do público receptor e de sua recepção. Por se tratar de outra oferta de informação para um novo público, o translador não seria capaz de oferecer a mesma informação que o produtor do TP. Assim, ele tentaria oferecer tantas informações quanto julgar necessárias ao público de chegada. Nesse sentido, ele não ofereceria menos ou mais informações, mas sim, informações diferentes de formas diferentes.

Aqui vemos também alguns temas que são característicos de propostas anteriores de Katharina Reiss, agora revistos. A teorizadora dedica-se a explorar o caso específico da tradução. A seu ver, uma tradução deve ser adequada, entendendo-se adequação como "a relação entre texto de chegada e texto de partida com a consideração a um objetivo (skopos) que se busca com o processo de translação" (REISS; VERMEER, 1984, p. 139). Assim, considera-se um translato adequado se as escolhas em torno de sua produção obedecerem a um objetivo; para que ele tenha "sentido", é necessário que ele seja reconhecido como voltado a um objetivo. Um translato, como vimos, não precisa ter a mesma função do TP correspondente. Assim, a crítica de tradução deveria nortear-se pela função do translato.

Contudo, conforme observa Reiss, uma tradução equivalente deve exercer uma função correspondente a seu TP:

[151-152] Äquivalenz bezeichne eine Relation zwischen einem Ziel- und einem Ausgangstext, die in der jeweiligen Kultur auf ranggleicher Ebene die gleiche kommunikative Funktion erfüllen (können). (...) Äquivalenz ist in unserer Definition Sondersorte von Adäquatheit, nämlich Adäquatheit bei Funktionskonstanz zwischen Ausgangs- und Zieltext. ${ }^{373}$

[Equivalência designaria uma relação entre um texto de chegada e um texto de partida que (pudessem) atingir na respectiva cultura em niveis comparáveis uma função comunicativa igual. (...) Equivalência é, em nossa definição, tipo especial de adequação, mais especificamente adequação com continuidade de função entre texto de partida e texto de chegada.]

\footnotetext{
${ }^{373}$ REISS, VERMEER, 1984, p. 139s.
} 
A partir do emprego do conceito de equivalência, nota-se que Reiss ainda se mostra adepta à noção de equivalência, ainda que de forma ressignificada. Diferente de sua posição anterior, aqui o fato de um TC não exercer a mesma função do TP não o desvalida como tradução.

Reiss observa que há uma variedade de fatores que determinam a constituição linguística de um texto; fatores referentes à situação comunicativa determinam a forma do texto tendo em vista o contexto em que o texto será usado no processo comunicativo. Com a mudança de contextos comunicativos, como ocorre na tradução, entrariam ainda outros fatores em jogo. Assim, ela esboça um modelo de FATORES, representando esquematicamente a estrutura de condicionantes para a translação. Nesse modelo estão inclusos: $o$ missor do TP $\left(\mathrm{E}_{1}\right)$, que, ao escrever o $\mathrm{TP}$, desencadeia um processo comunicativo $\left(\mathrm{C}_{1}\right)$; o tradutor, ao mesmo tempo receptor do TP $\left(\mathrm{R}_{1}\right)$ e emissor do $\mathrm{TC}\left(\mathrm{E}_{2}\right)$, que desencadeia outro processo comunicativo $\left(\mathrm{C}_{2}\right)$, derivado do primeiro; o texto ou oferta de informação de partida $\left(\mathrm{OI}_{1}\right)$ e o texto ou oferta de informação de chegada $\left(\mathrm{OI}_{2}\right)$, pertencentes a um gênero textual e que podem ser classificados como determinado tipo textual; o contexto situacional, que inclui os tempos $(\mathrm{T})$ e os lugares (L) de produção e de recepção, o contexto sociocultural e, evidentemente, o receptor do TC $\left(\mathrm{R}_{2}\right)$. Na figura 1 , vemos um esquema com todos esses fatores, inclusive como eles se influenciam.

A autora observa que todos esses fatores estão entrelaçados, formando uma rede, influenciando-se mutuamente e determinando tanto a produção do TP quanto do translato. É com base nessa rede que o tradutor compreenderá o TP, relacionando sempre elementos intratextuais e extratextuais. Na tradução, o tradutor confronta-se com um texto (de partida) em que aparecem os nós e as linhas dessa rede na forma de signos linguísticos, bem como as relações entre eles e com o "mundo". Os signos linguísticos orientam a compreensão textual e, associados com o conhecimento de mundo dos leitores, servem como indicadores da influência dos vários fatores nas escolhas do autor do texto. Ao se traduzir, devese reorganizar as relações dos traços semânticos e formais de uma língua noutra, de modo a um texto na língua de chegada atingir à mesma função comunicativa de um texto correlato na língua de partida. A mudança é, assim, essencial para que se haja equivalência - quando ela é exigida. 


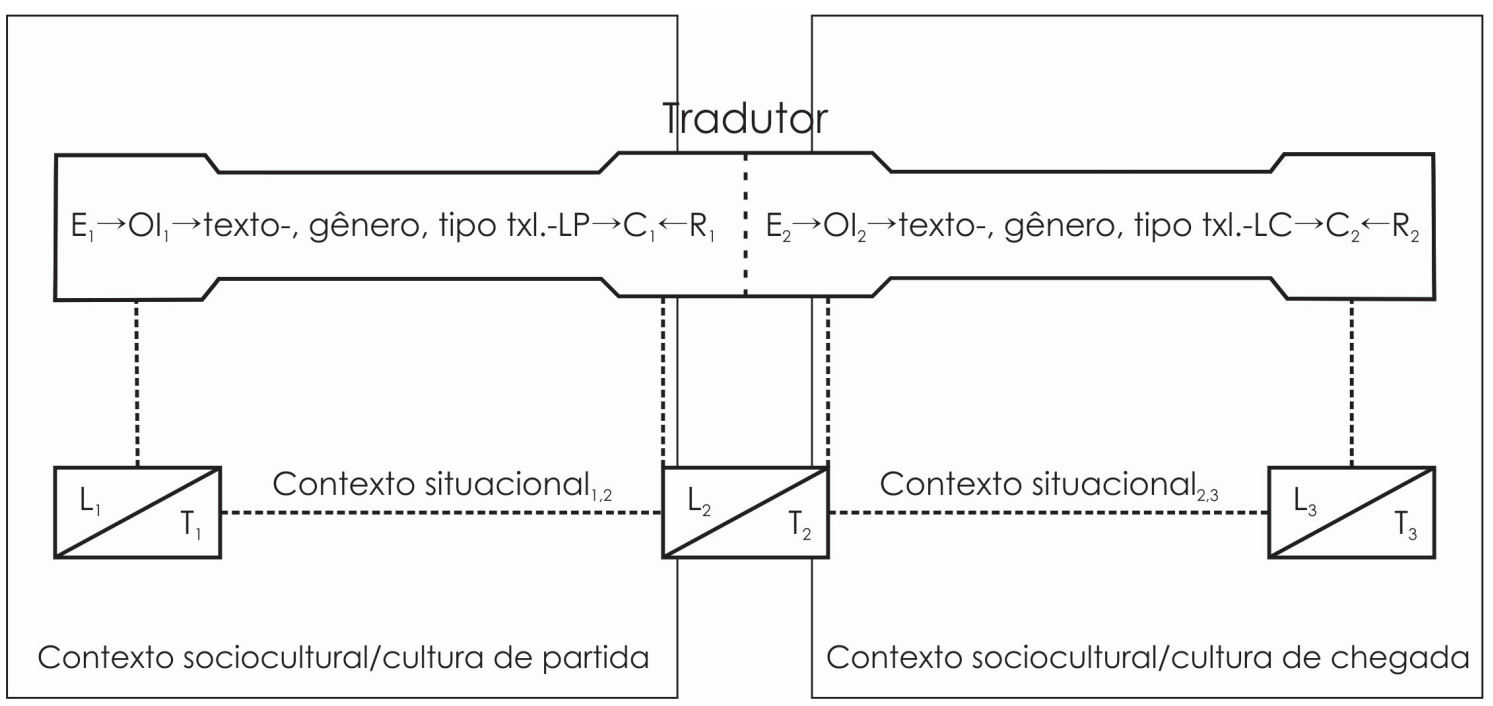

Gráfico 13: Modelo de fatores de Katharina Reiss (REISS; VERMEER, 1984, p. 148).

Reiss destaca o tradutor como fator decisivo e como centro do processo tradutório. O resultado da tradução depende, entre outros, da competência translacional do tradutor, de sua compreensão do $\mathrm{TP}$, de seus parâmetros de qualidade subjetivos, no que concerne à veiculação de conteúdo e forma, seu envolvimento com o texto e sua decisão sobre qual tipo de tradução ele pretende produzir. Faz parte das competências de um tradutor saber selecionar e hierarquizar os fatores mais predominantes num TP, sobretudo quando se almeja a uma tradução equivalente. Aqui, o que é dito sobre o tradutor serve também às equipes de tradução.

Apesar da ênfase à equivalência em sua proposta, Reiss propõe uma tipologia tradutória que apresenta diversas modalidades de tradução com diferentes tipos de adequação. O primeiro tipo é a versão interlinear, baseada na tradução palavra por palavra do $\mathrm{TP}$, sem adaptar à sintaxe da LC. O segundo tipo, a tradução literal, difere-se da versão interlinear por obedecer às regras sintáticas da LC. O terceiro tipo, a tradução filológica, corresponde ao postulado de Schleiermacher de "levar o leitor ao autor", visando a informar o seu leitor como o autor do texto de partida comunicou-se com seus leitores. Segundo Reiss, há um ideal de tradução "comunicativa" em seu tempo, compreendendo essa como uma informação acerca de uma oferta de informação mediante a "imitação" da oferta de informação de um texto de partida com os recursos da língua de chegada, de modo a não parecer uma tradução. Para ela, apenas traduções desse tipo podem ser consideradas equivalentes. Por 
fim, a tradução "criativa" refere-se aos casos em que, no TP, há determinados conceitos, modos de pensar, concepções e objetos ainda inexistentes na cultura de chegada. Assim, criam-se novos modos de pensar, conceitos, concepções e objetos e, com isto, também novas possibilidades de formação de palavras. A adequação ocorre através dos maiores esforços tradutórios e equivalência para esse tipo de tradução não seria possível - posto que o conhecimento prévio subjacente ao texto existe na cultura de partida, mas não na cultura de chegada e, assim, não há a constância da função.

Outro tema de interesse de Katharina Reiss são os gêneros e tipos textuais. Conforme explica-nos a autora, um texto num evento comunicativo é dotado de conteúdo, forma e sentido. Ao mesmo tempo em que ele é, em si, um "indivíduo" com características próprias, o texto está mais ou menos vinculado a um "gênero textual", compreendido como um tipo de ato de fala que, após repetidos usos em constelações de comunicação de natureza igual, apresenta padrões de uso de linguagem e de organização textual comuns numa mesma cultura. Os gêneros textuais se constituiriam através de regularidades, de padrões do comportamento linguístico em determinadas situações comunicativas, ocasionadas pela recorrência desses padrões. Essas características do gênero textual são designadas como convenções.

As convenções de um gênero textual são influenciadas pelo contexto cultural. Para Reiss, parte da identidade de um texto consiste em sua classificação num gênero textual, visto que, no momento de recepção de um texto, os gêneros textuais desempenham o papel de sinal de reconhecimento, desencadeador de expectativas e sinal de orientação para a compreensão do texto.

A convencionalidade está, segundo Reiss, na própria essência de uma língua: uma língua só pode servir à comunicação se na respectiva sociedade houver um acordo acerca dos usos linguísticos. Além disso, as convenções (1) estão sujeitas a mudanças no tempo; (2) não se aplicam a todos os usos linguísticos, mas servem para elucidar e orientar os usos singulares de determinados falantes e, ainda assim, promover comunicação; (3) constituem regras não escritas que determinam a produção textual; (4) são regras menos rígidas do que as regras gramaticais; (5) apesar de sua flexibilidade, refletem as atitudes em constante mutação de uma cultura ante os processos e objetos de comunicação. Naturalmente, por convenções, Reiss tem em vista sobretudo as convenções textuais, definidoras de tipos e gêneros textuais. 
Nem sempre os textos possuem uma classificação muito distinta, podendo textos de um determinado gênero incluir trechos textuais de outro gênero. Nesses casos, o tradutor não poderia estar familiarizado apenas com as convenções de um determinado gênero textual, mas deveria levar em conta as convenções textuais da cultura de chegada no que concerne a todos os gêneros envolvidos. Não obstante, Reiss explica que não se pode exigir do tradutor conhecimento profundo das convenções de todos os gêneros textuais, apenas que ele esteja ciente de que essas convenções existem nas duas culturas e que elas podem ser distintas, sendo necessário tomar contato com elas nas duas culturas.

Reiss observa que a pesquisa de gêneros textuais deve considerar a ancoragem do texto com a situação comunicativa - e com tudo que aí se inclui, por exemplo, o papel do produtor e do receptor na comunicação - visto que todos os processos de constituição e compreensão do texto de determinados gêneros textuais baseiam-se em regularidades do uso linguístico, nos níveis sintático, semântico e pragmático. Ainda que nas sociedades haja a taxonomia textual através da divisão de gêneros textuais, para a tradução e a crítica tradutória, Reiss acha mais produtivo recorrer a uma tipologia textual útil à tradução. Assim, ela recupera de trabalhos anteriores essa contribuição aos estudos da tradução.

Para estruturar sua tipologia textual, a teorizadora recorreu às funções do signo linguístico enumeradas por Bühler. Como vimos, a língua, segundo Bühler, pode exercer três diferentes funções, cada qual vinculada a uma relação estabelecida com o signo linguístico: (1) a relação do signo com o objeto referido por ele (função de representação); (2) a relação do signo com o falante (função de expressão) e; (3) a relação do signo com o ouvinte (função de apelo). Em última análise, segundo a concepção de Reiss, embora as convenções textuais sejam distintas culturalmente, as línguas teriam em comum o fato de o signo linguístico exercer essas mesmas funções, tornando-as "invariantes" no processo tradutório.

Embora um texto seja formado por signos linguísticos, e signos linguísticos, segundo Bühler, tenham funções próprias, os textos seriam mais do que a somatória de seus signos linguísticos - isto é, não se poderia identificar a função de um texto examinando a função dos signos que o compõem. Nem um só texto teria apenas uma só função: há partes do texto que podem ter funções diferentes. Assim, a classificação é feita segundo a função textual predominante no texto. Se é objetivo do tradutor produzir uma tradução equivalente ao TP, ele deveria definir suas estratégias de tradução de acordo com o tipo de texto que ele tem diante de si para traduzir. 


\subsubsection{Justa Holz-Mänttäri: a teoria da ação translacional}

O ano de 1984 foi reconhecidamente um ano marcante para a história do funcionalismo. Além de ter sido o ano em que foi publicado o manifesto funcionalista de Hans J. Vermeer e Katharina Reiss, vieram a público também as considerações teóricas de Justa Holz-Mänttäri, desenvolvidas durante seu doutoramento na Finlândia e reunidas no livro Translatorisches Handeln: Theorie und Methode [Ação translacional: teoria e método].

Nascida em Hamburgo em 1934, Holz-Mänttäri estudou a língua finlandesa na cidade natal, após desistir do curso de botânica e zoologia. Ela relata que o ensino do finlandês concentrava-se muito mais em parâmetros linguísticos do que culturais:

Em 1960, fui à Finlândia. Já havia cursado estudos fino-ugrianos na universidade em Hamburgo. O ensino tratava então de estruturas linguísticas; ocasionalmente se lia, nunca se falava. Também se aprendia quase nada sobre o estilo de vida e a cultura, que eram bastante diferentes dos alemães. ${ }^{374}$ (HOLZ-MÄNTTÄRI, 2012, p. 78)

Com a migração para a Finlândia, Holz-Mänttäri começou a trabalhar no GoetheInstitut de Helsinque. Em 1961, ela também iniciou uma nova atividade profissional: designer de textos para clientes que queriam textos em alemão a partir de textos em finlandês. Ela justifica a designação autoatribuída, afirmando que "design" evoca uma forma de trabalho livre e criativa, mas que também enfatiza a responsabilidade do profissional pelo produto de sua atividade. Já no primeiro ano de trabalho ela teria convencido seus superiores de que a responsabilidade pelos textos produzidos por ela deveriam recair sobre ela enquanto especialista. Ainda assim, ela observa que nunca teve um aprendizado formal no âmbito da tradução, tendo adquirido as competências necessárias para a atividade na prática.

Em 1971, Holz-Mänttäri dirigiu-se a Roland Freihoff, então diretor do Instituto de Tradução e Interpretação da Universidade de Tampere, Finlândia, com um portfólio resultante de dez anos de atuação profissional como designer de textos em busca de desenvolver um magister - um trabalho pós-graduação que, assim como o mestrado, qualifica o estudante para o doutorado. Ele então a colocou na posição de leitora na universidade, com a

\footnotetext{
3741960 ging ich nach Finnland. Finno-Ugristik hatte ich in Hamburg an der Universität studiert. Dabei ging es um Sprachstrukturen, gelesen wurde gelegentlich, gesprochen nie. Auch über die ja sehr von der deutschen verschiedenen Lebensweise und Kultur erfuhr man kaum etwas.
} 
condição de que ela escrevesse o magister no período de um ano - o que ela fez no âmbito da teoria literária e estética. Seu segundo magister, requerido na Finlândia para se qualificar para o doutorado, ela o fez no Instituto de Letras Germânicas. Graças a esses trabalhos, ela conquistou uma cadeira de Tradução e Interpretação nas universidades de Tampere e de Turku, com a condição de receber o título de doutora num prazo de dois anos, sob a orientação de Lauri Seppänen. O resultado dessa pesquisa foi organizado no livro Translatorisches Handeln, tema de nossa análise.

Segundo Holz-Mänttäri, à época praticamente não havia materiais teóricos nas bibliotecas das universidades finlandesas sobre os estudos da tradução. Assim, ela foi em busca de recursos em outros lugares. Uma das atitudes tomadas em busca de recursos foi sua filiação ao comitê dedicado à prática e ao ensino da translação da Associação Alemã de Tradutores e Intérpretes (Bundesverband der Dolmetscher und Übersetzer - BDÜ). Embora tenha se inscrito com o intuito de aprender mais para o trabalho em sua tese sobre a teoria e o método da ação translacional, logo ficou claro a ela que seriam suas experiências profissionais e docentes que contribuiriam ao comitê, não o contrário.

Nessa busca, ela também relata de um estágio de permanência em Saarbrücken, pago com uma bolsa do DAAD (Deutscher Akademischer Austauschdienst - Serviço Alemão de Intercâmbio Acadêmico), para se aprofundar na produção teórica no âmbito dos estudos da tradução da Alemanha. Foi nessa época que ela teve contato com a produção teórica de Vermeer. Ela observa que Vermeer e ela desenvolviam, desde os anos 1970, abordagens teóricas e metodológicas para a translação, sem no entanto terem conhecimento um do outro. Quando ela pediu a seu mentor, o professor da Universidade de Saarland, Wolfram Wilss, para debater com ela sobre as teses que ela havia encontrado, Wilss encaminhou-a diretamente a Vermeer na Universidade de Mainz-Germersheim:

\footnotetext{
Bastou um telefonema e, numa tarde de domingo, lá estava eu a caminho do apartamento de Vermeer em Heidelberg. Conversamos sem parar. Até a meianoite, Hans Vermeer andou de um lado para o outro e sua esposa abasteceu-nos com chás finos da cozinha indiana. Nós debatedores tínhamos, cada qual, suas próprias concepções teóricas e experiências práticas - Hans Vermeer, sobretudo como intérprete em Portugal. Eu exercia a profissão autônoma de designer de textos na Finlândia, sobretudo no âmbito do comércio exterior, mas também em muitas outras áreas - com permissão especial do reitor de minha universidade. Para Hans J. Vermeer, essas experiências eram novas. Mas com a receptividade que lhe era própria, também para o novo, discutimos o que poderíamos e deverí-
} 
amos agregar a nossas aulas e de que forma. Em nossa única publicação conjunta trabalhamos com discussões prolongadas. ${ }^{375}$ (HOLZ-MÄNTTÄRI, 2012, p. 79s.)

Holz-Mänttäri considerou Vermeer um importante interlocutor, que não apenas acompanhava suas reflexões, mas também oferecia uma nova perspectiva. A sinergia entre as propostas de ambos é evidente no prefácio de Translatorisches Handeln, em que declara que a obra é uma contribuição aos esforços de Reiss e Vermeer (1984), mas tomando outros caminhos e através de outros meios, a saber, através da fundamentação de competências cooperativas e comunicativas do indivíduo para a ação translacional ${ }^{376}$. Vermeer depois teria sido sugerido pelo orientador de Holz-Mänttäri, Lauri Seppänen, a compor a banca de defesa de seu doutorado, pois, conforme o próprio, Vermeer seria àquela época um dos professores mais importantes da área.

Durante a atividade docente, Holz-Mänttäri teria se confrontado com um sistema de formação de tradutores e intérpretes norteado por critérios subjetivos e por quadros metodológicos advindos da linguística e da linguística textual, os quais, a seu ver, teriam pouco a contribuir. Como observa, o ensino estava bastante distante do que era feito na prática da translação:

\begin{abstract}
Na prática pode-se, via de regra, chegar a um consenso numa conversa com um cliente sobre suas necessidades e sobre como satisfazê-las. No entanto, na formação nos então chamados institutos de línguas na Finlândia era preciso, por exemplo, convencer os linguistas de que também o uso de ferramentas como dicionários e bibliotecas com textos de uma determinada especialidade em pesquisas era um componente indispensável da prática profissional e, portanto, também deveria integrar exercícios no contexto de uma ação construtiva. É espantoso que isso não era algo óbvio. O exemplo banal mostra o status quo da compreensão que se tinha à época da tradução e da interpretação profissionais. ${ }^{377}$ (HOLZMÄNTTÄRI, 2012, p. 67)
\end{abstract}

375 Ein Anruf genügte, und ich war an einem Sonntagnachmittag unterwegs zu Vermeers Wohnung in Heidelberg. Wir redeten und redeten. Bis nach Mitternacht lief Hans Vermeer im Zimmer auf und ab, und seine Frau versorgte uns mit feinem Tee aus der indischen Teeküche. Wir Disputanten hatten je eigene theoretische Vorstellungen und praktische Erfahrungen - Hans Vermeer vor allem als Dolmetscher in Portugal. Ich war als freiberufliche Textdesignerin in Finnland vor allem im Außenhandel aktiv, aber auch in vielen anderen Bereichen - mit Sondergenehmigung des Rektors meiner Universität. Für Hans J. Vermeer waren diese Erfahrungen neu. Doch mit der ihm eigenen Offenheit, auch für Neues, diskutierten wir, was auf welche Weise in unsere Studiengänge eingebracht werden könnte und sollte. An der einzigen gemeinsamen Veröffentlichung arbeiteten wir mit ausgedehnten Diskussionen.

${ }^{376}$ HOLZ-MÄNTTÄRI, 1984, p. 5 et seq.

${ }^{377}$ In der Praxis lässt sich im Gespräch mit dem Kunden in der Regel ein Konsens über den Bedarf und die Bedarfsdeckung erreichen. In der Lehre an den damals noch so genannten Spracheninstituten in Finnland galt es aber zum Beispiel, die Linguisten davon zu überzeugen, dass auch der Umgang mit Werkzeugen wie Wörterbüchern und Fachbibliotheken bei Recherchen ein unabdingbarer Bestandteil der professionellen Praxis ist und daher Bestandteil von Übungen im Kontext von konstruktivem Handeln zu sein hat. Erstaunlich, dass das nicht selbstverständlich war. Das banale Beispiel zeigt den damaligen Status quo des Verständnisses für professionelles Übersetzen und Dolmetschen. 
Segundo a teorizadora, déficit da mesma natureza pôde ser identificado nas teorias de tradução à sua época, as quais não seriam suficientes para fornecer fundamentos necessários para a didática da translação. A falta de vínculo entre as esferas teórica, prática e didática da translação resultaria na perpetuação, sobretudo na mente dos contratantes, de uma noção de translação semelhante aos exercícios de tradução comuns em aulas de língua estrangeira, baseados em palavras isoladas e frases desconexas. Essa noção de translação alimentaria o pré-conceito acerca da atividade profissional e obrigaria o translador, à custa de seu tempo e energia, a explicar a cada novo cliente a natureza do seu trabalho.

Conforme explica Holz-Mänttäri, as sociedades modernas (ou, pelo menos, o mundo ocidental capitalista) estão organizadas por uma estrutura de divisão de trabalho conduzido por especialistas. Como forma de assegurar o trabalho especializado, elas teriam criado instituições de formação, que acumulariam também a tarefa de desenvolver a pesquisa científica no campo:

\begin{abstract}
Uma comunidade cumpre essa tarefa ao criar instituições de formação. A elas é dada a tarefa de elaborar, através de pesquisa, as condições para uma base teórica e uma organização metodológica e de, mediante o emprego didático dos resultados relevantes da pesquisa, formar especialistas que façam jus à sua função com competência teórica específica e qualificação pragmática. Essa tarefa deve referir-se, ao mesmo tempo, à própria instituição científica, posto que ela mesma, por sua vez, precisa de especialistas que tragam consigo um conceito de ação voltado à pesquisa e ao ensino que seja da mesma constelação de demanda e oferta, voltados à pesquisa e ao ensino. Ela [a instituição] necessita formar-se a si mesma $^{378}$. (HOLZ-MÄNTTÄRI, 1984, p. 164)
\end{abstract}

O mesmo princípio aconteceria com tradutores e intérpretes. A missão de conceber os fundamentos teóricos para a prática profissional e a didática da translação teria sido conferida aos estudos da tradução (referidos aqui através do termo Translatologie) ${ }^{379}$. Contudo, o que Holz-Mänttäri observa em sua época é a produção de conhecimento teórico sem qualquer aplicabilidade:

A partir de uma perspectiva translatológica, a qual de fato representa um aspecto ou um dos papéis no complexo sistêmico comum, é possível constatar como status quo o fato de que, até agora, faltava em grande parte do campo científico a orientação teórica e pragmática de especialistas: não havia um perfil científico,

\footnotetext{
${ }^{378}$ Diese Aufgabe löst eine Gemeinschaft, indem sie Ausbildungsinstitutionen schafft. Ihnen ist aufgegeben, durch Forschung die Bedingungen für eine theoretische Basis und eine methodologische Organisation zu erarbeiten und durch didaktische Umsetzung von relevanten Forschungsresultaten funktionsgerechte Experten mit sachtheoretischer Kompetenz und pragmatischer Qualifikation auszubilden. Diese Aufgabe ist gleichzeitig auf die eigene wissenschaftliche Institution zu beziehen, die ja ihrerseits Experten mit dem forschungs- und lehrebezogenen Handlungskonzept derselben Bedarfs- und Angebots-Konstellation braucht. Sie muss sie selbst ausbilden.

${ }^{379}$ HOLZ-MÄNTTÄRI, 1984, p. 92.
} 
nenhum conceito de ação de translatologia. Uma consequência disso é que, até agora, também faltava em grande parte do campo profissional a orientação teórica e pragmática de especialistas: não havia um perfil profissional, nenhum conceito de ação de translação. E a última consequência disso é que, no âmbito profissional, o portador de demanda enquanto não técnico no campo de especialidade age sem orientação, isto é, não de forma funcional; de fato, seu papel não consiste de maneira alguma em investigar os fundamentos. Portanto: Faltavam claras noções do padrão de cooperação translacional e de suas inerentes possibilidades $^{380}$. (HOLZ-MÄNTTÄRI, 1984, p. 165, grifos no original)

A única possibilidade de dissolução do status quo estaria em fomentar mudanças no campo científico. Nesse contexto, Holz-Mänttäri contribui com fundamentos teóricos e metodológicos para a translação, formulados a partir da sistematização de fatores comuns ao fenômeno da translação ${ }^{381}$. A importância de se oferecer não apenas um quadro teórico, mas também um quadro metodológico, estaria em viabilizar a aplicação dos preceitos teóricos no ensino e na prática de translação e, assim, afastar da teoria o perigo da esterilida$\mathrm{de}^{382}$.

A ação translacional teria sua razão de ser graças à capacidade humana de comunicação e à referida organização social pela divisão do trabalho ${ }^{383}$. De acordo com HolzMänttäri, a capacidade comunicativa pertence aos aparatos humanos fundamentais e dela é feito uso quando há a necessidade elementar de comunicação. Nesse contexto, a ação translacional teria seu lugar na interação humana diante da necessidade de comunicação para além de uma barreira cultural. Ademais, a existência humana não é autônoma, o que implica a necessidade de cooperação e de organização ${ }^{384}$.

O translador assumiria, assim, o posto de especialista na translação (al. Translations-Experte); outra pessoa, o posto de portador de demanda. Essa divisão de trabalho é vista por Holz-Mänttäri de modo co-operativo, no qual dois ou mais indivíduos atuam orientados por uma meta comum. Para dar suporte à sua teoria, Holz-Mänttäri recorre a teori-

\footnotetext{
${ }^{380}$ Aus translatologischer Sicht, die ja einen Aspekt oder eine der Rollen im Gesamtgefüge repräsentiert, ist zum Status quo festzustellen, dass im Wissenschaftsbereich theoretische und pragmatische Orientierung der Experten bisher weitgehend fehlte: Es gab kein Wissenschaftsprofil, kein translatologisches Handlungskonzept. Eine Folge ist, dass auch im Praxisbereich die theoretische und pragmatische Orientierung des Experten bisher weitgehend fehlte: Es gab kein Berufsprofil, kein translatorisches Handlungskonzept. Und der letzte Folgeschritt ist, dass im Praxisbereich der Bedarfsträger als Nicht-Fachmann im Sachgebiet orientierungslos, also nicht funktionsgemäss, handelt; zu seiner Rolle gehört es ja keinesfalls, die Grundlagen zu erforschen. Ergo: Es fehlten klare Vorstellungen vom translatorischen Kooperationsmuster und den darin liegenden Möglichkeiten.

${ }^{381}$ HOLZ-MÄNTTÄRI, 1984, p. 17.

${ }^{382}$ Ibid., p. 162.

${ }^{383}$ Ibid., p. 164.

${ }^{384}$ Ibid., p. 23.
} 
as sistêmicas e a teoria da ação de Rehbein (1977), bem como a noções da Skopostheorie $^{385}$

O exercício de uma atividade profissional responsável sempre foi o objetivo de Holz-Mänttäri, não apenas em sua produção teórica, mas também em sua atividade docente. Segundo relata, em suas aulas os alunos deveriam não apenas traduzir, mas descrever as etapas adotadas para a resolução de problemas. A seu ver, a tarefa mais importante de seus alunos era identificar casos problemáticos, solucioná-los e relatá-los em sala de aula. Dessa forma, seria possível despertar a consciência do próprio trabalho e posteriormente utilizar esse aprendizado para lidar com clientes, pessoas com conhecimentos na área e colegas de trabalho, além de também descrever o próprio proceder.

Acima de tudo, Holz-Mänttäri vê como parte integrante da tarefa do translador o "colocar-se no lugar do outro", constituindo, em sua proposta teórica, a fase da transferência:

\begin{abstract}
O termo "translação", do lat. transferre, designa um pretérito, uma ação concluída, na ação translacional a transferência mental antecipadora em situações possíveis de vida e de ação de outros. Assim surgem textos feitos sob medida cheios de vida, os quais, como portadores de mensagem, "inflamam", por assim dizer. Dominar ou assimilar línguas, assuntos e culturas fazem parte da competência específica da profissão, assim como saber escrever partituras e ter habilidade com os dedos sobre as teclas de um piano, sozinhos, não fazem de alguém um compositor. O som e a vibração internos querem ganhar vida, antes mesmo que possam ganhar expressão e registro. $\mathrm{O}$ "ter o coração em algo" é - quando coloco um disco para tocar - o que move até a minha cachorrinha a "cantar junto" internamente - e também externamente, como mostra claramente seu rabinho balançando. A vida é movimento. Um movimento autônomo, que vem do coração. Qualquer outra coisa é apenas manipulação de marionetes. Também no âmbito da produção textual. ${ }^{386}$ (HOLZ-MÄNTTÄRI, 2012, p. 82)
\end{abstract}

Em 1991, um grave acidente teria sido a causa para o afastamento da autora do mundo acadêmico. Contudo, ela continua aperfeiçoando sua teoria, estabelecendo a associação entre a ação translacional e a epistemologia evolutiva.

\footnotetext{
${ }^{385}$ HOLZ-MÄNTTÄRI, 1984, p. 23 et seq.

${ }^{386}$ Der Terminus ,Translation“ von lat. transferre bezeichnet ein Perfekt, eine vollzogene Handlung, im Translatorischen Handeln den antizipierenden geistigen Transfer in mögliche Lebens- und Handlungssituationen Anderer. So entstehen lebensvolle Designtexte, die als Botschaftsträger sozusagen ,zünden'. Dass man Sprachen, Sach- und Kulturwissen beherrscht oder sich aneignen kann, gehört zur fachlichen Kompetenz des Berufs. Auch das Notenschreiben oder die Fingerfertigkeit am Klavier machen noch keinen Komponisten. Das innere Klingen und Schwingen will erlebt sein, bevor es ausgedrückt und aufgezeichnet werden kann. Das Mit-dem-Herzen-dabei-Sein ist es, was - wenn ich eine Schallplatte auflege - selbst meine Dackelin bis zum ,Mitsingen“ innerlich ,bewegt" - und äußerlich, denn ihr Schwanzwedeln zeigt es deutlich an. Leben ist Bewegung. Eigenständige, aus dem Herzen aufsteigende Bewegung. Alles andere ist Manipulation von Marionetten. Auch im Textbaufach.
} 


\subsubsection{Análise}

O conceito de ação translacional [Translatorisches Handeln] é central na proposta teórica de Justa Holz-Mänttäri, haja vista que ela o elege para intitular seu livro seminal. Todavia, assim que iniciamos a incursão na teoria, a ação translacional revela-se uma noção bastante complexa, devido à variedade de novos conceitos envolvidos em sua definição. Sendo assim, optamos por antes abordar alguns deles, a começar pelo conceito de $a$ ção.

Em busca de uma definição para "ação", Holz-Hänttäri recorre, dentre outros, às reflexões de Bronislaw Malinowski. De acordo com o antropólogo polonês, uma ação, no contexto das relações humanas numa dada cultura, surge de uma necessidade. Sua função é, portanto, satisfazer essa necessidade através da cooperação com outras pessoas, do uso de ferramentas, do consumo de recursos etc. Ainda segundo Malinowski, para atingir um objetivo, alcançar uma meta, é necessário que as pessoas se organizem ${ }^{387}$.

A fim de explicar de que forma os seres humanos se organizam nas sociedades modernas, Holz-Mänttäri recupera ao conceito de "sistema" (al. Gefüge) introduzido por B. A. Serebrennikov. Um sistema seria composto por elementos e pelas relações entre eles. A rede de relações entre elementos recebe a denominação de estrutura. Apenas o conjunto de estruturas e de elementos formariam os sistemas. Visto que uma ação se organiza através de um sistema, ela seria também constituída de elementos e relações:

[7] Handeln setzt das Vorhandensein eines motivierten Aktanten voraus, der ein Gesamtziel erreichen will. Handeln hat den Zweck, Sachverhalte zu verändern und findet in einer Situation statt. Die genannten Faktoren sind Elemente eines Systems. Zwischen ihnen bestehen Beziehungen sowie Zusammenhänge, die sie funktional strukturieren (Serébrennikow 1977, 6ff). Erfolg hat eine Handlung, wenn sie aus der Sicht des Aktanten ihren Zweck erfüllt hat, also funktionsgerecht war. ${ }^{388}$

[Agir pressupõe a presença de um actante motivado que deseja alcançar uma meta comum. Agir tem como propósito alterar estados de coisas e ocorre numa situação. Os fatores citados são elementos de um sistema. Entre eles há relações, bem como conexões, que eles estruturam funcionalmente (SERÉBRENNI$K O W, 1977$, p. 6s.). Uma ação é bem sucedida quando ela, na visão dos actantes, tiver atingido seu objetivo, ou seja, quando fizer jus a sua função.]

\footnotetext{
${ }^{387}$ HOLZ-MÄNTTÄRI, 1984, p. 27.

${ }^{388}$ Ibid., p. 29.
} 
A partir do exposto, algumas considerações sobre o conceito de ação podem ser feitas. Em primeiro lugar, segundo Holz-Mänttäri, uma ação viria a alterar um estado de coisas. De fato, conforme a definição da própria autora, uma ação é uma "atividade voltada a um objetivo, a qual, após a comparação de um estado atual com um estado ideal, é executada de modo a alcançar o estado ideal almejado sob determinadas condições e numa determinada situação" ${ }^{389}$ (HOLZ-MÄNTTÄRI, 1984, p. 29s.). Com isso, em consonância com o que postulam Reiss e Vermeer, Holz-Mänttäri vê na mudança o objetivo e o resultado da ação. Em segundo lugar, os elementos de uma ação seriam actantes motivados, uma situação de ação e um objetivo a alcançar. Cada elemento de uma ação poderia ser visto, ele mesmo, como um sistema. De modo análogo, uma ação poderia também estar coadunada com outras num sistema superordenado ${ }^{390}$.

O primeiro pressuposto de uma ação seria a existência de actantes voltados a uma meta comum. Como afirma Holz-Mänttäri, indivíduos só passam a integrar um sistema quando há relações estabelecidas entre eles. Isso não significa que todos tenham que agir: em geral, enquanto alguns agem, outros são afetados por aquela ação ${ }^{391}$.

Actantes realizam ações numa dada SITUAÇÃO, que interferiria no modo de agir. Conforme Holz-Mänttäri explica, demarca-se uma situação a partir do momento em que circunscrevemos um tempo e um local:

[27-29] Aus dem Lauf der Geschichte, aus dem Gewimmel des Großstadtverkehrs, aus dem Weltenkontinuum lässt sich eine Situation ausgrenzen, indem Ort und Zeit festgelegt werden: hier und jetzt, dort und gestern, auf dem Mars am 20. Mai 2021. Das Verfahren ergibt eine Art Momentaufnahme, die die Konstellation der Elemente in dem einen Moment zeigt, aber starr festgehalten, ohne dynamische Beziehungen sichtbar werden zu lassen und damit verfälschend. Dieses Manko kann methodologisch integriert und damit relativiert werden: Alle Elemente (Faktoren) einer Situation sind als Prozesspunkte dynamisch auf ein Ziel hin auffassbar (vgl. 4.2.2). Mit der Erfassung der Situation sind die einschlägigen kulturellen Gegebenheiten im weitesten Sinne festgelegt, mit der dynamischen Erfassung alle an dem bestimmten Ort zu der bestimmten Zeit funktional aufeinander bezogenen Elemente des Gefüges. (...) Der Lärm in einer Montagehalle kann für ein Interview willkommene Milieufärbung sein, für den Führer einer Besuchergruppe ein Störfaktor bei der akustischen Verständigung und für das Werkstück irrelevant (während Staub z.B. relevant sein könnte). ${ }^{392}$

[Do decurso da história, do burburinho do trânsito de uma metrópole, do contínuo dos mundos pode-se delimitar uma situação, estipulando-se local e tempo:

\footnotetext{
389 [Handeln (...) sei aufgefasst als] zweckgerichtete Tätigkeit, die nach Vergleich eines Ist-Zustandes mit einem SollZustand zur Erreichung des gemeinten Soll-Zustandes unter bestimmten Bedingungen und in gegebener Situation ausgeführt wird.

${ }^{390}$ HOLZ-MÄNTTÄRI, op. cit., p. 30.

${ }^{391}$ Ibid., p. 38.

392 Ibid., p. 32.
} 
aqui e agora, lá e ontem, em Marte no dia 20 de maio de 2021. Esse procedimento resulta num tipo de registro de um momento, que mostra a constelação de elementos naquele momento singular, mas mantido de forma estática, sem deixar que as relações dinâmicas fiquem visíveis, trazendo assim uma visão enganosa. Esse déficit pode ser integrado metodologicamente e, com isso, pode ser relativizado: todos os elementos (fatores) de uma situação podem ser compreendidos dinamicamente como pontos de um processo rumo a um objetivo (cf. 4.2.2). Ao compreender uma situação, as condições culturais pertinentes, no sentido mais amplo, estão estabelecidas, com a compreensão dinâmica de todos os elementos do sistema relacionados funcionalmente um com o outro no local determinado e no tempo determinado. (...) O barulho numa montadora pode ser muito bem vindo numa entrevista para trazer a cor local; para o guia de uma excursão, pode atrapalhar a compreensão de seus ouvintes e para o produto pode ser irrelevante (enquanto poeira, por exemplo, poderia ser relevante).]

Nota-se, assim, que a um elemento da situação podem ser atribuídos valores diferentes, significados diferentes, conforme a sua relação com os demais elementos. Ele pode, inclusive, ter significado nenhum naquela situação. Com isso em vista, Holz-Mänttäri afirma que a situação determina quais são os elementos relevantes de uma estrutura.

Ainda que uma situação seja delimitada a partir de um recorte no espaço e no tempo, esse recorte costuma não ter contornos precisos. De fato, situações de ação poderiam envolver diferentes espaços e tempos. Sua duração dependeria das relações com os demais elementos do sistema, variando, assim, caso a caso. Ademais, uma ação não sofreria influência apenas das circunstâncias presentes, isto é, do tempo e do espaço em que a ação ocorre, mas também de fatores anteriores e posteriores a ela.

Uma forma de perceber que os fatores a determinar a ação não se limitam à situação em que ela ocorre estaria numa importante característica do pensamento humano de não se restringir à situação presente, real, mas ponderar também acerca de situações passadas e futuras. Desse modo, um actante poderia evocar experiências anteriores semelhantes, pesar prováveis consequências futuras e, assim, determinar como agir. Para designar essa abrangência do pensamento humano, Holz-Mänttäri faz uso do termo "espaço de pensamento" [Denkraum].

Além disso, a experiência do indivíduo com o mundo que o circunda também influencia o seu modo de agir. Conforme a teorizadora, todo indivíduo é parte de um contínuo de mundos. Através do processo de socialização, ele se torna parte de uma cultura, que influencia seu modo de pensar, sentir e agir. A porção da cultura que o indivíduo incorpora - seja sua própria cultura ou outras com que ele tenha tido contato - é referida pelo conceito de "espaço de cultura" [Kulturraum]. Sobre o conceito de cultura, falaremos posteriormen- 
te com mais detalhes. Aqui, cabe enfatizar que os limites do espaço de pensamento e do espaço de cultura de cada actante são determinados pela situação de ação ${ }^{393}$.

Por fim, a FUNÇÃo é o critério de orientação e de avaliação do sucesso de uma ação. Segundo Holz-Mänttäri, a função, conceito-chave da ação intencional, opera como dimensão norteadora que, num sistema aberto e dinâmico, ativa todos os elementos relevantes daquele sistema naquela situação. Dito de outro modo, todos os elementos importantes de um sistema para uma determinada ação devem operar para que se alcance o objetivo almejado. Consequentemente, apenas sob o critério da finalidade é possível determinar se o resultado da ação é satisfatório ${ }^{394}$.

Conforme mencionado, uma ação não apenas está organizada através de um sistema, mas pode também integrar, como elemento, um sistema de ações superior. Nesse caso, cada ação contribuiria para que se alcançasse uma meta comum. Assim, o conceito de sistema seria útil para explicar as relações de trabalho nas sociedades modernas: nessas sociedades, os indivíduos organizariam as relações sociais mediante a divisão de trabalho, que teria na disposição humana para a cooperação a sua raison d'être. É certo que, desde as primeiras organizações sociais, sempre houve a necessidade de conhecer uma atividade e de cooperar com outros indivíduos. Todavia, ao longo da história, as sociedades teriam se desenvolvido, criando estruturas complexas de relações, tais como as leis, o comércio, a organização das cidades e a ciência. Decorrentes desse desenvolvimento, surgiram novas demandas sociais, que requeriam conhecimentos e métodos de agir mais sofisticados. Se antes os indivíduos tinham conhecimentos e habilidades suficientes para realizar, sozinhos ou em pequenos grupos, as atividades que lhes eram exigidas pela vida em sociedade, com a modernidade vieram a segmentação, o planejamento antecipado das ações e a especialização dos indivíduos em áreas de atuação: agora, cada indivíduo seria responsável e deteria os conhecimentos de apenas parte do processo. A divisão social do trabalho costuma ser marcada por formas complexas de cooperação, para cujo sucesso seriam indispensáveis formas igualmente complexas de comunicação: a partir do momento em que um indivíduo deixa de conhecer todas as etapas de um processo, seria imprescindível a troca intensa de informações corretas entre eles para orientar as diferentes etapas do processo e, assim, atingir o objetivo almejado ${ }^{395}$.

\footnotetext{
${ }^{393}$ HOLZ-MÄNTTÄRI, 1984, p. 32 et seq.

${ }^{394}$ Ibid., p. 30.

${ }^{395}$ Ibid., p. 40.
} 
A criação da figura do especialista seria reflexo do crescimento de uma sociedade e do desenvolvimento da relação entre os indivíduos. Cada indivíduo concentraria seus conhecimentos numa atividade, sendo, assim, capaz de exercer uma profissão, um "papel social" convencional, referido por Malinowski através do termo "instituição". Segundo Holz-Mänttäri, o especialista conhece os procedimentos convencionais e pressupostos teóricos para exercer essa atividade - o chamado conceito de ação (al. Handlungskonzept). Essa é a propriedade que define o indivíduo como especialista. O "conceito de ação" é entendido como uma orientação teórica e pragmática para o desempenhar de um papel social por um especialista numa dada sociedade. Trata-se de uma noção geral de uma atividade profissional, que inclui os conhecimentos e habilidades exigidos por ela, bem como um proceder convencional. O conceito de ação é uma propriedade individual, que diz respeito apenas ao especialista.

No entanto, o conceito de ação não é a única propriedade que faz de um indivíduo um especialista numa área de atividade. O "padrão de cooperação" (al. Kooperationsmuster) refere-se a uma relação convencional entre o especialista e sua contraparte:

[111/99-100] Das beschriebene translatorische Handlungskonzept ist nicht identisch mit, sondern komplementär zu dem 'Kooperationsmuster Bedarfsträger + Translations-Experte', das in Kulturen (oder Sozietäten) für die arbeitsteilig zu bewältigende Bedarfsdeckung durch translatorisches Handeln besteht. [...] Es wurde festgestellt, dass Handlungsmuster entstehen, wenn in arbeitsteiligen Gesellschaften Experteninstitutionen geschaffen werden, weil ein spezifischer Bedarf nach Ko-Operation ausreichend häufig in vergleichbaren Situationen auftritt: Man wendet sich in solchen Fällen an den Experten für ' $\mathrm{X}$ '. Wir hatten daraus geschlossen, dass der Sozietät und dem Berufsstand entsprechend die Verpflichtung erwächst, dafür zu sorgen, dass derartige Expertenhandlungen wirklich nur von Experten ausgeführt resp. angeboten werden, weil in komplexen Sozietäten nicht mehr alle Individuen im Prinzip zur Ausführung aller Teilhandlungen befähigt sind. ${ }^{396}$

[O conceito de ação translacional não é idêntico, mas complementar ao 'padrão de cooperação portador de demanda + especialista em translação', existente em culturas (ou sociedades) organizadas pela divisão do trabalho para sanar demandas através da ação translacional. (...) Constatou-se que surgem padrões de ação quando em sociedades organizadas pela divisão do trabalho são criadas instituições de especialistas, pois uma demanda específica por co-operação aparece com frequência suficiente em situações comparáveis: recorre-se nesses casos aos especialistas em ' $\mathrm{X}$ '. Já havíamos constatado que, com isso, crescem sobre a sociedade e sobre a classe profissional a exigência de se certificarem de que esse tipo de especialidade realmente só possa ser exercida ou oferecida por profissionais, pois em sociedades complexas não é mais possível que todos os indivíduos estejam, em princípio, capacitados para executar todas as tarefas.]

\footnotetext{
${ }^{396}$ HOLZ-MÄNTTÄRI, 1984, p. 91.
} 
Os padrões de cooperação diriam respeito a determinadas expectativas associadas à ação de um especialista e principalmente à sua relação com o cliente. Não apenas a ação do especialista seria convencional, mas também a de seu interlocutor. Caso essas expectativas não sejam conhecidas do cliente, caberia ao especialista explicá-las a ele. O padrão de cooperação seria, então, o aspecto social da especialidade do indivíduo, que diz respeito à sua atuação em sociedade, que incluem suas responsabilidades.

Assim, para o indivíduo exercer seu papel social - sua "instituição" - e ser considerado um "especialista", ele precisaria conhecer o conceito de ação e o padrão de cooperação de sua profissão. Como vimos, a fim de garantir que a ação especializada seja praticada apenas por especialistas e que eles tenham o corpo de conhecimentos e habilidades necessário para a cooperação com outros indivíduos, as sociedades e as classes profissionais desenvolveram os centros de formação.

Elucidado o que se define por "ação" na proposta de Justa Holz-Mänttäri, é chegada a hora de compreender as especificidades da AÇÃO TRANSLACIONAL. De acordo com a teorizadora, ela é também a ação de um especialista - o translador - que tem como objetivo viabilizar a comunicação entre indivíduos que atuam em cooperação, quando essa não é mais possível devido a barreiras culturais. Nesse contexto, o translador viabilizaria a comunicação entre cooperantes através da produção de textos, os quais, na proposta de HolzMänttäri, recebem a denominação "portadores de mensagem" (al. Botschaftsträger):

[5] Als Expertenhandlung wird translatorisches Handeln definitorisch einerseits an die einschlägigen Grundfähigkeiten des menschlichen Individuums gebunden, andererseits setzt es im arbeitsteilig spezialisierten Individuum artifizierte und verfeinerte Kompetenz voraus. Die Produktion eines Botschaftsträgers für transkulturellen Botschaftstransfer kann also nur gelingen, wenn sie die Grundbedingungen von Kooperation und Kommunikation berücksichtigt. Das bedeutet, der Translator baut sich durch sein Handeln die Ausgangs- und Zielwelten selbst auf und schafft in der Zielwelt einen Botschaftsträger (-verbund), der seinen Funktionen gerecht werden kann. Es geht also nicht um Sprache allein. Es geht um Handlungen in 'Welten'.

[Enquanto ação de um especialista, a ação translacional, por definição, está ligada, por um lado, às aptidões básicas relevantes do indivíduo humano e, por outro lado, pressupõe competências construídas e refinadas no indivíduo especialista numa área de atuação. A produção de um portador de mensagens para a transferência transcultural de mensagens pode ser bem sucedida apenas quando leva em consideração as condições básicas de cooperação e comunicação. Isso significa que o translador reconstrói os mundos de partida e de chegada através de sua ação e cria no mundo de chegada um portador de mensagem (composto) que possa fazer jus à sua função. Logo, não se trata somente de línguas. Tratase de ações em "mundos".]

\footnotetext{
${ }^{397}$ HOLZ-MÄNTTÄRI, 1984, p. 6.
} 
A ação translacional, portanto, não seria uma operação centrada em questões linguísticas, não se tratando de estruturas gramaticais e lexicais. Ademais, a noção de língua vigente na proposta de Holz-Mänttäri não é o conceito abstrato de língua baseado nas estruturas linguísticas, como era a tônica na linguística tradicional e nas teorias de tradução à época. O aspecto da LÍNGUA que interessa à tradução, segundo a teorizadora, é a língua em uso, dentro de um contexto e de uma situação. Não se trata de seu aspecto abstrato e estático, mas concreto e dinâmico, construído a partir da relação do indivíduo com a sociedade.

Holz-Mänttäri parte das considerações de Wilhelm von Humbolt, o qual afirma que a constituição de uma língua perpassa a percepção subjetiva da realidade. As palavras, a seu ver, não representam objetos concretos, mas ideias desses objetos, construídas a partir da percepção deles por parte das pessoas. Contudo, segundo Humboldt, a percepção é também influenciada, ao menos parcialmente, pela língua. Além de características relativas ao próprio indivíduo, a percepção do mundo é também influenciada pela cultura.

Assim como Vermeer, Holz-Mänttäri recorre à definição que Göhring (1978) faz de cultura. No entanto, ela destaca aspectos que não foram abordados por Vermeer em sua arguição. Assim, ainda que a cultura seja o conjunto de conhecimentos, proficiências e sentimentos esperados de uma dada sociedade, o indivíduo teria a liberdade de decidir se agirá em conformidade com as expectativas ou contra elas. Com isso, ela ressalta a diferenciação feita entre competência cultural ativa e passiva, bem como a liberdade de agir de encontro às expectativas ou ao encontro delas. Para Holz-Mänttäri, esse pensamento é essencial à transferência de mensagens através de barreiras culturais, pois é através da liberdade de comportamento que se obtêm estratégias bem sucedidas de translação. Além disso, uma vez que a percepção de mundo é também determinada culturalmente, da cultura também faria parte tudo que se deve saber e sentir para perceber o mundo como o nativo de uma determinada sociedade. Sem ter acesso às percepções de mundo comuns às culturas envolvidas na transmissão transcultural de mensagens, o translador não teria os fundamentos para trabalhar, visto que ele é confrontado sempre pelo desafio de entender e decidir a partir do contexto, que subjaz a uma ação e lhe aponta a direção ${ }^{398}$.

Dessa forma, como Vermeer, Holz-Mänttäri defende que a língua seja vista como um componente de uma cultura. Com isso, ela reafirma sua aproximação com a teoria do skopos, distanciando-se das abordagens pautadas pela linguística tradicional. Ela evoca novamente Humboldt, que define a língua como uma estrutura em relação de troca com

\footnotetext{
${ }^{398}$ HOLZ-MÄNTTÄRI, 1984, p. 34s.
} 
todos os outros fenômenos humanos. Ela seria parte de uma cultura, e seus significados seriam dependentes da visão de mundo que traz uma cultura. Para ele, não seria pelo fato de as pessoas atribuírem signos às coisas que elas compreendem umas às outras, tampouco por decidirem de comum acordo ressaltar o mesmo conceito, mas por evocarem, através do uso das palavras, conceitos que, embora não sejam os mesmos, são correspondentes.

Se a ação translacional não se resume a uma operação linguística, Holz-Mänttäri defende que a formação de transladores vá além da formação linguística. Conhecimentos bilíngues ou um senso linguístico vago e acesso a dicionários bilíngues não bastariam para alguém exercer o papel social de translador. A formação linguística seria apenas um dos requisitos à formação de tradutores e intérpretes. Como vimos, ela deve incluir, dentre outros, uma formação cultural e um treinamento para a produção de portadores de mensagem. No entanto, o que se entende por portadores de mensagem?

Como vimos, quando um actante, que detém a compreensão do todo de uma ação, de suas condicionantes e de seus meios, não tem a habilidade de, ele mesmo, realizar a ação, ele precisa recorrer a outros indivíduos. Desse modo, esse indivíduo, a que HolzMänttäri denomina "iniciador" [Initiator], integra outros actantes e outras ações à sua, em busca de uma determinada meta comum. Todas essas ações, conforme mencionado, estão organizadas num sistema em que reina o princípio da cooperação. Ao integrá-las, é necessário reorganizar o planejamento, de modo a contemplar essas novas ações. É, portanto, necessário um planejamento estratégico e uma forma de comunicar essa estratégia aos demais actantes, o que pode ser feito através da concepção e transmissão de uma MENSAGEM [Botschaft]. Na proposta de Holz-Mänttäri, define-se mensagem da seguinte forma:

[6] Dann folgt die Konzeption von Botschaften als gedankliche Fassung von intendierten Handlungszwecken unter einem übergeordneten gemeinten Gesamtziel auf aktionale Kooperationssituationen hin, und zwar durch Aufladung von Vorstellungen über Sachverhalte mit strategischen Elementen zwecks Steuerung aktionaler Kooperation.

[Segue então a concepção de mensagens enquanto formulação mental dos objetivos almejados para a ação, subordinados a uma meta comum superordenada a partir de situações de cooperação acional, mais exatamente através da inclusão de ideias sobre estados de coisas com elementos estratégicos, a fim de orientar a cooperação acional.]

A mensagem é, assim, uma concepção mental, orientada a uma meta comum, com o propósito de coordenar a cooperação num sistema de ações. A concepção da mensagem integra uma ação comunicativa que tem como propósito de coordenar formas de cooperação. 
Em oposição ao que faz Vermeer, Holz-Mänttäri, distingue comunicação de interação. A seu ver, enquanto a interação pressupõe "consenso", isto é, o acordo entre interlocutores presentes numa dada situação, a comunicação é um ato de veiculação de informações, que não pressupõe o contato direto entre os interlocutores. A ação translacional seria um bom exemplo de ação comunicativa, pois o translador, embora nunca esteja em contato com os interlocutores, precisa viabilizar a veiculação de mensagens.

Uma mensagem é concebida quando há a necessidade de estabelecer comunicação com outras pessoas que cooperam entre si em prol de uma meta comum. A mensagem não tem a função apenas de veicular informações ao receptor, mas de movê-lo a agir. Para tanto, em sua concepção, além das informações, incluem-se elementos estratégicos que estimulam e orientam os interlocutores a agir. A mensagem, assim, representa a intenção comunicativa de quem a formula - na proposta de Holz-Mänttäri, o iniciador. Para que ela chegue aos parceiros da cooperação e cumpra sua função, a mensagem precisa deixar de existir apenas na mente do iniciador e adquirir forma comunicativa. Assim, o iniciador cria - ou comissiona a um profissional - um "PORTADOR DE MENSAGENS":

[27-28] Der Botschaftsträger besteht demnach aus Sach- und Strategie-Inhalten, und zwar bezogen auf die aktionale wie auf die kommunikative Kooperation. Die Inhalte sind dargestellt in fall- und funktionsspezifischen Formen, bei denen Ausdruckselemente von Verknüpfungselementen zu unterscheiden sind. Gleichzeitig eingesetzte, aufeinander bezogene, aber in verschiedenen Medien realisierte Botschaftsträger fungieren im Verbund. ${ }^{399}$

[O portador de mensagem é assim composto por conteúdos referenciais e estratégicos, relativos tanto à cooperação acional quanto à cooperação comunicativa. Os conteúdos são representados de formas específicas à função e ao caso, nas quais é necessário distinguir elementos de expressão de elementos de ligação. Portadores de mensagem empregados simultaneamente, em referência uns aos outros, mas concretizados por diferentes canais atuam em conjunto.]

Como vimos, a ação translacional tem como particularidade a produção de portadores de mensagem mediante a transmissão de mensagens através de uma barreira cultural. Desse modo, o translador deve produzir, no mundo de chegada, um portador de mensagens que tenha uma função a cumprir. Embora haja uma relação estreita entre a mensagem e o portador de mensagem, ela não seria linear: enquanto a mensagem é uma formulação mental que parte da necessidade de um indivíduo - o iniciador - interagir com outros para coordenar a cooperação entre eles, o portador de mensagem é concebido com foco na comunicação dessa mensagem. Ele só poderá orientar a cooperação entre os indivíduos, estimu-

\footnotetext{
${ }^{399}$ HOLZ-MÄNTTÄRI, 1984, p. 31.
} 
lando o receptor a agir e instruindo-o a como agir, se as estratégias incluídas no texto forem diretamente direcionadas aos receptores, antecipando componentes da situação de recepção e dos meios de realização. Enquanto o receptor, o contexto em que está inserido, o portador de mensagens e sua função são fatores ligados à situação de recepção, as formas de realização envolvem o canal e a natureza da ligação com o portador de mensagem e a técnica de transporte. Para conceber o portador de mensagem, é necessário repensar os dados da mensagem tendo o receptor em vista e depois incluir estratégias comunicativas, bem como modificações ligadas aos meios de realização.

Holz-Mänttäri chama a atenção para o fato de os textos não serem a única forma de portadores de mensagem possível:

[74-78/163-166] Texte als Botschaftsträger sind nicht die einzigen Kommunikationsmittel, die beim Botschaftstransfer über Kulturgrenzen eingesetzt werden können. Sie werden sogar oft im Verbund mit anderen Mitteln eingesetzt (Text + Melodie, Bild + Text usw.). Deshalb sei für Translation angesetzt, dass Texte im Handlungsprozess vorkommen müssen. 'Text' wird als Botschaftsträger im Verbund verstanden. Bei Translation ist auch Wechsel der Botschaftsträgerart denkbar, denn Art und Verwendungsweise von Botschaftsträgern sind kulturspezifisch.

[Textos enquanto portadores de mensagem não são os únicos meios de comunicação que podem empregados na transferência de mensagens através de barreiras culturais. Eles são até mesmo empregados com frequência em conjunto com outros meios (texto + melodia, imagem + texto etc.). Por isso estabeleceu-se que textos deveriam aparecer no processo da ação. Entende-se "texto" como um portador de mensagem composto. Na translação, é também possivel pensar na troca de tipo de portador de demanda, visto que o tipo e a forma de uso de portadores de demanda são especificas a cada cultura.]

O translador seria, assim, especialista na produção de textos enquanto portadores de mensagem compostos, o que significa que ele conhece outras forma de portador de mensagem e que conhece a influência deles na constituição dos textos e, mesmo que não seja especialista nessas outras formas, deveria saber lidar com elas.

Sendo o portador de mensagem também um sistema, ele seria composto por relações e elementos: um produtor, um receptor, uma função textual, a situação de produção e a situação de recepção, forma e conteúdo. A concepção de um portador de mensagem consistiria na textualização (verbal e/ou não verbal) de uma mensagem. Isso ocorreria com o emprego de meios de expressão e de elementos de ligação entre esses meios ${ }^{400}$. Informações e estratégias são componentes do conteúdo do texto; os recursos de expressão e os

\footnotetext{
${ }^{400}$ HOLZ-MÄNTTÄRI, 1984, p. 79.
} 
meios de ligação são componentes de sua forma. Conteúdo e forma são duas dimensões textuais, estruturadas, respectivamente, através da tectônica (al. Tektonik) e da textura (al. Textur).

O termo "tectônica" foi extraído da arquitetura e dos estudos literários e significa a construção artística interna de uma obra e é exatamente isso, segundo Holz-Mänttäri, que deve interessar o translador. Ela distingue as informações, que são estruturadas normalmente de forma lógico-argumentativa e lógico-material, de componentes estratégicos, cuja função é coordenar a cooperação acional e comunicativa. $O$ objetivo do translador deve ser identificar as expressões fundamentais, isto é, o núcleo da informação do texto, que depois seria reformulado pelo translador com a sua própria voz. Esse seria um processo importante para compreender o texto e para livrar-se da formulação original. Apesar de recomendar o "esquecimento ativo" das estruturas formais do texto de partida para a translação, distanciando essa da translação feita para fins de aprendizado de línguas, Holz-Mänttäri observa também que uma paráfrase completa e a simplificação do texto de partida para a mera troca de códigos não seria possível.

A textura, por sua vez, refere-se à estruturação dos meios de expressão e de ligação de um texto que lhe confere coerência no tocante à forma. Nesse caso entram conjunções e outras marcas textuais, bem como a pontuação e até mesmo as repetições. A textura de um texto é objeto de reflexão da estilística, que examina as seleções e as formas de disposição e ligação de elementos de expressão. Holz-Mänttäri alerta que, caso um translador queira lidar com um texto e avaliá-lo, ele deve compreender a tectônica e a textura desse texto e avaliar sua função.

Definir a comunicação como meio para coordenar a cooperação entre actantes, à primeira vista, pareceria sugerir que no horizonte de reflexão da autora estariam apenas os textos pragmáticos, não o texto literário. Contudo, Holz-Mänttäri não faz qualquer distinção entre a ação translacional que envolve portadores de mensagem "artísticos" daquelas que envolvem portadores de mensagem "cotidianos". A ação translacional, a seu ver, está voltada a todos os tipos de textos. Visto que o texto literário serve à transmissão de experiências, ele também estabelece uma comunicação. Trata-se ainda de uma comunicação criativa para ambos, produtor e receptor: da parte do autor, exige-se uma produção ativa, concebendo o texto através de uma forma de expressão não convencional; essa forma de expressão, por sua vez, exige também esforço do leitor, ou seja, uma recepção ativa para lêlo. Ao escrever uma obra, o escritor procura transmitir uma experiência. 
Além disso, Holz-Mänttäri expande o conceito de cooperação para um "desejo de coordenação de indivíduos organizados que pode ser realizada pela comunicação" 401 (HOLZ-MÄNTTÄRI, 1984, p. 57). Assim, mesmo a translação literária seria orientada por uma função, ou melhor, por diversas instâncias de função: pela função do complexo sistêmico superior, pela função do portador de mensagem no interior desse mesmo complexo sistêmico e, por fim, pela função dos elementos e relações do complexo sistêmico "portador de mensagem". Dada sua recorrência, por questões de economia, mesmo o texto literário estabelece padrões comunicativos, como outras formas de ação comunicativa. Também como outros padrões comunicativos, o padrão comunicativo formado pela tradução de texto literário é compreensível, descritível e avaliável em sua função e em consideração ao padrão estabelecido. Portanto, o conceito de função também serve ao texto literário.

Ao definir a ação translacional como a criação de portadores de mensagem por um profissional, Holz-Mänttäri destaca a característica criativa do processo, pois ao translador não resta outra alternativa a não ser ativar seu conhecimento de mundo e seu conhecimento técnico e, assim, também dar uma contribuição de sua parte para possibilitar a criação e a compreensão do texto. Para a teorizadora, além de criativa, a ação translacional é também uma ação analítica, sintética e avaliativa. Ela é analítica, pois o texto, mesmo sendo visto como um todo, deve ser compreendido como um todo formado por elementos relacionados uns com os outros. Com base no conhecimento de mundo e no conhecimento técnico do translador, a análise tem o objetivo de ressaltar componentes em função e de separar o útil do inútil. Ela é sintética, pois os elementos destacados pela análise devem ser vistos em conjunto, servindo o panorama não apenas à produção, mas também à crítica e a conclusões. Por fim, ela é avaliativa, pois por um lado, é da natureza da ação translacional tomar decisões e, por outro, é necessário que o tradutor verifique o seu trabalho o tempo todo.

De fato, as propriedades analíticas, sintéticas e avaliativas da ação translacional seriam decorrentes da tessitura de relações entre os actantes, cada um com suas motivações, intenções, visões de mundo, formação etc. São actantes envolvidos, direta ou indiretamente, na ação translacional o iniciador, o contratante, o autor do texto de partida, o translador, seus colegas, especialistas na área de domínio do texto, a instância responsável pelo uso do portador de mensagens e os receptores, dentre outros. O envolvimento de todos esses actantes demonstra que a ação translacional não é uma ação isolada, tampouco limita-se ao

\footnotetext{
${ }^{401}$ Entsprechend fassen wir den hier verwendeten Kooperationsbegriff ganz weit als generelles Koordinationsanliegen organisierter Individuen, das durch Kommunikation realisiert werden kann.
} 
contratante e ao translador. Trata-se de uma ação que integra um complexo sistema de ações, atuando o TRANSLADOR como participante do processo de cooperação.

Para agir conforme o esperado de seu papel social, o translador deve orientar-se tanto por um conceito de ação definidor de translação como pelo padrão de cooperação que se instaura entre si e o portador de demanda. O papel social do translador não deve em nada em relação ao papel de outros especialistas numa sociedade dividida pelo trabalho. Holz-Mänttäri define dois pressupostos da ação do translador: a competência técnica e a qualificação pragmática. A primeira estaria fundada numa teoria da comunicação individual humana; a segunda, numa teoria da ação social humana. De sua função no contexto da comunicação humana e da organização social, a ação translacional ganha identidade.

Por um lado, o conceito de ação está ligado a uma forma de organização da sociedade pautada pela divisão do trabalho, sendo que cada pessoa, especialista em algo, tem uma função social a cumprir. Os especialistas adquirem suas habilidades gerais, competências técnicas e qualificação pragmática em instituições de ensino, antes que eles possam exercer esse papel. Por outro lado, o próprio conceito de ação "translação" faz parte de uma estrutura, de um complexo sistêmico, de que se compõe também de um padrão de cooperação. No caso da translação, o padrão de cooperação é "Portador de demanda + Especialista em tradução". Esses dois elementos estão associados de tal maneira que não há um conceito de ação "translação" sem o padrão de cooperação, isto é, sem o "portador de demanda" (al. Bedarfsträger: o contratante) e o "especialista em translação" (ou o translador).

De acordo com Holz-Mänttäri, há três características definidoras do conceito de ação "translação":

a) Produção textual: Holz-Mänttäri dá ênfase à produção de portadores de mensagem compostos, isto é, não restritos ao meio verbal. Com isso, ela alerta para a necessidade de o translador conhecer as características constitutivas e a influência de outros tipos de portadores de mensagem sobre os textos verbais, ainda que não seja ele o responsável por essas outras formas textuais.

b) Cultura estrangeira à do contratante: os textos produzidos mediante o processo de translação, segundo Holz-Mänttäri, costumam ser produzidos para um sistema cultural e, portanto, para uma língua diferente da língua do contratante. 
c) Ação especializada: trata-se de um trabalho executado por um especialista, mediante competências que, embora fundadas na competência humana de se comunicar, foram aperfeiçoadas. De acordo com Holz-Mänttäri, ao aperfeiçoar a competência comunicativa humana presente no cotidiano das pessoas, ela se torna um novo tipo de ação: age-se não mais por conta própria, mas em nome de outrem. ${ }^{402}$

Quanto ao padrão de cooperação, trata-se de uma dimensão sociológica, que diz respeito às relações entre o translador e os demais actantes. Nesse contexto, é essencial afirmar que o translador, embora faça parte da cooperação, mesmo sendo produtor do TC, não seria parte integrante do processo comunicativo: ele não teria contato direto com seus interlocutores, tampouco sua produção textual partiria de uma necessidade comunicativa sua. Ele seria apenas um prestador de serviços, que faz textos sob medida num determinado lugar e tempo e para um determinado propósito. Mesmo dentro de uma estrutura de cooperação entre actantes, muitas vezes o translador só pode contar com sua "fantasia" bem orientada por conhecimento, por exemplo, dos ambientes culturais envolvidos para antecipar a coorientação entre os personagens envolvidos na comunicação.

Apesar de conhecer o seu ofício, o translador deve também poder confiar em métodos que lhe permitam trabalhar de forma funcional e tomar responsabilidade pelo resultado de seu trabalho. Holz-Mänttäri propõe, assim, um método que permita identificar os FATORES relevantes para a ação translacional. O método analítico visa a identificar dados referentes tanto ao receptor e à sua situação, quanto à produção do texto de partida e de sua intenção. Em primeiro lugar, estabelecer-se-ia um perfil do texto de partida. A partir dele e de diretrizes estabelecidas para a formulação do texto de chegada, ambos formulados a partir dos dados recolhidos durante a análise, seria possível, então, traçar um perfil do texto de chegada. Por fim, entra a qualificação do translador para que o texto seja concebido segundo a sua função ${ }^{403}$. Em poucas palavras, esses seriam, conforme Holz-Mänttäri, os procedimentos básicos da ação translacional.

Os objetos de análise contemplados pelo modelo de Holz-Mänttäri são fatores relativos à necessidade que desencadeia a ação (al. Bedarfsfaktor) e fatores relativos ao portador de mensagem. A análise começa pelos fatores que constituem a demanda do iniciador

\footnotetext{
${ }^{402}$ HOLZ-MÄNTTÄRI, 1984, p. 86 et seq.

${ }^{403}$ Ibid., p. 113 et seq.
} 
por um TC específico. Visto que a ação translacional seria, juntamente com outras ações, parte de um processo com uma meta comum, as condições de ação seriam ao menos em parte determinadas por essa meta comum e pelo objetivo da ação translacional, derivado da primeira. Analisando os fatores em torno da demanda, seria possível identificar mais claramente a meta comum desse sistema superordenado. Assim, os fatores de demanda estabeleceriam quais são as características que o contratante deseja que o TC tivesse, e apenas através da análise desses fatores seria possível estabelecer a função do TC.

O segundo elemento do modelo analítico diz respeito à própria produção de portadores de mensagem e envolve o material de partida, os textos de chegada e meios de pesquisa. Para analisá-lo, faz-se uso de um modelo de fatores semelhante ao modelo desenhado para analisar os fatores de demanda. A análise no âmbito dos portadores de mensagem visa primeiramente a complementar os dados sobre a mensagem identificados pela análise dos fatores da demanda para, em seguida, elaborar um perfil do TP.

O processo baseia-se em procedimentos de segmentação do conteúdo e da forma textuais e avaliação dos segmentos. A fase de segmentação, tanto dos fatores de demanda quanto do portador de mensagem, consiste na formulação de questões-chave acerca dos objetos de análise: as questões fundamentais são "QUEM-(Elemento gestor)-O QUÊ?”; as complementares, "POR QUÊ-PARA QUÊ-COMO?” etc. QUANDO e ONDE delineiam os elementos situacionais. A fase de segmentação permite vislumbrar a relação entre fatores uns com os outros.

O método analítico, segundo Holz-Mänttäri, teria a vantagem de afastar a subjetividade no reconhecimento do significado de um texto da parte do translador, tornando a sua ação, assim, passível de verificação. Desse modo, a teorizadora propõe um processo avaliativo composto por seis etapas:

(1) Em primeiro lugar, determina-se o objeto de análise por meio da segmentação (seja esse os elementos da constelação de fatos, fatores relativos aos papéis dos actantes, elemento da estrutura textual etc.). Ex.: “Qual é o objeto de análise?”- A resposta é sempre um elemento destacado pelo processo de segmentação, como, por exemplo, o iniciador da translação ou o fio condutor do texto de partida.

(2) O resultado é primeiro descrito quanto à sua estrutura e à sua função e depois, então, elucidado. Ex.: “O que é e como funciona?”- A resposta é a descrição e eluci- 
dação do objeto de análise, como, por exemplo, a descrição de um determinado elemento textual e o motivo pelo qual ele está lá.

(3) O resultado é classificado num "fator de referência", a partir do qual será avaliado. Ex.: "Qual é o fator de referência?" - A resposta é a classificação do objeto de análise determinado pela segmentação num fator do quadro de ação translacional, como, por exemplo, o fator de referência "estratégia de coordenação" para uma anedota contada num discurso.

(4) O resultado é avaliado em face do seu fator de referência, no tocante à adequação à função. Ex.: "O segmento é funcional no que concerne o seu fator de referência?" A resposta é uma avaliação, feita sempre com base num parâmetro específico, como, por exemplo, se um procedimento descrito no texto é funcional quanto a seu estilo textual.

(5) O resultado, em face de seu fator de referência, é avaliado no interior de uma situação, quanto à sua relevância no quadro do material de partida e no quadro do modelo de chegada. Ex.: "O segmento é funcional no que concerne ao aspecto de partida/de chegada?" - A resposta é uma decisão a que se chega ao se pesar a adequação desse objeto ao contexto de partida e ao contexto de chegada. Um elemento pode, por exemplo, ser apropriado no contexto do texto de partida e não igualmente apropriado no contexto de chegada.

(6) Chega-se a uma resolução para medidas posteriores. Ex.: "O que fazer então, no que diz respeito à funcionalidade da ação?" - A resposta deve ser encontrada após deliberação acerca do problema da quinta etapa, a fim de se chegar a uma solução ${ }^{404}$.

Dentre os fatores em torno da demanda, a distribuição de papéis entre os actantes da ação translatória é de grande influência para o trabalho do translador. Visto que sua ação estaria inserida num sistema de distribuição de trabalho entre actantes em prol de um bem comum, com a distribuição de papéis haveria também a atribuição de obrigações e responsabilidades para cada um. Isso interferiria no produto da ação do translador: o texto de chegada. Holz-Mänttäri identifica seis papéis fundamentais em torno da ação translacional:

\footnotetext{
${ }^{404}$ HOLZ-MÄNTTÄRI, 1984, p. 101 et seq.
} 
(1) o papel do iniciador (al. Initiator) ou contratante (al. Bedarfsträger): o iniciador principia a ação translacional, pois, para alcançar um objetivo específico, ele necessita de uma mensagem para a comunicação transcultural;

(2) o papel do solicitador (al. Besteller): ele recorre ao translador em busca de um texto voltado a uma determinada função para uma determinada situação;

(3) o papel do "textualizador" de partida (al. Ausgangstext-Texter): ele escreve o texto de partida, seja para fins específicos de translação, seja para outros fins;

(4) o papel do translador (al. Translator): é ele quem produz o texto de chegada. Ele pode agir em equipe, com a presença de outros especialistas;

(5) o papel do aplicador do texto de chegada (al. Zieltext-Applikator): ele trabalha com o texto, reproduz esse texto, vende-o etc.;

(6) o papel do receptor do texto de chegada (al. Zieltext-Rezipient): é para ele que a mensagem é concebida ${ }^{405}$.

Às ações de cada actante envolvido na ação translacional está vinculado também um propósito. Esse propósito é derivado da meta comum e pode ser considerado o primeiro fator passível de objetivação da ação translacional. Além da análise de papéis, também são analisadas as especificações do iniciador para o TC - o que requer do translador conseguir especificações claras sobre o tipo de mensagem e de portador de mensagem, sobre a situação comunicativa e o efeito desejado sobre o receptor.

Depois de reunidos os dados acerca dos fatores que circundam a demanda, obtêmse informações acerca dos materiais textuais. Do material de partida recolher-se-iam os dados referentes ao conteúdo e à forma do texto de partida; depois, essas informações seriam contrapostas com os dados que se têm sobre o texto de chegada, a fim de verificar quais e em que medida os elementos do texto de partida seriam compatíveis com as diretrizes estabelecidas para a produção do texto de chegada. A análise textual teria como objetivo, dentre outros, entender o conteúdo e a forma do texto de partida. O perfil do texto de partida seria contraposto com as diretrizes definidas para a produção do texto de chegada e, assim, construir-se-ia um modelo do texto de chegada. A função do texto de chegada será destinado é considerada diretriz principal para a ação translacional ${ }^{406}$. A análise concentrar-se-ia primeiramente nos dados referentes ao conteúdo do texto. Depois, buscar-se-ia

\footnotetext{
${ }^{405}$ HOLZ-MÄNTTÄRI, 1984, p. 110 et seq.

${ }^{406}$ Ibid., p. 127.
} 
desvendar a tectônica do texto, identificando o significado dos enunciados e formulando-os noutra língua. A textura, isto é, o modo como o texto é organizado, seria também analisada, para, com base nessas informações, o translador tomar decisões acerca da organização e da estilística do texto.

A partir desses procedimentos, o translador formularia o texto de chegada, e sua produção deve se dar de modo responsável. Mesmo que trabalhe em equipe, ele seria coresponsável por todas as partes. Ele deve ser capaz de atuar com outros especialistas na produção funcional de portadores de mensagem para a comunicação transcultural. $\mathrm{O}$ fato de se ter pouco discutido os padrões de cooperação envolvidos na ação translacional não permitia, segundo Holz-Mänttäri, identificar onde termina a responsabilidade do translador sobre o produto. Para a autora, (1) o layout de um texto influencia a textura do texto e, portanto, seria corresponsabilidade do translador; (2) o translador também guarda parte da responsabilidade por parte das revisões feitas, devendo ele trabalhar em conjunto com os revisores; (3) em publicações impressas com padrões altos de qualidade, o translador deve receber as provas tipográficas para evitar complicações de leitura vindas da impressão.

Vimos acima que o texto de partida é considerado por Holz-Mänttäri, dentro do processo analítico descrito, apenas parte do material de partida, tendo assim um status notadamente menos expressivo do que o de que desfruta na ciência da tradução. Nesse contexto, a teorizadora sugere que a produção do translato estaria sujeita a procedimentos que podem, de certa forma, destoar do perfil do texto de partida, caso alguns de seus elementos não sejam considerados funcionais:

[72] Bei transkultureller Textproduktion kann sich durchaus die Notwendigkeit ergeben, selbst Inhalte des Ausgangstextes durch funktionsgerechtere zu ersetzen. Jemand in vergleichbarer Situation in einer anderen Kultur, die nicht die geschilderten, sondern andere Konventionen hat, müsste Botschaft und Botschaftsträger anders konzipieren, damit sie funktionsgerecht ihren Zweck erfüllen. Es müsste ein gedanklicher Transfer vollzogen werden, analytisch, synthetisch, evaluativ und kreativ, nämlich zwecks Überwindung der Kultur- und damit Sprachbarriere. Damit ist manches Individuum überfordert. Deshalb werden dafür in arbeitsteiligen Gesellschaften Experteninstitutionen geschaffen. Wenn es um die Produktion von Botschaftsträgern für transkulturellen Botschaftstransfer geht, sind diese Experten Translatoren. ${ }^{407}$

[Na produção transcultural de textos, pode perfeitamente surgir a necessidade de se substituir mesmo conteúdos do texto de partida por conteúdos mais funcionais. Alguém numa situação comparável noutra cultura, que não tem as convenções expressas, mas convenções diferentes, precisaria conceber mensagem e portador de mensagem de forma diferente, de modo que eles pudessem cumprir

${ }^{407}$ HOLZ-MÄNTTÄRI, 1984, p. 126 
seu objetivo de acordo com sua função. Seria necessário ocorrer uma transferência mental, de forma analítica, sintética, avaliativa e criativa, mais exatamente, visando a transpor barreiras culturais e, assim, linguísticas. Um indivíduo qualquer sentiria como se estivesse além de sua capacidade. Por isso, são criadas instituições de especialistas em sociedades organizadas pela divisão do trabalho. Quando se trata da produção de portadores de mensagem para transferência transcultural de mensagens, esses especialistas são os transladores.]

Eis um ponto polêmico da proposta de Holz-Mänttäri: para alguns teorizadores, Holz-Mänttäri teria ido longe demais. Afinal, ao diminuir o status do texto de partida a tal ponto que seus conteúdos possam ser substituídos na translação por conteúdos mais funcionais, qual seria ainda o limite da translação? Estaria Holz-Mänttäri propondo que se poderia eventualmente prescindir do texto de partida? Essa questão foi posteriormente abordada por Christiane Nord (1997), que elucida esse tópico da teorização de HolzMänttäri, oferencendo uma resposta coerente a essas questões. Segundo observações da autora, embora a translação esteja limitada à criação de um texto de chegada com base num texto de partida, a ação do translador e suas responsabilidades, como vimos, vão além disso: a ação translacional consiste em estabelecer comunicação e viabilizar a cooperação através de barreiras culturais. Assim, a translação seria apenas uma forma de ação translacional, mais exatamente, a parte mais significativa - mas não a única ${ }^{408}$. $\mathrm{O}$ translador poderia, por exemplo, atuar como consultor cultural, oferecendo conselhos ou mesmo alertas acerca das formas de comunicação do contratante com receptores de uma determinada cultura. Dessa maneira, investigar o padrão de cooperação "Portador de demanda + Especialista em translação" é imprescindível para clarificar as responsabilidades do translador no exercício de sua ação translacional.

A esse entendimento, contudo, Christiane Nord não chegou num primeiro momento. De fato, a sua proposta teórica traz a revisão de alguns conceitos funcionalistas com os quais, a seu ver, Vermeer e Holz-Mänttäri teriam ido, de fato, longe demais.

\footnotetext{
${ }^{408}$ NORD, 1997, p. 17 et seq.
} 


\subsubsection{Christiane Nord: um modelo de análise textual}

Ainda que as bases para a abordagem funcional tenham sido estabelecidas pelos trabalhos de Reiss e Vermeer (1984) e de Holz-Mänttäri (1984), a principal responsável por sua difusão e popularização é, sem dúvidas, Christiane Nord.

Nord nasceu em 1943 em Eberswalde, uma cidade no leste alemão, a nordeste da capital Berlim. Completou o ensino fundamental no oeste do país e, em 1963, ingressou na Universidade de Heidelberg, iniciando sua formação de tradutora do inglês e do espanhol. Sobre esse período, Nord informa-nos que o aprendizado era fundamentado na aquisição de competências linguísticas e culturais: "A tradução corria em paralelo e baseava-se, em princípio, mais em gramática contrastiva, depois principalmente na estilística contrastiva, quando aprendíamos pelo menos tanto sobre nossa língua materna quanto sobre o espanhol." ${ }^{409}$ (NORD, 2004, p. 251) Embora Nord reconheça o valor do estudo contrastivo, esse deveria ser, a seu ver, pautado não nos conhecimentos linguísticos do estudante, mas num corpus de textos paralelos, uma postura que ela traz da linguística textual e das teorias de tradução emergentes durante a virada cultural.

Em sua atividade docente, Nord encontrou na linguística textual material tanto para a análise de textos como para a tradução. A linguística textual foi uma das fontes de sua contribuição para o funcionalismo, o livro Textanalyse und Übersetzen: Theoretische Grundlagen, Methode und didaktische Anwendung einer übersetzungsrelevanten Textanalyse $^{410}$ [Análise textual e tradução: bases teóricas, método e aplicação didática de uma análise textual relevante à tradução], publicado em 1988. Outra contribuição teria vindo da pragmática, da qual os estudos da tradução teriam se beneficiado em larga medida.

Todavia, é possível afirmar que a principal base teórica para o livro veio da teoria do skopos. Nesse contexto, Nord destaca a mudança de Vermeer para a Universidade de Heidelberg em 1984. Ele teria iniciado um círculo de discussões entre professores, em especial entre os docentes não titulados, sobre o ensino da tradução e a sua conexão com a teoria, a prática e a didática. Nesse momento, ficou clara para Nord a carência de recursos didáticos para o ensino de tradução, algo que sentira em sua época de estudante. Em muitas

\footnotetext{
${ }^{409}$ Übersetzen lief damit schon parallel und war zunächst eher kontrastive Grammatik, später vor allem kontrastive Stilistik, bei der wir mindestens ebenso viel über unsere Muttersprache wie über das Spanische lernten.

${ }^{410}$ A tradução para o português brasileiro recebeu o título Análise textual em tradução: bases teóricas, métodos e aplicação didática, cf. NORD, 2016.
} 
de suas publicações posteriores a Textanalyse und Übersetzen, a autora dedica-se a preencher essa lacuna. Para esse fim, ela encara a abordagem funcional como especialmente frutífera, como já haviam demonstrado Hönig e Kussmaul (1982):

\begin{abstract}
"Função", essa foi a palavra mágica através de que se pôde, de repente, explicar o porquê, conforme a situação, de receber conselhos diferentes ou, na melhor das hipóteses, de ouvir a mesma resposta insatisfatória "Depende", sempre que se perguntava "Como se traduz...?". E assim cheguei, enfim, a uma profissão paralela, que até agora me levou a percorrer meio mundo: "missionária" de assuntos relacionados à translação funcional. ${ }^{411}$ (NORD, 2004, p. 256)
\end{abstract}

O livro foi pensado com o propósito de formular um quadro metodológico baseado num modelo de análise textual útil não apenas ao tradutor em formação, mas também aos docentes e aos tradutores profissionais. A relevância de um modelo de análise textual não estaria apenas no auxílio à compreensão e à interpretação do texto de partida e de sua estrutura linguístico-textual, mas também e essencialmente em fornecer argumentos para as decisões de tradução:

O que se faz necessário é um modelo de análise do TF que possa ser aplicado a todos os tipos de texto e usado em qualquer tarefa de tradução que possa surgir. Tal modelo deve habilitar tradutores a entender de modo funcional os elementos ou características observadas no conteúdo e na estrutura do texto-fonte e interpretá-los à luz da finalidade da tradução. ${ }^{412}$ (NORD, 2016a, p. 16, tradução coordenada por Meta E. Zipser, nossa revisão)

Na construção de seu modelo, Nord fundamentou-se sobre a concepção de "texto" como definida pela Linguística Textual - texto como "ocorrência comunicativa" -, bem como sobre uma noção de tradução advinda da abordagem funcional, especialmente das propostas de Vermeer e de Holz-Mänttäri. O seu modelo de análise textual constituiu-se, assim, como uma forma de aplicação dos pressupostos teóricos funcionalistas à didática da tradução.

Após a publicação do livro, Nord tornou-se livre-docente em 1993, com uma tese orientada por Mary Snell-Hornby, que aborda a relação entre tradução e convenções textuais, exemplificada pela tradução de títulos de textos. Em 1996, após atuar como professora

\footnotetext{
411 "Funktion", das war das Zauberwort, durch das sich plötzlich klären ließ, warum man in der Ausbildung auf die Frage "Wie übersetzt man ...?" je nach Situation verschiedene gute Ratschläge oder bestenfalls die unbefriedigende Antwort "Das kommt drauf an" bekam. Und so kam ich schließlich zu einem Nebenberuf, der mich inzwischen um die halbe Welt geführt hat: "Missionarin" in Sachen Funktionale Translation.

${ }_{412}$ Dafür bedarf es eines auf alle möglichen Textsorten und -exemplare anwendbaren und für alle vorkommenden Übersetzungsaufgaben nutzbar zu machenden Faktorenmodells der Textanalyse, eines Analyseschemas, das den Translator in die Lage versetzt, die wahrgenommenen inhaltlichen und gestalterischen Merkmale des AT funktional zu verstehen und im Hinblick auf das Übersetzungsziel zu interpretieren.
} 
visitante em diferentes universidades, assumiu a cadeira de Linguística Aplicada e Estudos da Tradução na Universidade Técnica Magdeburg-Stendal, onde colocou em prática os princípios teóricos de seu modelo de análise textual. Nord exerceu a atividade docente em Magdeburg até a sua aposentadoria, em 2005. Desde então, ela visita instituições de ensino e pesquisa em diferentes partes do mundo para dar palestras e cursos sobre tradução fundamentada pela abordagem funcional ${ }^{413}$. Ademais, em conjunto com seu marido, o professor de teologia Dr. Klaus Berger, Nord aplicou os princípios funcionalistas na tradução de textos bíblicos.

Como parte de sua atuação como "missionária" do funcionalismo, Nord publicou em 1997 o livro Translating as a purposeful activity: Functionalist approaches explained [Traduzir como uma atividade proposital: explicando abordagens funcionalistas]. Neste, ela traça, em língua inglesa, um panorama dos principais preceitos da abordagem funcional, fornecendo exemplos e respondendo a críticas levantadas ao longo dos anos. Esse livro está em sua segunda edição revisada e foi traduzido para o chinês, francês, espanhol e coreano, enquanto o livro seminal de 1988, atualmente em sua quarta edição revisada, foi traduzido para o inglês, árabe, espanhol, chinês e português. Outra demonstração de sua importância para os estudos da tradução em todo mundo são os títulos honoríficos outorgados a ela pela Universidade de Genebra, Suíça, em 2015 e pela Universidade de Baja California, no México, em 2018.

\subsubsection{Análise}

Como vimos, Christiane Nord constrói sua teorização amparada em duas vertentes: o funcionalismo e a linguística textual. Na primeira definição que oferece do conceito em seu livro, a teorizadora afirma apenas que a TRANSLAÇÃO "ocorre numa situação comunicativa" e está relacionada a unidades que ela, em princípio, denomina intuitivamente "texto" (NORD, 1988, p. 13). A especificidade da SITUAÇÃo de translação, comparada a outras situações comunicativas, estaria no envolvimento de duas culturas e línguas e no fato de

\footnotetext{
${ }^{413}$ Algumas informações sobre suas andanças divulgando o funcionalismo podem ser obtidas de seu website oficial. $<$ http://www.christiane-nord.de/> Lá é possível encontrar, dentre outras, informações sobre as palestras ministradas em instituições de ensino superior em todo o mundo entre os anos de 2010 e 2018. Segundo as informações no site, nesse período ela esteve no Brasil numa única ocasião: em 2015 em Florianópolis, num evento que culminou no lançamento da tradução de sua obra seminal para o português.
} 
que a mensagem que circula entre o emissor/produtor do TP e o receptor do TC ser formulada através de elementos de códigos linguísticos diferentes.

A noção de TEXTO é tomada de empréstimo da linguística textual de Robert de Beaugrande e Wolfgang Dressler (1981). Para eles, texto é uma "ocorrência comunicativa". São requisitos para essa ocorrência comunicativa a existência de uma situação "fixa" num espaço e num tempo e a presença de pelo menos dois interlocutores interessados em comunicar-se um com o outro. O texto é visto como um instrumento de comunicação que tem uma determinada função comunicativa no contexto de uma situação comunicativa particular. Essa noção de texto está ancorada numa teoria da comunicação linguística, que vê a LíNGUA como meio de comunicação e interação social. Para tanto, é requisito que ela seja dotada de características como a intencionalidade, a semanticidade, a comunicabilidade e o vínculo com o interlocutor.

Ao analisar os atributos gerais de um texto, Nord aborda também a noção de textualidade. Segundo afirma, enquanto a textualidade diz respeito a características de ações comunicativas entre indivíduos, o texto é a realização concreta dessas características num dado meio comunicativo. Assim, para que um conjunto de enunciados seja considerado um texto, seria necessário satisfazer os critérios de textualidade. Beaugrande e Dressler identificam sete desses critérios: a coesão, a coerência, a intencionalidade, a aceitabilidade, a informatividade, a situacionalidade e a intertextualidade ${ }^{414}$. Além dos critérios de textualidade, é indispensável que o texto tenha uma função comunicativa. Nord reconhece, porém, que um texto comumente não exerce uma única função: partes do texto podem exercer funções comunicativas diferentes. Nesse caso, a função de casa parte deveria ser identificada por um método analítico.

A fim de assegurar uma definição de texto relevante à translação, Nord recorre a Kallmeyer et al. (1980), que define o texto como "o conjunto de sinais comunicativos que aparecem numa interação comunicativa" (KALLMEYER et al., 1980, p. $45^{415}$ apud NORD, 1988, p. 16). Por sinais comunicativos, não entendemos apenas signos linguísticos, mas também elementos não linguísticos:

[41-42] Der Text ist eine kommunikative Handlung, die durch eine Kombination aus verbalen und nonverbalen Mitteln realisiert werden kann.

\footnotetext{
${ }^{414}$ BEAUGRANDE; DRESSLER, 1981, p. 3et seq.; cf. MOREIRA, 2014, p. 76 et seq.

${ }^{415}$ KALLMEYER, W.; KLEIN, W.; MEYER-HERMANN, R.; NETZER, K.; SIEBERT, H. J. (org.). Lektürekolleg zur Textlinguistik. Bd. 1: Einführung. 3. Aufl., Frankfurt/Main, 1980.
} 


\begin{abstract}
Aus diesen Überlegungen zum Text- als Handlungsbegriff ergeben sich bereits im wesentlichen die Faktoren, die bei einem AT zu analysieren und - wenn die Analyse übersetzungsrelevant sein soll - mit den entsprechenden Faktoren des (angestrebten) ZT in Kontrast zu setzen sind, da der Zieltext ebenso wie der Ausgangstext in einen kommunikativen Rahmen eingebettet sein wird, von dem es abhängt, wie man ihn rezipiert. ${ }^{416}$

[O texto é uma ação comunicativa, que pode ser realizada através de uma combinação de recursos verbais e não verbais.

Dessas reflexões acerca dos conceitos de texto e ação já resultam essencialmente os fatores que devem ser analisados num TP e - se a análise for relevante à tradução - que devem ser contrapostos com os fatores correspondentes do TC (almejado), visto que o texto de chegada estará, da mesma forma que o texto de partida, inserido num quadro comunicativo do qual é dependente de como o recebem.]
\end{abstract}

Inspirada pela Estética da Recepção, vertente da teoria literária emergente na Alemanha entre as décadas de 1960 e 1970, Nord observa que a função textual e a situação comunicativa ganham materialidade apenas no momento de recepção do texto. Dessa maneira, o texto deixa de ser visto como a concretização da intenção comunicativa de seu emissor. Ora, se o texto adquire sua função apenas no momento de recepção, em tese ele teria inúmeras funções, quanto mais variado for seu público receptor, e mesmo um único indivíduo poderia atribuir funções diferentes ao mesmo texto ao longo de sua vida. Não obstante, Nord acredita que essa imensa variedade pode ser reduzida com uma rigorosa análise textual, envolvendo todos os elementos textuais, uma vez que, ainda que seja possível reconhecer diferentes funções num texto, há estratégias em sua estruturação que limitam essa variedade de funções possíveis.

Sendo um fator tão importante para a concepção do texto, a função textual influencia também a sua constituição. No entanto, a teorizadora observa que alguns componentes da estrutura textual podem exercer diferentes funções. Desse modo, seria mais seguro observar fatores internos e externos do para identificar com mais precisão as funções possíveis de um texto.

Da abordagem funcionalista, Nord resgata a definição de texto como parte de um "contínuo do mundo", interligado a outros elementos desse mundo numa relação de codependência. Isso significa dizer que a mudança de um elemento implica a mudança dos demais. Essa característica do texto é especialmente relevante para a translação.

Com isso, retomamos a explicação acerca do conceito de translação. Christiane Nord define-o da seguinte forma:

\footnotetext{
${ }^{416}$ NORD, 1988, p. 16.
} 
[62-64] Nach meiner Auffassung ist Translation folgendermaßen zu definieren: Translation ist die Produktion eines funktionsgerechten Zieltextes in einer je nach der angestrebten oder geforderten Funktion des Zieltextes (Translatskopos) unterschiedlich spezifizierten Anbindung an einen vorhandenen Ausgangstext. Durch die Translation wird eine kommunikative Handlung möglich, die ohne sie aufgrund vorhandener Sprach- und Kulturbarrieren nicht zustande gekommen wäre. ${ }^{417}$

[Segundo a minha concepção, translação pode ser definida da seguinte forma: Translação é a produção de um texto de chegada que faz jus à sua função e que tem uma ligação com um texto de partida existente. Essa ligação é especificada de diversas formas, conforme a função almejada ou exigida do texto de chegada (o skopos do translato). Através da translação, torna-se possivel uma ação comunicativa que, sem ela, não poderia ser executada devido a barreiras culturais e linguísticas presentes.]

O ponto de partida para a translação é a existência de um texto de partida, quase sempre trazido ao translador por um contratante, a quem Nord, a exemplo de HolzMänttäri (1984) denomina "iniciador". Ele recorre ao translador, pois precisa de um texto vertido à língua de chegada, sendo essa a língua do iniciador ou não. Aqui mais uma vez a FUNÇÃo da translação é eleita como critério central para orientar o processo de translação. Apesar de o iniciador ser considerado um fator decisivo para a translação, por ser ele a estabelecer as diretrizes para o TC e a definir o skopos desse texto, a responsabilidade pela translação seria toda do translador, posto que é ele o especialista em translação.

Nesse processo, o TRANSLADOR ocuparia posição central: ele seria receptor do TP, ainda que o texto não tenha sido formulado com vista à translação; ele seria também produtor do TC, compondo, assim, tanto a situação de partida quanto a situação de chegada. Em qualquer um desses papéis, ele se orientaria por diretrizes dadas pelo iniciador para a produção do TC, reunidas no encargo de tradução (al. Übersetzungsauftrag). Visto que a função do TC seria determinada através da situação comunicativa em que se inserirá esse texto, o encargo de tradução deveria conter o máximo de informações acerca dos fatores relativos à situação de recepção do TC: sobre o receptor, as condições temporais e espaciais de recepção, o canal etc. Nord explica que, quando o iniciador não consegue formular sozinho essas diretrizes, o translador deve converter as informações advindas do iniciador em diretrizes úteis para a concepção do TC.

Segundo Nord, enquanto receptor do TP, o translador distingue-se dos receptores originalmente almejados pelo emissor do texto por estar numa situação comunicativa espe-

\footnotetext{
${ }^{417}$ NORD, 1988, p. 31.
} 
cial: ele não ouve ou lê o texto para o seu próprio proveito, mas o faz "no lugar" do iniciador ou do receptor do TC. Sua recepção seria, assim, crítica e abrangente, norteada pelas informações contidas no encargo de tradução. Outro fator que influenciaria a recepção do texto por parte do translador é sua competência específica. Dele seria exigida uma competência translacional, a que pertencem a capacidade de recepção e produção textual, a capacidade de pesquisa e de conciliar as ações de recepção e produção. Ele deveria também ser capaz de simular a recepção do TP como se fizesse parte do grupo receptor a que o texto está originalmente dirigido, bem como de prever a recepção do translato por parte do grupo receptor da LC. Por fim, visto que a língua é componente de uma cultura, ele deveria ser proficiente nas culturas envolvidas no processo.

A recepção do TP exige do tradutor uma variedade de perspectivas: ele analisa o texto a partir do ponto de vista do receptor competente do TP, do ponto de vista de um "analista", projetando a real situação de recepção do TP, e do ponto de vista de um receptor competente da cultura de chegada, buscando ler o TP com os "olhos" do receptor do TC. Assim, ele deve lidar com diferentes situações de recepção: a sua própria, a do receptor pretendido do TP e a situação do receptor do TC, tentando antevê-la. Essa multiplicidade de perspectivas afetaria até mesmo o modo como o translador deve analisar a função comunicativa do texto: ela deve ser analisada do ponto de vista do emissor e do ponto de vista do receptor do texto. Do ponto de vista do emissor, seria especialmente importante considerar sua intenção com a produção textual, ou seja, a função comunicativa que ele almeja com o texto, a qual determina a estratégia de produção textual (questões de escolha lexical, estilo etc.) e influencia sua função, posto que o emissor se coloca no papel de seu pretenso receptor ao conceber o texto. Do ponto de vista do receptor, por sua vez, haveria uma determinada expectativa com o texto. Tanto sua expectativa quanto sua interpretação do texto poderiam não corresponder plenamente à intenção comunicativa do emissor. Se a questão da função do texto pode ser vista de duas perspectivas, e dada a posição intermediária do translador, ele deveria levar em conta tanto a função comunicativa almejada pelo emissor do TP em sua concepção, a qual determina a própria construção do texto, quanto a função comunicativa do TC, que determinará a sua própria estratégia de construção do texto (visto que o translador é ao mesmo tempo produtor do TC).

O fato de o translador ocupar o centro do processo de translação, segundo Nord, também determina a produção textual. A autora distingue emissor de produtor em consideração aos casos em que o texto não é produzido pela mesma pessoa de que parte a deman- 
da comunicativa. Nesse contexto, o translador passaria a exercer a função de produtor, não emissor, do texto de chegada, uma vez que produz o TC segundo as intenções comunicativas do emissor do TP ou do iniciador, incorporando-as e produzindo, desse modo, um texto.

Nord demonstra haver basicamente duas formas através de que se pode designar a relação entre a função de TP e a função de TC: o TC pode ter a função de "documentar" uma ação comunicativa anterior (i.e., o TP) ou o TC pode, a exemplo do TP, servir como instrumento comunicativo ante seu receptor na cultura de chegada. Essas duas diferentes relações entre os textos são designadas pelos termos tradução-documento e traduçãoinstrumento $^{418}$. A tradução-documento caracterizar-se-ia pela preservação de diferentes características ou níveis do texto de partida em detrimento (ou menor consideração) de outros. Assim, o receptor coloca-se conscientemente como observador numa situação alheia. A tradução-instrumento, por sua vez, teria como princípio o fato de a translação servir a uma nova situação comunicativa como instrumento, sem que o receptor tenha consciência de que não se trata de um texto novo, mas de um texto criado a partir de outro. A decisão de produzir um tipo ou o outro de translação seria tomada a partir da função comunicativa estabelecida para o TC, determinada, ao menos em parte, pela situação a que o TC está destinado.

A prevalência da função textual como critério fundamental de orientação da translação coloca a noção de translação defendida pela Skopostheorie em oposição aos preceitos da abordagem linguística tradicional, amparada no critério de equivalência. Nord critica mesmo as concepções de translação que a condicionam à equivalência entre funções comunicativas - como faz, por exemplo, Reiss (1971). Para Nord, a equivalência entre funções é apenas um dos casos de relação entre TP e TC, e nem chega a ser o caso mais "normal".

Ao definir em sua teoria do skopos a função como critério norteador da translação, Vermeer teria previsto os casos em que não há correspondência entre a função comunicativa do TP e do TC. Como vimos, ele define o texto como um elemento entre vários de um "contínuo do mundo", os quais estariam interligados, de modo que a mudança de um elemento implicaria a mudança dos demais. Na translação, há a óbvia mudança de língua e

\footnotetext{
${ }^{418}$ Para a tradução de "dokumentarische Übersetzung" e "instrumentelle Übersetzung", respectivamente, optamos por adotar os termos empregados na tradução da obra para o português (cf. NORD, 2016a, p. 134).
} 
cultura, bem como a mudança do público receptor. A mudança tornar-se-ia, assim, consequência natural da translação, projetando-se até mesmo sobre a função do translato.

No entanto, para a teorizadora, o predomínio da função sobre os demais critérios, inclusive sobre a coerência intertextual, podem exigir do translador uma postura pouco ética, em que os fins justificam os meios. A despeito da interpretação que faz dos trabalhos de Vermeer e de Holz-Mänttäri, Nord afirma que o translador não está relacionado unilateralmente com o receptor do translato e a situação comunicativa na cultura de chegada. Sobretudo o trabalho de Holz-Mänttäri dá ensejo a protestos da parte da autora, pois acredita que, para Holz-Mänttäri, o texto traduzido não seria necessariamente um texto "derivado" de outro, isto é, não teria ligação com um texto anterior. No entanto, a ausência dessa ligação, para Nord, não qualifica o texto como translação. Dessa maneira, a noção que HolzMänttäri, segundo seu entendimento, veicula de translação esvaziaria o texto de seu valor, tornando-o um mero instrumento para o cumprimento de uma função comunicativa, e não como um texto construído a partir de uma comunicação anterior. Vimos, no entanto, que posteriormente a própria Christiane Nord (1997c) revê seu posicionamento, pois percebe que a ação translacional, conforme definida por Justa Holz-Mänttäri, vai além do procedimento da translação: ela engloba as diversas atividades que são de responsabilidade do translador e que incluem, por exemplo, consultoria cultural ao cliente.

Para ela, a translação é uma ação transcultural que se baseia num texto de partida já existente. Além disso, a seu ver, o translador tem um compromisso de agir de forma ética com todos os envolvidos no processo de translação, o que inclui o emissor do TP. Ainda que deva entregar um translato que faça jus à função a ele designada, o translador deveria garantir a compatibilidade entre a função do TP e do TC, de modo a não falsear a intenção comunicativa do emissor do TP:

[72] Der Translator ist demnach bilateral gebunden: an den Ausgangstext und an die Ziel(text)Situation, und er trägt Verantwortung sowohl gegenüber dem AT-Sender (oder dem Initiator, sofern dieser Sender-Funktion übernimmt) als auch gegenüber dem Zieltextempfänger. Diese Verantwortung bezeichne ich als "Loyalität" - "Loyalität" ist eine ethische Qualität im Zusammenleben von Menschen; die "Treue" einer Übersetzung bezeichnet ein Abbildungsverhältnis zwischen Texten (vgl. NORD, denn.). ${ }^{419}$

[O translador está, então, compromissado bilateralmente: com o texto de partida e com a situação (do texto) de chegada, e ele tem responsabilidades tanto para com o emissor do TP (ou com o iniciador, contanto que esse assuma a função de emissor) quanto para com o receptor do texto de chegada. Essa responsabili-

\footnotetext{
${ }^{419}$ NORD, 1988, p. 32.
} 
dade denomino "lealdade" - A 'lealdade' é uma qualidade ética no convívio entre pessoas; a 'fidelidade' [Treue] de uma tradução refere-se a uma relação de imitação entre textos (cf. NORD, no prelo).]

A fim de elucidar como ocorre o processo de translação, Nord parte de alguns modelos apresentados em teorias de sua época. Ela observa nas teorias de tradução duas tendências de como representar o processo de translação: ora como um processo comunicativo composto por duas fases, ora como composto por três fases. O modelo bifásico, baseado em procedimentos de análise (a recepção do TP) e síntese (a produção do TC), consiste, segundo Nord, numa operação de "troca de código". Segundo Wilss, esse modelo de representação estaria mais próximo do que o translador de fato faz, ressaltando a dupla função do translador (receptor do TP e emissor do TC). Embora pareça especialmente condizente com a situação do intérprete simultâneo, Nord argumenta que esse grau de automatização na translação (que seria responsável por considerar irrelevante uma etapa de "transferência") aplica-se a apenas o mínimo dos casos. Ao analisar o esquema bifásico de translação, ela observa que, segundo as teorias que defendem essa noção de translação, bastaria apenas a competência receptiva na LP e a competência produtiva na LC para tornar um falante de línguas um translador.

O modelo trifásico, por sua vez, incluiria uma fase de transferência entre a análise e a síntese. Embora mais complexo do que o anterior, Nord destaca que parece contraditório definir o translador como receptor do TP e emissor do TC, pois, se a translação consiste numa comunicação entre pessoas através de barreiras linguísticas, então o emissor do TP (ou até mesmo o iniciador) não renuncia a sua posição de emissor, cabendo ao translador, como vimos, apenas o papel de produtor do TC.

Os dois modelos teriam em comum o fato de verem no texto de partida um "encargo de tradução imanente", a partir do qual estariam todas as instruções para a produção do translato. No entanto, se o texto adquire sua função do contexto de recepção, essa função imanente, definida a priori noutro ambiente de recepção não seria válida. Assim, ela observa ser mais plausível a postura dos funcionalistas de considerar o translato uma oferta de informação acerca de uma oferta de informação pré-existente. Ela acrescenta, marcando o lugar de subordinação do translador: ele faz uma oferta de informação a mando de um iniciador. Isso significa que, dependendo da função do TC, poder-se-iam oferecer diferentes informações do TP. 
Com isso, Nord oferece uma representação alternativa do processo de translação aos modelos bifásicos e trifásicos que dominavam até então a disciplina. A esse modelo, ela atribui a denominação "modelo circular", descrito, de forma resumida, da seguinte forma:

[89-91] Der Vorgang beginnt bei der Festlegung des Skopos (Z-Situation und Zieltextfunktion) durch den Initiator, eventuell unterstützt vom Translator, und der Analyse der betreffenden Angaben, die möglichst detailliert sein sollen, durch den Translator. Danach analysiert der Translator den AT-in-Situation in Bezug auf das darin enthaltene Translationsmaterial. Er isoliert die übersetzungsrelevanten AT-Elemente, transferiert sie gemäß dem Skopos in die Z-Kultur und produziert einen ZT, der in der Z-Situation den Zieltextvorgaben entspricht und damit funktionsgerecht ist.

[O processo começa com a fixação do skopos (situação de chegada e função do texto de chegada) pelo iniciador, ocasionalmente com o apoio do translador, e a análise dos dados correspondentes pelo translador, as quais devem ser as mais detalhadas possível. Depois disso, o translador analisa o TP-em-situação com referência ao material de translação nele contido. Ele isola os elementos do TP relevantes à tradução, transfere-os à cultura de chegada, de acordo com o skopos e produz um TC correspondente à situação de chegada e ao modelo do texto de chegada e, com isso, faz jus à função.]

Como produtor do TC, o translador está numa situação comparável à do produtor do TP (quando esse não é o emissor do TP): ele está sujeito à intenção comunicativa do emissor. A intenção do emissor é relevante à translação mesmo quando o TC deva exercer uma função diferente do TP: segundo o princípio de lealdade, mesmo voltado a uma nova função, o TC não poderia contradizer a intenção do emissor do TP.

O trabalho do translador também seria determinado pelos materiais de que dispõe: em posse de materiais de pesquisa, listas terminológicas e textos comparáveis na LC, o trabalho ficaria mais fácil. Por isso, numa translação o translador deveria contar com todos os materiais confiáveis a seu dispor para compensar o déficit de conhecimento entre o receptor almejado do TP e o receptor almejado do TC. Por conta de seu compromisso de lealdade, dentre esses materiais deve constar uma análise do TP que auxilie o translador a tomar decisões com base na função (ou no conjunto de funções) do TP. Ao formular uma oferta de informação sobre o TP, o tradutor decide, a partir da análise de fatores internos e externos do texto, quais informações são condizentes com a função do TC, devendo, assim, ser oferecidas ao novo público receptor. Assim, Nord apresenta o seu próprio modelo de análise textual, formulado com propósitos pedagógicos, mas que também se voltam à rotina do translador profissional. 
O modelo de análise textual de Christiane Nord envolve FATORES que interferem na constituição do texto. Dada a importância da situação comunicativa para a própria noção de texto, Nord destaca a análise dos fatores referentes à função comunicativa no modelo de análise textual do TP. A esses fatores, Nord utiliza a denominação "fatores extratextuais", em oposição aos fatores "intratextuais", referentes à constituição interna do texto. Assim como ocorre com Holz-Mänttäri (1984), o modelo de Nord é organizado na forma de questões. Uma cadeia de questões volta-se aos fatores extratextuais: produtor ou emissor do texto (quem?), intenção do emissor (para quê?), receptor (a quem?), canal (através de que meio?), local (onde?), tempo (quando?), e motivo (por quê?). A partir da resposta dessas questões definir-se-ia a função do texto (com que função?). A segunda cadeia de questões volta-se aos fatores intratextuais: assunto (sobre o quê?), conteúdo (o quê?), pressuposições (o que não?), estruturação (em que sequência?), os elementos não verbais (usando quais elementos não verbais?), léxico (com que palavras?), sintaxe (com que frases?) e características suprasegmentais (com que tom?). O fator "efeito" (com que efeito?) seria passível de identificação apenas observando a interação entre fatores intra- e extratextuais.

Os fatores extratextuais dizem respeito à situação comunicativa concreta em que se insere o texto, não a uma situação ficcional construída no próprio texto: emissor e sua intenção, receptor pretendido, canal, lugar, tempo e ocasião comunicativa. A função textual é definida como a(s) função(ões) comunicativa(s) de um texto, resultante da constelação de fatores que caracterizam a situação comunicativa. Sendo assim, a função textual estaria relacionada com o componente situacional do texto.

A investigação dos componentes relativos à situação comunicativa oferece indícios acerca das características internas do texto. Os fatores intratextuais, como mencionado anteriormente, são o tema, o conteúdo, as pressuposições, a estruturação do texto, os elementos não verbais, o léxico, a sintaxe e as características suprassegmentais. Nord observa que, segundo seu modelo de análise, as informações semânticas são contempladas pelas categorias "conteúdo", "tema" e "pressuposições"; léxico, sintaxe e características suprassegmentais, por sua vez, são elementos linguístico-estilísticos. Todavia, esses fatores só poderiam ser isolados a bem de um proceder metodológico, isto é, eles são considerados estruturas interdependentes.

Nesse contexto, o conceito de INFORMAÇÃo está sendo usado de modo próximo a "conteúdo" ou, ao menos, de "informação semântica" contida no texto. Aqui, para se atingir a compreensão, a informação do texto deve estar associada a uma "realidade". Se no 
caso se tratar da realidade de uma determinada cultura, essa deve estar no horizonte do tradutor. Nord observa que dentre a informação verbalizada num texto não há apenas informação na forma denotativa, mas também na forma conotativa, que está ligada a um determinado estilo. Inclui-se entre as informações semânticas de um texto também aquilo que não é verbalizado, mas que é requerido para entendê-lo: as pressuposições, isto é, as informações pressupostas dos receptores. Nesse sentido, as pressuposições que são desconhecidas e não são triviais ao público de chegada devem ser levadas em consideração pelo translador. A decisão do que é redundante num texto basear-se-ia numa expectativa, da parte do emissor, do nível de informação de que é dotado o receptor. Da mesma forma, o translador deve determinar o que é redundante e o que é essencial tendo em vista o nível de informação de que é dotado do receptor do TC.

Nord observa que alguns fatores intratextuais têm mais peso num encargo de tradução do que outros. Em alguns gêneros textuais, a análise enfatiza alguns fatores, enquanto outros são bastante previsíveis, dada sua convencionalidade. Também no caso dos fatores intertextuais há uma relação de interdependência, de modo que as informações sobre um fator aponta a características de outros fatores (ou pelo menos permite sua constatação). A categoria "efeito", por sua vez, deve ser vista como referente ao receptor. Um texto desencadeia determinado efeito sobre o receptor a partir da relação das características intratextuais com as expectativas construídas pelo leitor a partir dos fatores extratextuais.

Como forma de "didatizar" o seu modelo, Nord propõe a criação de uma tabela que contemple, na coluna à direita, as prescrições do encargo de tradução para o TC e, na coluna à esquerda, os fatores intratextuais e extratextuais do TP. Com isso, seria possível determinar os fatores mais determinantes para o caso em questão. Esses fatores não precisariam estar explícitos no encargo de tradução; as informações acerca de alguns fatores podem trazer, de forma implícita, informações acerca de outros fatores.

Nord observa que a compreensão de um texto muitas vezes depende de conhecimentos, da parte do leitor, do tema do texto - o que ela denomina o "horizonte" do leitor. Esse, a seu ver, não se diferencia apenas de pessoa para pessoa no nível individual, mas também entre culturas, e o translador deve estar ciente daquilo que está (e o que não está) no horizonte tanto dos receptores do TP como dos receptores do TC. Ele não pode ser, assim, um observador "desinteressado", mas sim, deve tentar encontrar uma justificativa objetiva para seu entendimento intuitivo. É importante que o translador seja bicultural, pois 
ele deveria reconhecer, por exemplo, idealmente todas as informações implícitas no TP que são triviais ao receptor-P, mas que não o são ao receptor-C.

Nord observa que o emissor de um texto tem uma determinada intenção com esse texto, que é exercer um determinado efeito sobre o receptor. A intenção presumiria, assim, uma antecipação do efeito do receptor e, com isso, ela determinaria as estratégias textuais adotadas pelo produtor do texto. Esse é um problema que atingiria tanto o produtor do TP como o translador, pois também esse deveria antecipar o efeito do texto sobre o receptor-C e adotar as estratégias textuais necessárias para isso. Assim, produtor do TP e translador devem ter conhecimento de causa e imaginação para se colocar no lugar de seu respectivo receptor, além da responsabilidade pelo resultado do processo.

As dificuldades de uma translação teriam muito a ver com a competência do translador: um problema de translação seria um problema, independente do fato de o translador ser inexperiente ou não, mas ele só representaria uma dificuldade de translação se o translador não tiver aprendido a contorná-lo ou não dispuser dos meios necessários para isso. Para Nord, no aprendizado de translação (mas também na atividade profissional), quanto mais o estudante (ou o translador) souber acerca dos fatores externos do texto, isto é, dos fatores relativos à situação comunicativa do texto, mais fácil será solucionar dificuldades de compreensão. Informações externas do texto seriam de grande ajuda na resolução de problemas relativos às características internas.

O grau de dificuldade de uma translação também teria a ver com a direção de translação: via de regra, por ter uma competência ativa maior na língua materna, o translador poderia ter mais dificuldades de translação para a língua estrangeira. No entanto, com a especialização correta, poder-se-ia chegar a um alto nível de translação mesmo para a língua estrangeira. As diferentes competências exigidas do translador deveriam ser desenvolvidas no curso de formação - em primeiro lugar, separadamente e, em segundo lugar, elas devem ser treinadas em conjunto.

Outra oportunidade de aplicação dos preceitos funcionalistas foi encontrada por Mary Snell-Hornby, que ansiava por unir duas áreas que pareciam se desenvolver separadas uma da outra: a linguística e a tradução literária. 


\subsubsection{Mary Snell-Hornby: a abordagem integrada}

Dos itens deste corpus, a inclusão da obra de Mary Snell-Hornby é a mais controversa. Na primeira edição de seu livro Introducing Translation Studies [Introduzindo os estudos da tradução], Jeremy Munday inclui a prototipologia de Snell-Hornby no capítulo "Translation studies as an interdiscipline" [Estudos da tradução como uma interdisciplina $]^{420}$; nas edições posteriores, ela é trazida para o capítulo "Functional theories of translation" [Teorias funcionais de tradução]. Anthony Pym (2010) também cita a abordagem da autora dentre as abordagens funcionalistas. Já Christiane Nord (2012a, p. 31) afirma que a classificação de Snell-Hornby como funcionalista é, "no mínimo, discutível". Ainda que reconheça as afinidades de sua proposta teórica com a vertente funcional, Snell-Hornby opta por denominá-la "abordagem integrada".

Mary Snell-Hornby nasceu em Mirfield, Inglaterra, em 1940. Segundo relata, sua carreira começou com a aspiração de seguir uma carreira diplomática, a fim de promover a queda de fronteiras e a união dos povos. Suas ambições levaram-na a estudar diversas línguas: graduou-se em Inglês, Francês, Alemão e Filosofia Moral na Universidade de St. Andrews, na Escócia, onde obteve, em 1962, o título de mestre em Língua e Literatura Alemã. No entanto, logo suas aspirações diplomáticas foram frustradas. Em 1964, estabeleceu-se em Munique, onde ministrou aulas de inglês e exercícios de tradução. O crescente interesse em suas aulas trouxe consigo um volume imenso de correções de exercícios e discussões de traduções in plenum, fornecendo, assim, o material para algumas de suas publicações e para sua livre-docência. Paralelamente, traduziu documentários, e o exercício da atividade profissional revelou diferenças em como proceder no exercício da profissão e no meio didático. A constatação a que ela chegou foi a de que "a tradução profissional funcionava claramente segundo regras diferentes da tradução filológica em sala de aula." ${ }^{421}$ (SNELL-HORNBY, 2004, p. 337)

Em suas viagens pelo mundo, Snell-Hornby confrontou-se com a complexidade da comunicação bilíngue e intercultural, uma complexidade muito maior do que se acreditava na universidade. Sua estrada acadêmica, no entanto, teria começado após o final de seu contrato na Universidade de Munique, em 1968, e a mudança para Zurique, em 1977. Em-

\footnotetext{
${ }^{420}$ Cf. MUNDAY, 2001 e 2008.

${ }^{421}$ Offensichtlich funktionierte das Berufsübersetzen nach anderen Regeln als das philologische Übersetzen im Hörsaal.
} 
bora pleiteasse um doutorado, o sistema acadêmico suíço qualificou seu trabalho como uma tese de livre-docência. Contudo, como faltava-lhe o título de doutora, a que se inscreveu com o trabalho Translation Studies - An Integrated Approach [Estudos da tradução uma abordagem integrada], em 1986:

Quando o manuscrito foi submetido para apreciação, seguindo as normas da universidade, um linguista do âmbito da anglística disse o seguinte: como estudo sobre tradução, o trabalho pertencia à sua área de competência, mas ele acreditava que aquele não era um "estudo linguístico propriamente dito" e, assim, precisaria ser inteiramente reformulado. Com o argumento de que o trabalho não deveria ser alocado nem no âmbito da linguística, nem no âmbito da teoria literária, mas, sim, no âmbito dos estudos da tradução, consegui me impor apenas depois de uma discussão difícil. De todo modo, foi publicado pela Benjamins (SNELLHORNBY, 1988) e ainda hoje é vendido em todo o mundo (recentemente também numa edição para o mercado chinês). ${ }^{422}$ (SNELL-HORNBY, 2004, p. 339)

Questões relativas à permissão de permanência na Suíça levaram Snell-Hornby, em 1981, a Heidelberg, ocupando o posto de professora substituta no Departamento de Inglês da universidade entre 1981 e 1983, onde conheceu, dentre outros, Fritz Paepcke, Radegundis Stolze, Christiane Nord, Heidrum Gerzymisch-Arbogast e, posteriormente, Hans J. Vermeer. A autora relata como foi vivenciar esse momento da abordagem funcional:

Com a recém-emergente abordagem funcional - junto com Holz-Mänttäri, também a Skopostheorie de Hans Vermeer, que representava a tradução não como uma transferência linguística, mas uma transferência cultural (cf. VERMEER, 1986) - os estudos da tradução, ou melhor, os estudos da translação desenvolveram-se durante a década de 1980 de uma subárea da linguística para uma disciplina autônoma. Sempre estive absolutamente convencida da abordagem funcional, sobretudo para a tradução técnica. Contudo, a abordagem não encontrou em Heidelberg apenas apoio - especialmente por parte dos filólogos de áreas vizinhas - e, assim como aconteceu em Munique, meu engajamento não foi de todo apreciado. ${ }^{423}$ (SNELL-HORNBY, 2004, p. 340)

Em 1983, Snell-Hornby encontrou-se novamente desempregada. Então, ela reuniu contribuições de autores ligados aos estudos da tradução alemães e, em 1986, publicou a

\footnotetext{
${ }^{422}$ Als das Manuskript gemäß Zürcher Vorschrift zur Einsicht auflag, meldete sich aber ein anglistischer Sprachwissenschaftler zu Wort: als Studie zur Übersetzung gehöre die Arbeit zu seinem Zuständigkeitsbereich, sie sei aber keine ,richtige linguistische Studie" und müsste daher gründlich überarbeitet werden. Mit dem Argument, die Arbeit sei weder in der Linguistik noch in der Literaturwissenschaft, sondern in der Übersetzungswissenschaft anzusiedeln, konnte ich mich nur nach einer schwierigen Auseinandersetzung durchsetzen. Die Studie erschien jedenfalls bei Benjamins (Snell-Hornby 1988) und wird heute noch in aller Welt (neuerdings auch in einer Fassung für den chinesischen Markt) verkauft.

${ }^{423}$ Mit dem neu entstandenen funktionalen Ansatz - neben Holz-Mänttäri auch die Skopostheorie von Hans Vermeer, der das Übersetzen nicht als sprachlichen, sondern als kulturellen Transfer darstellte (vgl. Vermeer 1986) - entwickelte sich die Übersetzungs-, oder vielmehr die Translationswissenschaft im Laufe der 80er Jahre von einem Teilbereich der Linguistik zur eigenständigen Disziplin. Vom funktionalen Ansatz war ich vor allem für das Fachübersetzen absolut überzeugt. Dieser fand aber in Heidelberg - besonders bei den Philologen der Nachbarfächer - nicht nur Unterstützung, und ähnlich wie in München wurde mein Engagement nicht überall geschätzt.
} 
antologia Übersetzungswissenschaft - Eine Neuorientierung [Estudos da tradução - uma reorientação]. Ao longo dos anos 1980, passou por diversas outras instituições e fez desses alguns dos anos academicamente mais produtivos.

O marco de sua produção acadêmica, contudo, foi a publicação, em 1988, de sua pesquisa de doutorado, Translation Studies [Estudos da tradução], voltada a questões referentes à tradução do texto literário. Como mencionamos há pouco, a teoria do skopos de Hans Vermeer emergiu do âmbito da Linguística, com a qual, ao menos em princípio, não intencionava romper. Como uma abordagem surgida da Linguística, ainda que se destinasse a contemplar todas as formas de tradução (e de interpretação), foi facilmente associada à tradução "técnica", isto é, ao texto não literário, o que acarretou acusações de que não seria uma abordagem apropriada à tradução do texto literário. Com o intuito de estabelecer a ponte entre a Linguística e a tradução literária, Snell-Hornby sustentou a convicção de que determinadas abordagens e métodos da Linguística poderiam ser aplicadas com sucesso a todos os tipos de tradução ${ }^{424}$.

O propósito de seu livro está relacionado a uma herança das abordagens tradicionais da tradução, isto é, à posição privilegiada da linguagem geral em comparação com a linguagem literária, considerada então como "desviante" por muitos linguistas. Segundo Snell-Hornby, isso representou uma cisão no âmbito mesmo das teorias de tradução: excluída da abordagem linguística, a tradução literária continuaria a ser tema de estudos da literatura comparada, cujas ponderações, naturalmente, não incluíam o texto técnico. Em face desse contexto, ela propôs não apenas uma nova forma de conceber esses dois tipos de tradução - sem fazer uso de tipologias estanques -, mas outra forma de conceber a tradução em si: em vez de resumido a uma questão de palavras isoladas, o conceito de tradução passaria a envolver um texto-em-situação, esse parte de um contexto cultural ${ }^{425}$. Observa-se que, com isso, Snell-Hornby incorporou em sua definição de tradução uma perspectiva funcionalista. Ao apoiar-se sobre bases funcionalistas, Snell-Hornby não apenas respondeu às críticas dirigidas à linguística, mas também ao funcionalismo, demonstrando que ambos também teriam muito a contribuir para a tradução literária.

Após o doutoramento, ingressou na Universidade de Viena, Áustria, onde atuou na reorganização do currículo com base nos novos "estudos da tradução". Orientou teses de doutorado e escreveu pareceres de teses de livre-docência de figuras proeminentes nos es-

\footnotetext{
${ }^{424}$ SNELL-HORNBY, 1988, p. vii-viii.

${ }^{425}$ Ibid., p. 1s.
} 
tudos da tradução, tais como Klaus Kaindl, Hanna Risku, Franz Pöchhacker, Michaela Wolf e a própria Christiane Nord. Além disso, organizou palestras, congressos e fomentou a troca de informações. Ela foi uma das fundadoras da European Society for Translation Studies (EST) [Sociedade Europeia para Estudos da Tradução], presidindo a associação entre os anos de 1992 e 1998.

\subsubsection{Análise}

De modo a introduzir o conceito de TRADUÇÃO, Mary Snell-Hornby faz uma citação de George Steiner, que, tendo em vista a tradução de textos literários, a descreve como um ato de abolição das multiplicidades e, ao mesmo tempo, a reinvenção da forma do sentido textual. $\mathrm{O}$ ofício do tradutor - novamente, o tradutor literário - seria marcado pela tensão radical entre o ímpeto da representação mais fidedigna e o ímpeto da recriação autoral. No entanto, a esse respeito, a teorizadora comenta que a "tensão radical" de que fala Steiner não é um dilema exclusivo do tradutor literário, mas de qualquer tradutor.

Ao longo da história, a teoria de tradução teria sido marcada por categorizações estanques e por polarizações dicotômicas, que incluem a divisão entre tradução literária e tradução não literária. Nesse contexto, a autora estabelece como objetivo para o livro a aproximação das diferentes modalidades de tradução ao trazer para a tradução literária desenvolvimentos recentes da linguística. Com isso, ela busca o abandono das dicotomias e a aceitação do caráter multidimensional da língua, bem como uma mudança na forma como se vê a tradução: não mais como uma questão de palavras, mas como um processo que tem início com um texto-em-situação como parte de um contexto cultural. Essa é uma noção do traduzir bastante alinhada às propostas defendidas pelas abordagens da chamada "virada cultural", em especial, pela abordagem funcionalista. Ela também revela a visão de tradutor que tentará sustentar em sua obra: a de um especialista dotado de máxima proficiência, de conhecimentos técnicos e da sensibilidade de um artista.

Ao trazer as abordagens linguísticas para o estudo da tradução literária, SnellHornby tenta integrar dois campos que até então desenvolviam-se afastados um do outro. Ela justifica esse posicionamento, afirmando que tanto o tradutor (prático) quanto o teorizador estão preocupados com um mundo entre disciplinas, línguas e culturas. Para conce- 
ber essa abordagem integrada, a autora vê a necessidade de mudar a forma de pensar língua e tradução, a começar pelas conceituações e categorizações empregadas no âmbito da tradução, substituindo a classificação em categorias estanques por uma abordagem holística. Com isso, "o caráter multidimensional da língua, com sua tensão dinâmica de paradoxos e forças aparentemente conflitantes, torna-se a base para a tradução" (SNELL-HORNBY, 1988, p. 2). Snell-Hornby propõe-se a abordar a língua como um todo, e não apenas as diferentes linguagens, por exemplo, a linguagem literária ou a linguagem técnica, as quais definem diferentes tipos de tradução. Ao evitar as divisões bem marcadas, ela pretende demonstrar que os estudos da tradução podem abarcar indistintamente os diferentes tipos do traduzir.

Segundo Snell-Hornby, um TEXTO não pode ser considerado um "espécime estático de língua" (ibid.), mas uma expressão verbalizada das intenções de um autor, tal como compreendidas pelo tradutor, que a recria a outro público leitor em outra cultura. Ele deve ser visto em termos de sua função comunicativa, como uma unidade numa dada situação e, ao mesmo tempo, parte de um contexto sociocultural mais amplo. A partir dessa observação de Snell-Hornby fica bem claro que o texto tomado em sua situação comunicativa é o objeto da tradução.

O vínculo do texto com uma situação comunicativa, isto é, com um tempo e espaço determinados, que influenciam na função e na própria estruturação do texto, impede que o texto adquira uma forma que seja perene ou ao menos que se mantenha atual para todos os públicos. Assim, há, de tempos em tempos, a necessidade de novas traduções. Esse processo dinâmico, conforme observa a teorizadora, explica por que não existe a "tradução perfeita".

Dessa forma, ela se afasta da noção tradicional de traduzir como um procedimento que ocorre entre línguas, orientado por critérios como a fidelidade ou a equivalência de significados. Para a autora, nessa noção está a origem das dicotomias nas teorias de tradução. A busca por "equivalência ideal" na tradução repousaria sobre uma falsa ideia de simetria entre as línguas, de modo que haveria em cada língua o correspondente ideal de outra. Destarte, bastaria ao tradutor a competência linguística para nortear a escolha do equivalente ideal.

Em oposição a essa ideia tradicional de tradução, Snell-Hornby exalta a definição para o verbete LÍNGUA da Encyclopaedia Britannica: 
[102-104] One aspect of the Encyclopaedia Britannica's modest contribution on translation does however give cause for optimism: unlike the traditional approach in linguistics (which for a long time endeavoured to draw a sharp dividing-line between language and what was called "extralinguistic reality"), language is not seen as an isolated phenomenon suspended in a vacuum but as an integral part of culture; the sub-section of which the few paragraphs on translation form a sub-division happens in fact to have the same title as this present chapter: Language and culture. ${ }^{426}$

[Um aspecto da modesta contribuição da Encyclopaedia Britannica para a tradução é, sim, causa para otimismo: diferente da abordagem tradicional na linguística (que por um longo tempo esforçou-se para delimitar as fronteiras entre língua e o que era chamado de "realidade extralinguística"), a língua não é vista como um fenômeno isolado suspenso no vácuo, mas como uma parte integral da cultura; a subseção em que os poucos parágrafos sobre tradução formam uma subdivisão vem, de fato, a ter o mesmo título que o presente capítulo: língua e cultura.]

A língua é considerada, portanto, "parte do mundo" Por sua vez, a tradução seria, assim, um processo que ocorre entre culturas, não meramente entre línguas. Esse é mais um indício da afinidade da abordagem integrada de Snell-Hornby com a abordagem funcional.

Outro indício está na concepção de cultura de que a autora se vale, a saber, a concepção de cultura como a totalidade de conhecimentos, proficiências e percepções, tal como definida por Ward H. Goodenough ${ }^{427}$ e por Heinz Göhring ${ }^{428}$. Ela destaca dessa definição a relação que se estabelece entre cultura e comportamento e o fato de a cultura depender de normas, sejam essas normas sociais ou de uso linguístico. Para exercer sua função profissional, o tradutor deveria ser proficiente não apenas em duas línguas, como também em duas culturas. A extensão do conhecimento, proficiência e percepção das duas culturas determinaria não apenas a habilidade do tradutor em produzir o TC, mas também a de entender o TP.

De modo semelhante ao que fez Justa Holz-Mänttäri, Snell-Hornby cita a associação estabelecida por Humboldt entre língua e cultura e entre língua e comportamento: ao mesmo tempo em que língua se define como atividade, ela é considerada expressão tanto de uma cultura como da individualidade do falante, que percebe o mundo através da linguagem. Essa tese traz efeitos sobre a própria noção de traduzibilidade: longe de ser o que Humboldt pretendeu com suas ideias, a tese de que a percepção do mundo é determinada pela linguagem é levada ao extremo na hipótese Sapir-Whorf - um extremo que afirma a

\footnotetext{
${ }^{426}$ SNELL-HORNBY, 1988, p. 39.

${ }^{427}$ GOODENOUGH, Ward H. Cultural Anthropology and Linguistics. In: HYMES, Dell (ed.). Language in Culture and Society. A Reader in Linguistics and Anthropology. New York: Harper \& Row, 1964, p. 36-40.

${ }_{428}$ GÖHRING, Heinz. Interkulturelle Kommunikation: Die überwindung der Trennung von Fremdsprachen- und Landeskundeunterricht durch einen integrierten Fremdverhaltensunterricht. In: Kongreßberichte der 8. Jahrestagung der Gesellschaft für Angewandte Linguistik GAL e. V., vol. IV, Mainz, 1977, p. 9-13.
} 
intraduzibilidade. Por outro lado, a tese de Chomsky de que haveria universais em comum entre todas as línguas desloca-nos para o outro extremo: a da plena traduzibilidade. Para Snell-Hornby, o ponto da escala a ser procurado é aquele que satisfaz cada caso particular.

No lugar da tradicional dicotomia estabelecida por Ferdinand de Saussure entre significante/significado, Snell-Hornby recorre a uma visão de língua mais complexa, como descrita por Eugenio Coseriu no artigo Sistema, norma y habla [Sistema, norma e fala]. Em vez de representada por uma dicotomia, a língua é representada por um espectro, no qual o sistema é o grau mais abstrato e a fala o grau mais concreto; entre eles estaria a norma. O texto, por sua vez, seria uma forma de fala, de enunciação concreta. Embora Snell-Hornby esteja de acordo com Coseriu no que tange ao fato de o sistema ser um vasto complexo de possibilidades, ela discorda no concernente ao caráter restritivo que o linguista atribui à norma. Em seu lugar, ela vê, no âmbito da tradução, a norma como uma questão de uso prototípico e de convenção. Enquanto o uso prototípico da norma poderia ser observado, por exemplo, no emprego das palavras, a convenção permite que normas sejam associadas a situações. A norma não se aplicaria apenas à língua, mas também a todos os níveis de vida social. Seu grau de prescrição também seria variável de comunidade para comunidade.

Uma ideia menos restritiva de norma teria sido adotada pela abordagem hermenêutica da tradução. Aqui "norma" não se limitaria à língua, mas aplicar-se-ia também à noção de cultura. Assim, embora seja fulcral conhecê-la, a norma (cultural e linguística) não seria limitadora, mas ofereceria um potencial infinito de criação. É o uso controlado, discriminado desse potencial criativo, bem como a variedade de relações existentes entre regras, normas e as realizações mais idiossincráticas dentro das possibilidades do sistema que permitiriam o contato entre norma e texto e entre a linguagem literária e a linguagem comum. Com isso, a língua passaria a abranger os diferentes tipos de linguagem, o que não justificaria, assim, a exclusão da linguagem literária do horizonte de reflexões da linguística.

A esse respeito, Snell-Hornby cita novamente Coseriu, que afirma que a linguagem literária não é um desvio, mas sim, a concretização das possibilidades da língua, enquanto a linguagem comum é vista por ele como uma redução do potencial da linguagem. Essa visão de língua está alinhada àquela adotada pela autora: a linguagem literária resulta da exploração do potencial de uma língua e volta-se a não apenas desafiar a norma estática e prescritiva, mas também criar uma norma própria. Na tradução literária, o grande dilema 
do tradutor é como verter à língua-alvo essas extensões criativas da linguagem do textofonte, sem infringir as regras de aceitabilidade linguística.

Mesmo que a concepção chomskyana de universais da linguagem e as noções de língua derivadas do estruturalismo não tenham dados subsídios relevantes para analisar o processo de tradução, a meta de Snell-Hornby é demonstrar que nem todas as contribuições da linguística são inúteis ao elucidar o caso da tradução. Além do trabalho supracitado de Eugenio Coseriu, ela menciona a ascensão de disciplinas que passaram a ver a língua em toda sua variabilidade e em relação com o comportamento e a percepção humana, com a cultura e com a comunicação. Em comum, essas disciplinas e abordagens apoiar-se-iam numa perspectiva que sintetiza em vez de separar; a língua seria vista como um fenômeno relacionado com o mundo em seu entorno e com outras disciplinas; elas também teriam aderido a diferenciações vinculadas com a cultura, em vez de teorias universalizantes, assim como trabalhariam com usos linguísticos empíricos.

Tendo em vista que Snell-Hornby escreve a partir de um contexto germanófono, ela analisa as tendências no âmbito das teorias de tradução pautando-se sobretudo no ambiente de expressão alemã. Segundo afirma, ainda que tenha havido anteriormente uma forte orientação hermenêutica, considerava-se em seu tempo a hermenêutica vaga demais para explicar o fenômeno tradutório. Na Alemanha, a vertente que desfrutava de maior popularidade era a vertente funcionalista. Ainda que naquela época não fosse considerada uma abordagem própria, Snell-Hornby reconhece muitas semelhanças nas propostas de Hönig e Kussmaul (1982), Reiss e Vermeer (1984) e Holz-Mänttäri (1984). Em comum, essas propostas teriam a orientação comum de considerar a tradução uma transferência mais cultural que linguística, a visão de tradução não como um processo de transcodificação, mas como um ato de comunicação e o fato de considerarem a função do TC (tradução prospectiva) um critério de orientação mais determinante do que a função do TP (tradução retrospectiva). Ela ainda cita a visão que os três compartilham de que o texto é parte integral do mundo, não um espécime isolado de língua. Para esses autores, o tradutor não exerce uma função passiva na compreensão do TP, mas um papel ativo e criativo.

Do livro de Hönig e Kussmaul, Snell-Hornby destaca alguns componentes teóricos, a começar pela definição de texto como "a parte verbalizada de uma sociocultura", isto é, o fato de o texto estar inserido numa dada situação, a qual é, ela mesma, condicionada pelo contexto sociocultural. Para os autores, o processo de tradução dependeria de definir-se uma função para o TC na cultura-alvo havendo duas possibilidades: a tradução pode ter a 
mesma função do texto de partida em sua cultura ou uma função diferente. Para a teorizadora, essa dependência demonstra, ao mesmo tempo, que não haveria uma só forma de traduzir, muito menos uma "tradução perfeita", sendo a tradução (mesmo a tradução literária) dependente da função prescrita pelo contratante ao texto de chegada - ainda que admita que na tradução literária o texto de partida costuma sustentar um status diferente do que tem em outras formas de tradução.

Ela também ressalta da proposta de Hönig e Kussmaul a noção de "grau necessário de diferenciação" como critério de avaliação de traduções. Segundo esse critério, trazem-se do TP os elementos do contexto sociocultural de partida apenas na medida necessária para que o texto de chegada exerça a função que lhe foi atribuída. Conforme ela afirma, eles rejeitam a avaliação comum nos institutos de formação de tradutores, que prescreve a manutenção dos elementos do TP "o máximo possível". Em seu lugar, eles afirmariam que o tradutor deve manter do TP "o máximo necessário para a função do texto". Eles se afastariam, assim, da concepção de tradução de palavras; trata-se aqui da tradução de textos e, quando necessário, de palavras-em-textos. Na proposta de ambos, Snell-Hornby identifica uma novidade no que concerne a ferramentas para a resolução de problemas. Contudo, os fundamentos teóricos teriam sido absorvidos de outras propostas, especialmente a de Hans J. Vermeer.

Da Skopostheorie de Vermeer, Snell-Hornby salienta a noção de translação como ação, mais exatamente, como uma transferência transcultural. Teria vindo de Vermeer a premissa da prevalência da função. Seu objeto de interesse não seriam palavras, mas textos em situação. Além disso, Vermeer afasta-se das discussões que preveem uma acepção estática e absoluta de texto; para ele, a situação opera como variante daquilo que definiria um texto, isto é, desconsiderando o aspecto material, não teria uma essência e um sentido imutáveis, mas seria interpretado de formas diferentes, conforme a situação comunicativa em que está inserido. Embora em princípio suas considerações apliquem-se a todos os tipos de textos, Snell-Hornby observa que Vermeer recorre frequentemente a exemplos não literários.

A teoria da ação translacional de Holz-Mänttäri é considerada bastante similar à Skopostheorie de Vermeer. Não obstante, segundo Snell-Hornby, Holz-Mänttäri é mais radical em seus métodos e em seu modelo conceitual. Snell-Hornby destaca a inclusão do conceito de mensagem, dissociado do conceito de texto: assim, para Holz-Mänttäri, o texto seria apenas veículo da mensagem. Ademais, Snell-Hornby enfatiza o fato de a ação trans- 
lacional ser um sistema de ações envolvendo a cooperação entre especialistas. Acima de tudo, ela lança luz sobre o perfil do translador traçado por Holz-Mänttäri: o de profissional especialista. Assim, Holz-Mänttäri iria de encontro à crença de que bastaria a competência bilíngue para ser translador.

Para Snell-Hornby, a tradução não pode basear-se apenas na substituição de palavras, mas, sim, deve recriar as dimensões do texto. Ela sistematiza as etapas do processo de tradução a partir da semântica de frames de Charles Fillmore. A semântica de frames exerce o papel de teoria do significado, integrando estrutura linguística, comportamento linguístico, compreensão linguística, mudança linguística e aquisição da linguagem.

O processo de tradução é descrito da seguinte forma:

[459-463] The translation process as interpreted in terms of the scenes-andframes theory may be described as follows:

Translation is a complex act of communication in which the SL-author, the reader as translator and translator as TL-author and the TL-reader interact. The translator starts from a presented frame (the text and its linguistic components); this was produced by an author who drew from his own repertoire of partly prototypical scenes. Based on the frame of the text, the translator-reader builds up his own scenes depending on his own level of experience and his internalized knowledge of the material concerned. As a non-native speaker, the translator might well activate scenes that diverge from the author's intentions or deviate from those activated by a native speaker of the source language (a frequent cause of translation error).

Based on the scenes he has activated, the translator must now find suitable TLframes; this involves a constant process of decision-making, whereby he depends entirely on his proficiency in the target language. It is at this stage of the translation process, where the translator shapes the new text, that has up to now been neglected in translation theory. The scenes-and-frames approach, which does not merely work with words and structures, but with a more holistic principle of interrelated textual elements, experience, perception and background situation, could provide a promising starting point. ${ }^{429}$

[O processo de tradução como interpretado em termos da teoria de scenes-eframes pode ser descrito da seguinte forma:

Tradução é um ato complexo de comunicação em que interagem o autor na LP, o leitor como tradutor e esse como autor na LC e o leitor da LC. O tradutor parte de um frame determinado (o texto e seus componentes linguísticos); que foi produzido por um autor que fez uso de seu próprio repertório de scenes parcialmente prototípicos. Com base no frame do texto, o tradutor-leitor constrói seus próprios scenes dependendo de seu próprio nível de experiência e seu conhecimento internalizado do material em questão. Como um falante não nativo, o tradutor pode bem ativar scenes que divergem das intenções do autor ou que se desviem daqueles ativados por um falante nativo da língua de partida (uma causa frequente para erros de tradução).

Com base nos scenes que ele ativou, o tradutor pode agora encontrar frames apropriados na LC. Isso envolve um processo constante de decisão, no qual ele depende inteiramente de sua proficiência na língua de chegada. É nesse estágio do processo de tradução em que o tradutor molda o novo texto, o que até agora

${ }^{429}$ SNELL-HORNBY, 1988, p. 81. 
havia sido negligenciado na teoria de tradução. A abordagem scenes-e-frames, que não trabalha meramente com palavras e estruturas, mas com um principio mais holístico de elementos textuais inter-relacionados, experiências, percepções e situação contextual, poderia proporcionar um ponto de partida promissor.]

O conceito de scene é definido aqui como uma situação vivenciada, ou de outro modo significativa, evocada por uma forma linguística. Não se trataria mais da situação em que um texto está inserido, mas sim, de uma situação no acervo de experiências do receptor, representada de forma verbal por um frame. Relacionar a situação evocada pelo texto com a própria experiência seria imprescindível ao leitor para assimilar o texto. Nesse processo, as situações evocadas seriam posteriormente associadas com outras situações, concebendo um todo significativo. Seria importante a construção de um mundo interior, que concedesse unidade, coerência a essa rede associativa, e ele dependeria da experiência subjetiva do leitor. Por esse motivo, um texto poderia ser interpretado de diferentes formas por pessoas diferentes.

O TRADUTOR teria participação ativa e criativa no processo, identificando scenes a partir dos frames do TP e encontrando, na LC, os frames mais apropriados para evocar esses scenes. Para tanto, é exigido do tradutor não apenas competência bilíngue, mas também competência bicultural. Em outros contextos, demandam-se do tradutor também competências que, na prática, mesmo alguns dentre os mais experientes não dispõem. Nesses casos, ele deve ser capaz de encontrar, por meio de pesquisa, os conhecimentos faltantes para realizar aquela tradução.

Para Snell-Hornby, mesmo na tradução literária, as decisões são tomadas segundo a FUNÇÃo do TC em seu contexto cultural. Essa é a tônica entre as novas abordagens da tradução, tornando-se no funcionalismo o critério-mor de orientação do processo tradutório. A função do TC, por seu turno, estaria vinculada à situação para a qual o texto foi escrito. O texto literário, contudo, à primeira vista parece isento de funções prescritas, dado que não seria produzido para uma situação específica. Entretanto, Snell-Hornby afirma que não se pode dizer que o texto literário tem função nenhuma - ela identifica três dimensões funcionais: (1) a função da coerência intratextual - o "mundo alternativo" fornece suas próprias funções internas para seu sistema ou cosmos de microtextos no interior de um texto; (2) esses são recebidos pelo leitor e integrados no processo de leitura, criando assim a segunda dimensão de "interação funcional"; (3) por trás da publicação da tradução de uma obra está o desejo (do tradutor ou do cliente) de recriar e, assim, perpetuar uma ficção ou 
um trabalho artístico no interior de uma cultura de chegada, numa dada língua e num dado tempo. Nesse sentido, a tradução literária seria um ato de comunicação como qualquer outro tipo de tradução e, por isso mesmo, correria o risco de ficar datada num momento histórico, demandando-se outras traduções. Seriam raras as vezes em que a função do texto literário aparece explícita. Por vezes, os editores teriam propósitos específicos e um tipo específico de leitores em mente ao comissionar uma tradução, sendo a obra literária, assim, tão funcional quanto qualquer artigo de jornal.

Entretanto, para entender a relação que o texto literário estabelece com as demais formas textuais, é necessário conhecer primeiramente a tipologia textual traçada por Mary Snell-Hornby. Vimos que o texto tomado em sua situação comunicativa é o objeto da tradução. Snell-Hornby observa que cresce nos estudos da tradução a consciência de que o texto é uma estrutura complexa e multidimensional, que consiste em mais do que a mera soma de suas partes.

No contexto da proposta de Snell-Hornby, a concepção acima de texto reflete a influência exercida pela Psicologia da Gestalt em suas considerações teóricas. Sistematizada por George Lakoff com base nos experimentos de Eleanor Rosch, a Psicologia da Gestalt desafia os princípios defendidos pela teoria clássica de categorização, caracterizada pela delimitação clara de fronteiras entre as categorias, o agrupamento de elementos segundo propriedades compartilhadas entre eles, a falta de flexibilidade das categorias, condições estritamente objetivas para a categorização, dentre outros critérios. Em contrapartida, ela sugere uma categorização segundo princípios holísticos e prototipologias de contornos esmaecidos. A principal premissa do gestaltismo é a de que o todo é mais do que a mera soma de suas partes, de modo que a análise das partes não pode fornecer a compreensão do todo $^{430}$.

Esse princípio gestaltiano teria impactos sobre a noção de língua adotada pela autora. A noção que prevalecia na linguística até então era uma noção de língua fragmentada, atomística e distante de seu uso concreto. Apenas nos anos de 1970 houve uma mudança de perspectiva para uma mais holística. A principal manifestação da influência da Psicologia da Gestalt na abordagem de Snell-Hornby é, no entanto, o seu modelo de prototipologia textual. Em seu livro, ele é precedido por uma análise da tipologia textual formulada por Reiss (1971), a qual é bastante criticada por Snell-Hornby, sobretudo por sua rigidez e pela tendência a generalizações:

\footnotetext{
${ }^{430}$ SNELL-HORNBY, 1988, p. 29.
} 
[48-49] Such prescriptive generalizations can be extremely misleading, and indeed Reiß has been severely criticized (cf. Koller 1979) for being too rigid. The vast majority of texts are in fact hybrid forms, multi-dimensional structures with a blend of sometimes seemingly conflicting features: Shakespeare's sonnets contain technical terminology of his day, while modern economic texts abound in lexicalized metaphor, and advertisements (which would be categorized by Reiß as strictly "appellbetont") are characterized by the varying methods they use to present information. As a starting-point Bühler's model undoubtedly has great possibilities for translation theory; as a frame of reference for objective criteria Reiß's typology is misconceived. What is wrong is the use of box-like categories as a kind of prescriptive grid, creating the illusion of clear-cut objectivity. When applied to real-life translation in all its complexity, Reiß's typology results, not in scientific objectivity, but in distortion. ${ }^{431}$ (SNELL-HORNBY, 1988, p. 31)(SNELL-HORNBY, 1988, p. 31)(SNELL-HORNBY, 1988, p. 31)(SNELLHORNBY, 1988, p. 31)(SNELL-HORNBY, 1988, p. 31)(SNELL-HORNBY, 1988, p. 31)(SNELL-HORNBY, 1988, p. 31)(SNELL-HORNBY, 1988, p. 31)(SNELL-HORNBY, 1988, p. 31)(SNELL-HORNBY, 1988, p. 31)

[Generalizações prescritivas desse tipo podem ser extremamente enganosas e, de fato, Reiss foi severamente criticada (cf. KOLLER, 1979) por ser rígida demais. A vasta maioria dos textos são, na verdade, formas híbridas, estruturas multidimensionais com um misto de características que podem parecer às vezes conflitantes: os sonetos de Shakespeare contêm terminologia técnica de sua época, enquanto textos atuais de economia abundam em metáforas lexicalizadas, e os anúncios (que seriam categorizados por Reiss como textos estritamente "appellbetont" [com ênfase no apelo]) são caracterizados pela variedade de métodos que usam para apresentar informação. Como um ponto de partida, o modelo de Bühler sem dúvida traz grandes possibilidades para a teoria da tradução; como um quadro de referência para critérios objetivos, a tipologia de Reiss foi mal concebida. O erro está no uso de categorias delimitadas como um tipo de grade prescritiva, criando a ilusão de uma objetividade evidente. Quando aplicada a traduções na vida real com toda a sua complexidade, a tipologia de Reiss resulta não em objetividade científica, mas em distorção.]

Por sua vez, Snell-Hornby propõe uma tipologia textual, ou melhor, uma "prototipologia" estruturada em diversos níveis, iniciando do nível do texto e terminando no nível microestrutural, em conformidade com o princípio holístico do Gestalt. De modo bastante sucinto, a prototipologia de Snell-Hornby, com todos os FATORES que influenciam a classificação textual, poderia ser descrita da seguinte forma. Em seu nível mais superior - nível A - estão as áreas convencionais de tradução, respectivamente a tradução literária, a tradução de linguagem geral e a tradução de linguagem especializada, também denominada "tradução técnica". No nível seguinte - nível B - constam os gêneros textuais básicos, que representam os principais objetos de ponderação de tradutores em seu cotidiano profissional. Como exemplos desses gêneros de tradução, mencionamos a tradução de textos bíblicos, a tradução de poesia, a tradução de textos jornalísticos e a tradução de textos científi-

\footnotetext{
${ }^{431}$ SNELL-HORNBY, 1988, p. 31.
} 
cos. No nível C estão reunidas as disciplinas "não linguísticas" que estão associadas de modo indissolúvel à tradução. O nível $\mathrm{D}$, subdividido em outros níveis, lista os mais importantes aspectos e critérios a reger o processo de tradução em si. No nível E estão as áreas da Linguística mais relevantes à tradução. As questões referentes a aspectos fonológicos, no entanto, encontram-se contempladas no nível F, nível mais inferior do modelo.

Além de propor uma nova forma de classificação textual, o modelo também estabeleceria as bases para conceber os estudos da tradução como uma disciplina independente e integrada, que cobriria todos os tipos de tradução. Embora recorra a diversas disciplinas correlatas, os estudos da tradução, segundo Snell-Hornby, não equivaleriam à soma de suas áreas de intersecção, nem mesmo dependeria delas.

A partir de sua prototipologia, Snell-Hornby procura deixar mais tênues os limites entre os tipos textuais, inclusive entre o texto literário e os demais textos. Ela apresenta a posição de Barthes, que afirma que, ao contrário da linguagem comum e de especialidade, a linguagem literária não está ligada a uma situação, mantendo sua indeterminação "profética" e sua ambiguidade. Iser, no contexto da Estética da Recepção, afirma que a "situação real" não está presente no texto literário, complementando que leitor e texto estão numa relação dinâmica um com o outro, não dada de antemão, mas construída no ato de leitura. Essa interação geraria a impressão do ocorrido, concedendo a ele a semelhança de realidade. Dressler e Beaugrande, no contexto da Linguística Textual, também são da opinião de que o texto literário é um texto cujo mundo está, de modo sistemático, em relação alternativa com o mundo que se aceita ser "o mundo real".

Entretanto, Snell-Hornby prefere considerar que o texto literário não tem existência no vácuo, isto é, que embora não esteja vinculado a uma situação única e específica, ele tem sua própria relação situacional com a realidade. Essa relação se construiria, por um lado, no ato da leitura e, por outro, pela imersão da obra literária em sua própria herança cultural. Um texto literário é recebido por leitores de diferentes lugares e tempos e, assim, essa recepção varia de acordo com os valores culturais de quem o lê, o que significa que a obra literária não é inteiramente "aberta", indeterminada. Um terceiro nível situacional constrói-se no próprio texto, isto é, nas situações construídas no próprio texto, que caracterizam esse mundo ficcional que a obra literária constrói.

Snell-Hornby estabelece algumas hipóteses acerca da lacuna que há entre a linguagem especializada e o texto literário: quanto mais vinculado a uma situação específica estiver o texto, mais fácil definir sua função e, assim, mais ele tenderá a estar em conformida- 
de com as normas da cultura de chegada. Por outro lado, quanto mais literário for o texto, mais a situação dependerá da assimilação que o leitor faz do texto. No que tange ao estilo textual, Snell-Hornby acrescenta uma hipótese: quanto mais específica a situação, mais o texto tenderá a estar em conformidade com um estilo convencional; quanto menos específica for a situação (como é o caso do texto literário), mais prevalecerá o estilo individual do autor. Por fim, quanto mais literário for o texto, maior será o status do texto de partida.

\subsubsection{Discussão dos dados}

Através da discussão dos conceitos funcionalistas acima, passamos a conhecer os preceitos fundamentais da abordagem teórica e, por conseguinte, vemos que ideias centrais unem esses tratados teóricos numa única abordagem. Iniciaremos essa discussão a partir das noções que todos parecem compartilhar.

Vimos anteriormente que todos os teorizadores cujas obras seminais foram analisadas até esse ponto no presente capítulo estiveram por anos engajados em universidades europeias na formação profissional de tradutores e intérpretes. Assim, não surpreende observar que o primeiro elemento comum entre as propostas é a sua motivação: elas foram escritas com o objetivo de diminuir a distância entre teoria e prática e oferecer, assim, um fundamento teórico que pudesse ser aplicado tanto para o ensino quanto para a prática profissional da tradução.

Migrando para o interior das propostas, constatamos que a tradução segundo a abordagem funcionalista consiste numa atividade produtiva, que resulta num texto. Nesse sentido, o texto é o objeto da tradução. Por sua vez, a substância que lhe concede materialidade é a língua. Logo, considera-se a tradução uma atividade que ocorre na língua e através da língua.

A tradução é uma atividade comunicativa/informativa, mas cujas necessidades de comunicação/informação não provêm do tradutor, posto que é uma atividade que existe a partir de uma atividade anterior. Na tradução há muitas variáveis, dentro e fora do texto, que determinam seu resultado. Por conseguinte, não se pode afirmar que exista só uma forma única e ideal de traduzir, como é postulado pelas teorias que se fundamentam na abordagem linguística tradicional. Esse é o primeiro ponto em que o funcionalismo de- 
monstra o rompimento com as noções alicerçadas pelo estruturalismo e pelo gerativismo da ciência da tradução, oferecendo, ao menos inicialmente ainda dentro do campo da linguística aplicada, uma nova perspectiva.

Algumas das variáveis mais relevantes a atuar no processo tradutório são a situação comunicativa e as culturas envolvidas. De modo geral, entende-se que a situação é composta por um tempo e um lugar e de pelo menos duas pessoas dispostas a se comunicarem. Considerando que não podemos dizer qualquer coisa em qualquer tempo e lugar, a situação determina o que e como será dito, ou seja, determina conteúdo e forma do texto. Assim, quando se afirma que o texto é o objeto da tradução, tem-se em mente o texto inserido numa situação comunicativa.

Outra importante variável da tradução é o próprio tradutor. No funcionalismo, o tradutor ocupa posição central: ele é, ao mesmo tempo, receptor do TP e produtor do TC. Ele não é, contudo, o receptor típico do TP, para quem o texto foi originalmente escrito. Consequentemente, seus interesses ao receber o texto não são os mesmos do receptor originalmente almejado pelo emissor: ele recebe o TP com vistas para a tradução. De todo modo, a tradução pressupõe a interpretação do TP pelo tradutor. Com isso, a tradução é também influenciada por fatores ligados à subjetividade do tradutor, que vão desde sua história individual até suas competências. De modo geral, exige-se do tradutor competências linguísticas e culturais. Alguns teorizadores do funcionalismo, no entanto, acrescentam ainda outras às competências necessárias para o tradutor profissional. Essas incluem a capacidade de pesquisa, de recepção e produção de textos e a capacidade de lidar com outros agentes no processo.

Se os textos servem à comunicação, todo texto exerce função comunicativa. A função comunicativa do TC determina as estratégias de tradução. Para melhor definir estratégias, o tradutor deve analisar os fatores envolvidos no processo tradutório. Alguns dos fatores citados pelos autores são a situação comunicativa e os participantes do processo comunicativo. Essas são algumas das noções que parecem ser comuns a todos os textos desse corpus.

Dos textos, o livro de Katharina Reiss (1971) parece ser o mais distante temporalmente - foi publicado sete anos antes do segundo texto mais antigo, o maior intervalo entre publicações dentre os componentes desse corpus - e em seus conceitos. A tradução é descrita por ela como um processo de busca por equivalentes ideais dentre equivalentes potenciais. Segundo afirma, ainda que a tradução seja um fenômeno da parole, ela só é possível 
graças à equivalência entre as línguas no nível da langue. Mesmo a função textual é justificada por atributos da língua, não da situação comunicativa: sua tipologia textual, que classifica os textos conforme a função predominante, baseia-se no modelo organon de Karl Bühler, que identifica três funções básicas do signo linguístico, as quais são estendidas por Reiss para o nível do texto. Embora Reiss reconheça a influência da cultura sobre o texto, ela nada diz acerca da influência da cultura sobre a língua.

A proposta teórica de Reiss é fundamentada pela noção de equivalência, tal como outras propostas defendidas à época de sua publicação. A teorizadora define a equivalência entre a função do TP e a função do TC como requisito para a tradução, segregando, assim, textos de chegada que exerçam uma função diferente de seu respectivo TP ou que se voltem a um público receptor não comparável com o público a que o TP está dirigido, relegando-os à condição de "transferências".

Nesse ponto, é importante considerar a época em que a obra foi escrita, marcada, como vimos, por uma noção de tradução amparada pela identidade entre os textos, exercendo o TP o papel de encargo de tradução imanente. Em sua obra escrita com Reiss, Vermeer menciona outras propostas que reconheceram o papel norteador da função na condução do trabalho tradutório, mas que, como Reiss, não previram a mudança de função ou de grupo receptor dentro dos limites da tradução ${ }^{432}$. Desse modo, ainda que não tenha partido de Reiss a guinada de perspectiva - de uma perspectiva retrospectiva, que determina a qualidade da tradução segundo sua similaridade com o TP, para uma perspectiva prospectiva, cujos critérios de tradução estão na cultura e no receptor de chegada - sua contribuição teórica - trazer a função comunicativa para o centro da discussão - é inegável.

Com o artigo de Vermeer (1978), fundou-se claramente o quadro teórico, mesmo que aqui ainda numa forma esboçada, em que foram alocadas as demais propostas. A partir desse texto, os funcionalistas passaram a compreender a tradução como uma ação intencional a se desenrolar entre culturas, e não apenas entre línguas. Foi depois dele também que a língua passou a ser vista como componente de uma cultura. Ainda que Reiss tenha destacado a importância do receptor na produção do texto, Vermeer enfatizou a importância do receptor na definição da função comunicativa dentro dos limites da tradução. Como afirma, é o receptor quem confere sentido ao texto, e a tradução só será considerada bem sucedida se o receptor avaliá-la como coerente com a sua situação.

\footnotetext{
${ }^{432}$ Cf. REISS; VERMEER, 1984, p. 54.
} 
Um dos grandes feitos dessa proposta foi lançar luz para a importância da função comunicativa na tradução. O principal critério para a tradução é a função comunicativa do translato em seu contexto situacional e seu ambiente cultural, ainda que essa não corresponda à função do TP. Comparando as duas abordagens, fica claro que, enquanto Reiss se orienta pela equivalência, Vermeer nega-a, substituindo-a pela exigência por coerência.

Hönig e Kussmaul (1982) incorporam a proposta esboçada de Vermeer e didatizam-na. Nesse processo, eles se tornam coautores dessa nova teoria, incorporando também outras fontes. Para eles, traduzir é ação, pois é um uso linguístico. Com isso, eles revelam suas raízes na pragmática.

O aspecto cultural do processo tradutório é destacado pela definição de texto como a parte verbalizada de uma sociocultura, definição de que Snell-Hornby posteriormente se valerá. Eles também definem texto como um conjunto ordenado de instruções, mas a escolha de segui-las só pode ser feita pelo receptor. Visto que é o receptor que atribui sentido ao texto, o tradutor deve antever a recepção do TC já na sua própria recepção do TP.

Assim como Vermeer, Hönig e Kussmaul vislumbram a possibilidade da não correspondência entre as funções do TP e do TC. Para eles, há duas relações possíveis entre as funções dos dois textos: continuidade ou mudança. Com isso, estabelece-se uma dicotomia entre dois tipos de tradução. O acréscimo mais notável dessa proposta ao quadro teórico de Vermeer veio, no entanto, com o conceito de grau necessário de diferenciação. Assim, tem-se um critério de escolha dos recursos para a criação do texto de chegada orientado pela função comunicativa.

Com o livro de 1984, Vermeer dá uma forma mais acabada a seu quadro teórico e integra as propostas de Reiss. Ele usa a oportunidade para detalhar alguns conceitos, introduzir outros e expandir o escopo de suas considerações. Um dos conceitos que ele opta por explorar com mais detalhes é o conceito de cultura. Assim, define cultura como tudo aquilo que se deve saber, dominar e sentir para agir de acordo com o que uma sociedade estabelece com aceitável. Essa é a definição para o conceito adotada pelos trabalhos seminais posteriores.

Vermeer opõe-se à compreensão de texto como instrução. Conforme afirma, entender o texto como um conjunto de instruções altera a relação de poder na comunicação, exercendo o produtor do texto poder sobre o receptor. Para Vermeer, entender o tex to como informação traz equilíbrio a essa relação, pois o receptor pode avaliar quais informações 
são de seu interesse. Contudo, nota-se que as definições de Hönig e Kussmaul e de Vermeer não se diferem fundamentalmente.

Outras noções introduzidas por Vermeer seriam posteriormente mais bem desenvolvidas por outros autores. Uma delas, por exemplo, a de que o texto é uma ação realizada no contexto de outras ações com uma meta comum em vista, foi mais bem desenvolvida por Holz-Mänttäri, constituindo-se parte essencial de sua teoria da ação translacional. Outros elementos são mantidos na nova proposta, em especial os axiomas a sustentar sua teoria do skopos: a regra do skopos, principal axioma da teoria, a regra da coerência e a regra da fidelidade. A eles, somaram-se a definição de tradução como oferta de informação acerca de uma oferta de informação e a de que a tradução é um processo não reversível.

Nota-se, assim, que a função continua a ter prevalência nesse novo tratado teórico. De fato, ele afirma que o objetivo tem prevalência sobre os meios para atingi-lo, uma posição considerada pouco ética por alguns autores nos estudos da tradução. Como vimos, uma das autoras a questionar esse posicionamento foi Christiane Nord, do que teve origem o seu conceito de lealdade.

Alterações podem ser percebidas também na proposta de Reiss. Ela acrescenta uma interessante discussão acerca dos gêneros textuais, além de uma tipologia de diferentes formas de traduzir segundo a relação entre a função do TC e a função do TP. Trata-se de uma classificação que vai além da divisão dicotômica entre continuidade e mudança de função, a exemplo do que propuseram Hönig e Kussmaul.

Para Reiss, a tradução deve visar à adequação, definindo o conceito de adequação como uma relação entre o TP e o TC que faça jus a uma função determinada. No entanto, para que a tradução seja equivalente, é necessário que essa relação seja de continuidade da função. Com isso, constatamos que, ainda que Reiss tivesse passado a aceitar como tradução os casos em que a função do TC não correspondia à função do TP, outrora excluídos de sua definição, ela nunca abdicou de seu ideal de equivalência.

Assim como Vermeer, Holz-Mänttäri (1984) formula a sua própria teoria, a teoria da ação translacional, trazendo um corpo conceitual próprio e também uma nova terminologia, de modo a marcar seu rompimento com as noções consensuais de tradução. Ainda que chegue a fundamentos bastante semelhantes aos de Vermeer, ela o faz por outros meios, trazendo outras referências e vislumbrando outras questões. Ela inova ao concentrar-se, de modo como nenhuma outra proposta teórica funcionalista fez nesse corpus, no aspecto profissional da tradução, identificando o lugar da atividade do tradutor dentro do sistema 
das sociedades modernas, organizadas pela divisão social do trabalho. O papel social do tradutor é observado com detalhes: ele é considerado especialista em tradução, cujas responsabilidades, no entanto, vão além da mera produção do texto para a transmissão transcultural de mensagens.

Assim como Vermeer e Hönig e Kussmaul fizeram antes dela, Holz-Mänttäri também define tradução como ação. A ação tem o objetivo de alterar um estado de coisas sob determinadas circunstâncias e numa determinada situação, itens também enfatizados pela definição de Vermeer. No entanto, a ação é compreendida sob um viés antropológico, como uma atividade desencadeada em face de uma necessidade humana. A ação do tradutor tem, assim, o propósito de coordenar a cooperação entre pessoas mediante comunicação através de barreiras culturais. Ainda que seja convergente com as definições de Vermeer, Holz-Mänttäri demonstra abordar a questão de um ângulo bastante diferente.

Mesmo o conceito de cultura demonstra pontos de aproximação e expansão. Ela adota a definição de Göhring usada por Vermeer para o conceito, mas destaca dessa definição alguns aspectos que não foram destacados previamente por Vermeer: a liberdade do indivíduo de decidir se agirá adequadamente ou não em relação ao que postula a cultura e a necessidade de o tradutor conhecer as culturas envolvidas no processo para saber o que está em conformidade com elas ou não.

O conceito de mensagem defendido por Holz-Mänttäri confunde-se com o conceito de informação, introduzido por Vermeer. Analisando os dois conceitos, nota-se que ambos se referem às intenções comunicativas do emissor, que ganham uma forma verbal. Idealmente, o texto seria a representação indistinta dessa intenção comunicativa. Contudo, há um vasto conjunto de variáveis que interferem na construção de um texto, e outro ainda maior na forma como o receptor interpreta a informação/mensagem. Logo, o texto não é nada além disso: um veículo, uma oferta, e cabe ao receptor interpretá-la.

A despeito das valiosas contribuições de Holz-Mänttäri ao funcionalismo, o seu modelo de análise de fatores, focado nas demandas do iniciador e no portador de mensagens, recebeu pouca atenção. Embora guarde similaridades relevantes em relação ao depois proposto por Christiane Nord, que incluem a análise de fatores intratextuais e extratextuais, não foi tão difundido como o de Nord.

Nord declara de modo evidente estar aplicando os preceitos funcionalistas em seu livro, somando a ele contribuições principalmente da linguística textual. A contribuição da linguística textual reflete-se, evidentemente, sobretudo na definição de texto como ocor- 
rência comunicativa. Ela está de acordo com os demais funcionalistas no que tange ao fato de o sentido textual ser atribuído, em última instância, pelo receptor. No entanto, assim como Hönig e Kussmaul, ela afirma que o produtor do texto utiliza-se de estratégias para deixar sua intenção comunicativa mais clara e limitar as possibilidades de interpretação de um texto.

Além disso, Nord também reconhece que a função do TC não precisa corresponder à função do TP. Assim como Hönig e Kussmaul, ela também recorre a uma dicotomia para expressar a relação entre a função desses textos: tradução-documento e traduçãoinstrumento. A aplicação dos preceitos teóricos de Vermeer e Holz-Mänttäri, no entanto, não ocorre sem ressalvas. Ela se inclui dentre aqueles que questionam a posição mais radical desses autores, temendo que a teoria justifique comportamento pouco ético da parte dos tradutores. Por isso, ela introduz o conceito de lealdade, uma de suas grandes contribuições para a abordagem funcionalista.

Todavia, o atributo da teorização de Nord mais repercutido nos estudos da tradução é o seu modelo de análise textual. Através do modelo, Nord enfatiza os fatores intratextuais e extratextuais que influenciam o processo de tradução. Ele se presta a identificar elementos relevantes do TP para a tradução e a formatar um perfil do TC, através do qual, então, o tradutor deve orientar seu trabalho. Embora destinado sobretudo a aprendizes, Nord observa que o modelo também pode ser de bastante utilidade aos profissionais da tradução.

Snell-Hornby, por fim, utiliza-se do quadro teórico funcionalista para aplicá-lo ao caso da tradução literária. Ela tem o objetivo de abdicar das categorias estanques e das polarizações dicotômicas, o que afeta tanto a tipologia textual de Reiss quanto a polarização entre tradução-documento e tradução-instrumento.

Snell-Hornby vê nas abordagens de Hönig e Kussmaul, Vermeer e Holz-Mänttäri semelhanças o suficiente para enquadrá-las numa mesma vertente teórica, utilizando-se dessa vertente como fonte para a sua teorização. De Hönig e Kussmaul ela destaca (1) o texto como parte verbalizada de uma sociocultura; (2) a existência de diversas formas de traduzir; (3) a dependência da função comunicativa na comunicação e (4) o grau necessário de diferenciação. De Vermeer, ela destaca a definição de translação como ação e como transferência cultural, o texto como objeto da tradução, a prevalência da função e a situação como variável da tradução. De Holz-Mänttäri, ela destaca o conceito de mensagem dissociado do conceito de texto, a tradução como sistema de ações envolvendo especialistas e o tradutor como especialista. 
Segundo nossa análise, as principais contribuições de Snell-Hornby ao funcionalismo são a integração de outras teorias linguísticas à proposta funcionalista e a sua prototipologia textual. No que tange à primeira contribuição, julgamos especialmente relevante a descrição que ela faz do processo de tradução a partir de preceitos advindos da semântica de scenes e frames. De modo bastante sucinto, ela descreve o processo de tradução como a busca, na língua e cultura de chegada, de frames que correspondam aos scenes evocados pelo texto de partida.

Por sua vez, sua prototipologia, baseada na psicologia gestalt, opõe-se à estaticidade da tipologia textual de Reiss, bem como a sua tendência a generalizações. Nela, as classificações ganham contornos difusos; mais importante é apontar os fatores que influenciam a construção e a tradução de um determinado texto. Além de oferecer uma nova forma de classificação textual, o modelo estabelece as bases para conceber os estudos da tradução como disciplina ao mesmo tempo autônoma e interdisciplinar.

O que pudemos observar ao longo do capítulo foi a construção de uma teoria. Vermeer, responsável por estabelecer as bases do funcionalismo, criou um quadro teórico sofisticado o bastante para oferecer, de modo convincente e pautado pela prática, respostas a questões que intrigavam os estudos da tradução, mas simples e aberto o bastante para agregar outras propostas alinhadas a seus princípios básicos. Nesse sentido, a proposta teórica de Holz-Mänttäri complementa-se de forma bastante satisfatória com a de Vermeer, formando, assim, um conjunto coeso, que compartilha fundamentos mas dá ênfase a questões diferentes.

Cada autor que se fez valer dos preceitos teóricos de Vermeer e Holz-Mänttäri trouxe algo consigo: novos enfoques teóricos, novos conceitos, novas metodologias ou apenas uma atitude mais multidisciplinar. Esses acréscimos não afetaram apenas os níveis superiores, mas a própria base, com a revisão de conceitos fundamentais. A esse respeito, consideramos o conceito de lealdade de Christiane Nord um exemplo bastante adequado.

Embora nossa pesquisa tenha contemplado uma amostra representativa, porém limitada das ideias centrais do funcionalismo, é possível estimar que esse processo de construção teórica tenha continuado e até hoje ainda esteja em curso, em cada pesquisa que faz uso do funcionalismo como fundamento teórico. Vejamos alguns exemplos disso com pesquisas de grau realizadas em instituições de ensino superior no Brasil. 


\subsection{Os trabalhos de grau - um exemplar de análise (C2)}

Essa seção é dedicada à análise de trabalhos de grau defendidos em IES no Brasil que tenham se valido de preceitos funcionalistas para fundamentar suas pesquisas. Aqui analisamos os quatro componentes do corpus C2: (1) a tese de doutoramento de João Azenha Jr. (1994), dedicada a explorar aspectos culturais envolvidos na produção e na tradução de textos técnicos; (2) a tese de doutorado de Meta Elisabeth Zipser (2004), voltada a explorar os aspectos culturais envolvidos na produção e na tradução de textos jornalísticos; (3) a dissertação de mestrado de Elisângela Liberatti (2012), que aborda diversas questões relacionadas com a tradução dos quadrinhos de Chico Bento e (4) A tese de doutorado de Maria José Laiño (2014), que busca, através do modelo de análise textual de Christiane Nord (1998), desenvolver uma interface para o emprego da tradução em aulas de língua estrangeira.

Como declarado na Introdução de sua tese, o tema de pesquisa surgiu da tentativa de conciliar duas situações antagônicas, com as quais João Azenha Jr. se confrontou no decurso de sua vida acadêmica e de sua atividade profissional: de um lado, a crença na univocidade dos textos técnicos, limitando a sua problemática a questões de ordem léxicoterminológica. De outro lado, a experiência profissional, marcada pela constante busca por soluções a problemas de tradução do texto técnico, os quais certamente não estavam limitados aos planos lexical e terminológico.

De modo a caracterizar melhor o estado de coisas, Azenha Jr. observa que, embora a tradução de textos técnicos representasse o maior volume de traduções realizadas por profissionais todos os dias, era predominante a opinião, sobretudo entre pesquisadores e tradutores devotados à tradução literária, de que a tradução técnica seria comparativamente "mais fácil". Essa pretensa facilidade, por seu turno, seria decorrente da ideia de que a tradução técnica não proporia dificuldades de tradução oriundas de diferenças de contextos culturais. Em oposição a essa ideia, estaria em crescimento nos ramos de estudo de linguagens de especialidade a convicção de que, além de questões terminológicas, o tradutor técnico deveria também ter domínio sobre um "estilo" técnico condicionado culturalmente. A polarização entre esses diferentes posicionamentos seria reflexo de uma separação, a marcar a história das teorias de tradução, entre a tradução literária e a tradução não literária, aparente único consenso entre seus partidários: 


\begin{abstract}
A despeito de toda a subjetividade reinante nas considerações sobre as relações entre tipo de texto e problema de tradução, podemos dizer que há consenso pelo menos no que se refere a uma distinção genérica entre dois grandes grupos de textos: os literários, de um lado, e os "outros" textos. A incipiência dos critérios de classificação e de caracterização, de um lado, e a falta de entendimento em torno de um termo de comparação, de outro, estimulam a emissão de juízos de valor, com prejuízos para a pesquisa. Tais ideias pré-concebidas sobre o aspecto valorativo de certos tipos de textos em relação a outros ainda hoje ocupam boa parte da discussão sobre problemas de tradução e podem ser detectadas tanto nas traduções propriamente ditas, quanto no que se diz - ou se escreve - sobre o assunto, seja no plano acadêmico, seja na situação didática, seja na crítica de traduções publicadas. (AZENHA JR., 1994, p. 6)
\end{abstract}

Nesse sentido, Azenha Jr. procura demonstrar que a rigidez nessas formas de classificação, amparadas por julgamentos de valor apriorísticos, impediria perceber o que essas distintas formas de traduzir têm em comum. Dessa maneira, ele parte da hipótese de que também questões relativas a diferenças de contextos socioculturais estariam implicadas na tradução de textos técnicos. Para colocá-la à prova, ele realiza uma análise contrastiva entre textos técnicos de instrução referentes a diferentes produtos, todos eles publicados em alemão e em português brasileiro. Com a análise, ele almeja verificar em que medida o emprego de certos recursos verbais e não verbais reflete os valores culturais subjacentes à produção desses textos.

Além desse objetivo, Azenha Jr. declara que é também sua intenção contribuir com conceitos teóricos para embasar a discussão sobre aspectos culturais envolvidos na tradução de textos técnicos. Para tanto, ele escolheu fundamentar-se sobre os preceitos funcionalistas. Visto que esse é certamente um dos primeiros trabalhos de grau a tomar o funcionalismo como fundamento teórico, a exposição dos conceitos da abordagem funcional revela-se um objetivo bastante justificável. Assim, além de contribuir para a discussão acerca da tradução técnica, um de seus principais méritos seria, sem dúvida, auxiliar na divulgação da abordagem teórica no Brasil.

Meta Zipser introduz a sua tese com a menção à visão profundamente enraizada no senso comum de texto jornalístico como um relato objetivo e imparcial de fatos da realidade. Embora ela reconheça o vínculo com a realidade, questiona a pretensa objetividade e imparcialidade do texto jornalístico ao identificar, nas diversas etapas de constituição de uma reportagem, a influência de perspectivas subjetivas e dos interesses dos diversos agentes envolvidos na veiculação de notícias. 
Conforme afirma Zipser, por ser um produto comercializável, o texto jornalístico, em suas diferentes modalidades, é determinado em larga medida pelo público a que se destina:

\begin{abstract}
O público e, por conseguinte, a forma de tratamento do fato noticioso, são variáveis que vêm somar-se às outras já citadas e que determinam características diferenciadas para os veículos de divulgação de notícias. Exemplos disso são os jornais diários de circulação internacional, nacional e regional, as revistas semanais de circulação internacional e nacional, as revistas especializadas (de circulação semanal, mensal), revistas ilustradas, entre outras. Seria o caso de se indagar, então, se o público receptor e a forma de tratamento do fato determinam as características dos veículos, ou se não seria o contrário. Na verdade, trata-se aqui de um conjunto de variáveis que se condicionam reciprocamente. (ZIPSER, 2002, p. 11)
\end{abstract}

Para Zipser, o fato de haver tantas abordagens possíveis para um mesmo fato noticioso, como demonstra a observação dos diferentes veículos de propagação de notícias em que um mesmo evento é descrito, é comprovação suficiente de que os textos jornalísticos veiculam mais do que um relato "neutro" de um fato, bem como de que esses textos estão inseridos em situação e contextos culturais diversos, refletem linhas editoriais e são formadores de opinião ${ }^{433}$.

Se aceitarmos que há tamanha diversidade de enfoques para um fato noticioso numa mesma cultura, é plausível supor que essa diversidade se intensifique no transporte de um fato de uma cultura a outra. No entanto, segundo Zipser, essa não seria a única consequência do transporte de fatos noticiosos entre culturas. A seu ver, seria possível ver efeitos disso na própria concepção de tradução. É neste ponto que Zipser traça a sua hipótese de pesquisa: se não há neutralidade no texto jornalístico, e se há variados enfoques para um mesmo fato noticioso numa dada cultura, então deve haver diferenças de perspectivas para um mesmo fato em culturas diferentes. Com isso, cabe aqui o questionamento acerca da adequação da tradução "fiel", isto é, de uma forma de tradução norteada pela equivalência semântica, de um texto jornalístico produzido numa determinada cultura de partida entre os receptores de uma cultura de chegada. Conforme a hipótese levantada pela pesquisadora, essa tradução provavelmente não atenderia às exigências do veículo e do público a que se destinam, sendo questionado inclusive o seu status de texto jornalístico. Isso, no entanto, não impediria que essa tradução pudesse servir de insumo à produção de um novo texto jornalístico na cultura de chegada.

\footnotetext{
${ }^{433}$ ZIPSER, 2002, p. 12.
} 
Dessa forma, Zipser estabelece como objetivos de pesquisa estreitar a lacuna entre as áreas jornalística e tradutológica, demonstrar as mudanças de enfoque de um mesmo fato noticioso entre diferentes veículos e culturas, discutir as consequências da mudança de perspectiva para a tradução e desenvolver um instrumental para a análise do texto jornalístico que seja relevante à tradução. A tese de doutoramento encontra-se na intersecção entre pelo menos duas disciplinas - o jornalismo e os estudos da tradução, e Zipser traz referenciais teóricos de ambos os domínios: do âmbito do jornalismo, ela se fundamenta nos estudos de Frank Esser, que descreve as características definidoras do texto jornalístico; dos estudos da tradução, ela traz preceitos da vertente funcionalista, em especial da obre teórica de Christiane Nord. Dessa maneira, Zipser contribui não apenas na divulgação dessas abordagens teóricas, mas concilia propostas de áreas tão diferentes.

Os quadrinhos têm uma longa história como produto cultural para o ensino e o entretenimento em todo o mundo. Entretanto, como observa Elisângela Liberatti, a produção acadêmica dedicada a esse tema ainda tem um longo caminho a percorrer. Sua contribuição à área vem através da tradução comentada de histórias em quadrinhos (HQs) de Chico Bento, uma das criações do cartunista brasileiro Maurício de Sousa. O fato de esta ser uma publicação voltada de modo predominante a crianças e de a ambientação do mundo de Chico Bento evocar as regiões rurais do centro-sul brasileiro traz à dissertação outras questões dignas de exame: por um lado, ainda que pertença ao gênero dos quadrinhos, as histórias ficcionais destinadas a crianças tornariam Chico Bento uma obra de literatura infantil e juvenil (LIJ); por outro, o uso de um "pseudodialeto caipira" para caracterizar os personagens e a ambientação da história traz à baila a questão da tradução dialetal.

Assim, o projeto de pesquisa fundamenta-se na tradução comentada de duas histórias de Chico Bento, utilizando "funcionalismo nordiano" como quadro teórico e metodológico. Visto que a proposta de tradução inclui encontrar soluções para o pseudodialeto caipira empregado por Maurício de Sousa, Liberatti busca orientação nos quadrinhos de Li'l Abner, publicado entre 1934 e 1977 nos Estados Unidos por Al Capp, um dos cartunistas de maior sucesso a representar o "típico caipira estadunidense". Segundo a pesquisadora, esses quadrinhos já são usados como orientação para a tradução das histórias de Chico Bento para o inglês, feita pela Maurício de Sousa Produções (MSP) ${ }^{434}$.

O objetivo de Liberatti é contribuir para as pesquisas no âmbito da tradução de LIJ, com especial referência à tradução de quadrinhos. Segundo levantamentos da própria auto-

\footnotetext{
${ }^{434}$ LIBERATTI, 2012, p. 29 et seq.
} 
ra, até então só havia vinte e uma teses e dissertações sobre os quadrinhos do Chico Bento, sem nenhuma delas abordar o caso da tradução, e catorze pesquisas sobre quadrinhos, mas nenhuma tratando do caso específico das histórias do Chico Bento. Além das traduções, Liberatti oferece como contribuição a compilação de um corpus que servirá de base para solucionar as questões relativas ao pseudodialeto caipira. Ainda consta dentre os objetivos de pesquisa avaliar a utilidade do aparato conceitual funcionalista para orientar a tradução. A hipótese que norteia o trabalho é a de que as escolhas tradutórias orientadas pela conservação da fala não padrão nas traduções de Chico Bento para o inglês assegurarão que a função pretendida para o TC se concretize em meio a seu público receptor.

Por fim, Maria Laiño debruça-se sobre o emprego de tradução em aulas de língua estrangeira. Outrora base do ensino de línguas, a tradução atualmente não seria vista com bons olhos dentre os professores atuantes no ensino de línguas estrangeiras (LE). A causa estaria no modo como a tradução foi empregada no que ficou conhecido como "Método Gramática e Tradução", baseado, como o próprio termo indica, no aprendizado de estruturas gramaticais e na tradução de orações isoladas da LE para a língua materna. Com a ascensão de outros modelos didáticos, a tradução deu lugar às explicações gramaticais e vocabulares na própria LE.

Para Laiño, contudo, a tradução pode ser uma ferramenta pedagógica com potencial de trazer grandes benefícios à aprendizagem. Ela dá o exemplo da tradução de textos publicitários, que pode dar ensejo a discussões ricas, na medida em que, além de possibilitar o contato com um novo vocabulário e com estruturas gramaticais, também convida à reflexão acerca de diferenças culturais ${ }^{435}$. De fato, conforme explica, o emprego de textos publicitários traz consigo a inevitável reflexão acerca do público a que ele se destina. Inclusive esse tema, a seu ver, teria prioridade sobre as questões referentes à gramática da língua estrangeira. A decisão de como (e quando) empregar a tradução como ferramenta pedagógica estaria, todavia, nas mãos do professor.

A proposta da pesquisadora é exemplificar formas de incluir a tradução de textos publicitários no ensino de LE. Para tanto, ela utiliza um exercício de tradução aplicado aos alunos do sétimo período de língua espanhola na Universidade Federal da Fronteira Sul (UFFS) em Chapecó, Santa Catarina, a partir da tradução para o espanhol argentino de textos de publicidade brasileiros dos anos de 1950 e 1970. Para avaliar essas traduções, Laiño faz uso do modelo de análise textual de Christiane Nord e das estratégias de produ-

\footnotetext{
${ }^{435}$ LAIÑO, 2014, p. 22 et seq.
} 
ção textual de Daniel Cassany. Com isso, ela almeja (1) propor o desenho de atividades de tradução para o ensino de LE, (2) propor um quadro de revisão/avaliação textual e (3) convidar o aluno a refletir sobre o aprendizado de LE através da tradução, em particular, a partir da produção do texto em língua estrangeira. A hipótese a orientar a pesquisa é, enfim, a de que o exercício tradutório fomentará o aprendizado de língua espanhola, tendo em vista que o estudante ativará mais de uma habilidade para elaborar seus textos de chegada - naturalmente, a habilidade mais desenvolvida, assim se espera, será a produção textual escrita.

A seguir, vejamos a abordagem dada por cada um dos trabalhos aos memes fundamentais para a abordagem funcional.

\subsubsection{Tradução}

Como modo de principiar a exposição dos pressupostos teóricos de sua tese, Azenha Jr. aborda as noções de linguagem e tradução, com ênfase em seu vínculo com o conceito de cultura. Entretanto, ele introduz a discussão com as noções de linguagem e tradução à época em voga nas teorias de tradução, caracterizadas, em larga medida, pela crença de que a tradução opera apenas no nível linguístico:

[89-93] A crença de que a tradução opera exclusivamente entre línguas tem marcado de forma particularmente enfática a reflexão, execução e critica de tradução. Dicotomias como "palavra vs. sentido", "fidelidade vs. infidelidade", "tradução literal vs. tradução livre", entre outras, têm como pontos centrais as noções de sentidos estáveis, isto é, conteúdos imunes a qualquer ação exterior na transferência de uma língua para outra, e de leituras definitivas, capazes de resistir às ações do tempo e às mudanças de espaço. A inalterabilidade de um sentido dito "original" e a possibilidade de uma leitura dita "fiel" seriam, em tese, os parâmetros para a realização e a crítica de traduções. ${ }^{436}$

Nessa época, a noção de traduzir referida acima estaria escorada numa concepção teórica de língua centrada no código, a qual seria também responsável pelo mito da univocidade do texto técnico. Como exposto acima, esse posicionamento envolveria também a falácia da "equivalência perfeita" e da "identidade conceitual", o que faria do texto técnico o espécime de linguagem apropriado para ser objeto de pesquisa da "ciência da tradução".

\footnotetext{
${ }^{436}$ AZENHA JR., 1994, p. 18.
} 
Todavia, apesar de reconhecer que encarar a tradução como uma operação entre línguas seja uma abordagem válida, Azenha Jr. alerta para o fato de a língua não ser a única condicionante do processo de tradução. Logo, o equívoco estaria em tratar a tradução como um proceder unicamente entre línguas. A seu ver, haveria outras condicionantes além da língua a determinar o desenrolar do processo tradutório, dentre as quais estão a própria figura do tradutor, a situação de produção e a situação de recepção do texto, bem como a intervenção de terceiros. Todas elas estariam ligadas a uma realidade histórico-cultural e seriam condicionadas por normas sociais e normas de uso linguístico em constante modificação.

Seja como for, não há como negar que a tradução consista numa operação realizada no interior da linguagem e através dela. Cumpre, no entanto, esclarecer o que se entende aqui por linguagem. Para esse fim, Azenha Jr. recorre à abordagem funcional, segundo a qual a linguagem é componente e manifestação de uma cultura. Em face dessa concepção de linguagem, torna-se imprescindível incluir o aspecto cultural no horizonte de reflexões dos estudos da tradução para que se possa entender o fenômeno tradutório.

Com o objetivo de propor uma base conceitual para discutir os aspectos culturais da tradução técnica, Azenha Jr. dedica parte de sua tese a uma exposição crítica dos preceitos funcionalistas. Segundo afirma, o reconhecimento do componente cultural na tradução, ainda que não tenha sido criação do funcionalismo, ganhou impulso com ele. Ademais, ele destaca a multiplicidade de fatores condicionantes levantados por esses autores. Ainda assim, elas teriam em comum o estabelecimento da função comunicativa do TC, numa clara orientação prospectiva, como critério norteador de estratégias de tradução. Para o funcionalismo, o tradutor toma posição central no processo, sendo responsável pelas decisões acerca de que estratégia adotar.

A abordagem funcional parece assim abandonar a noção até então vigente de tradução única, "perfeita" e atemporal. Os critérios para avaliar uma tradução não teriam mais como única referência o cotejamento com o TP, mas estariam nela própria: a liberdade do tradutor estaria condicionada pelos critérios que norteiam a tradução, quase sempre critérios determinados pela situação e pelo objetivo de trabalho. Ao reconhecer a diversidade de fatores implicados na tradução, a abordagem funcional proporia ao tradutor o desafio de lidar com eles no exercício de sua profissão. Para Azenha Jr., a solução exige do tradutor uma reflexão sobre o seu próprio trabalho. 
De modo a sintetizar as noções de tradução discutidas e delimitar a definição a adotar, Azenha Jr. cita Stolze, para quem a tradução é uma ação criativa:

[301] "A tradução é uma atividade criativa realizada com textos, e não uma comparação entre dois sistemas linguísticos. Esta atividade pressupõe indiscutivelmente o conhecimento de regras sintáticas e de componentes sociolinguísticos, mas também exige uma capacidade hermenêutica e sensibilidade no manejo da linguagem" (Stolze, 1982, p. 384) ${ }^{437}$

No concernente à tradução de textos técnicos, a análise contrastiva permitiu alguns insights bastante pertinentes. Como forma de apresentá-los, Azenha Jr. responde a algumas considerações feitas por Wolfram Wilss num texto dedicado à questão da tradução técnica. As ponderações contidas nesse texto seriam representativas da noção de tradução técnica e de texto técnico reinantes no senso comum.

De modo geral, as ponderações de Wilss referidas por Azenha Jr. foram as seguintes:

- o ponto de referência para avaliar a qualidade de uma tradução técnica seria a equivalência de conteúdo. Nesse contexto, o objetivo da tradução técnica não seria a "interpretação exaustiva" do TP, mas uma "sobreposição cognitiva" entre o TP e o TC;

- a tradução técnica deveria voltar-se ao "estreitamento léxico-terminológico", isto é, à máxima identidade conceitual entre termos. Assim, caberia ao tradutor fazer a mera troca de um termo por seu equivalente. Com isso, o campo de atuação estilística do tradutor estaria limitado à sintaxe e, assim, a tradução técnica perderia o caráter de processo decisório ostentada pela tradução literária;

- o texto técnico é descrito como unívoco, passível de uma interpretação apenas. Assim, emissor e receptor compartilhariam inevitavelmente da mesma interpretação do texto, sendo assim possível a tradução definitiva;

- quanto a uma perspectiva diacrônica da tradução técnica, Wilss observa que, de fato, só seria necessário traduzir o texto técnico uma única vez, dada a sua rápida obsolescência ante o desenvolvimento tecnológico;

- a irreversibilidade da tradução teria validade limitada na tradução técnica, posto que o texto técnico é um texto predominantemente informativo em que im-

${ }^{437}$ AZENHA JR., 1994, p. 94. 
pera a identidade semântico-conceitual. Nesse caso, a retrotradução seria suficiente para informar acerca dos significados veiculados pelo texto, podendo servir de método de avaliação qualitativa;

- em decorrência dessas características, ele seria o tipo textual mais apropriado à tradução automática, que se mostrou adequada como forma de comunicação entre línguas quando envolve textos de estilo simples, destinados unicamente à veiculação de informações.

A essas ponderações, Azenha Jr. argumenta que:

a) a equivalência de conteúdo não deve ser vista como a mera troca de palavras, mas sim, deve incluir a acomodação a outro espaço linguístico-cultural, de modo a traduzir o texto como um todo de modo funcional. Ademais, independente do tipo textual, toda tradução pressupõe interpretação, pois há sempre mais de uma forma de entender um texto;

b) o campo de atuação do tradutor não se limita aos planos lexicais ou sintáticos, mas envolvem também questões da macroestrutura textual. De fato, limitar o escopo de ação do tradutor a um só plano seria contraproducente, posto que, para que o texto seja comunicativo, há de se considerar todos os planos textuais. Azenha Jr. ainda faz menção a outros aspectos da atividade profissional do tradutor, relativos, por exemplo, às operações financeiras e ao envolvimento de novas tecnologias no cotidiano de sua profissão, demandando, assim, outras decisões de outros tipos;

c) ainda que as condições em torno do processo comunicativo constituído por meio da tradução técnica sejam passíveis de maior controle, ainda assim podem emergir problemas de tradução decorrentes de suas variáveis culturais;

d) conceitos - e textos - são dinâmicos, sujeitos a mudanças de significado, por exemplo, motivados pela evolução tecnológica, e sujeitos até mesmo à obsolescência. Em contrapartida, há textos técnicos que se tornam clássicos num campo, não perecendo com a evolução da tecnologia, mas sim, exigindo alguns ajustes;

e) ainda que se admita que frequentemente a "identidade" seja mesmo o ponto de referência para a avaliação de uma tradução técnica, só se pode falar, na me- 
lhor das hipóteses, de uma "tendência" de identidade conceitual. Mesmo que um TC seja avaliado como "conceitualmente correto" em relação ao TP, isso não o exime, muitas vezes, de ser reescrito, de modo a se adequar ao ambiente sociocultural para o qual está sendo traduzido;

f) ainda que o propósito de um texto técnico seja, em sua maioria, informar, não significa que ele não inclua recursos expressivos no plano lexical ou sintático, ou que não haja uma mudança de estilo na transposição de uma cultura a outra, o que pode trazer complicações na hora de se empreender uma tradução automática.

Nota-se que Azenha Jr. sustenta a tese de que a tradução técnica também envolve fatores de ordem cultural, negando, assim, a pretensa univocidade do texto técnico, ou mesmo a crença de que o processo de tradução do texto técnico envolveria apenas um proceder no plano léxico-terminológico. Com isso, ele derruba uma noção de tradução técnica a povoar não apenas o senso comum, mas também o âmbito teórico da tradução: como vimos, muitas das propriedades atribuídas ao texto técnico são também características de uma concepção do traduzir recorrente na abordagem linguística da tradução. Dessa forma, ele também justifica a escolha da abordagem funcional como fundamentação teórica de sua pesquisa, demonstrando a sua capacidade de contemplar questões de cunho cultural envolvidas também na tradução do texto técnico.

A esse respeito, gostaríamos de incluir algumas observações. Vimos que é consensual entre os teóricos da abordagem funcional a definição de translação como uma atividade criativa que envolve textos inseridos num contexto situacional determinado. Essas mesmas características se encontram na definição de Stolze que ele adota como noção de tradução a guiar a tese.

Em outra passagem, Azenha Jr. faz referência ao fato de, no contexto profissional, a tradução ser caracterizada como um trabalho em equipe, com diversos agentes operando em conjunto em função de um objetivo comum:

[304] É claro que o controle de muitas variáveis coloca o tradutor diante de decisões que, às vezes, fogem ao âmbito de sua atuação. Sua participação, porém, nos processos decisórios envolvidos, é importante como elemento unificador. A atividade de tradução se caracteriza, assim, como um trabalho de equipe, em 
que se dividem responsabilidades e se conciliam interesses muitas vezes conflitantes em função de um objetivo comum. ${ }^{438}$

As considerações acima sobre a atividade de tradução são muito próximas do modo como Holz-Mänttäri descreve a atividade do tradutor: a atuação de um especialista em cooperação com outros, orientados a uma meta comum.

Fazemos ainda menção a outra passagem, encontrada no capítulo dedicado ao método de pesquisa, em que Azenha Jr. discorre acerca da questão fundamental a orientar a escolha do corpus:

[317-318] A partir daí, a idéia subjacente à seleção de um córpus de textos pode ser resumida a uma questão muito simples: - Se na produção de textos correspondentes a um mesmo referencial - o produto ou o serviço - podemos perceber mudanças significativas autorizadas por uma mesma instância emissora - a empresa - em duas culturas diversas, por que na tradução desse tipo de texto - que também pode ser entendida como um tipo especial de produção de texto - as "regras" haveriam de ser diferentes? Porque, em última análise, dois pesos e duas medidas? E desde o momento em que tais indagações se colocaram, a resposta para elas pareceu estar atrelada mais a um modo de ver as coisas, ou seja, ao modo como cada um entende a tradução, do que propriamente à essência desse trabalho de transposição intercultural. ${ }^{439}$

Através desse trecho, Azenha Jr. justifica o fato de ter optado por um corpus comparável, de textos referentes a um mesmo produto, em princípio produzidos originalmente em suas respectivas culturas - no caso, as culturas alemã e brasileira - do que por um corpus paralelo, formado de textos de partida e suas respectivas traduções. Destacamos do texto, no entanto, a noção de traduzir como "um tipo especial de produção de texto", que não apenas evoca as definições funcionalistas de translação como atividade criativa, mas mesmo a definição dada por Vermeer (1978), segundo a qual "translação é um tipo especial de falar" ${ }^{440}$. Assim, com base no exposto até então, temos indícios de que, além das referências feitas expressamente, Azenha Jr. incorporou alguns dos preceitos funcionalistas a sua própria noção do traduzir, uma hipótese a ser confirmada pela análise dos demais conceitos.

Zipser também aborda a tradução de um tipo textual específico. Ela inicia sua argumentação fazendo referência a algumas noções pré-concebidas acerca da escrita e da tradução jornalística. De acordo com o senso comum, o texto jornalístico seria caracterizado pela veiculação neutra e imparcial de fatos da realidade. No entanto, a pesquisadora

\footnotetext{
${ }^{438}$ AZENHA JR., 1994, p. 97, itálico nosso.

${ }^{439}$ Ibid., p. 104, itálico nosso.

${ }^{440} \mathrm{Cf}$. tópico 3.1.1.1.
} 
questiona essa impressão de objetividade, afirmando que o texto jornalístico é, antes, fruto da perspectiva subjetiva de quem o noticia. Desse modo, não se poderia considerar a reportagem a representação isenta de um fato, visto que o fato estaria sujeito a diferentes óticas e formas de veiculação numa mesma cultura, tendo-se em referência, dentre diversas condicionantes, as exigências do público a que se destina. Zipser compreende o fazer jornalístico como uma atividade fundamentalmente orientada para um público receptor. A seu ver, se isso é válido para as notícias dentro de uma mesma cultura, não seria menos válido no caso da tradução de notícias ${ }^{441}$.

Com isso, Zipser aponta algumas semelhanças entre o fazer jornalístico e o fazer tradutório: ambos elegem o destinatário como o centro de interesse, visto que tanto o texto jornalístico quanto o texto traduzido cumpririam sua função apenas no momento de recepção. Outra semelhança entre as duas atividades estaria no contato com o Outro, através do que se atingiria a consciência das diferenças entre o Outro e o Próprio e do enriquecimento que esse contato pode prover. Na tradução, as fronteiras entre o Próprio e o Outro ganha contornos mais concretos pelas barreiras culturais.

Nesse contexto, seria possível dizer que no cerne do jornalismo e na tradução estão o receptor e a cultura:

[33-34] Em síntese: no centro de ambas as atividades, a do jornalista e a do tradutor, estão o destinatário e a cultura. É no interior da cultura e com os olhos voltados para seu destinatário que jornalistas e tradutores buscam e selecionam seu instrumental de trabalho, os recursos lingüísticos a seu ver mais adequados para a execução de uma tarefa. Assim como para a tradução já não se pode mais pensar numa acepção de transcodificação desvinculada da questão cultural, também para o jornalismo não se pode pensar na "tradução" de fatos sem a devida referência à cultura local. ${ }^{442}$

As noções de tradução e jornalismo veiculadas no senso comum amparam-se na pré-concepção de que seria possível a transposição isenta, isto é, a reprodução fiel do texto de partida na língua de chegada, bem como do fato em discurso. Contudo, da mesma forma que a tradução não seria uma mera troca de códigos, sem a interferência cultural e dos interesses do receptor, a escrita jornalística também não poderia ser vista como a mera "tradução" dos fatos sem a referência cultural local. Nesse ponto, cumpre salientar que, ao aproximar o jornalismo da tradução, Zipser parece trazer uma nova camada ao conceito de tradução.

\footnotetext{
${ }^{441}$ ZIPSER, 2004, p. 12s.

${ }^{442}$ Ibid., p. 19.
} 
O funcionalismo é integrado à tese de Zipser sobretudo por intermédio de Nord e Azenha Jr., sendo o último orientador da tese. De Nord, ela traz a definição de tradução como ação. Seja como processo ou como produto, a tradução seria caracterizada por seu dinamismo: como processo, envolveria diversas variáveis e seria direcionada com vistas ao receptor, a partir das diretrizes do encargo de tradução; como resultado, a tradução, como vimos, só adquiriria sentido no momento de recepção. De Azenha Jr., ela traz a compreensão de que a tradução é um processo realizado no interior da linguagem e através dela, resultando num texto que representa a imagem que o texto de partida se afigura ao tradutor. A língua, assim como se observa nas obras seminais funcionalistas e na tese de Azenha Jr., é entendida também aqui como um elemento de uma cultura.

Como vimos, um dos pontos dignos de destaque na proposta de Zipser é o fato de ela expandir o conceito de tradução, na medida em que traça paralelos entre o processo tradutório e a escritura do texto jornalístico: também uma atividade prospectiva, voltada ao receptor final, a escrita jornalística é considerada uma "tradução" do fato noticioso que, de modo semelhante à tradução, só se concretiza na recepção. Ainda assim, segundo Zipser, mesmo que seja uma atividade prospectiva, a tradução não deve desconsiderar o textofonte. O próprio funcionalismo prevê um processo constante de negociação gerenciado pelo tradutor: seja no momento de definir as diretrizes do trabalho no que compete ao grau de aproximação do leitor e de afastamento do texto-fonte.

Como Zipser demonstra em seu estudo, haveria a coocorrência de duas formas de tradução no âmbito jornalístico:

[137-139] Assim, o corpus desta pesquisa abarca dois enfoques distintos para o conceito de "tradução" nos textos escritos em português do Brasil:

1. tradução em sentido próprio, tradicional, com T5 e T6, na forma desenvolvida pelo tradutor que fez seu trabalho, produzindo em português textos a partir dos textos jornalísticos em alemão (Der Spiegel, de 1989 e 1999), sobre a queda do muro de Berlim, e

2. tradução como reelaboração de um fato, como "representação cultural", com $\mathrm{T} 2$ e T4, frutos do trabalho do(s) jornalista(s) brasileiro(s) que produziu(ram) textos em português para a "Veja" a partir do fato noticioso ocorrido na Alemanha em 1989 e 1999, para o que se levou em conta o horizonte cultural do leitor brasileiro.

Com os estudos de caso, Zipser confirma sua hipótese de pesquisa: as traduções "fiéis à letra", embora veiculem informação, não atendem as expectativas do leitor brasileiro, assim, não caracterizando um texto jornalístico. Esse tipo de tradução pode ser usado como material para a produção de textos jornalísticos mais adequados em português. Além 
disso, ela também confirma a coocorrência de dois tipos de tradução: a tradução "fiel" como insumo para a produção de novas matérias jornalísticas e a tradução do fato noticioso como "representação cultural". Zipser opta por designar assim as diferentes "traduções" dos fatos feitas pelas diferentes culturas no âmbito jornalístico, pois, a seu ver, o texto jornalístico é a própria representação do modo de uma cultura perceber um fato. Assim, menos do que um texto de partida, haveria uma cultura de partida a servir de base a esse segundo tipo de tradução, com sua própria visão do fato noticioso.

As questões culturais são também essenciais na tradução proposta por Liberatti. Em vista da diversidade de aspectos que a tradução dos quadrinhos do Chico Bento permite abordar, o estudo do conceito de tradução aqui inclui diferentes facetas da atividade tradutória. De modo mais específico, Liberatti trata, como mencionamos, da tradução de histórias em quadrinhos, da tradução dialetal e da tradução de literatura infantil e juvenil.

Como vimos, as histórias em quadrinhos (HQs) definem-se como um espaço narrativo, frequentemente ficcional, formado por elementos pictóricos e, de modo geral, também por mensagens verbais. Nos quadrinhos, os elementos pictóricos são tão ou mais constituintes de significado em relação às mensagens verbais, tendo primazia sobre elas.

Desde a sua concepção, os quadrinhos de Chico Bento destinam-se de forma predominante ao público infantil. Assim, Liberatti opta por enquadrá-lo no gênero de literatura infantil e juvenil (LIJ). Ele se distinguiria da literatura adulta menos nos temas que aborda e mais no concernente a seus receptores, sobretudo pela presença de instâncias mediadoras, que atuam no controle e na censura do conteúdo veiculado. Ainda que a diferença de idades entre os receptores reflita-se num uso mais simples das estruturas sintáticas, não haveria redução artística nas obras de LIJ.

De fato, a compreensão artística sobre a interação texto-imagem nos quadrinhos teria mudado ao longo dos anos, o que traria consequências para a tradução. Até a década de 1980, considerava-se que o horizonte de reflexão do tradutor de HQs deveria restringir-se ao texto. Mesmo após o reconhecimento de que as imagens contribuem para a construção do significado, acreditou-se por muito tempo que elas não sofressem interferência cultural. Todavia, Umberto Eco lembra-nos que as imagens possuem um código governado por convenções moldadas culturalmente. Logo, a tradução de quadrinhos vai além da compa- 
ração entre línguas, tomando língua no sentido mais estrito; a tradução envolveria, sim, diferentes sistemas semióticos ${ }^{443}$ :

\begin{abstract}
[96-100] Os quadrinhos são, acima de tudo, textos visuais (compostos pelos desenhos, chamados de signos icônicos), que podem ou não incluir componentes verbais (as palavras, chamadas de signos simbólicos). A imagem, nos quadrinhos, predomina sobre o texto verbal. Com isso, tradução de quadrinhos se dá dentro do contexto de interpretação das imagens, sendo que a linguagem é apenas um dos sistemas envolvidos na tradução de quadrinhos. Originais e suas respectivas traduções baseiam-se em diferentes sistemas de signos visuais, ao passo que cada língua possui uma cultura visual diferenciada: "A tradução de quadrinhos para outra língua é primeiramente sua tradução para outra cultura visual..." (ZANETIN, 2008, p. 12-20, grifos meus) ${ }^{444}$.
\end{abstract}

Embora de forma menos intensa do que nos quadrinhos, a relação entre texto e imagem seria um fator fundamental a ser considerado também nas traduções de LIJ de modo geral, dada a constante presença de ilustrações em obras desse gênero. Assim, não observar essa relação no ato de traduzir poderia levar a incongruências.

Ainda assim, Liberatti observa que o texto verbal é comumente o objeto de tradução, enquanto as imagens permanecem intactas. Apenas raramente as imagens do texto de partida seriam objeto de reedição, dado os custos adicionais envolvidos. Dessa forma, a relação entre imagem e texto limitaria as opções de escolha do tradutor. Outro fator limitador à tradução de HQ estaria no fato de esse ser um gênero textual governado por convenções, tais como limitações de espaço, os significados dos diferentes tipos de balão e o uso de imagens muitas vezes vinculadas à cultura para que se escreve. Logo, diferenças entre as convenções nas diversas culturas trariam problemas de tradução ${ }^{445}$. As diferenças de convenções entre culturas, contudo, não seriam observadas apenas no nível microtextual, nos quadros em si, mas também num nível macroestrutural, como as diferenças de layout ou mesmo na direção de leitura, a exemplo do caso dos mangás, em comparação com os quadrinhos ocidentais.

Cumpre ainda salientar que, em acréscimo às limitações próprias dos quadrinhos, as HQs voltadas a crianças, como obras de literatura infantil e juvenil, teriam as mesmas limitações que os demais textos desse tipo, sendo uma delas o fato de a criança ter um conhecimento de mundo geralmente mais limitado que o adulto e, assim, requerer mais adapta-

\footnotetext{
${ }^{443}$ LIBERATTI, 2012, p. 48.

${ }^{444}$ Ibid., p. 50.

${ }^{445}$ Ibid., p. 52.
} 
ções do texto literário. Isso incluiria a capacidade da criança de identificar as diferenças culturais, o que deveria ser levado em conta na tradução.

Soma-se à discussão a questão da tradução dialetal. Um dos principais problemas na tradução de dialetos seria a escolha de um equivalente cultural na cultura de chegada. Dialetos seriam representativos de uma dada região ou grupo social e comumente traz implicações sociais. Seu uso em textos literários serviria à caracterização dos personagens com a indicação de sua origem, devendo ser reconstituído na tradução. Assim, ao traduzir, dever-se-ia tentar evocar associações semelhantes àquelas que faz o dialeto na cultura de partida. Cada dialeto seria carregado de marcas sociais, históricas, culturais e econômicas; tornar "padrão" a fala desse personagem, apagando as especificidades da linguagem, poderia descaracterizá-lo.

Nesse contexto, Liberatti recorre a José Roberto O'Shea, tradutor de Shakespeare, que oferece um modo de proceder nas traduções dialetais: analisar o contexto sociocultural de origem do personagem expresso por seu dialeto e tentar reconstruir o mesmo efeito na língua de chegada, seja por desvios ou pela afirmação da norma culta. No caso da literatura, contudo, não é imprescindível a acuidade do dialeto, visto que o dialeto se presta à arte, não à dialetologia.

A fim de embasar as considerações feitas acerca das diversas facetas da tradução abordadas nesse estudo, Liberatti recorre à vertente funcionalista. Ela traz a concepção do traduzir defendida por Vermeer, que vê a tradução como um processo cultural e que possui um objetivo que determina as escolhas no processo de tradução. A equivalência textual, segundo o autor, não se prende ao TP: a orientação é a função do TC. O mesmo texto pode ser traduzido de diferentes formas, de acordo com as diferentes funções que ele pode exercer. Antes de Vermeer, Katharina Reiss teria proposto que a tradução deva ser orientada pela função comunicativa, discriminando três diferentes funções comunicativas para os textos, bem como uma tipologia para agrupá-los segundo a função predominante. A função comunicativa predominante determinaria, assim, as estratégias de tradução.

Os principais fundamentos teóricos a embasar a pesquisa, no entanto, são retirados de Nord, para quem a tradução é uma comunicação intercultural, em que TP e TC pertencem a sistemas culturais distintos. Segundo o funcionalismo de Nord, as traduções são uma ação comunicativa que considera três bases principais: as funções do TP e do TC, o público receptor e o contexto de recepção do texto. A função comunicativa desses textos nem sempre seria correspondente, devendo ser examinada com vistas para a situação de recep- 
ção de cada um dos textos. Visto que a função textual só se concretizaria no momento de recepção, os receptores dos textos seriam determinantes para o escopo. A tradução segundo Nord não é estática, pois há várias variáveis envolvidas no processo. A tradução partiria de um TP produzido numa língua e cultura de partida, numa determinada situação comunicativa e para um público específico. Essas são circunstâncias determinantes para a produção do texto. Na tradução, altera-se a situação - o tempo e o lugar -, e, em decorrência disso, por vezes muda-se o meio e altera-se sobretudo a relação com o público receptor.

O fato de sua proposta de tradução ter um embasamento teórico explícito seria, inclusive, o ponto de divergência de sua tradução em relação àquelas feitas pela Maurício de Sousa Produções. Apesar disso, não há, mesmo para a teoria funcionalista, uma única tradução possível. Admite-se, assim, que há mais formas de se traduzir, o que não torna a tradução proposta por ela a única correta.

Com Laiño, somos levados a refletir sobre a tradução a partir de uma perspectiva diferente, a saber, a partir de seu emprego no aprendizado de línguas estrangeiras. Segundo a própria pesquisadora, o emprego de traduções nas aulas de LE polariza opiniões, havendo aqueles que defendem seu emprego nos níveis mais avançados e aqueles que a rejeitam por completo, por pensar que a tradução afasta o aluno da língua estrangeira. Uma das prováveis causas para tamanha resistência teria bases históricas. O lugar tradicional da tradução no ensino de LE é como auxílio na produção e compreensão textuais no que ficou conhecido como Método Gramática e Tradução (MGT), baseado, como o nome sugere, no ensino de gramática e na aquisição de vocabulário via tradução da e para a cultura materna. Por focar na repetição de frases descontextualizadas e do pouco uso da LE nas aulas, o MGT teria sofrido com a acusação de não fomentar o pensamento do aluno na LE. Subjacente a ele estaria uma noção de língua como um conjunto de estruturas gramaticais, bem como a relação entre as línguas como uma relação unívoca, desconsiderando-se variações linguísticas e o contexto de uso da língua. Assim, o MGT teria se baseado em listas de palavras e o seu foco é a produção e compreensão escrita.

Com o advento do Método Direto, a tradução começaria a ser banida do ensino de LE, privilegiando-se o uso exclusivo da LE. Depois do deslocamento para o meio oral com o Método Audiolingual, o Método Comunicativo propõe-se a desenvolver as quatro habilidades concomitantemente, voltando-se para situações reais de comunicação. Nesse contexto, a tradução e as explicações gramaticais teriam papel secundário. No entanto, o papel secundário da tradução em decorrência de não se concatenar a uma "situação real de co- 
municação" não é, segundo Laiño, procedente: utiliza-se a tradução não apenas para entrar em contato com aspectos linguísticos, mas também culturais. Não aproveitar a tradução, enfim, mostraria uma visão limitada do aproveitamento de seus recursos.

A negatividade em torno da tradução como ferramenta pedagógica no ensino de LE decorre do modo como ela foi usada no MGT, que considerava apenas uma tradução correta. O ideal de tradução subjacente a esse método é o de equivalência da forma, não o de adequação a um objetivo comunicativo. Com essa pesquisa, Laiño propõe-se a mudar a imagem da tradução no âmbito do ensino de LE, revitalizando o conceito de tradução.

É certo que a consciência de que o que define o sucesso do emprego da tradução no aprendizado de LE não é a tradução em si, mas como ela é explorada pelo docente, já começa a se espalhar no campo de aquisição de LE. De fato, a tradução é vista como inerente ao próprio processo de aprendizado de uma língua estrangeira:

[83-84] Como colocado na introdução desta pesquisa, a tradução é um elemento que pode ser considerado intrínseco ao processo de aprendizado de uma nova língua, Ottoni (2005) apud Rego (2008, p. 17) nos esclarece que na medida em que aprendo uma língua estrangeira, a partir da minha língua materna, a tradução torna-se um processo inerente e fundante desse processo de aprendizagem. Não aprendemos completamente uma língua estrangeira, não traduzimos completamente, assim como não sabemos completamente sobre nossa língua materna. (...) A relação que um aprendiz estabelece entre língua materna e língua estrangeira é sempre individual.

Segundo Jakobson, a interpretação de uma mensagem, isto é, o nível cognitivo da linguagem, tem menos a ver com operações gramaticais e mais a ver com operações metalinguísticas, em que se usa o próprio código para compreender a mensagem - num processo de recodificação, ou melhor, de tradução. Assim, a tradução seria intrínseca ao processo cognitivo.

Para a opinião de que a tradução afasta o aluno da LE ao utilizar a língua materna, Amparo Hurtado Albir oferece uma resposta, demonstrando que pode haver três diferentes tipos de tradução em sala de aula: a tradução interiorizada, constituinte do próprio processo de aprendizagem de uma LE, quando o aluno confronta a LE com sua língua materna; a tradução explicativa, quando a tradução é usada para explicar palavras e expressões aos estudantes; a tradução pedagógica, que são os exercícios de tradução propostos pelo professor, variados segundo o objetivo didático. Em comum, esses exercícios levariam à reflexão da melhor forma de se expressar em LE. 
A tradução como ferramenta pedagógica distinguir-se-ia da tradução praticada em situações reais de comunicação em três aspectos: função, objetivo e destinatário. A função da tradução pedagógica seria melhorar a proficiência em língua estrangeira. Ela seria uma ferramenta para o desenvolvimento das diferentes habilidades envolvidas no aprendizado de LE, enquanto a tradução real seria um processo, que perpassaria a compreensão do texto, a definição de um público-alvo e de estratégias tradutórias. Ainda que se trate de uma ferramenta, mesmo a tradução pedagógica não prescindiria dessas etapas. O objetivo da tradução pedagógica seria demonstrar o nível de proficiência de LE ao docente, enquanto o objetivo da tradução real seria normalmente estabelecer comunicação. Por fim, com relação ao receptor, o leitor da tradução pedagógica seria sempre o professor, enquanto o leitor da tradução real seria o indivíduo em busca das informações oferecidas pelo texto. Ainda assim, o professor poderia orientar o aluno a pensar num grupo receptor específico, podendo assim avaliar as escolhas do aprendiz num determinado contexto cultural.

Como uma ferramenta pedagógica, a tradução poderia sensibilizar os alunos para diferentes aspectos da língua estrangeira através do contraste com a língua materna, inclusive para questões envolvendo a variação linguística e a produção textual. No entanto, para Laiño, ela não se limita a explorar aspectos linguísticos, mas também culturais, colocando culturas em contraste. Ao demonstrar a utilidade da tradução na veiculação de elementos da cultura estrangeira, a pesquisadora constata que o exercício tradutório não é algo simulado, artificial, mas real, a partir de situações reais de comunicação, não havendo, assim, qualquer motivo para ser banido da abordagem comunicativa.

Laiño salienta a necessidade de se ter um aparato teórico para embasar a noção de tradução, mesmo na tradução pedagógica. O arcabouço teórico que ela elege para sua pesquisa e prática é a teoria funcionalista, sobretudo pelo trabalho de Christiane Nord. Nord mantém, através dos conceitos de funcionalidade e de lealdade o compromisso com a intenção comunicativa do autor, com a função da tradução e com as expectativas do leitor. No funcionalismo nordiano o conceito de fidelidade remete ao autor do texto original e a sua intenção comunicativa. A lealdade, por sua vez, remeteria ao receptor, num movimento prospectivo de tradução.

A tradução é vista como uma atividade dinâmica em que se deve levar em consideração a intenção comunicativa do autor e se deve antecipar as expectativas do leitor do TC. De fato, o destinatário é considerado o mais importante dentre os fatores situacionais. Quanto mais claro estiver para o tradutor quem é seu destinatário, mais fácil será para ele 
conformar a tradução para seu leitor. Além disso, Nord destaca que a tradução não ocorre apenas entre línguas, mas também entre culturas - o que se nota até na proposta didática de Laiño.

Sob a ótica do funcionalismo nordiano, a tradução é um movimento retrospectivo e prospectivo, isto é, um olhar para o autor do TP e suas intenções comunicativas e um olhar para o destinatário e suas expectativas. Esse processo é intermediado pelo tradutor. Nesse contexto, todos os personagens (autor, tradutor e destinatário) são fundamentais para o processo.

Como ferramenta didática para a tradução, Nord elaborou um modelo de análise textual que pode também ser usado pelos tradutores profissionais. Ele se volta a contemplar todos os aspectos intra- e extratextuais, de modo que o tradutor tenha uma compreensão ampla do texto, tenha claras as estruturas linguístico-textuais do TP, possa determinar a função de cada elemento textual numa determinada situação comunicativa e disponha, assim, de uma base confiável para suas decisões tradutórias.

Em sua proposta didática, Laiño destaca a necessidade de se orientar segundo a intenção comunicativa do emissor, ainda que a função da tradução seja diferente. Contudo, isso não significa que o exercício tenha que ser orientado pela noção de equivalência, dado que, segundo Nord, a equivalência, que está intimamente associada à noção de língua, representa uma barreira que impossibilita a preocupação com o público-alvo. Assim, para que a tradução funcione, o receptor-C deve estaria no centro das preocupações do tradutor. A figura do receptor seria decisiva na hora de estabelecer a função da tradução - não só a figura do receptor-C, mas também a do receptor-P. Dever-se-ia, assim, analisar as diferenças entre eles e, com isso, mensurar as mudanças necessárias para o novo público. Para Nord, a falta de atenção ao destinatário, posto que nem sempre presente nas traduções, leva a traduções que não comunicam.

Além da proposta teórica de Christiane Nord, Laiño tem também Vermeer como fonte. Segundo o autor, não se produzem palavras e frases, mas textos inseridos em situações específicas. Considerar a situação comunicativa facilitaria na orientação de escolhas de elementos verbais e não verbais do texto. Laiño também recupera de Vermeer a citação de que, se o tradutor se depara com um TP ruim, ele deve melhorá-lo, em vez de imitar o TP em sua imperfeição, na confecção do TC. Se a "melhoria" vem de uma diferença de contextos comunicativos, ela está contemplada pela segunda regra da teoria do skopos: uma tradução deve ser coerente com sua situação comunicativa. 
Nord coloca-se, ela mesma, numa posição intermediária entre a abordagem da equivalência e o funcionalismo radical, apregoando o respeito aos dois lados do processo tradutório: o autor de partida e sua intenção comunicativa, o receptor de chegada em seu ambiente cultural e em sua situação comunicativa. Para ela, no entanto, a orientação segundo a função comunicativa continua a ser a diretriz fundamental da tradução.

\subsubsection{Função}

$\mathrm{Na}$ exposição dos fundamentos teóricos de sua tese, Azenha Jr. destaca a orientação do processo tradutório segundo a função comunicativa do TC como fio condutor entre as propostas. Nesse contexto, o tradutor definiria as estratégias de tradução conforme a função do translato, podendo essa corresponder à função comunicativa do TP ou divergir dela. Uma vez tomadas as decisões acerca das estratégias de tradução, toda a rede de relações entre os elementos linguísticos e entre os valores culturais seria restabelecida na cultura de chegada.

A definição de estratégias é de suma importância para orientar a recepção. Nesse contexto, Azenha Jr. observa que a função textual tem sua concretização apenas no momento de recepção do texto e no contexto da situação comunicativa em que esse receptor se encontra. Assim, ainda que seja considerada um reflexo da intenção comunicativa do autor, um texto só seria compatível com a função se a interpretação do receptor corresponder a essa intenção. Nesse caso, o produtor do texto introduziria elementos que deixem clara sua intenção, assegurando dessa forma a compreensão que deseja de seu receptor.

Naturalmente, essas ponderações são igualmente válidas para a produção - e para a tradução - de textos técnicos. De fato, Azenha Jr. nota que, na composição de um texto de especialidade, o tema não exerce um papel tão determinante na escolha dos recursos linguísticos quanto o faz a função comunicativa. Assim como ocorre com outros tipos de texto, a função do texto técnico só se concretiza no momento de recepção textual. Desse modo, caberia ao produtor do texto elaborar estratégias para elevar as chances de que o texto exerça um efeito comunicativo sobre o receptor similar ao que ele intenciona. Tendo isso em vista, é possível concluir que, seja de modo geral, seja no caso específico do texto téc- 
nico, há uma correlação entre o plano linguístico-estrutural e o plano funcionalcomunicativo do texto.

Como vimos, um dos princípios básicos do funcionalismo em tradução - a função do texto só se realiza no momento de recepção - é observado também na produção jornalística. De modo geral, a função principal do texto jornalístico é informativa, uma vez que um dos objetivos das matérias jornalísticas é formar opinião. Caberia o leitor, assim, adquirir o texto, compreender a informação oferecida por ele e construir uma opinião com base nessas informações. Sem isso, o texto jornalístico não teria razão de ser.

De modo geral, os principais conceitos funcionalistas utilizados por Zipser seguem as definições de Christiane Nord, e com o conceito de função não é diferente. A função do texto, segundo Nord, só pode ser identificada quando observamos os fatores externos do texto, ligados à situação comunicativa em que ele é usado como instrumento comunicativo. O autor elaboraria o texto com uma intenção comunicativa. No entanto, se essa intenção atinge ou não seus objetivos dependeria do receptor, pois é ele - e ele apenas - quem atribuiria uma função ao texto. Ele o faz através de certas condições situacionais, mas também por conta de suas necessidades comunicativas individuais. No entanto, Zipser observa que a identificação da função não se limita aos fatores externos, mas considera também os fatores internos do texto. Quando se desloca um fator, mesmo um fator interno, há uma modificação na função.

Ainda que considere que a função primordial do texto jornalístico é informativa, Zipser constatou de sua pesquisa que o texto jornalístico também tem uma função expressiva da parte de seu emissor:

[25-29] O ponto de partida para as primeiras análises foi uma reflexão sobre a função informativa dos textos jornalísticos, aceita consensualmente como sua caraterística (sic) principal. Desconfiava-se, desde o início, que essa função embora preponderante em muitos casos - competisse com a função expressiva dos textos jornalísticos, sobre a qual se deveria embasar a perspectiva de enfoque do redator e do veículo. Assim, a atenção se voltou para o trabalho do emissor, do jornalista por trás do texto. Nesse momento, surgiram perguntas tais como: por que uma matéria sobre o mesmo fato se inicia por uma revisão da história e a outra não? Por que não se obedece a uma mesma seqüência na exposição do assunto? Por que se atribui uma intensidade diferenciada a um mesmo aspecto do fato? Quais comentários e posicionamentos frente aos fatos estão presentes ao longo do texto? Eles manifestam alguma opinião?

As primeiras respostas a essas perguntas, permitiram constatar que havia efetivamente mudanças na perspectiva de enfoque das matérias, o que apontava para a comprovação da hipótese e para a viabilidade do estudo. Assim, alguns textos pareciam possuir um caráter mais crítico, ao passo que outros colocavam sua ênfase na perspectiva histórica local e outros, ainda, na repercussão do fato em escala mundial. De qualquer forma, ao se deslocar a atenção da função informativa 
dos textos para a função expressiva desses mesmos textos, percebia-se que cada vez menos se podia falar de uma "representação isenta" do fato.

Com isso, Zipser nega a ilusão de objetividade e neutralidade no texto jornalístico, posto que é impossível o emissor se isentar na veiculação de informações. $O$ texto jornalístico sempre será uma representação de um fato noticioso, resultante da percepção individual do jornalista.

Liberatti observa que, para a Skopostheorie, a função do texto de chegada sobrepõese a qualquer exigência por equivalência ao texto de partida nos níveis lexical, sintático e semântico em tradução. Haveria assim diferentes formas de se traduzir um texto, cada qual segundo uma função diferente.

Segundo Liberatti, Nord também salienta o papel da função da tradução nas escolhas tradutórias. Ela, no entanto, distinguiria entre intenção/propósito comunicativo, ligados ao remetente do texto, e função textual, ligada ao receptor. Nord expressa também que nem sempre há congruência entre a intenção comunicativa do emissor e a função identificada pelo receptor, sobretudo quando eles estão separados por uma grande distância cultural.

Para identificar a função do texto, segundo Nord, seria necessário levantar informações sobre a situação comunicativa em que o texto é produzido, que incluiriam a intenção do emissor, as expectativas do receptor, mas também outros fatores mais secundários, como o emissor, o meio, o lugar, o tempo e o propósito. Mesmo que possa haver diferentes funções num texto, haveria sempre uma função predominante.

Laiño opta por principiar a abordagem ao conceito de função a partir da definição de Daniel Cassany da função dos gêneros discursivos. Segundo afirma Cassany, os gêneros discursivos desempenham três funções: (1) função cognitiva, pois a partir dos gêneros discursivos podemos aprofundar nossos conhecimentos numa determinada esfera do saber; (2) função interpessoal, referente ao fato de agirmos diferente dependendo do contexto; (3) função sociopolítica, ligada à função anterior, que relaciona comportamento linguístico e grau de poder. Nesse contexto, os gêneros textuais seriam mais determinados por suas funções comunicativas, cognitivas e institucionais do que por características linguísticas ou estruturais. Suas características também dependeriam da cultura e do tempo em que estão inseridos.

Das funções acima descritas, Laiño destaca a função interpessoal como especialmente relevante para o contexto escolar. A partir do momento em que os alunos conhecem 
os diferentes gêneros e seus diferentes graus de formalidade, eles são sensibilizados para as diferentes formas de manifestação linguística, facilitando a definição de estratégias de escrita e fala.

Ainda que a função de um texto não dependa inteiramente do gênero textual, Laiño observa que ambas estão diretamente relacionadas, de modo que função textual e o aspecto estrutural de cada gênero textual são indissociáveis. No entanto, Daniel Cassany considera que a função primeira de um texto é comunicar uma mensagem. Para tanto, o produtor do texto deve manter a adequação, a coesão e a coerência. Sem isso, não se atingiria a função comunicativa.

Por outro lado, admite-se que a função comunicativa depende do destinatário do texto. Isso é especialmente relevante no caso do texto publicitário, eleito por Laiño como componente de sua metodologia pedagógica. Conforme explica, esse gênero textual faz transparecer o contexto sociocultural em que o texto é criado, pois está a serviço do consumidor e tem a função de aproximar-se do destinatário, com o objetivo de convencê-lo a comprar ou a movê-lo para a ação. Em última medida, a função seria concretizada no momento de recepção, sendo fulcral levar o receptor em consideração e, portanto, conhecer o receptor.

Seria também essencial considerar a cultura para a qual se está produzindo um texto, inclusive, mas não exclusivamente, no caso da tradução. Se é o receptor quem atribuiria a função ao texto, não seria possível considerar que ela seja inerente ao texto, isto é, que ela se manteria estável na mudança do tempo e das culturas. Concebe-se que, quando ocorre uma mudança de leitor, a própria função textual muda.

\subsubsection{Texto}

Além de uma nova concepção de tradução, Azenha Jr. adota do funcionalismo uma nova concepção de texto. De modo geral, o texto seria para as propostas funcionalistas muito mais do que sua parte verbalizada e, portanto, o trabalho com textos não poderia prescindir de um ponto de vista mais amplo, que levasse em conta também os fatores extralinguísticos a determinar o plano linguístico. O texto seria, de fato, determinado por um contexto situacional que, por seu turno, integraria um contexto cultural mais abrangente. Ademais, e por decorrência disso, a inclusão dos elementos situacionais e culturais na pró- 
pria definição de texto elevaria significativamente o número de variáveis envolvidas no manejo com eles.

Do funcionalismo também são advindos os dois modelos de tipologia textual examinados por Azenha Jr.: trata-se dos modelos formulados por Katharina Reiss (1976) e por Mary Snell-Hornby (1988), sobre os quais discorremos brevemente no presente capítulo. O objetivo com a análise, segundo elucida o autor, é reexaminar os critérios de classificação tipológica de textos, bem como suas consequências para a produção e a avaliação de traduções. Ao abordar os modelos, Azenha Jr. comenta que, em comum, ambos consideram que o texto vai além do plano linguístico-textual, estando relacionado com uma realidade sociocultural de que é ao mesmo tempo parte integrante e para que concede manifestação verbal.

Azenha Jr. introduz o modelo de Reiss, ressaltando que nesse os tipos textuais distinguem-se segundo a função predominante de um texto, a cada tipo textual estando associada determinada estratégia de tradução. Ao comparar os modelos, contudo, concordando com Snell-Hornby, ele salienta que o modelo de Reiss destoa da realidade dos textos, posto que, como formas frequentemente híbridas, é bastante difícil identificar uma só função nos texto ou mesmo uma função textual predominante.

Em contrapartida, o modelo de Snell-Hornby contemplaria uma constelação de fatores que interferem na tradução de textos. Assim, em vez de propor estratégias, a tipologia textual de Snell-Hornby permitiria um vislumbre da cadeia de fatores em torno de um único texto, possibilitando um tratamento individualizado. Seu principal mérito, no entanto, seria propor uma maior integração nos estudos da tradução, voltando os olhos a aspectos internos e externos do texto. Por outro lado, embora se preste à sedimentação de uma visão mais abrangente de tradução, a tipologia de Snell-Hornby não possibilitaria o agrupamento de diferentes textos numa mesma categoria, o que tornaria a pesquisa com um corpus formado por vários textos mais desafiadora.

Pesando vantagens e desvantagens de ambos, Azenha Jr. sugere a conciliação desses dois modelos, a se realizar de acordo com os objetivos de pesquisa. A esse respeito, ele ainda observa que as tipologias textuais não podem perder de vista nem a dimensão funcional-comunicativo-cultural dos textos, nem a dimensão linguístico-estrutural. Como vimos em tópico anterior, ambos os planos estão inter-relacionados num texto. Dessa forma, ainda que os tipos de texto sejam determinados por sua área de aplicação e por sua recep- 
ção, eles carregariam características em sua superfície que apontam a determinados tipos textuais, tornando a classificação mais transparente.

Assim como feito no caso da tradução, Azenha Jr. opta por principiar a discussão acerca do texto técnico com algumas considerações sobre a linguagem de especialidade:

\begin{abstract}
[262] Esse primeiro contato com a diversidade das linguagens técnicas, tanto interna (no plano vertical) quanto externamente (no plano horizontal) permite-nos concluir algumas coisas: 1) as linguagens técnicas são subgrupos de um sistema; portanto, valem para elas mutatis mutandis as mesmas leis que regem o sistema lingüístico como um todo e suas realizações; 2) as linguagens técnicas podem ser consideradas de um ponto de vista lingüístico-estrutural, ou funcionalcomunicativo; e 3) dada a relação descrita anteriormente (Parte I deste capítulo) entre língua e cultura, o interesse para as questões da tradução de textos técnicos deve estar localizado provavelmente nas relações de interdependência entre o plano lingüístico-estrutural e o plano funcional-comunicativo. ${ }^{446}$
\end{abstract}

Nesse sentido, a relação entre linguagem técnica e linguagem geral poderia ser estendida ao plano textual: dado que as diferenças entre a linguagem geral e a linguagem técnica são diferenças de grau, não de essência, a produção de textos técnicos também não seria, em essência, diferente da produção de outros tipos de texto. Por conseguinte, assim como os demais tipos textuais, os textos técnicos estariam envoltos por diversas variáveis que determinam sua produção, recepção e tradução. Essas variáveis, relativas ao emissor, ao receptor, à situação comunicativa e ao objetivo da comunicação, seriam também determinantes na escolha dos recursos linguísticos.

O reconhecimento da interdependência, no plano textual, entre recursos linguísticos e determinantes extralinguísticos esteve presente, como constatado na seção anterior, em todas as definições de texto em propostas funcionalistas. O texto não é visto como um espécime isolado de língua, mas sim, no contexto de uma situação de comunicação, exercendo função comunicativa. O sentido do texto nasce, por sua vez, da interação entre esses o plano linguístico e comunicativo, ganhando concretude no momento da recepção. Desse modo, é essencial considerar na tradução de textos técnicos tanto a estrutura linguísticoestrutural como a estrutura funcional-comunicativa.

Temos, assim, mais um indício do alinhamento das propostas, bem como a comprovação da adequação do funcionalismo para tratar do caso específico do texto técnico. Também o vínculo do texto com um determinado contexto cultural, como reiterado diversas vezes pela abordagem funcional, ganha comprovação empírica através da análise feita

\footnotetext{
${ }^{446}$ AZENHA JR., 1994, p. 67, grifos no original.
} 
por Azenha Jr. com os textos técnicos de instrução. Ele chega à conclusão de que o envolvimento dos textos com realidades extralinguísticas diferentes faz com que essas diferenças se manifestem em todos os níveis de construção textual. Além disso, ele afirma que, por resultar de um ato comunicativo ocorrido sob determinadas circunstâncias de um contexto sociocultural, cada texto traria as chaves para acessar os valores culturais de onde veio, o que demanda do tradutor uma reflexão sobre os contextos culturais envolvidos: o estrangeiro e o seu próprio. E essa, a seu ver, é uma tarefa para o tradutor de quaisquer tipos textuais.

Zipser trata do conceito de texto no contexto específico da tradução jornalística. $O$ senso comum concebe o texto jornalístico como um texto essencialmente informativo, caracterizado pela neutralidade na veiculação de notícias. Desconstruir essa imagem é fundamental para a argumentação da pesquisadora. Com base em sua pesquisa, ela pôde observar que a exigência de imparcialidade e neutralidade contrasta com uma atividade que se baseia na percepção humana, inserido numa situação comunicativa. Trata-se de um texto dinâmico, através do qual um fato noticioso é apresentado a um receptor que pertence a uma determinada cultura. De fato, como outros autores com que trabalhamos na presente pesquisa, Zipser defende que o significado e a função do texto ganham concretude apenas no ato de recepção textual. A razão de ser do texto jornalístico é ser lido pelo receptor, informá-lo e formar sua opinião.

Por se tratar de uma forma textual comercializável, o texto jornalístico deveria adequar-se às expectativas de seu receptor, que incluiriam uma forma de estruturação do texto baseada em convenções de uma dada cultura. Essas convenções, por sua vez, seriam influenciadas por condicionantes sociais, históricas, jurídicas e econômicas, de modo que cada cultura teria suas próprias convenções na formulação do texto jornalístico.

É certo que um dos princípios mais importantes a regular a atividade jornalística é a ética profissional. Zipser, contudo, observa que a observação à ética no fazer jornalístico difere de cultura para cultura. Além disso, é comum que outros fatores sobreponham-se à ética profissional, tais como os interesses das empresas que veiculam as notícias ou de instâncias econômicas e políticas que frequentemente definem o que noticiar e como.

Nota-se que alguns elementos que constituem o conceito de "texto" são também advindos da teoria funcionalista. Zipser observa que Nord define o texto como um "instrumento de comunicação" inserido num "jogo comunicativo", em que, além de fatores linguísticos, estão envolvidos fatores não linguísticos, que incluem os interlocutores, com 
suas próprias experiências e expectativas. Ainda que, em última medida, seja o receptor quem atribui o significado e a função ao texto, haveria no próprio texto manifestações da intenção comunicativa de seu emissor, o que limitaria as opções de interpretação textual.

Zipser também observa que, apesar de Nord dividir os fatores que influenciam na constituição do texto entre fatores intratextuais e extratextuais, essa divisão teria tão somente fins didáticos, uma vez que seria difícil distinguir o ponto em que termina o texto e começa a realidade extralinguística, dada a simbiose entre eles.

O impacto mais significativo para a definição do conceito de texto jornalístico trazido pela pesquisa veio através da comparação de textos jornalísticos produzidos em momentos históricos e em culturas diferentes, bem como da tradução de alguns desses textos. Em sua pesquisa, Zipser constatou que a adequação do texto jornalístico à realidade e aos interesses de seu receptor é uma característica imprescindível a esse gênero textual, de tal modo que a tradução "fiel" do texto jornalístico que deixe de considerar o público para o qual se traduz não resulta num texto jornalístico, mas, na melhor das hipóteses, resulta num insumo para a produção de um novo texto que veicule o fato noticioso a uma nova cultura. Ainda que essa tradução seja bem sucedida em transmitir informações sobre o fato noticioso ao público da cultura de chegada, ela seria insatisfatória em atender às expectativas do receptor e, assim, dificilmente seria reconhecida como um texto jornalístico por esse público. Com isso, a tradução deixa de ser uma operação que envolve meramente textos e passa a ser vista como uma operação que envolve culturas.

Liberatti também busca fundamentação nos funcionalistas para construir a noção de texto a orientar o seu trabalho. Também aqui compreende-se o texto como um ato comunicativo que ganha completude no momento de recepção, o que torna o papel do receptor essencial no processo. Caberia, assim, ao receptor atribuir significado ao texto. Isso significa que um texto poderia ser interpretado de maneiras diferentes por receptores diferentes e até mesmo por um único receptor em diferentes épocas.

O texto seria uma interação comunicativa, determinada pela situação em que ocorre e pelo contexto cultural para o qual é produzido. Como um ato intencional, um texto exerce uma função. Segundo Jakobson, ainda que num texto possam se reconhecer diferentes funções, há sempre uma hierarquia de funções, com uma função que lhe é predominante.

O estudo das traduções de Chico Bento dão ensejo à Liberatti para abordar duas formas textuais: de modo mais amplo, a literatura infantil e juvenil e, de modo mais específico, os quadrinhos voltados a crianças. Assim, nos quadrinhos de Chico Bento, ela reco- 
nhece algumas características de textos de literatura infantil e juvenil, a saber, a leitura fácil e prazerosa, os recursos mais simples do que um texto voltado a adultos e as histórias escritas para crianças com o intuito de entreter, transmitir noções morais e apresentar temas apropriados à faixa etária. A intenção do autor de LIJ não seria apenas descrever a realidade, mas também motivar percepções pessoais sobre a realidade ao descrever um mundo fictício. Assim, complementa-se no texto literário a reprodução mimética do mundo com a expressividade do autor e, assim, a função expressiva da linguagem tem prevalência sobre a função referencial.

Mais espaço, no entanto, é dado à caracterização dos quadrinhos. Pertence ao senso comum de que o texto restringe-se ao componente verbal dos quadrinhos, sendo esse o objeto do tradutor, como exemplificado pelo excerto abaixo:

[15-17] Traduções entre duas ou mais línguas são essenciais para possibilitar a difusão de textos entre países de línguas e culturas distintas, e isso não é diferente em relação à tradução de HQs, que também constituem um texto. De acordo com Lopes (2006, paginação irregular), "História em quadrinhos [...] é uma forma de arte que conjuga texto e imagens com o objetivo de narrar histórias dos mais variados gêneros e estilos". Partindo-se do princípio de que histórias em quadrinhos são distribuídas no mundo todo, necessitando-se de tradutores para esta disseminação, faz-se de grande valia estudos de procedimentos adotados pelo tradutor no que tange a certos aspectos linguísticos concernentes à língua em uso.

No entanto, como vimos, as imagens nas HQs são imprescindíveis na construção do sentido do texto, exercendo nos quadrinhos um papel ainda mais predominante do que o componente verbal. Vimos também que não apenas em torno do componente verbal, mas também em torno do componente imagético, há convenções culturais que não podem ser simplesmente transpostas de uma cultura a outra. De fato, as imagens constituiriam uma linguagem de mérito próprio, com sua própria ancoragem cultural. Assim, tanto a forma linguística quanto a forma imagética dos quadrinhos configuram-se textos. De mesmo modo, ambas são culturalmente marcadas, consequentemente desencadeando diferentes interpretações em diferentes culturas e, portanto, devem ser igualmente consideradas no processo de tradução:

[31] A tradução de quadrinhos não envolve somente transferência de uma língua a outra(s), mas também interpretações de outros sistemas de signos, tais como tradições culturais diferenciadas e diferentes convenções concernentes às HQs, que estão condicionadas a dimensões de espaço e tempo. A imagem dialoga com o texto e com o leitor, principalmente nos casos em que o autor é o próprio ilus- 
trador. Por meio dela, o público infanto-juvenil desvenda o restante do enredo e decifra as pistas deixadas pelo autor e pelo ilustrador.

Dessa maneira, rompe-se com a noção pré-concebida de que as imagens, por serem mais próximas da realidade, não representariam um problema de tradução. Ainda assim, os problemas de incongruências entre texto verbal e texto não verbal na tradução tenderiam a ser resolvidos por adaptações no plano verbal. Seriam raros os casos em que se opta por adaptar as imagens, quando mesmo os jogos estéticos de linguagem não são capazes de resolver essa incongruência. Isso ocorre, pois as editoras não estariam dispostas a adaptar as imagens dos quadrinhos, tendo em vista, como vimos, os custos e prazos extras envolvidos nessas mudanças.

Além das ideias funcionalistas, Laiño constrói sua noção de texto com o auxílio das reflexões de Daniel Cassany, especialista em análise do discurso e em aprendizagem de línguas estrangeiras. Segundo Laiño, os funcionalistas consideram textos como pontes entre interlocutores. Nessa visão, especialmente para Nord, todo texto seria formulado por um emissor com o objetivo de comunicar algo. Desse modo, por trás da formulação de um texto haveria uma intenção comunicativa, que influencia sua forma e seu conteúdo. Por outro lado, ainda que seja necessário considerar na tradução a intenção comunicativa do emissor e o público a que esse texto originalmente se destina, haveria outros elementos constituintes do texto que também precisam ser considerados, em especial sua ancoragem cultural e as discrepâncias entre a cultura de partida e a cultura de chegada.

Para o funcionalismo, o texto, e não palavras ou frases, é o objeto de tradução. Ele se destina a um receptor ou a um grupo receptor específico, o qual é, em última análise, o responsável pela construção do sentido textual. Ainda que diferentes receptores possam originar diferentes interpretações a um texto, costuma haver também semelhanças em suas interpretações, dado que esses receptores, segundo Vermeer, fazem parte de uma mesma cultura. No processo de tradução, essa situação muda: texto de partida e texto de chegada passam a coexistir em contextos culturais diferentes, a representar usos linguísticos diferentes e, ainda que pertençam a um mesmo tipo textual, constroem-se segundo convenções diferentes. As diferenças culturais precisam, assim, ser equilibradas na tradução, compensando no TC os conhecimentos culturais necessários para interpretar as informações sobre a cultura de partida que faltam aos receptores de chegada.

Cassany, por sua vez, toca em assuntos mais ligados à produção textual. Ele observa que a formulação de um texto presume planejamento. Esse planejamento consistiria na 
organização das ideias e em decisões acerca das características a compor esse texto. Para tanto, seria indispensável refletir acerca de seu potencial destinatário. As decisões tomadas, considerando todas as circunstâncias, influenciariam no sucesso da comunicação, facilitando a compreensão do leitor.

Ele também estaria de acordo com a ideia de que o texto tem função primária de comunicar uma mensagem. Para fazer isso, seria necessário seguir as regras de adequação, coesão e coerência, sendo essas regras mais importantes do que as próprias regras gramaticais de uma língua. O linguista brasileiro Luiz Antônio Marcuschi afirma que toda produção textual envolve três aspectos, a saber, aspectos linguísticos, sociais e cognitivos. Para ele, no contexto de produção de um texto, produtor e receptor estão conectados, cada qual inserido numa situação determinada. Marcuschi ainda resgata da linguística textual os critérios de textualidade: coesão, coerência e aceitabilidade (relativas à reação do destinatário); intencionalidade (relativa à intenção do produtor); informatividade (relativo à transmissão de informações pretendida pelo emissor e pela transmissão não prevista por ele); situacionalidade (o fato de o texto está inserido numa situação comunicativa, cultural, social, etc.); intertextualidade (relativo ao fato de os textos serem formados a partir de outros).

Em comum, Nord e Cassany teriam considerado que a produção textual não envolve apenas elementos linguísticos, mas também elementos culturais e que o texto deve ser elaborado com vistas ao receptor, devendo ser claro não só linguisticamente, mas também no que concerne às marcas culturais.

De modo específico, o texto publicitário é abordado brevemente. Para Laiño, ele se caracteriza por sua função, a saber, a de convencer consumidores a consumir produtos. Suas mensagens seriam geralmente curtas, diretas e positivas, com predomínio da abordagem direta e não raro o uso de imperativo. Ele também recorreria à linguagem não verbal e servir-se-ia do apelo emocional através de padrões sociais e estéticos. Por objetivar levar o receptor ao consumo, o texto publicitário seria considerado um texto conscientemente construído com o leitor em prospecção. Eles refletiriam nossas relações com a sociedade e com o que ela representa. Assim, nenhum recurso utilizado em sua construção seria gratuito. 


\subsubsection{Língua}

A pretensa neutralidade da linguagem de especialidade era uma das noções mais duradouras por trás da tradução técnica no senso comum. Segundo Azenha Jr., esse consenso sobre a univocidade dos textos técnicos parece ter raízes numa concepção de língua vigente nas teorias de tradução pelo menos até o início dos anos de 1980: a língua como código e, por conseguinte, a tradução como transcodificação. Pautada em critérios como equivalência e identidade conceptual, a passagem entre línguas, segundo essa visão, não implicaria mudanças e os problemas da tradução técnica seriam tão somente de natureza lexical-terminológica. De fato, esse ideal de língua teria sido responsável por dicotomias ao longo da história, fundamentadas numa noção de sentidos estáveis, imutáveis à passagem do tempo e ao deslocamento entre culturas.

Na contramão desse ideal de língua, o estudo das linguagens técnicas reconhece no uso dessas formas de linguagem uma dimensão cultural extralinguística, algo que foi compartilhado pelos funcionalistas no âmbito da tradução. Como vimos, os funcionalistas descrevem a língua como componente e manifestação de uma cultura, vinculada, assim, a uma realidade exterior à língua. A tradução, por sua vez, seria uma atividade que, antes de envolver línguas, envolveria culturas.

Essa compreensão do traduzir deslocaria os estudos da tradução para o interior do âmbito dos estudos culturais. No entanto, isso não significa que as teorias linguísticas estariam banidas do funcionalismo. Azenha Jr. observa que Katharina Reiss formula sua tipologia textual, parte cardeal de sua proposta teórica, a partir de uma perspectiva linguística inspirada na noção saussuriana de que a língua é um meio de comunicação e expressão. $\mathrm{O}$ linguista Karl Bühler, uma das principais fontes para o trabalho de Reiss, identifica três diferentes funções para o signo linguístico: (1) comunicar um conteúdo, (2) expressar algo da interioridade do locutor e (3) dirigir-se a alguém. Reiss estende essas funções do signo linguístico para o âmbito do texto, construindo assim sua tipologia textual. A seu ver, em todo texto estariam manifestas, em maior ou menor grau, essas mesmas três funções do signo linguístico.

Mary Snell-Hornby, que tenta estabelecer a ponte entre as esferas da tradução literária e da tradução não literária, estaria de acordo com Reiss no tangente ao fato de a linguagem exercer funções, mas opor-se-ia a ela quanto à categorização estanque das funções 
da língua. Como explica Azenha Jr., Snell-Hornby orienta-se por um princípio gestaltiano, de modo que uma análise das partes separadas não permite compreender o todo. Essa suavização dos limites, como vimos, reflete-se em sua prototipologia textual.

A noção menos rígida dos limites da linguagem, bem como a compreensão de que a tradução é um fenômeno da parole, não da langue, são essenciais para essa nova perspectiva sobre a tradução. De Radegundis Stolze, Azenha Jr. obtém o entendimento de que as línguas constituem formações dinâmicas transformando-se continuamente:

[49] "... a ciência da tradução (deveria) deixar de lado o dogma metódico de buscar pontos comuns entre dois sistemas linguísticos na tradução, pois a equivalência interlingual é uma ilusão. As línguas não são sistemas rígidos, mas formações dinâmicas em constante mutação, combinação e evolução, além de estarem ligadas ao seus usuários (Stolze, 1982, p. 384, grifos da autora) ${ }^{447}$

Algumas dessas noções são também observadas nos estudos relativos à linguagem de especialidade. Compreende-se a linguagem de especialidade como um subsistema dentro de uma língua, com características que a distinguem dos demais subsistemas em todos os níveis linguísticos. Porém, para diferenciar esses diferentes subsistemas que compõem o conjunto das linguagens técnicas seria necessário proceder analiticamente. Wolfram Wilss e Lothar Hoffmann afirmam ser possível estabelecer essa diferenciação a partir de dois planos, um plano horizontal e um plano vertical. No plano horizontal, elas seriam diferenciadas segundo áreas de comunicação e segundo a frequência e o grau de coincidência de recursos expressivos empregados. A distinção básica seria então entre recursos linguísticos comuns em todos os subsistemas, recursos linguísticos comuns em linguagens técnicas e recursos linguísticos que ocorrem numa única linguagem técnica. Ainda que se constituam como subsistemas distintos, haveria a interação e a mútua influência entre linguagem técnica e linguagem cotidiana. Esse seria, conforme Azenha Jr., uma forma de enriquecimento do vocabulário e da gramática de ambos os domínios.

O plano vertical diria respeito à estratificação interna das linguagens técnicas, isto é, a seu nível de especialização e consequente distanciamento dos outros conjuntos de subsistemas. Nesse aspecto, entraria também o fator comunicativo: a linguagem usada entre dois membros do campo técnico diferencia-se da linguagem adotada entre um indivíduo de dentro do campo e um indivíduo de fora dele. Nesse caso, interfeririam circunstâncias do contexto situacional-comunicativo e, de modo mais amplo, também do contexto cultural.

\footnotetext{
${ }^{447}$ In: AZENHA JR., 1994, p. 94.
} 
Por serem subsistemas de um sistema linguístico, Azenha Jr. conclui que as linguagens de especialidade estão sujeitas às mesmas leis que regem o sistema como um todo. Ele também observa que as linguagens técnicas podem ser consideradas a partir de um enfoque linguístico-estrutural (referente às características estruturais que as distinguem das demais) ou funcional-comunicativo (referente às situações de uso linguístico). Considerando a relação entre língua e cultura, as questões em torno da tradução de textos técnicos deveriam envolver as relações entre o plano estrutural e o plano comunicativo. De Hoffmann, o pesquisador traz a seguinte definição de linguagem técnica:

[41/98] "A linguagem técnica é a totalidade de todos os recursos lingüísticos empregados no âmbito da comunicação restrita a uma área específica, a fim de garantir a compreensão entre as pessoas atuantes nesta área. Tais recursos formam uma sublíngua, à medida que são parte do inventário geral da língua. Sua escolha e ordenação na produção de textos técnicos é determinada primeiramente pela especificidade do conteúdo e, em segundo lugar, pela função comunicativa, ou seja, pela finalidade da declaração, além de sofrer a influência de uma série de outros fatores subjetivos e objetivos presentes no processo de comunicação" (p. $92)^{448}$

Azenha Jr. faz, no entanto, algumas ressalvas à definição acima. Em primeiro lugar, Hoffmann pareceria não considerar os recursos não verbais, como os sinais, imagens e tipografia, componentes sobretudo do texto escrito. Em segundo lugar, a linguagem técnica não precisaria estar restrita à área, podendo interagir com elementos de fora da especialidade. Em terceiro lugar, a produção e tradução de textos técnicos deveria basear-se na função comunicativa. Por fim, seria necessária a inclusão, na definição, de variáveis ligadas aos parceiros da comunicação e às condições comunicativas concretas, o que aproxima a definição da realidade da linguagem técnica.

Wilss pareceria discordar de Hoffmann no que tange à divergência entre a linguagem especializada da linguagem cotidiana:

[104-108] Diferentemente de Hoffmann, para quem os pontos divergentes entre linguagem técnica e linguagem comum se distribuem de forma mais ou menos equilibrada entre os diversos níveis de organização textual, Wilss acredita ser o inventario lexical e, dentro dele, a classe dos substantivos, o lugar por excelência em que as linguagens técnicas diferem da linguagem comum. Ao longo de toda a sua exposição, a ênfase do critério diferenciador continua centrada no léxico, cuja estruturação e relações seriam capazes de garantir às linguagens técnicas uma tal univocidade de sentido, que a identificação muitas vezes "um-a-um" entre conceito e denominação permitiria ao receptor do texto técnico identificar de-

${ }^{448}$ In: AZENHA JR., 1994, p. 67. 
notativamente e comprovar concretamente o que foi expresso pelo texto técnico. $^{449}$

Para Azenha Jr., a afirmação de que a principal distinção entre a linguagem técnica e a linguagem comum é o léxico estaria fundamentada pelo fato de o léxico das linguagens técnicas ser supostamente mais passível de controle que outros níveis. Apesar disso, o léxico não é o único elemento distintivo da linguagem técnica. Segundo Wilss, a linguagem técnica seria um subsistema parasitário, que seleciona do sistema linguístico de que faz parte as melhores condições para realizar seus objetivos comunicativos.

Enquanto no léxico as diferenças entre os subsistemas aparecem de modo bastante evidente, ainda não haveria indícios suficientes para afirmar que a linguagem técnica dispõe de uma sintaxe própria, apenas alguns usos mais recorrentes na linguagem técnica em comparação com a linguagem cotidiana. Azenha Jr. aponta para o fato de a função comunicativa ser de vital importância na escolha das estruturas sintáticas, mas também na escolha lexical, na estruturação textual e na seleção dos recursos gráficos e tipográficos.

Com base em seu exame, Azenha Jr. conclui que, as diferenças entre a linguagem comum e as linguagens técnicas são diferenças de grau, não de essência, isto é, elas utilizam-se dos mesmos recursos em proporções diferentes, não de recursos diferentes. Com isso, ele chama a atenção para o fato de a linguagem comum e a linguagem técnica não serem coisas distintas, pois ambas estariam sujeitas às mesmas regras do sistema linguístico e frequentemente uma tomaria elementos de empréstimo da outra, tais como o léxico ou fraseologias.

Zipser não se detém muito ao definir o conceito de língua. Ela também traz do funcionalismo a noção de língua como componente de uma cultura, e ainda a partir de uma citação ao trabalho de Azenha Jr.:

[5-7] Sempre que mencionamos processos e nos ocupamos deles, cabem definições das variáveis que os compõem. Se tratamos a tradução como um processo que se realiza no interior e através da linguagem (Azenha, 1994), nossa primeira definição deve caber à linguagem. Segundo Azenha, a linguagem deve ser vista como um elemento integrante de uma cultura, como uma de suas manifestações mais poderosas, e "não como um fenômeno isolado, suspenso no vácuo" (Snell-Hornby, 1988,39, citada em Azenha, 1994, 22), desatrelado de uma realidade extralingüística. ${ }^{450}$

\footnotetext{
${ }^{449}$ AZENHA JR., 1994, p. 69 et seq.

${ }^{450}$ ZIPSER, 2004, p. 36
} 
Mais relevante, no entanto, é a associação que Zipser estabelece entre linguagem e jornalismo. De Lima, ela traz a definição de jornalismo como "manifestação verbal" de apreciação de acontecimentos. Assim, se a linguagem é uma manifestação cultural, o jornalismo não poderia se limitar à transcodificação linguística, mas deveria considerar em seus processos de tradução sobretudo o componente cultural.

O conceito de cultura empregado é também de inspiração funcionalista: cultura seria o conhecimento, em oposição à herança biológica, indispensável aos membros de uma sociedade para agir nessa sociedade de modo aceitável. O conceito de cultura aqui empregado refere-se à organização das coisas na sociedade, isto é, a forma das coisas na mente de seus membros, seus modelos de percepção, relação e interpretação. A cultura, dessa forma, teria a função de agrupar pessoas e distinguir esse grupo de outros. Dentre os diversos conhecimentos de que se compõe a cultura estaria, assim, a língua.

Na pesquisa conduzida por Liberatti, questões gerais acerca da língua perdem espaço para questões bastante específicas, a saber, o nível de linguagem para públicos específicos, a relação entre texto e imagem como uma forma de linguagem e, principalmente, questões de variação linguística. Sobre a linguagem empregada no âmbito da literatura infantil e juvenil, há apenas a menção ao fato de essa ser mais simplificada em relação à linguagem adulta. Contudo, para a pesquisadora, isso não significa a perda de atributos artísticos nas obras literárias dedicadas a crianças e jovens.

No que tange às HQs, Liberatti traz a compreensão de quadrinhos como uma forma de linguagem que explora dois recursos semióticos diferentes. Trata-se de duas linguagens com mérito próprio, inter-relacionadas de modo indissociável. Ainda que o objeto de tradução sejam normalmente os textos verbalizados, reconhece-se que a linguagem dos quadrinhos, que inclui as imagens, não é universal. Cada região teria suas próprias convenções em relação às HQs, que se refletiriam, por exemplo, no ritmo de leitura, estilo de desenhos ou mesmo nos temas.

Aqui, maior espaço é dado à questão da variação linguística, mais especificamente da tradução de dialetos. Segundo afirma Liberatti, um dialeto é uma variante linguística carregada de marcas históricas, sociais, culturais e econômicas, distinguindo-se da neutralidade da fala padrão.

As dimensões do tempo e do espaço são dois fatores essenciais do modelo de análise textual de Christiane Nord. Segundo aponta, as variantes linguísticas indicam a origem de um texto ou de um personagem, bem como o tempo de produção de um texto. Liberatti 
explica que, nas obras literárias, essas informações costumam ressaltar determinadas características pessoais de um dado personagem. Consequentemente, o emprego de dialetos em textos literários costuma ser um grave problema de tradução, pois desafia o tradutor a encontrar uma correspondência com algum dialeto da cultura de chegada que evoque as associações almejadas pelo autor da obra. Logo, optar por traduzir um dialeto de uma língua pela fala padrão de outra resultaria na descaracterização do personagem e no empobrecimento do valor artístico. Por outro lado, cada língua e cada dialeto estariam inseridos numa cultura e seriam definidos histórica e socialmente. Assim, ao transpor um dialeto para outra cultura, não seria possível trazer tudo o que a ele está associado, isto é, não haveria correspondência completa entre dialetos em sociedades e culturas diferentes.

No caso da tradução do Chico Bento, o tradutor estaria lidando não com um dialeto genuíno, mas com uma fala ficcional, artística. Assim, Liberatti escolhe para essa fala a designação "pseudodialeto". O linguista Marcos Bagno explica que o termo "pseudodialeto" representa melhor a linguagem adotada nos quadrinhos de Chico Bento por não corresponder a uma variante linguística real, mas ser uma tentativa de representação do dialeto caipira, feita, contudo, de modo ficcional, sem o compromisso de corresponder com a realidade. A proposta de Maurício de Sousa teria sido, assim, criar uma atmosfera característica da vida no campo, na medida em que contrasta com a forma de escrita padrão. O linguista nota ainda que muitas das marcas características desse pseudodialeto nada mais são do que a representação ortográfica de traços fonéticos adotados de forma abundante no Brasil, mesmo nas grandes cidades.

A recriação do pseudodialeto nas traduções de Chico Bento para o inglês estadunidense seria, assim, imprescindível, visto que, além de caracterizar os personagens, dialogaria ainda com uma representação pictórica de um ambiente rural. Para Liberatti, há uma associação, um diálogo intenso entre imagem e texto, como é típico das histórias em quadrinhos.

Na pesquisa de Laiño, voltada a abordar o emprego de traduções em aulas de língua estrangeira, o conceito de língua ocupa evidentemente posição central. Assim, um dos primeiros passos de pesquisa é definir propriamente o que significa "língua". De Marcuschi vem a lembrança de que o conceito recebeu diferentes definições ao longo das décadas:

[45/5-6] Em sua discussão sobre o percurso da Linguística no século XX, Marcuschi $(2008$, p. 41) apresenta quatro perspectivas apresentadas por Eduardo Guimarães (2001) que simbolizam o cenário contemporâneo da Linguística: 
a) o estruturalismo saussuriano com a visão de língua como fenômeno social, mas autônomo enquanto objeto de análise; b) o cognitivismo naturalista chomskiano para o qual o linguista se instaura no interior das ciências naturais com seu caráter biologilizante; c) a perspectiva interdisciplinar que tenta conciliar o exterior da linguagem (sociedade, história, cultura, etc.) com a interioridade; d) posições como a análise de discurso, que põem em cena a questão de que não se pode reduzir o linguístico nem ao social (antropológico) nem ao psicológico, pois a linguagem é, ao lado de integralmente linguística - num certo sentido saussuriano - também integralmente histórica. ${ }^{451}$

Dentre as noções de língua supracitadas, Laiño optará pela terceira. Ela vê língua como um fenômeno que vai além de estruturas gramaticais. Para ela, língua e cultura são dois fenômenos integrados:

[46] Entendemos que qualquer manifestação linguística está permeada pelo con-
texto sociocultural do indivíduo, assim como também por suas experiências, as
quais são necessárias para a construção de cada um. Ainda de acordo com Mar-
cuschi (2008, p. 44), o funcionalismo tem como objetivo "observar os aspectos
que conduzem de maneira mais adequada os processos interativos e comunicati-
vos nas relações entre os interlocutores ou nos contextos comunicativos". A lín-
gua aqui é entendida como "atividade sociointerativa situada" (p. 59), isto é,
considera o elemento sistêmico linguístico dentro de um plano real histórico, so-
cial e cognitivo (ibid). ${ }^{452}$

Dessa definição, compreendemos que a língua não está dissociada da sociedade e da história. Com base em Bakhtin e Jakobson, Laiño entende língua como um fenômeno social e dialógico, que não pode prescindir de interlocutores e cujo uso tem uma função comunicativa. Para Bakhtin, a essência da linguagem é a comunicação; presume-se assim uma intenção comunicativa por parte do emissor. Todavia, isso não significa que todo texto seja um diálogo: de acordo com Bakhtin, mesmo uma enunciação monológica constituiria um elemento de comunicação verbal.

Laiño compara o conceito de língua que subjaz as teorias gerativista e funcionalista: enquanto o gerativismo veria a linguagem como uma aptidão inata, isto é, o indivíduo já teriam internalizados todos os princípios da linguagem e apenas vai exteriorizando-os ao longo do crescimento, no funcionalismo a linguagem e os textos produzidos por ela teriam função social, de ligar falante e ouvinte e o processo de significação, em vez de unidirecional, é compartilhado entre eles. Nesse contexto, se a língua é comunicação, ela é então dinâmica, adaptando-se a novas situações e ganhando significados de acordo com a neces-

\footnotetext{
${ }^{451}$ LAIÑO, 2014, p. 30 et seq.

452 Ibid., p. 31.
} 
sidade daqueles que a compartilham. Mesmo ao utilizar os gêneros textuais, relativamente estáveis, os indivíduos o fariam de maneiras diferentes.

Bagno, por sua vez, defende que a língua, em vez de um repositório de palavras, é nada mais que seus falantes. A seu ver, a língua não existe como "essência"; o que existe são seus falantes. Dessa maneira, em vez de algo abstrato, ela seria tão concreta quanto aqueles que fazem uso dela.

A definição de um conceito de língua é relevante para a presente pesquisa, pois, conforme observa Laiño, por trás de um conceito de tradução há uma noção bastante específica de língua, ainda que não consciente. Por trás do Método Gramática e Tradução, havia uma compreensão de língua como um conjunto de vocábulos e estruturas gramaticais que poderiam ser estudados de forma isolada e sem contextualização. Ainda que reconheça que os falantes de uma língua façam uso de esquemas gramaticais para falar uma língua, nota-se que Laiño não tem uma noção estruturalista de língua, o que traz impactos para a noção de tradução que ela pretende trazer à sala de aula. Do exposto até aqui, podemos entender que a noção de tradução trazida por ela é uma noção funcionalista, que vê a língua como um fenômeno em constante transformação e que reconhece a língua como componente de uma cultura.

\subsubsection{Tradutor}

Azenha Jr. coloca no papel suas reflexões amparadas não apenas em sua experiência como pesquisador, mas também como tradutor técnico. Ele relata ter vivenciado diversas situações em que, ao contrário do estipulado pelo senso comum, os problemas de tradução extrapolaram o nível lexical-terminológico, englobando questões de sintaxe e estilo, de convenções e normas de duas culturas diferentes. Desse modo, ele nota que a tradução técnica também envolve fatores que se pensavam ser exclusivos da tradução literária.

Sua pesquisa parece fornecer mais indícios que corroboram essa impressão baseada na experiência. Ele menciona algumas conclusões dos estudos das linguagens técnicas, dentre as quais, a de que o horizonte de reflexão do tradutor não deve se limitar ao plano terminológico, mas deve incluir o domínio de um estilo técnico preciso. Do funcionalismo, ele extrai ainda mais argumentos: visto o vasto campo de atuação do tradutor - tradutor 
técnico em empresas, tradutor literário a serviço de editoras, acompanhante de delegações estrangeiras etc. - há, em cada atividade, um conjunto de variáveis a interferir no processo tradutório. De fato, o próprio tradutor, com suas competências específicas e sua subjetividade, torna-se uma variável na tradução, haja visto que nenhuma tradução é idêntica a outra.

Azenha Jr. explica que, segundo o funcionalismo, o tradutor assume posição central nas decisões da tradução. Como especialista na comunicação intercultural, ele determina a natureza da relação entre as funções do TP e do TC e, assim, determina as estratégias de trabalho. Trazer o tradutor para o centro do processo é, na opinião do pesquisador, a maior contribuição do funcionalismo. Assim, a tradução, ao menos no âmbito da teoria, passaria a ser vista como uma atividade profissional exercida idealmente por um indivíduo que dispõe das competências necessárias para a sua execução. $O$ tradutor deixaria de ser visto como sujeito passivo, a mercê dos sistemas linguísticos, munido apenas de conhecimentos de língua e de um dicionário, e passaria a ser um sujeito ativo, que se posiciona na tradução, tomando decisões em sua execução.

Se, por um lado, a perspectiva funcionalista seria capaz de refletir, com mais nitidez, acerca da complexidade do processo de tradução, por outro, ela imporia ao tradutor uma gama larga de variáveis a considerar na tradução. Sendo assim, Azenha Jr. sugere que o tradutor reflita sobre si mesmo, suas capacidades e seu objeto de trabalho. Em seguida, ele deve aplicar o produto dessas reflexões a seu objeto de estudos, tomando a consciência de que traduzir um texto significa lidar com realidades culturais diferentes. Por fim, o interesse do tradutor deve ser o de identificar de que formas estão manifestas as marcas da realidade cultural no texto e como elas se relacionam com as condições de produção do TP e com a cultura de que o TP teve origem, para enfim elaborar de uma estratégia de como remontar essa rede de relações na cultura de chegada.

Os limites da responsabilidade do tradutor se estenderiam para a macroestrutura textual e poderiam se estender até para o âmbito dos recursos gráficos e tipográficos. Logo, no exercício de sua atividade, o tradutor lidaria com variáveis múltiplas, algumas delas além de suas competências e de seu âmbito de atuação. Nesse caso, seria necessário muitas vezes trabalhar em conjunto com profissionais de outras áreas. Ainda assim, segundo Azenha Jr., a participação do tradutor é um elemento unificador desse processo. Considera-se a tradução, assim, uma atividade de equipe, com partilha de responsabilidades em prol de uma meta comum. 
Do tradutor técnico exigem-se, além das competências tradutórias, também familiaridade com a área técnica em que estão alocados os textos que traduz. Esse conhecimento técnico, como explica Azenha Jr., é fundamental para desambiguizar estruturas sintáticas ou verificar discrepância entre os termos usados em culturas diferentes. No entanto, definilo como pré-requisito para a tradução técnica implicaria exigir do tradutor uma formação $a$ priori em determinada área - uma formação que, sozinha, não garantiria a qualidade do texto técnico. Essa especialização, no Brasil, ocorreria após o tradutor conseguir uma posição no mercado.

Com a mudança de paradigma nas teorias de tradução, alteram-se também os limites de atuação do tradutor, que passa a abranger responsabilidades para além do nível lexical-terminológico. Com isso, também mudam os critérios de avaliação de seu trabalho. Para ser bem sucedido, o tradutor deveria ter ciência das variáveis a desempenhar um papel na tradução e saber controlá-las com objetos e estratégias claros. Ademais, o tradutor, independente de sua área, teria a tarefa de desmontar e remontar sentidos. Ao atualizar a relação entre as culturas envolvidas na tradução, o próprio tradutor seria convidado a refletir sobre seus próprios valores, o que também impactaria seu trabalho.

Como vimos, Zipser estabelece alguns paralelos entre a atividade do tradutor e a atividade do jornalista. A primeira semelhança entre as duas atividades seria, como vimos, o fato de ambas pressuporem o contato com o Outro. Para Esser, a imprensa de cada nação e de cada cultura descobre a si mesma com o contato com outra prática de imprensa. Da mesma forma, o contato entre culturas seria a essência da tradução: o crescimento pelo contato com outras culturas foi exaltado pelos próprios românticos alemães em seu projeto de Weltliteratur. Assim, a tarefa do jornalista e do tradutor guardariam essa semelhança: através do contato com o Outro em sua diferença e do retorno a si mesmo chegar-se-ia à autoconsciência cultural.

Outra semelhança estaria na posição intermediadora do tradutor e do jornalista. Para o funcionalismo, o tradutor seria um mediador cultural, não um transcodificador linguístico. O mesmo é dito do jornalista: como mediador cultural, ele "traduziria" fatos em textos, com referência a seu destinatário, à situação e a cultura. O jornalista não "traduz" fatos sem referência à cultura local.

Outra aproximação entre o trabalho do tradutor e do jornalista é feita a partir do conceito de "filtro cultural" de Juliane House: assim como o tradutor deve ler o TP através dos "óculos" da cultura de chegada, o jornalista deve observar o fato noticioso a partir do 
filtro cultural de seu público, transportando-se para o lugar de seu receptor, procurando criar identificação. Quanto à recepção do tradutor, segundo Vermeer, o tradutor seria, em primeiro lugar, um receptor crítico do texto de partida. Por "crítico", compreende-se que o tradutor não realiza uma leitura isenta do texto, mas uma leitura não prevista pelo emissor, a fim de estabelecer a ponte entre o TP e o TC. Ao mesmo tempo em que gerencia uma série de variáveis, o tradutor não pode evitar que a sua própria leitura do texto de partida se faça presente em sua tradução.

Zipser apresenta o modelo de análise de fatores intratextuais e extratextuais de Nord. Ela observa, contudo, que o tradutor não se contenta em meramente analisar o TP: sendo o objetivo dele traduzir aquilo que ele lê, em sua análise ele já pode eleger os pontos e níveis de análise mais significativos para aquela tradução específica. O modelo permitiria ao tradutor ter uma visão mais ampla de todas as variáveis relevantes ao processo de tradução, prevendo procedimentos e problemas ao longo do processo. Assim, o tradutor, tanto o iniciante como o profissional, poderia verificar se suas estratégias são apropriadas para a tarefa diante de si. É certo que tradutores mais experientes poderiam prescindir de algumas etapas, mas o modelo é de extrema importância aos iniciantes, visto que o ajuda a refletir sistematicamente sobre seu trabalho e chama atenção a aspectos do trabalho para os quais provavelmente não estaria, em princípio, voltada a sua atenção.

Liberatti faz menção a alguns pontos importantes envolvendo a atividade do tradutor. Em primeiro lugar, ela observa que, em muitos casos, a profissão do tradutor foi vista com desconfiança, como se a tradução fosse uma segunda opção profissional, no caso de a primeira fracassar. Isso é especialmente grave em modalidades de tradução como a literatura infantil e juvenil, por exemplo, vista como "mais fácil" ou "de menor valor" em relação à literatura adulta. Para desconstruir essa visão, ela enfatiza que os tradutores podem atuar - e atuam - como agentes de disseminação de produtos culturais, tais como, por exemplo, as histórias em quadrinhos.

Ocupando posição central no processo tradutório, o tradutor no funcionalismo seria descrito como produtor de textos, produzindo um novo instrumento comunicativo a partir de informações acerca da intenção comunicativa (ou da interpretação que faz dela) do autor do texto de partida. O tradutor estaria em posição de tomar decisões constantemente no processo tradutório, de modo a intermediar culturas e variedades linguísticas diversas. Aqui vemos que Liberatti também enfatiza que, para que a tradução seja funcional, cumpre ao tradutor analisar todos os fatores que envolvem a tradução, sobretudo fatores intratextu- 
ais e extratextuais. Com base nessas informações, ele decidiria quais elementos manter e quais elementos descartar - que, em princípio, incluiriam os elementos não verbais. No entanto, raramente é permitido na tradução de HQs descartar ou alterar algum elemento não verbal. Essa decisão, afinal, faria parte das responsabilidades da editora, não do tradutor.

A exemplo dos representantes da virada cultural na tradução, Laiño questiona a imagem de tradutor mais difundida no senso comum, a saber, a de mero transportador de significados, sem o direito de interferir no texto traduzido. A pesquisadora argumenta que, se assim fosse, a tradução seria uma atividade mecânica, e não teria motivo para ser aplicada na sala de aula, visto que se espera um resultado particular, sem desafio aos estudantes.

$\mathrm{Na}$ sua visão, compartilhada pelos funcionalistas, sobretudo por Nord, o tradutor ocupa posição intermediária entre remetente e destinatário, estando compromissado com todos os envolvidos no processo tradutório. Nord teria qualificado o tradutor como produtor do TC. Ele não seria emissor do TC, pois, como mencionamos, não partiria dele a intenção comunicativa, mas incorporaria a intenção comunicativa do emissor do TP ou do iniciador, seja criando um instrumento comunicativo na cultura de chegada, seja criando um documento na LC da comunicação ocorrida na LP.

Por fazer parte do processo tradutório, o tradutor, assim como os demais participantes, seria uma variável, de modo que dois tradutores que partissem de um mesmo TP não chegariam a um TC integralmente igual. Laiño explica que alguns fatores ligados à figura do tradutor interferem no processo de tradução, tais como seu critério subjetivo de análise e o fato de ser, ao mesmo tempo, receptor do TP e pertencer à cultura de chegada. O tradutor deve considerar que o emissor produz seu texto e, assim, oferece uma informação, na maioria das vezes, para um público receptor que pertence a seu mesmo contexto cultural. $\mathrm{Na}$ tradução, o tradutor deve ponderar todos os fatores envolvidos na língua e na cultura de partida e ainda manter em mente o contexto de chegada. 


\subsubsection{Situação}

A situação comunicativa é considerada por Azenha Jr. como um dos fatores geradores de variáveis na tradução. Estariam aí inclusas tanto a situação de recepção do TP por parte do tradutor como a situação de produção do TC. A situação seria relevante na produção textual, pois ela se manifesta no próprio texto - afinal, não se escreve ou diz qualquer coisa em qualquer momento e em qualquer lugar. Ademais, ela seria determinante na função comunicativa de um texto, mesmo nos casos dos textos técnicos.

Azenha Jr. cita Halliday e Hasan ${ }^{453}$, que discutem acerca da situação ao definirem o conceito de cultura. Subjaz ao contexto da situação, segundo os autores, o contexto de cultura. Assim, qualquer contexto de situação de que se originou um texto seria um todo complexo, que reuniria coisas típicas da cultura correspondente: age-se, e a ação tem um valor determinado culturalmente. $\mathrm{O}$ contexto de situação e o contexto de cultura seriam determinantes na construção de sentido do texto. No entanto, segundo Halliday e Hasan, a relação é dialética: o texto cria o contexto tanto quanto o contexto cria o texto, surgindo o sentido do atrito de ambos.

Zipser também faz menção à noção defendida pelos funcionalistas de que um texto só exerceria uma função no contexto de uma situação comunicativa e, assim, a tradução só envolveria textos em situação. Segundo Nord, fatores referentes à situação comunicativa seriam os seguintes: o emissor do texto, sua intenção, o receptor, o canal de transmissão do texto, local e época de produção textual e a razão da comunicação. Com base nesses fatores seria possível, a seu ver, identificar a função do texto.

Durante a análise, Zipser constata que a diferença de situações reflete-se tanto na construção do texto quanto, como é o caso analisado, no uso de recursos - aqui, recursos visuais. Assim, enquanto na reportagem brasileira sobre a queda do Muro de Berlim as fotos teriam função ilustrativa, para mostrar os acontecimentos ao leitor brasileiro, na reportagem alemã sobre mesmo tema as fotos tem valor emocional, como apelo à nostalgia dos leitores. Além disso, a análise comprovaria a tese de que uma tradução retrospectiva do texto jornalístico, que se atém à letra do TP, não está em conformidade com a situação comunicativa e com as expectativas do leitor levantadas no contexto dessa situação comuni-

\footnotetext{
${ }^{453}$ HALLIDAY, M. A. K.; HASAN, R. Language, context and text: aspects of language in a social-semiotic perspective. London: Oxford University Press, 1990.
} 
cativa. Para que o texto pudesse ser classificado como jornalístico, para que ele funcionasse como um texto jornalístico, seria imprescindível que ele levasse o receptor e suas expectativas dentro da situação comunicativa em conta.

Liberatti também ressalta a relação destacada pelos funcionalistas entre função e situação comunicativa. Segundo afirma, cada texto é uma interação comunicativa determinada pela situação em que ocorre. $\mathrm{O}$ autor de um texto o escreve segundo a avaliação que faz da situação para a qual escreve. Na tradução, o tradutor teria que escrever segundo a avaliação que tem de uma situação bastante diferente: a do receptor do texto traduzido. Assim, para realizar uma tradução, seria imprescindível ao tradutor conhecer os fatores que cercam a situação comunicativa do texto de partida e verificar se esses fatores poderiam ser também funcionais na situação de recepção do texto de chegada. No modelo proposto por Nord foram distinguidos dois conjuntos de fatores: os fatores internos do texto e fatores externos do texto. Esses últimos dizem respeito à situação comunicativa em que o texto se insere.

Laiño também defende que uma mensagem adquire sua função comunicativa e sua riqueza de sentido no contexto de sua situação comunicativa. Como aponta a linguística textual, um dos critérios de textualidade é a situacionalidade, isto é, o fato de um texto estar inserido numa situação comunicativa. Assim, seria impensável conceber um texto dissociado de uma situação comunicativa, social, cultural e contextual. A situação afetaria a produção textual, seu conteúdo e forma. Por sua vez, a tradução não poderia prescindir de tomar o texto dentro de uma situação específica. Não se traduziriam palavras ou frases, mas textos em situação.

Com isso, Laiño responde a uma das principais críticas feitas ao uso de traduções nas aulas de língua estrangeira, a partir de uma ideia de tradução baseada no Método Gramática e Tradução: a tradução de frases isoladas, dissociada de uma situação comunicativa real. A defesa do método comunicativo em face dos métodos predecessores de ensino de língua estrangeira seria justamente o foco em situações reais, cotidianas de comunicação. Na verdade, o que seria feito em sala de aula é a simulação de situações reais de comunicação a partir de situações prototípicas, de ocorrência recorrente. Por "situação real", entende-se aqui uma situação cotidiana de comunicação, como pedir informações na rua, conversar com amigos num bar, entre outros.

Ao trazer uma proposta funcionalista de tradução para as aulas de LE, Laiño presume o emprego de textos genuínos, escritos originalmente para uma situação comunicati- 
va determinada. Nesse exercício, os textos seriam traduzidos para outra situação comunicativa simulada, mas próxima da realidade, com potenciais receptores em vista. A escolha por trabalhar com gêneros discursivos ajuda em simular uma situação comunicativa, uma vez que, segundo a pesquisadora, associados aos gêneros discursivos estariam usos típicos da linguagem em situações típicas de sentido. Laiño cita Maurer, para quem os gêneros textuais dependem da cultura e da situação comunicativa.

No caso do texto de publicidade, a situação comunicativa em que o texto é produzido determina a forma do texto e ela, em si, é dependente da cultura. Laiño ilustra essa assertiva com o caso das propagandas de cerveja - outrora não podia explorar a imagem feminina, passou a ser a norma na passagem entre o século XX e XXI.

\subsubsection{Informação}

Não há na tese de Azenha Jr. muitas considerações acerca do conceito de informação. Ele cita a noção de texto defendida por Ammann como uma "informação oferecida" (ou, "oferta de informação"), não sendo, portanto, algo fixado. Segundo essa concepção, o texto só se transformaria em texto quando lido por alguém, concretizando-se no momento de recepção.

Zipser observa que o conceito de informação é essencial ao jornalismo, posto que representaria o principal compromisso do empreendimento jornalístico: informar os leitores, isto é, traduzir um acontecimento para a comunicação com o outro e para a formação de opinião. Assim, é possível pensar que o termo "informação" está sendo utilizado aqui como substituto para "fato noticioso" ou, pelo menos, para a sua representação verbal. Nesse sentido, "informação" em jornalismo parece estar, ao menos no senso comum, atrelado à noção de neutralidade. Zipser, no entanto, argumenta contra a neutralidade plena, questionando algumas noções pré-concebidas sobre o texto jornalístico.

De fato, conforme a pesquisadora, mesmo no meio jornalístico reconhece-se que a neutralidade plena é impossível, pois é inevitável o jornalista, enquanto produtor de sentidos, deixar marcas em seu trabalho. Caberia, no entanto, ao jornalista não abusar do poder de produtor de sentidos para fins ideológicos, políticos e pessoais. Da parte do leitor, Zip- 
ser observa, com base na teoria funcionalista, que a informação veiculada pela notícia é processada e porventura transformada numa opinião acerca do fato noticioso.

De modo geral, o emprego do termo por Liberatti parece sugerir que informação aqui se refere à informação semântica do texto. O conceito faria referência a uma característica transmitida pelas estruturas lexicais e gramaticais. Ele diria respeito à função referencial da linguagem. Nesse contexto, ao discutir a função da linguagem predominante nos quadrinhos de Chico Bento, Liberatti observa que eles não se restringem à função referencial, pois não há apenas a transmissão de informações, mas também a função expressiva, pois o autor faz uso de recursos artísticos para imprimir sua voz.

Para Laiño, textos têm função cognitiva, isto é, de veiculação de informações para a aquisição de conhecimentos. No caso do texto publicitário, a informação veiculada não teria o objetivo apenas de aprofundar os conhecimentos do receptor, mas de persuadi-lo. Para tanto, fazem-se uso de recursos verbais e não verbais, com a integração de informações veiculadas por um suporte verbal com informações veiculadas por outros suportes por exemplo, as imagens.

\subsubsection{Fatores}

Embora considere a atenção ao código linguístico uma abordagem válida à tradução, Azenha Jr. enfatiza o perigo de reduzir a problemática da tradução a uma mera questão de troca de códigos linguísticos, dado que a tradução é uma atividade complexa, com diversos fatores que exercem influência sobre o resultado final, tais como o tradutor, o texto a ser traduzido, a situação de tradução, a interferência de terceiros (agentes, editoras, revisores), a situação de recepção, dentre outros. Todos esses fatores estariam ligados a uma realidade histórico-cultural e são condicionados por normas sociais e de uso linguístico em constante transformação. A própria profissão do tradutor seria multifacetada, com diversas modalidades de atuação. Desse modo, por um lado, o tradutor deveria desenvolver e manter ativas competências que vão muito além da mera competência linguística e, por outro, o estudioso deveria esclarecer o ponto de vista a partir de que fala de tradução.

Não obstante, o nível linguístico poderia ser ponto de partida para aprofundar o exame da relação entre os recursos linguísticos e a realidade extralinguística. Além de fato- 
res intralinguísticos, haveria também fatores extralinguísticos, tanto considerados objetivos (relativos à situação comunicativa) quanto considerados subjetivos (ligados aos parceiros do processo comunicativo e ao tradutor). Reconhecendo a complexidade de fatores a influenciar o processo de tradução, os autores funcionalistas teriam elegido a função como fio condutor para orientar o quadro de condicionantes da tradução. A estratégia de tradução seria definida a partir da relação entre esses condicionantes.

No âmbito do jornalismo, Zipser afirma que os fatores que atuam na concepção do texto jornalístico ainda não foram suficientemente pesquisados. Ela cita Esser, segundo o qual exerceriam influência sobre a prática jornalística de cada país fatores de base histórica, social, jurídica e econômica. Esses fatores teriam sido sistematizados por McCombs e remeteriam a quatro esferas da vida de uma sociedade: a esfera social (a história e a tradição da imprensa nessa sociedade, o conceito de objetividade, as condicionantes sociopolíticas, etc.), a esfera de estrutura da mídia (direito de imprensa, condições econômicas do mercado e da mídia, parâmetros éticos, sindicatos e formação de jornalistas), esfera institucional (perfil das atividades dos jornalistas, estrutura organizacional da empresa de mídia, o proceder na redação e as tecnologias empregadas) e a esfera subjetiva (valores subjetivos e postura política do jornalista, profissionalização, posição demográfica, etc.). Para Esser, nenhum desses fatores operariam isoladamente; todos se condicionariam reciprocamente.

No âmbito da tradução, Nord estabelece os fatores de seu modelo de análise textual, dividindo-os, para fins didáticos, entre fatores intratextuais, localizados no interior do texto, e fatores extratextuais, relativos à situação comunicativa. O modelo de Nord, como vimos, estrutura-se em perguntas introduzidas por pronomes interrogativos (quem? quando? o quê? etc.) a exemplo da Lei de Lasswell, empregada no âmbito jornalístico, que determina algumas informações a serem clarificadas logo no início do texto jornalístico. Nord teria estruturado seu modelo assim para elucidar a linha pragmática do texto.

No modelo de Nord, os fatores externos, referentes à situação comunicativa, seriam o emissor, a intenção do emissor, o receptor, o canal, o lugar, o tempo e a razão da comunicação. Quanto aos fatores internos, esses seriam tema, conteúdo, pressuposições, estrutura textual, elementos não verbais, léxico, sintaxe e marcas suprassegmentais. Além de terem sido divididos arbitrariamente entre fatores intratextuais e extratextuais, divisão essa feita por motivação didática, Nord reitera que esses fatores seriam recorrentes, isto é, eles se influenciam reciprocamente. A função do texto depreende-se da combinação de fatores 
externos e internos. Como eles estão inter-relacionados, a mudança de um deles causa uma modificação na função.

Liberatti também utiliza o modelo de análise de fatores intratextuais e extratextuais de Christiane Nord, mas para a tradução de quadrinhos. Segundo afirma, na tradução de HQs há alguns fatores que merecem consideração especial. Ela destaca o fato de textos e imagens estarem inter-relacionados na construção de sentido. Considerando que texto e imagem são duas linguagens culturalmente determinadas, na mudança de cultura seria de se esperar a mudança de ambos. Na prática, as editoras não estão dispostas a mudar as imagens, devido aos custos associados a essa mudança. Caberia ao tradutor, assim, encontrar soluções verbais para adequar o texto verbal ao texto não verbal. Mesmo as imagens refletiriam algumas convenções do gênero, que diferem de cultura para cultura. Não só fatores referentes ao nível microtextual, mas também referentes ao nível macrotextual como, por exemplo, o leiaute típico da revista em quadrinhos - podem ser problemas de tradução.

A exemplo da tradução de quadrinhos, em que o intercâmbio entre elementos verbais e não verbais é essencial na constituição de sentido, Laiño observa que algo semelhante ocorre na tradução de textos publicitários: o fatores intratextuais do texto de publicidade não se restringiriam aos elementos verbais, mas especialmente no texto publicitário os elementos não verbais seriam de extrema importância. Ela também faz uso do modelo de Nord para a avaliação das traduções dos alunos.

Além de Nord, Laiño também faz menção a Reiss e Vermeer, que identificam o tradutor como um fator a determinar o resultado final da tradução, especialmente no tangente à compreensão que o ele tem do $\mathrm{TP}$, a imagem que ele projeta do TC. Outros fatores influentes seriam o emissor e a língua/cultura - o tempo e o local - em que está inserido, o gênero textual, o receptor da tradução e a língua/cultura - o tempo e o local - em que está inserido. A mudança de fatores relativos à situação exigiria que fossem repensadas questões ligadas à própria formulação do texto. 


\subsubsection{Discussão dos dados}

Nessa seção do trabalho, vimos quatro aplicações dos preceitos teóricos introduzidos e sustentados pela abordagem funcionalista, dedicadas ao exame de casos específicos da tradução. Em cada pesquisa, teorizações acerca do problema de tradução específico somaram-se ao funcionalismo, trazendo seus próprios conceitos e modelos. A partir da integração entre eles, cada uma das pesquisas aqui apresentadas agregou à vertente funcionalista, promovendo seu crescimento. Vejamos, contudo, com mais detalhes como isso ocorreu, a começar por apontar o que cada pesquisador destacou dos textos seminais que abordamos na primeira seção desse capítulo.

Assim, começamos por examinar o conceito de tradução. Azenha Jr. destaca o fato de a abordagem funcionalista opor-se à concepção de tradução predominante à época de uma operação centrada em códigos linguísticos, orientada por instruções advindas do próprio texto de partida, resultando num produto ideal. Ele e Liberatti concordam que há diferentes formas de se traduzir, pois - e todos parecem enfatizar essa característica - há diversas variáveis que interferem no processo tradutório. Ele também enfatiza que a tradução é uma atividade criativa, produtora de textos, e que, como observam Vermeer e principalmente Holz-Mänttäri, envolve diferentes agentes e diferentes ações.

Influenciada por Azenha Jr., Zipser define a tradução como um processo realizado no interior da língua e através dela. Zipser e Liberatti definem o conceito como uma ação comunicativa, caracterizada por seu dinamismo. Não se trata de uma transferência objetiva de significados, mas de uma transposição influenciada por fatores relativos à percepção subjetiva e - como também expressa Laiño - por fatores culturais. De fato, Liberatti compreende a tradução como uma comunicação intercultural. Zipser e Laiño também salientam a importância do receptor da tradução, considerando-o o fator mais importante do processo.

A essas características da tradução, os pesquisadores incluem outras, agora referentes ao problema de tradução a que se dedicam em suas pesquisas. Azenha Jr. caracteriza a tradução técnica como um processo que, ao contrário do que postula o senso comum, não se resume a questões lexicais e terminológicas. O tradutor trabalha com todos os planos textuais, de modo a acomodar um texto noutro espaço linguístico e cultural. De fato, o destaque dado ao componente cultural é o pilar de sustentação de sua tese: ainda que as condi- 
ções em torno da tradução técnica permitam mais controle, comparativamente à tradução literária, ela também envolve condicionantes culturais. O texto técnico não está isento do emprego de recursos expressivos, e sua tradução exige muitas vezes reformulações de trechos seus para que ele se adéque ao novo ambiente sociocultural. Nesse contexto, pode-se falar apenas que a tradução técnica tende à identidade conceitual, sem inferir com isso a equivalência de formas linguísticas.

Zipser traça constantemente um paralelo entre a atividade tradutória e a atividade jornalística, identificando algumas características comuns entre elas. Dentre as quais, o jornalismo também é uma atividade voltada a um público receptor e é igualmente influenciado por fatores relativos à observação subjetiva do jornalista e por fatores culturais. Salientar o componente subjetivo da percepção do tradutor e do jornalista, cada qual em sua atividade, bem como o fato de ambas se voltarem a um receptor tem o propósito de lutar contra um estigma que perdura não apenas sobre o jornalismo, através do mito da imparcialidade, mas também sobre os diferentes tipos de tradução senão a tradução literária. Essa é provavelmente um dos principais fatores que atraíram Azenha Jr. e Zipser para o funcionalismo. Quanto à tradução em si, Zipser identifica no jornalismo a coocorrência de duas formas de tradução: uma tradução "fiel à letra" de um texto jornalístico publicado noutra cultura e uma "representação cultural" do fato noticioso veiculado pelo texto jornalístico estrangeiro, reescrito na cultura de chegada para melhor adaptar-se a seu público-alvo.

O componente cultural da tradução é também fundamental para Liberatti, tendo em vista que a tradução dos quadrinhos de Chico Bento envolvem elementos profundamente enraizados na cultura brasileira: a representação pictórica do mundo, a ideia de produção literária para crianças, a linguagem dos quadrinhos e a própria questão dialetal, que envolve representações sociais. Logo, ela faz um estudo de caso complexo, visto que envolve diferentes problemas de tradução. Dessa forma, ela procura caracterizar cada um desses casos de tradução. Do caso da tradução de quadrinhos, ela lança luz para o fato de eles serem constituídos por imagens e textos e de o significado resultar da relação entre esses dois meios semióticos diferentes. Dessa forma, embora o objeto de trabalho do tradutor de quadrinhos seja normalmente apenas o texto verbal, as imagens também são objeto da interpretação do tradutor.

A tradução de quadrinhos é governada por limitações, por exemplo, pela interferência das imagens e pela limitação de espaços. No caso dos quadrinhos para crianças, somam-se a essas as limitações advindas da tradução de LIJ. O caso dos quadrinhos de Chico 
Bento ainda trazem o problema de adaptar usos de dialetos, de modo que eles evoquem implicações sociais semelhantes àquelas que o dialeto do TP tem em seu contexto social.

Por fim, Laiño trata de uma modalidade de tradução bastante peculiar: a tradução pedagógica. Embora ela se difira da tradução real no que concerne à função, ao objetivo e ao destinatário, o professor pode aproximar o exercício de uma situação comunicativa real, simulando um contexto verídico de tradução para dar mais contexto à tradução pedagógica. Ela justifica o uso da tradução pedagógica como um exercício válido para o aprendizado de língua estrangeira (LE), dado o uso que a tradução teve historicamente nesse meio, mais focada em estruturas gramaticais e menos focada em situações reais de comunicação. Com isso, o funcionalismo traz um conceito de tradução que não só presume um texto numa situação real de comunicação, como também pode se ajustar a diferentes propósitos e ainda permite a sensibilização dos alunos para as diferenças entre a cultura materna e a cultura estrangeira.

É interessante observar que a ênfase no componente cultural da tradução foi, de fato, o que atraiu os pesquisadores ao funcionalismo, visto que a questão cultural está bem no cerne das quatro teses defendidas nos trabalhos de grau. Em alguns casos, o componente cultural serve à subversão de uma visão consensual de um tipo específico de tradução; em outros, o componente cultural é o próprio componente de pesquisa.

No conceito de função, encontramos mais similaridades entre o que foi apresentado pelos pesquisadores. Azenha Jr. e Liberatti compreendem a função como principal critério norteador do processo de tradução, sobrepondo-se a quaisquer exigências por equivalência. Através da função comunicativa, o tradutor define suas estratégias de tradução. De modo unânime, reconhece-se que a função é concretizada no momento de recepção do texto, o que torna o receptor, como indicam Zipser e Laiño, o fator mais determinante na definição da função comunicativa de um texto. Azenha Jr. e Liberatti ainda observam que a congruência entre as funções nem sempre é possível ou desejada. Com base no modelo de análise textual de Nord, Zipser e Liberatti afirmam que a função comunicativa de um texto pode ser constatada a partir da análise dos fatores externos ao texto, ligados à situação comunicativa. Liberatti e Laiño ainda incluem a observação de que uma mudança de função implica num modo diferente de se traduzir.

Azenha Jr. chega à constatação de que, na constituição do texto técnico, o tema não exerce uma influência tão forte na escolha dos recursos linguísticos quanto o faz a função. Assim, há no texto técnico - mas não há motivos para supor que o mesmo não aconteceria 
com outros gêneros textuais - uma forte correlação entre os planos linguístico-estrutural e funcional-comunicativo.

No caso do texto jornalístico, Zipser enfatizar que a função é definida em conformidade com o receptor da tradução, pois é ele quem concretiza a função textual, só vem a aproximar ainda mais a atividade tradutória da atividade jornalística, governada pelas mesmas diretrizes. Ademais, ainda que o senso comum identifique no texto jornalístico somente uma função informativa, Zipser constata que está presente nesse gênero textual também função expressiva, a fim de distanciar-se da concepção de objetividade jornalística.

Como vimos, Liberatti elegeu um objeto de pesquisa que traz em si restrições de diferentes ordens em sua tradução. Desse modo, por entender que a função textual é critério para definição de estratégias tradutórias, ela pode assim justificar a própria definição de estratégias para contornar as restrições impostas por seu objeto de pesquisas.

No trabalho de Laiño, a noção de função tradutória entra em contato com a noção de função comunicativa dos gêneros textuais-discursivos. De Cassany, ela cita três diferentes funções dos gêneros discursivos: a função cognitiva, que estabelece que, através dos gêneros discursivos, podemos conhecer mais de uma área; a função interpessoal, que estabelece que agimos diferente de acordo com o contexto; a função sociopolítica, que relaciona comportamento linguístico e grau de poder. Essas funções seriam mais determinantes para os gêneros discursivos do que as características linguístico-textuais. No entanto, a função tradutória, o critério definidor de estratégias, não depende apenas da função dos gêneros textuais, mas também do destinatário. Essas observações vão ao encontro não apenas do gênero textual escolhido - o texto publicitário, extremamente dependente do receptor - mas também do propósito da tradução, que é possibilitar o contato dos alunos com formas linguísticas e textuais da LE e de componentes culturais, mediante a simulação de uma situação real de tradução.

Em vista do exposto, é possível conjecturar que a discussão acerca da tradução de gêneros discursivos convide à reflexão acerca dos propósitos da tradução e de seu público receptor. Diferente do texto literário, âmbito em que não há consenso quanto a isso, reconhece-se nos outros gêneros textuais de uma função determinada (ou mais de uma).

Zipser e Liberatti associam texto e contexto comunicativo. Liberatti define texto como um ato comunicativo que ganha concretude no ato de sua recepção. Assim, caberia ao receptor atribuir significado ao texto, postulado com que Laiño concorda. Zipser vê no 
texto um instrumento comunicativo. Azenha Jr. defende que o texto é mais do que a sua parte verbalizada. Em comum entre eles está o reconhecimento de que no texto estão implicados fatores externos a ele, relativos à situação comunicativa. Azenha Jr., Zipser e Laiño também chamam a atenção para o fato de o texto ser expressão de uma intenção comunicativa, que nem sempre corresponde com a interpretação que o receptor faz dela ao ter contato com o texto. Ainda assim, como observam Azenha Jr. e Zipser - a exemplo de Hönig e Kussmaul e Nord - o emissor inclui elementos que limitam as possibilidades interpretativas do texto. Laiño, por sua vez, atribui a Vermeer a observação de que a limitação das interpretações possíveis do texto teriam como causa o fato de seus receptores estarem inseridos numa mesma cultura.

De modo a trazer as classificações textuais à baila, Azenha Jr. analisa os modelos de tipologia textual de Katharina Reiss e de Mary Snell-Hornby. Do modelo de Reiss, ele ressalta a associação entre tipo textual e função comunicativa, mas critica sua rigidez, alegando que o modelo destoa da realidade híbrida dos textos. De Snell-Hornby, ele destaca o fato de o modelo evidenciar a constelação de fatores que interferem na tradução e elogia sua proposta de maior integração nos estudos da tradução. Apesar disso, critica o fato de o modelo não possibilitar o agrupamento de diferentes textos num mesmo tipo textual, o que torna a formação de corpora textuais mais desafiadora. Assim, ele advoga pela conciliação de ambos os modelos. A seu ver, as tipologias devem levar em conta tanto a função comunicativa quanto a estrutura linguística dos textos.

No tangente ao texto técnico, Azenha Jr. afirma que as diferenças que ele guarda com os demais gêneros textuais é de grau, não de essência. Desse modo, a produção de textos técnicos não se diferenciaria tanto da produção de outros gêneros textuais, estando sujeita às mesmas variáveis. Ele acrescenta ainda que o texto técnico só existe no contexto de uma situação comunicativa, seu sentido nascendo da interação entre os planos linguístico e comunicativo e ganhando concretude na recepção. Ademais, reitera que os textos técnicos também trazem vínculos com a cultura em que foram produzidos.

Sobre o texto jornalístico, Zipser explica que o jornalismo baseia-se na percepção humana e está inserido numa situação. Por ser concebido mediante o filtro subjetivo do jornalista, o texto jornalístico não pode ser considerado um texto neutro e imparcial. Tratase de um tipo de texto comercializável e, como tal, adéqua-se às expectativas do receptor, sofrendo também influências de convenções históricas, jurídicas e econômicas. Sua característica definidora mais significativa, contudo, é a sua adequação ao receptor, de modo 
que um texto jornalístico que não leva seu receptor em consideração não pode ser considerado um texto jornalístico.

Como parte das questões em seu horizonte de reflexão, Liberatti descreve algumas características de textos de LIJ e de histórias em quadrinhos. Segundo afirma, os textos de LIJ costumam oferecer uma leitura fácil e prazerosa através do emprego de recursos linguísticos mais simples do que aqueles empregados em obras literárias voltadas a adultos. Eles têm o objetivo de entreter e educar, normalmente descrevem um mundo fictício e são marcados pela expressividade de seu autor. Quanto aos quadrinhos, trata-se de uma forma de arte que associa imagens com textos verbais, tendo as imagens a prevalência. É um gênero textual marcado por convenções culturais determinadas culturalmente, que se refletem no texto, nos temas e, sobretudo, nas imagens.

Considerando que Laiño tem preocupações pedagógicas, ela trata de algumas questões relacionadas à escrita de textos, as quais depois são trazidas ao plano didático. Ela fundamenta sua argumentação pelo trabalho de Cassany, segundo o qual a produção textual demanda planejamento e, para tanto, o autor precisa ter um receptor em mente. Os textos teriam função primária de comunicar mensagens e, a fim de atingir esse objetivo, seu autor precisa seguir regras de adequação, coesão e coerência.

Laiño também descreve algumas características do texto publicitário, gênero textual utilizado em seus exercícios didáticos. Esse texto caracteriza-se por sua função, que é convencer seus consumidores. Geralmente tem mensagens diretas, curtas e positivas e apela às emoções do receptor também pelo uso de linguagem não verbal, em especial imagens. Assim como o texto jornalístico, é um texto comercializável e, assim, adéqua-se a seu receptor.

O fato de que o texto se destina a um receptor é requisito para a abordagem de Zipser e extremamente relevante para as demais. Apenas Azenha Jr. não ressalta o vínculo entre texto e destinatário, mas reflete acerca dos fatores envolvidos na produção textual e na definição de tipos textuais.

Da definição funcionalista para o conceito de língua, a única menção unânime foi ao fato de a língua ser um componente de uma cultura. Azenha Jr. observa que a linguagem técnica é um subgrupo da língua que, no entanto, está em estreita relação com a linguagem comum. Por ser subsistema de um sistema linguístico, a linguagem técnica está sujeita às mesmas leis que regem o sistema como um todo. Ela não está restrita à área, pois pode interagir com elementos fora da especialidade, inclusive através do intercâmbio de 
termos. Além de ser determinada, em primeiro lugar, por sua função comunicativa e, depois, por seu conteúdo, a linguagem técnica é também determinada pela relação entre interlocutores e sua situação de uso.

Zipser observa que o jornalismo é definido como manifestação verbal de um acontecimento, ou seja, o fato noticioso expresso na forma verbal, mediante, evidentemente, o uso da língua. Assim, se a língua é componente de uma cultura, o jornalismo não pode deixar de considerar a cultura.

Liberatti opta por tratar acerca de questões mais particulares relativas à língua, mais especificamente, ela trata da questão da variação linguística. Considera-se um dialeto uma variante linguística carregada de marcas históricas, econômicas, sociais e culturais que se distingue da neutralidade da fala padrão. Dadas essas características, sua presença numa obra literária pode trazer problemas de tradução, uma vez que essas marcas passam a fazer parte da própria caracterização do personagem. A seleção de dialetos que evoquem implicações semelhantes na cultura alvo nem sempre é possível, dadas as diferenças históricas e sociais entre as culturas.

Além disso, ela dedica parte do seu trabalho a analisar a relação entre imagem e texto que constitui as histórias em quadrinhos. Ela chama a atenção para o fato de a imagem, em vez de ser acessória ao texto e, como diz o senso comum, representar objetivamente elementos da realidade, ela consiste numa representação subjetiva da realidade, pautada por convenções e influenciada pelo contexto cultural de que teve origem. Logo, ela divide características com a linguagem verbal, devendo ser reconhecida como uma linguagem de mérito próprio.

O conceito de língua empregado por Laiño associa a exterioridade da língua, isto é, aspectos sociais, históricos e culturais, com a sua interioridade. De Bakhtin, ela extrai a compreensão de língua como um fenômeno social e dialógico, que não pode prescindir dos interlocutores e cujo uso tem função comunicativa. Segundo essa concepção, a essência da linguagem é a comunicação. Para Bagno, a língua nada mais é do que seus falantes, sendo tão concreta como eles são.

Novamente, o fato de o componente cultural ter atraído esses pesquisadores para o funcionalismo reflete-se na definição de língua. Diferente das outras propostas teóricas, que abordam as especificidades do objeto de pesquisas através do conceito de texto, Azenha Jr. o faz através do conceito de língua. Pressupomos que isso se deva ao cabedal teórico escolhido pelo pesquisador para tratar da tradução técnica, a saber, os estudos das lin- 
guagens de especialidade. Ver a língua como um fenômeno social que presume interlocutores é essencial à teorização de Laiño, tendo em vista que o seu objeto é o ensino de LE, no qual se destaca o aspecto comunicativo da língua. Essa definição corrobora também a noção de tradução que fundamenta os exercícios pedagógicos, que imagina um interlocutor mesmo quando o objetivo é, no último limiar, adquirir conhecimentos linguísticos e culturais.

Todos concordam que o tradutor ocupa no processo de tradução uma posição central, estando ele entre duas línguas, duas culturas e dois processos comunicativos. Azenha Jr., Zipser e Liberatti destacam que o tradutor exerce função ativa no processo tradutório, pois é dele a responsabilidade de tomar decisões. Segundo Azenha Jr., o tradutor é o especialista em tradução, e é dele, em última instância, a responsabilidade de estabelecer uma função pretendida ao texto de chegada. Para tanto, segundo Zipser e Liberatti, ele pode fazer uso de um modelo de análise textual, tal como elaborado por Nord. Azenha Jr. e Laiño identificam nele também uma variável para o processo de tradução.

Para Azenha Jr., trazer o tradutor para o centro do processo teria sido a maior contribuição do funcionalismo. Ao mesmo tempo que reconhece a sua autoridade, a abordagem funcional trouxe ao tradutor uma série de variáveis com as quais deve lidar. Nesses casos, Azenha Jr. sugere ao tradutor a autorreflexão, o reconhecimento de seus conhecimentos e habilidades. Assim como Holz-Mänttäri, ele reconhece que a atividade tradutória vai além da produção do TC. O tradutor deve saber trabalhar com outras pessoas ao longo do processo de tradução. No que diz respeito às competências do tradutor técnico, além da competência linguística e cultural, Azenha Jr. enfatiza a importância do conhecimento técnico, mas esse não pode ser exigido do tradutor a priori, visto que isso demandaria uma nova formação do tradutor.

É especialmente na descrição das atividades do tradutor que Zipser identifica as semelhanças com a atividade do jornalista. A seu ver, ambas as atividades presumem o contato com o Outro. Ambos também atuam como mediadores culturais, que absorvem as informações através do filtro da cultura de chegada. A própria interpretação do tradutor e do jornalista interfeririam no texto resultante.

Liberatti não se estende nas considerações sobre o tradutor: dos pontos relevantes de sua dissertação, destacamos apenas o fato de ela considerar os tradutores agentes de disseminação de produtos culturais. O tradutor está em posição de tomar decisões no pro- 
cesso tradutório. Contudo, no caso das HQs, suas decisões estão limitadas pela interação entre texto e imagem.

De Laiño estima-se que o retrato que faz dos tradutores corresponda à postura que exija de seus aprendizes de LE: um tradutor compromissado com todos os envolvidos no processo de tradução e que incorpore a intenção comunicativa do emissor do TP. Nesse caso, fica ainda mais evidente como o tradutor pode interferir no TC: por se tratarem de aprendizes de LE, as suas limitações no que concerne à língua e à cultura estrangeiras devem estar flagrantes no texto.

Observa-se que apenas a proposta teórica de Azenha Jr. dedica-se mais a explorar a figura do tradutor no exercício de sua atividade profissional, possivelmente pois o autor escreve também a partir de sua experiência profissional. Assim, ele inclui uma reflexão sobre as responsabilidades do tradutor e sobre o fato de sua atividade estar concatenada com outras. Liberatti também aborda a questão das responsabilidades do tradutor, uma vez que definir o escopo do trabalho do tradutor é vital para avaliar seu poder de decisão, sobretudo no que concerne à relação entre texto e imagem.

Sobre a situação, os autores concordam que ela se reflete na construção do texto. Azenha Jr. e Liberatti mencionam também que ela determina a função comunicativa, enquanto Zipser e Laiño mencionam também que um texto só exerce função comunicativa no contexto de uma situação. Subjacente à situação estaria a cultura.

No que se refere a esse conceito, Laiño sustenta a sua defesa do emprego da tradução em aula ao desfazer a impressão negativa deixada pelo Método Gramática e Tradução no que concerne ao caso: seus exercícios preveem o uso de textos genuínos em sala de aula, de modo a trazer situações comunicativas mais próximas da realidade ao aprendizado de LE. A ênfase dada por Laiño a esse conceito tem, assim, a motivação de responder às críticas feitas contra o uso da tradução no aprendizado de LE.

O conceito de informação teve empregos difusos. Apenas Azenha Jr. faz menção ao conceito como proposto por Vermeer ao definir um texto como uma "oferta de informação". Zipser utiliza "informação" como termo ligado ao fato noticioso, relativo à sua expressão num texto. Ao empregar o termo, Liberatti tende a se referir à informação semântica dos textos, e o mesmo é observado de Laiño. Para essa, no entanto, a informação, por exemplo, nos textos publicitários não tem apenas o intuito de informar, mas sobretudo o de persuadir. 
Nota-se que, ao contrário dos demais, o conceito de informação faz pouca ou nenhuma referência às definições funcionalistas. Uma razão para isso pode estar no fato de o conceito, já nos textos funcionalistas, aparecer ocasionalmente de modo difuso. Assim, percebe-se que o conceito de informação empregado pelos pesquisadores está mais próximo do senso comum do que do arcabouço funcionalista.

No que diz respeito aos fatores, todos os trabalhos fazem menção aos fatores contemplados pelo modelo de análise textual formulado por Nord, com exceção o de Azenha Jr., ainda que a obra de Nord conste dentre suas referências bibliográficas. Laiño faz ainda menção aos fatores descritos pelo modelo de fatores de Katharina Reiss, que vimos acima na exposição de seu livro escrito em conjunto com Hans Vermeer. Azenha Jr., por sua vez, cita como fatores influentes na tradução as línguas envolvidas, o tradutor, os textos, a situação comunicativa, a interferência de terceiros, entre outros.

Em qualquer um dos casos de tradução, reconhece-se que a conjunção de fatores intratextuais e extratextuais interfere na tradução, além de fatores ligados ao tipo de texto a ser traduzido, por exemplo, a relação entre texto e imagem, citada por Liberatti. Azenha Jr. e Laiño também fazem menção ao tradutor como um fator condicionante, provavelmente em decorrência da posição de tradutor profissional de que fala Azenha Jr. e do fato de os tradutores, no caso de Laiño, não serem tradutores profissionais, mas aprendizes de LE. Nesse caso, em vez de estimular a comunicação, a tradução é um fim em si mesmo.

A partir do exposto através dessa discussão, chegamos a algumas conclusões. Em primeiro lugar, observamos que cada um dos trabalhos não se encerra numa discussão puramente teórica. De fato, como trabalhos que se dispõem a aplicar os preceitos funcionalistas a casos específicos de tradução, eles também incluem uma etapa empírica de pesquisa. Assim, a reflexão em torno dos conceitos funcionalistas é embasada pela observação e pela experiência.

É notório que as pesquisas envolvendo problemas específicos da tradução comprovam alguns preceitos centrais da abordagem funcionalista, demonstrando, assim, a validade da abordagem teórica. Dentre os princípios do funcionalismo, a relevância da função comunicativa e do receptor na construção do texto - e na constituição dos gêneros textuais -, o papel da situação comunicativa e a interferência das implicações culturais representam as contribuições mais significativas para os trabalhos analisados.

Por outro lado, em razão do caráter particular dos problemas abordados por cada um dos autores, é possível afirmar que todos vislumbram o funcionalismo a partir de uma 
perspectiva própria. Com isso, em vez de evocar todo o corpo conceitual contido nos textos seminais funcionalistas, eles fizeram recortes dos aspectos conceituais mais relevantes. Isso é observado mesmo nos trabalhos que exercem um papel pioneiro de divulgação dos conceitos funcionalistas no Brasil, como é o caso, por exemplo, da tese de Doutorado de Azenha Jr.

Diante do quadro analisado, seria possível especular que os recortes foram motivados pelos diferentes objetos de pesquisa. No entanto, julgamos ser mais coerente pensar que as escolhas foram também pautadas pelo objetivo de pesquisa e pelo arcabouço teórico trazido de outras disciplinas para enriquecer a formulação teórica. Uma pesquisa que averigue a conexão entre recorte conceitual e objeto de pesquisa no âmbito do funcionalismo ainda está por vir.

Em vista disso, somos levados a mais uma constatação: o funcionalismo não se basta para elucidar os casos específicos. Em cada um deles foi necessário trazer contribuições com enfoque maior no objeto de pesquisa. O funcionalismo forneceria, assim, um quadro teórico no âmbito dos estudos da tradução, que acomodaria investigações interdisciplinares. Nesse contexto, a eficiência desse quadro teórico está em viabilizar pesquisas em seu interior, fornecendo um cabedal conceitual a investigações de naturezas diversas. Os conceitos teriam, assim, a potencialidade de adequarem-se aos mais diversos casos particulares.

No entanto, isso não significa que, a despeito de sua adaptabilidade, mesmo esses conceitos não podem ser revistos. Azenha Jr. destaca o papel das condicionantes culturais na formulação e na tradução do texto de especialidade, algo que, embora em conformidade com os demais, opõe-se ao que postula Reiss (1971) ao definir o texto técnico um texto puramente informativo, cujas questões estariam restritas à transmissão de um conteúdo semântico. Ademais, ele analisa as tipologias textuais de Reiss e Snell-Hornby (1988), destacando pontos positivos, mas também traçando críticas a elas, propondo, enfim, uma conciliação dos dois modelos.

Por sua vez, ao traçar repetidos paralelos entre a atividade de tradução e a atividade jornalística, inclusive reconhecendo postulados da teoria funcionalista no jornalismo, Zipser associa ambas as atividades e agrega ao conceito de tradução um aspecto pouco explorado pela teoria: o jornalismo como uma tradução de fatos em textos. Embora ressaltem o fato de a tradução envolver percepções subjetivas, Zipser define a tradução não apenas 
como uma forma de transferência entre produtos da expressão humana, mas também entre percepções do real e sua forma num sistema semiótico.

No campo dos quadrinhos, Liberatti agrega à concepção de língua, identificando propriedades do sistema linguístico num sistema imagético: a convencionalidade, a construção de significados e a influência cultural. Com isso, ao pensar na tradução de quadrinhos, somos induzidos a pensar em dois processos paralelos de tradução: a tradução dos recursos verbais e a tradução, mediante recursos verbais, dos recursos imagéticos que, dadas as políticas editoriais, permanecem inalterados.

Laiño, por fim, traz para as considerações teóricas do funcionalismo, formuladas tendo o ensino de tradução e a atividade profissional em mente, para o âmbito da aprendizagem de LE. O envolvimento da tradução na aquisição de linguagem deixa de ser, assim, restrito a veicular estruturas linguísticas e passa a ser um exercício que ajuda a desenvolver, além das estruturas linguísticas, vocabulário e das quatro habilidades básicas de uma língua, também a proficiência cultural.

Cumpre, no entanto, observar que a contribuição desses trabalhos ao funcionalismo não se restringe a repensar ou incluir conceitos, mas também à divulgação da teoria nos estudos da tradução no Brasil. Aqui, damos o reconhecimento aos trabalhos de Azenha Jr. e de Zipser que lhe são devidos. Para além de uma nova perspectiva sobre o texto técnico, o trabalho de Azenha Jr., até onde pudemos chegar com nossa pesquisa, foi o primeiro a basear-se no funcionalismo. Dessa forma, ele introduz o funcionalismo ao campo de pesquisas em tradução no Brasil. Ainda que não tenha natureza tão pioneira, o trabalho de Zipser confirmou-se, na pesquisa realizada no capítulo anterior, como uma fonte de consulta importante sobre o funcionalismo, sobretudo na UFSC, tornando-se texto cânone para a aplicação da teoria no âmbito da tradução jornalística.

Isso, contudo, muito deve ao fato de ambos serem docentes em importantes universidades brasileiras, tendo orientado trabalhos com esse aporte teórico, alguns incluídos nesse corpus: João Azenha Jr. orientou o trabalho de Meta Zipser que, por sua vez, orientou o trabalho de Maria Laiño e esteve na banca de defesa do trabalho de Elisângela Liberatti. Essa constatação, no entanto, só demonstra a necessidade de uma pesquisa que contemple o interior e o exterior do campo disciplinar. 
Conclusões 
Chegado o final de nossas considerações, é hora de relembrarmos os nossos objetivos de trabalho. A presente pesquisa propôs-se a rastrear as condições de recepção do funcionalismo no Brasil, bem como a examinar os desdobramentos da abordagem teórica entre nós. Além do objetivo central de nossa tese de Doutorado, elencamos na Introdução cinco contribuições desse trabalho para o campo disciplinar. Contudo, àquele ponto da pesquisa, essas razões cumpriam a função de objetivos secundários. Realizadas as etapas de pesquisa, cumpre verificar se o trabalho fez jus a esse compromisso.

Como primeiro argumento para justificar a importância do presente trabalho, ressaltamos a necessidade de construir uma metodologia para pesquisa histórica dos estudos da tradução, respaldada por um arcabouço teórico multidisciplinar, que contemplasse tanto o interior de nosso campo científico quanto o seu entorno. Essa necessidade, como observamos, advém da carência de propostas metodológicas para esse fim, ainda que os métodos empregados não sejam inteiramente desconhecidos de pesquisadores dedicados a esse tipo de investigação. Poderíamos dizer que subjaz à proposta metodológica também o desejo de que a história de nosso campo disciplinar se torne um tema atrativo de pesquisas. É certo que nos últimos anos vem crescendo o interesse pela pesquisa de tradutores e traduções. Todavia, no que tange à pesquisa acerca da história de nossa própria disciplina, ainda estamos sub-representados, seja em eventos, seja em publicações.

Assim, trazemos uma metodologia que permite a investigação histórica dos estudos da tradução, através de uma análise quantitativa e qualitativa, sob os enfoques externalista e internalista. A pesquisa externalista baseia-se em métodos utilizados pela cientometria para o estudo da história de um campo científico. Com base em artigos científicos publicados em periódicos devotados ao campo dos estudos da tradução, bem como em números especiais, dedicados à área, de revistas voltadas a diversos campos de estudo das Letras, esboçamos um mapeamento do campo científico entre os anos de 1992 e 2005, sustentado por relatos de importantes nomes dos estudos da tradução no país que vivenciaram o desenrolar dessa história. Logo, a pesquisa pauta-se em dados e testemunhos. Ao notar que o período estipulado de pesquisa não contemplaria importantes contribuições no âmbito do funcionalismo, estendemos o levantamento de artigos amparados pela vertente teórica até o ano de 2017, em busca de tendências de aplicação teórica e de seus principais representantes no país. Embora estejamos alertas para as limitações da pesquisa com artigos científicos, estamos convictos de ter fornecido uma contribuição robusta para compreender a história de nosso campo disciplinar nas últimas décadas. 
Por sua vez, a pesquisa internalista fundamenta-se em métodos da linguística de corpus. Esses métodos foram úteis não apenas para identificar, em textos seminais funcionalistas, os principais conceitos defendidos pela abordagem teórica, como também para examiná-los nesses mesmos textos e em trabalhos de grau defendidos em instituições de ensino superior brasileiras. Orientada pelos resultados do levantamento de artigos científicos, a escolha dos trabalhos de grau considerou as principais esferas de aplicação da teoria e os trabalhos mais citados. Uma vez compilados os corpora, isto é, o corpus de trabalhos seminais e o corpus de trabalhos de grau, a linguística de corpus realmente viabilizou sua análise quantitativa - por exemplo, na escolha das palavras-chave, a partir dos termos mais referidos do corpus - e a análise qualitativa - na observação dessas palavras-chave em cada item do corpus.

Portanto, avaliamos que, de modo geral, a metodologia cumpriu o seu papel, oferecendo os meios para explorar os mais diversos aspectos do estudo histórico do campo disciplinar. Ao mesmo tempo, estamos convencidos de que a metodologia possa ser aplicada ao estudo histórico de quaisquer outras vertentes nos mais diversos campos disciplinares das ciências humanas. Essa convicção é sustentada não apenas pela adequação dos métodos aqui apresentados para a investigação das dimensões epistemológica e social das ditas "ciências moles", marcadas pela convivência de diferentes cinosuras paradigmáticas no mesmo momento histórico, mas também pelo embasamento teóricos desses métodos.

Com isso, aproveitamos o ensejo para destacar a importância do arcabouço teórico escolhido para o presente trabalho. A análise externalista foi embasada pela filosofia e pela sociologia da ciência. A nosso ver, o maior contributo dessas disciplinas é, por um lado, chamar a atenção para o fato de que o desenvolvimento científico implica constantes lutas epistemológicas; por outro lado, elas mostram que o avanço das disciplinas não ocorre dissociado das relações interpessoais. De fato, a dinâmica entre pesquisadores, bem como a posse de instrumentos de pesquisa e de divulgação determinam teorias emergentes em cada tempo e o predomínio delas no campo disciplinar. Ainda que as disciplinas nas ciências humanas tolerem a concomitância de diferentes vertentes teóricas, algumas vertentes podem ter prevalência sobre as outras, relegadas a posições marginais dentro do campo científico. Nesse contexto, é fundamental entender os mecanismos sociais da comunidade científica que favorecem um frente a outros.

No que diz respeito à análise internalista, o respaldo veio da história dos conceitos e da sociobiologia. A história dos conceitos alertou-nos para o fato de que um mesmo con- 
ceito pode acumular experiências e expectativas ao longo da história. No caso específico de um campo disciplinar, a cada novo paradigma é necessária uma redefinição conceitual, de modo a extirpar as acepções que destoam daquelas que defendem as novas vertentes teóricas. Da sociobiologia extraímos a noção de meme, unidade conceitual que replica através do processo de imitação, de modo análogo a que fazem os genes durante o processo de reprodução. A partir da aplicação desse conceito ao campo dos estudos da tradução, descobrimos que é possível pensar numa história do campo de reflexões a partir da definição que se faz de um conceito central como "tradução".

Cabe aqui fazermos menção a alguns problemas enfrentados com a aplicação da metodologia. Para conduzir a análise externalista, fizemos uso do software SciMAT (COBO et al., 2012), desenvolvido com o objetivo de servir como um instrumento auxiliar em análises bibliométricas complexas. Esse, assim como outros recursos computacionais de análise bibliométrica, baseiam suas análises em dados extraídos de sistemas online de indexação de citações científicas, com informações sobre artigos publicados nas mais diversas áreas. Todavia, os sistemas de indexação conhecidos privilegiam áreas majoritárias e publicações internacionais, de modo que não encontramos os dados referentes aos artigos publicados no âmbito dos estudos da tradução no país. Com isso, foi necessário incluir esses dados manualmente em nosso banco de dados, o que tomou uma parte considerável do tempo de pesquisa. Dessa forma, ainda que possamos atestar a eficácia da metodologia e a utilidade do recurso computacional, sobretudo no que respeita à organização e ao armazenamento dos dados, o tempo gasto no registro dos dados é um fator a ser considerado na definição do corpus de futuras pesquisas.

Outro problema emergente no decorrer da pesquisa diz respeito à identificação dos temas e à clusterização das palavras-chave. Alguns dos artigos de nosso corpus não continham resumo, tampouco palavras-chave. Nesses casos, foi necessário recorrer à linguística de corpus. Assim, mediante o uso da ferramenta de identificação de palavras-chave do WordSmith Tools e da consulta aos textos, propusemos palavras-chave que identificassem o tema e/ou a filiação teórica do artigo. Mesmo após cumprida a tarefa, a clusterização das palavras-chave foi dificultada pela ausência de parâmetros de indexação para os estudos da tradução, pesando, assim, o agrupamento de palavras-chave sobre a interpretação e sobre a concepção epistemológica do pesquisador. Com isso, reiteramos a necessidade de esforços conjuntos de professores de todos os domínios dos estudos da tradução no país para definir formas de indexação padrão que nos auxilie não apenas a identificar os principais temas e 
aportes teóricos contidos nos trabalhos acadêmicos, mas também que permitam agrupar trabalhos com temas e abordagens semelhantes.

A segunda contribuição do presente trabalho foi agregar ao mapeamento dos estudos da tradução no Brasil, mediante o estudo bibliométrico de artigos científicos, e, de maneira especial especial, contribuir também para o mapeamento do funcionalismo no país. Nosso mapeamento visou a acrescentar a esforços já empreendidos na área, a exemplo dos trabalhos mencionados de Pagano e Vasconcellos (2003) e Alves e Vasconcellos (2016). Os comentários a seguir, no entanto, não se limitam ao estudo bibliométrico, mas englobam toda a discussão conduzida no capítulo dedicado à análise externalista.

A partir de testemunhos e de outros estudos historiográficos, fomos informados de que o processo de institucionalização dos estudos da tradução no Brasil foi estimulado por uma demanda externa, a saber, a formação profissional de tradutores e intérpretes qualificados para atender às demandas do mercado. Assim, os primeiros cursos surgiram com a regulamentação da Lei de Diretrizes e Bases da Educação Nacional. Até então, o âmbito da tradução nas universidades era predominantemente a literatura comparada, estando desse modo restrita à tradução literária. $\mathrm{O}$ fato de os cursos terem sido erigidos sob a estrutura dos cursos de Letras já existentes, associado ao fato de a principal oferta de traduções ser a tradução de textos de especialidade, trouxe o conflito: como orientar a formação profissional de tradutores e intérpretes de modo a contemplar as principais exigências do mercado? A resposta foi depositar ênfase no desenvolvimento de competência linguística.

Logo, a ênfase no aprendizado de línguas refletia não apenas o clima intelectual da época, mas também o estágio de desenvolvimento dos estudos da tradução no país. Não tardou para que se reconhecesse que apenas o desenvolvimento de competência linguística não seria suficiente. Consequentemente, as necessidades de compreender o trabalho profissional do tradutor e de desenvolver a didática da tradução deram impulso à abordagem científica e à pesquisa nesse âmbito. De forma gradativa, as universidades passaram a incluir a tradução nos domínios da pós-graduação, através da inclusão de linhas de pesquisa e de áreas de concentração em programas de pós-graduação já sedimentados.

Uma das consequências da institucionalização dos estudos da tradução foi conferirlhe cientificidade. Como vimos, os escritos teóricos no princípio dos estudos da tradução no Brasil resumiam-se a considerações a partir da experiência prática de tradutores. O que difere aquela produção precursora do que atualmente é realizado no país está no fato de que hoje, tendo a tradução ocupado espaços na universidade, construiu-se um perfil de 
pesquisador, sendo as próprias universidades responsáveis por formarem esses pesquisadores, por transmitirem a eles o habitus do estudioso da tradução, distinguindo seu trabalho das reflexões assistemáticas pautadas na prática. Esse foi um movimento de afastamento dos estudos da tradução do campo social e um indício do processo de aquisição da tão necessária autonomia.

O desenvolvimento dos estudos da tradução no Brasil seguiu etapas semelhantes às descritas por Bourdieu: a criação dos cursos de tradução levou o domínio da tradução às universidades; a demanda por professores de tradução gerada por esses cursos, por sua vez, amparada pelo desenvolvimento da área no contexto internacional, gerou uma prática de pesquisa. Por fim, a criação de associações como a ABRAPT ensejou a identificação do corpo de pesquisadores da área. Aqui cumpre ressaltar o papel de associações como o GTTRAD e a ABRAPT no desenvolvimento do campo no país: elas foram essenciais para conjugar a pesquisa no âmbito dos estudos da tradução, sobretudo em tempos em que os meios de comunicação não estavam tão desenvolvidos como hoje.

Outro importante movimento na institucionalização dos estudos da tradução foi a constituição de meios próprios da disciplina para a divulgação científica. Eventos como os Encontros Nacionais de Tradutores, importantes fóruns de discussão, são até hoje um termômetro para o desenvolvimento da área, apontando novas tendências de pesquisa. Contudo, é curioso observar que a institucionalização da tradução, um processo principiado com o objetivo de viabilizar a formação profissional de tradutores e intérpretes acabou por se afastar do âmbito da prática. Isso é comprovado pelo fato de a participação de profissionais nesses fóruns de discussão ter sido reduzida e o perfil de eventos dessa natureza ter se tornado mais acadêmico.

Destacamos ainda a criação de periódicos dedicados exclusivamente aos estudos da tradução. Tendo início nos anos de 1980, os periódicos começaram a se estabelecer como um importante veículo de divulgação científica no campo disciplinar nos anos de 1990, com o início da publicação das revistas TradTerm e Cadernos de Tradução. Como vimos na exposição de nossa fundamentação teórica, os artigos científicos fornecem indicações não apenas das tendências de pesquisa num dado campo disciplinar, mas também da distribuição de capital científico.

Nesse contexto, a pesquisa bibliométrica sugere que as abordagens pós-modernas dos estudos da tradução, especialmente em torno da figura de Rosemary Arrojo, concentraram capital científico num período significativo da história examinada, colocando-se numa 
posição central dentro do campo, o que significa que a interface entre filosofia e tradução teve bastante aceitação entre nós. Como vimos, Bourdieu traz de Ben-David e Collins o conceito de "hibridização", que faz referência à aplicação, por membros de um determinado campo disciplinar, de fundamentos e métodos de sua disciplina noutro campo menos concorrido, com a finalidade de acumular capital simbólico. No entanto, é arriscado falarmos de hibridização nesse caso, posto que os estudos da tradução são um campo interdisciplinar por excelência. De todo modo, outros possíveis fatores para o crescimento dessa abordagem não devem ser desconsiderados, tais como a liderança carismática de Arrojo ou o pioneirismo da UNICAMP no que concerne ao processo de institucionalização dos estudos da tradução.

De todo modo, segundo os relatos, a emergência das teorias pós-modernas teriam resultado numa "virada cultural" à brasileira: a crença na transparência absoluta dos textos, no autor como fonte original e na tradução como operação linguística teria cedido lugar ao reconhecimento da interferência de fatores culturais e às possibilidades de diferentes significações no ato de recepção de um texto. Nos estudos da tradução no Brasil, essa mudança de perspectiva não teria sido sentida apenas nas pesquisas, mas também na formação de tradutores. A formação não seria mais pautada pela competência linguística, mas incluiria questões culturais, tendo em vista o público receptor da tradução. A esse despeito, a importância da reflexão teórica como parte da formação do tradutor e do intérprete teria demorado a ser reconhecida tanto da parte de professores como da parte de estudantes de tradução.

No que respeita ao avanço do campo em território brasileiro, os relatos acerca da história da tradução e a pesquisa bibliométrica apontam para uma mesma realidade, a saber, o crescimento e a descentralização dos estudos da tradução no país. Tomemos como exemplo o desenvolvimento do GTTRAD e da ABRAPT: o GT de Tradução da ANPOLL foi criado através da sugestão do Prof. Edson Rosa da Silva, da UFRJ. Sua primeira coordenadora foi a Prof. Maria Candida Bordenave, da PUC-RJ, que exerceu o cargo até 1989. Em 1990, dada a pouca adesão à reunião do GT de Tradução daquele ano, a Prof. Rosemary Arrojo, da UNICAMP, sugeriu a criação de Grupos de Trabalho regionais, e os primeiros GTs foram criados conforme os pesquisadores ali reunidos. Assim, Rio de Janeiro, São Paulo, Minas Gerais e Rio Grande do Sul foram os primeiros estados a realizarem as reuniões regionais. Em 1996, foram criados mais dois GTs: o GT da Bahia e o de Santa Catarina, sinalizando o crescimento da pesquisa em tradução e interpretação nesses locais. Nos anos de 2000, o GTTRAD passou a registrar pesquisadores de todo o país. 
Quanto à ABRAPT, a ideia de sua fundação surge durante um dos encontros do GT regional de São Paulo, concretizando-se em 1992. Com sede em São Paulo, foi coordenada por professores ligados a universidades paulistas até 2005, quando a gestão passou para as mãos do Prof. Fabio Alves, da UFMG. Atualmente, elege-se uma nova gestão ao término de cada triênio, recaindo sobre uma universidade numa localidade diferente do país: em 2007 na UFOP, em 2010 na UFSC, em 2013 na UFU e em 2016 na UFPB. Por sua vez, o crescimento das atividades da associação permite-se notar através do crescente volume de trabalhos submetido para cada Encontro Nacional de Tradutores, evento organizado pela ABRAPT.

Com isso, nota-se que o controle das associações, outrora concentrado nas mãos de centros de formação principalmente do sudeste brasileiro, passou a ser distribuído por instituições em outros lugares do país. O levantamento bibliométrico vem a corroborar essa afirmação: entre 1992 e 1995, foram encontrados artigos escritos por pesquisadores vinculados apenas a sete instituições brasileiras. Ao longo do tempo, o número de instituições representadas cresceu, chegando a trinta e duas no período entre 2001 e 2005. Esse movimento "centrífugo" é também observado nos temas. Como vimos, nos Anais do III Encontro Nacional de Tradutores, realizado em 1987, os resumos das comunicações foram organizados em cinco áreas temáticas; na última edição do evento, realizada em 2016, esse número já havia subido para dezesseis áreas temáticas. Por sua vez, as palavras-chave dos artigos publicados entre 1992 e 1995 puderam ser agrupados em 30 temas e afiliações teóricas diferentes; entre 2001 e 2005, já foram 53 diferentes temas e afiliações teóricas.

Aproveitamos o ensejo para abordar as mudanças no que concerne aos temas mais abordados em nossa pesquisa bibliométrica. De modo geral, percebemos que temas ligados à tradução literária, à teoria da tradução, à atividade do tradutor e pesquisas do léxico ocuparam, segundo nosso levantamento, o centro da pesquisa no âmbito da tradução no momento das primeiras manifestações funcionalistas no país, sendo as abordagens pósmodernas as vertentes preponderantes do campo disciplinar. Ainda que a tradução literária tenha se mantido no centro do campo, ascenderam ao longo do tempo questões ligadas aos limites da tradução, ao ensino e à história da tradução. Por outro lado, as áreas de pesquisa do léxico tiveram decréscimo de pesquisas. Esse, como vimos, é um percurso natural, decorrente das transformações no campo no Brasil e no exterior, caracterizadas pela emergência de vertentes com ênfase no aspecto cultural em detrimento do aspecto linguístico. No período final de nossa pesquisa, questões ligadas a cultura e identidade, bem como es- 
tudos de corpus e tradução intersemiótica ascenderam a posições nucleares no campo, enquanto questões ligadas à dimensão política da tradução e à pós-modernidade tornaram-se menos centrais.

Mencionamos o argumento de Barbosa (2009) de que o pós-estruturalismo teria pouca serventia na análise e no ensino de traduções como provável justificativa para a queda no volume de artigos respaldados pelas abordagens pós-modernas. No entanto, é necessário considerar também a importância das lideranças intelectuais no desenvolvimento da abordagem teórica. Essa queda foi percebida sobretudo no último período de nossa investigação, o período entre 2001 e 2005. Nesse período, mais exatamente em 2003, Arrojo muda-se para os Estados Unidos, onde assume a cadeira de Literatura Comparada na Binghamton University. Dois anos antes, Else Vieira estabelece-se na Queen Mary - University of London, na Inglaterra, onde passa a lecionar Estudos Culturais Brasileiros. Logo, as duas abordagens fulcrais da pós-modernidade no Brasil - o pós-estruturalismo e a antropofagia - perdem suas principais defensoras.

Outra vantagem do estudo bibliométrico está em mostrar que a criação de periódicos dedicados à área não só contribuíram para o desenvolvimento dos estudos da tradução como um todo, mas contribuíram especialmente para o crescimento dos estudos da tradução entre as instituições que detêm o controle sobre eles, concedendo visibilidade a suas pesquisas. Esse, como vimos, foi o caso do desenvolvimento dos estudos da tradução na USP e, principalmente, na UFSC. Ressaltamos, contudo, que esse não foi o único fator a contribuir para o crescimento da produção intelectual no âmbito dos estudos da tradução nessas instituições: os esforços para institucionalização da área em ambas as universidades, com a criação de linhas de pesquisa em tradução e posteriormente programas de pósgraduação dedicados aos estudos da tradução foram essenciais para esse crescimento.

Desse modo, parece-nos que a institucionalização do campo disciplinar é condição sine qua non para o seu crescimento. Assim, as instituições que investem nesse movimento ganham destaque sobre as outras nesse campo específico. Entretanto, essa é uma hipótese que ainda carece de comprovação, o que pode ser conquistado com a análise da produção intelectual no âmbito dos estudos da tradução da década atual, contemplando assim programas de pós-graduação em estudos da tradução criados noutras instituições, tais como a UnB, a USP e a UFC. Os indícios obtidos a partir dos dados analisados até aqui, contudo, parecem apontar para essa conclusão. 
A despeito do crescimento dos estudos da tradução e de sua institucionalização, a área disciplinar ainda não foi reconhecida como Área de Conhecimento nas agências de fomento federais e estaduais. Como vimos, o não reconhecimento da autonomia dos estudos da tradução por agências como a CAPES e o CNPq impacta o financiamento da pesquisa e da sua divulgação e a falta de representantes da área junto às agências impede o apoio institucional. Dessa forma, embora os estudos da tradução tenham crescido ainda nessas condições, o que garante a autonomia de uma disciplina e a liberdade de selecionar diferentes tópicos de pesquisa é, como explica Bourdieu, o financiamento do estado. Esse é um desafio para o futuro do campo disciplinar no país.

No que tange ao mapeamento dos trabalhos funcionalistas no Brasil, o rastreamento da passagem dos funcionalistas pelo país, o levantamento de artigos e a análise bibliométrica revelaram-nos que os primeiros movimentos de inserção da abordagem teórica no país foram, como era esperado, iniciativa das lideranças intelectuais do Funcionalismo, sobretudo de Hans Vermeer, no início dos anos de 1990, e de Christiane Nord, especialmente entre 1995 e 2005. Essa inserção deu-se através da participação desses autores em eventos acadêmicos e da publicação de artigos, e foi incisiva a ponto de Nord emergir como uma das autoras mais produtivas de nosso levantamento.

Apesar disso, durante o primeiro período pesquisado, entre 1992 e 2005, o funcionalismo embasou apenas uma minoria muito pouco expressiva dos artigos publicados por pesquisadores brasileiros, de modo que foi impossível, apenas com os dados desse primeiro levantamento, determinar tendências de aplicação teórica no âmbito dos estudos da tradução no Brasil. Com isso, estendemos o levantamento até o ano de 2017, o que nos trouxe mais informações.

Em primeiro lugar, UFSC e USP emergiram como pontos de irradiação da pesquisa, concentrando a maior parte das publicações funcionalistas. Nesse contexto, destacam-se Azenha Jr., como pioneiro e divulgador das ideias funcionalistas, e Zipser, como fomentadora de pesquisas amparadas sobretudo pela proposta teórica de Christiane Nord. De fato, Nord revelou-se como principal fonte de consulta sobre o funcionalismo. Uma justificativa para isso pode estar na atuação tenaz da autora. Pensamos que as constantes visitas de Christiane Nord ao sul de nosso país, região com massiva colonização alemã, pode ter incentivado a boa recepção da teoria na UFSC, a qual, graças também à estrutura institucional que estava construindo, tornou-se esse centro de irradiação do funcionalismo. 
Ademais, o funcionalismo parece, ainda que timidamente, estar ganhando novos terrenos, com representantes em outras instituições, como a UFCG, a UFC e a UTFPR. Verificar a ação dessas instâncias difusoras é, no entanto, uma pesquisa ainda por vir. Quanto às tendências de aplicação do funcionalismo, destacaram-se trabalhos com foco na tradução técnica, na tradução de histórias em quadrinhos e no ensino de língua estrangeira através da tradução. Apesar de o maior montante de artigos funcionalistas tocar, em alguma medida, no tema da tradução literária, não encontramos referências significativas a projetos de pesquisa que enfatizem investigações dessa natureza. Entendemos, portanto, que tais artigos representem mais exercícios de aplicação da teoria no âmbito da tradução literária, contrariando o senso comum sobre a abordagem de que ela teria pouco a contribuir para a tradução de literatura, e menos pesquisas de grau de cunho científico.

Com isso, adentramos o campo da análise hermenêutica do funcionalismo, fazendo jus ao terceiro argumento em favor da relevância do presente trabalho: fomentar a divulgação de conceitos centrais do funcionalismo em língua portuguesa. Para tanto, analisamos primeiramente algumas dentre as obras mais relevantes para a constituição dessa vertente teórica.

O funcionalismo constitui-se como uma "escola", ainda que formado por diferentes proposições teóricas, pelas semelhanças ideológicas e pela intercomunicação mantida por seus teorizadores, como demonstrado na reconstituição dos passos dos membros pioneiros. $\mathrm{Na}$ Alemanha, a designação "funcionalista" criou uma identidade comum a esses autores, e a promoção de veículos de divulgação teórica, tais como a mencionada revista TEXTcon$T E X T$ e a série de livros th = translatorisches handeln, criou a estrutura de difusão teórica necessária ao seu crescimento. Como consequência, o funcionalismo tornou-se uma abordagem dominante no âmbito dos estudos da tradução do ambiente de expressão alemã.

De fato, a ascensão do funcionalismo na Alemanha pode ser interpretada realmente como uma revolução científica no campo, pois trouxe um novo corpo teórico e um novo programa de pesquisas. Tendo nascido no contexto da formação de tradutores e intérpretes, sua intenção foi desvincular-se da tradição em voga, opondo-se ao antigo paradigma - a abordagem linguística tradicional - por considerar que esse não oferecia respostas convincentes para o problema da formação profissional de tradutores.

É importante notar que o funcionalismo voltou-se a romper com a abordagem linguística da tradução, não com a linguística em si. Seus defensores, em especial Vermeer, propuseram uma reconfiguração na própria forma como as disciplinas de Letras se confi- 
guram, aproximando a linguística dos estudos culturais. Essa mudança, um contributo para alterar a dinâmica das disciplinas e elevar a tradução a uma posição mais central no campo de Letras, no entanto, só seria possível com capital político. Ainda assim, ao contrário do que afirma Pym (2010), que restringe a emergência da abordagem teórica à mera disputa de poder, consideramos que, mesmo havendo um componente político na ascensão do funcionalismo, ele não se restringe a isso. Com isso, aproximamo-nos de Bourdieu, que presume nas atitudes dos cientistas também motivações epistemológicas.

Como dissemos, o funcionalismo propõe-se a romper com noções de tradução resultantes de uma longa tradição, que estabelecem o texto de partida como critério-mor para as decisões tradutórias. Uma das formas pelas quais a vertente teórica faz isso é através da proposta de uma nova terminologia. Com a introdução de termos como "translação", "oferta de informação" e "portador de mensagem", a nova proposta terminológica tem um propósito epistemológico e sociológico: epistemológico, pois ao introduzir novos termos para designar elementos presentes no campo milenar da tradução, afasta do termo as experiências ou, como também podemos dizer, os memes acumulados ao longo da história, indicando a introdução de uma nova "teoria", isto é, de uma nova forma de ver o objeto; sociológico, pois ela também indica o rompimento com uma escola, com um grupo de teorizadores, e a constituição de um novo grupo.

A mudança de terminologia, além de afastar as experiências sobre tradução com as quais os funcionalistas se opõem, experiências essas acumuladas pelo conceito através de uma reflexão milenar acerca da tradução, amparada por noções como a fidelidade e a equivalência, prepara o objeto para novas experiências. Ao mesmo tempo, para demarcar a mudança, há os esforços para garantir que alguns elementos semânticos e pragmáticos referentes ao conceito de tradução permaneçam inalterados. A tradução continua a ser representada como uma atividade de produção textual a partir de um texto anterior - essa é a identidade que o conceito preserva com a tradução. Apesar da ênfase na recepção do texto traduzido, os teorizadores nunca negaram o vínculo desse com o texto de partida. O que mudam são os critérios que orientam essa produção, e aí está a novidade. Por outro lado, mesmo esse posicionamento não é de todo inovador, tendo em vista que há agentes históricos que destacaram a importância de considerar o público leitor no processo tradutório. Ainda assim, esse posicionamento é, no contexto de emergência do funcionalismo, desafiador o suficiente do estado de coisas da tradução à época. Em última análise, pode-se dizer que o conceito de tradução do funcionalismo vem a substituir uma noção de tradução que, 
a despeito de sua história milenar e de seu acúmulo de experiências, aproxima-se de um conceito de expectativas. Pautados na experiência profissional e didática, os funcionalistas veem na mudança do conceito uma forma de trazer noções úteis a ambas as atividades.

Assim, sob a perspectiva da sociobiologia e de seu emprego no âmbito dos estudos da tradução, a "virada cultural" trouxe o deslocamento dos supermemes no pool de memes: enquanto a "equivalência" e a "intraduzibilidade" foram relegadas a posições mais periféricas, outros memes como "toda escrita é tradução" foram trazidos a posições mais centrais. É importante, no entanto, notar que mesmo o funcionalismo não foi capaz de extinguir memes como o da equivalência, mas incorporou-os a partir de uma reinterpretação. Talvez o fato de memes como a equivalência serem tão longevos explique-se por sua constante retradução.

Ao enfatizar as condições a partir das quais o funcionalismo teve origem, esperamos ter alcançado mais um objetivo de pesquisa: demonstrar que a produção intelectual, como textos, não ocorre desvinculada de um contexto cultural, intelectual e institucional, mas que representa um contínuo do mundo - um princípio que está no próprio cerne da proposta funcionalista.

Cumpre ainda observar a aplicação dos preceitos funcionalistas em casos específicos de tradução. Em vez de tratarmos com profundidade o tratamento conceitual dos conceitos funcionalistas a partir de uma única perspectiva, isto é, a partir de um único tema ou objetos de pesquisa de um mesmo tipo, optamos por verificar esse tratamento conceitual em diferentes usos da teoria, de forma a identificar, independente do objeto, quais foram os aspectos da teoria geral mais bem absorvidos pelos pesquisadores brasileiros. Segundo nossa avaliação, a definição de tradução como um processo entre culturas, a importância da situação comunicativa, da função do texto e de seu receptor na construção do texto foram os aspectos da teoria funcionalista que se manifestaram em todos os textos analisados e constitui, assim, o cerne da concepção de teoria funcionalista no país.

Nesse contexto, notamos que a hipótese levantada durante a análise externalista foi confirmada pelas leituras dos trabalhos de grau: de fato, as teorias funcionalistas foram recebidas no Brasil, de modo preponderante, por intermédio das obras de Christiane Nord, que figura como principal fonte de consulta em três das quatro obras analisadas.

Quanto ao que difere os trabalhos no tratamento conceitual conferido aos conceitos centrais do funcionalismo, observamos que a seleção de conceitos foi orientada menos segundo os objetos de pesquisa e mais pelo cabedal teórico selecionado pelos pesquisado- 
res para abordar esses mesmos objetos. Vimos que na pesquisa de Azenha Jr. o funcionalismo é acrescido por considerações feitas no âmbito das linguagens de especialidade; na proposta de Zipser, o modelo teórico de Nord foi posto em contraste com a teoria do texto jornalístico de Frank Esser; na dissertação de Liberatti, o funcionalismo é intercalado com noções advindas sobretudo da sociolinguística; na tese de Laiño, os conceitos funcionalistas são complementados com ideias vindas do âmbito da produção textual, em especial destinada às aulas de língua estrangeira. Desse modo, os conceitos funcionalistas são postos em relação com conceitos de outras referências teóricas, mais focados no objeto de tradução. Além disso, os objetivos de pesquisa também interferem na escolha.

Acima de tudo, no emprego do funcionalismo em casos especiais, vemos um novo acréscimo de experiências aos conceitos, de modo agora a contemplar as particularidades desses casos específicos. Se os funcionalistas trouxeram uma revisão do conceito de tradução, destituindo-o de expectativas não cumpridas - desencadeadas pelas noções de fidelidade e equivalência - e ressignificando essas noções, os estudos de caso aprofundam esse processo, trazendo as considerações gerais para os casos específicos. Eles, enfim, complementam os conceitos com mais experiências, advindas de uma faceta prática das pesquisas conduzidas, essas muitas vezes validadas teoricamente por outros campos, mais ligados ao caso específico.

Com isso, chegamos à constatação de que o funcionalismo, como uma teoria geral, não basta para explicar todos os casos específicos de tradução ou, ao menos, não de forma isolada. Para aplicá-la a casos específicos de tradução, é necessário trazer à pesquisa a contribuição de outras áreas, mais voltadas a elucidar características do objeto sob análise ou dos usos da tradução. Nesse sentido, o funcionalismo forneceria um quadro teórico, no interior do qual devem ser inseridas noções advindas de outros campos disciplinares. No entanto, essa não seria uma condição de todas as teorias de tradução?

Dessa maneira, atingimos nosso quinto objetivo de pesquisa, a saber, desvelar a conexão do funcionalismo com diferentes vertentes, desvelando assim também a natureza multidisciplinar dos estudos da tradução. A diversidade de abordagens teóricas em nosso campo disciplinar revelou tentativas de compreender a tradução a partir de diferentes facetas desse objeto. Contudo, em face da complexidade do fenômeno da tradução e da sua mutabilidade, o anseio por uma teoria fechada e acabada é vão, o que não impede de continuarmos a refletir acerca da tradução e de suas condicionantes. 
Ao longo da presente pesquisa, deparamo-nos com alguns fenômenos relacionados ao crescimento dos estudos da tradução no Brasil e à presença do funcionalismo no campo disciplinar que, dado o escopo do presente trabalho, não puderam ser aprofundados. Dessa forma, cabe deixar aqui algumas sugestões de pesquisas posteriores.

Como vimos, a análise bibliométrica traz consigo muitas possibilidades para compreendermos melhor nosso campo de estudos. Desse modo, é imprescindível estender pesquisas de cunho bibliométrico, e as possibilidades são bastante numerosas: podem ser feitas pesquisas com foco em temas e abordagens específicos, bem como pesquisas com foco na produção dos pesquisadores de uma determinada instituição, ou mesmo de nomes relevantes para o desenvolvimento do campo disciplinar. Ademais, é fulcral continuar o mapeamento da disciplina, lançando mão de outras fontes, tais como anais de congressos e obras monográficas, de modo a formar um quadro mais completo dos estudos da tradução no país.

Dois tópicos de pesquisas futuras parecem-nos mais prementes: no presente estudo, tomamos a decisão metodológica de abordar apenas um trabalho de grau exemplar de uma determinada área de aplicação da teoria funcionalista. Assim, embora tenhamos uma noção melhor de quais conceitos ressoaram melhor entre os pesquisadores no Brasil, não pudemos definir quais conceitos prevalecem na aplicação da teoria para um caso específico por exemplo, a tradução técnico-científica. Assim, incentivamos pesquisas conceituais posteriores que analisem diversos textos funcionalistas versando sobre um mesmo tema em busca por regularidades quanto ao tratamento conceitual. De fato, encorajamos especialmente a pesquisa no âmbito das aplicações do funcionalismo na tradução literária, que foi pouco explorada em nosso estudo.

Um segundo tópico de pesquisa que sugerimos enfaticamente, este vinculado ao desenvolvimento geral dos estudos da tradução no Brasil, diz respeito ao impacto da criação de outros programas de pós-graduação em estudos da tradução em instituições de ensino superior no país, especialmente a partir do ano de 2011. A nossa pesquisa identificou o papel protagonista assumido pela UFSC devido, segundo nossa interpretação, a seu pioneirismo na criação do PGET, em 2004. Defendemos, assim, a tese da institucionalização como elemento definidor para o acúmulo de capital científico de uma instituição numa determinada área. Essa tese, no entanto, deve ser colocada à prova por outros estudos, de modo a verificar se esse é, de fato, um fator decisivo no crescimento da produção intelec- 
tual de uma dada instituição no âmbito desse campo disciplinar ou se esse é um caso específico, que envolve fatores de outra natureza.

Se é possível pensarmos em mais uma contribuição do presente trabalho, essa seria uma contribuição de todos os trabalhos dedicados a investigar nosso campo disciplinar: se passado, presente e futuro estão inter-relacionados na história, de modo que as experiências passadas se fazem presentes hoje e constroem nossas expectativas para o futuro, examinar o passado dos estudos da tradução pode ajudar-nos a definir estratégias para nossas ações futuras, especialmente no que tange à luta pelo reconhecimento da profissão do tradutor como uma profissão especializada e pelo reconhecimento dos estudos da tradução como um campo disciplinar com mérito próprio. $\mathrm{O}$ caminho da institucionalização revelou-se, como está claro neste estudo, bastante frutífero. Devemos continuar lutando para que a tradução siga galgando novos espaços em seu caminho evolutivo, por exemplo, aprofundando a sua presença na pós-graduação brasileira, tornando o campo mais diverso quanto mais instituições aderirem a ele. Além disso, não se deve perder de vista a relação entre ensino, pesquisa e prática, estabelecendo sempre o diálogo entre as associações acadêmicas, como o GTTRAD e a ABRAPT, e as associações de profisssionais, como a ABRATES e o SINTRA. Lutar pelo reconhecimento da tradução no âmbito acadêmico eleva as chances de estendermos futuramente esse reconhecimento para o campo profissional. 


\section{Bibliografia}


Corpus de obras seminais funcionalistas (C1):

HOLZ-MÄNTTÄRI, Justa. Translatorisches Handeln. Theorie und Methode. Helsinki: Soumalainen Tiedeakatemia, 1984.

HÖNIG, Hans G.; KUSSMAUL, Paul. Strategie der Übersetzung. Ein Lehr- und Arbeitsbuch. Tübingen: Gunter Narr, 1982.

NORD, Christiane. Textanalyse und Übersetzen. Theoretische Grundlagen, Methode und didaktische Anwendung einer übersetzungsrelevanten Textanalyse. Heidelberg: Julius Gross, 1988.

REISS, Katharina. Möglichkeiten und Grenzen der Übersetzungskritik: Kategorien und Kriterien für eine sachgerechte Beurteilung von Übersetzungen. München: Hueber, 1971.

; VERMEER, Hans J. Grundlegung einer allgemeinen Translationstheorie. Tübingen: Max Niemeyer, 1984.

SNELL-HORNBY, Mary. Translation Studies. An integrated approach. AmsterdamPhiladelphia: John Benjamins, 1988.

VERMEER, Hans J. Ein Rahmen für eine allgemeine Translationstheorie. Lebende Sprachen 23 (3), 1978, p. 99-102.

Corpus de trabalhos de grau (C2):

AZENHA JR., João. Aspectos culturais na produção e tradução de textos técnicos de instrução alemão-português: teoria e prática. 249f., Tese (Doutorado em Letras) - Orientadora: de Prof. Dr. Ruth Mayer - Faculdade de Filosofia, Letras e Ciências Humanas, Universidade de São Paulo, São Paulo, 1994.

LAIÑO, Maria José. A tradução pedagógica como estratégia à produção escrita em LE a partir do gênero publicidade. 234p., Tese (Doutorado em Letras: Estudos da Tradução) - Orientadora: Prof. Dr. Meta Elisabeth Zipser. - Centro de Comunicação e Expressão, Universidade Federal de Santa Catarina, Florianópolis, 2014.

LIBERATTI, Elisângela. Ara, Chico; $\boldsymbol{A w}$, Chuck: uma tradução funcionalista de quadrinhos do Chico Bento. 157p., Dissertação (Mestrado em Letras: Estudos da Tradução) - Orientador: Prof. Dr. Lincoln Paulo Fernandes. - Centro de Comunicação e Expressão, Universidade Federal de Santa Catarina, Florianópolis, 2012.

ZIPSER, Meta Elisabeth. Do fato à reportagem: as diferenças de enfoque e a tradução como representação cultural. 274f., Tese (Doutorado em Letras) - Orientador: Prof. Dr. João Azenha Jr. - Faculdade de Filosofia, Letras e Ciências Humanas, Universidade de São Paulo, São Paulo, 2002. 


\section{Demais referências:}

ABREU, R. DE. Descrição da tradução para o português de marcas de oralidade no romance Les Fleurs Bleues, de Raymond Queneau. TradTerm, v. 16, p. 231-255, 2010.

ALMEIDA, Hutan do Céu. Brasil e Canadá: o texto jornalístico como tradução cultu-ral e a relação dos leitores nas revistas Veja e Maclean's. 125f., Dissertação (Mestrado em Letras) - Centro de Comunicação e Expressão, Universidade Federal de Santa Catarina, Florianópolis, 2005.

ALVES, D. A. S.; VASCONCELLOS, M. L. B. Metodologias de pesquisa em Estudos da Tradução: uma análise bibliométrica de teses e dissertações produzidas no Brasil entre 2006-2010. D.E.L.T.A., v. 32, n. 2, p. 375-404, 2016.

ALVES, F. Apresentação - O processo de tradução: Delimitação de um objeto de estudo. Cadernos de Tradução, v. 2, n. 10, p. 9-22, 2002.

; MAGALHÃES, C. M. Using small corpora to tap and map the process-product interface in translation. Tradterm, v. 10, p. 179-211, 2004.

ALVES, I. M. Apresentação. TradTerm, São Paulo: Humanitas, n. 7, p. 7-8, 2001.

ARAGÃO, S. Ils sont fous ces traducteurs: considerações sobre a tradução do humor em Astérix. In-Traduções, v. 6, n. 10, p. 142-163, 2014.

ARROJO, R. Literariness and the desire for unt ranslat ability: Some reflections on "Grande Sertao: Veredas". TEXTconTEXT, v. 5, n. 1, p. 75-81, 1990.

Oficina de tradução: a teoria na prática. 5a. ed. ed. São Paulo: Ática, 2007.

ARRUDA, J. J. A. Historiografia: Teoria e Prática. 1. ed. São Paulo: Alameda, 2014.

AUBERT, F. H. Apresentação. TradTerm, São Paulo: Humanitas, v. 5, n. 1, p. 7-8, 1998.

Apresentação. TradTerm, São Paulo: Humanitas, v. 9, p. 55-57, 2003.

1994.

.; ALVES, I. M. TradTerm. TradTerm, São Paulo: Humanitas, n. 1, p. 9-13,

AUSTIN, J. L. How to Do Things with Words. Oxford: Claredon Press, 1962.

AZENHA JR., J. Tradução Técnica, Condicionantes Culturais e os Limites da Responsabilidade do Tradutor. Cadernos de Tradução, v. 1, n. 1, p. 137-149, 1996.

Tradução técnica e condicionantes culturais: primeiros passos para um estudo integrado. São Paulo: Humanitas, 1999. 
AZENHA JR., J. Carta ao leitor. TradTerm, São Paulo: Humanitas, v. 6, p. 7-8, 2000.

. O Curso de Tradução na Universidade de São Paulo: algumas reflexões sobre seu momento fundador. In: . (org.). Os caminhos da institucionalização dos Estudos da Tradução no Brasil. [s.1.], 2006a, p. 29-38.

. Lingüística Textual e redação: Redefinindo o conceito de "marca cultural". Tradterm, v. 12, p. 13-32, 2006 b.

. Transferência cultural em tradução: contextualização, desdobramentos, desafios. Tradterm, v. 16, p. 37-66, 2010.

- Competência cultural e competência linguística na formação de tradutores e intérpretes: dois conceitos distintos? Tradução em Revista, v. 1, n. 14, p. 121-136, 2013.

O Curso de Especialização em Tradução da USP (1978-2006): histórico e desdobramentos. In: UPHOFF, D. et al. (org.). 75 anos de alemão na USP: reflexões sobre uma germanística brasileira. São Paulo: Humanitas, 2015a. p. 35-45.

1985-2015: A recepção do Funcionalismo alemão e a consolidação da tradução na Área de Alemão da USP. In: UPHOFF, D. et al. (org.). 75 anos de alemão na USP: reflexões sobre uma germanística brasileira. São Paulo: Humanitas, 2015b. p. 149-177.

BAKER, M. Corpus Linguistics and Translation Studies: Implications and Applications. In: BAKER, M.; FRANCIS, G.; TOGNINI-BONELLI, E. (org.). Text and Technology: In Honour of John Sinclair. Amsterdam-Philadelphia: John Benjamins, 1993. p. 233-250.

BAKER, P. Using Corpora in Discourse Analysis. London-New York: Continuum, 2006.

BANDIA, P. F.; BASTIN, G. L. (org.). Charting the Future of Translation History Current Discourses and methodology. Ottawa: University of Ottawa Press, 2006.

BARBOSA, D. M.; AIRES, L.; SILVA, M. M. Unexpected moment: possibilidades de tradução. Belas Infiéis, v. 5, n. 1, p. 27-37, 2016.

BARBOSA, H. G. Caminhos e Descaminhos dos Estudos da Tradução e Interpretação no Brasil. Revista Trama, v. 5, n. 9, p. 27-47, 2009.

BARONI, M.; BERNARDINI, S. BootCaT: Bootstrapping corpora and terms from the web. Proceedings of LREC 2004. 2004

BARROS, J. D. Teoria da História. 5a. ed. Petrópólis, RJ: Vozes, 2014. v. 1

BEAUGRANDE, R.-A.; DRESSLER, W. U. Introduction to Text Linguistics. LondonNew York: Longman, 1981.

BERBER SARDINHA, T. Lingüística de Corpus. Barueri, SP: Manole, 2004. 
BLUME, R. F.; HUMMITZSCH, M. A tradução como mediação cultural: Antologia de contos de escritoras brasileiras contemporâneas em alemão. Cadernos de Tradução, v. 2, n. 24, p. 47-64, 2009.

BORDENAVE, M. C. D. Apresentação do II Encontro Nacional de Tradutores. Tradução em Revista, v. 13, n. 2, p. 1-3, 2012.

BOURDIEU, P. Os usos sociais da ciência: por uma sociologia clínica do campo científico. Tradução Denice Barbara Catani. São Paulo: Editora UNESP, 2004. $70,2015$.

Para uma sociologia da ciência. Tradução Pedro Elói Duarte. Lisboa: Edições

BRANCO, S. O. A New Look upon the Use of Borrowings in Brazil: The Linguistic/Cultural Border. Cadernos de Tradução, v. 2, n. 1, p. 145-163, 2001.

As faces e funções da tradução em sala de aula de LE. Cadernos de Tradução, v. 1, n. 27, p. 161-178, 2011. $\overline{49-60,2012 .}$

Os Estudos da Tradução no Brasil: relatos de pesquisa. Traduzires, v. 1, n. 1, p.

; ARAÚJO, A. A. DE. A tradução como recurso em atividades de um livro didático de língua inglesa. Belas Infiéis, v. 1, n. 1, p. 183-202, 2012.

BREZOLIN, A. A institucionalização dos Estudos da Tradução no Brasil: o curso de Letras, Tradutores e Intérpretes do Unibero. In: AZENHA JR., J. (org.). Os caminhos da institucionalização dos Estudos da Tradução no Brasil. [s.1.], 2006, p. 26-28.

BÜHLER, K. Theory of Language: the representational function of language. Tradução Donald Fraser Goodwin. Amsterdam-Philadelphia: John Benjamins, 1990.

CARDOZO, M. M. Solidão e Encontro: prática e espaço da Crítica de Tradução Literária. [s.1.] Universidade de São Paulo, 2004.

; HEIDERMANN, W.; WEININGER, M. J. (org.). A escola tradutológica de Leipzig. Frankfurt/Main u.a.: P. Lang, 2009. v. 50

CHESTERMAN, A. Memes of Translation: the spread of ideas in translation theory. Amsterdam-Philadelphia: John Benjamins, 1997.

CINTRÃO, H. P. Sobre a capacidade de análise lingüística e literária como componentes da competência do tradutor. Tradterm, v. 11, p. 71-106, 2005.

COBO, M. J. et al. SciMAT: A new Science Mapping Analysis Software Tool. Journal of the American Society for Information Science and Technology, v. 63, n. 8, p. 16091630, 2012. 
COSERIU, E. Falsche und richtige Fragestellungen in der Übersetzungstheorie / O falso e o verdadeiro na Teoria da Tradução. 1978. In: HEIDERMANN, W. (org.). Clássicos da Teoria da Tradução. 2. ed. Florianópolis: UFSC/Núcleo de Pesquisas em Literatura e Tradução, 2010. v. 1 Alemão-Pp. 252-289.

COSTA, M. J. D.; ZIPSER, M. E.; SOARES, R. L. (org.). Transpondo fronteiras: a tradução e o jornalismo nas suas interfaces. Florianópolis: LLE/CCE/UFSC, 2016.

COULTHARD, M. Introductory remarks. Ilha do Desterro, n. 28, p. 7, 1992.

CRONIN, M. Foreword. mTm Journal, v. 4, p. 7-9, 2012.

DAWKINS, R. O gene egoísta. Tradução de Rejane Rubino. São Paulo: Companhia das Letras, 2007.

DE BELLIS, N. Bibliometrics and Citation Analysis: From the Science Citation Index to Cybermetrics. Lanham, Maryland: The Scarecrow Press, 2009.

DILLER, H.-J.; KORNELIUS, J. Linguistische Probleme der Übersetzung. Tübingen: Max Niemeyer, 1978.

DINIZ, T. F. N. Apresentação. Cadernos de Tradução, v. 1, n. 7, p. 9-17, 2001.

DUDENHÖFER, M. The travels of skopos theory. mTm Journal, v. 4, p. 12-26, 2012.

EVERS, A. et al. Reconsidering Poe's Readership:A Comparative Study of two translations of The Fall of the House of Usher. Cadernos de Tradução, v. 1, n. 25, p. 153-176, 2010.

FERREIRA, L. C. A Tradução da Ironia. Revista Brasileira de Linguística Aplicada, v. 2, n. 2, 2002.

FERREIRA, S. M. G. Following the Paths of Translation in Language Teaching: From Disregard in the Past Decades to Revival Towards the 21st Century. Cadernos de Tradução, v. 1, n. 4, p. 355-371, 1999.

FROTA, M. P. O GT de Tradução da ANPOLL: história e perspectivas. In: AZENHA JR., J. (org.). Os caminhos da institucionalização dos Estudos da Tradução no Brasil. [s.1.], 2006, p. 3-22.

Um balanço dos estudos da tradução no Brasil. Cadernos de Tradução, v. 1, n. 19, p. 135-169, 2007.

FURLAN, M.; ALTHOFF, G. Scientia Traductionis, última edição. Scientia Traductionis, n. 16, p. 1-2, 2014.

GONÇALVES, D. S. Tradução Comentada do Ato III da peça Savages, de Christopher Hampton, 1974: Literatura Traduzida como Reminiscência Histórica. Belas Infiéis, v. 5, n. 3, p. 237-251, 2016. 
GUEDES, C. P.; MOZZILLO, I. Tradução de marcadores culturais em textos técnicos: a função do texto e o papel do tradutor no contato entre línguas e culturas. Scientia Traductionis, n. 15, p. 279-292, 2014.

GUERINI, A.; TORRES, M.-H. C.; COSTA, W. C. (org.). Os estudos da tradução no Brasil nos séculos XX e XXI. Florianópolis: PGET/UFSC, 2013a.

GUERINI, A.; TORRES, M.-H. C.; COSTA, W. C. Um pioneirismo inesperado: breve história da PGET/UFSC. In: GUERINI, A.; TORRES, M.-H. C.; COSTA, W. C. (org.). Os Estudos da Tradução no Brasil nos séculos XX e XXI. Florianópolis: PGET/UFSC, 2013b. p. 13-32.

HALLIDAY, M. A. K.; MATTHIESSEN, C. M. I. M. Halliday's introduction to functional grammar. 4th. ed. ed. London-New York: Routledge, 2014.

HOLMES, J. S. The Name and Nature of Translation Studies. In: VENUTI, L. (org.). The Translation Studies Reader. London-New York: Routledge, 2000. p. 172-185.

HOLZ-MÄNTTÄRI, J. Translatorisches Handeln, Bewusstwerdung, Evolution und das Universum der Quantenphysik. mTm Journal, v. 4, n. Special issue, p. 66-90, 2012.

.; NORD, C. (org.). Traducere Navem. Festschrift für Katharina Reiß zum 70. Geburtstag. Tampere: Tampereen Yliopisto, 1993.

HÖNIG, H. G. Translating: The Constructive Way. Ilha do Desterro, v. 33, p. 13-25, 1997.

HÖRSTER, M. A. F. A cadeira de tradução alemão-português I (linguagem comum) apontamentos didácticos. Tradterm, v. 4, n. 1, p. 47-68, 1997.

HYMES, D. H. Essays in the History of Linguistic Anthropology. AmsterdamPhiladelphia: John Benjamins, 1983.

JAKOBSON, R. Linguística e comunicação. Tradução Izidoro Blikstein; José Paulo Paes. 22a. ed. ed. São Paulo: Cultrix, 2010.

KOSELLECK, R. Begriffsgeschichten. 1. Aufl. ed. Frankfurt/Main: Suhrkamp, 2006a. v. 1926

Futuro passado: contribuições à semântica dos tempos históricos. Tradução de Wilma Patrícia Maas e Carlos Almeida Pereira. Rio de Janeiro: Contraponto-Ed. PUC-Rio, 2006b.

KRAGH, H. Introdução à Historiografia da Ciência. Tradução de Carlos Grifo Babo. Porto: Porto Editora, 2003.

KUHN, T. S. The Structure of Scientific Revolutions. 2nd ed., e ed. Chicago: The University of Chicago Press, 1970. v. 2-N. 2 
KUHN, T. S. A estrutura das revoluções científicas. Tradução de Beatriz Vianna Boeira e Nelson Boeira. 10a. ed. ed. São Paulo: Perspectiva, 2011.

KUSSMAUL, P. Functional Approaches in Translation Studies in Germany. Ilha do Desterro, v. 33, p. 27-40, 1997.

Skopos theory: exploring semantic detail. mTm Journal, v. 4, p. 167-180, 2012.

LAGES, S. K. O tradutor e a melancolia. Trabalhos em Linguística Aplicada, v. 19, n. Jan/Jun 1992, p. 91-98, 1992.

LEAL, A. B. Funcionalismo e tradução literária: o modelo de Christiane Nord em três contos ingleses contemporâneos. Scientia Traductionis, n. 2, 2006.

LEITÃO, R. G. DE C. Estratégias na tradução de onomatopeias japonesas nos mangás: reflexões e classificação. TradTerm, v. 16, p. 281-311, 2010.

LIBERATTI, E. Chico Bento em inglês: uma proposta funcionalista. Belas Infiéis, v. 2, n. 1, p. 171-189, 2013.

. Uma proposta didática para traduzir as histórias em quadrinhos. Tradterm, v. 27, p. 181-200, 2016.

LÖRSCHER, W. Introduction. Ilha do Desterro, n. 33, p. 9-11, 1997.

LOURENÇO, F. M. A.; MARTINS, T. B. A tradução da morte de Khadafi. Belas Infiéis, v. 1, n. 1, p. 129-141, 2012.

MALASZKIEWICZ, P. F.; VANDAELE, S.; REUILLARD, P. C. R. Conceptualização metafórica da anatomia em português: artérias, veias e nervos. Tradterm, v. 26, p. 269$290,2015$.

MARTINS, L. A.-C. P. História da ciência: objetos, métodos e problemas. Ciência \& Educação, v. 11, n. 2, p. 305-317, 2005.

MARTINS, M. A. P. Descriptive translation studies: uma revisão crítica. Gragoatá, v. 7, n. 13, p. 33-52, 2002.

Quatro décadas de tradução na PUC-Rio: 1968-2006. In: AZENHA JR., J. (org.). Os caminhos da institucionalização dos Estudos da Tradução no Brasil. [s.1.], 2006 p. $23-25$.

A institucionalização da tradução no Brasil: o caso da Puc-Rio. Cadernos de Tradução, v. 1, n. 19, p. 171-192, 2007.

MARTINS, R. A. História e história da ciência: encontros e desencontros. In: Actas do $\mathbf{1}^{\mathbf{0}}$. Congresso Luso-Brasileiro de História da Ciência e da Técnica (Universidade de Évora e Universidade de Aveiro). Évora: Centro de Estudos de História e Filosofia da Ciência da Universidade de Évora, 2001, p. 11-46. 
MATTOS, D. Nota do editor. In: MATTOS, D. (org.). Estudos de Tradutologia 1. Brasília: Kontakt, 1981. p. 7-8.

MIKAELYAN, Y. Zapoviédnik, de Serguei Dovlátov: traduzindo a cultura e o riso. Tradterm, v. 24, p. 263-279, 2014.

MILTON, J. The Birth of Translation Studies on the Periphery: The Case of Brazil. In: SOUSA, G. H. P. (org.). História da tradução: ensaios de teoria, crítica e tradução literária. Campinas, SP: Pontes Editores, 2015. p. 93-109.

2003.

.; TORRES, M.-H. C. Apresentação. Cadernos de Tradução, v. 1, n. 11, p. 9-17,

MOREIRA, M. V. S. O reconto como categoria de tradução - aspectos da tradução/adaptação em literatura infantil. São Paulo: Universidade de São Paulo, 2009.

Estudos funcionais da tradução: rupturas e continuidades. São Paulo: Universidade de São Paulo, 2014.

MOREJÓN, J. G. G. Pórtico. Tradução \& Comunicação: Revista Brasileira de Tradutores, n. 10, p. 11, 2001.

MULlinS, N. C. Theories and theory groups revisited. Sociological Theory, v. 1, n. 1983, p. 319-337, 1983.

MUNDT, R. S. D. Traduzir para a criança: uma brincadeira muito séria. 143f., Dissertação (Mestrado em Letras). Faculdade de Filosofia, Letras e Ciências Humanas, Universidade de São Paulo, São Paulo, 2001.

NATALINO, L. G. A semiótica e as tramas de ênfase como contribuição para a tradução do conceito, do imaginário e do cultural. Traduzires, v. 2, n. 1, p. 75-90, 2013.

NORD, C. Loyalität statt Treue. Vorschläge zu einer funktionalen Übersetzungstypologie. Lebende Sprachen, v. 34, n. 3, p. 100-105, 1989.

. Defining Translation Functions. The Translation Brief as a Guideline for the Trainee Translator. Ilha do Desterro, v. 33, p. 41-55, 1997a.

El texto buscado - los textos auxiliares en la enseñanza de traducción. Tradterm, v. 4, n. 1, p. 101-124, 1997 b. 2000.

. Training Functional Translators. Cadernos de Tradução, v. 1, n. 5, p. 27-46,

Faszinosum Übersetzen Einmal Wissenschaft und zurück. In: PÖCKL, W. (org.). Übersetzungswissenschaft Dolmetschwissenschaft: Wege in eine neue Disziplin. Wien: Edition Praesens, 2004. p. 249-258. 
NORD, C. Translating as a purposeful activity: a prospective approach. Tradterm, v. 11, p. 15-28, 2005.

. Quo vadis, functional translatology? Target, v. 24, n. 1, p. 26-42, $2012 \mathrm{a}$.

. Texto base - texto meta: Un modelo funcional de análisis pretranslativo. Tradução de Christiane Nord. Castelló de la Plana: Publicacions de la Universitat Jaume I, $2012 b$.

Análise textual em tradução: bases teóricas, métodos e aplicação didática. Tradução Meta Elisabeth Zipser. São Paulo: Rafael Copetti Editor, 2016a.

Lealdade em vez de fidelidade: proposta de uma tipologia funcional da tradução. Cadernos de Tradução, n. Número especial, p. 9-24, 2016 b.

O’SHEA, J. R. Preface. Ilha do Desterro, n. 36, p. 9-14, 1999.

ORTEGA Y GASSET, J. Miseria y esplendor de la traducción. In: Obras Completas: Tomo V (1933-1941). Madrid: Revista de Occidente, 1947. p. 427-448.

Miseria y esplendor de la traducción. Elend und Glanz der Übersetzung. Tradução Katharina Reiss. München: Deutscher Taschenbuch-Verlag, 1976.

PAGANO, A.; VASCONCELLOS, M. L. Estudos da Tradução no Brasil: Reflexões sobre teses e dissertações elaboradas por pesquisadores brasileiros nas décadas de 1980 e 1990 . D.E.L.T.A.: Documentação de Estudos em Lingüística Teórica e Aplicada, v. 19, n. Especial, p. 1-25, 2003.

PAGURA, R. A interpretação de conferências: interfaces com a tradução escrita e implicações para a formação de intérpretes e tradutores. DELTA: Documentação de Estudos em Linguística Teórica e Aplicada, v. Especial, n. 19, p. 209-236, 2003.

PEREIRA, G. H.; RIDD, M. D. Os Estudos da Tradução na Universidade de Brasília: graduação e pós-graduação. In: GUERINI, A.; TORRES, M.-H. C.; COSTA, W. C. (org.). Os Estudos da Tradução no Brasil nos séculos XX e XXI. Florianópolis: PGET/UFSC, 2013. p. 71-84.

POLCHLOPEK, S. A. Tradução e narratividade: o mundo pós "11 de setembro" retraduzido por títulos jornalísticos. Tradução \& Comunicação: Revista Brasileira de Tradutores, v. 22, p. 133-147, $2011 \mathrm{a}$.

O mundo pós "11 de setembro": tecendo fios/textos entre a tradução e a narratividade jornalística. Tese (Doutorado em Estudos da Tradução) - Centro de Comunicação e Expressão, Universidade Federal de Santa Catarina, Florianópolis, 2011 b.

; AIO, M. DE A. Tradução técnica: armadilhas e desafios. Tradução \& Comunicação: Revista Brasileira de Tradutores, v. 19, p. 101-113, 2009. 
POLCHLOPEK, S. A.; AIO, M. DE A.; ALMEIDA, H. Tradução Técnica: das armadilhas às responsabilidades do tradutor. In-Traduções, v. 2, n. 3, p. 26-39, 2010.

; ZIPSER, M. E. Manner schnitten em foco: especificidades, estratégias e interculturalidade na tradução de uma embalagem de wafer. In-Traduções, v. 2, n. 3, p. $56-65,2010$.

PONTES, V. O.; PEREIRA, L. L. A tradução a partir do modelo funcionalista de Christiane Nord: perspectivas para o ensino de línguas estrangeiras. Tradterm, v. 28, p. 338-363, 2016a.

. Traduzir para ensinar a variação linguística nas formas de tratamento da língua espanhola, por que não? Cadernos de Tradução, v. 36, n. 2, p. 66-90, 2016b.

PYM, A. The Relations Between Translation and Material Text TransferTarget, 1992.

Exploring Translation Theories. London-New York: Routledge, 2010.

. Explorando as teorias de tradução. Tradução Rodrigo Borges de Faveri; Claudia Borges de Faveri. São Paulo: Perspectiva, 2017.

QUENTAL, R. DE F. A dicotomia tradicional teoria/prática no ensino de tradução. Trabalhos em Linguística Aplicada, v. 26, p. 37-48, 1995.

RADNITZKY, G. Contemporary Schools of Metascience. Göteborg: Göteborg University Press, 1970.

REISS, K. Texttyp und Übersetzungsmethode: Der operative Text. Kronberg: Scriptor, 1976.

Comprender un texto - ¿qué significa para el traductor? In: MATTOS, D. DE (Ed.). . Estudos de Tradutologia 1. Brasília: Kontakt, 1981a. p. 33-49.

. - Miseria y esplendor de la traducción - o bien: ¿Qué tiene que ver la traducción con los hombrecitos verdes de Marte? In: MATTOS, D. (org.). Estudos de Tradutologia 1. Brasília: Kontakt, 1981b. p. 111-123. 2, p. 7-19, 1982

Como averiguar o grau de dificuldade de uma tradução. Letras de Hoje, v. 17, n.

REISS, K.; VERMEER, H. J. Mitä kääntäminen on? Teoriaa ja käytäntöä. Tradução Pauli Roinila. Helsinki: Gaudeamus, 1986.

Towards a General Theory of Translational Action: Skopos Theory Explained. Tradução de Christiane Nord; revisão de Marina Dudenhöfer. London-New York: Routledge, 2014.

RIECHE, A. C. O conceito de equivalência e sua relação com a localização de software. Tradução \& Comunicação: Revista Brasileira de Tradutores, v. 15, p. 1-12, 2006. 
RIGO, N. S. Tradução de libras para português de textos acadêmicos: considerações sobre a prática. Cadernos de Tradução, v. 35, n. 2, p. 458-478, 2015.

ROCHA, M.; SPONHOLZ, I.; GERBER, R. M. Apresentação. Cadernos de Tradução, v. 2, n. 14, p. 9-15, 2004.

RODRIGUES, C. Processos Mentais e Ensino da Tradução. Uma Revisão Bibliográfica. Cadernos de Tradução, v. 1, n. 2, p. 55-74, 1997.

A Abordagem Processual nos Estudos da Tradução: uma meta-análise qualitativa. Cadernos de Tradução, v. 2, n. 10, p. 23-57, 2002.

RODRIGUES, C. C. Tradução e práticas político-culturais. Tradterm, v. 1, p. 49-56, 1994.

. Os Estudos de Tradução nos programas brasileiros de pós-graduação. In: GUERINI, A.; TORRES, M.-H. C.; COSTA, W. C. (org.). Os Estudos da Tradução no Brasil nos séculos XX e XXI. Florianópolis: PGET/UFSC, 2013. p. 51-69.

ROSAS, M. Por uma teoria da tradução do humor. DELTA: Documentação de Estudos em Linguística Teórica e Aplicada, v. Especial, n. 19, p. 133-161, 2003.

RÜSEN, J. Reconstrução do passado. Tradução de Asta-Rose Alcaide. Brasília: Editora Universidade de Brasilia, 2010. v. Teoria da História.

SANTANA, P. M. S. A long and winding road: the difficult work of translating written texts in Brazil. In-Traduções, v. 5, n. 8, p. 67-83, 2013.

SANTOS, E. C. P. The Raven e o seu voo para a língua brasileira de sinais. Cadernos de Tradução, v. 37, n. 2, p. 132-158, 2017.

SCHEFFELMEIER, M. P. A tradução técnica no meio empresarial: um estudo descritivo de caso. 104f., Dissertação (Mestrado em Letras) - Faculdade de Filosofia, Letras e Ciências Humanas, Universidade de São Paulo, São Paulo, 2001.

SCHMITZ, J. R. The Promise and Perils of Equivalence in Translation Studies. Tradução \& Comunicação: Revista Brasileira de Tradutores, n. 10, p. 57-74, 2001.

SCOTT, M. WordSmith Tools version 7. StroudLexical Analysis Software, 2016.

SILVA, A. J. O.; ESQUEDA, M. D.; CAMPOS, T. L. Os Estudos da Tradução no Brasil: a ABRAPT e o Encontro Nacional de Tradutores. Domínios de Lingu@gem, v. 11, n. 5, p. 1454-1474, 2017.

SILVA, B. Z. As traduções dos nomes próprios nas histórias em quadrinhos: um estudo de caso das tiras de Mafalda, de Quino. Tradterm, v. 27, p. 155-179, 2016. 
SILVA, J. A.; DANIEL, F. DE G.; ESQUERDA, M. D. O papel do tradutor e seu enfoque nos Cadernos de Tradução da Universidade Federal de Santa Catarina. Cadernos de Tradução, v. 2, n. 20, p. 71-100, 2007.

SNELL-HORNBY, M. Übersetzen, Sprache, Kultur. In:____. (org.). Übersetzungswissenschaft - eine Neuorientierung: zur Integrierung von Theorie und Praxis. Tübingen: Francke, 1986. p. 9-29.

Diplomatischer Dienst, oder die Lust auf Abenteuer. Ein Weg (mit Hindernissen) in die Translationswissenschaft. In: PÖCKL, W. (org.). Übersetzungswissenschaft Dolmetschwissenschaft: Wege in eine neue Disziplin. Wien: Edition Praesens, 2004. p. 335-343.

The Turns of Translation Studies: New paradigms or shifting viewpoints? Amsterdam-Philadelphia: John Benjamins, 2006. v. 66

A "estrangeirização" de Venuti: o legado de Friedrich Schleiermacher aos estudos da tradução? Tradução de Marcelo Victor de Souza Moreira; revisão de Tinka Reichmann. Pandaemonium germanicum. [online]. 2012a, vol.15, n.19, pp.185-212.

The legacy of Hans J. Vermeer. A tribute to a great translation scholar. mTm Journal, v. 4, p. 284-287, 2012 b.

Comunicação na aldeia global: sobre linguagem, tradução e identidade cultural. Tradução de Matheus Bezerra Evaristo e Cristiane Roscoe Bessa. Belas Infiéis, 3(1), 2014, p. 131-152.

SOUZA, L. M. F. Traduções em diálogo. Scientia Traductionis, n. 1, p. 1-22, 2005.

SPIRY, Z. Escola de Tradutores, de Paulo Rónai, marco zero na história dos Estudos da Tradução no Brasil - a genética de uma trajetória. São Paulo, Universidade de São Paulo, 2016.

ST. ANDRÉ, J. History. In: BAKER, Mona; SALDANHA, Gabriela (org.). Routledge Encyclopedia of Translation Studies. 2nd ed. London-New York: Routledge, 2011, p. 133-136.

STOLZE, R. Indicadores de qualidade para a avaliação de traduções no âmbito da didática. Tradterm, v. 4, n. 1, p. 141-156, 1997.

TAGNIN, S. E. O. Apresentação. Cadernos de Tradução, v. 1, n. 9, p. 9-14, 2002.

Apresentação. TradTerm, São Paulo: Humanitas, v. 10, p. 7-17, 2004.

. A Linguística de Corpus na e para a Tradução. In: VIANA, V.; TAGNIN, S. E. O.

(org.). Corpora na tradução. São Paulo: Hub Editorial, 2015. p. 19-56. 
TAHIR-GÜRÇAĞLAR, Ş. Translation history. In: MILLÁN, C.; BARTRINA, F. (org.). The Routledge Handbook of Translation Studies. London-New York: Routledge, 2013, p. 131-143.

TEIXEIRA, E. D. Especificidades da tradução técnica de receitas - alguns problemas e possíveis soluções. Tradterm, v. 15, p. 173-196, 2009.

TORRES, M.-H. C. A virada institucional nos Estudos da Tradução no Brasil. In: SOUSA, G. H. P. (org.). História da tradução: ensaios de teoria, crítica e tradução literária. Campinas, SP: Pontes Editores, 2015. p. 111-122.

UMBACH, R. U. K. Os neologismos de Guimarães Rosa em "As margens da alegria” e suas traduções para o alemão e o inglês. Letras, n. 8, p. 103-111, 1994.

VANNUZINI, A. M. S. Texto, imagem e projeto gráfico na tradução de literatura infantojuvenil. Scientia Traductionis, n. 4, 2007.

VASCONCELLOS, M. L. B. "Function" Revisited: Expanding the role of translation in the receptor context. Cadernos de Tradução, v. 1, n. 1, p. 165-179, 1996.

Os Estudos da Tradução no Brasil nos Séculos XX e XXI: ComUNIDADE na diversidade dos Estudos da Tradução? In: GUERINI, A.; TORRES, M.-H. C.; COSTA, W. C. (org.). Os Estudos da Tradução no Brasil nos séculos XX e XXI. Florianópolis: PGET/UFSC, 2013. p. 33-50.

VERMEER, H. J. Esboço de uma teoria de tradução. Lisboa: Edições Asa, 1986. 25-33, 1987.

What does it mean to translate? Indian Journal of Applied Linguistics, v. 13, p.

Skopos and commission in translational action. In: CHESTERMAN, A. (org.). Readings in Translation. Helsinki: Oy Finn Lectura Ab, 1989. p. 173-187.

VERMEER, H. J. Aplicação de princípios da Teoria da Recepção à Teoria da Tradução. Anais do IV Encontro Nacional de Tradutores - "A tradução: alvos e ferramentas". São Paulo: 1990a

Day-dreaming a dialogue: Rosemary Arrojo's article on the struggle for power between the author and the reader. TEXTconTEXT, v. 5, n. 1, p. 82-85, 1990 b.

Um plano piloto para a formação de tradutores e intérpretes. Anais do IV Encontro Nacional de Tradutores - "A tradução: alvos e ferramentas". São Paulo: 1990c $\overline{49,1992 .}$

Is Translation a Linguistic or a Cultural Process? Ilha do Desterro, v. 28, p. 37-

Katharina Reiß zum Geburtstag. Statt Lebenslauf. In: HOLZ-MÄNTTÄRI, J.; NORD, C. (org.). 1993. p. 1-2. 
VERMEER, H. J. El mundo como proceso - reflexiones traslatológicos. Trabalhos em Linguística Aplicada, v. 24, p. 5-18, 1994.

A formação de tradutores/intérpretes. IV Encontro de Professores de Línguas e Literaturas Estrangeiras - Alemão, Espanhol, Francês, Inglês, Italiano e Japonês. Anais...São Paulo: Arte \& Ciência, 1996

Vorwort von Hans J. Vermeer. In: WOLF, M. (org.). Übersetzungswissenschaft in Brasilien: Beiträge zum Status von "Original" und Übersetzung. Tübingen: Stauffenburg Verlag, 1997. p. 9-11.

VIANA, V.; TAGNIN, S. (org.). Corpora na tradução. São Paulo: Hub Editorial, 2015.

WILSS, W. Übersetzungswissenschaft: Probleme und Methoden. Stuttgart: Ernst Klett, 1977.

WOLF, M. (org.). Übersetzungswissenschaft in Brasilien: Beiträge zum Status von "Original" und Übersetzung. Tradução Helge Ahrens et al. Tübingen: Stauffenburg Verlag, 1997.

WOODSWORTH, J. History of Translation. In: BAKER, M. (org.). Routledge Encyclopedia of Translation Studies. London-New York: Routledge, 1998, p. 100-105.

WOTJAK, G. (org.). 50 Jahre Leipziger Übersetzungswissenschaftliche Schule. Ein Rückschau anhand von ausgewählten Schriften und Textpassagen. Frankfurt am Main u.a.: Peter Lang, 2006. v. 1

ZIPSER, M. E. A tradução de notícias: novos rumos para a pesquisa em tradução. Tradução \& Comunicação: Revista Brasileira de Tradutores, v. 15, p. 45-53, 2006.

.; POLCHLOPEK, S. A.; COSTA, M. J. R. D. Tradução como ação comunicativa: a perspectiva do funcionalismo nos estudos da tradução. Tradução \& Comunicação: Revista Brasileira de Tradutores, v. 24, p. 21-37, 2012. 